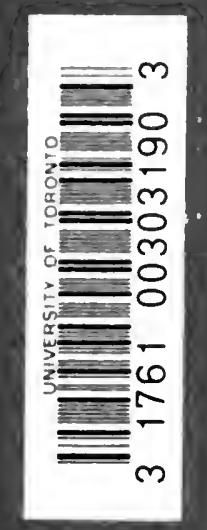



Digitized by the Internet Archive in 2007 with funding from Microsoft Corporation 



\title{
Political History of Secession
}

To the Beginning of the American Civil War

\author{
By \\ Daniel Wait Howe \\ President of the Indiana Historical Society \\ Author of "The Puritan Republic," "Civil War Times"
}

"The best way to come to truth being to examine things as really they are, and not to conclude they are as we fancy of ourselves or have been taught by others to imagine,"-LOCKE.

G. P. Putnam's Sons

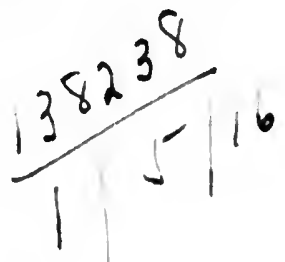

New York and London

Tbe Knickerbocker Dress

1914 
Copyright, I9I 4

BY

DANIEL WAIT HOWE 


\section{PREFACE}

"DRELIMINARY EGOTISM" is the title that Horace Greeley gives to the preface of The Great American Confict. Few authors can afford to be as frank in their prefaces as Horace Greeley was in his, for he had the advantage of knowing that many would be interested in hearing whatever he might have to say and that there was some foundation for any seeming egotism.

The preface to a volume like this is usually the last and the hardest thing to write. I have repeatedly rewritten this, in a vain effort to make it satisfactory to myself. I do not propose to expand it by telling what the book is about, or to apologize for writing it. The title and table of contents sufficiently indicate its general character.

I have endeavored in a volume of moderate size to give a concise history of the development of the causes, of which slavery was the chief, but not the only one, that culminated in the Civil War.

Although it is difficult to find new facts, it is still possible to array old facts in such a way as to give them a new interest, and to develop new theories more or less interesting and instructive. But to avoid writing too much or too little; to escape the criticism that what is good is not new and what is new is not good; above all to make what is written as accurate as possible,-to do all this is not an easy task.

One of the chief difficulties in the preparation of a book of this kind is in estimating the relative importance of the events narrated, so that the significance of each may be clearly understood, and to do this without allotting too 
much space to one and too little to another. Therefore, while endeavoring to avoid prolixity, I have also tried to avoid sacrificing accuracy to brevity, believing that any event of sufficient historical importance to merit reference should be stated fully enough to make its importance understood. For example, I have devoted much more space to the history of the Dred Scott case than is given to it by most historians, because it is impossible for any historian to convey in two or three pages a correct understanding of this important and far-reaching case.

Tastes vary as to the best method of presenting history. I have little to say about my own. While never losing sight of the necessity of accuracy in recording historical facts, I have endeavored to state them in such a way as not to repel the general reader by giving the book the appearance of one designed only for schools of the Gradgrind kind where facts and "nothing but facts" are taught-hard, dry facts without a touch of coloring that art, poetry, humor, or fancy might lend to make the story of them attractive.

As I write from the standpoint of one who is a descendant of old Massachusetts Puritan stock and who served in the Civil War as a soldier of the Union Army, it is not to be expected that my opinions will receive the assent of those who view the subject from a Southern standpoint. On the other hand, it is probable that some of my opinions of men and events will not receive the assent of all Northern readers.

In consequence of new historical facts that are every day coming to light, few men in either the North or the South now entertain the same opinions of men prominent in and of events significant to the history of secession that they entertained in earlier years. It is not yet possible, however, for Northern and Southern writers to agree in their conclusions. They will, therefore, continue to advocate their special theories and the little that each contributes will add to the fund of knowledge from which future historians will construct their histories. 


\section{Preface}

Something has been gained for history in the fifty years following the Civil War. A marked improvement in tone is to be noted in the books about secession written in recent years over that of the books written soon after the close of the war. Rhodes is much fairer to the South than was Greeley or Von Holst or Henry Wilson, and we of the North, while not concurring in the theories advanced by Herbert in his Abolition Crusade, can at least recognize his candor and sincerity, and we can see in the general tone of his book a vast change from the bitter spirit which characterized Pollard's Lost Cause.

More still has been gained; and it is probably safe to say that the great body of conservative men in both the North and the South now rejoice that the Union safely passed through the Civil War and the horrible nightmare of Reconstruction and survived the perils of both.

While I do not expect general assent to any of my conclusions, I trust that not many inaccuracies will be found in my statement of facts and that I may be given credit for having tried to write fairly and honestly.

With this explanation the present volume must speak for itself. I am under special obligations to my friend, Mr. Charles R. Williams, long and favorably known as editor of the Indianapolis Neres For the third time he has been my trusted pilot to guide me in my literary voyages. I have also been greatly aided by the personal advice and suggestions of Doctor James A. Woodburn of the Indiana University.

Daniel Wait Howe.

INDIANAPOLIS, INDIANA. 



\section{TABLE OF CONTENTS}

\section{CHAPTER I}

\section{ENTRANCE OF SLAVERY INTO AMERICAN POLITICS}

Difference between people of Northern and those of Southern colonies,r. Rural life in the North and in the South, 2. Early introduction of slavery in the Southern colonies, 2. Relations of owners of great plantations in the South to their dependents, 2. Virginia and South Carolina in colonial times, 2. Effect of slavery on social life and character, 3, 4. Effects of slavery in South Carolina and Georgia, 4. Concessions to slavery in United States Constitution, and in early territorial cessions, 9. Progress of emancipation in Southern states, 10. Colonization societies in the South, 10. Effect on South of the antislavery societies of the North, 10. Growing belief in South of righteousness of slavery, Ix. Effect on slavery of introduction of the cotton-gin and other improvements in the production of cotton, Ir. Political antagonism between New England and slave States, Ir. Events prior to the election of Monroe that distracted attention from slavery, 12. Acquisition of Louisiana Territory, 12. Opposition of New England Federalists, 12. Protection and extension of slavery becomes paramount question in the South, 13. Failure to get foothold for slavery in the Northwest Territory, 13. Election of James Monroe as President, 13

\section{CHAPTER II}

\section{THE BEGINNINGS OF SECESSION}

Gains of North over South in commercial prosperity, 15. The doctrine of secession in the North, 17. Opposition of vii 
New England Federalists to I,ouisiana Purchase, I7. Talk in New England of Northern Confederacy in War of 1812, 17. The Hartford Convention, 17. Contrast between manner in which doctrine of secession was viewed in North and in the South, 18. Political doctrines peculiar to South, 19. Right of secession as viewed in the South, I9. Basis of doctrine, 20. The Alien and Sedition Acts, 20. The Virginia and Kentucky resolutions, 21. Responses of other state legislatures, 23. How far the resolutions justify doctrine of nullification, 25. Madison's and Jefferson's construction of the Virginia and Kentucky resolutions, 27. Principle of, adopted by South Carolina political leaders, 27. Also adopted by Democratic party, 27. The great debate on nullification between Webster and Hayne, 28. Nullification in South Carolina in 1832,28 . The Force Bill, 29. Calhoun's resolution and speech, 29. Webster's reply, 30. Clay's compromise tariff bill of 1833, 36. Calhoun's doctrine adopted for extension and protection of slavery, 36 .

\section{CHAPTER III}

\section{SLAVERY IN THE TERRITORIES}

Question early becomes prominent, 37. Southern sentiment favoring prohibition of slavery in territories speedily disappears, 37. Reservations of rights of slavery in cessions to United States by Virginia, North Carolina, and Georgia, 37. Demand of South for preservation of the "equilibrium," 38. Question assumes new importance after acquisitions from Mexico, 38. Southern doctrine of "equality of rights" in the territories, 40. Calhoun's arguments in favor of, 40. Difficulties in way of settling question, 43. Efforts to devise some compromise policy, 43. The question from slave-holder's point of view, 43. Doctrine of "popular sovereignty," 44. Doctrine of "non-interference," 45. Doctrine that Constitution of United States guaranteed right of slavery in territories, 48. Calhoun's and Webster's arguments on question, 48. Fallacy of Calhoun's arguments, 50. Views of Dix, Webster, and Clay, 5o. Calhoun main advocate of doctrine, 52. Estimate of Calhoun, 53. . 


\section{Table of Contents}

\section{CHAPTER IV}

THE MISSOURI COMPROMISE; BEGINNING A NEW POLITICAL ERA

Division of Louisiana Territory, 55. Petitions for admission of Missouri and Arkansas, 55. Tallmadge's proposed amendment prohibiting slavery in territories, 55. Arguments of those opposed to Tallmadge's amendment, 56 . Jefferson's argument against it, 57. Threats in the South of disunion, 57. Division of parties on geographical lines, 58. Jefferson's forebodings, 58. Maine and Arkansas admitted, 59. The Missouri Compromise finally agreed on, 59. The questions submitted by President Monroe to his cabinet, 59. The Missouri Constitution, 60. Quarrel between Clay and Randolph, 60. The Compromise favored by Southern leaders, 60 . Excitement in the North over the Compromise, 60. Subsidence of excitement and inauguration of "era of good feeling," 6r. Douglas's eulogy upon the Missouri Compromise, 61. Slavery now becomes an important factor in American politics, 6r. . . . . .

PAGE $55-61$

\section{CHAPTER V}

\section{FROM I820 TO 1840; GROWTH OF ANTI-SLAVERY SENTIMENT}

\section{IN THE NORTH}

"Era of good feeling," 62. Andrew Jackson and his administration, 62. Organization in North of anti-slavery societies, 63. Establishing abolition newspapers, 64 . Garrison's Liberator; its creed, 64. Nat Turner's insurrection, 66. Stringent slave legislation in the South, 66. Rewards offered in South for Northern Abolitionists, 66. Slave-holders' appeals to Northern legislatures to suppress Abolitionists, 67. Attempt to suppress circulation of Abolition pamphlets and papers through the mails, 67 . Attempts to suppress right of petition, 68. Abolition petitions and memorials to Congress, 69. John Quincy Adams advocate of right of petition, 69. His resolution for a constitutional amendment prohibiting slavery, and other anti-slavery resolutions, 69. Slade's resolution, 
71. The Atherton Gag, 72. Adams presents petition for PAGE dissolution of the Union, 72. Opposition of 'Northern Democrats to gag rule, 73. How Abolition petitions were disposed of after gag rule was abolished, 73. Calhoun's argument in favor of suppressing Abolition petitions, 73 . On petition presented by James Buchanan, 75. Northern opposition to Abolitionists, 76. Attitude of Northern churches to Abolitionism, 76. Garrison and his friends burn the Constitution, 77. They advocate dissolution of Union, 78. Refuse to vote, 78. Excuse given by clergy for not preaching against slavery, 78. Other "isms" advocated by Abolitionists render them unpopular, 79. The mob year (1835), 79. Mobbing of Garrison, 80. Murder of Lovejoy, 8o. The meeting in Faneuil Hall, 8o. Wendell Phillips's speech, 8o. Dissolution of American Anti-Slavery Society in 1840,81 . Last number of the Liberator, 82. Estimate of Garrison, 82. He and Abolitionists not responsible for the Civil War, 83 .

\section{CHAPTER VI}

\section{THE POLITICAL CAMPAIGN OF I840; "TIPPECANOE AND TYLER TOO"}

Estimate of Martin Van Buren, 85. Disasters of his administration, 85. Changes in political parties prior to end of his term, 86. The Whig National Convention of 1839,86 . Convention fails to adopt any platform of principles, 87 . Nomination of Harrison for President and Tyler for Vice-President, 87. Tyler's political antecedents, 87. Harrison's prior military and civil record, 88. Democratic National Convention of 1840 ; nominates Van Buren for President; its platform on slavery, 89. Abolitionists nominate James G. Birney for President, 89. Van Buren's record on slavery question, 89. Harrison's record on slavery question, 89. Personal characteristics of Harrison and Van Buren, 92. Characteristics of campaign, 93. Popular campaign oratory, 96. Speeches of Henry Clay and Daniel Webster, 96. Harrison's speeches, 97. Preëminently a singing campaign, 98. Campaign a carnival of hilarity, 100. Effort of politicians to smother slavery agitation, I03. Harrison elected, ro3. His inaugural, ro3. Harrison 


\section{Table of Contents}

dies and troubles of Whigs begin, ro4. Tyler's course, PAGE 104. Changes in his cabinet, 104. Efforts for annexation of Texas, ro4. Opposition to annexation in the North, 105. Democratic National Convention of 1844 ; nominates James $\mathrm{K}$. Polk and favors annexation of Texas and occupation of Oregon, 106. Whigs nominate Henry Clay; causes of his defeat, 107. Liberty party nominates James G. Birney, 107. Rise of Native American party, 107. William H. Seward in this campaign, 108. Estimate of Seward, 108. Seward's speeches in this campaign, rog. Passage of joint resolution for annexation of Texas, I ro. James Buchanan's gratification for reẽstablishing the Missouri Compromisc, I ro . .

85-1 10

\section{CHAPTER VII}

\section{THE OREGON BOUNDARY QUESTION; POLK'S BACKDOWN}

Slavery question important factor, IIx. Long-pending controversy, between Great Britain and United States, III. Treaties of 1818 and 1827, II2. Failure of efforts to arbitrate or compromise, I12. Increasing danger of conflict of jurisdiction, I13. Growing demand in United States for occupation by Federal government, 113. Convention at Cincinnati, Ohio, in I843, Ir4. Prior Congressional resolutions and bills, I I5. President Tyler's message on subject, 117 . Reasons for linking the annexation of Texas and occupation of Oregon, I17. President Polk's inaugural address, 117. Resumption of negotiations between Great Britain and United States on subject, I17. President Polk's annual message of 1845 , I 18 . Efforts of Fifty-four Forties in Congress, 118. Tone of Democratic press, 120. Chief advocates in Congress of policy of the Fifty-four Forties, 120. Speech of Senator William Allen, 121. Speech of Senator Edward Hannegan, 123. Gravity of situation realized in Great Britain and in United States, 124. Controversy practically narrowed to one over strip between 49 degrees north parallel and $54^{\circ} 40^{\prime}, 124$. Speeches of Senator Thomas H. Benton and Reverdy Johnson, 125. Danger of war between Great Britain and United States at that time, 124. Speeches of Crittenden, Berrien, Yancey and others in opposition to policy of Fifty-four 
Forties, 126. Shifting of party lines in Congress during discussions, 130. Position of John Quincy Adams, I3I. Speech of Joshua R. Giddings, r3I. Senator Hannegan accuses Southern Democrats of bad faith, 134. Senate modifies House resolution and as modified it passes both houses, 136. Negotiations between Great Britain and United States over controversy resumed, r37. President Polk's change of Oregon policy, r38. Speech of Senator William Haywood in defense of President Polk, 138. Reply of Senator Hannegan, 138. Democratic papers oppose "backdown," I39. 49 degrees north parallel agreed on by Great Britain and United States as a compromise, 139. How President Polk was extricated from his dilemma, r4o. Treaty approved by Congress, 142 . Complete failure of Fifty-four Forties, r42. Status of slavery in territories left unsettled, I42.

III-I 42

\section{CHAPTER VIII}

\section{WAR WITH MEXICO; DIVIDING THE SPOILS OF VICTORY}

War declared in 1846 and peace in 1848,143 . Mexico's request for provision in treaty prohibiting slavery, rejected, 144 . The Wilmot proviso, 144. Calhoun's resolution declaring that Constitution protected slavery in the territories, 145. Calhoun's letter on "forcing the issues," I45. Advises retaliatory legislation by South, 146. Controversy between Texas and New Mexico, 147. Stephen A. Douglas reports various bills for territorial organization of Oregon, 147. Action of House and Senate on same, 147. Efforts to provide territorial organizations for California, New Mexico, and Utah, I48. Democratic National Convention in 1848 , I48. Whig National Convention in 1848; skulks on slavery question and nominates General Zachary Taylor for President, 148. Care taken by Whig leaders to avoid any expression by party or candidates on the slavery question, I49. Antislavery men organize Free-soil party and nominate Martin Van Buren for President and Charles Francis Adams for Vice-President, 150 . Political conditions in New York in state of chaos, I50. General Taylor elected President, I51. William H. Seward and Abraham Lincoln take active part in campaign in support of Taylor, 151. 
Horace Greeley's lament over the defeat of Henry Clay,

152. Beginning of second session of thirtieth Congress, 152. Vast extent of territory still unprovided with state or territorial government, 153. Senator Benton presents petition of people of New Mexico for territorial government without slavery, 154. Opposition of Senato: Calhoun, I54. House territorial committee directed to report bills for organization of New Mexico and California prohibiting slavery, 154. Senator Walker's amendment to general appropriation bill, extending constitution to territories, 155. Debates disclose strong anti-slavery sentiment in the North, 155. Secret meetings of Southern members of Congress, 156. They issue an address to their constituents, 156 . Abraham Lincoln's Congressional record, 156. Horace Greeley's Congressional record, $\mathrm{I} 57$. . . . . . 143-158

\section{CHAPTER IX}

\section{FORCING THE ISSUES; THE COMPROMISE MEASURES OF I850}

President Taylor inaugurated, 159. First Session of 31st Congress shows growing opposition to slavery, 159 . The new President a political enigma, 159. President favors admission of California, under a free-state constitution, 160. California convention adopts free-state constitution, 160. Growing Southern sentiment in favor of Calhoun's idea of "equality of rights" in the territories, 160. Violence of party feeling, 161. Political complexion of 3 Ist Congress, 16r. Political leaders in Senate and House, 164. The new senators, 164. President Taylor's message recommending admission of California, I67. Senator Foote's resolution, for territorial governments for California, Deseret, and New Mexico, 167. Clay's compromise resolutions, 167. Bell's compromise resolutions, I68. Foote's resolution for Senate committee of thirteen, I68. Debates on these resolutions, I68. Speech of Henry Clay, I68. Speech of John C. Calhoun, 169. Speech of Daniel Webster, 170. Speech of William H. Seward, 174. Speech of Salmon P. Chase, 175. Speech of Jefferson Davis, 176. Position of Stephen A. Douglas, 176. Death of Calhoun and President Taylor, 176. Compromise measures 
passed, I76. Features of bill for a territorial government for New Mexico, I77. Compromise measures unsatisfactory to North and South, 179. Features of Fugitive Slave Law, I79. What the South gained and what it lost by the compromise measures, I79. The Nashville, Tennessee, Convention in 1850, 180. Effect of compromise measures in Mississippi, I8I. The Georgia platform, 181. The Alabama platform, 182. The Southern League, I82. Yancey's letter to Slaughter, 183. Little accomplished by compromise measures, I83.

\section{CHAPTER X}

THE ELECTION OF PIERCE; REPEAL OF THE MISSOURI COMPROMISE

Reaction in North after passage of compromise measures, against further slavery agitation, 184 . Causes for passage of Fugitive Slave Law of 1850 , I84. The underground railroad, I84. Opposition to Fugitive Slave Law of 1793, 185. Reasons for temporary acquiescence of North in Fugitive Slave Law of 1850, 185. Feeling in southern parts of Ohio, Indiana, and Illinois, I86. Feeling in New England, I86. Attitude of Northern churches, 187. Influence of Uncle Tom's Cabin, 187. Influence of New York Tribune, I88. National Democratic Convention in 1852; its platform, 189. Nominates Franklin Pierce for President, I89. Whig National Convention of I852; nominates General Winfield Scott, I89. The Whig platform, 190. Scott's stumping tour, I90. Pierce elected, 190. Estimate of Pierce, 190. Appoints Jefferson Davis Secretary of War, 19I. Pierce's admiration for Davis, I91. Pierce's prophecy of result in case of civil war, I91. Pierce's inaugural address, I92. General desire in North for peace, 192. Demands of South for extension of slave territory, 192. Supposed inconsistency between Missouri Compromise and Compromise Measures of 1850 , I94. Douglas reports bill for organization of Territory of Nebraska, 195. Dixon's amendment, 195. Sumner's proposed amendment, 195. New bill reported for organization of two territories, Kansas and Nebraska, 196. The sections repealing the 
Missouri Compromise, 196. Origin of the repealing sections, 198. Address of the Independent Democrats, 198. Attitude of Democrats and Whigs, 199. Speech of Salmon P. Chase, 199. Speech of William H. Seward, 201. Final vote in House, 202. Seward's second speech, 202. Speech of William Pitt Fessenden, 203. Estimate of Fessenden, 203. Crowning glory of Fessenden's political life, 204. Fessenden's reply to Senator Butler, of South Carolina, 205. Douglas's speech, 206. Final vote on bill in Senate, 212. Repeal of Missouri Compromise, due chiefly to Douglas, 213. Consequences of the repeal, 214. Excitement in North over passage of the Kansas-Nebraska bill, 215. Feeling in North against Douglas, 215. Political effects of the repeal, 216

\section{CHAPTER XI}

\section{NULLIFICATION IN THE NORTH}

Continual friction between North and South on account of fugitive slaves, 217. The original fugitive slave act of 1793, 217. The case of Prigg vs. Pennsylvania, 217. Personal liberty bills of Northern states, 218 . Northern opposition to Fugitive Slave Law of 1850,218 . The "higher-law" doctrine, 219. Failure of Fugitive Slave Law to meet expectations of South, 220. Northern opposition to it, 22I. The Shadrach rescue case, 222. The Jerry rescue case, 222. Northern opposition not confined to any party or class, 223. Democratic and Whig politicians strive to suppress slavery agitation, 223 . The anti-agitation compact, 223. Union-saving meetings, 224. Daniel Webster's speeches, 226. The slave catchers and kidnappers, 226. Efforts of Pierce's administration to enforce Fugitive Slave Law, 227. Rulings of Judge Grier and Judge Kane, 228. The prosecutions for treason against Hanway and Lewis, 228. Attempts to enforce law make it more odious, 229. The Glover rescue case, 229. Prosecution of Sherman M. Booth and litigation growing out of it, 230. United States Supreme Court reverses judgments of Wisconsin Supreme Court in the Booth cases, 233. Opinion settles question as to supremacy of Federal over state courts in 
construction of Federal statutes, 233. How United States Supreme Court decision was regarded in the North, 234. Wisconsin state election in $185^{8}$ turns on question of "states' rights," 235. Wisconsin Supreme Court refuses to obey mandate of United States Supreme Court in the Booth cases, 236. Booth again arrested and imprisoned on the judgment on the old indictment, 236. Excitement in Wisconsin over the Booth cases, 236. Resolutions of Wisconsin Legislature, affirming the nullification doctrine of the Virginia and Kentucky resolutions of 1798,236 . Booth finally pardoned by President Buchanan, 238. The case of Antony Burns in Boston, 239. Increased activity of anti-slavery societies, 239. Additional personal liberty laws enacted by Northern states, 240. The personal liberty laws of Massachusetts and Vermont, 240. In Northern opposition to Fugitive Slave Law, slavery received its first serious check, 242 . $2 . \quad . \quad . \quad . \quad$.

\section{CHAPTER XII}

\section{POPULAR SOVEREIGNTY IN PRACTICE}

Determined efforts to make Kansas a slave state, 243. Organization of New England Emigrant Aid Society, 243. Excitement in Kansas, spreads throughout the nation, 245. Territorial elections, 246. Meeting of territorial legislatures and laws enacted, 246. Legislature calls constitutional convention which adopts Lecompton Constitution, 247. Provides for only limited submission of constitution to the people, 247. Free-State men meet at Topeka and adopt Topeka Constitution, 247. President Pierce's message and proclamation, 248. Appointment of Judge S. D. Lecompte, 249. Persecution of free-State men, 249. Sack of Lawrence, 250. Lawless condition of Territory, 25I. John Brown of Ossawatomie becomes conspicuous, 252. The Pottawatomie massacre, 253. Douglas reports bill for admission of Kansas, 254. Douglas's speech, 254. Seward's speech in reply to Douglas, 256. Efforts to get definite interpretation of "popular sovereignty," 259. Senator Cass's speech, 259. Construction of Kansas-Nebraska act left in doubt until Dred Scott decision, 262. Comments of 


\section{Table of Contents}

xvii

Northern writers on Douglas's speech, 262. Beginning

PACE of Douglas's political transformation, 263. Change in public mind as to relative position of Douglas and Seward 263

\section{CHAPTER XIII}

\section{THE CRIME AGAINST KANSAS AND THE CRIME AGAINST SUMNER}

Charles Sumner; estimate of, 264. His speech on "The Crime against Kansas," 265. Striking features of speech, 265. Reference to Senator Butler, of South Carolina, 267. Speech delights Northern Abolitionists, but angers pro-slavery men, 268. Douglas's answer, 268. Sumner's reply, 269. Assault on Sumner by Preston Brooks of South Carolina, 27I. Proceedings in Senate; speeches of Wilson, Slidell, and others, 272. Proceedings in House, 273. Brooks's statement in House, 273. Speech of Burlingame in House, 273. Brooks challenges Burlingame, 274. Brooks's assault generally approved in the South, 275. Jefferson Davis approves, 275. Comments of Southern papers, 275. Assault excites great indignation in Massachusetts and throughout the North, 276. Sumner's return to Senate, 277

\section{CHAPTER XIV}

\section{BIRTH OF THE REPUBLICAN PARTY AND ITS FIRST BATTLE}

Slavery propagandists grow more aggressive, 278. Toombs's speech in Boston, 278. Times now ripe for new party, 279. Slow growth of enduring political parties, 280. Disintegration of old parties began with passage of Kansas-Nebraska act, 281. Meeting of opponents of extension of slavery at Ripon, Wisconsin, 281. Finding a party name, 28r. Various causes diverting attention from the slavery question, 282. All other political questions finally merged in slavery question, 283. Call issued in 1855 for Republican National Convention, to be held at Pittsburgh, Pa., 283. Names and character of delegates, 284. Owen Lovejoy's prayer, 287. Speeches of Horace 
Greeley and others, 287. Resolutions adopted, 288. Comments on character of convention, 288. Call issued, for National Republican Convention to meet at Philadelphia, 289. Names and character of delegates, 290. Henry S. Lane chosen president; his appearance and speech, 290. The platform, 29r. John C. Fremont and William L. Dayton nominated for President and Vice-President, 292. Why Seward was not nominated, 292. Frémont's qualifications as a vote-getter, 293. Democratic National Convention at Cincinnati nominates James Buchanan and John C. Breckinridge for President and Vice-President, 293. Its platform, 293. Conflicting views as to meaning of popular sovereignty plank, 295. American or Know-Nothing party splits on slavery question, 295. Nominates Millard Fillmore and Andrew J. Donelson for President and Vice-President, 295. Buchanan's orthodoxy on slavery question vouched for by Southern leaders and newspapers, 295. Affairs in Kansas grow worse, 296. New political leaders come to the front, 296. Prominent Republican leaders, 297. Campaign songs, 299. Marked difference between campaign of 1856 and that of 1840 , 3or. Frémont's qualifications, 30r. Elements of Democratic political strength, 301. Buchanan elected, 302. Southern threats of secession during campaign, 302. Preliminary preparations for secession, 302. Frémont's defeat not a national calamity, 303. Pierce's last annual message, 305. Sherman's reply to it, 308. The last of Pierce, 309. Author's personal recollections of campaign of 1856, 3 I0

\section{CHAPTER XV}

\section{THE DRED SCOTT CASE}

Democratic prospects at inauguration of James Buchanan, 314. His inaugural address, 314 . Reference in inaugural to Dred Scott case, 315. Statement of case, 316. The Judges of the Supreme Court, 316. The principal questions involved, 317 . The first opinion, $3 \mathbf{1 8 .}$ Effort of Justice Wayne to get decision on constitutionality of the Missouri Compromise, 319. The second argument, 320. The judgment of the Court, 320. 


\section{Table of Contents}

Diversity of opinions, 321. Opinion of Chicf Justice PAGE Taney, 321. Opinion of Justice Curtis, 321. Popular verdict on the decision, 323. Condemnation in North of Taney's opinion, 325. Establishes ultra Calhoun doctrine, 326. Decision disposes of "popular sovereignty," 327. Ominous sentence in opinion of Justice Nelson, 328. Northern fear of ultimate results of decision, 328. Lincoln's opinion of, 329. Northern suspicion of "plot," implicating Buchanan, 33r. Lincoln's views on subject, 33I. Seward's charges, 332. Views of historians on alleged plot, 334. Correspondence between Buchanan and Justices Catron and Grier, 335. Summary of facts proved by this correspondence, 339. Alteration of Taney's opinion before publication, 343. Correspondence shows gross breach of executive and judicial propriety, 344. No talk in North of forcible resistance of decision, 344. How Lincoln proposed to overthrow decision, 344. Oliver P. Morton's views on subject, 345. Importance of decision, 346 . Its political consequences, 346

\section{CHAPTER XVI}

CONTINUATION OF THE IRREPRESSIBLE CONFLICT IN KANSAS

\section{AND IN CONGRESS}

Affairs in Kansas grow worse, 348. Frequent changes of governors, 348. Congressional committee's report, 348. President over Douglas's protest sends special message recommending admission of Kansas under Lecompton Constitution, 350. Stormy debates in Congress, 350. Douglas breaks with President, 350. His great speech against the bill to admit Kansas under the Lecompton Constitution, 35I. Senator Crittenden's proposed substitute for pending bill defeated in Senate, 352. Bill to admit Kansas under Lecompton Constitution passes Senate, but is defeated in House, 353. The English Bill passed, 352. Defeat of Lecompton Constitution bill due chiefly to Douglas, 353 . Increases his popularity in North but makes him hated in South, 353. Abatement of Republican enthusiasm in 1857,353 . Speedy recovery from defeat of 1856,354 . Speech of Senator Hammond of South Carolina in Senate on 
March 6, 1858, 354. Speech makes a great impression on the North, 360. Seward's Rochester, N. Y., speech on October 25,1858 , on the "Irrepressible Conflict," 360 . By end of $185^{8}$ the Republican party well organized, enthusiastic, and aggressive, 363 .

\section{CHAPTER XVII}

\section{THE LINCOLN-DOUGLAS DEBATES}

Douglas candidate for reelection for Senate in 1858, 364 . Lincoln unanimous choice of Illinois Republicans to oppose Douglas, 364. Lincoln's prior political career, 364. Douglas's prior political career, 365. Many Republicans against opposing his reëlection, 365 . Douglas opposed by the Buchanan administration, 365 . Also handicapped by his doctrine of "popular sovereignty," 366. Lincoln's fitness 'as Douglas's opponent, 366. Lincoln's speech on "popular sovereignty," 367 . Lincoln's and Douglas's speeches prior to beginning of joint debates, 368. Lincoln's challenge accepted by Douglas and seven joint debates arranged for, 369 . Neither Lincoln nor Douglas at first fully meet expectations, 370. Widespread interest in the debates, 370 . Douglas inclined to "pettifogging," 370. Lincoln master of art of convincing his hearers by quaint illustrations and homely phrases, 371. Lincoln's eulogy on Declaration of Independence, 371. Answer to Douglas's charge that negroes had no inalienable rights, 372 . Answer to Douglas's charge that Republicans favored negro equality, 373. Answer to Douglas's charge that Republicans favored rebellious disobedience to Dred Scott decision, 373. Lincoln turns tables on Douglas by referring to some Illinois history, 373. Answers Douglas's charge against the Republican party of "sectionalism," 374. Secret of Lincoln's power as an orator, 375. Eloquent passages in Lincoln's speeches, 375. Forces Douglas to avow "unfriendly legislation" as remedy of people of territories to keep out slavery, 376. Lincoln's prophecy that Douglas's avowal of this doctrine would defeat him for the presidency, 378. Comparative merits of Lincoln and Douglas as political debaters, 378 . Lincoln defeated in contest for senatorship, 378. Debates make Lincoln President and Douglas an exile from his party in the South, 378 


\section{CHAPTER XVIII}

\section{PREPARING FOR PRESIDENTIAL CAMPAIGN OF 1860; SOURCES 'OF REPUBLICAN GAINS}

Great Republican gains in 1858,379 . Political complexion PAGE of 36th Congress, 379. Helper's Impending Crisis; its political effects, 380. John Brown; his Kansas record, 380. Prepares plans for invading Virginia, 380. Raid on Harpers Ferry, 38o. Conflicting estimates of Brown, 381. His offenses against the moral law, 382. He and his defenders reject plea of insanity, 383. Effect of Brown's raid in the North, 383 . Its effect in the South, 384. Brown's place in history, 384. Efforts of Democratic leaders to implicate prominent Republicans in Brown's raid, 385. Contest in House over speakership, 386. Disgraceful scenes on floor of House, 386 . William Pennington, of New Jersey, elected speaker, 387. Slaveholding interests vitally interested in ensuing presidential election, 387. Quarrel between Pryor and Potter, 388. Main efforts of Southern leaders in Congress now bent to extermination of Douglas, 389 . Jefferson Davis's resolutions, 390. Douglas's defiant attitude towards the pro-slavery leaders, 392. Speech of William H. Seward, 393. Lincoln's Cooper Institute speech, 394. Sources of Republican gains, 395. Gains from the Germans, 396. Growth of Western vote, 40I. Great increase in political power of the free States prior to 1860, 405. New Western Republican political leaders, 405

\section{CHAPTER XIX}

\section{THE POLITICAL CAMPAIGN OF $1860^{\circ}$}

Slavery now the sole political question, 406. Period of intense political excitement, 406. Causes of irritation in the North and in the South, 407. Southern feeling towards people of the North, 407. Democratic National Convention at Charleston in 1860,410 . Prominent delegates present, 4II. Marked opposition of Southern 
delegates to Douglas, 412. Benjamin Butler conspicuous, 412. Caleb Cushing of Massachusetts elected president of convention, 4I2. Resolutions Committee fails to agree and submits majority and minority reports, 412. Stormy debates on the platform, 413. Yancey's speech, 415. George E. Pugh's speech, 415. Committee on Resolutions again report inability to agree, 415 . Resolutions of majority and minority, 416. Resolutions of minority adopted, 4I7. Various Southern delegates now withdraw from convention, 417. Speech of D. C. Glenn, 417. Speech of Gaulden of Georgia on Christianizing effect of slave trade, 418. Result of balloting for presidential nomination, 419. Convention adjourns to meet in Baltimore, Md., on June I8, 419. Seceding delegates meet and hold convention in Charleston as representatives of "Constitutional Democracy," 4I9. Secession of Southern delegates the forerunner of secession of the Southern states, 420. Remnants of Whig and American parties meet in Baltimore on May 9, I860, 42I. Prominent delegates present, 42I. Adopt brief and meaningless platform, 422. Nominates John Bell of Tennessee and Edward Everett of Massachusetts for President and Vice-President, 422 . . . .

\section{CHAPTER XX}

\section{POLITICAL CAMPAIGN OF I860 (Continued)}

Republican National Convention asssembles in Chicago, 423. The candidates for President and their managers, 423. The New York delegation, 424. Political curiosities exhibited, 424. Prominent delegates present, 425. Horace Greeley "of Oregon," 425. George Ashmun, of Massachusetts, selected as permanent chairman, 425. Opposition to seating delegates from Southern states that had no constituencies, 426. Giddings's unsuccessful effort to incorporate in platform clause from Declaration of Independence, 426. George William Curtis comes to Giddings's aid and rescues the Declaration, 426. The platform, 427. Indications at close of second day point to nomination of Seward, 428. James G. Blaine's prediction, 428. Objections to Seward, 429. The balloting, 


\section{Table of Contents}

xxiii

430. Lincoln nominated for President and Hannibal Hamlin for Vice-President, 431. Regular Democratic Convention assembles in Baltimore on June 18; contest over seats, 432. Great bitterness of feeling, 433 . Committee on credentials submit majority and minority reports, 435. Vote on these reports favorable to Douglas wing, 435. Various Southern delcgates secede, 435. Caleb Cushing and Benjamin Butler also secede, 435. Butler's spasm of conscience, 435. Douglas and Fitzgerald nominated, 436. Fitzgerald declines and Herschel V. Johnston afterwards substituted, 436. The seceders meet at Baltimore and elect Caleb Cushing president, 436. Adopts Charleston minority platform, 437. Nominates John C. Breckinridge of Kentucky and Joseph Lane of Oregon for President and Vice-President, 437. South Carolina not represented in either of the Baltimore conventions, 437. The Richmond, Virginia, Democratic Convention endorses these nominations, 437 . Continued opposition to Douglas in Congress, 438. Davis's resolutions pass in Senate, 438. Defiant attitude of Douglas, 439. No public interest in party platforms outside slavery question, 440 . The American party and its candidates, 440. The Liberty party nominates Gerrit Smith for President and Samuel McFarland for Vice-President, 441. Garrisonian Abolitionists refuse to vote, 44I. In the South overwhelming sentiment in favor of Breckinridge, 441. Republicans in North harmonious and enthusiastic, 441. Republican masses shout Lincoln, but trust to Seward, 44I. Abolitionists denounce Lincoln, 442. Seward's triumphal speaking tour, 442. Carl Schurz in the campaign; his great influence over the German vote, 442. Influence of New York Tribune, 443. Bitter opposition to Douglas of Buchanan administration and of Southern leaders, 443. Douglas still bold and defiant, 444. His speaking tour in the South and his loyalty to the Union, 444. October state elections go Republican, 445. Douglas cancels Northern speaking engagements and goes South to try to stay the tide of secession, 446. Lincoln elected by plurality but not by majority of votes, 446 . Campaign a memorable one, 446. Political transformation of Douglas, 447. His uncompromising stand for the Union, 447. Election proves impossibility of lasting compromise between freedom and slavery, 447 


\section{CHAPTER XXI}

\section{SECESSION IN BLOOM}

Threats of secession in 1860,449 . South Carolina takes lead, 449. Secession contemplated before Lincoln's election, 450. The second session of 36 th Congress, 450 . Buchanan consults with Jefferson Davis, concerning annual message, 450. Buchanan's message on question of secession, 45I. Blaine's description of Buchanan at this period, 45I. President with his message submits opinion of Attorney-General Black, 452. Black's character and political views, 453. Interpretation of Black's opinion, 454. Anti-secession sentiment in South, 455. Position of Alexander Stephens, 455. Feeling in border states, 456 . How secession feeling was promoted, 456 . . . . . . . .

\section{CHAPTER XXII}

\section{PREPARING PEACE PANACEAS}

Congress flooded with peace petitions and memorials, 459. House appoints committee of thirty-three and Senate a committee of thirteen to consider condition of country, 459. Senator Crittenden submits series of compromise resolutions, 459. Meeting of members of Congress from the border states, 459. President Buchanan sends to Congress special message, 460. Virginia proposes a peace conference, 460 . Senate committee of thirteen reports inability to agree, 461 . House committee of thirty-three also considers great number of propositions, 46I. House committee of thirty-three reports series of resolutions and nine minority reports, 463. Resolutions not voted on until late in session, 463. The Crittenden resolutions, 463. The propositions of representatives of border states, 465. Virginia proposition for peace convention not enthusiastically received in North, 465. Peace convention delegates meet in Washington and organize, 466. Irreconcilable divergence of views of delegates, 467 . Convention transmits report to Congress recommending various amendments to United States Constitution, 471. Opposition to report in 


\section{Table of Contents}

XXV

PAGE

Senate, 474. Action on report in House, 475. Senator Chandler's letter to Governor Blair of Michigan on the peace convention, 476. The final vote in Senate on Crittenden resolutions, 476 . Joint resolution of Senate and House submitting proposed constitutional amendments, 476

\section{CHAPTER XXIII}

\section{CONGRESSIONAL DEBATES; CLOSE OF THIRTY-SIXTH CONGRESS}

General interest in progress of peace propositions in Congress, 478. Speech of Senator Clingman of North Carolina, 478. Speech of Senator Iverson of Georgia, 480. Speech of Senator Mason of Virginia, 483. Speech of Senator Toombs of Georgia, 483. Speeches of Senator Wigfall of Texas, 484. Jefferson Davis's resolution, 491. Republican claims, 491. Speech of Senator Hale of New Hampshire, 492. Speech of Senator Wade of Ohio, 49.4. Speech of Senator Seward, 495. Conflicting opinions of Seward's speech, 496. Speech of Senator Douglas, 498. Speech of Senator Trumbull, 499. Speech of Roger A. Pryor, of Virginia, 508. Speech of Thaddeus Stevens, of Pennsylvania, 510. Opinion of Abraham Lincoln on peace propositions, 5 II. Debates demonstrate futility of proposed compromise, 512. Judge Robertson's mission to the seceded states a failure, 512. Speeches of Southern members on withdrawing from Congress, 512. All the peace propositions come to naught, 513 . Closing session of 36 th Congress memorable for what it did not do, 513 .

- 478-514

\section{CHAPTER XXIV}

\section{THE CLOSING MONTHS OF BUCHANAN'S ADMINISTRATION}

Exciting period between election and inauguration of Lincoln, 515. Original plans of secessionists, 516. Plan to capture City of Washington, 516. Their reliance upon sympathy of members of Buchanan's cabinet, $5 \times 6$. 
Members of his cabinet at time of Lincoln's election, ${ }_{5}^{16 .}$ Resignations of Cobb, Cass, and Thompson, 516. Treasonable conduct of Floyd in transferring arms from Northern to Southern arsenals, 518. His order for transfer from Pittsburg arsenal, 518. Secessionists' opinion of Toucey, 519. Floyd's and Trescott's complicity in transfer of arms to South Carolina, 520. Efforts of secessionists to get possession of forts in the South, 520 . Major Anderson assigned to command of forts in Chärleston Harbor, 520. His appeal for reinforcements, 520. Floyd's orders and correspondence with Major Anderson, 521. Floyd indicted for complicity in frauds in Department of Interior, 525. The South Carolina commissioners arrive in Washington and seek to open official communications, 525. Interviews and correspondence between them and Buchanan, 525 . General Scott protests against conduct of Floyd in ignoring him, 527. The alleged "truce" between the Administration and the South Carolina authorities, 527. The South Carolina commissioners accuse Buchanan of bad faith, 528. A stormy cabinet meeting at which Floyd urges abandonment of Fort Sumter, 529. Protests of Black, Stanton, and Holt, 529. Floyd resigns, 530. His subsequent appearance in Confederate army, followed by his disappearance from Confederate history, 530. Buchanan submits to his cabinet a draft of his answer to the South Carolina commissioners, 53I. Black prepares new draft of answer, 532. Black's loyalty to the Union, 535. Further correspondence between the South Carolina commissioners and the President, 535. The President's version of the alleged agreement for a "truce," 536. The version of the South Carolina representatives, 536. The President's version of the secret instructions given by Floyd to Major Anderson, 537. The South Carolina commissioners' final letter to the President, 538. Black's subsequent attitude, 539. Holt's loyalty to the Union cause, 539. John A. Dix, the new Secretary of the Treasury, 539. Edwin M. Stanton, the new Attorney General, 540. Reorganization of cabinet the turningpoint in Buchanan's Administration and in Union cause, 540. Attempt to reinforce Fort Sumter, 540. Buchanan's special message to Congress, 54I. His subsequent policy, 54I 


\section{Table of Contents}

\section{CHAPTER XXV}

\section{CLOSING MONTHS OF BUCHANAN'S ADMINISTRATION (Continued)}

Defensive measures prompted by Black, Stanton, and Holt, 542. Miscalculations in original plans of secession leaders, 542. Necessity of changing plans, 544. Revolutionary Council formed; its meetings and operations, 544. Resolutions adopted, 547. Determined that Southern representatives should not all leave Congress at once, 547. Ordinances of secession passed by cotton states, 548. Mecting of Confederate Congress in Montgomery, Alabama, 548. Organization of Confederate States of America, 548. Preparations to organize permanent government and put on war footing, 549. Close of Buchanan's Administration, 550. Pollard's estimate of Buchanan, 550. Blaine's estimate, 55r. General Crawford's estimate, 552. Defense of Buchanan's Administration in its closing months, 552. Comparison of close of Buchanan's with beginning of Lincoln's Administration, 553. Summary of Buchanan's course in the closing months of Administration, 554

\section{CHAPTER XXVI}

\section{DEVELOPMENT OF WAR SPIRIT IN THE NORTH}

Threats of secession in campaign of 1860,556 . Shock to the North by news of secession of South Carolina, 556. Anxiety of Republicans to propitiate the South, 556. Memorial by New York capitalists favoring concessions to the South, 557. Peace sentiment in Philadelphia, 557. Mayor and Council of Boston and 22,000 citizens petition Congress to adopt the Crittenden compromise, 557. Shameful concessions advocated, 558. People of North divided into four classes, 558. Only a small number of Republicans in favor of suppressing secession by arms, 558. Many Democratic papers opposed to coercing the seceding states back into the Union, 558 . 
Fernando Wood, the Mayor of New York, suggests secession of New York City, 559. General sentiment against coercion, 560. Utterances of some of leading Republican papers advising letting the seceding states "go in peace," 560. Oliver P. Morton's speech, 561. Hostile and defiant attitude of secessionists makes pro-found impression on North, 562. Arguments of the radical Republicans, 562. People of North gradually recover their senses, their self-respect, and their courage, 563. Great diversity of opinion in the North continues up to Lincoln's inauguration, 563. Feeling of suspense in the border states, 563. All waiting to see what would be the policy of Lincoln's Administration, 564 . .

\section{CHAPTER XXVII}

\section{THE COMING OF LINCOLN}

Lincoln starts from Springfield, Ill., to be inaugurated, 565 . His passage through Baltimore, 565. His inauguration, 565. Stephen A. Douglas conspicuous at inauguration, 565. Conciliatory tone of the inaugural, 566 . Leaves no doubt as to Lincoln's intention to preserve the Union, 566. Closes with touching appeal to his "dissatisfied countrymen," 566. How Lincoln was then regarded in the South, 566. Views of later Southern writers, 567. Selection of his cabinet, 567. Opposition to Simon Cameron, 568. Cabinet not harmonious, 570. The difficulties which confronted Lincoln in the beginning of his Administration, 570. The rush for office, 572. Lincoln not yet fully trusted by the people of the North, 573. Stephen A. Douglas one of his trusted advisers, 574. General Beauregard examines and reports to Confederate government as to condition of Fort Sumter, 575. Governor of South Carolina restrained from beginning bombardment before Lincoln's inauguration,

575. Preparations for bombardment rapidly pushed, 576. Confederate government sends commissioners to Washington to negotiate terms of peace, 576. National Government wholly unprepared for war, 577. Strength of National Army and Navy, 577. Few Northern states prepared for war, 577 


\section{CHAPTER XXVIII}

\section{ADMINISTRATION POLICIES}

Lincoln's ruling idea, 578. The complex problems presented, 578. Consequences of a mistake in choosing a policy, 581. Importance of considering state of public sentiment in the States still in the Union, 58r. Greater importance of considering state of public sentiment in the North, 581. Who could have done better than Lincoln? 582. Lincoln's war policy finally forced upon him, 582. Composition of the cabinet, 583. Seward's assumption of authority, 583. Seward's peace views, 583. The Confederate commissioners, 584. Their purpose, 584. Their efforts to get into official communication with the National Government, 585. Justice Campbell of the United States Supreme Court acts as a go-between for commissioners and Seward, 585. How Campbell and the commissioners deceived Seward, 586. Military authorities advise against attempting relief of Fort Sumter, 587. Majority of cabinet at first against making attempt, 588. Lincoln sends Hurlbut and Lamon to Charleston and they report situation, 589. Lincoln again submits the question to cabinet which reverses its former decision, 590. Lincoln at once orders preparations for expeditions to reinforce both Fort Sumter and Fort Pickens, 590. Seward's extraordinary "suggestions" to Lincoln, 591. Lincoln's answer, 593. Seward's embarrassing position with reference to the Confederate commissioners, 593. Further conference between him and Campbell, 593. The commissioners leave Washington, 594. Controversy as to whether the commissioners were deceived by Seward, 594. Senator Douglas communicates his apprehensions to Seward, 595 . . . . .

\section{CHAPTER XXIX}

THE EFFORTS TO SUCCOR MAJOR ANDERSON

Major Anderson's loyalty, 597. Anderson's correspondence with Beauregard, 598. His correspondence with the War Department, 599. Expeditions sail for relief of 
Fort Pickens and Fort Sumter, 600. Seward's bungling interference with expeditions for relief of Fort Sumter and Fort Pickens, 600. Harvey's dispatch to Confederates, 601. Explanations and criticisms of Seward's course, 601. Subsequent movement for his removal from office of Secretary of State, 605

\section{CHAPTER XXX}

\section{WAITING FOR THE SOUND OF THE CANNON}

War spirit now fully aroused in both North and South, 608 . The tension in the South, 608. Notice given by Administration to Governor Pickens, 609. Confederate authorities order immediate bombardment of Fort Sumter, 6ro. The bombardment begins, 6ro. Bombardment fires the Northern as well as the Southern hearts, 6II. Douglas proffers his support to Lincoln, 6I I. His last public speech, 6ir. Lincoln's call to arms and the response, 612. The strange paradox presented by the Civil War, 612 


\section{Political History of Secession}





\section{Political History of Secession}

\section{CHAPTER I}

\section{ENTRANCE OF SLAVERY INTO AMERICAN POLITICS}

I ONG before the War of the Revolution there existed L marked differences between the people of the colonies, especially between the people of New England and those of South Carolina and Georgia.

One historian has attributed these differences largely to differences of climate. He thinks that "had the Puritans settled in the Southern States they would have become extinct. They settled above the January isothermal of $4 \mathrm{I}^{\circ}$, the line that marks the boundary of intellectual freedom. They prospered because nature was propitious." Draper's theories have generally been regarded by others as fanciful. Despotisms, oligarchies, and bigotry are not limited by zones and isothermal lines. The past proves that they flourish equally in the frigid atmosphere of Russia and in the balmy clime of Spain. In this country political and religious intolerance have been found to thrive on one side of Mason and Dixon's line as well as on the other.

There were differences far more marked than those caused by differences of climate. The people of New Eng- Rel . land were almost exclusively of English Puritan stock. In the rural regions there were few large landowners and the

' Draper, History of the American Civil War, vol. i., pp. I1o, 156. 
small farmers generally tilled their farms by the labor of themselves and their families. Local self-government was the cardinal idea, not only of the town, but of the church government, and each separate community was a little democracy where there were no great distinctions based on rank or wealth. Many in the North devoted themselves to manufacturing and commercial pursuits.

In the Southern colonies there were few Puritans. In pee Virginia and in South Carolina the Cavalier element and the doctrines of the Church of England predominated, and in those sections, notwithstanding all that has been said about the bigotry of the New England Puritan, the Puritans were as unwelcome and as unpopular and as rigorously persecuted as the believers in the Church of England were in Massachusetts. ${ }^{x}$

While there was not much urban life in the Northern colonies in early times, there was far less in the South, and the number of those who devoted themselves to manufacturing and commercial pursuits was far less in the South than in the North. Nothing like the New England town system existed in the South. In the South the owners of the great plantations resembled in their relations to their dependents and the smaller landowners the old English barons. These plantations were at first cultivated by those condemned to labor for limited periods on account of crime or debt, but later by slave labor.

As slavery increased, the community of interest that bound the slaveholders together became much stronger than any tie binding together the people of New England, and the result was that there grew up in the Southern colonies, especially in Virginia and South Carolina, an oligarchy of slaveholders. An impartial historian, ${ }^{2}$ gives this description of Virginia in colonial times:

"It is not too much to say that the whole order of South-

$\therefore$ Howe, The Puritan Republic, p. 26r.

" Doyle, The English Colonies in America: "Virginia, Maryland, and the Carolinas," chap. xiii., p. 39 r. 
ern society, its manner of life and forms of industry, were fashioned by slavery. We have already seen how the early conditions of Virginian life tended to throw the land of the colony into the hands of a few large proprietors. That tendency was confirmed and intensified by slavery. For slave labor can only be employed profitably in large gangs, and such gangs can only be worked on wide territories and in the hands of great capitalists. In Maryland we hear of thirteen hundred slaves belonging to a single master. In Virginia nine hundred seems to be the largest number recorded. The peculiar industry of Carolina, ricegrowing, adapted itself better to moderate-sized holdings. Thirty slaves, we are told, was the average staff of a plantation.

"In this way the possession of slaves did for the Southern colonies what land does for long-settled countries. Where land is abundant and labor and cattle dear, there is no likelihood of a landed aristocracy growing up. No one will care to acquire land when he can extract no profit from it. If the titular supremacy over land is valued as among the Highlanders of Scotland, it is not for the sake of the soil itself, but of certain rights over the clansmen which that supremacy carries with it. Thus in primitive society cattle are the measure of wealth, and the rich man is not he who can let land, but he who can supply his inferiors with live stock. If the Southern colonies had depended on free labor a tract of land in Virginia or Maryland would have been a merely nominal property. Slavery came in as the one means by which the capitalist could assert his superiority over the man who owned nothing but his own labor.

I The result was the establishment of a landed aristocracy, I a result which was facilitated by the tastes and tendencies which the Southern colonists had carried to their new homes. But it must be remembered that the Southern planter was primarily a slaveholder and only incidentally a landowner. His estate was merely a needful condition for utilizing the capital which he had invested in human labor. 
"Thus grew up that strange form of life peculiar to slaveholding states, such as the Southern colonies of America and the West Indian Islands. Each plantation became a separate community, well-nigh independent and selfsupporting. There were no towns and conscquently no shops. The freeman rebelled against the idea of becoming a laborer, and thus there were no artisans. Beyond the rough clothing of the slaves, almost every necessary of life was brought from England. Clothes, shoes, household furniture, crockery, even wooden bowls, were imported. Such was the lack of mechanical skill that we even hear of the timber for a house being sent in the rough to England and returned fashioned and ready to be put together. Fifty years later Jefferson wrote, 'While we have land to labor let us never wish to see our citizens occupied at a work-bench or twirling a distaff.' "

Of South Carolina Doyle says: "In South Carolina country life played a less important part. But the oligarchical spirit, if weaker in that respect, was fortified by other influences. The city life of Charleston developed an amount of mental culture which was denied to the Virginian planter. In South Carolina, as in the communities of the ancient world, a system of agriculture founded on slave labor was the condition under which a city population led a life of cultivated leisure. This and the vast dimensions which slavery soon reached intensified the feeling which bound together the oligarchy of slaveholders.

"Thus the prejudices of race, strengthened by the consciousness of higher intelligence and culture, acquired an intensity unknown elsewhere, and South Carolina became the very type of a slaveholding aristocracy. If slavery had been confined to Virginia and Maryland, it might have died out in the eighteenth century, crushed beneath the weight of its moral and economical shortcomings. In Carolina it became a corner-stone of a political system, a motive power in the world's history."

A Southern historian, a Virginian, eminent as an educa- 
tor and member of Congress, and certainly not prejudiced against the South or against slavery, ${ }^{2}$ expresses the following conclusions as to the effect of slavery upon the social life and character of the people of the Southern slaveholding communities:

"In those colonies in which the slaves were most numerous, the inhabitants, having more leisure, were more given to social pleasures and amusements-to the sports of the turf, the cockpit, the chase, and the gaming table. They had a more delicate and sensitive self-respect, which sometimes degenerated into haughtiness and sometimes produced that union of courtesy, frankness, and ease that is rarely seen in Europe except in the higher ranks of life. The social habits of the Southern planter often made him profuse, and plunged him in debt to the English and Scotch merchant who sold his exported products and furnished him with his foreign supplies. He was often improvident and sometimes not punctual in his pecuniary engagements. With these moral defects, incident to his condition as a slaveholder, he derived some virtues from the same source. Besides his agreeable, companionable qualities, he often acquired habits of forbearance and self-restraint, which are essential to the formation of virtuous character. The evil effect of slavery on the temper and disposition of the master has been exhibited in glowing colors by Mr. Jefferson, but his view of it, however plausible, seems to be contradicted both by philosophy and experience."

Without attempting to contrast the characteristics of the slaveholding communities of the South with those of the early Puritan settlements of New England, it is sufficient to say here that the differences were very marked. ${ }^{2}$

A striking illustration of the character of the slaveholding oligarchy in South Carolina is seen in the first of

. Tucker, History of the United States, vol. i., p. 97.

In another volume-The Puritan Republic-the author of the present work has attempted to portray the leading characteristics of the New England Puritans. 
its extant slave codes, the first enacted in America and the most atrocious. :

Under Governor Oglethorpe's administration of the colony of Georgia slavery was prohibited, but among the planters about Savannah there was an early and insistent demand for its introduction, as the "one thing needful" for the development of the country. Hearing of the movement of the Savannah planters, some of the settlers at New Inverness in 1739 petitioned Governor Oglethorpe, protesting against it, assigning in their petition, among other reasons, that: "It is shocking to human nature that any race of mankind and their posterity should be sentenced to perpetual slavery, nor injustice can we think otherwise of it than that they are thrown amongst us, to be our scourge one day or other for our sins; and, as freedom to them must be as dear as to us, what a scene of horror must it bring about! And the longer it is unexecuted the bloody scene must be greater." 2 How much more earnest the Inverness petitioners would have been if they could have foreseen that, in addition to the dire consequences predicted by them, slavery would, within the next century, be the chief cause of one of the most sanguinary civil wars in history, that some of the bloodiest battles of that war would be fought on Georgia soil, and that a great Northern army would sweep through the State from one end to the other, carrying in its wake wide-spread ruin and desolation!

After Oglethorpe's removal from Georgia renewed pressure was brought to bear on the colony trustees to permit the introduction of slaves. To quiet the religious scruples of those opposed to it, it was urged that many of the slaves "had already been made freemen of the heavenly Jerusalem." George Whitefield, the noted Methodist revivalist, had gone to Georgia to help spread the gospel and even

I A pretty full abstract of it is given by Hildreth, History of the United States, vol. ii., pp., 271-275. See also Olmsted, A Journey in the Seaboard Slave States, vol. ii., pp. 131-135.

2 Wylly, Colony of Georgia, p. 29. 
he pleaded with the trustees to permit the introduction of slaves as an effective means of propagating the Christian religion. ${ }^{x}$ Finally the trustees yielded and revoked the prohibition against slavery, and long before the War of the Revolution slavery had become as firmly established in Georgia as it was in South Carolina.

As the country grew, the differences between the Northern and the Southern colonies became more and more apparent. ${ }^{2}$ That slavery, in the interval between colonial times and the beginning of the Civil War, had not improved the moral, social, industrial, and political conditions in the Southern States, as for example, in South Carolina, is shown in the narrative of Mr. Frederick Law Olmsted, a clearheaded careful observer and a judicious writer, who, as correspondent of the New York Times, made two extensive tours through the Southern seaboard States in 1853 and I $854 .^{3}$

The later effects of slavery were also manifest in Georgia, the "Empire State" of the South, although not so marked as they were in South Carolina. For this we have the testimony of a recent writer who was born and reared in Georgia and who served in a Georgia regiment in the Civil War. ${ }^{4}$ The evil effects of slavery were not seen in the home life of the owners of large plantations. That life was delightful, marked by courtly demeanor, courtesy of speech, refinement of manners, and above all by a charming hospitality, the best characteristics of ancient chivalry

${ }^{3}$ See Hildreth, History of the United States, Ist series, vol. ii., p. 4 I 7.

"See Doyle, English Colonies in America: "The Colonies under the House of Hanover," chapter i.: Eugene Lawrence on Colonial Progress: First Century of the Republic, p. 17.

3 His letters were published in 1856 in book form, under the title of, A Journey in the Seaboard Slave States. A revised edition was published in 1904 .

4 Charles Spalding Wylly, The Colony of Georgia. The full title of this highly interesting little volume is The Seed that was Sown in the Colony of Georgia. It is entirely devoid of anything like bombast or rancor and bears all the evidences of having been written in a fair and conscientious spirit. 
transplanted in America. But the influence of slavery in retarding the development of the State was clearly marked. Wylly says that: "In comparison with the western, eastern, and northern States, Georgia had made slow progress in the march to wealth and population. In the one hundred and twenty-eight years that had elapsed between 1732 and I86I, her largest city had only attained to a population of twenty-five thousand. Not one rolling mill, foundry of capacity, or ore furnace testified to the richness of the mineral belt. No coal mines had been opened in her mountain region. A few small cotton factories, with perhaps a little more than one thousand miles of railway, alone bore witness to a growing spirit of enterprise and of expansion into internal improvements." .

Not the least interesting part of Mr. Wylly's volume is that in which he speaks of the "poor whites," an "overwhelming plurality of ignorant and poverty-stricken whites, dwelling in the backwoods and differing only in their degrees of utter shiftlessness," and tells how it was that the slaveholding minority compelled their political allegiance. "In a society so formed, and mingled in such proportions, it was inevitable that this poorest, but in a democratic state, through its numbers, most powerful class, should sink into a state of dependence upon those who, possessing the richer lands and greatest wealth, were able in time of need to offer the most effectual aid and help. There was little solicitation-by an almost tacit agreement the rôle of patron was assumed by one, and that of client adopted by the other. Equally unspoken was the promise of political support. That went without saying, and, with that, there followed a rule of the minority, a minority which was represented entirely by the wealthy families of the district and which was immensely the superior in intelligence, education, and foresight. In South Carolina this result was attained by virtue of the State's constitution, a freehold of $\$ 1500$ being there a requisite for eligibility to a $\therefore$ Wylly, The Colony of Georgia, p. 54 . 


\section{Entrance of Slavery into Politics}

seat in the upper house of the 'Assembly'; and, again, the number of representatives in the districts was not fixed by the number of white citizens, but by the amount of property returned. In Georgia, in theory a purely democratic government, the law I have before cited-the inexorable law of environment-issued its fiat, and, in practice, a minority represented always by the wealthier class of citizenship ruled and governed the State."

While there was from an early period a feeling in many of the colonies where slavery existed that it was wrong and that measures should be taken for its ultimate extinction, there is no evidence that such feeling ever existed to any considerable extent in what was afterwards known as the "cotton belt." In the original draft of the Declaration of Independence there was a clause reprobating the African slave trade, but this was stricken out, as Jefferson tells us, "in complaisance to South Carolina and Georgia, who had never attempted to restrain the importation of slaves, and who, on the contrary, still wished to continue it," to which he somewhat naively adds: "Our Northern brethren, also, I believe, felt a little tender under those censures, for though their people had very few slaves themselves, yet they had been pretty considerable carriers of them to others." 2

It is certain that South Carolina and Georgia would not ratify the Constitution without the concessions made to slavery, one of which was that the apportionment for the purpose of representation in Congress should be made on the basis of allowing the same representation for five slaves as for three free men. Another was that there should be no interference before the year 1808 , twenty years ahead, with the "migration or importation of such persons as any of the States now existing shall think proper to admit," by which it was meant, although avoiding calling it by name, that there should be no prohibition of the African slave

-Wylly, The Colony of Georgia, pp. 42, 43.

- Jefferson's Works, vol. i., p. 19. 
trade until the expiration of that period. Moreover after the ratification of the Federal Constitution, when Virginia ceded to the general government the territory now included in Kentucky, when North Carolina ceded what is now the State of Tennessee, and when Georgia ceded what is now included in the States of Alabama and Mississippi, in each instance the cession was made upon the express condition that Congress should pass no law prohibiting slavery in the ceded territory.

Great changes had taken place in the period intervening between the adoption of the Federal Constitution and the election of Monroe in 1816 in reference to the slavery question, but more in the South than in the North. There had been a few anti-slavery societies in the South, which advocated emancipation, but emancipation made little headway, and in Virginia all such efforts to induce the Legislature to take steps for that purpose had been abandoned.

The Colonization Society was also established, the purpose of which was to transport the free negroes to $\mathrm{Li}$ beria, and to this scheme many eminent Southern statesmen lent their support. It soon became manifest, however, that the main purpose of the movement was not to free the negroes in the South, but to get those who were already free out of the country where they were not wanted.

The increasing activity of the anti-slavery societies in the North also began to have a manifestly irritating effect on the South. Even a man who acknowledges himself to be a sinner becomes restive under the preacher who preaches all the time at him, and while one man cannot in morals be allowed to set off his neighbor's sin against his own, he is very apt to suggest to his neighbor that passage of Scripture about first casting the beam out of your own eye before trying to pull out the mote in your brother's eye. There were some beams in the eyes of the people of New England, and to their accusations against the slaveholders of the South, based on the atrocities of the African slave 


\section{Entrance of Slavery into Politics}

trade, the latter retorted that, while Northern men were sc ready to denounce the sin, they had been quite ready to furnish the ships and share the profits, and in this there was much truth.

There were, however, now many in the South who did not concede slavery to be wrong. On the contrary, they maintained that it was right, and adduced plenty of Scripture to prove it. Olmsted found that belief in the divine sanction of slavery was especially manifest in South Carolina where "the ruling intellect of the State has now [r853], as it originally had, more than that of any other American community, a profound conviction that God created men to live in distinct classes or castes, one beneath another, one subject to another." s

The causes that, more than all others, tended to popularize and perpetuate slavery in the South were the improvements, especially the cotton-gin, in the production of cotton. In an incredibly short time these had revolutionized that industry in the South and had opened a source of wealth hitherto undreamed of. In I79I, two years before the invention of Whitney's cotton-gin, 200,000 pounds of cotton, mostly raised in the South, were exported from the United States; in $1800,17,000,000$ pounds, valued at $\$ 5,000,000$; in 1820 , $127,000,000$ pounds, valued at $\$ 22,000,000 .^{2}$ This made cotton raising the most profitable industry in the country and gave rise to a largely increased demand for slave labor, made slave breeding profitable in Virginia and Maryland, imparted a new impetus to the African slave trade, and put an end to all hope of a voluntary extinction of slavery in the South. As might be supposed, the similarity of conditions of one kind tended to produce a unity of political sentiment in the South, while similarity of conditions of another kind tended to produce a unity of political sentiment in the North, with a natural antagonism between the political sentiment of one section and that of the other. This

A Journey in the Seaboard Slave States, rev. ed., vol. ii., p. 136.

'DeBow, Industrial Resources, Statistics, etc., vol. i., p. 122. 
antagonism became more and more marked with the increase of slavery.

Some Southern writers advocate the theory that slavery would have yielded to the softening influence of Christianity and would have disappeared, even in the Slave States, if the Southern people had been let alone by Garrison and his followers, and that the formation of the Abolition societies founded by them was "the initial cause of all our troubles." I It is precisely at this point that the divergence between the views of Northern and Southern writers becomes clearly marked, the differences being as yet irreconcilable by any process of reasoning, certainly not by continued crimination and recrimination.

There had been many things to distract public attention from slavery between the time of the first election of Washington and the election of Monroe; a war with Great Britain had intervened; there had been fierce contests between the Federalists and the Republicans; the whole country had been wrought up over the Alien and Sedition laws; Presidents Washington, Adams, Jefferson, Madison had come and gone; and yet slavery had not become a disturbing political factor.

A vast area of land had been added to the public domain in the acquisition of Louisiana Territory. Its acquisition was the chief glory of Jefferson's administration and the opposition to it was the crowning folly of the Federalists, who, reversing the maxim that "the King can do no wrong," insisted that "Jefferson could do nothing right." The opposition of the Federalists, especially those of New England, was not based on opposition to the possible extension of slavery. It was nominally based on doubts both of the constitutionality and the advisability of adding to the original domain so large a territory peopled with a nondescript population of French, Spaniards, and Creoles, and ultimately filling Congress with "the wild men of Missouri," and thus overthrowing the whole of the political system

"Herbert, The Abolition Crusade, pp. 48, 205. 
established by the Fathers of the Republic. There was doubtless also a fear on the part of the politicians of New England that in this way the New England States might be shorn of the political power hitherto exercised by them. Substantially the same objections were made to the admission of the State of Louisiana in 1812, and it was in the course of the debate on this question that Josiah Quincy, of Massachusetts, made a violent speech declaring that if Louisiana were admitted "the bonds of this Union are virtually dissolved; that the States which compose it are frec from their moral obligation; and that, as it will be the right of all, so it will be the duty of some, to prepare definitely for a separation, amicably if they can, violently if they must."

During all this time the advocates of slavery never lost sight of its interests. There was now in the South no thought of its abolition, near or remote. There was no thought of restricting its territory; on the contrary, there was a constant effort to expand it. Whatever the people of the North may have been thinking about, whatever political questions may have been agitated, the advocates of slavery never for a moment lost sight of it, and all other questions were considered and weighed with reference to their bearing upon the interests of the slaveholders.

Hitherto the admission of slave States into the Union had kept pace with the admission of free States. Determined and persistent, but unsuccessful, efforts had been made to get a foothold for slavery in the Northwest Territory, notwithstanding the prohibition of the Ordinance of 1787 , and but for that prohibition it is not improbable that both Indiana and Illinois, which were largely peopled by settlers from Kentucky, Tennessee, Virginia, and North Carolina, would have established slavery. There was now no outlet for the extension of slavery except in the vast territory west of the Mississippi River.

President Monroe was elected in 1816. All the old 
political parties had gone to pieces and nothing betokened any political excitement of any kind, when, without any premonition of its coming, a political storm of great fury suddenly broke forth and revealed the danger to the Union that lurked in the slavery question. 


\section{CHAPTER II}

\section{THE BEGINNINGS OF SECESSION}

$\Lambda$ LTHOUGH slavery was the chief, it was not the only, A factor in causing the secession of the Southern States. From the formation of the government, the North had continually gained while the South had lost in commercial prosperity. The foreign imports that in colonial times went largely to Charleston began going to New York and other Northern cities. The North was increasing far more rapidly than the South in manufactures and in wealth. It was claimed by the Southern political leaders that this gain had been brought about largely by unequal legislation, tariff and other laws which, it was asserted, in their practical operations worked chiefly for the benefit of the North and to the detriment of the South, and as early as I798 there was talk of Virginia and North Carolina organizing a separate confederacy in order to cut loose from the alleged domination of Massachusetts and the other New England States, a project which was discouraged by Jefferson, not on any constitutional grounds, but chiefly because he did not then deem it necessary to resort to secession. ${ }^{2}$ Benton, after giving the figures showing the great increase of commerce in the North and a corresponding decrease in the South, thus dispassionately and graphically portrays the state of feeling thereby developed in the Southern States:

"This is what the dry and naked figures show. To the

- See Von Holst, Const. and Pol. Hist. of the United States, chap. xvii., vol. iii., p. 563 , comparing the progress of the North with that of the South; Pollard, Lost Cause, chap. iii., p. 54 .

${ }^{2}$ See his letter of June I, I798, to John Taylor of Virginia, Jefferson's Works, vol. iv., pp. 245-248. 
memory and imagination it is worse; for it is a tradition of the colonies that the South had been the seat of wealth and happiness, of power and opulence; that a rich population covered the land, dispensing a baronial hospitality, and diffusing the felicity which themselves enjoyed; that all was life, and joy, and affluence then. And this tradition was not without similitude to the reality, as this writer can testify; for he was old enough to have seen (after the Revolution) the still surviving state of the Southern colonial manners, when no traveler was allowed to go to a tavern but was handed over from family to family through entire States; when holidays were days of festivity and expectation, long prepared for, and celebrated by master and slave with music and feasting, and great concourse of friends and relatives; when gold was kept in desks or chests (after the downfall of continental paper) and weighed in scales, and lent to neighbors for short terms without note, interest, witness, or security; and on bond and land security for long years and lawful usance; and when petty litigation was at so low an ebb that it required a fine of forty pounds of tobacco to make a man serve as constable.

"The reverse of all this was now seen and felt-not to the whole extent which fancy or policy painted-but to extent enough to constitute a reverse, and to make a contrast, and to excite the regrets which the memory of past joys never fails to awaken. A real change had come, and this change, the effect of many causes, was wholly attributed to one-the unequal working of the Federal government-which gave all the benefits of the Union to the North, and all its burdens to the South. And that was the point on which Southern discontent broke out-on which it openly rested until I 835 ; when it was shifted to the danger of slave property."

It was in view of these conditions that Madison made this forecast in a letter to Edward Coles written August 29, $1834^{2}$ :

× Benton, Thirty Years, vol. ii., p. 133 .

'Madison's Writings, vol. iv., p. 357. 


\section{The Beginnings of Secession}

"It is not probable that this offspring [nullification] of the discontents of South Carolina will ever approach success in a majority of the States. But a susceptibility of the contagion in the Southern States is visible and the danger is not to be concealed that the sympathies arising from known causes and the inculcated impression of a permanent incompatibility of interests between the South and the North may put it in the power of popular lcaders aspiring to the highest stations, and despairing of success on the Federal theater, to unite the South on some critical occasion in a course that will end in creating a new theater of great, though inferior, extent. In pursuing this course the first and most obvious step is nullification; the next secession, and the last a farewell separation."

Southern writers, in discussing the doctrine of secession, have generally attempted to show that it was not peculiar to the South, but was recognized at various periods in the North, and in proof of this they refer to fragmentary speeches of Josiah Quincy and other Northern men, but more especially to the utterances of some of the Federalists in opposition to the Louisiana Purchase and to the embargo and other war measures of the War of 1812 , laying particular stress upon the Hartford Convention of $1814 .^{x}$

There is no doubt that the opposition of the New England Federalists to the Louisiana Purchase inspired some of their leaders in Congress to favor a dissolution of the Union and the formation of a Northern confederacy. But Hamilton, the greatest of the Federal leaders, was bitterly opposed to this scheme. So were other prominent leaders of the party in New York and in New England. "In short," says Lodge, "reception of the scheme concocted in Washington was crushed by the leaders of the party elsewhere and the whole project came to nothing."

Talk of a Northern confederacy was again revived in New

- See Davis, Rise and Fall, vol. i., pp. 70-76; Pollard, Lost Cause, p. 85 .

- Life and Letters of George Cabot, p. 439. 
England during the War of 1812 , when its ships were rotting in the harbors, its commerce ruined, and its manufactures prostrated by the embargo acts and other war measures of the War of I8I2. It was during this war that the celebrated Hartford Convention met at Hartford, Connecticut, on December 15, 1814. Its sessions were held behind closed doors and the utmost secrecy was enjoined upon its members; but there is no doubt that one of the objects of it, though not openly avowed in the journal of its proceedings and in the report which it put forth, was a dissolution of the Union and the formation of a New England confederacy, in the event that no relief could otherwise be obtained from the grievances complained of.

The story of the opposition of the New England Federalists to the Louisiana Purchase and to the obnoxious government measures of the War of 1812 has been fully told by eminent historians. ${ }^{x}$ When we read the vigorous denunciation of the Hartford Convention by John Quincy Adams and the equally vigorous defense by Henry Cabot Lodge we feel assured that nothing has been left unsaid that could explain the motives and the purposes of the men who participated in or approved the objects of the Hartford Convention.

All this throws little, if any, light upon the origin and development of the doctrine of secession as understood and advocated in the South. It is important, however, to contrast the manner in which the promulgation of the doctrine of secession was received in the North, with the manner in which it was received in the South. The Federal party, as a party, had no part in the Hartford Convention. Only three States-Massachusetts (which then included what is now the State of Maine), Connecticut, and Rhode Island-sent delegates, twelve from Massachusetts, seven from Connecticut, and four from Rhode

I Hildreth, History of the United States, vol. ii., p. 494; vol. iii., p. 533 et seq., 2d series; Von Holst, Const. and Pol. Hist., vol. i., p. 193 et seq.; Lodge, Life and Letters of George Cabot; Adams, New England Federalism. 
Island. Two more from two counties in New Hampshire and one from a county in Vermont, not sent by those States, also attended the convention, making twenty-six members in all. The convention, however, left such a taint of treason upon the Federal party as to render it odious even in New England. Nearly all the delegates to the convention became, in consequence, political outcasts and the convention was one of the chief causes of the speedy downfall of the Federal party, which never after recovered its standing as a political party. Since the Hartford Convention no considerable party in New England or elsewhere in the North has ever advocated the right of a State to secede from the Union. Not even the Abolitionists, at least not the majority of them, advocated such doctrine. It was advocated only by Garrison and his handful of followers, upon grounds and arguments which, it is needless to add, were not relied upon by Southern leaders as justifying the secession of the South.

On the other hand, the right of secession was advocated in the South from an early date. Not only was there a very general belief in the South in this right, but the belief became part of the political creed of all parties. Although not written in party platforms, it was as much part of them as the unwritten law of England is part of its jurisprudence.

There were three political doctrines that were peculiar to the South, and that explain the political course of the Southern States prior to the beginning of the Civil War.

1 One was the doctrine of the right of secession.

Another was the preservation of the so-called "equilib" 2 rium" between the slaveholding and the non-slaveholding States.

3 Another was the doctrine that the Constitution of the United States protected the slaveholder in his right to take his slaves into the new Territories and to keep them there so long as such Territories remained in a territorial condition, and that neither Congress nor the territorial legislatures had any power to prohibit him from so doing. 
The first of these doctrines was enunciated at an early period in the history of the nation and those who advocated it claimed that it was recognized in the Declaration of Independence, in which it was asserted that among the inalienable rights were the rights of life, liberty, and the pursuit of happiness and that "to secure these rights governments are instituted among men, deriving their just powers from the consent of the governed; that whenever any form of government becomes destructive of these ends, it is the right of the people to alter or to abolish it, and to institute new government, laying its foundation on such principles, and organizing its powers in such form, as to them shall seem most likely to effect their safety and happiness." Probably this idea was largely based upon the "social contract" theory of Rousseau, Locke, and others that all governments are nothing more than social compacts with implied limitations. But the Southern statesmen did not base their right of secession solely upon any implied contract. They construed the Constitution of the United States as an express contract between the States and claimed that each State had a right, equal to that of any other or of all the other States, to determine for itself whether the contract had been broken so as to justify an abandonment of it by the State aggrieved by the alleged infractions of the contract. This theory was embodied in the Virginia and Kentucky Resolutions of $1798-9$, which grew out of the passage of the Alien and Sedition laws.

During the administration of President John Adams, and while the Federalists were in political control of the government, several emissaries of the French Directory made themselves obnoxious by their virulent attacks through pamphlets and newspapers upon the policy of the administration. This led to the passage of two acts, since generally known as the "Alien and Sedition Acts," which were among the chief causes of the final overthrow of the Federal party. Among other provisions of the Alien Act was one which authorized the President, whenever he deemed it necessary 
for the public safety, to remove out of the country all persons in prison in pursuance of the act, and all who had been ordered to depart, but who had remained without license, and that on their return they might be imprisoned so long as, in the opinion of the President, the public safety might require it.

The most objectionable provision in the Sedition Act was one which provided that any person who should write, print, utter, or publish, or aid in writing, printing, uttering, or publishing any false, scandalous, or malicious writing against the government, Congress, or the President of the United States, with intent to defame them, or to bring them into disrepute, or to stir up sedition within the United States, or to excite any unlawful combinations for opposing or resisting any law of the United States, or any act of the President done in pursuance of any such law, or to resist or defeat any such law, or to aid or abet any hostile design or designs of any foreign nation against the United States, their people or government, should be liable to be fined not exceeding $\$ 2000$ and imprisoned not exceeding two years.

These laws, so inconsistent with American ideas of personal liberty and freedom of speech and of the press, naturally excited the most bitter and determined opposition, not only among the Republicans, as the party of Jefferson was then called, but among large numbers of the Federalists. It was urged against both these laws that they vested arbitrary and despotic power in the hands of the President, and that both laws were unconstitutional, the first as depriving the accused of the right of trial by jury, and the second as an unwarranted infringement of the constitutional rights of freedom of speech and of the press.

Jefferson, who professed belief that the Federalists were aiming to establish a monarchy, imagined that he could see in the Alien and Sedition Acts the initial steps of a deeplaid conspiracy to subjugate the people and destroy their liberties. In order to get the matter before the public through the various State legislatures, he prepared a draft 
of a series of resolutions to be introduced by some of his political friends in the Kentucky Legislature. His agency in the matter was at the time kept a profound secret, but the discovery among his papers after his death of a copy of the original draft of the Kentucky Resolutions, in his own handwriting, leaves no doubt of his authorship. ${ }^{x}$

Jefferson's original draft contains this significant sentence: "Where powers are assumed [by the Federal government] which have not been delegated, a nullification of the act is the rightful remedy; but every State has a natural right in cases not within the contract (casus non feederis) to nullify of their own authority all assumptions of power by others within their limits."

The resolutions were introduced in the Kentucky Legislature and were passed by that body on November I4, 1798 . They were passed substantially as drafted by Jefferson, except that Jefferson's nullification clause was considerably toned down, probably because of reluctance of the Kentucky legislators to make public avowal of so radical an utterance. The pith of the Kentucky resolutions of that year was contained in the first, in these words "Resolved, that the several States composing the United States of America are not united on the principle of unlimited submission to their general government; but that by compact under the style and title of a Constitution for the United States, and of amendments thereto, they constituted a general government for special purposes, delegated to that government definite powers, reserving each State to itself, the residuary mass of right to their own self-government; and that whensoever the general government assumes undelegated powers, its acts are unauthoritative, void, and of no force; that to this compact each State acceded as a State, and is an integral party; that this government, created by this compact, was not made the exclusive or final judge of the extent of the powers delegated to itself; since that would have made its discretion, and not the Constitution, the measure of its

rSee Jefferson's Works, vol. iv., p. 258; vol. vii., p. 229; vol. ix., p. 464. 


\section{The Beginnings of Secession}

powers; but that, as in all other cases of compact among parties having no common judge, each party has an equal right to judge for itself, as well of infractions as of the mode and measure of redress."

Jefferson sent a copy of his draft of the Kentucky Resolutions to James Madison, with a request that he lay them or resolutions of a similar character before the Virginia Legislature. $^{\mathbf{I}}$ Madison accordingly drew up a series of resolutions of his own, considerably briefer and in more guarded language than those of Jefferson, in which, though affirming the "compact" theory, the remedy accorded an aggrieved State for unconstitutional Federal legislation was the right to "interpose" instead of the right to "nullify." This idea was expressed in the Virginia Resolutions in the following language:

"That this Assembly doth explicitly and peremptorily declare, that it views the powers of the Federal government, as resulting from the compact to which the States are parties, as limited by the plain sense and intention of the instrument constituting that compact, as no farther valid than they are authorized by the grants enumerated in that compact; and that in case of a deliberate, palpable, and dangerous exercise of other powers, not granted by said compact, the States, who are parties thereto, have the right, and are in duty bound, to interpose for arresting the progress of the evil, and for maintaining within their respective limits the authorities, rights, and liberties appertaining to them." 2

These were passed and are known as the "Virginia Resolutions of I798." Copies of these were sent to the governors of the other States, to be communicated to the State legislatures. No responses were received approving the resolutions, but all concurred in asserting that the power to determine whether a law of the United States was constitutional or not was a judicial question to be determined

I Jefferson's Works, vol. iv., p. 255.

'Cooper, American Politics, book ii., p. 3. 
ultimately by the Supreme Court of the United States. The New York Legislature in its answer disapproved the doctrine of the Virginia Resolutions as "inflammatory and pernicious" and "no less repugnant to the Constitution of the United States and the principles of their union than destructive of the Federal government."

The Connecticut Assembly answered that it "viewed with regret and explicitly disavowed the principles contained in the aforesaid resolutions."

The Vermont Legislature also "highly disapproved of the resolutions of the General Assembly of the State of Virginia as being unconstitutional in their nature and dangerous in their tendency."

The Delaware Legislature answered that "they consider the resolutions from the State of Virginia as a very unjustifiable interference with the general government and constituted authorities of the United States and of a dangerous tendency and therefore not fit subject for the further consideration of the General Assembly."

The responses of the several States to the Kentucky and Virginia Resolutions were unsatisfactory to the framers of them, particularly so to Jefferson whose views were more radical than those of Madison. In order to counteract the effect on public sentiment, which it was anticipated might be produced by the responses of the other States, it was deemed expedient that some sort of a reply should be promulgated, and for this purpose resort was again had to the Kentucky and Virginia legislatures. Accordingly, doubtless through Jefferson's influence, another set of resolutions was passed in 1799 by the Kentucky Legislature, reaffirming, but in more emphatic language, the resolutions of I 798, and expressly approving Jefferson's doctrine of nullification in the following language: "That the seyeral States who formed that instrument [the Constitution of the United States] being sovereign and independent, have the unquestionable right to judge of the infraction; and that a nullification by those sovereignties of all unauthorized acts 


\section{The Beginnings of Secession}

done under color of that instrument is the rightful remedy." $x$ It will be noticed that in the resolutions of 1799 the Kentucky Legislature, which in 1798 had balked over Jefferson's nullification doctrine as too radical, now adopted it in almost precisely Jefferson's own language.

In the same year, Madison, chairman of a committee of the Virginia Legislature to consider the answers of the several State legislatures to the resolutions passed by it, submitted an elaborate report reaffirming the general principles of the resolutions of 1798 , but in language noticeably more guarded and evidently intended to avoid announcing what should be the future policy of a State in case its protest against alleged unconstitutional Federal legislation should be disregarded.

The Alien Act was never enforced and the Sedition Act expired by its own limitation on March 3, 1801, and so no further action was taken on the Kentucky and Virginia Resolutions. Nevertheless, ever since their passage, they have occupied a prominent place in the history of the country. They have given rise to much discussion of the question whether they sanctioned either nullification or secession, or both, as these terms were understood at a later period, and to still more extended discussion of the question as to Jefferson's attitude on the doctrine of nullification.

If we give to the language of the resolutions, especially to the language of the Kentucky Resolutions of I 799, the meaning which the words employed are commonly understood to bear, and follow out this meaning to all its logical consequences, it will be seen that it goes far to sustain the inter- . pretation afterwards placed upon it by Calhoun. Indeed Hildreth, Von Holst, and other historians interpret these resolutions as explicitly affirming the doctrine of nullification and regard Jefferson and not Calhoun as the originator of the doctrine. ${ }^{2}$ Johnston, an historian of acknowledged

Cooper, American Politics, book ii., p. I4.

'Hildreth, History of the U. S., 2d series, vol. ii., pp. 272-77, 31921 ; Von Holst, Const. and Pol. History of the U. S., vol. i., p. 144. See also McMaster, History of the U. S., vol. ii., pp. 419-23, 495. 
authority, in discussing the Kentucky and Virginia Resolutions and Jefferson's attitude on nullification, expresses this view, which is more favorable to Jefferson than that of the historians above quoted: "Before considering the question whether the term 'nullification,' as used by Jefferson in the Kentucky Resolutions of I799, was identical with the same word as used by Calhoun, it is well to notice how carefully the Virginia Resolutions avoid any suggestion of action by a single State. They certainly maintain the doctrine that 'each State acceded to the Union as a State and is an integral party' to the 'compact under the style and title of a Constitution of the United States'; and from this doctrine-the Calhoun program derives its justification, but in the application of the doctrine by Jefferson and Madison, it is always 'the sovereignties' which are to undo unconstitutional laws-'the States,' not 'a State'; and practically-the-Jeffersonian doctrine seems to have been that there were but two parties to the 'compact,' the States of the one part and the Federal government of the other, and that the former in national convention were to be frequently assembled to decide on the constitutionality of the latter's acts.

"Webster, long afterwards, ridiculed unsparingly the idea that the States could form a compact with another party which was only created by the compact and non-existent before it; and Calhoun's theory that the 'compact' was between the States themselves, and that the Federal government was the result of it and not a party to it, seems more logical than Jefferson's. Logical or illogical, however, Jefferson's theory was infinitely less destructive than Calhoun's, was strictly in line of constitutional practice, and is perfectly in accord with the Constitution's provisions for its own amendment.

"The State sovereignty preamble in the first Kentucky resolution and third Virginia resolution is not essential and is, in fact, only a hindrance to the spirit of the resolutions, which is simply that desire for a national convention of the States which has since been the first thought of all Jefferson's 
disciples in times of difficulty or danger. This Jeffersonian idea of the ultimate interpreter of doubtful constitutional questions cannot be more strongly put than in Jefferson's own words in his letter of June 12, I823, to Justice Johnson: 'the ultimate arbiter is the people of the Union, assembled by their deputies in convention at the call of Congress, or of two thirds of the States, to let them decide to which they mean to give an authority claimed by two of their organs.'

"Though State sovereignty was by no means essential as a basis for the resolutions it was the shortest and easiest way to justify them. It is, therefore, important to notice that in the hands of Jefferson and Madison State sovereignty, separate or collective, was to be a shield for the protection of the individual; in the hands of Calhoun it was to be a shield for a section and for slavery. The distinction is not trivial, it is vital, as can be seen most easily from its necessary results."

It is certain that at a later date, when the nation was thrown into a turmoil by the South Carolina nullification ordinance of 1832 , Madison himself denied that the Virginia Resolutions were intended to sanction the idea that any single State had a constitutional right to nullify a law of the United States, and it is claimed that Jefferson coincided with Madison's views. ${ }^{2}$

Whatever may be the proper construction of the Virginia and Kentucky Resolutions, the South Carolina political leaders based upon them their claim, not only to the right of nullification, but also to the right of secession. Moreover, they afterwards became part of the Democratic party creed. In 1852 the Democratic National Convention expressly resolved "That the Democratic party will faithfully abide by and uphold the principles laid down in the Kentucky and Virginia Resolutions of 1798 , and in the report of Mr. Madison to the Virginia Legislature in 1799 ; that it adopts those

'Johnston, American Political History, Woodburn's edition, vol. i., pp. 194-95.

Benton, Thirty Years, vol.i., pp. 347-60. 
principles as constituting one of the main foundations of its political creed and is resolved to carry them out in their obvious meaning and import." This resolution was reaffirmed in the platform adopted by the Democratic National Convention in 1856. :

The right of nullification came up in a debate in the United States Senate, in 1830, on the resolution of Senator Foot of Connecticut in relation to the public lands, a debate which has ever since been called "the great debate." It took a wide range, including many subjects, embracing States' rights, nullification, federalism, and other subjects that, if not irrelevant to the resolution, were but remotely connected with it. In this debate Colonel Hayne, Senator of South Carolina, brought prominently forward the right of State nullification and secession, expressly basing it upon the doctrine of the Virginia and Kentucky Resolutions of 1798. Webster's "Reply to Hayne" is known to every schoolboy.

The right of State nullification and secession again came prominently before the nation in 1832 when South Carolina, claiming that the tariff act of 1828 was an unwarranted discrimination against the people of the State, passed the celebrated nullification ordinance and took active steps to raise a military force with a view to armed resistance to the enforcement of the act. At this time Andrew Jackson, then President of the United States, issued his proclamation denouncing the action of the South Carolina authorities as treason and threatened to raise a military force to enforce by arms, if necessary, obedience by the citizens of South Carolina to the laws of the United States.

Calhoun, who was Vice-President during the debate on the Foot resolution, had broken with Jackson, had resigned the office of Vice-President, and had been elected to the United States Senate. He appeared in the Senate while the excitement over the nullification ordinance was at its height. President Jackson had issued his proclamation on December

× Cooper, American Politics, book ii., pp. 32, 38 . 


\section{The Beginnings of Secession}

10,1832 , and on January 21,1833 , the famous Force bill was introduced in the Senate. On the same day, Calhoun introduced a series of resolutions, the second of which, reaffirming the doctrine and using almost the exact language

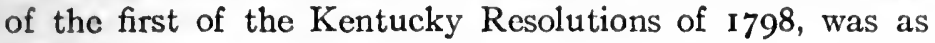
follows:

"Resolved, That the people of the several States thus united by the constitutional compact in forming that instrument, and in creating a general government to carry into effect the objects for which it was formed, delegated to that government, for that purpose, certain definite powers, to be exercised jointly, reserving, at the same time, each State to itself, the residuary mass of powers, to be exercised by its own separate government; and that, whenever the general government assumes the exercise of powers not delegated by the compact, its acts are unauthorized, void, and of no effect; and that the said government is not made the final judge of the powers delegated to it, since that would make its discretion, and not the Constitution, the measure of its powers; but that, as in all other cases of compact among sovereign parties, without any common judge, each has an equal right to judge for itself, as well of the infraction, as of the mode and measure of redress." $x$

Calhoun attacked the Force bill in an elaborate speech on February 15 and 16 , in the course of which he said:

"It is next objected, that the enforcing acts have legislated the United States out of South Carolina. I have already replied to this objection on another occasion, and will now but repeat what I then said: that they have been legislated out only to the extent that they had no right to enter. The Constitution has admitted the jurisdiction of the United States within the limits of the several States only so far as the delegated powers authorize; beyond that they are intruders, and may rightfully be expelled; and that they have been efficiently expelled by the legislation of the State through her civil process, as has been acknowledged on all

x Calhoun's Works, vol. ii., p. 262. 
sides in the debate, is only a confirmation of the truth of the doctrine for which the majority in Carolina have contended.

"The very point at issue between the two parties there is, whether nullification is a peaceable and an efficient remedy against an unconstitutional act of the general government, and may be asserted, as such, through the State tribunals. Both parties agree that the acts against which it is directed are unconstitutional and oppressive. The controversy is only as to the means by which our citizens may be protected against the acknowledged encroachments on their rights. This being the point at issue between the parties, and the very object of the majority being an efficient protection of the citizens through the State tribunals, the measures adopted to enforce the ordinance of course received the most decisive character. We were not children, to act by halves. Yet for acting thus efficiently the State is denounced, and this bill reported to overrule by military force the civil tribunals and civil process of the State! Sir, I consider this bill, and the arguments which have been urged on this floor in its support, as the most triumphant acknowledgment that nullification is peaceful and efficient, and so deeply intrenched in the principles of our system, that it cannot be assailed but by prostrating the Constitution, and substituting the supremacy of military force in lieu of the supremacy of the laws."

By common consent all looked to Webster to answer the speech of Calhoun. In the course of his speech Webster said:

"The first resolution declares that the people of the several States 'acceded' to the Constitution, or to the constitutional compact, as it is called. This word 'accede,' not found either in the Constitution itself, or in the ratification of it by any one of the States, has been chosen for use here, doubtless, not without a well-considered purpose. The natural converse of accession is secession; and, therefore,

Calhoun's Works, vol. ii., pp. 225, 226. 
when it is stated that the people of the States acceded to the Union, it may be more plausibly argued that they may secede from it. If, in adopting the Constitution, nothing was done but acceding to a compact, nothing would seem necessary, in order to break it up, but to secede from the same compact. But the term is wholly out of place. Accession, as a word applied to political associations, implies coming into a league, treaty, or confederacy, by one hitherto a stranger to it; and secession implies departing from such league or confederacy. The people of the United States have used no such form of expression in establishing the present government. They do not say that they accede to a league, but they declare that they ordain and establish a Constitution." $x$

\section{Again:}

"I admit, of course, that the people may, if they choose, overthrow the government. But, then, that is revolution. The doctrine now contended for is, that, by nullification or secession, the obligations and authority of the government may be set aside or rejected, without revolution. But that is what I deny; and what I say is, that no man can state the case with historical accuracy, and in constitutional language, without showing that the honorable gentleman's right, as asserted in his conclusion, is a revolutionary right merely; that it does not and cannot exist under the Constitution, or agreeably to the Constitution, but can come into existence only when the Constitution is overthrown." 2

Again:

"The Constitution does not provide for events which must be preceded by its own destruction. Secession, therefore, since it must bring these consequences with it, is revolutionary, and nullification is equally revolutionary. What is revolution? Why, Sir, that is revolution which overturns or controls, or successfully resists, the existing public authority; that which arrests the exercise of the

Webster's Works, vol. iii., pp. 453-55.

'Id., vol. iii., p. $45^{6}$. 
supreme power; that which introduces a new paramount authority into the rule of the state. Now, Sir, this is the precise object of nullification. It attempts to supersede the supreme legislative authority. It arrests the arm of the executive magistrate. It interrupts the exercise of the accustomed judicial power. Under the name of an ordinance, it declares null and void, within the State, all the revenue laws of the United States. Is not this revolutionary? Sir, so soon as this ordinance shall be carried into effect, a revolution will have commenced in South Carolina.". Again:

"Nullification, if successful, arrests the power of the law, absolves citizens from their duty, subverts the foundation both of protection and obedience, dispenses with oaths and obligations of allegiance, and elevates another authority to supreme command. Is not this revolution? And it raises to supreme command four-and-twenty distinct powers, each professing to be under a general government, and yet each setting its laws at defiance at pleasure. Is not this anarchy, as well as revolution? Sir, the Constitution of the United States was received as a whole, and for the whole country. If it cannot stand altogether, it cannot stand in parts; and if the laws cannot be executed everywhere, they cannot long be executed anywhere." 2

Summing up in a nutshell his answers to Calhoun's arguments, and the principles included in his resolution, Webster said:

"Mr. President, if we are to receive the Constitution as the text, and then to lay down in its margin the contradictory commentaries which have been, and which may be, made by different States, the whole page would be a polyglot indeed. It would speak with as many tongues as the builders of Babel, and in dialects as much confused, and mutually as unintelligible. The very instance now before us presents a practical illustration. The law of the last session is declared unconstitutional in South Carolina, and obedience

I Webster's Works, vol. iii., pp. 459-60.

2Id., p. 461 . 


\section{The Beginnings of Secession}

to it is refused. In other States, it is admitted to be strictly constitutional. You walk over the limit of its authority, therefore, when you pass a State line. On one side it is law, on the other side a nullity; and yet it is passed by a common government, having the same authority in all the States.

"Such, Sir, are the inevitable results of this doctrine. Beginning with the original error, that the Constitution of the United States is nothing but a compact between sovereign States; asserting, in the next step, that each State has a right to be its own sole judge of the extent of its own obligations, and consequently of the constitutionality of laws of Congress; and, in the next, that it may oppose whatever it sees fit to declare unconstitutional, and that it decides for itself on the mode and measure of redress-the argument arrives at once at the conclusion, that what a State dissents from, it may nullify; what it opposes, it may oppose by force; what it decides for itself, it may execute by its own power; and that, in short, it is itself supreme over the legislation of Congress, and supreme over the decisions of the national judicature; supreme over the Constitution of the country, supreme over the supreme law of the land. However, it seeks to protect itself against these plain inferences, by saying that an unconstitutional law is no law, and that it only opposes such laws as are unconstitutional, yet this does not in the slightest degree vary the result; since it insists on deciding this question for itself; and, in opposition to reason and argument, in opposition to practice and experience, in opposition to the judgment of others, having an equal right to judge, it says, only, 'Such is my opinion, and my opinion shall be my law, and I will support it by my own strong hand. I denounce the law, I declare it unconstitutional; that is enough; it shall not be executed. Men in arms are ready to resist its execution. An attempt to enforce it shall cover the land with blood. Elsewhere it may be binding; but here it is trampled under foot." "s

To Webster's speech Calhoun made a reply on February × Webster's Works, vol. iii., pp. 463-64. 
26, in which he reiterated his doctrine of nullification and secession, quoting in support of his argument the Virginia Resolutions of $1798 . x$ It is impossible in a brief outline to present fully Calhoun's theory that the Constitution is merely a compact between the States, which any one of them, upon causes deemed sufficient by it, has a right to break. This theory is elaborated in his speeches and in the first volume of his Works, which includes his Disquisition on Government and also $A$ Discourse on the Constitution and Government of the United States. It is needless to say that his arguments in support of it are presented with great force and skill. They have not lost their importance by reason of the Civil War. By that war it was determined that the reserved rights of the States did not include the right of secession, but it left the States supreme within the proper limits of State sovereignty, as it left the national government supreme within the proper limits defined by the Constitution. The framers of the Constitution intended to define by carefully expressed limitations the boundaries of national as well as those of State sovereignty and the powers, rights, and responsibilities belonging to each, regarding a violation of these limitations by the national government and a violation of them by the States as equally dangerous to the general welfare. In the study of these limitations, powers, rights, and responsibilities the student should carefully read the writings of both Calhoun and Webster.

In studying the question of States' rights the student may also profitably consult the work of Alexander H. Stephens on The War Between the States. It is written, in imitation of the examples of Plato and Cicero, in the form of a colloquy between the author and certain fictitious characters, "Judge Bynum of Massachusetts" representing the radical Republicans, "Professor Norton of Connecticut", representing the conservatives, and "Major Heister of Pennsylvania" representing the War Democrats. Stephens so

×See Calhoun's Works, vol. ii., p. 262. 
manages the colloquy that the other parties to it are invariably forced to admit that in any opinions they may have before entertained in conflict with those of Stephens, they were altogether wrong and that Stephens is altogether right. By this ingenious process Stephens proves, at least to his own satisfaction, divers conclusions, some of which most Northern readers will be apt to believe to be equally as imaginary as are the characters who take part in the colloquy. Nevertheless, Stephens's views are clearly expressed and ably argued. $\mathrm{He}$ follows substantially Calhoun's compact theory. He also maintains that the compact was first broken by the aggression of the Northern States, particularly by the passing of personal liberty bills, laying stress especially on those of Vermont and Massachusetts, apparently overlooking the inconsistency of attempting to hold all the Northern States responsible for the laws of a few of them on the compact theory or on any other theory of the Constitution, and forgetting that it would be as unreasonable to hold the other Northern States responsible for the laws of Vermont and Massachusetts as it would be to hold all the Southern States responsible for the nullification laws of South Carolina in 1832 . Stephens also maintains that in the Civil War the North was the first aggressor, and that, although South Carolina fired the first gun, the North committed the first act of war. The argument in support of this contention is that when South Carolina seceded, she resumed her sovereignty over all the forts in Charleston harbor and that the preparation of the national government to reinforce and hold them was an act of war. It will be seen in a subsequent chapter that the South Carolina Commissioners went further than Stephens, claiming that when Major Anderson abandoned Fort Moultrie he "waged war," committing "a hostile act in the highest sense."

Calhoun's doctrine of nullification and secession, at the time when he made the speech above quoted, received but little encouragement from any other Senators of either the 
North or the South. Benton denounced the doctrine in an elaborate speech. Finally, the South Carolina matter was smoothed over by a new compromise tariff bill, introduced by Henry Clay and known as the tariff bill of $I 833^{*}$

Up to this time the doctrine of the right of secession was not an outgrowth of the slavery question, and had no connection with it, but Calhoun's arguments, whatever their effect elsewhere, made a deep impression on the minds of the Southern people, and the doctrine advocated by him, though never adopted in any national political platform, was never lost sight of by them. It was afterwards adopted and applied by Calhoun and by Jefferson Davis and other Southern leaders in advocating the extension of slavery, and continued to be asserted by them. It was finally settled, not by arguments, but by the Civil War. That it was a doctrine generally believed by a large portion of the people of the South is a fact that should be understood in explanation of the subsequent conduct of the Southern States in seceding from the Union. The people of that section did not consider secession as rebellion but as an exercise of a right recognized by the Constitution itself.

s Benton, Thirty Years, vol. i., pp. 342-47. 


\section{CHAPTER III}

\section{SLAVERY IN THE TERRITORIES}

REFORE the beginning of the American Civil War the $B$ conflict between freedom and slavery was manifested in diverse ways - in disputes over fugitive slaves, in the antagonisms developed by the operation of the "underground railway, "and by the circulation of Abolition literature, and in various other ways. Prior to 1820 , there had been little cause of complaint from any of these sources, either in the North or in the South. The phase of the slavery question that first became, and that ever afterward continued to be, more prominent than any other, was that relating to the status of slavery in the Territories. There had not been any serious controversy over this question prior to the time when Missouri applied for admission into the Union. From an early period there had been a strong sentiment in the North favoring the prohibition of slavery in the Territories, and there was sufficient of this sentiment in the South, as well as in the North, to secure the prohibition of slavery in the Northwest Territory in the Ordinance of $1787 . \cdots$ But what little there was of such feeling in the South speedily disappeared. As stated in the preceding chapter, in the cession by Virginia to the general government of the territory now included in Kentucky, it was expressly provided that Congress should pass no law prohibiting slavery in the ceded territory, and similar provisos were inserted in the cession by North Carolina of the Tennessee territory and in that by Georgia of the Alabama and Mississippi territories. After the Louisiana Purchase, and especially after 
the acquisition of the territory acquired from Mexico, the constant effort of the slaveholding interests of the South was not to restrict but to enlarge the boundaries of slavery, not to prohibit it in the Territories, but to introduce it.

From the beginning of the national government there had been a demand in the South for the preservation of the "equilibrium," by which it was designed to keep the slave and the free states equal in numbers, and it had been the policy of the South, in the admission of new States, to see that no more free States than slave States were admitted. In the beginning the extension of slavery does not seem to have been the controlling consideration in the pursuit of this policy. The New England States had been closely allied long prior to the Revolution. There were, as has been already pointed out, marked differences in the characteristics of the population of the seven original free States and the six original slave States. So that, wholly independent of the question of slavery, the people of the slave States were desirous of preserving, as far as practicable, such an equilibrium as would enable them to protect their own interests against any combination in the making of laws and in the administration of the government that might be made by the original free States and new States peopled by them or their descendants, who would naturally be in sympathy with them, and that might lead to encroachments upon the rights of the citizens of the slave States.

As slavery became more and more important, as a political question, the solicitude of the South for the preservation of the equilibrium became more and more marked. It was not expected, especially in view of the more rapid growth in population of the free States, to secure equality in the Electoral College, or in the House of Representatives, but it was hoped to preserve the equilibrium in the Senate, so long as there were no more free States than there were slave States.

For this reason the admission of new States had been so skillfully managed, that for a long time the new free and the new slave States were practically admitted in pairs. Thus 
there were admitted, not at precisely the same time, but at only short interims between, Kentucky and Vermont, Tennessee and Ohio, Mississippi and Indiana, Alabama and Illinois, Missouri and Maine, Arkansas and Michigan, Florida and Iowa; so that at the beginning of President Polk's administration in 1845 there were fourteen free and fourteen slave States.

This policy had been pursued so long that it was plausibly argued by the members of Congress from the slave States that it had become a settled governmental policy. Hence we find the Southern States persistently opposing the admission of a free State unless coupled with the admission of a slave State or at least with some kind of assurance that the admission of a free State should be compensated by the future admission of a slave State, or the setting apart of some portion of the new Territories in which slavery should not be prohibited by Congress, leaving it open to slaveholders until the formation of a State government. The question of slavery in the Territories became still more important after the acquisition of the territory secured from Mexico. Webster said in 1850: "Nobody can look over the face of this country at the present moment, nobody can see where its population is the most dense and growing, without being ready to admit, and compelled to admit, that erelong the strength of America will be in the valley of the Mississippi." There is no doubt that Webster saw this long before he made the prediction quoted, nor is there any doubt that Calhoun also saw it.

It was foreseen that the new Territories would be rapidly filled, and that it would be necessary to create new States. It was also foreseen that the flowing tide of immigration to the new Territories from the free States would, in all probability, largely exceed that from the slave States. If all, or the greater part, of the area included in the Louisiana Purchase, together with that acquired from Mexico, should be converted into free States, what would become of the

'Webster's Works, vol. v., p. 362. 
equilibrium? And what would be the ultimate effect on slavery in the slave States if they should become hemmed in on every side by free States peopled by those hostile to slavery?

Out of these considerations grew another peculiarly Southern political doctrine, that of "equality of rights" in the Territories. There was plausibility in the claim of the South to equal rights with the North in the Territories. Southern men had helped fight for them and had helped pay for them. The Southern slaveholder desired, equally with the Northern farmer, to go where he could find cheaper and better lands for himself and his children, and honestly believed that he had as much right to take his slaves with him as the Northern farmer had to take with him his cattle. Above all other considerations was the menace to slavery in the slave States that lurked in the probable destruction of the political equilibrium in the event that the new Territories should ultimately be converted into free States. This demand of equality of rights in the Territories was voiced by Calhoun in his speech on the Oregon bill, in which he said:

"Now I put the question solemnly to the Senators from the North: Can you rightly and justly exclude the South from Territories of the United States, and monopolize them for yourselves, even if, in your opinion, you should have the power? It is this question I wish to press on your attention with all due solemnity and decorum. The North and the South stand in the relation of partners in a common Union, with equal dignity and equal rights. We of the South have contributed our full share of funds, and shed our full share of blood for the acquisition of our Territories. Can you, then, on any principle of equity and justice, deprive us of our full share in their benefit and advantage? Are you ready to affirm that a majority of the partners in a joint concern have the right to monopolize its benefits to the exclusion of the minority, even in cases where they have contributed their full share to the concern? But, to present the case more strongly and vividly, I shall descend from generals to par- 


\section{Slavery in the Territories}

ticulars, and shall begin with the Oregon Territory. Our title to it is founded first, and in my opinion mainly, on our purchase of Louisiana; that was strengthened by the Florida treaty, which transferred to us the title also of Spain; and both by the discovery of the mouth of the Columbia River by Captain Gray, and the exploration of the entire stream, from its source down to its mouth, by Lewis and Clark. The purchase of Louisiana cost fifteen millions of dollars; and we paid Spain five millions for the Florida treaty, making twenty in all. This large sum was advanced out of the common funds of the Union; the South, to say the least, contributing her full share. The discovery was made, it is true, by a citizen of Massachusetts; but he sailed under the flag and protection of the Union, and of course, whatever title was derived from his discovery accrued to the benefit of the Union. The exploration of Lewis and Clark was at the expense of the Union. We are now about to form it into a Territory; the expense of governing which, while it remains so, must be met out of the common fund, and towards which the South must contribute her full share. The expense will not be small. Already there is an Indian war to be put down, and a regiment for that purpose, and to protect the Territory, has been ordered there. To what extent the expense may go we know not, but it will, not improbably, involve millions before the Territory becomes a State. I now ask, Is it right, is it just-after having contributed our full share for the acquisition of the Territory, with the liability of contributing in addition our full share of the expense for its government-that we should be shut out of the Territory, and be excluded from participating in its benefits? What would be thought of such conduct in the case of individuals? And can that be right and just in government which every right-minded man would cry out to be base and dishonest in private life? If it would be so pronounced in a partnership of thirty individuals, how can it be pronounced otherwise in one of thirty States?

"The case of our recently acquired territory from Mexico 
is, if possible, more marked. The events connected with the acquisition are too well known to require a long narrative. It was won by arms, and a great sacrifice of men and money. The South, in the contest, performed her full share of military duty, and earned a full share of military honor; has poured out her full share of blood freely, and has and will bear a full share of the expense; has evinced a full share of skill and bravery, and if I were to say even more than her full share of both, I would not go beyond the truth; to be attributed, however, to no superiority in either respect, but to accidental circumstances, which gave both its officers and soldiers more favorable opportunities for their display. All have done their duty nobly, and high courage and gallantry are but common attributes of our people. Would it be right and just to close a territory thus won against the South, and leave it open exclusively to the North? Would it deserve the name of free soil, if one half of the Union should be excluded and the other half should monopolize it, when it was won by the joint expense and joint efforts of all? Is the great law to be reversed-that which is won by all should be equally enjoyed by all? These are questions which address themselves more to the heart than the head. Feeble must be the intellect which does not see what is right and just, and bad must be the heart, unless unconsciously under the control of deep and abiding prejudice, which hesitates in pronouncing on which side they are to be found. Now, I put the question to the Senators from the North: What are you prepared to do? Are you prepared to prostrate the barriers of the Constitution, and in open defiance of the dictates of equity and justice, to exclude the South from the Territories and monopolize them for the North? If so, vote against the amendment offered by the Senator from Mississippi [Mr. Davis], and if that should fail vote against striking out the I2th section. We shall then know what to expect. If not, place us on some ground where we can stand as equals in rights and dignity, and where we shall not be excluded from what has been acquired 


\section{Slavery in the Territories}

at the common expense, and won by common skill and gallantry. All we demand is to stand on the same level with yourselves, and to participate equally in what belongs to all. Less we cannot take."

The difficulties in the way of settling the question of the status of slavery in the Territories were obvious. Slavery cannot exist anywhere without some law to uphold it, some authority to protect the slave-owner's right of property in his slaves and to punish the violation of it, a necessity which gives rise to very stringent legislation in countries where slavery is recognized by law. Without some such authority for the protection of his right of property in his slaves the slave-owner would naturally be reluctant to carry them with him into a Territory where such right was not protected. On the other hand if slavery should be established by law in a Territory, especially if established by such legislation as existed in most of the slave States, the manifest tendency of such legislation would be to discourage free-State immigrants from settling in such Territory, because the poor white man would be unwilling to settle where he would be obliged to compete with the labor of the slave and would be despised by the master; even the man able to buy a quarter section of land would be reluctant to have for his neighbor a slaveholder owning a plantation of a thousand acres and a hundred or more slaves.

Indeed the question of slavery in the Territories, from an early period, became the most perplexing of all the questions involved in the irrepressible conflict. For forty years politicians tried to devise some policy by which slavery and freedom could dwell together in the Territories, but this was impossible and so the irrepressible conflict continued to the beginning of the Civil War.

Looking at the question from the slaveholder's point of view it was all-important, if slavery were to be given a foothold in the new States, that it should be planted there while they were yet in a territorial condition, for, if excluded

'Calhoun's Works, vol. iv., pp. 50I-503. 
from the Territory until they were filled with a free-State population, there would be little hope of inducing the people to establish slavery in the constitution which they might adopt preparatory to admission as a State. Various policies were from time to time proposed for settling the status of slavery in the Territories.

One policy-a makeshift policy-proposed for the settlement of the question of slavery in the Territories was that of "popular sovereignty," as advocated at various periods by Dickinson, Cass, and Douglas. It was not intended by them, as sometimes assumed by those, like Calhoun, who opposed what they contemptuously termed "squatter sovereignty," that the first dozen or more settlers should determine the question. Douglas's contention was that the inhabitants should be permitted to determine the question by appropriate laws after the formation of a territorial legislature. This doctrine was opposed alike by the radical pro-slavery advocates of the South and by the radical antislavery advocates of the North. The radicals of the South, following the lead of Calhoun, contended that the people of a Territory had no right to exclude slavery from such Territory at any time prior to the period when, pursuant to an enabling act of Congress, they might meet to form a constitution preparatory to admission as a State. Calhoun gave no countenance whatever to the "squatter sovereignty" doctrine, as advocated by either Cass or Douglas, declaring that this "of all the positions ever taken" was "the most absurd." Benton characterized it as "claptrap blarney." Under this theory the final determination of the question might have been postponed indefinitely, for it was wholly discretionary with Congress when it should pass such an enabling act. Michigan Territory was organized in 1805 , but the State of Michigan was not admitted into the Union until 1835 . On the other hand, the radical anti-slavery advocates of the North maintained that the people of the Territory had no right at any time-at least so long as the

s Speech on the Oregon bill. Calhoun's Works, vol. iv., p. 498. 
Territory remained in a territorial condition-to admit slavery.

Even Douglas's interpretation of the doctrine of popular sovereignty would not have enabled the opponents of slavery to exclude that institution until after the organization of a territorial government. The time when Congress should pass an act for the organization of a territorial government, and the body in which the legislative power should be vested, and the time when the people should be permitted to have a direct voice in the government, were all matters wholly discretionary with Congress, as seen in the various territorial acts cnacted by it. In the interim between the settlement of the Territory and the time when the people might be permitted to exercise the right of popular sovereignty, there was no authority, in the absence of an act of Congress to such effect, to prohibit slaveholders from settling in the Territories with their slaves in such numbers as might insure the permanence of slavery, as was the case in the Territory of Missouri, and as would probably have been the case in the Indiana Territory and in the Illinois Territory but for the prohibition in the Ordinance of 1787 .

The doctrine of popular sovereignty was never incorporated in any congressional act until the passage of the Kansas-Nebraska act in I854. It was short-lived, lasting only a few years, when the Supreme Court of the United States put an end to it by its decision in the Dred Scott case, affirming Calhoun's construction of the Constitution on the question of the status of slavery in the Territories.

Another makeshift policy was that of "non-interference or non-action." During Calhoun's lifetime the Southern leaders realized that it would be vain to expect that Congress would by any legislation expressly establish slavery in any Territory where it did not already exist. They also knew that, even if slaveholders should be permitted to take their slaves with them into the new Territories, it was probable that Northern immigrants would largely outnumber them and would vote, as soon as given an opportunity to do 


\section{6 Political History of Secession}

so, to exclude slavery, as they did, not only in Oregon, but also in California and in New Mexico. Therefore, in order to prevent hostile legislation, either congressional or territorial, it was insisted that neither should interfere, leaving the Territories "free and open to immigration by all the world so long as they continue so, and when they become States to adopt whatever constitution they please, with the simple restriction to be republican in order to their admission into the Union."

At the Democratic National Convention held in Baltimore in May, 1848 , William L. Yancey, of Alabama, offered the following resolution: "Resolved, that the doctrine of noninterference with the rights of property of any portion of the people of the confederacy, be it in the States or Territories thereof, by any other than the parties interested in them, is the true republican doctrine recognized by this body." "It is evident," says Mr. Foote, " "that it was intended by this adroit movement to get the whole Democratic party committed against any legislation in the Territories either on the part of Congress or the local legislatures, and to prevent even any action by conventions called for the purpose of forming State constitutions with a view to admission into the Federal Union in any of said Territories, which should be of a nature to affect the rights of property in slaves, unless with the consent of the individual owners. A proposition so absurd and dangerous could receive but few votes in a convention constituted of such intelligent and patriotic men as were then assembled in Baltimore, and accordingly out of 252 votes only 36 persons were found radical enough to follow Mr. Yancey's lead."

I Henry S. Foote, War of the Rebellion, p. 82. Foote was one of the Senators of Mississippi and was a colleague of Jefferson Davis. After the organization of the Southern Confederacy he fell out with Davis and left the country. In his book, the preface of which is dated December, I865, Foote makes a good many statements such as we would hardly expect from one who had been so prominently identified as was he with the Southern leaders before and during the Civil War. 
A plank favoring non-interference, but not going so far as the one proposed by Yancey in the Baltimore convention, was incorporated in the Democratic national platform of 1856 . It was as deceptive as the plank in the same platform supposed to favor popular sovereignty. As generally understood in the North, at least by those favoring the doctrine of popular sovereignty, it meant non-interference by Congress, leaving the question to be determined by the people of the Territory. In the South it was understood in a variety of ways. The ultra slavery advocates, starting with the assumption that the Constitution recognized slave property in the Territories, the same as any other species of property, claimed that neither Congress nor the territorial legislatures had any authority to impair such right of property, and that the slaveholders had a right to take their slaves with them to the Territories just as the Northern farmers had a right to go there and take with them their cattle, and that after the slaveholders had settled in a Territory with their slaves, it was the duty of Congress not to interfere with them or their slave property, but to let them alone. This was virtually admitted by Foote and other Southern leaders. It may be observed in this connection that this was precisely the doctrine afterwards contended for by the secessionists, who claimed that under the Constitution they had a right to secede from the Union, take and hold all the government forts and arsenals in the seceding territory, and set up a government of their own, and that, after they had done all this, all they desired was to be let alone.

The Southern doctrine of non-interference would have been almost as effectual in establishing slavery in a Territory as would have been legislation expressly authorizing it, for what is not forbidden by law is as lawful as that which is authorized.

Both the doctrines of popular sovereignty and non-interference, as understood in the South, were merely preliminary steps to the establishment of the doctrine advocated by 
Calhoun, that the Constitution itself protected slavery in the Territories from any interference by either congressional or territorial legislation. This was what Benton styled the "crowning dogma" of the Calhoun school.

Calhoun's theory of the constitutional guarantee of the right of the slaveholder to hold his slaves as property in the Territories was enunciated in a series of resolutions presented by him in the United States Senate on February $19,1847.5$ It was urged by him again in a speech on the bill providing for the organization of Oregon Territory, in which he reiterated the doctrine that the Constitution protected slavery in the Territories: "that Congress has no power whatever to prevent the citizens of the Southern States from emigrating with their property into the Territories of the United States or to give an exclusive monopoly of them to the North."

Some of the Southern leaders, for a time, seem to have thought it to be necessary that there should be some sort of congressional legislation to transport the Constitution into the Territories, and a provision of that kind was incorporated in the act for the organization of the Territory of New Mexico. This idea may have been suggested in order to meet Webster's argument that the Constitution cannot execute itself but must be supplemented by legislation.

But in the debates on the Oregon bill, Calhoun maintained that the Constitution extended itself into the Territories. "The simple question," he said, "is: Does the Constitution extend to the Territories or does it not extend to them? Why, the Constitution interprets itself. It pronounces itself the law of the land"; to which Webster replied as follows: "The Constitution of the United States extending over the Territories, and no other law existing there! Why, I beg to know how any government could proceed without any other authority existing there than such as is created by the Constitution of the United States? Does the Constitution of the United States settle titles to

' Calhoun's Works, vol. iv., p. 348. 


\section{Slavery in the Territories}

land? Does it regulate the rights of property? Does it fix the relations of parent and child, guardian and ward?" Benton and several other Southern Senators took Webster's view and opposed Calhoun's contention.

Calhoun was right in his contention that the Constitution needed no legislation to carry it into the Territories, for the Constitution goes into all the Territories, and goes there before any legislation of any kind. But, conceding this, the question still remained whether the Constitution, after it got into a Territory, recognized the right of a slaveholder to go there with his slaves and hold them there as his property.

On the other hand, Webster was undoubtedly right in his contention that, even if the Constitution guaranteed the right to hold slaves in a Territory, the constitutional guaranty would be a mere barren right unless supplemented by legislation to render it effective - such as laws punishing violation of such right of property, laws for its conveyance, descent, and the like. But if, as Calhoun contended, the Constitution guaranteed the right to hold slaves as property in a Territory, the same as any other kind of property, then it followed, as a logical conclusion, that, if additional legislation should be required, it would be the duty of Congress to supply it, just as it was the duty of Congress to enact such legislation as was found to be necessary to effectuate the constitutional provisions in regard to fugitive slaves. This was precisely the conclusion incorporated in the fifth of the eight resolutions introduced by Jefferson Davis in the Thirty-sixth Congress, and adopted in the Breckinridge and Lane Democratic platform in 1860 , and which provided that if the territorial governments should fail to give proper protection to slavery then it would be "the duty of Congress to supply such deficiency." By that time it had been found necessary to abandon the non-interference policy and to favor congressional interference in order to head off Douglas's "unfriendly legislation" theory by which he sought to evade the decision of the Supreme Court in the Dred Scott case and to bolster up his doctrine of popular sovereignty. 
Calhoun was also right in his contention that the Constitution recognized the right to hold slaves as property; but this was true only to a limited extent. The Constitution undoubtedly recognized the right of a slave-owner in a slave State, as, for example, in South Carolina, to hold slaves as property there, and to reclaim them if they should escape into a free State. But did the Consiitution guarantee to the South Carolina slave-owner the right to take his slaves to a Territory and hold them as slaves there? Calhoun maintained the affirmative of this question and made it the major premise of all his arguments. Webster and others denied it. The arguments used by Calhoun were able and plausible. They may be found in his speeches and writings but they cannot be condensed into a short statement. Those who opposed them argued in substance as follows. They maintained that the fallacy of Calhoun's proposition was in assuming that the Constitution made no distinction between the right of property in a slave and the right of property in a horse. But there was a vast difference. The right of property in a horse is founded upon natural right, a right recognized by the common law. When the owner of a horse emigrates from Massachusetts and takes his horse with him anywhere, to a State, a Territory, or to England, he holds his property, not by virtue of the laws of Massachusetts, but by virtue of the laws of the place to which he has emigrated, or if to a Territory where there are no special laws recognizing the right of property in a horse, then by virtue of the common law or by virtue of natural law. But the right of one man to hold another in slavery is not a natural right; it is not a common law right; as tersely stated by John A. Dix, " "it is the law of man, doing violence to all the dictates of nature, that makes a country slaveholding, either by its own voluntary act, or by the act of others forcing slavery upon it."

Hence it has always and everywhere been conceded that

- Speech in Senate on July 26,1848 , on the bills for organization of the territories acquired from Mexico: Dix's Speeches, vol. i., p. 375 . 
the right of property in a slave can exist only in the place where he is held and there only when the laws of that place sanction it. The Constitution of the United States nowhere recognizes, as a natural or common law right, the right of one man to hold another as a slave. The Constitution did recognize as a fact that the laws of South Carolina authorized one man to hold another as a slave in that State. But it nowhere recognized the right of the owner of the slave to take him to Massachusetts or to a free Territory and hold him as a slave there, for that would be to recognize the right of the slave-owner to take with him in his migrations not only his slave but also the slave laws of South Carolina.

All this was conceded by Benton and by many other Southern statesmen. It was clearly shown by Webster in his speech on August 12, 1848, on the bill to organize the territorial government for Oregon. ${ }^{x}$ "It will not be contended," he said, "that this sort of personal slavery exists by general law. It exists only by local law. I do not mean to deny the validity of that local law where it is established; but I say it is, after all, local law. It is nothing more, and wherever that local law does not extend, property in persons does not exist. Well, sir, what is now the demand on the part of our Southern friends? They say, 'we will carry our local laws with us wherever we go. We insist that Congress does us injustice unless it establishes in the Territory in which we wish to go our own local laws.' . . . If any question arose as to the status of an individual in Rome he was presumed to be free until he was proved to be a slave, because slavery is an exception to the general rule. Such, I suppose, is the general law of mankind."

Henry Clay was equally explicit. In the debates on the compromise measures he said: "There are gentlemen who maintain that, by virtue of the Constitution, the right to carry slaves south of that line $\left(36^{\circ} 30^{\prime}\right)$ already exists. If I had not heard that opinion avowed I should have regarded

'Webster's Works, vol. v., p. 308. 
it one of the most extraordinary assumptions, and the most indefensible position that was ever taken by man. The Constitution neither created, nor does it continue, slavery. Slavery existed independent of the Constitution and antecedent to the Constitution; and it was dependent in the States, not upon the will of Congress, but upon the laws of the respective States. The Constitution is silent and passive upon the subject of the institution of slavery; or, rather, it deals with the fact as it exists in the State, without having created it or continued it or being responsible for it in the slightest degree. . . . If slaves are voluntarily carried into such a jurisdiction [where slavery does not exist] their chains instantly drop off, and they become free, emancipated, liberated from their bondage. . . . If the Constitution possesses the paramount authority attributed to it [that is to protect slavery in the Territories] the laws even of the free States of the Union would yield to that paramount authority. . . . You cannot put your finger on the part of the Constitution which conveys the right or the power to carry slaves from one of the States of the Union to any Territory of the United States." x

Calhoun maintained his contention as long as he lived and in his very last speech-it may be called his dying speech-in the Senate. What would have been the ultimate development of his doctrine as to the constitutional right to hold slave property in the Territories if it had not been cut short by the Civil War, is now a matter of speculation. He himself was apparently doubtful whether the adoption of this doctrine would, of itself, be sufficient to preserve the "equality of rights" and the "equilibrium" so essential, in his view, to the preservation of slavery and the perpetuity of the Union. In his last speech he intimated that, in order to secure these results, further amendments to the Constitution might be necessary. What amendments he had in view he did not then define. Presumably they were those more fully developed in his

: Colton, Last Years of Henry Clay, p. 175. 


\section{Slavery in the Territories}

Disquisition on Government, ${ }^{3}$ in which he advocated amendments that, if adopted, would have materially curtailed the powers of both the executive and judicial departments of the government, and would have substituted a complicated scheme of government involving two or more Presidents, each with a negative or veto power over the action of the others, a scheme which would have required the total abandonment of our present system-all this in order to preserve and maintain the slaveholding interests of the South.

Some of the political doctrines advocated by Calhoun were urged when Missouri applied for admission into the Union. Then for the first time the free and the slave States were arrayed against each other on the question of slavery. It was Calhoun who put the demands of the Southern slaveholding interests in plausible shape and who was their chief advocate as long as he lived. Born in 1782 , Calhoun had entered political life at an early age. From I8II, when he entered Congress as a member of the House, he was almost continuously in public life, serving as a member of both the House and the Senate, as Secretary of State, and as Vice-President. He was master of the art of logic and ranks with the foremost of America's reasoners, the peer of Jonathan Edwards and Daniel Webster. Calhoun scorned the tricks and subterfuges of political trimmers and there was never any doubt as to where he stood on any political question. His great political opponent, Webster, was accused of casting aside his political convictions of a lifetime in order to gain the Presidency. No such charge was ever made against Calhoun. Indeed, throughout his whole career not a particle of evidence can be found sufficient to justify even a suspicion that he was ever influenced by ambition or by any thought of personal aggrandizement. Throughout his life he was a steadfast defender of slavery, but it was because he sincerely believed slavery to be right and that the welfare of the South depended upon main-

'Calhoun's Works, Cralle's ed., vol. i. 
taining it. Although he advocated what were then regarded as ultra Southern views, no one ever suspected his sincerity-much less that his utterances were intended merely "to fire the Southern heart." During his life he urged them with unremitting zeal and with an eye single to the interests of the slaveholding States, but during his life the times were not ripe for their adoption, either by Congress or by the Democratic party in the North. No Congress, no national convention, no court ever ventured to sanction them. After his death they were reiterated and pressed with increasing vehemence by Jefferson Davis, Toombs, Yancey, and others of the Calhoun school. It remained for Chief Justice Taney and his associates, following closely in Calhoun's steps and using his arguments, to give to his contention that the Constitution itself protected slavery in the Territories the sanction of the highest judicial tribunal in the land.

In subsequent chapters it will be more fully shown how Calhoun's doctrines were developed and modified. He died battling and hoping to the last for the success of the cause to which he had devoted his life, but Davis lived to see it forever lost. He lived long enough, however, to see slavery rapidly nearing the domain of freedom. So near did it get that Chief Justice Taney had pointed out the promised land, and it seemed that nothing could stay its further progress until the storm came that swept slavery from the land; not slavery only but all the bulwarks, all the laws, all the arguments, that had been constructed with such infinite labor and care for its protection.

We look wonderingly at all the vast piles of volumes, of treatises, of speeches, of Calhoun and his disciples. These fossils, relics of the Lost Cause, have lost the life, the power to convince, which they once had. They and all that they stood for are dead, dead past resurrection. 


\section{CHAPTER IV}

THE MISSOURI COMPROMISE; BEGINNING A NEW POLITICAL ERA

ON March 26, I804, the newly acquired territory of Louisiana was cut into two parts. All south of thirty-three degrees north latitude was called the Territory of Orleans and was afterwards admitted into the Union as a State under the name of Louisiana. Subsequently all of the original Louisiana territory north of thirty-three degrees north latitude, including what is now embraced in the State of Arkansas, was organized into a Territory called the Territory of Missouri. Large numbers of slaveholders had moved into it from Virginia, North Carolina, and other Southern States, and petitions of the inhabitants for admission into the Union as a State were presented to Congress in 1817 . At the second session of the Fifteenth Congress, which convened on November 16,1818 , a petition was again presented, together with another from the inhabitants of the south part of the Territory asking the admission of the State under the name of Arkansas. The congressional committee to which the matter was referred reported a bill on February 13,1819 , to enable the inhabitants to form a State constitution preparatory to admission as a State. At this point James Tallmadge, Jr., of New York, proposed an amendment forbidding the further introduction of slaves into the Territory and another providing that all children born after the admission of the State should be free after arriving at the age of twenty-five years.

As when some ravenous beast of prey, rudely disturbed 
in its lair, leaps forth roáring with rage, so slavery now bounded into the field fierce and defiant. For nearly two years the subject was discussed in and out of Congress. Henry Clay angrily and vehemently opposed the proposed amendment; so did William Pinkney, of Maryland, then standing at the head of American orators, who drew great throngs whenever he spoke on any theme. In support of the amendment the strongest speech made was the one made by Rufus King, of New York.

Such a restriction, said those who opposed it, is unconstitutional, unwise, and not possible to carry out. It is unconstitutional because Congress has no power to lay any restriction on any State as a condition of its admission into the Union; because, by the treaty of purchase, Congress is pledged to form Louisiana into States and admit them into the Union on the same footing with the original States; because Missouri will not be on an equal footing with the original States if forced to abolish slavery before coming into the Union; and because the citizens of each State are entitled to all the rights, privileges, and immunities of the citizens of the several States. One of these rights is that of going wherever a man listeth with his property - a right which will be most seriously impaired if the citizens of the slave States are forbidden to settle in Missouri with that kind of property which consists of slaves. Such a restriction would be unwise, because it would shut out the Southern emigrant from Missouri and open that splendid region to free-State men alone; because such a diminution of emigrants would lessen the number of purchasers of land; because a decrease in the number of purchasers would be followed by a fall in the price of public land, and this, in turn, by a serious lessening of the public revenue. Such a restriction could never be carried out, for, though the people of Missouri should accept the condition and should come into the Union as a free State, they could, whenever they pleased, amend their constitution and reëstablish slavery-an act no one 
who knew them could for a moment doubt that they would commit.

A favorite argument used by the opponents of slavery restriction was one expressed by Jefferson in a letter to General Lafayette on December 26, I820: "All know that permitting the slaves of the South to spread into the West will not add one being to that unfortunate condition; that it will increase the happiness of those existing, and by spreading them over a larger surface will dilute the evil everywhere, and facilitate the means of getting finally rid of it."

It is not probable that many were convinced by such an argument although backed by the great name of Jefferson. A farm can never be rid of weeds by digging up part of them in one field and transplanting them into another. The strange thing is, and it shows the straits to which the advocates of slavery were driven, that such an argument should have been made at all.

Threats of disunion by Southern members in case of the passage of the Tallmadge amendment were not infrequently heard in the halls of Congress during the debate. When the compromise afterwards adopted was first proposed, by which the people of Missouri were to be allowed to adopt a constitution without any restrictions as to slavery, but coupled with the prohibition against slavery in all other Territories lying north of $36^{\circ} 30^{\prime}$ north latitude, it was opposed by the radical members both of the North and of the South. The Northern opponents wanted to prohibit slavery in Missouri as well as elsewhere in the Territories; the Southern members wanted Missouri admitted unconditionally, without any restrictions as to slavery there or elsewhere in the Territories. Among those of the Southern members who maintained this doctrine was John Randolph, one of the Virginia representatives. While the bill for the admission of Missouri was pending the inhabitants of what is now Arkansas were also petitioning for admission. So were the people of Maine, but the Southern members

- Jefferson's Works, vol. vii., p. 194. 
refused to vote for the admission of Maine unless Missouri should also be admitted without restriction as to slavery.

The votes taken during the pendency of all these measures showed for the first time in the history of the country a division on geographical and not on party lines. For the first time the division was practically between the free States and the slave States. So intense was the feeling that at one time John Randolph proposed to Henry Clay that all the Southern members of the House withdraw in a body. ${ }^{\mathrm{I}}$

The excitement in Congress spread throughout the nation. Meetings were held and State legislatures passed resolutions, those of the North opposing, and those of the South favoring the admission of Missouri without any restriction of slavery. Jefferson was filled with gloomy forebodings. To William Short he wrote on April I3, I 820: "The Missouri question aroused and filled me with alarm. The old schism of Federal and Republican threatened nothing, because it existed in every State and united them together by the fraternalism of party. But the coincidence of a marked principle, moral and political, with a geographical line, once conceived, I feared would never more be obliterated from the mind; that it would be recurring on every occasion and renewing irritations until it would kindle such mutual and mortal hatred as to render separation preferable to eternal discord. I have been among the most sanguine in believing that our Union would be of long duration. I now doubt it very much and see the event at no great distance, and the direct consequence of this question." Again on April 22, 1820, he wrote with prophetic vision to John Holmes: "But this momentous question, like a fire-bell in the night, awakened and filled me with terror. I considered it at once as the knell of the Union. It is hushed indeed for the moment. But this is a reprieve only, not a final sentence. A geographical line, coinciding with a marked principle, moral and political, once conceived and held up to the

× Colton, Life of Henry Clay, vol. ii., p. 263. 


\section{The Missouri Compromise}

angry passions of men, will never be obliterated, and every new irritation will mark it deeper and deeper.":

In the early stages of the controversy the opponents of slavery extension were in the majority but before it was ended there appeared in Congress many new members, so that in the end the result was that Arkansas was admitted as a slave State and Maine as a free State, and a bill was passed allowing Missouri to form a State constitution preparatory to admission without restriction as to slavery, but coupled with a provision forever prohibiting slavery north of $36^{\circ} 30^{\prime}$ north latitude, a line which nearly evenly divided the north from the south half of the original Louisiana territory.

A significant incident occurred before the final approval of the Missouri bill. President Monroe summoned his Cabinet and submitted to the members two questions, first, whether Congress had a constitutional right to prohibit slavery in a Territory, and second, whether such prohibition would be operative after the formation of the Territory into a State. To the first question all the members including John Quincy Adams, John C. Calhoun, William H. Crawford, and William Wirt answered in the affirmative. To the second question Calhoun, Crawford, and Wirt thought that the prohibition continued only while the Territory remained such, while Adams thought that it continued after the formation of the State. At Calhoun's suggestion the second question was changed to this form: "Is the eighth section of the Missouri bill consistent with the Constitution?" Both questions were answered in writing in the affirmative and the President signed the bill. ${ }^{2}$

The Missouri bill was approved on March 2, 1820, and the Maine bill on March 3. This, however, was not the end of the controversy, for when the people of Missouri, pursuant to the enabling act, reported their constitution

Jefferson's Works, vol. vii., pp. 158, 159.

2 See speech of John A. Dix in United States Senate, June 26, I848, Dix's Speeches, vol. i., pp. 354-361. 
it was found that it contained a provision forbidding the Legislature from ever passing a law emancipating slaves without the consent of their masters, and another forbidding free negroes or mulattoes from entering the State on any pretext whatever. This again reopened the controversy and the debate upon it was of the most acrimonious character. Henry Clay was Speaker and exerted all his power to secure the admission of Missouri under the constitution adopted. Randolph had moved for a reconsideration of one of the votes taken, but Clay ruled that he was out of order and refused to recognize him until his name should be reached in the regular order, but before that time arrived Clay had hurriedly signed the bill and sent it to the Senate and when Randolph's name was called Clay reported that the bill was then beyond the control of the House. For this, which Randolph denounced as a shabby parliamentary trick, he never forgave Clay.

It was during the debate on the Missouri bill that Randolph dubbed the Northern members who had voted against the restriction of slavery as "doughfaces," a term ever afterwards used to characterize the Northern politicians who betrayed the interests of the North in order to curry favor in the South.

In after years it was claimed that the South was opposed to the concessions made by the representatives of that section in the Missouri bill. Whatever may have been their attitude in the beginning of the controversy there can be no doubt as to their attitude at a later period. It was, as stated by Benton": "The work of the South sustained by the united voice of Mr. Monroe's Cabinet, the united voices of the Southern Senators, and a majority of the Southern representatives."

During the excitement attending the controversy over Missouri a few Northern members were burned in effigy and most of those who had voted for the admission of Missouri were defeated for reelection, but after the admission of the

"Thirty Years, etc., vol. i., p. 8. 


\section{The Missouri Compromise}

State the political tumult subsided almost as suddenly as it had arisen, and what has been known as an "era of good feeling" continued during the remainder of the administration of President Monroe. The nation seemed to rest under the delusion that the slavery question had been finally settled. But morals cannot be surveyed like land. Slavery could not be wrong north of $36^{\circ} 30^{\prime}$ and right south of it. The compromise had passed the House of Representatives by a narrow majority. It was not satisfactory either

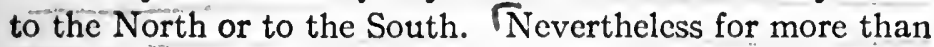
thirty years the people, at least those of the North, thought that the Missouri Compromise had forever barred the extension of slavery north of the line fixed. Stephen A. Douglas said of it: "It is canonized in the hearts of the American people and no ruthless hand will ever dare to disturb it,"-and yet his, more than any other hand, was the hand that afterwards helped to tear it up by the roots and cast it at the feet of the slave power to be trampled and utterly destroyed.

From this period American politics takes a distinct departure and slavery becomes an important and finally a controlling political factor. It was the strong thread woven into the warp and woof of American politics by those of the South who never relaxed their work, never, for one moment, lost sight of their thread. The end finally crowned their work, but the end was not that for which they had so long labored and hoped. 


\section{CHAPTER V}

FROM I 820 TO I 840 ; GROWTH OF ANTI-SLAVERY SENTIMENT IN THE NORTH

JAMES MONROE was reëlected President in I820, practically without opposition, the only President so elected since George Washington. Out of 232 electoral votes he received all but one and that was cast by John Tyler of Virginia. Monroe's second term embraced what has been called "the era of good feeling." The country was prosperous; many from the East and from the South were finding homes in the fertile regions of the West. There were no wars nor rumors of wars, and the people were not giving themselves much concern about politics. From the beginning of the government in 1789 to the end of Monroe's second term in 1825 all the Presidents had been chosen from Virginia and Massachusetts, four from Virginia and two from Massachusetts, including the sixth, John Quincy Adams, who was elected in 1824. Adams was succeeded by General Andrew Jackson, the hero of the battle of New Orleans, a man totally unlike any of his predecessors, with glaring faults combined with sterling virtues, the idol of the common people, especially those of the West and South, and to this day looked upon as one of the patron saints of the Democratic party. Jackson was again elected in 1832 and his administration from the beginning of his first to the end of his second term was as stormy as Monroe's had been peaceful. Mention has already been made of South Carolina's attempted nullification of the tariff laws in 1832 and 
how it was promptly nipped in the bud by Jackson. Many other exciting political questions engaged the attention of the people, but those which were chicfly discussed related to the United States bank, internal improvements, the tariff, and removal from office. Possibly more attention would have been given to the slavery question if Jackson had not kept the nation in a continual ferment about something else; but he was too intent on annihilating the United States bank and on exterminating Federal officeholders to give much attention to slavery and the Abolitionists. Jackson was succeeded in 1837 by Martin Van Buren, who served four years.

From the beginning of the government there had been more or less opposition to the extension of slavery, but the opposition had not been crystallized into an important political factor prior to 1830 . About that time anti-slavery societies began to be organized in the North, which led to the formation of the New England Anti-Slavery Society in I832, of the New York society in October, I833, and of the national organization called the American Anti-Slavery Society in December, 1833. In its declaration of principles adopted by the national society in Philadelphia on December $4,1833^{\circ}$ it condemned slavery in strong terms and asserted "that the slaves ought instantly to be set free and brought under the protection of the law." It expressly declared that "we fully and unanimously recognize the sovereignty of each State to legislate exclusively on the subject of the slavery which is tolerated within its limits; we concede that Congress under the present national compact has no right to interfere with any of the slave States in relation to this momentous subject"; ${ }^{2}$ but it maintained that Congress should abolish slavery in the District of Columbia and in the Territories and should prohibit the domestic slave trade between the several States. To accomplish these ends the means to be employed were stated to be as follows:

Johnson, Garrison, p. 473.

Ibid., p. 477. 


\section{Political History of Secession}

"We shall organize anti-slavery societies if possible in every city, town, and village in our land.

"We shall send forth agents to lift up the voice of remonstrance, of warning, of entreaty, and rebuke.

"We shall circulate unsparingly and extensively antislavery tracts and periodicals.

"We shall enlist the pulpit and the press in the cause of the suffering and the dumb.

"We shall aim at a purification of the churches from all participation in the guilt of slavery.

"We shall encourage the labor of free men rather than that of slaves by giving a preference to their productions.

"We shall spare no exertions nor means to bring the whole nation to a speedy repentance." $\mathrm{s}$

Simultaneously or nearly so with the organization of these anti-slavery societies, affiliated local societies were formed in many localities in the North, and it has been stated that within nine years after the organization of the national society there were in the United States over two hundred societies with a membership of two hundred thousand. Abolition newspapers were started in different parts of the United States, one by William Lloyd Garrison, entitled The Liberator, at Boston in the year $183 \mathrm{I}$; another called The Emancipator, at New York City in 1833 ; another, The Philanthropist, at Cincinnati in 1836; another, The Alton Observer, at Alton, Illinois, and others at various other points.

Of all these newspapers, the one most influential in creating sentiment and most odious to the slave interests was The Liberator. Garrison was one of the foremost of the antislavery pioneers. Born in Newburyport, Massachusetts, in 1804, he became a printer at an early age and later was connected with various newspapers. In I 829 he became associated with Benjamin Lundy in the publication at Baltimore, Maryland, of the Genius of Universal Emancipation, but his vigorous attacks on slavery stirred up a furious

'Johnson, Garrison, p. 478. 


\section{Growth of Anti-Slavery Sentiment}

ferment in Baltimore and soon got him in the Baltimore jail. After forty-nine days' imprisonment, he was released and later established in Boston The Liberator, the first number of which was issued on January I, 1831. From this time until the adoption of the Thirteenth Amendment to the Constitution of the United States Garrison devoted his life to the publication of The Liberator and to unceasing warfare against slavery. He and his associates were like the early English Puritans, the followers of Robert Browne, who wanted "Reformation without Tarying for Anie." Hence they opposed all schemes for gradual emancipation and insisted that it should begin at once.

Burke once said: "Where there is abuse there ought to be clamor because it is better to have a slumber broken by the fire-bell than to perish amidst the flame in our bed." Garrison believed that in order to stop the further spread of slavery it was time to ring the fire-bell and to raise a clamor, and this he proceeded to do. He gave no quarter and asked for none.

His bold, defiant, uncompromising spirit blazed forth in the first number of The Liberator. In his salutatory he boldly threw down the gauntlet when he said: "I am aware that many object to the severity of my language; but is there not cause for severity? I will be as harsh as truth, and as uncompromising as justice. On this subject I do not wish to think, or speak, or write with moderation. No! No! Tell a man whose house is on fire to give a moderate alarm; tell him to moderately rescue his wife from the hands of the ravisher; tell the mother to gradually extricate her babe from the fire into which it has fallenbut urge me not to use moderation in a cause like the present. I am in earnest-I will not equivocate-I will not excuseI will not retreat a single inch-and I wILL BE HEARD. The apathy of the people is enough to make every statue leap from its pedestal and to hasten the resurrection of the dead."

-William Lloyd Garrison, by his Children, vol. i., p. 225. 
Not only would Garrison make no concession to slavery; he would make no concessions even to win the alliance of those opposed to it if such concession would involve the slightest deviation from the line of attack which he ad- vocated. Like Grant in later years, he proposed to fight it out on this line and on no other.

The Liberator was not less offensive to the slaveholders by reason of the character of its attacks than it was by its frontispiece, which was a pictorial representation of an auction of "slaves, horses, and other cattle," with a slave tied to a whipping-post and being whipped by an overseer, and a picture of the capitol of Virginia with a flag on which was delineated Liberty floating over the dome. ${ }^{x}$

In the summer of 1831 , a few months after the establishment of The Liberator, there occurred in Virginia an insurrection of slaves, led by Nat Turner, a negro, in which sixty-one white people, including men, women, and children, were ruthlessly slaughtered. It was never shown, and probably was not true, that Turner or his associates had ever read or heard of any Abolition papers or tracts, but it was believed in the South that Turner had been in some way inspired by them in starting the insurrection.

All these things, as might well be supposed, created throughout the South a very intense and bitter feeling against all Abolitionists everywhere. More stringent slave legislation was enacted throughout the South and severe laws were passed making it a crime to circulate Abolition papers or documents. No known Abolitionist's life was safe in that region. Rewards were offered by Southern committees, and some by State legislatures, for the capture of leading Northern Abolitionists, the prices offered varying according to the prominence of the Abolitionist. A vigilance committee in Loulsiana advertised in a New Orleans paper a reward of $\$ 50$,ooo for the capture and delivery of Arthur Tappan, the president of the American Anti-Slavery

A reduced facsimile of this frontispiece is shown in Garrison and his Times, p. 393 . 


\section{Growth of Anti-Slavery Sentiment}

Society. The Georgia Legislature offered a reward of $\$ 5000$ for the arrest and conviction of Garrison. The South Carolina Legislature passed a resolution requesting the governors of the non-slaveholding States to "promptly and effectively suppress all those associations within their respective limits purporting to be Abolition societies." Other Southern Legislatures adopted similar resolutions which were transmitted to the governors of the non-slaveholding States and by them to the Legislatures of their respective States. No Northern Legislature acceded to these requests. One Northern Governor, Edward Everett, then Governor of Massachusetts, recommended the passage of such legislation, but the Massachusetts Legislature refused to follow his recommendation.

In his annual message of December 7, 1835, President Jackson invited special attention "to the painful excitement produced in the South by attempts to circulate through the mails inflammatory appeals addressed to the passions of the slaves in prints and in various sorts of publications, calculated to stimulate them to insurrection and to produce all the horrors of a servile war," and recommending the "passing of such a law as would prohibit under severe penalties the circulation in the Southern States, through the mail, of incendiary publications intended to instigate the slaves to insurrection." 2 In the Senate the matter was referred to a select committee of which John C. Calhoun was chairman and the committce reported a bill making it a penal offense for any postmaster to knowingly receive and put into the mail any publication or picture touching the subject of slavery to go into any State or Territory in which the circulation of such publication or picture should be forbidden by the State law. This was so palpable an infringement on the freedom of the press that Clay, Crittenden, Benton, and four other Southern Senators voted against it and the bill was rejected by a vote of twenty-five to nineteen. Only three

'Garrison and his Times, p. 214.

'Presidents' Messages, vol. iii., pp. 175, 176. 
Senators of the Northern States voted in favor of it: John Robinson, of Illinois, Silas Wright, of New York, and James Buchanan, of Pennsylvania. $x$

During Van Buren's administration the constitutional right of petition was severely tested. This right was so highly regarded by our English ancestors that it was expressly provided in the Bill of Rights "that it is the right of the subject to petition the king and all commitments and prosecutions for said petitioning are illegal."

A striking object-lesson of the value of the right of petition had been given in the early colonial history of Massachusetts, when Samuel Maverick and others presented to the General Court a petition setting forth, among other grievances, that the fundamental laws of England were not owned by the colony, and that the petitioners had been excluded from the civil and religious rights and privileges to which they were entitled solely for the reason that they were members of the Church of England, "though otherwise sober, righteous, and godly," and praying that if their civil and religious liberties were denied them they might be freed from the heavy taxes and other burdens imposed upon them. They were brought before the General Court, where they pleaded their right of petition, but their plea was disregarded and they were heavily fined. ${ }^{2}$

In view of its importance the right of petition was carefully guarded in the Constitution of the United States and in the first section of the bill of rights it is expressly provided that Congress shall make no law abridging the right of the people "to petition the government for a recress of grievances."

This much has been said about the right of petition in order to show that it was regarded both by our English and our American ancestors as a constitutional right of the utmost importance. Its value was soon put to the test by

Benton, Thirty Years, etc., vol. i., pp. 580-88; Curtis, Buchanan, vol. i., p. 357 .

2 Hutchinson, History of Massachusetts, vol. i., p. I37. 


\section{Growth of Anti-Slavery Sentiment}

the presentation of petitions and memorials to Congress for the abolition of slavery, especially in the District of Columbia. These began at an early date. The constantly increasing flood of such petitions and memorials greatly incensed the slaveholders of the South.

John Quincy Adams entered the House in 1831. Of a distinguished Massachusetts family, himself an ex-President and the son of a former President, he had, after having filled many important offices, expected to retire to private life, when in 1830 , being then over sixty years of age, he was elected by his Massachusetts constituents to represent them in the United States House of Representatives, an office which he held by successive reëlections until his death on February 23, 1848. Adams, long before either Seward or Lincoln, predicted the "irrepressible conflict." "The Union," he said, "will fall before slavery or it will fall before the Union." While not in sympathy with the political methods advocated by the Abolitionists, which he believed to be impracticable, he was in favor of the abolition of slavery by all constitutional methods and in 1839 he offered a resolution for submitting to the people of the several States an amendment of the Constitution providing that every child born in the United States after July 4,1842 , should be free and that thereafter no State, except Florida, should ever be admitted as a slave State. He was from the beginning a strenuous advocate of the right of every person to present to Congress a petition for a redress of grievances, and of the right and duty of a representative to present it, whether he himself approved the petition or not. At the first session of Congress after he became a member he introduced fifteen memorials for the abolition of slavery and the slave trade in the District of Columbia.

On February 6, 1837, Adams addressed the Speaker of the House and stated that he held in his hand a paper purporting to come from slaves and desired the decision of the Speaker on the question whether it came within the 
rules of the House respecting such petitions. Some of the Southern members immediately flew into a great rage and sought to have Adams brought to the bar of the House and censured. One member thought that the petition ought to be taken and burned; another, Waddy Thompson of South Carolina, said that Adams's conduct was a proper subject of inquiry by the grand jury of the District of Columbia, as it would be under the law in South Carolina.

To all this Adams made a dignified but spirited defense. To the objections urged that the signers of the petition were free negroes and persons of immoral character he answered: "Where is your law which says that the mean, the low, and the degraded shall be deprived of the right of petition, if their moral character is not good? Where, in the land of freemen, was the right of petition ever placed on the exclusive basis of morality and virtue? Petition is supplicationit is entreaty-it is prayer! And where is the degree of vice or immorality which shall deprive the citizen of the right to supplicate for a boon, or to pray for mercy? Where is such a law to be found? It does not belong to the most abject despotism. There is no absolute monarch on earth who is not compelled, by the constitution of his country, to receive the petitions of his people, whosoever they may be. The Sultan of Constantinople cannot walk the streets and refuse to receive petitions from the meanest and vilest in the land. This is the law even of despotism; and what does your law say? Does it say that, before presenting a petition, you shall look into it, and see whether it comes from the virtuous, and the great, and the mighty? No sir; it says no such thing. The right of petition belongs to all; and so far from refusing to present a petition because it might come from those low in the estimation of the world, it would be an additional incentive, if such an incentive were wanting."

To Thompson's suggestion that the matter should be laid before the grand jury of the District of Columbia, he said:

"If this is true-if a member is there made amenable to 
the grand jury for words spoken in debate-I thank God I am not a citizen of South Carolina! Such a threat, when brought before the world, would excite nothing but contempt and amazement. What! are we from the Northern States to be indicted as felons and incendiaries for presenting petitions not exactly agreeable to some members from the South, by a jury of twelve men, appointed by a marshal, his office at the pleasure of the President! If the gentleman from South Carolina, by bringing forward this resolution of censure, thinks to frighten me from my purpose, he has mistaken his man. I am not to be intimidated by him, nor by all the grand juries of the univérse."

The debate lasted four days. In the meantime the fact, overlooked by Adams's enemies in their rage and eagerness to have him censured, at last dawned upon them, that he had neither presented nor offered to present the petition, but had mercly asked the opinion of the Speaker of the House whether it came within the rules or not, and that the most that they had accomplished was to catch a tartar.

It also came out that the petition was a forgery, a contemptible hoax, which the perpetrators of it had succeeded in palming off upon the House and upon Adams himself; so that by this time Adams's foes as well as his friends were thoroughly disgusted with the whole matter and the attempt to censure resulted in flat failure. Thus Adams escaped censure and came out victorious in his fight for the right of petition. ${ }^{x}$

The Southern members of Congress became wrought up to the highest pitch of exasperation when in 1838 William Slade of Vermont presented a set of resolutions of the Vermont Legislature accompanied with various memorials in favor of suppressing slavery and the slave trade in the District of Columbia, and moved their reference to a select committee with instructions to report a bill for that purpose. This at once precipitated what Benton characterized as "the most angry and portentous debate which had yet 'Quincy, Life of John Quincy Adams, pp. 251-57. 
taken place in Congress." $\mathrm{s}$ Wilson agrees with Benton as to the exciting character of the debate, but, of course, takes an entirely different view of the question from that taken by Benton. ${ }^{2}$ The Southern members after adjournment held a caucus in which some were in favor of taking immeliate steps for a dissolution of the Union, but the next day, in order to head off Abolition memorials and petitions to Congress without interfering with the constitutional right of petition, an ingenious device was resorted to by the adoption of Rule $2 \mathrm{I}$ of the House, afterwards known as the "Atherton gag," by which it was provided that "eviery petition, memorial, resolution, proposition, or paper, touching or relating in any way, or to any extent whatever, to slavery or the abolition thereof shall, on presentation, without any further action thereon, be laid upon the table without being debated, printed, or referred."'3 A similar rule was adopted in the Senate and the House and Senate rules remained in force until I 845 .

Adams persisted in his advocacy of the right of petition and in 1842 presented a petition from divers citizens of Haverhill, Massachusetts, praying for a dissolution of the Union. For this he was bitterly assailed in Congress and out of it, and again an attempt was made to have him censured by the House, but again he stood his ground, defying his enemies and promising to show in his defense that "a portion of the country from which his assailants came was endeavoring to destroy the right of habeas corpus and of trial by jury and all the rights in which the liberties of the country consisted," and that there was in that portion of the country "a systematic attempt even to carry it to the dissolution of the Union, with a continual system and purpose to destroy all the principles of civil liberty among the

Thirty Years, vol. ii., p. 150.

$=$ Rise and Fall, vol. i., pp. 350-53.

${ }^{3}$ It was suspected at the time that John C. Calhoun was the real author of this rule. 
free States and by power to force the detested principles of slavery on the free States of this Union." After eleven days of stormy debate the whole subject was laid on the table by a vote of one hundred and six to ninety-three. Again Adams was victorious in his fight for the right of petition.:

By this time opposition to the further extension of slavery was making inroads into the Democratic party in the North. John P. Hale, a Democrat from New Hampshire, Hannibal Hamlin, a Democrat from Maine, and a few from other sections of the North had entered Congress and were vigorously opposed to the further extension of slavery and in favor of the rejection of the "gag rule," but it was not finally abrogated until 1845 . After that the method adopted to smother Abolition petitions was to refer them to a carefully sclected committee composed of members who could be relied on not to report them but to let them die in the committee. Still the principle of the right of petition had been vindicated and preserved. Had it not been for the efforts of Adams and those who sided with him in his opposition to the "gag rule" no one can now say what inroads might have been made by rules and legislation upon the right of petition. ${ }^{2}$ We may safely assume that it is dangerous to liberty to relax either the right of petition or any other of the cardinal safeguards of liberty for which our English or our American ancestors strove through centuries of struggle to compel their rulers to concede.

It would be unjust to Calhoun and his followers to omit any mention of the rcasors they urged for suppressing the anti-slavery petitions. In the first place they denied that the absolute right of petition went any further than the presentation of it and claimed that after its presentation the future disposition of it rested wholly in the discretion of

'Quincy, Life of John Quincy Adams, pp. 343-352.

'See Wilson, Rise and Fall, vol. i., p. 395; Seward's Oration on John Quincy Adams, Seward's Works, vol. iii., pp. 95-97. 


\section{$74 \quad$ Political History of Secession}

the legislative body to which the petition was addressed, which might refer it to a committee, lay it on the table, or reject it. In the next place they claimed, and this was true, that most of the petitions were presented without any expectation whatever of favorable action upon them. Indeed, John Quincy Adams almost always prefaced his remarks in presenting the petitions introduced by him with the statement that he did not concur in the views of the petitioners and that he should vote against them. This being so, they claimed that no useful purpose would be subserved by daily discussions of such petitions, but on the contrary such discussions, characterized, as they always were, with denunciations of the sin of slavery, could have no other result than to arouse the angry passions of the members, many of whom were slaveholders themselves, to increase the growing feeling of bitterness between the North and the South, and to endanger the stability of the Union. Therefore they claimed that the best course on such petitions was summarily to reject them.

There was much truth in what was said by the Southern people about the petitions that prayed for the abolition of slavery in the States where it was conceded to be protected by the Constitution of the United States and over which Congress had no jurisdiction whatever. Possibly no great objection would have been raised to the rejection of petitions for the abolition of slavery in the District of Columbia, for slavery existed there when it was ceded by Maryland and Virginia to the Federal government. But the petitions for the abolition of the slave trade in the District of Columbia stood upon a different ground. The advocates of slavery might have expected that there would be continued and emphatic protests against the location in the District of Columbia of slave pens and auction blocks where men, women, and children were herded and sold like cattle, all this in full view of the halls of Congress and in sight of all the ambassadors and other representatives of civilized nations, nearly every one of which had abolished slavery 
and had declared the carrying of slaves on the high seas to be piracy. Nobody denied that Congress had the power to abolish the slave trade in the District, and it is probable that there were many among the slaveholders themselves who were not unwilling that it should be abolished there.

The question of the right of petition was sharply presented in a petition presented on January II, 1836, by James Buchanan, then a Senator of Pennsylvania, signed by the members of a Pennsylvania Quaker society and praying for the abolition of slavery in the District of Columbia. Buchanan had made the usual prefatory specch disclaiming any sympathy with the petitioners, denouncing the Abolitionists, and recommending that the petition be immediately rejected. : This called forth a speech from Calhoun ${ }^{2}$ in which he very clearly and forcibly defined his views on the limits of the constitutional right of petition, citing numerous English precedents to prove that the absolute right of petition extended no further than the right to present it. Deprive deliberative bodies of the essential and primary right to determine at their pleasure what to receive and what to reject "and they would," he argued, "become the passive receptacle, indifferently, of all that is frivolous, absurd, unconstitutional, immoral, and impious, as well as what may properly demand thcir deliberation and action. Establish this monstrous, this impious principle, as it would prove to be in practice, and what must be the consequence? To what would we commit ourselves? If a petition should be presented praying the abolition of the Constitution (which we are all bound by our oaths to protect), according to this abominable doctrine it must be received. So, if it prayed the abolition of the Decalogue or of the Bible itself. I go further: if the Abolition societics should be converted into a body of Atheists, and should ask the passage of a law denying the existence of the Almighty Being above us, the Creator of all, according to

- Curtis, Life of Buchanan, vol. i., p. 319.

2 March 9, 1836 . Calhoun's Works, vol. ii., p. 48x. 
this blasphemous doctrine we would be bound to receive the petition, to take jurisdiction of it."

Disclaiming any "disrespect" to Buchanan, whose "intention" Calhoun believed to be good and whose "feelings" were with the South, Calhoun nevertheless denounced Buchanan's proposed method of disposing of such petition in severe terms. "The Senator from Pennsylvania has fallen on a device to receive this petition and immediately reject it without consideration or reflection. To my mind the movement looks like a trick-a mere piece of artifice to juggle and deceive." It must be admitted that Calhoun's plan of disposing of the Abolition petitions was much more honest and straightforward than that of Buchanan.

Notwithstanding the resolute stand of the little band in Congress that stood opposed to the further extension of slavery, and the efforts of the anti-slavery societies in the North, opposition to the Abolitionists seemed for a time to be growing in the North, until in many places it seemed to be scarcely less intense than it was in the South.

There was in the North a strong love of the Union and a desire to avoid stirring up a feeling in the South that might lead to its dissolution. The excitement growing out of the passing of the Missouri Compromise soon died out and there was a strong aversion to renewing it. A profitable trade had grown up between the commercial and manufacturing sections of the North and the Southern States. In New England there had been a great increase in the number of cotton mills, in which a large amount of capital had been invested and which employed many operatives. Everywhere in the North the commercial interests were hostile to the Abolitionists. Few in the North had seen the worst features of slavery, the floggings of slaves, the auction block, where men and women were sold like cattle, the tearing asunder of parents and their children. What they had seen in social intercourse was chiefly the courtly manners and the charming hospitality of Southern society.

At this day it is difficult to understand the attitude of 


\section{Growth of Anti-Slavery Sentiment}

northern churches on the question of slavery. Some of the old Abolition pamphlets like that of Parker Pillsbury, The Church as it is; or the Forlorn Hope of Slavery, are now curious reading, but Pillsbury's statements, in view of well-established facts, cannot be deemed to be greatly exaggerated. Strange as it may seem, at the twelfth General Conference of Methodists in Cincinnati in 1836 the disciples of John Wesley, who had denounced slavery as "the sum of all villainies," censured two of the members for having addressed an Abolition meeting in the city. Stranger still was the action of the Friends or Quakers, among the first in the North to denounce slavery. As late as 1842 the Yearly Meeting in Indiana forbade opening their meeting houses to Abolitionist speakers and silenced Charles Osborn and other preachers because they persisted in so doing.

Garrison, convinced that the Constitution of the United States recognized slavery and that Congress could not constitutionally abolish it in the States where it existed, denounced it as "a covenant with death and an agreement with Hell." ${ }^{\prime \prime}$ To emphasize their abhorrence of it Garrison and his friends burned the Constitution in public at Framingham, Massachusetts, on July 4, 1854. This dramatic performance began with first burning a copy of the Fugitive Slave Law, next the decision of Edward G. Loring in the case of Anthony Burns, next the charge of Judge Benjamin R. Curtis to the Federal Grand Jury, and lastly the climax, the burning of the "covenant with death and the agreement with Hell," at which from the Abolitionists gathered to witness the spectacle "a tremendous shout of 'Amen' went up to Heaven in ratification of the deed." 3

Reminiscences of Levi Coffin, pp. 230-32; George W. Julian, paper on "The Rank of Charles Osborn as an Anti-Slavery Pioneer," Indiana Historical Society Publications, vol. ii., pp. 264, 265.

2 For this he found scriptural texts which scemed to apply: "Because ye have said, we have made a covenant with death and with Hell are we at agreement"; " and your covenant with death shall be disannulled, and your agreement with Hell shall not stand." Isaiah xxviii., 15; 18.

3 William Lloyd Garrison, by his Children, vol. iii., p. 412. 
So long as the Union was maintained and was governed by the Constitution, and the slave States would not, of their own accord, abolish slavery, Garrison saw no way to dissolve what he deemed to be an unholy alliance, but for the free States themselves to withdraw from the Union, and so he advocated, "No Union with slaveholders" and the dissolution of the Union.

Deeming it wrong to take part in helping to carry on a government which recognized and protected slavery, he and his followers finally resolved to abstain from voting and continued in this resolution until after the beginning of the Civil War.

Failing to enlist the clergy, Garrison became more and more bitter in his denunciation of the Church-not of the Christian religion itself, but of the clergy who refused to espouse the Abolition cause. The Abolitionists were inflamed all the more by the excuses given by the clergy. The excuse usually given by the clergy was, as the Abolition historians give it, " "that they were just as much opposed to slavery as the Abolitionists, but"- -and then followed a long string of excuses about the danger of immediate emancipation; that the slaves themselves were not prepared for it; that the colonization scheme was much preferable; that the discussion of the subject tended to produce riot and a dissolution of the Union; together with plentiful quotations from the Scriptures such as those used by the slaveholders in the South.

Nevertheless the clergy remained obdurate to the appeals of the Abolitionists and went on compounding for the sins their congregations

\section{"were inclined to \\ By damning those they had no mind to,"}

preaching about the sins of men who had been dead for two thousand years or more, but carefully avoiding any allusion to the sin of holding men and women in bondage in

- Garrison and his Times, p. 159. 


\section{Growth of Anti-Slavery Sentiment}

America in the nineteenth century. But there never was a time when there were not great preachers, like Channing and Parker and Henry Ward Beecher, who denounced slavery and who would not be silenced.

What added to the odium in which Abolitionists were held at this period was the fact that many of those who espoused and advocated the cause of Abolition also advocated many other newfangled "isms," wild and visionary notions of state and church policy, that were excecdingly obnoxious to the people generally, until in the popular mind the term "Abolitionist" came to represent almost everything that was odious. According to Andrew D. Whites "there followed in the train of the nobler thinkers and orators the 'Fool Reformers'- -sundry long-haired men and short-haired women, who thought it their duty to stir good Christian people with blasphemy, to deluge the founders of the Republic with blackguardism, and to invent ever more and more ingenious ways for driving every sober-minded man and woman out of the anti-slavcry fold. More than once in those days I hung my head in disgust as I listened to these people and wondered for the moment whether, after all, even the supremacy of slaveholders might not be more tolerable than the new heavens and the new earth in which should dwell such bedraggled, screaming, denunciatory creatures."

The result was that Abolitionism finally came to be regarded as not respectable and the Abolitionists were wellnigh ostracized in churches, colleges, and in business and social circles. Naturally all this led to alarming riots. Abolition newspaper offices all over the North were raided and destroyed, and prominent Abolition speakers were insulted and mobbed. In Abolition literature, the year 1835 is referred to as "the mob year," though there were mobs before and after that time. Two of these in particular marked the heights of popular frenzy against the Abolitionists.

Autobiography, vol. i., pp. 64, 65. 
In 1835 , Garrison himself was mobbed, a rope was tied around his body by which he was dragged through the streets of Boston, and he was finally placed in jail, on the walls of which he traced these memorable words: "William Lloyd Garrison was put into this cell on Wednesday afternoon, October $2 \mathrm{I}, \mathbf{I} 835$, to save him from the violence of a 'respectable' and influential mob who sought to destroy him for preaching the abominable and dangerous doctrine that 'all men are created equal' and that all oppression is odious in the sight of God."

In 1837 the Rev. Elijah Lovejoy was murdered by a mob in Alton, Illinois, for persisting in the publication of an Abolition paper. The shock was felt with even greater force on the shores of Massachusetts Bay than it was on the banks of the Mississippi. A meeting was held in Faneuil Hall to express disapproval of the murder of Lovejoy and the suppression of freedom of speech and of the press; but at that period an Abolitionist was almost as odious in Boston as he would have been in South Carolina. A large number of those who opposed the object of the meeting attended, undoubtedly for the purpose of breaking up the meeting, or at least intimidating those who were in sympathy with the object of it. James T. Austin, then Attorney-General of the State, was present, and rising from his seat in the gallery made an offensive speech, comparing those who would free the slaves to men who would let loose a menagerie of lions, tigers, hyenas, and other wild beasts. He bitterly denounced Lovejoy and said that "he died as the fool dieth." Wendell Phillips was present. He was not one of the invited speakers and he had gone to the meeting without any intention of taking an active part in it. He was a young man, only twenty-four years old, of ancient and honorable lineage, a descendant of one of the oldest and most highly honored families of Massachusetts, rich, highly educated, eloquent. To be one of the first families counts for as much in Massachusetts as it does in Virginia and Wendell Phillips was one of the first. Through his veins coursed the bluest 


\section{Growth of Anti-Slavery Sentiment 8I}

of Puritan blue blood. One of his ancestor's, the Rev. George Phillips, six generations back of him, had been the first Puritan minister at Watertown. His father had been the first Mayor of Boston; one of his kinsmen had been Lieutenant-Governor of Massachusetts; two others had founded Phillips' Academy at Andover, and one Phillips' Academy at Exeter. The highest political honors were in his reach if he would side with the Democratic party, then in power, but he would not. He would not practice law because, before he could do so, he would be obliged to take an oath to support the Constitution of the United States, and this he would not do because it recognized slavery.

As soon as Austin concluded young Phillips walked uninvited to the platform and began speaking in defiance of the hissing and jeering crowd before him. "Mr. Chairman," he said, "when I heard the gentleman lay down principles which placed the rioters, incendiaries, and murderers of Alton side by side with Otis and Hancock, with Quincy and Adams, I thought these pictured lips [pointing to their portraits on the wall] would have broken into voice to rebuke the recreant American, the slandercr of the dead. ... Sir, for the sentiments he has uttered on soil consecrated by the prayers of Puritans and the blood of patriots the earth should have yawned and swallowed him up."

Considering the time, the occasion, and the circumstances, it must be conceded that the moral courage that inspired this oration was of a far higher type than the courage that inspires men on the field of battle. It placed Phillips in the front rank of American orators, a position that he retains to this day; while Austin is remembered only because Phillips once denounced him and so rescued his name from oblivion.

But neither Garrison's heroism nor Phillips's eloquence made Abolition popular in Boston or elsewhere in the North. The great body of the Abolitionists did not agree with the extreme views of Garrison and his followers and a dissolution of the American Anti-Slavery Society followed in 1840 .

3 Johnson, Garrison and his Times, pp. 227-29. 
After Garrison separated from the main body of the Abolitionists he still maintained his fight against slavery, and continued the publication of The Liberator until the end of the year 1865. He set in type with his own hands and published in the next to the last number of his paper the Thirteenth Amendment to the Constitution of the United States. With the publication of the next number the publication ceased. He had the good fortune that falls to the lot of few reformers to see accomplished before his death the reform to which he had devoted his life work.

It is difficult even yet to measure the meed of praise or censure of this remarkable man. Of the purity of his private life, his courage, his unselfish devotion to the cause which he espoused as his life work, there can be no doubt. When he began his labors the North was fast settling into a sort of stupor of indifference to slavery. Garrison gave it a rude awakening, but it roused the North from its lethargy. He was a born fighter. He had all the qualifications needed for a soldier on the firing line, but he lacked the essential qualifications of a commander. His temperament was such that he could fight his foes better than he could work in harmony with those whom he should have made his allies. He would make no concession to either friends or foes. He would batter down any obstacle that stood in his way without deviating a hair's breadth in order to go around it, even in cases where most men would not have considered it as involving any sacrifice of principle to go around.

The chief defect in Garrison's plans of opposing slavery was in his persistent refusal to favor any organized political action, the very thing the Abolitionists most needed-in fact absolutely indispensable to any successful opposition to the encroachments of the slave power. If making faces at Southern slaveholders and firing paper wads at them had been kept up until doomsday not a single slaveholder would have been converted. Indeed the "irrepressible conflict" would probably have ended in the country becoming all slave instead of all free, unless, indeed, which is the more 


\section{Growth of Anti-Slavery Sentiment}

probable, there had been a secession of part of the Northern States, in which case secession would probably have begun with that of the New England States instead of the cotton States. Nevertheless Garrison made a beginning, and at times when the anti-slavery sentiment in the North seemed to be burning low, showing scarcely a sign of a living spark, he and his co-workers fanned into life the smoldering embers and kept them alive.

Probably too much credit has been given Garrison and the Abolitionists by Northern writers, and too much blame by those of the South. Reference has been made in a former chapter ${ }^{1}$ to the theory of Mr. Herbert that the formation of the Abolition societies in the North was "the initial cause of all our troubles." All arguments on this subject, however, are finally reduced to one, involving a single question: whether slavery was right or wrong. If it was an evil, the logical conclusion must be that it never could have been extinguished simply by letting it alone. So long as any great political or social evil exists, there will be, and must be, agitation in order to eradicate or restrain it. The methods of the reformers who seek to accomplish this end may be often they are erroneous, but it would be illogical for this reason alone to charge them with culpability for the continuance of the evil itself. It is as illogical to charge Garrison and the Abolitionists with responsibility for the continuance of slavery and the Civil War that resulted from the attempts to perpetuate it, as it would be to charge the continuance of intemperance and its attendant evil consequences to the efforts, however ill-advised, of those who seek to prohibit or to check it.

Historical facts seem, at least to those who believe that American slavery was an evil, to justify the conclusion that the initial cause of the Civil War was slavery itself and the efforts to perpetuate and extend it, and that it was slavery's insatiate greed for more territory and its increasing demands for further concessions, growing more and more exacting

: Chapter I., p. I2. 


\section{$84 \quad$ Political History of Secession}

and exasperating to the people of the North, that at last kindled the flames of the Civil War. Northern people generally believe that it was slavery itself that, in its madness, supplied the fuel for the fire in which it was utterly consumed, root and branch. 


\section{CHAPTER VI}

THE POLITICAL CAMPAIGN OF 1840 . TIPPECANOE AND TYLER TOO

ARTIN VAN BUREN was much ridiculed by the
Whigs in the campaign of 1840 . He does not rank in history with any of his predecessors; nevertheless his training in office at home and abroad had made him familiar with the requirements of the presidential office, especially in the management of the national finances. In these respects he was far better fitted for the office of President than were many of his successors, certainly far better fitted than was his competitor, General William Henry Harrison, in the campaign of 1840 .

Van Buren had faithfully endeavored to carry out President Jackson's policies, with the result that the blame for all the alleged evil consequences of those policies fell upon Van Buren, and his administration encountered disasters at the very outset; one of the most serious being the financial panic of 1837 , a panic of great severity and wide-spread in its havoc, ruining for a time business of all kinds, wrecking private fortunes, and causing universal suffering and distress. Indeed his administration has been characterized as "the most inglorious, the most vexatious to the incumbent, of all the administrations since the adoption of the Constitution." $x$

Very great changes in political parties had occurred between the beginning of Monroe's administration and the end of Van Buren's. The Federal party had died of a

s Tucker, History of the United States, vol. iv., p. 396. 
complication of diseases, but was certainly dead beyond any hope of resurrection. Its opponent, the Republican party, broke into fragments known for a time as National Republican and Democratic Republican. Out of the ruins of all the old parties there sprang up in 1832 the Democratic party, which absorbed most of the Democratic or Jeffersonian Republicans, and in 1834 the Whig party, which took over most of the old Federalists and National Republicans. None of the political parties up to this time had taken a decided stand on the slavery question.

Before the close of Van Buren's term the political parties began to make preparations for the election of his successor. The old caucus system of nominating candidates for President and Vice-President had been abandoned and thereafter nominations were made by national conventions. Van Buren was a candidate for a second term and had no considerable opposition in the Democratic party; but there were several aspirants for the nomination in the Whig party, including General William Henry Harrison, Henry Clay, and Daniel Webster.

The Whig National Convention met in Harrisburg, Pennsylvania, on December 4, I839. While nominally a Whig convention it was aimed by its managers to unite all the elements of opposition to Van Buren. An artfully devised scheme was contrived by which to enable a few to control the nominations. Henry Clay and his friends had confidently counted upon his being made the presidential candidate, but he was sacrificed for a candidate thought to be more available. The anti-Masons were charged with being largely instrumental in bringing about the result. John Quincy Adams wrote in his diary: "He [Gales] told me that the nomination of Harrison at Harrisburg was the triumph of anti-Masonry and was entirely the work of W. H. Seward, the present Governor of New York."I At any rate the convention nominated William Henry Harrison of

I Memoirs of John Quincy Adams, vol. x., p. 152. See Von Holst, Const. and Pol. Hist., vol. ii., pp. 366 et seq. 
Ohio for President and John Tyler of Virginia for VicePresident, but did not adopt a platform. So careful was the convention to avoid committing the party to any definite political principles of any kind on slavery, tariff, sub-treasury, banks, or anything else, that it refused even to issue an address or any declaration of principles whatever, after a speech made by Mr. Burnell of Massachusetts who declared: "There was no need of an address. If the voice of the West, rolling down from the mountains and along the valleys of the Atlantic, be not better than all the addresses that were ever issued, then indeed a miracle had been wrought." And so the Whig party, afraid to adopt any declaration of principles, skulked behind the reputation of its candidate, relying for success mainly upon the voice of the West "rolling down from the mountains"- the whoops and hurrahs for "Tippecanoe and Tyler too."

In their eagerness to find a vote-getter for President the Whigs made the mistake that has more than once been made since, of not sufficiently scrutinizing the qualifications of the candidate for Vice-President. Tyler was not the turncoat and traitor to his party that we might suppose him to be from the charges made by the Whigs after the death of Harrison. It is true that he had little in common with the Whigs, but this they might have known if they had taken any pains to examine his prior record, which showed him to be opposed to the United States Bank and to the Whig ideas of a protective tariff and internal improvements. Upon the question of slavery he was at one with John. C. Calhoun in favoring the admission of Missouri as a slave State and in advocating the doctrine of the constitutional right of Southern slaveholders to take their slaves into any of the Territories. In the final vote in the Senate on the Force bill, which was intended to vest in President Jackson sufficient military force to suppress nullification in South Carolina, Tyler cast the only vote given against it in the Senate; but as it was "anything to beat Van Buren," and it was supposed that Tyler would add some strength to the 
ticket, he was chosen unanimously as candidate for VicePresident. ${ }^{x}$

The convention was not mistaken in its estimate of Harrison's popularity. He was by birth a Virginian "of the first families." His father, Benjamin Harrison, was one of the signers of the Declaration of Independence and had been Governor of Virginia and Speaker of the Continental Congress. General Harrison himself at the age of nineteen had entered the military service of the United States. He had served with distinction as an aide of General Wayne, "Mad Anthony," in the Indian wars in the Northwest and had been complimented for his gallantry by Wayne in his official reports. He had achieved national renown for his victory in I8I I at the battle of Tippecanoe and afterwards had served with distinction in the War of I 812 as commander of the army of the Northwest, achieving additional renown for his victory over the allied forces of the British and the Indians under Tecumseh at the battle of the Thames in 1813 . For these reasons he had become the idol of all the soldiers who had served with him, those of Virginia and Pennsylvania and especially those of Kentucky, Ohio, Indiana, and Illinois. Harrison had also served with credit in Congress as delegate from the Northwest Territory, as Governor of Indiana Territory, and as a member of both the House and the Senate from Ohio. His last public service prior to his election to the Presidency was that of Minister to Colombia, to which post he had been appointed in $\mathbf{1} 828$ by President John Quincy Adams and from which he was removed by General Jackson during his wholesale removal of Federal officeholders. After retiring from public life he had settled on a farm near North Bend in Ohio, where he had dwelt in a log cabin, living the simple life of a plain farmer, sharing with his neighbors in the hardships of Western pioneer life. He had been nominated by the Legislatures of several States for President in 1836 and, out of a

See Fiske's Essay on Harrison, Tyler, and the Whig Campaign, Essays, vol. i., p. 315 . 


\section{The Political Campaign of 1840}

total electoral vote of 294 , he received 73 , standing next to Van Buren, who received 170.

The Democratic National Convention met in Baltimore on May 6, 1840, and nominateduMartin Van Buren for President, but made no nomination for Vice-President. It also adopted a platform, but the only resolution touching slavery was the seventh which was as follows: "Resolved that Congress has no power under the Constitution to interfere with or control any domestic institutions of the several States; and that such States are the sole and proper judges of everything pertaining to their own affairs, not prohibited by the Constitution; that all efforts, by Abolitionists or others, made to induce Congress to interfere with questions of slavery, or to take incipient steps in relation thereto, are calculated to lead to the most alarming and dangerous consequences, and that all such efforts have an inevitable tendency to diminish the happiness of the people and endanger the stability and permanence of the Union and ought not to be countenanced by any friend to our political institutions."

The Abolitionists for the first time put a candidate for President in the field, nominating James G. Birney, of New York, for President and Francis Le Moyne, of Pennsylvania, for Vice-President.

Neither Van Buren nor Harrison had taken any pronounced position on the slavery question calculated to excite active hostility in either the North or the South. Van Buren had never offended the Southern slaveholders. Indeed, he had on one occasion, as Vice-President, given the casting vote in favor of excluding abolition publications from the mail. Harrison's record was still more satisfactory to the South. It is true that in an address on July 4, 1833, in Hamilton County, Ohio, he had said: "I am accused of being friendly to slavery. From my earliest youth to the present moment I have been an ardent friend of human liberty. At the age of eighteen I became a member of an Abolition society established at Richmond, Virginia, the 
object of which was to ameliorate the condition of slaves and procure their freedom by every legal means." s But at the time when Harrison joined the Abolition society of Richmond, Washington, Jefferson, and many other slaveholders of Virginia were in favor of the abolition of slavery. This at most, therefore, was only one of the indiscretions of youth. In the campaign of 1840 , however, in a speech at Columbus, Ohio, he felt called upon to refute as a base slander a campaign story which represented him "as confessing to a young man on a steamboat that he was an Abolitionist." 2 Harrison's record on the slavery question left no doubt as to where he stood in 1840 . As Governor of Indiana Territory he had aided the Virginia party there which sought to suspend, at least temporarily, the operation of the provision of the Ordinance of 1787 prohibiting slavery in the Northwest Territory. ${ }^{3}$ As a member of Congress from Ohio he had voted for the admission of Missouri without any restriction as to slavery. In the Fourth of July speech in Hamilton County, Ohio, already mentioned, he had justified his vote in Congress on the admission of Missouri, claiming that it was not just to Virginia, which had ceded so large a territory as that of the Northwest Territory, consenting that slavery should be forever excluded therefrom, "to exclude her citizens from every part of the territory purchased out of the common fund," thus using one of the very arguments used by Calhoun. In a speech at Vincennes, Indiana, in May, 1835, he strongly denounced the Abolitionists and the presumption of "an unfledged youth" who "at the moment of his leaving-indeed in many instances before he has left it-his theological seminary

Niles, Tippecanoe Text-Book, p. 69.

2 Norton, The Tippecanoe Campaign, p. I75.

3 Homer Webster, paper on "William Henry Harrison's Administration of Indiana Territory," Indiana Historical Society Publications, vol. iv., p. 195; Jacob Piatt Dunn, History of Indiana, 2d ed., pp. 355 et seq.; paper by same author on "Slavery Petitions and Papers" in Indiana Historical Society Publications, vol. ii., p. 443. 


\section{The Political Campaign of 1840}

undertakes to give lectures upon morals to the countrymen of Wythe, Tucker, Pendleton, and Lowndes, and lessons of political wisdom to States whose affairs have so recently been directed by Jefferson and Madison, Macon and Crawford." While admitting the constitutional provisions for the protection of freedom of speech and of the press, he asserted that "it could never have been expected that it [the constitutional provision] would be used by the citizens of one portion of the State for the purpose of depriving those of another portion of the right which they had reserved at the adoption of the Constitution, and in the exercise of which none but themselves had any concern or interest. If slavery is an evil it is with them." The operations of the Abolition societies, he claimed, "should be stopped immediately. This can only be done by the force of public opinion, and that cannot too soon be brought into operation. Every movement which is made by the Abolitionists in the non-slaveholding States is viewed by our Southern brethren as an attack upon their rights, and which, if persisted in, must in the end eradicate those feelings of attachment and affection between the citizens of all the States which was [were] produced by the community of interests and dangers in the war of the Revolution, which was the foundation of our happy Union and by a continuance of which it can alone be preserved. I entreat you then to frown upon the measures which are to produce the results so much to be deprecated." surely no disciple of Calhoun could have given more convincing proof of his loyalty to the slaveholding cause.

The slavery question was the vital one in the South, and in that part of the country the voters were far more interested in knowing how Harrison stood upon that question than in knowing how he stood upon the tariff, banks, subtreasury, or any other question. His Vincennes speech, however, and published letters of the same tenor were considered as entirely satisfactory. The Charleston (S. C.)

${ }^{2}$ Niles, Tippecanoe Text-Book, pp. 71, 72. 
Courier said: "We give below further evidence of General Harrison's soundness on the subject of Abolition. No further confirmation is needed by us, since our knowledge of his Vincennes speech and his recent renewed avowal of it in an extract of a letter from him published in our paper." The New Orleans Bee in speaking of Harrison's opinions on the "rights of the South" and of "his entire soundness upon that absorbing topic," declared: "The evidences heretofore laid before the public were sufficient to convince any one open to human testimony that the slave States had not a faster friend than William Henry Harrison, or one who. would more rigidly guard the rights secured to us by our sacred Constitution." $x$

In the North, however, the question of slavery had very little effect on the election following. There were other factors that gave the Whigs the advantage in the start. The country had not yet recovered from the disastrous financial panic of 1837 and many people were povertystricken. At such times the party in power is usually at a disadvantage and the voters are apt to be actuated not so much by abstract questions as they are by a desire to punish the party supposed to be responsible for their misfortunes or to aid the party that promises them the best assurance of relief from their burdens.

Moreover, Harrison had the advantage of Van Buren in some of the characteristics that in such times naturally affect the popularity of a candidate. Harrison was the hero of the battle of Tippecanoe. He had campaigned with the old soldiers in the War of 1812 ; he had been a comrade of the Western backwoodsmen in their battles with the Indians. He had been a fellow-pioneer with the Western frontiersmen, living their simple life and sharing with them their hardships and privations. On the other hand, it was charged that Van Buren was a shrewd New York politician; that he had held office for thirty years; he was reputed to be rich. Such being the conditions the

Niles, Tippecanoe Text-Book, p. 73. 


\section{The Political Campaign of 1840}

Democrats committed the unpardonable blunder of ridiculing General Harrison for the very things that contributed to render him popular. He lived, they said, in a log cabin covered with coonskins. He also drank hard cider and drank it out of a gourd; he was nothing more than an ordinary farmer; not fit to be President. This was enough. The Whigs immediately took up the Democratic guns and turned them against the enemy with great effect. If Harrison drank cider, they said, Van Buren drank champagne. The temperance question, it may be observed, was not involved, for at that time the people of New England drank rum and plenty of it and people of the West drank copiously of whisky; but champagne was a costly beverage that only the rich could afford to drink; if Harrison drank out of a gourd, Van Buren, it was said, used gold spoons on his table-gold spoons, when many poor people could afford nothing better than horn spoons or no spoons at all! How could there be any hesitation in choosing between a man who drank hard cider out of a gourd and one who drank champagne and used gold spoons?

The play by the Whig orators upon the combination of spoons and champagne was irresistible, quite as much so as the play upon "chops and tomato sauce" by which the renowned sergeant Buzfuz gained a verdict in the celebrated case of Bardell against Pickwick. Even Van Buren's son John came in for popular ridicule and he was nicknamed "Prince John," a sobriquet that stuck to him as long as he lived. The result was a singular and senseless campaign, singular because it was so senseless. It was, in fact, one continuous uproarious frolic in which the people went wild over miniature $\log$ cabins bedecked with coonskins and with outhanging latchstrings, immense canoes, typical of Tippecanoe, all these being prominent features in the great processions that characterized this campaign. At their meetings hard cider flowed in profusion and greatly stimulated the general hilarity.

There was in this campaign an extraordinary amount of 


\section{Political History of Secession}

vituperation. To the Whig abuse of Van Buren the Democrats retorted by calling Harrison "a coward," "a granny," "a petticoat hero," "a black cockade Federalist." It was even said that the Whigs were so fearful that if Harrison were allowed to be at large he might commit some indiscretion, that he was kept in a cage and under the watch of a committee appointed to guard him. But such charges were plainly so far from the truth that they only increased the zeal of Harrison's supporters.

Of course in such a campaign it was very dangerous for any man to be suspected of being an "aristocrat." Even Webster felt called upon to clear himself from Democratic slanders, charging him with being one, which he vehemently denied in a speech in New York in which he said, "The man who says I am an aristocrat is a liar," which utterance we are told caused "tremendous cheering."

Monster Whig meetings were held, characterized by great processions and all the peculiar features of this most peculiar campaign. One was held at Utica, New York, on August 12, 1840, at which there was a procession said to have been nine miles long. In the procession was a car drawn by six horses carrying a boy seated upon a throne representing Van Buren "dressed like King George in purple, velvet, and fine linen; by his side he had a splendid sword, the same as worn by one of the knights of old, and around his neck a diamond chain, to which was connected a large gold key; one hand strongly grasping and holding a key of the treasury, the other the sword; immediately behind the throne came the contrast-there sat old 'Tip' by the side of his log cabin with flail in hand, the very picture of comfort and kindness, his right hand extended to some worn-out soldiers." 1

It was in the West, however, that the greatest meetings were held and where there was the greatest enthusiasm. Here, among the old soldiers with whom he had campaigned under General Wayne and in the War of 1812 , the veterans

s Norton, The Tippecanoe Campaign, p. 26r. 


\section{The Political Campaign of 1840}

of the battle of Tippecanoe, and the farmers, Harrison was another McGregor on his native heath.

The campaign opened in Ohio on February 22, 1840, with a monster meeting at Columbus to which men came through the mud in wagons and on horseback, some from a distance of one hundred and fifty miles. But this meeting was eclipsed by a still greater meeting at Dayton, Ohio, on September 10, I840, which is said to have covered ten acres of ground and the crowd was estimated all the way from sixty thousand to one hundred thousand. Another great meeting, long celebratcd in Indiana and in the Northwest, was one held at the Tippecanoe battleground. The crowd was estimated at over twenty thousand, an enormous attendance considering that there were then no railroads in that part of the State. People came from all the adjoining States and from others even more remote. George W. Julian rode on horseback over one hundred and fifty miles through swamps and thickets to attend it. People came on foot, on horseback, in wagons, in log cabins and canoes mounted on wheels, bringing their tents and provisions. The meeting lasted for three days. Many of the veterans who had fought in the battle were also in attendance and many noted speakers were there, and there was a great abundance of hard cider, which was dispensed in the old primitive style in gourds.

Another singular feature of the campaign was a great paper ball, ten or twelve feet in diameter, that was rolled from State to State. On it were inscribed some campaign verses telling how

With heart and soul

This ball to roll,

May times improve

As on we move.

- Farewell dear Van,

You are not our man;

To guide the ship

We'll try old Tip. 
In such a campaign we should not expect to see classic models of oratory. A speech that was probably very effective was that of Charles Ogle, a Whig orator, delivered in the House of Representatives on April I6, I840, in which he said: "Yes, sir, Martin Van Buren has spent more than seventy dollars for each and every minute since he was sworn into the presidential office. How often has the clock ticked since that fatal hour? During the four months of last year that he passed on his electioneering tour in the State of New York, how many times did the clock tick then? The people's hard dollars were going at the rate of $\$ 70$ a minute, while he was dancing with the Countess of Westmoreland at Saratoga. That was dancing to a pretty dear tune, but the people paid the piper."

We must look to the speeches of Henry Clay and Daniel Webster and a few others to find anything like a sane discussion of political questions - to find indeed any trace of a vital political question of any kind. Ordinarily old political speeches are apt to lose the flavor they had when delivered, but Clay's are interesting even at this date. ${ }^{2}$ Webster made two notable speeches, one at Saratoga, New York, on August I9, I840, another at Richmond, Virginia, on October 5, $1840 .{ }^{3}$ In his speech at Richmond, after stating that "there is one perpetual outcry in all the administration papers from Baltimore south, admonishing the people of the South that their own State governments and the property they hold under them are not secure if they admit a Northern man to any considerable share in the administration of the government," he continued as follows: "'Well,' exclaimed Mr. Webster, in trumpet notes that seemed to be echoed

I Norton, The Tippecanoe Campaign, p. $7 \mathbf{r}$.

'As specimens of Clay's campaign speeches see his speech at Taylorsville, Virginia, on June 27, 1840, and his speech at Nashville, Tennessee, on August 17, 1840. Mallory, Life and Speeches of Henry Clay, vol. ii., pp. 408,427 .

3 Webster's Works, vol. ii., pp. 5, 83. The quotation from his Richmond speech is taken from the report as given by Norton in The Tippecanoe Campaign, pp. 333, 334. 


\section{The Political Campaign of 1840}

back from the whole country around, 'I do repeat-proclaim it on the wings of the winds-tell it to all your friends. [Cries of 'We will! we will!'] Tell it, I say, that, standing here in the Capitol of Virginia, beneath an October sun, in the midst of this assemblage, before the entire country and upon all the responsibility which belongs to me, I say that there is no power directly or indirectly in Congress or the General Government to interfere in the slightest degree with the institutions of the South." " The report states that "The cheering was renewed, and several voices cricd and repeated, 'That gives two thousand votes more for Harrison.'

'“'And now,' added Mr. Webster, 'I ask you to do me only one favor. Carry that paper home. Read it; read it to your neighbors, and when you hear the question, "Shall Daniel Webster, the Abolitionist, profane the soil of Virginia-"' Here the orator was interrupted by the most cordial shouts of applause that we ever heard. Every hat and every handkerchief was waved in the air-the chorus of cheering being led by the most distinguished men of Virginia who seemed to vie with each other in reprobating the foul and infamous slander. 'Welcome! welcome! Heaven bless you, Webster! Huzza! We scorn their abuse of you!' etc., etc., etc., burst from the thousands before him. A more exciting scene was never presented; and his choking voice, and burning teardrop that gathered in his eye, and trickled slowly down his pale cheek, showed how deeply the orator himself was moved."

In this speech Webster was speaking more for himself and his future candidacy than he was for Harrison. His speech was undoubtedly intended chiefly for Southern circulation. If Webster had announced a similar doctrine before, he did not announce it with such peculiar and picturesque em. phasis as that given at Richmond. He made no such speech in the North during that campaign.

Harrison himself made a few speeches in which he made occasional references to the sub-treasury, paper money, and 
the exercise of executive power, but his speeches were mainly in answer to Democratic campaign charges, and in appeals to the old soldiers and farmers which were far more effective than those of either Clay or Webster in getting votes. For example, in his speech at Dayton, Ohio, on September Io, I840, Harrison said: "I am not a professional speaker, nor a studied orator, but I am an old soldier and a farmer, and as my object is to speak what I think, you will excuse me if I do it in my own way," whereat we are told that there were "shouts of applause and cries of "the old soldier and farmer for us." "

The campaign was preëminently a singing campaign. A writcr describing the Whig meeting at Columbus says that "there was no organization and no speaking to amount to anything, the whole day being taken up in marching, hurrahing, and singing. It was the singing that did the work. Some of the songs I shall never forget. They rang in my ears wherever I went, morning, noon, and night, during the whole of that campaign. Men, women, and children did nothing but sing. It worried, annoyed, dumbfounded, crushed the Democrats, but there was no use trying to escape. It was a ceaseless torrent of music, still beginning, never ending. If a Democrat tried to speak, argue, or answer anything that was said or done, he was only saluted with a fresh deluge of music. If a Democrat would say that John Tyler was no Whig, the Whigs would join in a derisive laugh and a song which ended with the chorus:

And we'll vote for Tyler, therefore, Without a why or wherefore.

When compelled to listen to such arguments many of the old hardshell Democrats would become angry; but this only pleased the Whigs, and they 'rubbed it in' the harder."x

The following was one of the popular campaign songs:

I Norton, The Tippecanoe Campaign, p. 374. 


\section{The Political Campaign of 1840 . 99}

In a cabin made of logs,

By the Riverside,

There the Honest Farmer lives

Free from sloth and pride.

To the gorgeous palace turn

And his rival see

In his robes of regal state, Tinselled finery.

See the farmer to his meal Joyfully repair,

Crackers, cheese, and cider too, A hard but homely fare.

Martin to his breakfast comes

At the hour of noon,

Sipping from a china cup

With a golden spoon.

Martin's steeds impatient wait

At the palace door,

Outriders behind the coach

And lackeys on before.

One of the most popular songs ran in this way:

What has caused the great commotion, motion, motion,

Our country through?

It is the ball a-rolling on, on,

For Tippecanoe and Tyler too-Tippecanoe and Tyler too,

And with them we'll beat little Van, Van, Van;

Van is a used up man;

And with them we'll beat little Van.

Another song depicted the expected arrival of "Farmer Harrison" at the White House and there finding "Prince" John Van Buren and his aristocratic friends making merry over their champagne.

They were all very merry and drinking champagne,

When Farmer impatient knocked louder again,

$\mathrm{Oh}$, Oh, said Prince John I very much fear

We must quit this place in the very next year. 
Colonel Richard M. Johnson, the Democratic candidate for Vice-President, had fought with great credit, as well as had Harrison, at the battle of Tippecanoe, but he was sung out of the campaign in a song, one couplet of which was as follows:

They shout and sing, Oh, humpsey dumpsey, Colonel Johnson killed Tecumseh.

After the Maine election the Whigs added another song to their repertoire:

\author{
And have you heard the news from Maine \\ And what old Maine can do; \\ She went hell bent \\ For Governor Kent \\ And Tippecanoe and Tyler too, \\ And Tippecanoe and Tyler too.
}

All the historians who write from personal recollection of this campaign unite in describing it as partaking more of the character of a carnival of hilarity than of one in which there was anything like a sober discussion of important political questions. Benton says of it: "The class of inducements addressed to the passions and imaginations of the people were such as history blushes to record. Log cabins, coonskins, and hard cider were taken as symbols of the party, and to show its identification with the poorest and humblest of the people; and these cabins were actually raised in the most public parts of the richest cities, ornamented with coonskins after the fashion of frontier huts, and cider drank in them out of gourds in the public meetings which gathered about them; and the virtues of these cabins, these skins, and this cider were celebrated by traveling and stationary orators. The whole country was put into commotion by traveling parties and public gatherings. Steamboats and all public conveyances were crowded with parties singing doggerel ballads made for the occasion accompanied with the music of drums, fifes, and fiddles, 


\section{The Political Campaign of 1840}

and incited by incessant speaking. A system of public gatherings was got up which pervaded every State, county, and town-which took place by day and by night, accompanied by every preparation to excite; and many of which gatherings were truly enormous in their numbers-only to be estimated by the acre; attempts at counting or computing such masses being out of the question. By arts like these the community was worked up into a delirium and the election was carricd by storm." $\mathrm{x}$ George W. Julian says that it was a campaign characterized by "monster meetings and music, its infinite drolleries, its rollicking fun, and its strong flavor of political lunacy." Andrew D. White describes the campaign as follows ${ }^{2}$ :

"The campaign was an apotheosis of tomfoolery. General Harrison had lived the life mainly of a Western farmer and for a time, doubtless, exercised amid his rude surroundings the primitive hospitality natural to sturdy Western pioneers. On these facts the changes were rung; in every town and village a log cabin was erected where the Whigs held their meetings and the bringing of logs with singing and shouting to build it was a great event; its front door must have a wooden latch on the inside, but the latchstring must run through the door; for the claim which the friends of General Harrison especially insisted upon was that he not only lived in a log cabin, but that his latchstring was always out, in token that all his fellow-citizens were welcome at his fireside. Another element in the campaign was hard cider. Every log cabin must have its barrel of this acrid fluid as the antithesis of the alleged beverage of President Van Buren at the White House. He, it was asserted, drank champagne. . . . Another feature at the log cabin and in all political processions was at least one raccoon; and if not a live raccoon in a cage, at least a raccoon skin nailed upon the outside of the cabin. This gave local color, but hence came sundry jibes from the

'Benton, Thirty Years, vol. ii., pp. 205, 206.

- Autobiography, vol. i., p. 47. 
Democrats, for they were wont to refer to the Whigs as 'coons' and to their log cabins as 'coon-pens.' . . . Among the features of that period which excited my imagination were the enormous mass meetings, with processions, coming in from all points of the compass, miles in length, and bearing every patriotic device and political emblem. Here the Whigs had infinitely the advantage. Their campaign was positive and aggressive; on platform wagons were men working at every trade which expected to be benefited by Whig success; log cabins of all sorts and sizes, hard cider barrels, coon-pens, great canvas balls, which were kept 'a-rolling on,' canoes such as General Harrison had used in crossing Western rivers, eagles that screamed in defiance, and cocks that crowed for victory. . . . Against all this the Democrats, with their negative and defensive platform, found themselves more and more at a disadvantage; they fought with desperation, but in vain."I

It will be noted that throughout the campaign there was little discussion of the slavery question. The South felt assured that the interests of slavery would be protected in

'See also Julian, Political Recollections, p. Ir; E. D. Mansfield, Personal Memoirs, p. 3 I I. One of the strangest episodes in American political history, that suggests something like political retribution, is shown in the gubernatorial campaign in Indiana in 1876 . In that year, the financial conditions following the panic of 1873 were much like those which in 1840 followed the panic of 1837 . Many persons had lost all their property; factories were closed; building operations of all kinds were almost suspended and the period was one of general distress. The Republicans had nominated as their candidate for governor, Benjamin Harrison, a grandson of William Henry Harrison, and the Democrats had nominated James Williams, an honest man of irreproachable private character, but far inferior intellectually to Harrison. He had been a farmer and throughout the campaign wore a suit of blue jeans. The Republicans, who should have remembered the campaign of 1840 , committed the grievous mistake of ridiculing him by nicknaming him "Blue Jeans." The Democrats at once took up the nickname and the people voted for him as the exponent of retrenchment and economy in public affairs and the representative of the poor against the rich, and he was elected by a large majority. 


\section{The Political Campaign of 1840}

the event of the election of either of the presidential candidates. In the North the Whigs were too busy in making $\log$ cabins and canoes and in shouting and singing for "Tippecanoe and Tyler too" to think much of anything else, and the voices of the Democrats were drowned in the general din. It is manifest that the politicians, both Democratic and Whig, at least those of the North, were anxious to smother the further agitation of the slavery question. But the Garrisonians were still fulminating against slavery and the Birney Abolitionists were making a bold though hopeless fight for their candidate. It was largely because of their combined efforts that the antislavery fires in the North were kept from going out entirely. Looking back over the threescore and ten years that have passed since the campaign of 1840 we may laugh at its tomfoolery, but we must admit that it was less harmful than the wholesale corruption that has marked some of the campaigns since the close of the Civil War.

The Democrats stood their ground, but their attempts to beat back the overwhelming Harrison tide were as futile as were those of Mother Partington, when she sought to mop back the Atlantic. Harrison was elected by a large majority, carrying all the twenty-six States in the Union except seven and receiving 234 of the 294 electoral votes. Birney did not get any electoral votes and received only 7059 of the popular vote.

Harrison died on April 4, 1841, within a month after his inauguration. Had he lived his administration might have been as great a disappointment to the anti-slavery Whigs as was his death. He lived long enough, however, to rebuke in his inaugural message the anti-slavery agitators of the North. "Experience," he said, "has abundantly taught us that the agitation by citizens in one part of the Union of a subject not confided to the General Government, but exclusively under the guardianship of the local authorities, is productive of no other consequences than bitterness, alienation. discord, and injury to the very cause which is intended 


\section{I04 Political History of Secession}

to be advanced." Another part of his inaugural was construed as discountenancing any legislation for the abolition of either slavery or the slave trade in the District of Columbia.

With the death of Harrison the troubles of the Whigs began. Tyler had little or nothing in common with the Whig party. He began at once to antagonize its leaders and their favorite policies. Among his first official acts were his vetoes of the bills favored by the Whig leaders in Congress for the establishment of a national bank. He had invited all the members of Harrison's Cabinet to remain, but all resigned except Webster, Secretary of State, who lingered until May, I843, when he too resigned. The Whigs had now lost "Tippecanoe and Tyler too," the one by death, the other by desertion. Tyler's plight was peculiar, if not pitiable. He was repudiated by the Whigs who had elected him and by whom he was now spoken of as an apostate and renegade. The Democratic party refused to own him and he was utterly unable to muster a respectable following. Indeed, friendship for Tyler seemed to leave a taint upon the political character of every man who ventured to espouse his cause, so much so that it was difficult for Tyler to fill any offices the appointment to which required confirmation by the Senate. The number of his nominations rejected by the Senate probably exceeded those of all his predecessors combined.

Early in his administration schemes for the annexation of Texas, favored by Tyler himself, were set on foot. To these Webster was opposed and in May, I843, he resigned. He was succeeded by Hugh S. Legaré of South Carolina, and then by Abel P. Upshur of Virginia, and finally on March 6, I 844, by John C. Calhoun. Calhoun had before exercised a powerful influence over Tyler, but from the time of his appointment as Secretary of State his influence in the Cabinet was well-nigh supreme. All the energies of the Administration were now bent to secure the annexation of Texas. The treaty first proposed was rejected in the Senate 


\section{The Political Campaign of 1840}

by a decisive vote, a few only of the Northern Democrats, including James Buchanan, voting for it, while Benton, Clayton, Crittenden, and several Southern Senators voted

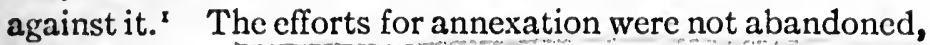
but were renewed in the shape of a joint resolution for annexation introduced in 1845 in the twenty-eighth Congress. It was well understood that the South was in favor of annexation chiefly for the reason that it offercd new territory for the extension of slavery, and equally well understood that annexation would probably lead to war with Mexico. For these reasons it was opposed in the North. During the discussions of the question repeated threats of disunion were heard in the South unless Texas should be admitted into the Union, and a movement looking to secession was begun in South Carolina, where annexation was enthusiastically favored. Such a movement also obtained some encouragement in some of the other cotton States, but elsewhere in the South the idea of secession was coldly received, and the proposal to hold conventions in Tennessee and Virginia with a view to secession aroused such vigorous protests in both States that the project of secession was abandoned. ${ }^{2}$

The opposition to annexation in the North was especially manifest in New England and particularly in Massachusetts. We sce again the cotton States, with South Carolina in the lead, arrayed against New England, with Massachusetts in the lead. The opposition was based in part upon the manner in which it was sought to admit Texas into the Union. But the chief reasons were those already stated. John Quincy Adams, Joshua R. Giddings, and others issued an address in 1843 in which it was asserted that the proposed annexation "would be a violation of our national compact, its objects and designs, and the great elementary principles which entered into its formation, of a character so deep and

'Benton, Thirty Years, vol. ii., p. 619.

See Young, American Statesmen, pp. 827, 828; Benton, Thirty Years, vol. ii., pp. 616-19. 


\section{I06 Political History of Secession}

fundamental, and would be an attempt to eternize an institution and a power of a nature so unjust in themselves, so injurious to the interests and abhorrent to the feeling of the people of the free States, as, in our opinion, not only inevitably to result in a dissolution of the Union, but fully to justify it; and we not only assert that the people of the free States ought not to submit to it, but we say with confidence they would not submit to it." In I844, the Massachusetts Legislature resolved that "the project of the annexation of Texas, unless arrested on the threshold, may tend to drive these States into a dissolution of the Union."

There were cogent reasons for annexation, wholly disconnected with slavery, that made it popular in other portions of the North, particularly in the Middle and Western States. Undoubtedly there was in the North considerable of that desire for expansion of territory that holds out alluring prospects to those seeking to better their condition by emigrating to new fields. There were also evident advantages to the nation in securing control of the territory on the Gulf of Mexico adjacent to the mouth of the Mississippi; advantages that were made more prominent by rumors that England and France were endeavoring to gain a foothold there. A published letter of ex-President Andrew Jackson favoring annexation also had great influence in rendering it popular. ${ }^{\mathbf{X}}$

At its National Convention at Baltimore in 1844, the Democratic party nominated James K. Polk for President and George M. Dallas for Vice-President and pronounced not only in favor of the annexation of Texas, but also in favor of the occupation of Oregon. Both projects were linked together in a resolution in which it was resolved: "That our title to the whole of the territory of Oregon is clear and unquestionable, and that no portion of the same ought to be ceded to England or any other power, and that the re-occupation of Oregon and the re-annexation of Texas

: See letter of Jackson to A. B. Brown, Young, American Statesman, pp. 822,823 . 


\section{The Political Campaign of 1840}

at the earliest practicable period are great American measures which this convention recommends to the cordial support of the Democracy of the Union."

The slavery question had now become an important and controlling factor in politics and the Southern Democrats insisted upon a presidential candidate committed to the annexation of Texas. Van Buren had declared himself opposed to annexation so long as Mexico refused to acknowledge the independence of Texas. At the Democratic National Convention in 1844 Calhoun would not allow his name to go before the convention as a candidate for the presidential nomination and Tyler was not to be thought of. Van Buren received a majority of the votes, but opposition of the Southern Democrats was such as to prevent him from getting the two thirds required to nominate, and so the nomination went to James $\mathrm{K}$. Polk, of Tennessee, who was known to be in favor of annexation. The Whigs nominated Henry Clay for President upon a platform noncommittal on either annexation or slavery. Clay had originally been opposed to annexation, but later in the campaign, in order to pacify Southern Whigs, who were in favor of annexation, he wrote a letter in which he stated that personally he had no objections to annexation. This got him into hot water with the Northern Whigs, who were as much opposed to annexation as the Southern Whigs were in favor of it. He continued to write letters, but the more he wrote the more he seemed to flounder, and his letters proved to be his undoing.

The Liberty party nominated James G. Birney for President. The result was that many Northern Whigs who would have otherwise voted for Clay voted for Birney. New York was a pivotal State and Birney drew enough votes from Clay to give the electoral vote of the State to Polk, and secured his election. In this campaign the Native American party, founded chiefly on opposition to foreigners and the Catholic Church, acquired considerable impor- 
tance as a political factor, but took no stand on the slavery question. ${ }^{\mathrm{x}}$

During the campaign William $\mathrm{H}$. Seward made an active canvass in behalf of Clay, in which he added a national to his established State reputation. He had been elected by the Whigs as Governor of New York in I 838 and had served for two years. His efforts now earned for him the leadership that he held from that time forward in New York and afterwards in the North of the opponents of the further extension of slavery. He fills a large place in the history of the nation but neither his contemporaries nor historical writers since his death agree in their estimates of his character. One of his marked characteristics was his excessive optimism. At an early period he began to cherish an ambition to be President of the United States. He was not wholly free from vanity. John Quincy Adams and Thurlow Weed, two men of diametrically different dispositions, were instrumental in forming his political character, and $\mathrm{Mr}$. Frederick Bancroft, one of his latest biographers, though not an overzealous eulogist, has advanced the theory that in Seward's public utterances we sometimes hear the voice of John Quincy Adams Seward and at other times we hear the voice of Thurlow Weed Seward. ${ }^{2}$

It was this seemingly dual character that has given rise to doubts as to Seward's sincerity at different periods of his life. Whatever impression his admiration of John Quincy Adams may have left upon his political character, it is certain that through life it showed the marks of Thurlow Weed's political tutoring. It is difficult to make a satisfactory compound of politician and patriot, and for this and the other reasons mentioned, it is difficult to assign Seward's proper rank as a statesman, or to reconcile some of the apparent inconsistencies and contradictions in his character. We cannot upon any theory account for some of Seward's conduct and utterances, such as his letter to Lincoln shortly

× McMaster, History of the United States, vol. vii., p. 369 et seg.

'Life of Seward, vol. i., p. 200; vol. ii., p. 86. 


\section{The Political Campaign of 1840}

after entering his Cabinet, except by attributing them to some mental idiosyncrasy, a term used by the doctors to designate the cause of some physical disorders which they cannot otherwise account for. At any rate Seward never attained the high level in the confidence of his country that John Bright secured in England, a level that under our system of politics, which so often subordinates honesty to expediency, it is difficult for any politician in this country to reach. ${ }^{\mathrm{x}}$

Seward never showed to better advantage than he did in the presidential campaign of 1844 . In his last speech in that campaign he said, "I desire to say that, as I have spoken here, I have everywhere spoken, not as a mere apologist of the Whig party or of its leaders, but as an advocate of the interests and the honor of my country paramount to the interest of all partisans and of all parties. . . . Let others hereafter do what they may, I shall stand on the

For a Democratic estimate of Seward we have the views of Jeremiah S. Black, Buchanan's Attorney-General, in a letter to Charles Francis Adams, Essays and Speeches of Jeremiah S. Black, pp. 134-157. The letter cannot be commended as a model of calm and dispassionate historical writing, but it is a good specimen of Black's clear and forcible English. Alluding to Seward's connection with the anti-Masons, in whose cause he first attained celebrity, Black says that Seward and his associates fostered the growth of anti-Masonry until it was large enough to sell-" "just as a dealer in live stock fattens a calf until it is ready for the market and then lets it go for what it will fetch." Alluding to Seward's refusal to support the Free-soil candidates in 1848 and to his support of General Taylor, a Southern slaveholder, which greatly grieved Seward's anti-slavery friends, Black charges that Seward thought a bird in the hand worth two in the bush; that the Free-soil party had nothing to give him, while "Whiggery was strong enough to make him a Senator in Congress, for which he was at that time a candidate." Of course Black denounces Seward's "higher law" and "irrepressible conflict" doctrines in the severest terms. Seward was, however, according to Black, true to the Whigs. "He went through thick and thin for tariffs, banks, internal improvements by the general government, distribution of surplus revenue-all their superstitions; and in 1840 he kindled in the general blaze of enthusiasm for hard cider and coonskins." 
same ground I now occupy, always demanding the abolition of slavery in America by political argument and suffrage, and by the constitutional action of all public authorities. I trust in the instincts of the Whig party, that it will prove faithful to that cause, and when it shall prove false in any hour of trial it will be time enough to look elsewhere for more effective agency."

After the election of Polk, but before his inauguration, ${ }^{2}$ the joint resolution for the annexation of Texas which Polk was known to favor passed both houses of Congress. It expressly reaffirmed the Missouri Compromise and in a speech favoring it James Buchanan, then Senator from Pennsylvania, expressed himself as pleased with it because "these resolutions went to reëstablish the Missouri Compromise by fixing a line within which slavery was to be in future confined. . . W Was it desirable again to have the Missouri question brought home to the people to goad them to fury? That question between the two great interests in our country had been well discussed and well decided; and from that moment he had set down his feet on the solid ground then established and there he would let the question stand forever. Who could complain of the terms of that compromise?"'3

I Seward's Works, vol. iii., p. 274.

3 Benton, Thirty Years, vol. ii., pp. 633, 634 .

2 March I, 1845. 


\section{CHAPTER VII}

THE OREGON BOUNDARY QUESTION: POLK'S BACKDOWN

NE starting into the study of the controversy between Great Britain and the United States over the boundary line between the two nations in the part of North America formerly known as the Oregon country, would scarcely expect to find that the slavery question was an important factor in the determination of it; yet such is the fact.

The 49th parallel of north latitude was agreed upon as the boundary line between Great Britain and the United States from the Lake of the Woods to the summit of the main ridge of the Rocky Mountains, but for half a century there was a dispute as to the boundary line west of the Rocky Mountains to the Pacific Ocean. The territory in dispute was then known as the Oregon country, embracing the lands now included in the States of Oregon, Washington, and Idaho, and parts of Montana and Wyoming. By treaties between Russia and Great Britain, and between Russia and the United States, the southern boundary of Russia's possessions in North America had been fixed at $54^{\circ} 40^{\prime}$, but no agreement was reached between Great Britain and the United States as to the boundary line which should divide the Oregon country.

The rule in actions at law between individuals for the possession of land is that the plaintiff must recover, if at all, upon the strength of his own title, and not upon the weakness of his adversary's, and that the law will not oust a defendant in possession under a claim of right until some 
one proves a better title. The same rule applies in controversies between nations over disputed territory. The chief difficulty encountered in establishing the claim of the United States to the whole of Oregon was not so much in proving flaws in Great Britain's title as it was in proving that the United States had a better one. Neither party to the controversy asserted any title based on any grant from the native occupants, but their claims were based largely on alleged discoveries and settlements, the boundaries of which were ill-defined, disputed, and conflicting. Great Britain also asserted claims based on treaties with Spain, and subsequently with Russia also, and the United States asserted claims based on treaties with France and Spain; but the titles of France, Spain, and Russia, based, as they were, on alleged discoveries and settlements, were very flimsy, and added little, if any, strength to the titles claimed by Great Britain and the United States based on their own discoveries and settlements. Moreover, Great Britain had been for years in actual possession, exercising the rights of sovereignty, of considerable portions of the disputed territory, which constituted the only outlet for her other North American possessions to the Pacific Ocean, and it was idle to expect that she would voluntarily surrender all of it to the United States.

The Monroe doctrine was not hatched until the controversy over Oregon had been pending for many years, and, of course, it had no influence with Great Britain in bringing the controversy to a conclusion. In consequence of their inability to agree upon a boundary line west of the Rocky Mountains, a treaty was concluded between the two countries, at London on October 20, I818, and ratified on January 19,1819 , by which provision was made for the joint occupation of the territory "that may be claimed by either party in the northwest coast of America west of the Stony [Rocky] Mountains" for a term of ten years. Before the expiration of the ten years, further attempts to agree having proved to be fruitless, another treaty was concluded on 


\section{The Oregon Boundary Question}

August 6, 1827, by which the provisions of the former treaty providing for a joint occupation were "indefinitely extended and continued in force," with a further provision that either of the contracting parties should have the right to abrogate the treaty on giving twelve months' notice to the other. Negotiations were continued, during which Great Britain claimed as far south as the $42 \mathrm{~d}$ parallel, while the United States claimed as far north as $54^{\circ} 40^{\prime}$. During these negotiations it became clear that Great Britain would never concede the claim of the United States up to $54^{\circ} 40^{\prime}$. It was equally evident that the United States would never concede any of the territory south of the 49th parallel; so that the principal controversy was narrowed down to the strip between the 49th parallel and the line of $54^{\circ} 40^{\prime}$.

All attempts at arbitration failed. Twice during the course of the negotiations the United States offered to compromise on the line of the 49th parallel but the offer was rejected by Great Britain. Afterward Great Britain proposed as a compromise the 49th parallel from the Rocky Mountains to its intersection with the northeasternmost branch of the Columbia River, and thence down that river to the Pacific Ocean, but the proposition was rejected by the United States. No substantial results were reached in these negotiations, and so the matter drifted along until the latter part of President Tyler's administration.

Meanwhile, both American and English immigrants, but mostly American, were moving into the territory and making settlements and there was constantly increasing danger of conflicts of jurisdiction inimical to peaceful relations between the two nations. The Americans already settled in the territory and those in other parts of the country, especially in the West and Northwest, who wanted to settle there, were clamoring for the government of the United States to extend the protection of its laws over the territory. In the year I843, many public meetings and 


\section{4 Political History of Secession}

conventions were held in the United States, at which resolutions were adopted favoring prompt action by the national government in reference to Oregon. At all, or nearly all, these meetings inflammatory resolutions were adopted, assuming the title of the United States to the whole of Oregon up to the line of $54^{\circ} 40^{\prime}$ to be unquestionable, denouncing the arrogance and insolence of Great Britain, and recommending the immediate occupation of the whole of the territory by the United States, the building of forts and stockades, and the maintenance of a fleet on the Pacific coast. ${ }^{\mathrm{I}}$

In April, I843, a call was issued for a convention of the Southern and Western States to be held at Cincinnati, Ohio, in July following, the purpose of which was to induce government action in relation to Oregon. The convention was held on July 3, 4, and 5. Colonel Richard M. Johnson of Kentucky, ex-Vice-President, presided. There were present some ninety or more delegates from six different states, in the Mississippi Valley. Among other resolutions adopted were the following:

"Resolved: That the right of the United States to the Oregon territory from $42^{\circ}$ to $54^{\circ} 40^{\prime}$ north latitude is unquestionable, and that it is the imperative duty of the general government forthwith to extend the laws of the United States over said territory.

"Resolved, further, That to encourage migration to and the permanent and secure settlement of said territory, the Congress of the United States ought to establish a line of forts from the Missouri River to the Pacific Ocean, and provide also an efficient naval force for the protection of the territory and its citizens."

The convention also put forth "A Declaration of Citizens of the Mississippi Valley," in which it was stated, "that, however indignant at the avarice, pride, and ambition of Great Britain, so frequently, lawlessly, and so lately evinced, we yet believe that it is for the benefit of all civilized nations

I McMaster, History of the U. S., vol. vii., p. 295. 


\section{The Oregon Boundary Question}

that we should fulfill a legitimate destiny; but that she should be checked in her career of aggression with impunity and dominion without right. . . . That, so far as regards our rights to the territory in question, we are assured of their perfect integrity, based, as they are, on the discovery and exploration by our own citizens and government and on purchase and cession from those powers having the pretense of the reality of any right to the same. That beyond these rights, so perfectly established, we would feel compelled to retain the whole territory in accordance with Mr. Monroe's universally approved declaration of $\mathbf{I} 823$ that the American continents were not thenceforth to be considered subjects for future colonization by any foreign power." The declaration wound up by remonstrating "against the possession of any part of the northwest coast of the Pacific Ocean by the powcr of Great Britain." Copies of the resolutions and declaration were sent to the President, the governors of the several States, and to each member of Congress. ${ }^{x}$ It is obvious that this jumble of "unquestionable title," "manifest destiny," Monroe doctrine, and denunciation of the "Blarsted Britishers, " was intended for political effect. It was well calculated to appeal to all who sought to better their condition by securing cheap homes, and especially to the bold and adventurous frontiersmen of the West, who were always pushing beyond the outposts of civilization.

The possibility of war with Great Britain was not entirely overlooked, but this rather increased than diminished the ardor of those in whose breasts there still rankled the feelings of resentment against England that had come down from generation to generation since the days of the War of the Revolution and the War of 1812 .

Various resolutions and bills looking to the extension by the United States of government control over the Oregon

'See an account of the meeting in Niles's Register of July 22, I843, vol. xiv., p. 327. See also McMaster, History of the U. S., vol. vii., p. 295. 
country had, from time to time, been introduced in Congress prior to the beginning of Polk's administration.

John Floyd, a member of the House from Virginia, had a scheme to effect a settlement on the Pacific coast at the mouth of the Columbia River, and in I82I he introduced a bill for that purpose. He urged, in support of his bill, the profits that would accrue from the whale-fishery, and also from the trade with China and India, which he predicted "would one day take that direction." The objections then urged to Floyd's scheme now make curious reading. "To most of the House these views appeared to be altogether visionary. Supposing the coasts of the Pacific to be much nearer to China than those of the Atlantic, yet it was thought that the transportation overland of from two to three thousand miles would more than counterbalance the saving in the sea voyage, and though that were not the case, it was said that when countries were so distant as the Atlantic States from the regions of the Pacific, and were separated by such a barrier as the Rocky Mountains, it was not probable they would continue long united. Having a separate set of local interests, and a separate commerce and foreign connections, a political union would be to both a source of more inconvenience than of benefit. With such a probable result, why, it was asked, should we be wasting the resources of the country to hasten the period of separation and expend money which must eventually be lost to us? These views seemed satisfactory to a large majority of the House, and on the mere question of calling up the bill which General Floyd had introduced for the occupation of the Columbia River, the vote against the consideration was one hundred to sixty-one."

In 1828 , Polk, then a member of the House from Tennessee, argued against the proposition to establish a territorial government for Oregon, on the ground that to erect a territorial government, enforce revenue laws, and grant land to settlers was a violation of the treaty with Great Britain

I Tucker, History of the United States, vol. iii., pp. 355-6. 


\section{The Oregon Boundary Question}

then in force. ${ }^{x}$ But the agitation for governmental action of some kind continued, and other bills for that purpose were introduced, one by Senator Linn of Missouri in 1838 . All these bills, however, had failed. President Tyler in his annual message to Congress in December, 1843 , declared his opinion, "after the most rigid and, as far as practicable, unbiased examination of the subject," that "the United States have always contended that their rights appertain to the entire region of country lying on the Pacific and embraced between latitude $42^{\circ}$ and $54^{\circ} 40^{\prime}$."

The controversy got into politics and, as before stated, ${ }^{2}$ the national Democratic platform adopted at Baltimore in 1844 contained a resolution favoring both the annexation of Texas and the occupation of Oregon. The reasons for linking together in one resolution two such dissimilar objects became clearer afterwards. The South was far more interested in the annexation of Texas than it was in the occupancy of Oregon, but the West and Northwest were far more interested in the occupation of Oregon than they. were in the annexation of Texas. To unite those favoring the annexation of Texas and those favoring the occupation of Oregon would add to the strength of both, and uniting the two objects in one plank of the Democratic platform was what may be called "shrewd politics." During the presidential campaign of 1844 there were no more inspiring political rallying cries than those of "All of Oregon or none" and "Fifty-four forty or fight."

After the election of Polk, the advocates of the occupation of the whole of Oregon up tu $54^{\circ} 40^{\prime}$ at once began to insist that the new administration should redeem its party's campaign pledges. In his inaugural address President Polk expressly approved the position of the Democratic National Convention on the Oregon question. He could scarcely have done otherwise, as the position of the Democratic party on that question had undoubtedly contributed largely to his election. After Polk's inauguration negotia-

z Cong. Debates, 2oth Cong., 2d sess., p. 130.

a Ante, p. 106. 


\section{8 Political History of Secession}

tions were resumed and the United States again proposed a compromise on the line of the 49th parallel, but without conceding to Great Britain the free navigation of the Columbia River. This proposition having been rejected, the proposition made before by the United States was, by Polk's direction, withdrawn, and title was asserted to the whole of the Oregon territory.

The President devoted a considerable portion of his annual message of December 2, 1845, to the Oregon question, reviewing the actions of his own and of the preceding administrations upon the subject.' In his message he referred to "the extraordinary and wholly inadmissible demands of the British government," and expressed the opinion that "no compromise which the United States ought to accept can be effected," and that the title of the United States to the whole of Oregon territory could be "maintained by irrefragable facts and arguments," and he advised that Congress consider "what measures it may be proper to adopt for the security and protection of our citizens, now inhabiting, or who may hereafter inhabit, Oregon, and for the maintenance of our just title to that territory." For this purpose he recommended that "the protection of our laws and our jurisdiction, civil and criminal, ought to be immediately extended over our citizens in Oregon." $\mathrm{He}$ also recommended the establishment of stockades and forts and an adequate force of mounted riflemen for the protection of immigrants while on their way to the territory. Continuing, he said that, "At the end of the year's notice, should Congress think it proper to make provision for giving that notice, we shall have reached a period when the national rights in Oregon must either be abandoned or firmly maintained. That they cannot be abandoned without a sacrifice of both national honor and interest, is too clear to admit of doubt."

Spurred by such a message, the Fifty-Four Forties, as Benton called them, were not slow to act, and the Oregon question was promptly taken up in both houses of Congress. 


\section{The Oregon Boundary Question}

In the House on December 19, I845, Stephen A. Douglas of Illinois, then chairman of the Committee on Territories, moved the adoption of the following resolutions:

"I. Resolved: that the title to any part of the Oregon territory south of the $54^{\circ} 4 \mathrm{o}^{\prime}$ of north latitude is not open to compromise so as to surrender any part of said territory.

"2. Resolved: that the question of title to that territory should not be left to arbitration."

On January 5, I846, C. J. Ingersoll, chairman of the House Committee on Foreign Relations, reported a joint resolution, providing, "That the President of the United States forthwith cause notice to be given to the government of Great Britain that the convention between the United States and Great Britain concerning the territory of Oregon of the sixth of August, 1827, signed at London, shall be annulled and abrogated twelve months after the expiration of the said term of notice conformably to the second article of the said convention of the sixth of August, I 827." Ingersoll's resolution was somewhat toned down by an amendment adding the words "that nothing herein contained is intended to interfere with the right and discretion of the proper authorities of the two contracting parties to renew or pursue negotiations for an amicable settlement of the controversy respecting the Oregon territory," and in this form the resolution passed the House on February 9, I846, by a vote of 163 to $54 .^{2}$

In the Senate on December 27, I845, Senator Hannegan of Indiana, one of the most ultra of all the Fifty-Four Forties, introduced the following resolutions:

"Resolved: that the country included within the parallels of 42 and 54 degrees and 40 minutes north latitude, and extending from the Rocky Mountains to the Pacific Ocean, known as the territory of Oregon, is the property, and part and parcel, of the United States.

"Resolved: that there exists no power in this government to transfer its soil and the allegiance of its citizens to the

× Cong. Globe, 29th Cong., Ist sess., p. 86.

a Ibid., p. 349 . 
dominion, authority, control, and subjection of any foreign prince, state, or sovereignty.

"Resolved: that the abandonment or surrender of any portion of the territory of Oregon would be an abandonment of the honor, the character, and the best interests of the American people."

Prolonged and exciting debates on the Oregon question followed in both houses of Congress, which disclosed a very belligerent spirit against Great Britain, especially in the West and Northwest. The general tone of the Democratic press throughout the country was equally belligerent. In the Senate the chief advocates of the Administration's Oregon policy were Senator William Allen of Ohio, chairman of the Senate Committee on Foreign Relations, Senator Lewis Cass of Michigan, Senator Edward A. Hannegan of Indiana, and Senator David Atchison of Missouri. Conspicuous among the supporters of this policy in the House was Stephen A. Douglas. The most eloquent and at the same time the most bitter of all the Fifty-Four Forties was Senator Hannegan. Although born in Ohio, he was of Irish descent and was animated by a hatred of Great Britain which he made no attempt to conceal. While the excitement in Congress over the Oregon question was at its height, in response to an invitation to attend a meeting of the friends of Vice-President Dallas in Philadelphia, on January 8,1846 , Hannegan sent a letter in which he proposed as a toast, "Oregon-every foot or not an inch; fiftyfour degrees and forty minutes, or delenda est Britannia;" to which the committee replied: "The honorable Edward A. Hannegan, the true-hearted American statesman, who truly represents the people on the Oregon question-the whole of it or none, Oregon or War."

It was not so difficult to meet the arguments of the FiftyFour Forties, which were of a very flimsy character, as it was to counteract their inflammatory appeals; appeals by

I Cong. Globe, 29th Cong., Ist sess., p. IoI.

2 Woollen, Biographical Sketches of Early Indiana, p. 212. 


\section{The Oregon Boundary Question}

which the whole country had been wrought up to frenzy; appeals based on the alleged arrogance of Great Britain, and upon the assumption of the certainty of victory of the great American republic over an effete monarchy, in which the seeds of dissolution were rapidly germinating; appeals that stirred afresh the feclings of resentment for all the wrongs, real and imaginary, ever inflicted by Great Britain upon this country and upon cvery other since the time of William the Conqueror. An example of the general style of these speeches is seen in the long tirade of Senator Allen of Ohio, ${ }^{\mathrm{r}}$ who said: "With these facts before us, does it become us, as the representatives of a free and gallant people-does it comport with the interest and honor, with the safety of this government-does it become our glorious position as the first republic on earth, and the safeguard of all others, to cringe, and quail, and cower to Great Britain, as often as she chooses to set up a claim, without right, to our soil, and to shake her trident in our face?"

Then he went on to recount the manifold aggressions of England: "I allude not to the numberless aggressions committed by England against us-aggressions beginning before the treaty of peace of 1783 was dry-aggressions extending to and resulting in the late war. I say nothing of the manifold outrages committed upon our commerce-nothing of the impressment of our seamen-of her studied delay in delivering certain posts and islands, as by that treaty she was bound - of her protracted refusal to execute the boundary, as well as the commercial, provisions of that treatyof her constant efforts to traduce the character and outrage the flag of our country in all parts of the world. I say nothing of her horrible practice during the late war of bribing the pitiless Indian to butcher our women and children of the West, whilst asleep at night in their cabins. I say nothing of her having, within a few years past, despatched an armed force, at midnight, to invade our shoresto board an American steamer moored to our soil-to cut

- Cong. Globe, 29th Cong., rst sess., App., 836. 
it from its moorings-to murder a part of its crew-to leave others for the murder of the flames-to put the torch to the boat, and then to send her, freighted with the dead bodies of our countrymen, headlong over the cataract of Niagara. Of these things I speak not. No, I shall begin with the treaty signed at Ghent on the 24th of December, 1814."

Expatiating on the internal weakness of the British Empire, which he asserted portended its speedy dissolution, and upon the great advantages the United States would have in case of war between the two nations, he asserted that England "will not, because she dare not, all other state reasons aside, make war, single-handed, against the United States for the Oregon territory." $\mathrm{He}$ wound up with this extraordinary peroration: "In these things, sir, it is that the strength of our, and the weakness of the British government, consists. Ours, resting upon the heartshers, upon the backs of the people. What, then, have we to do, to secure Oregon? Extend over it our laws. What else have we to do for its defense? Tell the people the truth. Tell them it is their soil. Tell them this, prove it to them-as we have before told them, and before proven it. Tell them that arrogant England-their hereditary enemy, the enemy of all free governments-is seeking to snatch it from them, to fence us out from the Pacific Ocean, to belt us about yet more closely with her kingly despotism. Tell them these things, and then ask them if they will surrender this large part of their country-surrender it to that government which, in two wars, employed savages to hack to pieces, in cold blood, the women and children of America - surrender it to that government which hates ours, because it is free-which envies our people for their happiness in proportion to the misery of its own. Tell them these things, and ask if they are ready thus to surrender this vast territory from the mere dread of invasion by a rabble of armed paupers, threatened to be sent by a bankrupt government, whose whole power of the sword and dungeon is required to stifle the cries of famine at home, or to protect 


\section{The Oregon Boundary Question}

its own life against the uplifted hands of starving millions. Tell them these things, ask them if they are ready to make this surrender. Ask the American people this and they will give you an answer which shall make the British Empire tremble throughout its whole frame and foundation."

Senator Hannegan of Indiana and Senator Cass of Michigan spoke in much the same strain. Hannegan's speech ${ }^{x}$ was a model of its kind, commonly designated as "spreadeagle" eloquence. "Where is your warrant," he asked, "for ceding away five degrees and a half of Oregon? Where is your warrant for withdrawing the ægis of your Constitution and laws from any, even the meanest of your citizens who may have fixed his habitation on the most remote and sterile point in all your dominions? Is the Senator from South Carolina prepared and willing to transfer any, even though it be the poor pioneer, whose sinewy form first parts the tangled forests to let in upon the eternal solitudes the light of day; from whose rude hut the first smoke of the paleface curls in the wilderness? Shall freedom's Sabbath be no more for him? Far, far away and lonely as he is, he has his domestic altar, and before it God and freedom are worshiped together. $\mathrm{He}$ has his household gods-the names his mother taught him, perhaps in South Carolina, perhaps in Massachusetts, when he, a fair-haired boy, played by her side. He has taught in turn, and he hears them daily from lisping childhood, and first of these is Washington. Where is the steel-clad hand, where the iron heart, that would break down this altar, desecrate this worship, and change upon his children's lips the name of Washington for England's Queen? Rather, were that hut mine, should its fire go out forever; rather, far rather, should the serpent wind its devious way among the lifeless bodies of the best loved of my heart, to coil and hiss unharmed upon the hearthstone. . . But it is not the West alone that forbids it. History, speaking from the sepulcher of the sainted dead, forbids it. The shades of Washington,

'January 24, 1846, Cong. Globe, 29th Cong., 1st sess., App., p. 312. 
of Adams, of Henry, of the whole host of revolutionary sires, forbid it. A still small voice from Lexington and Concord forbids it. The holy blood which ran in torrents on the parched fields of Monmouth and Brandywine and Camden forbids it. All the past-the specter form of the past with mournful looks-forbids it. The present forbids it. Seven tenths of the American people forbid it. The future with one long-continued, stern, unbroken front forbids it. By all the past glory of our country, and in the name of posterity, of the unborn millions, whose fortune it shall be to direct free and proud America on her high destiny, I protest against the dismemberment of her territory, the abandonment of her interests, and the sacrifice of her honor, before any and every altar of earth, but especially and above all others, before the altar of English ambition."

Great Britain had not been unmindful of what was going on in the United States in reference to Oregon and was now in fighting mood. A British warship was ordered to the Oregon coast and arrangements were made for a military reconnaissance of the territory in order to be better prepared for war, if war should ensue.

The gravity of the situation was now apparent to the thinking people of both Great Britain and the United States. Sober-minded persons in this country now realized that the controversy over Oregon had passed beyond the domain of party politics, and that it must be settled by other arguments than those that had been heard in stump speeches in the presidential campaign. It was also realized that a halt must be called in the headlong policy of the Administration, and a curbing of the impetuosity of the Fifty-Four Forties, or that the inevitable result would be war with Great Britain, and that at no distant day.

Practically, as already stated, the controversy had been narrowed down to a dispute over the strip lying between the 49th parallel and the line of $54^{\circ} 40^{\prime}$. No question of principle or national honor was involved. Would it be wise, it was asked, to precipitate war with Great Britain 


\section{The Oregon Boundary Question}

over this strip, at least so long as there remained any reasonable prospect of settling the controversy by peaceful negotiations? It had been confidently asserted by the Fifty-Four Forties that the claim of the United States to the disputed territory was "unquestionable," but it was now very plain that it was questioned, and very vigorously questioned, by Great Britain. The more the matter was discussed in Congress, the clearer it appeared that the claim of title of the United States to the line of $54^{\circ} 40^{\prime \prime}$ rested upon very flimsy foundations. This was shown by Senator Benton of Missouri, in an elaborate and exhaustive discussion of the question in a speech made by him in the Senate. ${ }^{\mathbf{x}}$ Senator Reverdy Johnson of Maryland also made a strong speech in accord with Benton's. ${ }^{2}$ Webster, Calhoun, and other able statesmen in Congress, while not going so far as Benton, were nevertheless of the opinion that the claim of the Fifty-Four Forties was too doubtful to justify the risk of war to maintain it.

War with Great Britain, at any time, was quite another business from war with Mexico, and Great Britain had never been better prepared for war over Oregon than she was then. She was mistress of the seas; she had no foreign wars on hand of any consequence; she could reach Oregon by sea or land far more easily and quickly than could the United States. The United States had then only about five thousand miles of railroad, all told; there were no roads of any kind suitable for transporting men and munitions of war to Oregon; there was no navy fit to cope with that of Great Britain, and what few vessels there were would have been compelled to make a long and difficult voyage around Cape Horn in order to reach the Oregon coast. The damage to the commerce of the country in the event of war with Great Britain was evident; the probable damage to the cotton industry of the South was not overlooked. Nor

${ }^{x}$ Cong. Globe, 29th Cong., Ist sess., pp. 851, 857, 894.

Id., p. $48 \mathrm{r}$. 
was the probability of an alliance between Great Britain and Mexico in the event of war with the latter, then imminent, unheeded.

Considering the whole matter carefully, sober-minded statesmen foresaw the probability that in case of war, this country, instead of gaining "all of Oregon," would lose it all, and that an alliance between Great Britain and Mexico would bring war to the very threshold of the South; and, if so, that there would be more danger of losing Texas than there would be probability of acquiring additional territory from Mexico.

For months the whole country was in a state of feverish suspense and anxiety. There were other considerations that, although not openly expressed, undoubtedly had great influence with the Southern leaders. An unsuccessful war with Great Britain would not only be disastrous to the country, but disastrous to all who had advocated it, and might possibly be extremely so to the South. On the other hand, suppose that, in the event of war, the United States should succeed in acquiring all of Oregon territory: its soil and climate were not adapted to slave labor; its inhabitants were opposed to slavery; and the result would be more free States and more senators and representatives in Congress hostile to slavery.

Such harangues as those of Allen and Hannegan, however effective they may have been at the hustings, had little weight with the Senate and called forth several caustic responses. The most significant came from the Southern members of Congress. Senator Crittenden of Kentucky made an admirable speech ${ }^{\mathrm{i}}$ in which he said: "No hasty conclusions between individual negotiators; no little pouting and fretting or strutting upon the stage can be any justification to the American people, or before the world at large, that out of these cabinet squabbles or diplomatic quarrels two nations and the world shall be set to war and to cut each other's throats. No, sir, the people of the United

$\therefore$ February 26, I846, Cong. Globe, 29th Cong., Ist sess., p. 431. 
States will regard it in a different light. We have no necessity to go to war to make a character. None. We have a character, sir. We are not obliged to set up idle pretensions lest the world doubt or mistrust us." In a later speech ${ }^{x}$ he said: "The matter in dispute involves no question of national honor. It is simply a question of boundary; and in such a case an honest statesman, before procceding to the extremity of war, would stop a little to compare the value and importance of the territory in dispute with the cost and consequences of that war. 'Greatly to find a quarrel in a straw' is a sort of ambition to which the world no longer gives countenance. All such heroics have passed away and have given place to the juster sentiment which requires of the statesman and ruler, intrusted with the interest and happiness of his country, to save and protect it from the calamity of unnecessary war."

Senator Berrien of Georgia, made a strong speech, ${ }^{2}$ in which he said: "On such a subject all mere declamation is obviously out of place. Excited appeals to our sense of national honor and to our patriotism; exaggerated descriptions of the arrogance and impotence of Great Britain, and glowing representations of our own prowess, seem to me alike inappropriate to the place and to the occasion. The attempt is merely vain, to influence the conduct of any man who has mind enough to form his own judgment, and 'nerve' enough to do its bidding, by appeals of this description. Why, sir, who is insensible to the calls of national honor? Who does not know and regret, that it may sometimes be necessary to vindicate the honor of the nation on the battlefield? Who does not know and rejoice that a bloody hand is not the only symbol of a nation's honor? And patriotism-truly sir, patriotism is a virtue which it behooves freemen especially to cherish. But what American Senator, what American citizen, requires to be reminded of this duty? The arrogance of Great Britain! For aught

:April 16, 1846, Cong. Globe, Id., App., p. 842.

' March 17, 1846, Id., App., p. 505. 
I know, sir, arrogance may be characteristic of the AngloSaxon. I quarrel with no man who asserts that it is so, and yet, speaking for myself, I would be ashamed to say that I had found any exhibition of this feeling in the recent correspondence of the British plenipotentiary. The future impotence of the British Government is a subject for the speculations of the political philosophers, who see, or think they see, sown broadcast in her extended empire and separated dependencies, the seeds of her dissolution. But how do these speculations, whether they be founded on reason or are merely visionary, affect the question before us? We know, unless we close our eyes to facts which are obvious to all the world beside, that Great Britain is at this moment in the fullness of her strength, and prepared to inflict a blow which it will require all our energy to repel. With a view to our decision of this question, that is all which it concerns us to know. And our own prowess! We, it is said, need not fear the conflict. We are prepared, or can be so on the instant, to win the triumphs which await us. God forbid that I should depreciate the valor of my countrymen; but if we are to enter into this conflict, if Great Britain is once more to become our adversary on the battlefield, I trust we shall not rely upon her impotence, but prepare to meet 'a strong man armed.' And, lest we should prove ourselves capable rather to endure blows than to inflict them, I hope we shall not calculate too largely on our own undeveloped energies-on our capacity to 'extract sunbeams from cucumbers,' of which the process is difficult, or what is equivalent, to make men-of-war out of packet-ships."

Another significant speech was that of William L. Yancey, a member of the House from Alabama, afterwards characterized as the "Prince of Fire Eaters." I After referring to the territory that the United States had acquired by peaceful means, "more magnificent in domain, and more pregnant with national grandeur, than any that the blooddripping eagles of imperial Rome ever flew over in their × January 7, 1846, Cong. Globe, Id., App., p. 85. 


\section{The Oregon Boundary Question}

conquering and devastating career," he said: "Yet, though such are the fruits of such a policy, I see around me crowds of American statesmen, yearning to break this mighty and glorious spell; whose hearts are panting for war, whose hands itch to grasp the sword, whose feet are raised to trample the olive branch, whose every impulse is to grapple with England, to decide by the terrible law of arms a territorial right.

"Sir, I respect, though I must disapprove of, the feeling which animates the men of the West on this question. Sympathy for their friends in the far-off Oregon; impatience -indignant impatience, it may be - at any restraint which England may have thrown in the way of a full assertion of our rights there; and a longing, natural to brave hearts, to avenge the oppressions which that haughty power may have committed for centuries upon the nations of the earth, are all feelings, which, however much I may deem well calculated to cloud the judgment upon a matter of such grave import, are likewise well calculated to elicit a sympathetic response from every American heart. Strong, too, in all the elements of greatness and strength, we may not fear a contest with any nation.

"But we should be careful lest prosperity and continued success should blind us to consequences-lest, in our pride, we do not fall. Sir, it cannot be treason, it cannot be cowardly, it cannot be unwise, for us calmly and dispassionately to consider our true position in this matter; and I beg of our friends, in the West in particular (and surely a Southerner may well claim that sacred relationship to the sons of the West), that if some of us of the South are disposed to put a curb on this hot impetuosity, we shall not be deemed their enemies on this great issuc. Like them, I am for all of Orcgon. With them, I believe our title to it to be complete against the world. My only desire is, that we so regulate our movements as to be able to secure it all. To do so is not without great difficulty. On whichever side you turn that difficulty stares you in the face. To overcome it 
requires moderation-calculation as well as firmness. Haste and impetuous valor may lose us all or give us but a part."

Calhoun's position was well understood. He had said in his discussion of the Oregon question in 1842 that, "time is acting for us, and if we shall have the wisdom to trust its operation it will assert and maintain our right with resistless force, without costing a cent of money or a drop of blood. There is often in the affairs of government more efficiency and wisdom in non-action, than in action. All we want to effect our object in this case is 'a wise and masterly inactivity.' Our population is rolling toward the shores of the Pacific with an impetus greater than we can realize. ... It will soon, far sooner than anticipated, reach the Rocky Mountains, and be ready to pour into Oregon territory, when it will come into our possession without resistance or struggle, or, if there would be resistance or struggle, it would be ineffectual. We should then be as much stronger there comparatively than Great Britain, as she is now stronger than we are, and it would then be as idle in her to attempt to assume and maintain her exclusive claim to the territory against us, as it would now be in us to attempt it against her." ${ }$

He made a speech in opposition to Hannegan's resolutions, ${ }^{2}$ in which he advocated a pacific course for the adjustment of the disputed boundary, saying that, "if war should come it will be no common war," and that, "while he would give every support to his country, he would hold those responsible by whose rashness it had been provoked," and that he believed "that precipitancy will lose you Oregon forever, no, not forever, but it will lose you Oregon in the first struggle and then it will require another struggle hereafter, when we become stronger, to regain it."

In the progress of the discussions in Congress, there was a singular shifting of party lines. Polk might naturally

× Cong. Globe, 27th Cong., 3d sess., App., p. 139.

2 Dec. 30, 1845, Cong. Globe, 29th Cong., Ist sess., pp. I09I, 10. 
have expected, and probably did expect, the support of his own party, and especially the support of the Democratic Southern leaders. But most of the Southern Democrats, following the lead of Calhoun and Benton, opposed the Administration's Oregon policy. On the other hand general surprise was created by the course of the venerable exPresident, John Quincy Adams, who made an elaborate speech in support of the claim of all of Oregon up to the line of $54^{\circ} 40^{\prime}$. He said that "there would be no war in his opinion, even if we persevered in these measures, and that what he most feared was that our rights would be sacrificed by the backing out of the Administration and its supporters." $x$

Stranger still was the position of Joshua R. Giddings, the well-known Abolition member of the House from Ohio. Giddings made a remarkable speech. ${ }^{2}$ Referring to the zeal and the warlike spirit with which the Southern leaders had advocated the annexation of Texas, and contrasting this with the mild and conciliatory tone in which they discussed the Oregon question, and their apparent reluctance to adopt any policy that might lead to war with Great Britain, he taunted them by insinuating that they had acted in bad faith towards their Northern allies, that having secured the annexation of Texas, they were now ready to desert them and let them fight the battle for Oregon alone. He said: "Last year our Southern friends expressed great anxiety for 'Texas and the whole of Oregon.' Having obtained Texas, and with it the balance of political power, they now demand an abandonment of their policy, and that the government of the nation be left in their hands, and Oregon remain as it is. They now see difficulties before them; dangers present themselves to the further pursuit of their plan of territorial aggrandizement. They have suddenly called to mind the declaration of British statesmen, that 'a war with the United States will be a war of

Cong. Globe, Id., p. 324.

- January 5, I846, Id., App., p. 73. 
emancipation.' They see in prospect the black regiments of the British West India islands landing among them, and their slaves flocking to the enemy's standard. Servile insurrections torment their imaginations; rapine, blood, and murder dance before their affrighted visions. They are now seen in every part of the hall, calling on Whigs and Democrats to save them from the dreadful consequences of their own policy. Well, sir, I reply to them, This is your policy, not ours; you have forced us into it against our will and our utmost opposition; you have prepared the poisoned chalice, and we will press it to your lips until you swallow the very dregs." Giddings, like Adams, did not believe that there would be any war with England, and gave his reasons in these sarcastic but prophetic words: "But, Mr. Speaker, I am unwilling to resume my seat until I express my perfect conviction that this policy cannot be carried out by the party in power. The Northern Democrats will soon be deserted by their Southern slaveholding allies. They have been betrayed by the slave power. Texas is admitted, and the Southern wing of the Democratic party will now desert their Northern friends, and leave Oregon where it is. They are like the militia captain who, when going into battle, informed his men that 'as he was lame, he would commence his retreat then; but his soldiers, being quick upon the foot, he thcught they could overtake him if they waited until after the battle.' If this resolution should be adopted, the Executive would find means to escape from the dilemma into which this Southern policy has precipitated him. It is most obvious to my judgment that he cannot be driven into a war with England. As I have already stated, a war with that nation must prove the total overthrow of slavery. Every reflecting statesman must see this as clearly as any event can be foretold by human perception. I do not think the slaveholding portion of the Democratic-party-were aware that the carrying out of their Baltimore resolutions would sacrifice that institution. They rather believed that by obtaining Texas, the price of human flesh would be 


\section{The Oregon Boundary Question}

enhanced and slavery supported. The consequences of seizing upon the 'whole of Oregon' were not considered. Mr. Polk, in his inaugural address, and in his annual message, evidently overlooked the momentous effect which his twicedeclared policy would produce upon the slave interest to which he is indissolubly wedded. He and his Cabinet and his party have made a fatal blunder. They will soon discover their error and will recede from their position. With the same degree of confidence that I have in my own existence, I declare, that they will, before the nation and the world, back out from their avowed policy, and will surrender up all that portion of Oregon north of the 49th parallel of latitude, or let the subject remain as it now is. I wish to place this prediction on record for future reference. Nor would I confine my remarks to the Democratic party. Those Southern slaveholding Whigs who voted for Texas will now, if necessary, turn around and vote to give up a part of Oregon. It is a question between the slave States and the free States; and the vote when taken will, with few exceptions, exhibit that character. The great masterspirit of Southern policy [Calhoun] has left his retirement and taken his position in the other end of the capitol, for the avowed purpose of now defeating the identical policy, the promotion of which occupied his whole attention only twelve months since. He is an adept in his political versatility. He will, however, carry the President and the Southern statesmen generally with him, and will defeat the measure to which he and his party stand solemnly pledged. Yes, sir; should this resolution pass both houses of Congress, the President will find means to give up a part of Oregon, or even the whole of it, rather than subject the institution of slavery to the sure destruction which a war with England would bring upon it. I again repeat, what I have endeavored to impress upon you, gentlemen, that this policy is not mine. I wash my hands of it. I feel a deep and an abiding conviction, that, if carried out, it will inevitably overthrow our government, and dissolve the Union; but 
that these consequences will be retarded by a continuance of the policy, rather than by leaving the government subject to the slave power, as it now is. By carrying out the policy, it will place the Northern and Southern portions of the Union upon terms approximating to equality. And when, from its broad extent, this Republic, like the Roman Empire, shall fall asunder of its own weight, the free States will redeem and purify themselves from the foul disgrace of supporting an institution hated of men and cursed of God."

He was against the policy of extending our territory, but, inasmuch as Texas had been annexed, he wanted all of Oregon territory with which to offset new free States against the slave states which would be, or might be, made out of Texas and the territory expected to be acquired from Mexico. If war with England should result, he admitted that it would be attended with great destruction to the commerce and wealth of the North. But the greatest difficulty of the North would be, he said, not "in defending ourselves or in taking Canada," but that "our principal burden will be the protection of the South, the weak, helpless, dependent, slaveholding South." In case of war, he predicted that "all the slave States collectively would be unable to do more than protect themselves against their internal foes."

It is probable that both Adams and Giddings were looked upon by the Southern leaders in the light of "gift-bearing Greeks." Giddings's speech in particular, though professedly in support of the President's policy, did far more to condemn it in the eyes of the Southern leaders than any speech he could have made in direct opposition to it.

Senator Hannegan, speaking from an entirely different standpoint from that of Giddings, dwelt upon the fact that in the speeches of the Southern members upon the Oregon question, there was an entire absence of the belligerent tone that characterized their speeches in favor of the annexation 


\section{The Oregon Boundary Question}

of Texas, and charged them with Punic faith in having deserted and betrayed their allies in the West and Northwest who had aided them in securing the annexation of Texas. "There had been," he said, "a singular course pursued on this Oregon question, and with reference to which he must detain the Senate a moment. It contrasted so strangely, so wonderfully, with a precisely similar question-the annexation of Texas. Texas and Oregon were born the same instant, nursed and cradled in the same cradle-the Baltimore convention - and they were at the same instant adopted by the Democracy throughout the land. There was not a moment's hesitation, until Texas was admitted; but the moment she was admitted the peculiar friends of Texas turned, and were doing all they could to strangle Oregon! But the country was not blind or deaf. The people see, they comprehend, and he trusted they would speak. It was a most singular state of things. We were told that we must be careful not to involve ourselves in a war with England on a question of disputed boundary. There was a question of disputed boundary between us and Mexico; but did we hear from the same quarter any warnings against a collision with Mexico, when we were about to consummate the annexation of Texas? We were told by those who knew something of those matters, that the Nueces was the proper boundary of Texas! And how did they find the friends of Texas moving on that occasion? Did we, for a single instant, halt on the banks of the Nueces? No; at a single bound we crossed the Nueces, and the blasts of our trumpets and the prancing of our war horses were heard on the banks of the Rio del Norte, one hundred miles beyond. Nearly one hundred miles of disputed territory gives no cause for a moment's hesitation! There was no negotiation then, so far as Mexico was concerned; we took all. But when Oregon is brought into question, we are called on, as an act proper and right, to give away a whole empire on the Pacific if England desire it. He never would consent to a surrender of any portion of the country 


\section{I36 Political History of Secession}

north of $49^{\circ}$, nor one foot, by treaty or otherwise, under $54^{\circ} 40^{\prime}$." 1

Replying to Senator Calhoun, he said: "A single word as to the precipitancy of which the distinguished Senator had spoken. Perhaps it would not be out of place to say that the precipitancy of the honorable Senator's course in relation to the annexation of Texas presented a remarkable contrast to his 'wise and masterly inactivity' with reference to Oregon. He did not intend to charge any improper motives in the distinguished Senator; but it appeared strange to him that, when a question of territorial acquisition arises in the Northwest, there should be found such a backwardness on the part of Southern gentlemen to give their aid. Precipitancy in relation to Texas was wise, in the view of the Senator from South Carolina, but it would not be wise in the case of Oregon. In the first instance, the 'golden opportunity' was to be seized. Now, Heaven knows, time enough has been given to maturing plans; it is now time to act. The two countries are arrayed front to front, and my life on it, if it were a question between the United States and Mexico, on the possession of Cuba or California, or if it were for the acquisition of some territory farther still (for he had heard a whisper of Panama), this would be the golden moment."

But the tide had already begun to set strongly against the policy of the Fifty-Four Forties. The Senate refused to adopt the joint resolution for notice to Great Britain passed by the House, and it was modified so as to relieve it of its abruptness by inserting a preamble reciting "that it has now become desirable, that the respective claims of the United States and Great Britain should be definitely settled and that said territory may no longer than need be remain subject to the evil consequences of the divided allegiance of its American and British population, and of the confusion and conflict of national jurisdiction, dangerous to the cherished peace and good understanding of the two

r Cong. Globe, 29th Cong. Ist sess., p. 1 Io. 


\section{The Oregon Boundary Question}

countries, and therefore that steps may be taken for the abrogation of the said conventions of the 6th of August, 1827, in the mode prescribed in its second article, that the attention of the governments of both countries may be more earnestly directed to the importance of speedy adjustment of all these differences and disputes in respect to said territory," etc.

The joint resolution, so modified, passed in the House on April 18,1846 , by the decided vote of 144 to $40 .^{x}$ The President at once gave the notice and the country now breathed easier, relieved, for the time being, of the pressure of suspense that for months had hung over it while confronted with imminent danger of war.

Although Great Britain and the United States had been brought to the verge of war by the policy of the Polk Administration and the reckless course of the Fifty-Four Forties, negotiations between the two nations had not ceased, and after the notice given by the Administration, they were diligently pursued; the United States being represented by James Buchanan, Secretary of State. Whatever else may be said of him it must be conceded that for such business he was admirably equipped.

It was plain, as it had been all along, that Great Britain would never concede any of the disputed territory north of the 49th parallel, but Buchanan thought that she might be willing to compromise on that parallel as the boundary line, and he so advised the President; to compromise on that line would, of course, be a backdown for the Administration from the policy unequivocally declared by the Baltimore Democratic platform and as unequivocally advocated by Polk in his inaugural address and in his annual message. But that was the most that could be got from Great Britain without war, and the President's advisers deemed it wiser to back down from an indefensible, or at least a very doubtful, claim, than it was to risk the hazards of war in attempting to maintain it. Finally,

- Cong. Globe, Id., p. 69I. 
Polk himself, if not converted to the wisdom, yielded to the necessity, of abandoning his former Oregon policy.

The next thing to do was to break the news of the President's change of policy to the Senate and to the country, but to do this in such a way as to let the President down as easily as possible. For this purpose Senator Haywood, of North Carolina, a personal and political friend of the President, was enlisted in his behalf. It was the mission of Haywood not only to announce the President's change of policy but to show that he was not guilty of any inconsistency. This, of course, was a difficult, if not an impossible undertaking, but Haywood performed it as well as any one could have done in a speech in the Senate on March 4, $1846 .{ }^{x}$

Haywood's speech excited the ire of Hannegan and Allen, who at once demanded to know whether Haywood spoke by the authority of the President or not, but Haywood avoided giving a direct answer, although we have Benton's word for it that he was so authorized. ${ }^{2}$ Then Hannegan, pretending to believe that Haywood had spoken without authority of the President, proceeded to show, and to show very clearly, by extracts from the President's messages, that his present policy, if it was that attributed to him by Haywood, was altogether inconsistent with that formerly advocated by him. Going still further, he proceeded to exhaust his stock of invectives in berating the President over Haywood's shoulders for an abandonment of his political principles and for treason to his party.

"In plain words," he said, "he [Haywood] represents the President as parenthetically sticking in a few hollow and false words to cajole the 'ultraisms of the country.' What is this, need I ask, but charging upon the President conduct the most vile and infamous? If this allegation be true, these intentions of the President must sooner or later come to light and, when brought to light, what must follow but irretrievable disgrace? So long as one human eye remains

× Cong. Globe, Id., App., p. 369.

2 Thirty Years, vol. ii., pp. 662-663. 


\section{The Oregon Boundary Question}

to linger on the page of history the story of his abasement will be read, sending him and his name together to an infamy so profound, a damnation so deep, that the hand of resurrection will never be able to drag him forth. He who is a traitor to his country can never have forgiveness of God, and cannot ask mercy of man." Continuing, he said: "I have only to add that, so far as the whole tone, spirit, and meaning of the remarks of the Senator from North Carolina are concerned, if they speak the language of James K. Polk, James K. Polk has spoken words of falsehood, and with the tongue of a serpent.".

The Democratic papers throughout the country followed the lead of Hannegan in denouncing the proposed backdown, but all this, according to Benton, was mere "stage thunder," the fact being that the leaders of the Democratic party, including Polk himself, were eager to find some plausible pretext for washing their hands of the Oregon question. Hannegan and his little squad of Western fire eaters continued to roar, but the Administration was now bent on retreat.

Buchanan continued to negotiate with Pakenham, the British representative, and the negotiations resulted in Pakenham making an offer to Buchanan on June 6, I846, to compromise on the 49th parallel as the boundary line, together with the free navigation of the Columbia River. The next step, according to long-established practice in such cases, would have been for the President to direct a treaty to be drawn, embodying the terms agreed on, and then to submit it to the Senate for ratification. But this would have thrown upon the President the responsibility and odium for the backdown. Moreover, the President was uncertain as to what would be the attitude of the Whigs. The Whig Senators from the first had been opposed to the policy of the Fifty-Four Forties; but would they now support the President in his new backdown policy, or would they veer round and oppose it in order to embarrass

\footnotetext{
Cong. Globe, 29th Cong., Ist sess., p. 460.
} 
the Administration, according to the vernacular of politicians, "to put it in a hole"? How the President was extricated from the embarrassing dilemma in which he now found himself, is thus naively told by Benton:

"Mr. Pakenham made his offer; it was not a case for delay; and acceptance or rejection became inevitable. It was accepted, and nothing remained but to put the treaty into form. A device was necessary, and it was found in the early practice of the government-that of the President asking the advice of the Senate upon the articles of a treaty before the negotiation. Mr. Benton proposed this course to Mr. Polk. He was pleased with it, but feared its feasibility. The advice of the Senate would be his sufficient shield; but could it be obtained? The chances seemed to be against it. It was an uphill business, requiring a vote of two thirds; it was a novelty, not practiced since the time of Washington; it was a submission to the Whigs, with the risk of defeat, for unless they stood by the President against the dominant division of his own friends, the advice desired would not be given and the embarrassment of the Administration would be greater than ever. In this uneasy and uncertain state of mind, the President had many conferences with Mr. Benton, the point of which was to know, beyond the chance of mistake, how far he could rely upon the Whig Senators. Mr. Benton talked with them all, with Webster, Archer, Berrien, John M. Clayton, Crittenden, Corwin, Davis of Massachusetts, Dayton, Greene of Rhode Island, Huntington of Connecticut, Reverdy Johnson, Henry Johnson of Louisiana, Miller of New Jersey, Phelps, Simmons, Upham, Woodbridge, and saw fully that they intended to act for their country and not for their party, and reported to the President that he would be safe in trusting to them-that their united voice would be in favor of the advice, which, added to the minority of the Democracy, would make the two thirds which were requisite. The most auspicious mode of applying for this advice was

1 Thirty Years, vol. ii., pp. 674-675. 
deemed to be the submission of a projel of a treaty, presented by the British Minister, and to be laid before the Senate for their opinion upon its acceptance. The projet was accordingly received by Mr. Buchanan, a message drawn up, and the desired advice was to be asked the next day, roth of June. A prey to anxiety as to the conduct of the Whigs, the mere absence of part of whom would defeat the measure, the President sent for Mr. Benton the night before to get himself reassured on that point. Mr. Benton was clear and positive that they would be in their places, and would vote the advice, and that the measure would be carried. The next day the projet of the trcaty was sent in, and with it a message from the President, asking the advice which he desired."

The national Democratic papers at Washington and elsewhere vehemently denounced the proposed treaty. "It was a new thing under the sun," Benton tells us, "to see the Senator daily assailed in the government papers for carrying into effect the wishes of the government; to see him attacked in the morning for what the President was hurrying him to do the night before."

By this loud cannonading of the rear-guard it was intended to cover the retreat of the Administration and the Democratic party, which had now assumed the character of a stampede. Indeed, Benton assures us that those who were so bitterly assailing the Administration's change of policy were "underhandedly" doing what they could "to allay the storm which was raging, encouraging Mr. Haywood, Benton, and others to speak." All were glad, none more so than Polk himself, to banish the perplexing question. Polk, in order to shield himself from responsibility, added to his message submitting Great Britain's proposition a statement, which Benton calls a "salvo," "that my opinions and my action on the Oregon question were fully made known to Congress in my annual message of the second of December last, and my opinions therein expressed remain unchanged." 


\section{I42 Political History of Secession}

After the opponents of the treaty in the Senate had exhausted all the known parliamentary tactics in efforts to postpone and to amend, the question came to a vote on January 10,1846 , and on January 15,1846 , the treaty itself was ratified by the Senate by a vote of thirty-eight to twelve. ${ }^{x}$ Of the twelve who voted against ratifying the treaty, only two, Atchison of Missouri and Westcott of Florida, were from the slave States.

So ended the long controversy over the Oregon boundary question. As Giddings had predicted, there had been a complete backdown by the Administration from its original Oregon policy. The Fifty-Four Forties did not get "all of Oregon." They did not get a "fight." They got only so much of Oregon as Great Britain was willing to concede and no more, but their Southern allies had gained the annexation of Texas, all that they cared for, all that they had fought for in the preceding presidential campaign. Another great area was now added to the vast territorial domain of the United States in which the status of slavery was yet to be settled. ${ }^{2}$

- Cong. Globe, 29th Cong., Ist sess., p. 1224.

2In order to soothe Hannegan's lacerated feelings he was appointed by Polk Minister to Prussia and his appointment was confirmed during the closing days of the Thirtieth Congress. He was, however, recalled by the succeeding Administration. After that he returned to Indiana, where he remained a few years, and then removed to St. Louis, Missouri, where he died on January 25, 1859 . Senator Allen at a much later date, in 1873 , during one of those occasional political upheavals that sometimes happen in this country, when men of his type are popular, came to the surface again and was elected Governor of Ohio. He died in 1879. 


\section{CHAPTER VIII}

WAR WITH MEXICO: DIVIDING THE SPOILS OF VICTORY

$A^{S}$ had been predicted, the annexation of Texas was A speedily followed by war with Mexico, which was declared on May 13, 1846. It lasted over two years. Although there had been much opposition to it in the free States before it began, the North was not backward in contributing men and money for its prosecution. The war again demonstrated the valor of American soldiers of both North and South. General Winfield Scott and General Zachary Taylor achicved lasting renown in the war, and Taylor's military record gained for him the Presidency. Peace was declared on February 2, 1848, was ratified on May 30,1848 , and proclamation was made on July 4, 1848 . By the terms of the treaty of peace a vast area was ceded by Mexico, including a large tract to which Texas laid claim that was disputed by Mexico and that most historians assert had no substantial basis.

The peace was especially fortunate for Polk's Administration. After two years of war it was found that it was costing the United States in men and in money far more than had been anticipated and the people had begun to grumble against it. Moreover, there was danger that the war, if much longer protracted, would degenerate into a guerrilla warfare of indefinite duration, thereby creating new and difficult problems. To anything like a war for the conquest of the whole of Mexico, the North, and probably many in the South, would have been inflexibly opposed.

During the preliminary negotiations for peace a significant 


\section{I44 Political History of Secession}

incident occurred which clearly demonstrated the attitude and expectations of the Administration and the slaveholders of the South in reference to the status of slavery in the territory expected to be acquired from Mexico. Mexico wished to incorporate in the proposed peace treaty a provision securing the ceded territory against the introduction of slavery and the Mexican commissioners suggested this to Nicholas P. Trist, Assistant Secretary of State, who had been sent to receive any peace propositions that Mexico might offer. To this suggestion Trist reported that he answered "that the bare mention of the subject in any treaty to which the United States were a party was an absolute impossibility; that no President of the United States would dare to present any such treaty to the Senate; and that if it were in their power to offer me the whole territory described in our project, increased tenfold in value, and, in addition to that, covered a foot thick all over with pure gold upon the single condition that slavery should be excluded therefrom, I could not entertain the offer for a moment, nor think of communicating it to Washington. The matter ended in their being fully satisfied that this topic was not one to be touched." Both Buchanan and Polk seem to have been fully satisfied with Trist's conduct in the matter, and his statement to the Mexican commissioners undoubtedly voiced the sentiment of the pro-slavery men of the South. ${ }^{\mathrm{x}}$

In 1846 , after the beginning of the war but in anticipation of its termination and the acquisition by the United States of additional territory, David Wilmot, a Democratic member of the House of Representatives from Pennsylvania, introduced his famous proviso, afterwards known as the "Wilmot Proviso," declaring it to be "an express and fundamental condition to the acquisition of any territory in Mexico, that neither slavery nor involuntary servitude shall ever exist therein." The resolution passed the House but was defeated in the Senate. The debate upon it was

${ }^{x}$ See Von Holst, Const. and Pol. Hist., vol. iii., p. 334. 


\section{War with Mexico: Dividing the Spoils}

long and excited and the vote upon it clearly indicated the disruption of partics that afterwards followed, nearly all the Northern Whigs being for it, while the Democrats of the North were divided; nearly all the Whigs and Democrats of the South were against it. About the same time Calhoun introduced his resolutions, already mentioned, affirming the doctrine that the Constitution of the United States protected slavery in the Territories and that neither Congress nor the territorial legislatures could prohibit it there so long as the Territories remained in a territorial condition.

A remarkable letter by Calhoun to a member of the Alabama Legislature, written in 1847 , but not published until a later date, throws much light on the views then entertained by Calhoun and other Southern leaders. ${ }^{\text {In }}$ this letter he said: "I am much gratified with the tone and views of your letter, and concur entirely in the opinion you express that, instead of shunning, we ought to court, the issue with the North on the slavery question. I would even go one step farther and add that it is our duty-due to ourselves, to the Union, and our political institutions-to force the issue on the North. We are now stronger relatively than we shall be hereafter, politically and morally. Unless we bring on the issue delay to us will be dangerous indeed. It is the true policy of those enemies who seek our destruction. Its effects are and have been, and will be, to weaken us politically and morally and to strengthen them. Such has been my opinion from the first. Had the South, or even my own State, backed me, I would have forced the issue on the North in 1835, when the spirit of Abolitionisin first developed itself to any considerable extent. It is a true maxim to meet danger on the frontier in politics as well as war. Thus thinking, I am of the impression that if the South act as it ought, the Wilmot Proviso, instead of proving to be the means of successfully assailing us and our peculiar institution, may be made the occasion of successfully asserting our equality and rights by enabling us to

: Benton, Thirty Years, vol. ii., p. 698. 


\section{I46 Political History of Secession}

force the issue on the North. Something of the kind. was indispensable to rouse and unite the South. On the contrary, if we should not meet it as we ought, I fear, greatly fear, our doom will be fixed. It would prove that we either have not the sense or spirit to defend ourselves and our institution."

He then alludes to the acts of the legislatures of Pennsylvania and other States designed to embarrass the execution of the existing Federal fugitive slave law and said: "I go farther, and hold that if we have a right to hold our slaves we have a right to hold them in peace and quiet and that the toleration in the non-slaveholding States of the establishment of societies and presses, and the delivery of lectures, with the express intention of calling in question our right to our slaves, and of seducing and abducting them from the service of their masters and finally overthrowing the institution itself, as not only a violation of international laws, but also of the Federal contract. I hold also that we cannot acquiesce in such wrongs without the certain destruction of the relation of master and slave and without the ruin of the South." Continuing he said: "With this impression I would regard any compromise or adjustment of the proviso or even its defeat, without meeting the danger in its whole length and breadth, as very unfortunate for us. It would lull us to sleep again, without removing the danger or materially diminishing it."

Coming then to the question how the danger to the South could be met "without resorting to the dissolution of the Union," an "extreme remedy" not to be resorted to "until all others have failed and then only in defense of our liberty and safety," he said: "There is and can be but one remedy short of disunion, and that is to retaliate on our part by refusing to fulfill the stipulations in their favor, or such as we may select as the most efficient. Among these the right of their ships and commerce to enter and depart from our ports is the most effectual, and can be enforced. That the refusal on their part would justify us to refuse to fulfill on 


\section{War with Mexico: Dividing the Spoils}

our part those in their favor is too clear to admit of argument. That it would be effectual in compelling them to fulfill those in our favor can hardly be doubted when the immense profit they make by trade and navigation out of us is regarded; and also the advantages we would derive from the direct trade it would establish between the rest of the world and our ports." This doctrine was the South $\therefore$ Carolina nullification doctrine vamped over, and certain, if put into practice, to lead to secession and civil war.

Scarcely had the ink dried on the treaty of peace with Mexico until distressing controversies arose over the division of the spoils of victory. There was a controversy between Texas and the people of New Mexico as to boundary lines, and Texas wanted compensation from the United States for relinquishing her claims. Above all other questions was that of slavery in the Territories, not only in the territory recently acquired from Mexico, but in the remainder of Louisiana territory not yet organized into States, and in the Oregon territory, whose boundaries had been fixed and whose inhabitants were now anxious for a territorial government.

On August 6, 1846, during the first session of the Twentyninth Congress, Stephen A. Douglas, chairman of the House Committee on Territories, reported a bill for the territorial organization of Oregon, the bill being silent on the slavery question. It was amended in the House by inserting a provision prohibiting slavery, but it was so near the close of the session that no action upon it was taken by the Senate. At the next session Douglas again reported a bill for the territorial organization of Oregon, which passed the House by a large majority, but when it reached the Senate it was laid on the table, and no further action was had during that session, which ended on March 3, 1847. At the first session of the Thirtieth Congress, which began on December 6, 1847, and ended on August 14, 1848, the House again passed the Oregon bill with a provision prohibiting slavery.

s Benton, Thirty Years, vol. ii., p. 698. 


\section{I48 Political History of Secession}

When it got to the Senate, Douglas, now in the Senate and Chairman of the Committee on Territories, on August 5, I848, reported the House bill with an amendment extending the Missouri Compromise to the Pacific Ocean. The bill as amended was passed by the Senate by a vote of 33 to 22, but the House rejected the amendment by the decisive vote of I2I to 82 , and on Auguist 14,1848 , the last day of the session, the Senate receded from its amendment and the bill was passed as it came from the House. The bill as passed was vigorously opposed by Calhoun, Davis, and other Southern Senators, not because they expected that the inhabitants of Oregon would ever favor the establishment of slavery there, but in vindication of the principle for which Calhoun had all along contended that Congress had no right to prohibit slavery in any Territory. Probably it was also expected by some of the Southern members of Congress that by opposition to the prohibition of slavery in Oregon, some concessions might be gained favorable to the establishment of slavery in the territory acquired from Mexico.

Soon after the close of the war with Mexico in 1848, during the first session of the Thirtieth Congress, bills were introduced providing for territorial organization for California, New Mexico, and Utah, but no substantial progress was made in the passage of any of these bills during the Thirtieth Congress.

The Democratic party at its National Convention in Baltimore in 1848 named as its candidates for President and Vice-President General Lewis Cass of Michigan and William O. Butler of Kentucky on a platform deprecating the further agitation of the slavery question.

The Whig National Convention met at Philadelphia in June, 1848 , and again skulked on the question of slavery in the Territories. Not a word was said in the platform upon that or upon any other phase of the slavery question, and all motions introduced to elicit from either the convention or its candidates any declaration on the subject were promptly 


\section{War with Mexico: Dividing the Spoils}

declared out of order or were voted down amid jeers and hisses. Then the convention nominated as its candidates for President and Vice-President General Zachary Taylor and Millard Fillmore. In selecting its candidate for President, Henry Clay and all the old political leaders who represented what were supposed to be the cardinal principles of the Whig party were thrust aside and "Old Rough and Ready" was selected solely because it was thought that his military record would enable him to get the most votes and pull the party through. No importance whatever was attached to his political principles. Indeed if he had any fixed political principles he had never given any public expression of them. He was a Louisiana slaveholder and this was a sufficient pledge to the Southern Whigs that his Administration would not be hostile to slavery in the States where it existed. But what assurance did Northern Whigs have that he would not favor its extension to free Territories?

During the progress of the campaign the utmost care was used by the Whig managers to see that no unguarded expression of opinion upon any phase of the slavery question might slip from the lips or pen of its candidate for President, and to guard against such a mishap a sort of censorship was exercised over all of Taylor's political correspondence and all his political letters were carefully phrased so as to be as meaningless as possible. So shameful an abandonment of all political principles, so barefaced a policy of "anything to win" as were shown by the Whig party in 1848 were never seen before or since in the history of American politics.

Against this cowardly policy of the party some protests were made in the convention itself. Allen, a delegate from Massachusetts, boldly said in the convention that it was evident that the terms of union between the Northern and Southern Whigs were "the perpetual surrender by the former of the high offices and powers of the Government to their Southern confederates" and that to these terms the free States would no longer submit. Continuing he said: 
"I declare to this convention that the Whig party is here and this day dissolved." Another delegate, Henry Wilson, afterwards Senator from Massachusetts, spoke still more plainly. "I came to the convention," he said, "a Whig, committed unreservedly to the principles of the Whig party and to its organization. I ask of this convention the nomination of a Whig who is unreservedly committed to the principles of liberty. We have nominated a candidate who has said to the nation that he will not be bound by the principles of any party. Sir, I will go home and, so help me God, I will do all I can to defeat the election of that candidate."

The anti-slavery men of the North had now no abiding place in either the Democratic or Whig parties, and in August, I 848, a convention was held in Buffalo, New York, designed to fuse all the opponents of slavery extension into one party, under the name of the Free-soil party. The convention nominated Martin Van Buren for President and Charles Francis Adams for Vice-President, upon a platform declaring for Free Soil, Free Speech, Free Labor, and Free Men. The Northern Whigs of anti-slavery conviction were placed in an embarrassing position. It was hard for them to break away from old party ties and affiliations. Many of them could not reconcile themselves to voting for their old antagonist, Van Buren. They distrusted him on the slavery question and he was not in accord with them on any of the cardinal principles of the old Whig party. Moreover there was still a faint hope, encouraged by Seward and other Whig leaders, that the Whig party of the North might yet be converted into an anti-slavery party. So the great body of the Whigs in the North supported their party candidate. Nevertheless, Taylor would probably have been defeated but for the political conditions existing in New York, which was a pivotal State. By this time the Democratic party in that State had been split into two factions on the question of extending the Wilmot Proviso to the newly acquired Territories. One faction favored it, and was likened by its opponents to the old Dutchman who 


\section{War with Mexico: Dividing the Spoils}

burned his barn to get rid of the rats and therefore nicknamed "Barnburners"; those of the other faction which opposed the Wilmot Proviso were styled by their opponents "Hunkers," a name conveying very much the same meaning that the term "Standpatters" has come to signify in more recent years.

John A. Dix, a Barnburner Democrat, had been nominated by the New York Free-soilers for governor. Political conditions there were in a state of chaos. It is difficult for any one living outside of New York ever to get a clear understanding of the politics of that State. It seems, however, that occasionally there is set aside there a year for settling old political scores. The year 1848 happened to be such a year. Van Buren's friends attributed his defeat for the presidential nomination in 1844 largely to the influence of General Cass. The presidential aspirations of another prominent New York Democrat, Silas Wright, had been nipped in the bud by Polk's Administration, and the friends of both Van Buren and Wright availed themselves of the opportunity now offered of getting even. The result was that Van Buren received in New York State one hundred and twenty thousand votes, drawing enough from Cass to give the electoral vote of the State to Taylor and thereby securing for him a majority of votes in the electoral college.

In this campaign, Seward took an active part, speaking in support of Taylor. Abraham Lincoln, then a member of Congress from Illinois, also took an active part in behalf of Taylor. He spoke in several places in New England, speaking together with Seward in Boston, where, according to the local papers of the time, he was received "with great applause" and making a "powerful and convincing speech which was cheered to the echo." In his speech at Worcester, Mass., he made one of his characteristic droll comparisons, comparing the Free-soil platform to a pair of trousers which a Yankee peddler recommended as "large enough for any man and small enough for any boy." 
Deep down in the hearts of many Northern Whigs there was no doubt a feeling over the election of Taylor in accord with that which found expression in Horace Greeley's report of Taylor's inauguration ball, in which is this pathetic lament for the defeat of Henry Clay: "Let those who will flatter the chief dispenser of executive patronage, discovering in every act and feature some resemblance to Washington; I am content to wait, and watch, and hope. I burn no incense on his altar, attach no flattering epithets to his name. I turn from this imposing pageant, so rich in glitter, so poor in feeling, to think of him who should have been the central figure of this grand panorama-the distant, the powerless, the unforgotten-'behind the mountains, but not setting'-the eloquent champion of Liberty in both hemispheres-whose voice thrilled the hearts of the uprising, the long-trampled sons of Leonidas and Xenophonwhose appeals for South American independence were read to the hastily mustered squadrons of Bolivar, and nerved them to sweep from this fair continent the myrmidons of Spanish oppression. My heart is with him in his far southern abiding-place-with him, the early advocate of African emancipation; the life-long champion of a diversified Home Industry; of Internal Improvement; and not less glorious in his later years as the stern reprover of the fatal spirit of conquest and aggression. Let the exulting thousands quaff their red wines at the revel to the victor of Monterey and Buena Vista, while wit points the sentiment with an epigram, and beauty crowns it with her smiles: more grateful to me the stillness of my lonely chamber, this cup of crystal water in which I honor the cherished memory with the old, familiar aspiration:

\section{'Here's to you, Harry Clay!'” s}

The second session of the Thirtieth Congress began on December 4, I848, and continued until March 3, I849. As

× Parton, Life of Horace Greeley, p. 317. 
already stated, the bill providing a territorial government for Oregon had passed on August I4, 1848, but there was left a vast area in which the status of slavery was still to be determined. In the second volume of McMaster's History of the United States is a map showing the territory acquired by the United States since the adoption of the Federal Constitution, with the sources and dates of acquisition. By looking at this map we shall get a clearer idea than we can from any written description of the vast area included in the Louisiana Purchase and in the cession from Mexico. Out of the Louisiana Purchase, three slave States, Louisiana, Arkansas, and Missouri, and one free State, Iowa, had been created. The remainder was still unprovided with even a territorial organization. The whole of the territory acquired from Mexico was still without either a State or a territorial organization.

A considerable part of the unorganized Louisiana Purchase, and nearly all the in habitable region acquired from Mexico was supposed to be adapted to slave labor. For California, to which a large lawless element had flocked, the necessity of providing a government of some kind was immediate and imperative. But at the threshold of all legislation respecting the Territories stood the slavery question. Should all this domain be opened to slavery, or should it all be closed against it? If apportioned, how should the division be made? Not only the question of the "equilibrium" was involved, but the very existence of slavery itself. Indeed the question of slavery in the Territories had now become far more important than ever before and overshadowed all others. The stake was of tremendous importance and the political game for it absorbed the attention and taxed to the utmost the skill of the ablest statesmen in the land.

It was impossible to devise any plan for the settlement of the question of slavery in the Territories that did not at once excite such violent opposition as to show the impossibility of securing harmony between the advocates and the 
opponents of slavery. Senator John M. Clayton of Delaware, chairman of the special committee of eight that had been appointed to consider the portion of the President's message relating to the subject, submitted a report on July 19, I 848 , admitting the inability of the members of the committee to agree to any recommendation except that Congress take no action whatever, but should leave the matter to be determined by the territorial courts with a right of appeal to the Supreme Court of the United States. This method of permitting Congress to shirk responsibility, by shifting it upon unknown territorial judges who might be appointed by the President, found little favor in any quarter.

On December 13, I848, Senator Benton presented a petition from the people of New Mexico "for the speedy organization, by law, of a territorial government for us," in which they said: "We respectfully but firmly protest against the dismemberment of our territory in favor of Texas or for any other cause. We do not desire to have domestic slavery within our borders, and until the time shall arrive for our admission into the Union as a State we desire to be protected by Congress against its introduction among us." Calhoun at once arose and said: "I rise to express my opinion that the people of this territory, under all the circumstances of the case, have not made a respectful petition to this Senate, but on the contrary, that they have made a most insolent one." Continuing he said: "I look upon the rights of the Southern States proposed to be excluded from this territory as a high constitutional principle. Our right to go there with our property is unquestionable and guaranteed and supported by the Constitution. The territory belongs to us-to the United States. It belongs to the States of Carolina and Virginia as much as it does to New York and Massachusetts."

On the same day that Benton introduced his New Mexico petition in the Senate, the House Committee on Territories,

r Cong. Globe, 3oth Cong., 2d sess., p. 33 . 


\section{War with Mexico: Dividing the Spoils 155}

on motion of Root of Ohio, was directed by a vote of 106 to 80 to report a bill or bills for the territorial organization of New Mexico and California, with a provision prohibiting slavery therein.

On motion of Daniel Gott of New York, the Committee on the District of Columbia was instructed by a vote of 98 to 88 to report a bill for the abolition of slavery in the District of Columbia, but the vote was afterwards reconsidered and no further action was taken upon the motion.

On February 19, 1849, Senator Walker of Wisconsin succeeded in getting an amendment tacked to the general appropriation bill while it was in the Senate, extending the Constitution to all the newly acquired territory and giving the President authority "to prescribe and establish all proper and useful regulations in conformity with the Constitution of the United States." I The debate upon this motion at once disclosed the purpose of the amendment, which was to get the Constitution extended to the Territories with Calhoun's construction of it, namely, that it protected slavery therein so long as the Territories remained in a territorial condition. This gave rise to a protracted debate, Calhoun again advocating his theory of the constitutional guarantee of slavery, which was vigorously combated by Webster. There was imminent danger that the session would end without the passage of the appropriation bill, but on the last night of the session the Walker amendment was defeated.

During the session several bills had been introduced providing territorial governments for California and New Mexico, but as soon as introduced amendments would be proposed for tacking to them the Wilmot Proviso, until the introduction of any bill became the signal for an acrimonious debate on the question of slavery, and the session adjourned without any definite action having been taken on any of the bills. Although nothing had been accomplished in the

Benton claims that the amendment was prompted by Senator Calhoun. Examination of the Dred Scolt case, p. i33. 


\section{I56 Political History of Secession}

way of legislation affecting siavery in the Territories or elsewhere, enough had been done to disclose a strong antislavery sentiment in the North and thoroughly to alarm the slaveholding interests in the South.

Benton asserts that during the last days of Polk's Administration there were nightly secret meetings of large numbers of members of Congress from the slaveholding States, to devise means for the defense and protection of the South, and that Calhoun was at the bottom of the movement. These meetings were conducted he says "with extraordinary precautions to avoid publicity; none but slave State members were admitted; no reporters were permitted to be present; nor any spectators or auditors." A committee of which Calhoun was the chairman was appointed to draft an address. The address, entitled, "An address of the Southern delegates in Congress to their constituents," and modeled after the Declaration of Independence, recited a long list of grievances charged against the North and was soon followed by a call from the legislatures of South Carolina and Mississippi "for the assembling of a 'Southern Congress' to put the machinery of the 'United States South' into operation." $x$ Mention is made in the next chapter of the results of this address.

In this Congress we find the name of Abraham Lincoln, a member of the House from Illinois. The congressional reports show that he proposed some resolutions, submitted some reports, and made a few speeches. His most elaborate speeches were one on internal improvements and two criticizing President Polk's message on the Mexican War. One of these, a speech delivered on July $27,1848,{ }^{2}$ probably amused the House, for in it Lincoln related a number of anecdotes, all of a humorous character and pat in point. It closed with an anecdote, referring to the dissensions among the New York Democrats, one that can be fully

× Benton, Thirty Years, vol. ii., pp. 733-736. See also Von Holst, Const. and Pol. History, vol. iii., pp. 413-423.

2 Cong. Globe, 3oth Cong., rst sess., App., ro 4 r. 


\section{War with Mexico: Dividing the Spoils}

appreciated by lawyers familiar with the rules of criminal pleadings. "I have heard some things from New York," he said, "and if they are true we might well say of your party there as a drunken fellow once said when he heard the reading of an indictment for hog stealing. The clerk read on till he got to and through the words 'Did steal, take, and carry away ten boars, ten sows, ten shoats, and ten pigs,' at which he exclaimed- 'Well, by golly, that is the most equally divided gang of hogs that I ever did hear of.' If there is any gang of hogs more equally divided than the Democrats of New York about this time, I have never heard of it."

In Lincoln's speeches in Congress we see little of the classic order, but we do sec in them something of his strength as a reasoner and his remarkable power to enforce his arguments by apt anecdotes and striking illustrations. Nevertheless his speeches in Congress gave no promise of his future reputation. It was well for him that he did not attempt to base it upon his ability to tell funny stories, else he might have met the fate so much lamented by the inimitable Thomas Corwin. For a period of nearly ten years after Lincoln's brief congressional career he seems almost entirely to have dropped out of sight in national politics.

In this Congress we also find the name of Horace Greeley, who had been elected a member of the House to fill a vacancy from New York. He served only three months but seems from the records to have been a busy member. $\mathrm{He}$ favored many public reforms and voted against slavery whenever he had an opportunity to do so. A considerable part of his time seems to have been taken up in vain struggles to get the floor in order to make speeches that were never delivered but were carefully written out and published in the New York Tribune, where they probably did far more effective service than they would have done if submerged in the great mass of speeches embalmed in the Congressional Globe, under leave to print.

Greeley made himself especially conspicuous by his ef- 


\section{$5^{8}$ Political History of Secession}

forts to bring about a reformation of the mileage abuses, and thereby drew upon himself a torrent of denunciation from all sides. When accused of having drawn a dollar or two too much, he vindicated himself by showing that he had discovered the excess and had paid it back into the Treasury. The committee to which the matter was referred refused to make any recommendation on the subject; the members continued to cling to their perquisites and to draw mileage as usual and the whole matter ended in what Greeley characterized as a "dry haul."

At the end of his three months' service, Greeley wrote a farewell letter to his constituents, in which he apologized for his own shortcomings but consoled himself with the reflection, in which he was undoubtedly correct, "that if you had sent to Washington (as you doubtless might have done) a more sternly honest and fearless representative, he would have made himself more unpopular with a large portion of the House than I did." $:$ He never afterwards appeared as a candidate for a public office until the year I872, when the strangest anomaly ever exhibited in American politics was presented by his appearance as a candidate for President of the party that he had spent almost his entire life in opposing and denouncing.

IParton, Life of Greeley, p. 318. 


\section{CHAPTER IX}

FORCING THE ISSUE: THE COMPROMISE MEASURES OF I850

THE new President was inaugurated on March 5, I 849. The first session of the Thirty-first Congress began on December 3, 1849, and continued until September 30, 1850 . At the opening of the session the political parties were in no amiable mood. The opposition of the North to the recapture of fugitive slaves continued; the Abolition societies and the underground railroad were in full blast; the free-soil element in the Democratic party was growing; there was a persistent and increasing demand of the anti-slavery element in the North for the prohibition of slavery in the Territories, and petitions continued to pour into Congress. not only for the abolition of the slave trade in the District of Columbia, but also for the abolition of slavery itself in the District and for the prohibition of the inter-State slave trade.

The new President was yet a political enigma. Although a Southern man, it was evident that he was of a type entirely different from that of Tyler, and that he would not be dominated by any party or politicians. In a letter of Henry Clay to his friend James Harlan, written on March I6, I850, ${ }^{\mathrm{I}}$ he said: "My relations to the Executive are civil but cold. We have very little intercourse of any kind. Instead of any disposition to oblige me I feel that a contrary disposition has been sometimes manifested. . . . I have never before seen such an administration. There is very little cooperation or concord between the two ends of the

' Colton, Private Correspondence of Henry Clay, p. 603. 
avenue. There is not, I believe, a prominent Whig in either House that has any confidential intercourse with the Executive. Mr. Seward, it is said, had; but his late Abolition speech has, I presume, cut him off from any such intercourse as it has eradicated the respect of almost all men for him."

Moreover, it was understood that the President favored the admission of California under a free-State constitution. It was this unexpected turn of affairs that added to the anger of the South. At the conclusion of the war with Mexico it was confidently expected in the South that California, or at least a part of it, would come into the Union as a slave State. But the discovery of the gold fields of California was followed by political consequences that no one had anticipated. An unprecedented tide of immigration set in which brought with it a large lawless element, so that it speedily became necessary to set up some kind of civil government. Congress having failed to pass any bill establishing either a territorial or a State government, a convention of the people of the Territory was called by General Riley, the provisional Governor, acting under instructions from the President. The convention met at Monterey on September I, I849, continuing its session to October 13, I 849, and adopted a constitution which was submitted to the people and ratified by them on November I3, I849, by a vote of 12,061 to 811 . As soon as adopted the constitution was transmitted to Washington. In the constitution it was provided that: "Neither slavery nor involuntary servitude, except for the punishment of crime, shall ever be tolerated in this State."

If California should now come in as a free State the equilibrium would be broken, and there was no Territory then in. sight out of which to make another slave State so that the equilibrium might be restored.

It was now evident that a large number of Southern members of Congress, Democrats and Whigs alike, had become converts to Calhoun's ideas on the slavery question, espe- 


\section{The Compromise Measures of 1850 I6I}

cially to his idea of "equality of rights" in the Territories, and that they were now in full accord with Calhoun's plan of "forcing the issue upon the North," and of compelling the North to choose between the alternative of acceding to the demands of the South or of a dissolution of the Union. The slavery question had now become the all-absorbing question of the hour. In his letter to Harlan, already mentioned, Clay said: "The all-engrossing subject of slavery continues to agitate us and paralyze almost all legislation. My hopes are strong that the question will ultimately be amicably adjusted, although when or how cannot be clearly seen." The question intruded itself into every debate and the discussion of any question pertaining to it dragged into it all others directly or indirectly connected with it.

The violence of party feeling, the anger of the Southern members over the prospect of California coming in as a free State, and the hatred of Benton for favoring it, are shown in the encounter in the early part of the session between the latter and Senator Foote of Mississippi. Benton had incurred the animosity of the Southern leaders by what they termed his treachery to the cause of the South. The most bitter of his critics was Foote, a man of irascible temperament and rasping speech. He had on several occasions made offensive personal allusions to Benton, comparing him to Catiline and using other insulting epithets. On one occasion, after Foote had goaded Benton to the verge of frenzy, the burly Missourian strode toward Foote in a towering rage, for the avowed purpose of inflicting personal chastisement upon him, when Foote suddenly drew a pistol, pointing it directly at Benton. Before he could fire other members rushed in and disarmed Foote, while others restrained Benton, and thus terminated a disgraceful scene that otherwise might have ended in murder upon the floor of the Senate.

The new Congress was one of the most notable in the history of the country. The Senate had sixty members, politically classified as follows: 


\section{2 \\ Political History of Secession}

\begin{tabular}{|c|c|c|c|c|}
\hline Free States & Democratic & Whig & Free-soil & Total \\
\hline \multirow{12}{*}{ 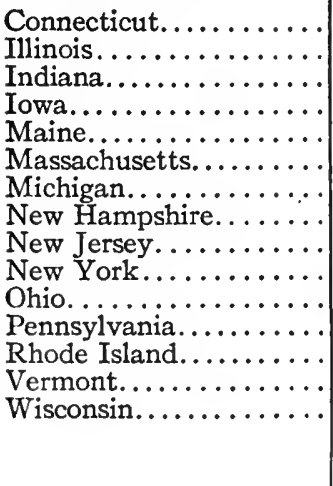 } & & 2 & s & 2 \\
\hline & 2 & & & 2 \\
\hline & 2 & & & 2 \\
\hline & 2 & 2 & & $\begin{array}{l}2 \\
2\end{array}$ \\
\hline & 2 & & & 2 \\
\hline & I & & $\mathbf{I}$ & 2 \\
\hline & I & $\begin{array}{l}2 \\
I\end{array}$ & & $\begin{array}{l}2 \\
2\end{array}$ \\
\hline & & I & I & 2 \\
\hline & I & $\mathbf{I}$ & & 2 \\
\hline & & 2 & & 2 \\
\hline & 2 & 2 & & $\begin{array}{l}2 \\
2\end{array}$ \\
\hline & I5 & I3 & 2 & 30 \\
\hline
\end{tabular}

\begin{tabular}{|c|c|c|c|c|}
\hline Slave States & Democratic & Whig & Free-soil & Total \\
\hline 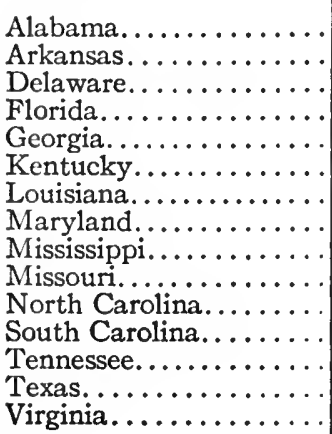 & $\begin{array}{r}2 \\
2 \\
I\end{array}$ & $\begin{array}{l}2 \\
1 \\
2 \\
2 \\
2\end{array}$ & & $\begin{array}{l}2 \\
2 \\
2 \\
2 \\
2 \\
2 \\
2 \\
2 \\
2 \\
2 \\
2 \\
2 \\
2 \\
2 \\
2 \\
2 \\
2\end{array}$ \\
\hline & 18 & 12 & & 30 \\
\hline \multicolumn{5}{|c|}{ SUMMARY } \\
\hline & Democratic & Whig & Free-soil & Total \\
\hline \multirow[t]{2}{*}{$\begin{array}{l}\text { Free States........... } \\
\text { Slave States.......... }\end{array}$} & $\begin{array}{l}\text { I5 } \\
\text { I8 }\end{array}$ & $\begin{array}{l}13 \\
12\end{array}$ & 2 & $\begin{array}{l}30 \\
30\end{array}$ \\
\hline & 33 & 25 & 2 & 60 \\
\hline
\end{tabular}




\section{The Compromise Measures of 1850163}

In the House the States were represented by 230 members and the Territories by two, politically classified as follows:

\begin{tabular}{|c|c|c|c|c|}
\hline Free States & Democratic & Whig & Free-soil & Total \\
\hline 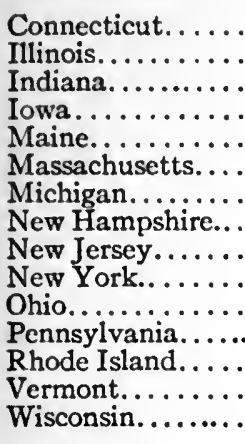 & $\begin{array}{r}2 \\
6 \\
8 \\
2 \\
4 \\
2 \\
2 \\
1 \\
1 \\
11 \\
8 \\
8 \\
1 \\
2\end{array}$ & $\begin{array}{r}\mathbf{I} \\
\mathbf{I} \\
\mathbf{I} \\
3 \\
7 \\
7 \\
\mathbf{I} \\
4 \\
32 \\
7 \\
\mathbf{1} \\
2 \\
3\end{array}$ & $\begin{array}{l}\text { I } \\
\text { I } \\
2 \text { (I vacancy) } \\
\text { I } \\
\text { I } \\
3 \\
2\end{array}$ & $\begin{array}{r}4 \\
7 \\
10 \\
2 \\
7 \\
9 \\
9 \\
3 \\
4 \\
5 \\
34 \\
21 \\
24 \\
2 \\
4 \\
3\end{array}$ \\
\hline & 50 & 76 & I3 & I39 \\
\hline
\end{tabular}

\begin{tabular}{|c|c|c|c|c|}
\hline Slave States & Democratic & Whig & Free-soil & Total \\
\hline 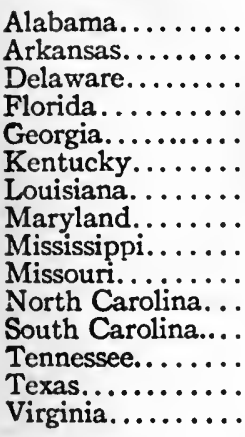 & $\begin{array}{r}4 \\
4 \\
3 \\
3 \\
4 \\
5 \\
3 \\
7 \\
7 \\
2 \\
13\end{array}$ & $\begin{array}{l}2 \\
\text { I } \\
\text { I } \\
4 \\
6 \\
1 \\
3 \\
\\
6 \\
4 \\
2\end{array}$ & & $\begin{array}{r}7 \\
1 \\
1 \\
1 \\
8 \\
10 \\
4 \\
6 \\
4 \\
5 \\
9 \\
7 \\
11 \\
2 \\
15\end{array}$ \\
\hline & $6 \mathrm{I}$ & 30 & & 91 \\
\hline
\end{tabular}


SUMMARY

\begin{tabular}{|c|c|c|c|c|}
\hline & Democratic & Whig & Free-soil & Total \\
\hline \multirow[t]{2}{*}{$\begin{array}{l}\text { Free States........ } \\
\text { Slave States...... }\end{array}$} & $\begin{array}{l}50 \\
6 \mathrm{I}\end{array}$ & $\begin{array}{l}76 \\
30\end{array}$ & 13 & $\begin{array}{r}139 \\
91\end{array}$ \\
\hline & III & 106 & $I_{3}$ & 230 \\
\hline
\end{tabular}

In addition to the above the two Territories, Oregon and Minnesota, were each represented by one delegate, both delegates being Democrats.

The great leaders, Calhoun, Clay, and Webster, were still in the Senate. Next to these were others afterwards more widely known, including among the Democrats such men as Jefferson Davis and Stephen A. Douglas; among the Whigs, William H. Seward; among the Free-soilers and Liberty party, John P. Hale of New Hampshire and Salmon P. Chase of Ohio. Hale and Douglas entered the Senate in 1847 ; Chase and Seward in 1849 . Hale was conspicuous among the opponents of slavery in the Senate. Born in Rochester, New Hampshire, in 1806 , he became active at an early date in State politics and was appointed United States District Attorney for New Hampshire by President Van Buren in 1834 . In 1843 he was elected member of Congress. Although elected as a Democrat, he opposed the suppression of the right of petition and also opposed the annexation of Texas. For this he incurred the hostility of Franklin Pierce and other leading Democrats of New Hampshire and, although he had been renominated by his constituents for reëlection to Congress, his name was taken off the ticket and that of another candidate was substituted. Nothing daunted, Hale continued his opposition; his constituents stood by him and in 1846 he was elected to the State Legislature, by which he was elected Speaker, and in 1847 he was elected to the United States Senate and was reelected in 1853. From the date of his 


\section{The Compromise Measures of 1850165}

entrance into the United States Senate, Hale's sole political mission seemed to be to antagonize slavery and it had no abler antagonist in the North. Of imperturbable good nature, eloquent, resourceful in debate, and ready in witty repartee, he was from his first entrance into the Senate a prominent figure there. He never allowed an opportunity to slip without giving a sharp thrust at slavery.

In the House, among the Democrats were James L. Orr of South Carolina, Howell Cobb of Georgia, Jacob Thompson of Mississippi, Andrew Johnson of Tennessee, John A. McClernand, William A. Richardson, and John Wentworth of Illinois, and Joseph E. McDonald of Indiana. Among the Whigs were Robert C. Winthrop and George Ashmun of Massachusetts, Thaddeus Stevens of Pennsylvania, Alexander H. Stephens and Robert Toombs of Georgia, Thomas L. Clingman of North Carolina, Humphrey Marshall of Kentucky. Among the Free-soilers were David Wilmot of Pennsylvania, Preston King of New York, Horace Mann of Massachusetts, Joshua R. Giddings of Ohio, and George W. Julian of Indiana.

Of the new Senators several were destined to become conspicuous figures in American history. Jefferson Davis, a graduate from West Point, had served one term in Congress as a Representative from Mississippi. Later he served with distinction in the Mexican War. He was afterwards appointed United States Senator from Mississippi to fill a vacancy, and was elected to the same position for a term expiring in 1851 , and was filling that office in 1850 .

Stephen A. Douglas of Illinois was born in. Vermont in I 813 , beginning his career as a poor boy in the business of cabinetmaker. He removed to the State of New York where he studied law. Afterwards he removed to Cleveland, Ohio, and from there to Jacksonville, Illinois, where he taught school and did clerical work of various kinds, at the same time pursuing his legal studies. In I 834 he was admitted to the bar and soon obtained a lucrative practice. After serving as Attorney-General of the State, he was 
in I 840 elected Secretary of State, and the following year as one of the judges of the Illinois Supreme Court. In I843, he was elected Representative to Congress and held that office for four years, during which time he served as Chairman of the House Committee on Territories. In 1847 he was elected to the United States Senate for the term ending in 1853 , and in 1850 was serving as Chairman of the Senate Committee on Territories. He was an untiring worker, exceedingly well-versed in the political history of the United States, bold even to the point of audacity. As a ready political debater he has had few equals, and no superior in the United States Senate. In the short time that he had served in the United States Senate he was ready at all times to measure lances with such old and experienced leaders as Calhoun and Webster, and such was the ability with which he always maintained himself that he had already acquired a national reputation.

Another of the new men in the Senate was William H. Seward of New York. He was elected United States Senator in 1849 , and took his seat in 1850 .

Another new Senator was Salmon P. Chase of Ohio. He was a man of commanding presence and an untiring worker. He had early taken a pronounced stand against the extension of slavery and had acquired distinction by the ability with which he conducted the defense of various persons prosecuted for violations of the Fugitive Slave Law, especially in the Van Zandt case, in which he was associated with William H. Seward. He had been influential in organizing the Liberty party in Ohio, and was the author of an address issued by a great convention, "The Southern and Western Liberty Convention," in Cincinnati in June, I845, an address of which more than one hundred thousand copies were circulated, producing a widespread effect in the North. He was a member of the Free-soil convention at Buffalo in I 848 , and in 1849 was elected as an anti-slavery Democrat to the United States Senate, taking his seat in that body for the first time in 1850 . 


\section{The Compromise Measures of $1850 \quad 167$}

As before stated, bills providing territorial governments for California, Utah, and New Mexico had been introduced in the second session of the Thirtieth Congress that had evoked considerable discussion, but no definite results had been reached. The whole question was now opened up afresh by the message of President Taylor, recommending the admission of California under its free-State constitution and the admission of New Mexico as soon as ready for admission. The introduction of any bill having the remotest bearing on the question of slavery in the Territories at once disclosed the same irreconcilable conflict of opinion and aroused the same antagonisms that had characterized the debates of the preceding session of Congress. "I do not believe," said Douglas, "that the Senate can agree upon any principle by which a bill can pass giving governments to the Territories in which the word slavery is mentioned. If you prohibit, if you establish, if you recognize, if you control, if you touch the question of slavery, your bill cannot, in my opinion, pass this body." $\mathrm{x}$ On December 27, I849, Senator Foote introduced a resolution providing for territorial governments for California, Deseret, and New Mexico. Amendments were immediately offered for the exclusion of slavery from these Territories. Later, bills were introduced for the passage of a fugitive slave law and bills for establishing the boundaries of Texas. On January 29 Senator Henry Clay of Kentucky offered a series of eight compromise resolutions, proposing to admit California without reference to slavery, to establish territorial governments in the remaining Territories, without any restriction as to slavery; also fixing the boundaries of Texas and providing for the payment of the debt of Texas, on condition that she should relinquish every claim to New Mexico; declaring it inexpedient to abolish slavery in the District of Columbia, but prohibiting the slave traffic in the District; also provisions strengthening the fugitive slave laws, and declaring that Congress had no

Cong. Globe, 3 Ist Cong., Ist sess., p. III6. 
power to prohibit the domestic slave trade between the States.

Later, on February 28, Senator John Bell of Tennessee also offered a series of compromise resolutions. Senator Foote at once moved to refer the resolutions to a committee of thirteen with authority to report a compromise for the adjustment of all pending differences between the North and South growing out of the institution of slavery. Finally Foote's resolution for the appointment of a committee of thirteen was passed, but was amended so as also to submit to the committee the resolutions of Senators Clay and Bell, and a committee was appointed, consisting of three Democrats and three Whigs for the free States, and three Democrats and three Whigs for the slave States, with the addition of Clay who was made Chairman. On May 8, I850, Clay's committee reported a bill in thirteen sections.

The debate on these various resolutions, bills, and amendments was long and acrimonious. They were opposed alike by the extreme pro-slavery men of the South and by the extreme anti-slavery men of the North. The extreme Southern views as to the question of slavery in the Territories were substantially those already mentioned that had been before advocated by Calhoun, Davis, and other Southern leaders. The claims of the Sorthern leaders were vigorously denied by the anti-slavery Democrats and Whigs and by the Free-soilers. Prominent among those favoring the compromise measures in the Senate were Henry Clay, Webster, and Stephen A. Douglas. The speeches which commanded the greatest attention were those of Clay, Calhoun, and Webster. Clay, who had voluntarily retired from politics after a long and honorable career, had been unanimously elected by the Kentucky Legislature to serve his State and country again in the United States Senate, in the expectation that his past experience as a legislator and the unbounded confidence of the nation in his wisdom and patriotism would enable him to be of great help in quieting the angry political passions that had again assumed so threatening an 


\section{The Compromise Measures of $1850 \quad 169$}

aspect. Clay spoke ably and earnestly in favor of the compromise measures.

No speech was heard with greater interest than that of John C. Calhoun on March 4, I850. The conditions under which he spoke made his utterances all the more impressive. Suffering from a bronchial disease, from which he died on March 3I, he was unable to deliver his speech, but sat in a chair nearby while it was read by Senator Hunter of Virginia. Pale, emaciated, and suffering, it seemed that life had already left him, except for the light that gleamed from his great sunken eyes, and his words had all the impressiveness of those of a dying man. In his speech Calhoun denounced the prior legislation of Congress as "destroying the equilibrium between the two sections," by means of which "what was once a constitutional federal republic is now converted in reality into one as absolute as that of the autocrat of Russia, and as despotic in its tendency as any absolute government that ever existed." Prophesying disunion as the inevitable result of the continuance of the slavery agitation, he said: "Disunion must be the work of time. It is only through a long process, and successively, that the cords can be snapped, until the whole fabric falls asunder. Already the agitation of the slavery question has snapped some of the most important, and has greatly weakened all the others, as I shall proceed to show."

The Union, he said, could not be preserved by eulogies, "however splendid or numerous"; nothing could be found in the history of Washington "to deter us from seceding from the Union, should it fail to fulfill the objects for which it was instituted, by being permanently and hopelessly converted into the means of oppressing instead of protecting us. On the contrary, we find much in his example to encourage us, should we be forced to the extremity of deciding between submission and disunion." 2

Coming to the question, "How can the Union be saved?"

' Calhoun's Works, vol. iv., p. 556.

'Id., vol. iv., p. 56 r. 


\section{I70 Political History of Secession}

he said: "But can this be done? Yes, easily; not by the weaker party, for it can of itself do nothing-not even protect itself, but by the stronger. The North has only to will it to accomplish it - to do justice by conceding to the South an equal right in the acquired territory, and to do her duty by causing the stipulations relative to fugitive slaves to be faithfully fulfilled - to cease the agitation of the slave question, and to provide for the insertion of a provision in the Constitution, by an amendment, which will restore to the South, in substance, the power she possessed of protecting herself, before the equilibrium between the sections was destroyed by the action of this government. There will be no difficulty in devising such a provision-one that will protect the South, and which, at the same time, will improve and strengthen the government, instead of impairing and weakening it." ×

Another speech that was awaited with breathless interest was that of Daniel Webster, the great expounder of the Constitution, the orator whose eloquent sentences had so often thrilled the nation, whose reply to Hayne will ever rank with the classic efforts of the most famous orators of ancient or modern times. He was the idol of the Whigs, and especially of the Whigs of Massachusetts, and it was hoped that when he spoke he would speak in behalf of freedom. But Webster had yielded to the political siren that sang the deceitful song which has lured so many aspirants to the presidential office to their destruction, and yielding to the temptation he sacrificed all that had endeared him to the North in order to make friends with the South. Webster spoke on March $7 .^{2}$ In his speech he skillfully arrayed all the arguments in favor of slavery, not overlooking the historical and Scriptural authorities relied on by the advocates of slavery. He did not expressly approve of these arguments, neither did he express dissent from them. In this respect his line of argument was much like that followed

'Calhoun's Works, vol. iv., p. 572.

- Webster's Works, vol. v., p. 325. 


\section{The Compromise Measures of 1850 171}

later by Chief Justice Taney in his opinion in the Dred Scott case. He did go so far, however, as to say: "At the introduction of Christianity the Roman world was full of slaves, and I suppose there is to be found no injunction against this relation between man and man in the teachings of the Gospel of Jesus Christ or any of his apostles." Continuing he said: "There are thousands of religious men, with consciences as tender as any of their brethren in the North, who do not see the unlawfulness of slavery," and that "candor obliges me to say that I believe they are just as conscientious, many of them, and religious people all of them, as they are at the North, who hold different opinions." He opposed tacking the Wilmot Proviso to the bill providing a territorial government for New Mexico. The reason he gave for this was that the soil and climate of the Territory were such that slavery could not exist there; that there was nothing there "that could by any possibility induce anybody to go there with slaves"; that prohibiting slavery there was as useless as a prohibition against slavery in Canada, as useless as it would be "to reaffirm an ordinance of nature" or to "reēnact the will of God"; that such a prohibition would be regarded by the South as "a taunt or a reproach" and that he was unwilling thus "to wound the pride" of the citizens of the Southern States. As showing that Webster's judgment, if not his conscience, was at fault, it may be noted that in 1859 the territorial legislature of New Mexico adopted a slave code containing all the standard provisions of such codes, with an additional provision forbidding emancipation. ${ }^{x}$

Concerning the proposed Fugitive Slave Law he said that the South had just cause of complaint against the North for a disinclination "among individuals and among legislators" to "perform fully their constitutional duties in regard to the return of persons bound to service, who had escaped into the free States." Continuing he said that

I Greeley, American Conflict, vol. i., pp. 302-3; Wilson, Rise and Fall, vol. ii., p. 634 . 


\section{I72 Political History of Secession}

"no man fulfills his duty in any legislature who sets himself to find excuses, evasions, escapes from this constitutional obligation," and therefore he proposed to support the pending bill "with all its provisions to the fullest extent."

Nobody could successfully dispute, and nobody except the radical Abolitionists did dispute, the existence and binding obligation of the constitutional provision providing for the return of fugitive slaves, and few would have objected if Webster had voted for a reasonable bill, that, while protecting the constitutional rights of the master, also protected the rights of the alleged fugitive, who, upon a fair trial, might be able to prove that he was not a slave; but Webster's argument wholly failed to convince the anti-slavery people of the North, and particularly those of Massachusetts, that he was justified in voting for a bill containing so many obnoxious, and, as many thought, unconstitutional, provisions, as the one that passed and to which Webster gave his unqualified assent.

Concerning the Abolition societies in the North he said, "I do not think them useful; I think that their operations for the last twenty years have produced nothing good or valuable."

Later in the session, on July $15,{ }^{\mathbf{I}}$ he said, speaking of the Wilmot Proviso: "Now, sir, allow me to say that the Wilmot Proviso is no matter of principle. It is a means to an end and it cannot be raised to the dignity of a principle. . . . What is it, then, that is yielded by the North but a mere abstraction, a naked possibility upon which no man would act? ... Why should we proceed upon the ground of adhering to the Wilmot Proviso as an abstract notion? And I must be permitted to say, that, as applied to this case, it is all an abstraction. I do not mean to say that the injunction against slavery in the Ordinance of 1787 was a mere abstraction; on the contrary, it had its uses; but I say the application of that rule to this case is a mere abstraction and nothing else."' Speaking of the Fugitive Slave Law, he said that the prejudice against it in Massachusetts was

'Webster's Works, vol. v., p. $42 \mathrm{I}$.

'Id., vol. v., pp. 422-23. 


\section{The Compromise Measures of $1850 \quad 173$}

largely due to "an exaggerated sense of the actual evil of the reclamation of fugitive slaves felt by Massachusetts and the other New England States," and had bcen created "by the incessant action on the public mind of Abolition societies, Abolition presses, and Abolition lecturers. ... No drumhead, in the longest day's march, was ever more incessantly beaten and smitten than public sentiment in the North has been, every month, and day, and hour, by the din and roll and rub-a-dub of Abolition writers and Abolition lecturers. That it is which has created the prejudice." In cnumerating the complaints of the North he made no mention of those against the continued existence of the slave trade in the District of Columbia, and on this subject he refrained from expressing any opinions of his own.

To steer between the anti-slavery feeling in the North and the pro-slavery feeling in the South was far more hazardous than trying to sail between Scylla and Charybdis, and Webster wrecked his political life in the attempt. To be told that the Wilmot Proviso was "a mere abstraction" and that there was no cause for the feeling in Massachusetts against the Fugitive Slave Law except what had been produced by the "din and roll and rub-a-dub of Abolition writers and lecturers" gave a great shock to Webster's former anti-slavery friends. The words were indeed familiar but they had a strange, discordant sound coming from a Massachusetts Senator, especially when coming from the lips of Daniel Webster. And yet it was not a cry of rage that went up from Massachusetts. It was rather the wail of King David for Absalom. Whittier mournfully set forth his own feelings, and those of multitudes in Massachusetts and throughout the North, in Ichabod, a weird, poetical obituary of Webster, a sad lament "as for the dead," written while he was yet living.

So fallen! so lost! the light withdrawn

Which once he wore!

The glory from his gray hairs gone

Forevermore. ... 


\section{I74 Political History of Secession}

All else is gone! from those great eyes

The soul has fled,

When faith is lost, when honor dies,

The man is dead!

Other notable speeches were made in the Senate. Seward spoke on March II and it was in this speech that he announced what was afterwards known as the "higher-law" doctrine. He argued that: "The Constitution regulates our stewardship; the Constitution devotes the domain to union, to justice, to defense, to welfare, and to liberty. But there is a higher law than the Constitution, which regulates our authority over the domain and devotes it to the same noble purposes." $x$ Similar language had been heard before from Abolitionists of the most ultra type. Joshua $\mathrm{R}$. Giddings had before said of the Fugitive Slave Law: "Yet we are told we must obey this law and perpetrate these crimes, until a slave-ridden Congress shall see fit to reclaim us from such sin against God by repealing the law. Whether it be right to obey God rather than man, judge ye. . . . The authors of this law may take from me my substance, may imprison me, or take my life; but they have not the power to degrade me by compelling me to commit such transcendent crimes against my fellow-man and against God's law." In fact this was out-and-out Abolition doctrine, for in the platform of the Liberty party adopted at Buffalo in August, 1843, one of the planks expressly affirmed that "it is a principle of universal morality that the moral laws of the Creator are paramount to all human laws; or in the language of an apostle that 'we ought to obey God rather than man," "and upon these premises proceeded to base a further resolution affirming that "whereas the third clause of the second section of the fourth article of the Constitution of the United States, when construed as providing for the surrender of the fugitive slave does rest upon such a basis in that it is a contract to rob a man of a

×Seward's Works, vol. i., p. 74 . 


\section{The Compromise Measures of $1850 \quad 175$}

natural right-namely his natural right to his own libertyand is therefore absolutely void."

Lord Brougham, in his speech on negro slavery in the House of Commons, July 13,1830 , in advocating the abolition of the slave trade in the West Indies, had announced the higher-law doctrine before either Giddings or Seward. "Tell me not of rights," he said, "talk not of the property of the planter in his slaves. I deny the right-I acknowledge not the property. The principles, the feclings of our common nature rise in rebellion against it. Be the appeal made to the understanding or to the heart, the sentence is the same that rejects it. In vain you tell me of the laws that sanction such a claim! There is a law above all the enactments of human codes-the same throughout the world, the same in all times - such as it was before the daring genius of Columbus pierced the night of ages, and opened to one world the sources of power, wealth, and knowledge; to another, all unutterable woes. Such it is at this day. It is the law written on the heart of man by the finger of God; and by that law, unchangeable and eternal, while men despise fraud, and loathe rapine, and abhor blood, they will reject with indignation the wild and guilty phantasy that man can hold property in man."

But such a doctrine coming from a Senator and former Governor of the State of New York created a great ferment, and it was denounced in unmeasured terms by leading Whig and Democratic journals and speakers in the North as well as in the South.

Seward's higher-law doctrine was hailed with enthusiasm by the Abolitionists and the more radical anti-slavery advocates in the North, but it did not command the approval of the conservative elements in the North, and was one of the causes, and probably the chief cause, of the defeat of Seward as a presidential candidate in the Republican National Convention at Chicago in 1860.

Chase's speech, though not characterized by polished sentences like those of Seward, was clear and direct. "Shall 


\section{I76 Political History of Secession}

we yield," he said, "to this outcry [for the extension of slavery]? For one, I say, Never! In my judgment, it is time to pause. We have yielded point after point; we have crowded concession on concession, until duty, honor, patriotism, shame, demand that we should stop.... Let us understand each other. Let us cease from endeavoring to agree in the support of the same candidate upon opposite grounds. . . . Least of all does the stale cry of disunion alarm me. . . . It may be, however, that you will succeed here in sacrificing the claims of freedom by some settlement carried through the forms of legislation. But the people will unsettle your settlement. It may be that you will determine that the Territories shall not be secured by law against the ingress of slavery. The people will reverse your determination. It may be that you will succeed in burying the Ordinance of Freedom. But the people will write upon its tomb, Resurgam; and the same history which records its resurrection may also inform posterity that they who fancied that they had killed the proviso only committed political suicide.".

Jefferson Davis said: "I here assert that I never will take less than the Missouri Compromise line extended to the ocean, with the specific recognition of the right to hold slaves below that line; and that before such Territories are admitted as States, slaves may be taken there from any of the United States, at the option of their owners."

Douglas favored the compromise measures, disagreeing with both Calhoun and Davis.

Calhoun died on March 3I, I850, and President Taylor on July 9, when Vice-President Millard Fillmore assumed the duties of Chief Executive. The omnibus bill as reported by Clay was defeated, but before the close of the session separate bills were passed embodying substantially all the leading provisions of the bills reported by Clay. The bill for the admission of California passed on September 9, $1850 .^{2}$

B Bancroft, Life of Seward, vol. i., p. 266.

${ }^{2} 9$ U. S. Stat., p. $45^{2}$. 


\section{The Compromise Measures of $1850 \quad 177$}

The bill for the organization of a territorial government in New Mexico also passed on September 9, I850." Section 23 of this act was as follows: "The Constitution and all laws of the United States which are not locally inapplicable shall have the same force and effect within the said Territory of New Mexico as elsewhere in the United States." Section 7 provided that "all the laws passed by the legislative assembly and governor shall be submitted to the Congress of the United States and, if disapproved, shall be null and of no effect." The bill providing for a new fugitive slave law passed on September I8, $1850 .^{2}$ The bill abolishing the slave trade in the District of Columbia passed September 20, $1850 .{ }^{3}$ By section I of this act it was provided that "it shall not be lawful to bring into the District of Columbia any slave whatever for the purpose of being sold, or for the purpose of being placed in depot, to be subsequently transferred to any other State or place to be sold as merchandise. And if any slave shall be brought into the said District by its owner, or by the authority or consent of its owner contrary to the provision of this act, such slave shall tkereupon become liberated and free."

It will be observed that the only one of the compromise measures that dealt with the question of slavery in the Territories was the one for the organization of the Territory of New Mexico. It is true that the compromise bill extended the Constitution of the United States to the Territory and that this was what it had been sought to accomplish at the previous session by the Walker amendment to the general appropriation bill; but the compromise bill did not vest in the President any such power as the Walker amendment attempted to give him, namely "to prescribe and establish all proper and useful regulations in conformity with the Constitution of the United States." On the contrary, the compromise bill vested the lawmaking power in the territorial legislature, but expressly provided

9 U. S. Stat., p. 447.

Id., p. 462 .

3 Id., p. 467. 


\section{I78 Political History of Secession}

that all territorial laws should be submitted to Congress for its approval. This left the ultimate power of determining whether slavery should be protected or prohibited in the Territories still vested in Congress, where, as acknowledged by a long course of prior congressional legislation, it was generally conceded to be vested before Calhoun set up the doctrine advocated by him. Indeed, until the Dred Scott decision, it continued to be the general understanding, even after the passage of the compromise measures, that the ultimate power to determine whether slavery should be protected or prohibited in the Territory remained vested in Congress.

A few years later the claim was made, based on reasoning then and still unintelligible to the ordinary mind, even to the ordinary legal mind, that the Missouri Compromise was "inconsistent with the principle of non-intervention by Congress with slavery in the State and Territory, as recognized by the legislation of $185^{\circ}$, commonly called the compromise measures," and it was for this reason declared to be "inoperative and void."

This was not a full recognition of the doctrine of Calhoun that the Constitution of the United States, of itself, without either congressional or territorial legislation, protected slavery in the Territories and forbade the prohibition of it there by either Congress or the territorial legislatures. Indeed this doctrine was not fully developed until it was declared in the Dred Scott decision. It had never been approved by Congress or by any national political convention. It was afterwards asserted by Abraham Lincoln and other opponents of slavery extension that the way for this decision had been prepared beforehand, beginning as far back as the passage of the compromise measures, or at least as far back as the passage of the Kansas-Nebraska act. Had it been generally understood at the time when the compromise measures were pending that the effect of them would be, as was afterwards claimed, to repeal the Missouri Compromise, it is certain that they would not have re- 
ceived the assent of the North and could not have been passed. Even as they were understood at the time of their passage, they were not satisfactory to either the North or the South.

The bill most strenuously opposed by the pro-slavery members of Congress was the bill for the admission of California; and the bill most strenuously opposed by the anti-slavery members was the Fugitive Slave Law. Of all the compromise measures, this was the most obnoxious in many sections of the North. Its provisions were far more drastic than those of any prior Federal act. Under it, on an affidavit filed before some Federal commissioner, a writ for the arrest of the alleged fugitive was issued and the officer whose duty it was to serve it might, if he chose to do so, summon to his aid all the citizens of the county. Upon arrest the alleged fugitive, although in fact he may never have been a slave, could be manacled and taken to the commissioner, before whom a summary hearing was had. At this hearing the supposed slave was denied a writ of habeas corpus, denied the right of trial by jury, and denied the right to testify in his own behalf. Moreover, the commissioner was given a fee of $\$$ Io if he decided against the fugitive but was given a fee of only $\$ 5$ if the decision was in his favor. Every person obstructing arrest of the fugitive, rescuing, aiding him to escape, or harboring or concealing him, was liable to a fine of $\$ 1000$ and six months' imprisonment, and was also liable to a civil action for damages to the amount of $\$ 1000 .^{x}$

The South was probably more dissatisfied than the North with the compromise measures. It had gained a new $\mathrm{Fu}$ gitive Slave Law and, although it had lost the right to carry on the slave trade in the District of Columbia, the loss probably did not greatly grieve the slaveholders, for it had possibly occurred to them that it might be better policy to cease exposing the ugliest and most revolting features of slavery to the gaze of the world in the most public places in

9 U. S. Stat., p. 462. 
the capital of the nation. Moreover, the right to hold slaves in the District for all purposes except to barter and sell them was left unmolested. But the South had lost California, and what was probably a still greater disappointment to the advocates of slavery, they had utterly failed to get any recognition of the Calhoun doctrine of the "equality of rights" of the North and the South in the Territories.

In the preceding chapter mention was made of the "address" issued by Calhoun and his colleagues. South Carolina and Mississippi responded to the address with alacrity and led off in resolutions of their State legislatures pursuant to which a Southern convention was assembled at Nashville, Tennessee, in June, I850. The convention adopted thirteen resolutions in which were enumerated the grievances of the South at the hands of the North, but resolved that inasmuch as Congress was then in session "it does not feel at liberty to discuss the methods suitable for a resistance to measures not yet adopted, which might involve a dishonor to the Southern States." 1

The convention reassembled at Nashville on November I4, I850, and adopted another set of resolutions. In one the right of secession was expressly affirmed; in another the compromise measures were denounced; in another it was recommended that another convention should be held "to deliberate and act with the view and intention of arresting further aggression, and, if possible, of restoring the constitutional rights of the South, and, if not, to provide for their future safety and independence." 2 Most of the slaveholding States held aloof from the convention altogether and a majority of the delegates who attended opposed the secession schemes of South Carolina and Mississippi. The governor of Georgia, pursuant to the recommendation of the Nashville convention, called a State convention, but when the delegates got together they voted by a large majority to abide by the compromise measures "as a

× The resolutions are given in full in Cluskey's Political Text-Book, pp. 532-33.

'Id., pp. 533-35. 


\section{The Compromise Measures of I850 I81}

permanent adjustment of this sectional controversy." Finally when the question of secession was submitted to the people of South Carolina and Mississippi, it was voted down in both States, but it was probably so voted down, not because of any love of the Union, but because the political leaders in those States believed that the times were not yet ripe for secession, at least by these two States alone. The Mississippi Legislature had passed resolutions censuring Senator Foote for voting for the compromise measures, but Foote canvassed the State on this issue and came out victorious. So this particular attempt at secession, started by Calhoun and pushed by South Carolina and Mississippi, was blighted in the bud. ${ }^{2}$

Nevertheless the Union sentiment in the South was not so deep as, upon the surface, it appeared to be. The action of the Georgia convention upon the question of secession has been referred to. It is the more significant because at that time the Union sentiment was stronger in Georgia than it was in any other of the cotton States. The convention adopted a set of resolutions, afterwards known as the "Georgia platform." It was generally regarded in the North as strongly expressive of a desire for the perpetuation of the Union, but when carefully examined it will be seen that in the minds of the framers of the platform the preservation of the Union was secondary to the fulfillment of various conditions specified in the resolutions adopted and emphasized in the fourth and fifth, which were as follows:

"Fourthly. That the State of Georgia, in the judgment of this convention, will and ought to resist, even (as a last resort) to a disruption of every tie which binds her to the Union, any future act of Congress abolishing slavery in the District of Columbia, without the consent and petition of the slaveholders thereof, or any act abolishing slavery in places within the slaveholding States, purchased by the

: Cluskey, Political Text-Book, pp. 536-37.

- See Von Holst, Const. and Pol. History, vol. iii., p. 532; vol. iv., pp. 3-9; Benton, Thirty Years, vol. ii., pp. 780-87. 


\section{2 Political History of Secession}

United States for the erection of forts, magazines, arsenals, dockyards, navy-yards, and other like purposes; or any act suppressing the slave trade between slaveholding States; or any refusal to admit as a State any Territory hereafter applying, because of the existence of slavery therein; or any act prohibiting the introduction of slaves into the Territories of Utah and New Mexico; or any act repealing or materially modifying the laws now in force for the recovery of fugitive slaves.

"Fifthly. That it is the deliberate opinion of this convention that upon the faithful execution of the Fugitive Slave Bill by the proper authorities depends the preservation of our much loved Union." $x$

Alabama had preceded Georgia and the other cotton States in the adoption of a State platform on the slavery question. At the Alabama Democratic State Convention in 1848 a platform was adopted, afterwards known as the Alabama platform, containing a series of resolutions, said to have been prepared by William L. Yancey. These were the basis of the slavery non-interference resolution proposed by him, but defeated, in the Democratic National Convention in 1848. Nevertheless, the Democratic party in Alabama continued to assert the doctrines of the platform of 1848 from that time until $\mathrm{I} 860$, and Yancey, the most eloquent of all the Southern leaders, continued to-urge the people of the South, without regard to their differences on other political questions, to stand together on the question of slavery.

As a result of the efforts of Yancey and other Southern leaders, the seeds of secession sentiment were spread far and wide in the South. In 1858 a Southern League was formed in Nashville, Tennessee, not significant for the number belonging to that particular organization, but significant as expressing the sentiments of a large class in the South, particularly in the cotton States. The first article of the League was as follows:

× Cluskey, Political Text-Book, p. 537. 


\section{The Compromise Measures of I850 183}

"First. The members of this organization shall be known as 'The League of the South' and our motto shall be 'A Southern Republic is our only safety." '

A letter of Yancy, to James S. Slaughter, written June I5, 1858 , and afterwards made public, left no doubt as to the purposes of the League. In this letter Yancey advised the formation in all the cotton States of committees of safety, through which, he said, "we shall fire the Southern heart, instruct the Southern mind, give courage to each other, and, at the proper moment, by one organized, concerted action, we can precipitate the cotton States into a revolution." The resolutions of the Nashville convention and those of the Georgia and Alabama platforms all embodicd, in one form or another, the doctrines of John C. Calhoun on the question of slavery, now fully accepted by the ultra pro-slavery politicians, Democratic and Whig alike, of the South.

It was generally thought at the time of the passage of the compromise measures that they had gone far to establish an enduring peace between the North and the South on the slavery question. In fact, they had accomplished very little, if anything. They operated as a temporary plaster that for a time covered but did not heal the sore, which continued to fester. In both North and South efforts were at once begun to undo the work of the compromisers; in the North by the passage of personal liberty bills and otherwise to thwart the enforcement of the Fugitive Slave Law, and in the South by renewed efforts to extend slavery into the Territories. There was for a time, however, a lull, or what seemed to be a lull, in the storm, which in less than four years broke forth with greater fury than ever before, beginning with the repeal of the Missouri Compromise." 


\section{CHAPTER X}

THE ELECTION OF PIERCE; REPEAL OF THE MISSOURI COMPROMISE

$T^{H E}$ excitement caused by the debates on the com1 promise measures of 1850 was soon succeeded by what seemed to be a reaction in the North, not in favor of slavery, but against further discussion of it, a longing for peace, mingled with a strong love of the Union and a desire to make some concessions for the preservation of it.

Northern opposition to the compromise measures of 1850 was directed chiefly against the Fugitive Slave Law of that year. There were two principal causes that had brought about the passage of the law. One was the continuous and increasing activity of the emissaries of the various Abolition societies in aiding and encouraging the escape of the fugitive slaves. These emissaries, in the guise of peddlers, book agents, surveyors, land agents, and in all sorts of disguises, penetrated the slave States, especially the border States, and whenever a suitable and safe opportunity offered, induced all the slaves whom they could persuade to make the attempt to leave their masters and seek their freedom in the Northern States or in Canada. What was called in those days the "underground railroad" was established, consisting of well-known routes by which fugitives traveled, with stations "scattered along where friends awaited to help forward those on their journey to the next station." $x$

Another reason for the passage of the Fugitive Slave Law

See Levi Coffin, Reminiscences; Wilson, Rise and Fall, vol. ii., pp. 61-86; Cockrum, Pioneer History of Indiana, p. 598. 


\section{The Election of Pierce}

of 1850 was the opposition in the North to the old Fugitive Slave Law of 1793, manifested in the almost universal refusal of the people to aid the master in the recovery of his fugitive slave and in the passage by various Northern legislatures of the so-called personal liberty laws. All this had been a constant source of irritation to the South, which claimed that the North had failed to carry out in good faith the clause of the Constitution of the United States relating to fugitives from service or labor and that it was the duty of Congress to enact a more stringent fugitive slave law. It was for these reasons that the Fugitive Slave Law of 1850 was passed as one of the compromise measures of that year.

Harsh and odious as its provisions were in the eyes of many in the North at the time of its passage, their harshness was not generally appreciated until they began to be felt in the efforts to enforce the law. Until then the people of the North generally, though reluctantly and not universally, acquiesced or scemed to acquiesce in the compromise measures of $185^{\circ}$, including the Fugitive Slave Law. This was not because they hated slavery less but because they loved the Union more and because there was a general feeling that, unless some concessions were made to the Southern States, they would secede. It was also generally believed in the North that the compromise measures of I850 made a finality of slavery agitation, or at least a finality of any attempt to break down the barrier of the Missouri Compromise against the further extension of slavery north of thirty-six degrces thirty minutes. No one in the North could then have foreseen that it would ever be claimed by Southern leaders that the compromise measures of $185^{\circ}$ had virtually repealed the Missouri Compromise.

There were other influences that helped to keep alive in the North opposition to further slavery agitation and induce acquiescence in the compromise measures. This feeling

sec. II., Art. IV. 
of acquiescence was manifest in those parts of the West, as in southern Illinois and Indiana, which had been peopled largely by settlers from Kentucky, Tennessee, Virginia, and North Carolina and where, even in territorial times, there was a strong pro-slavery sentiment. It was also manifest in portions of Ohio, particularly in Cincinnati which carried on a large Southern trade. Opposition to further slavery agitation was also found in all the large commercial and manufacturing centers of the North which carried on a profitable trade with the South.

The reasons for the opposition in New England to the further agitation of the slavery question may easily be found in the United States Census of 1850. Cotton was king in the South. It had many allies in the North in the commercial and manufacturing centers, especially in those of New England. According to the Census of 1850 there were in the United States in that year I094 cotton manufacturing establishments, with a capital of $\$ 74,500,93 \mathrm{I}$, using annually $64 \mathrm{I}, 240$ bales of cotton. Of these establishments there were in the New England States 564 (over half) with a capital of $\$ 5 I, 686,355$ (over half), using annually 430,603 bales (over two-thirds), Massachusetts alone having of these establishments 213 , with a capital of $\$ 28,455,630$, and using annually 223,607 bales of cotton.

Besides the products of the cotton manufacturers, the products of many other kinds of Northern manufacture went to the South in exchange for its cotton. Cotton could not, as it was then supposed, be profitably raised in the South except by slave labor, and so when slavery was touched the touch was felt in the North as well as in the South, but more in Northern pockets than it was in Northern consciences. Wherever the ramifications of Southern trade extended slavery seemed to be insidiously sapping away Northern opposition. It was felt in the great Northern colleges like Yale, which were largely patronized by young men from the South. ${ }^{\mathrm{x}}$

${ }^{2}$ See Andrew White, Autobiography, vol. i., p. 67. 
Again the spell of slavery seemed to have fallen upon the Northern churches. It is not difficult to understand how this came about. In considering the propelling forces of the Church the contribution-box must not be overlooked. There must be something more than the widow's mite to fill it; there must be big contributions with which to build big churches and to pay big salaries to the preachers. But the men who furnished the big contributions in the commercial and manufacturing centers of the North were opposed to the agitation of the slavery question. It threatened to cut down the per cent. of their profits. Why, therefore, keep hammering away in the pulpit on the sin of slavery, at the risk of stopping such contributions, when there was a plenty of other sins to preach about? It is admitted that this argument was faulty; nevertheless, it was very effective. Many aspiring preachers in the North, misled by it, groping to find the path of duty, missed it, or, finding it, did not have the courage to follow it. But the voice of the Church was stifled only for a season; its conscience, though stilled for a time, was not dead.

There was, however, no diminution but rather an increase of sentiment in the North against further extension of slavery. There were several influences besides the Fugitive Slave Law that served to develop and keep alive this sentiment. A book, Uncle Tom's Cabin, created a great impression throughout the North. It was not distinguished for literary merit and many of its pictures of slavery were overdrawn, but it had a great sale and was widely read and it set many persons to thinking about slavery who had never before given it serious consideration. Rufus Choate predicted that the book would make two million Abolitionists. By this time Choate himself seems to have felt the force of the "agitation" that he had so recently deprecated in his Faneuil Hall speech. It was first published in the National $E r a$ in numbers between the 5th of June, 1851 , and April I, 1852 , and published in book form in 1852 . "In eight weeks 100,000 copies were sold; in a year, 200,000 . In 1856 , 
313,000 had been circulated. In London thirty editions were published in six months. In the British Museum there are forty-three different editions in English. In I852, I, $, 000,000$ copies had been sold in England. All over Europe the book had a like rapid and large success. Translations were made into French, German, Dutch, Italian, Prussian, Magyar, Wallachian, Welsh, Danish, Swedish, Portuguese, Spanish, Polish, Armenian, Arabic, Chinese, and Japanese. There are more than fifty-five different translations of this book now [1884] in the British Museum."

In considering the potent influences in developing the anti-slavery sentiment of the North, the New York Tribune must not be overlooked. In the year I 831 Horace Greeley, then a pale-faced printer boy of twenty, carrying all his possessions in a small bundle, arrived in New York City seeking employment. His home was in Westhaven, Vermont, but he was born in New Hampshire, and his ancestors were of old Puritan and Scotch-Irish stock. After several failures he secured a foothold. In I840, he became widely known as the editor of the Log Cabin, a Whig campaign paper that attained an enormous circulation in that year. The next year he established the Tribune and at a still later date Charles A. Dana, Richard S. Hildreth, and other wellknown writers became his associates on the editorial staff of that paper. In the course of its career, the Tribune advocated Fourierism and various other "isms" not popular with the great mass of the people of the United States, but in its fearless, steadfast, and persistent opposition to slavery, especially after the passage of the Kansas-Nebraska act, it touched a popular chord whose vibrations were felt in every nook and corner of the North. The Tribune soon became the leader of that portion of the press that opposed the extension of slavery, and its powerful editorials probably did more than any other single agency to rouse public sentiment and crystallize hostility to slavery into active and aggressive political opposition. In the early days of

×Clarke, Anti-Slavery Days, p. 147. 
the Republican party the influence of the Tribune in shaping its course and in helping to establish it on firm foundations can hardly be overestimated.

Such was the general situation at the time of the beginning of the political campaign of $185^{2}$, a campaign which is interesting chiefly as marking the rise of the Democratic party to the zenith of its power and the downfall of the Whig party. At the Democratic National Convention in Baltimore, on June I, I852, there was practically entire unanimity of political sentiment. The Hunkers and the Barnburners of New York had buried the hatchet and many of the Free-soil Democrats who had before strayed away were now back in the Democratic fold. The Freesoil vote had fallen from 291,263 in 1848 to 156,140 in 1852 . The compromise measures, including the Fugitive Slave Law, were enthusiastically endorsed and it was resolved that "the Democratic party will resist all attempts at renewing, in Congress or out of it, the agitation of the slavery question, under whatever shape or color the attempt may be made." General Lewis Cass, James Buchanan, Stephen A. Douglas, and ex-Governor Marcy of New York were candidates for the presidential nomination. Douglas, though then but thirty-nine years of age, was third on the first ballot, but no one of the three could secure the two thirds vote required to nominate, and on the forty-ninth ballot Franklin Pierce of New Hampshire was nominated as a compromise candidate.

The Whig National Convention met at Baltimore two weeks later. On the fifth day of the convention, and on the fifty-third ballot, General Winfield Scott received the presidential nomination. Daniel Webster was mercilessly slaughtered, receiving on the first ballot only twenty-nine votes. Millard Fillmore received the solid vote of the Southern delegates, except one in Virginia given for Scott. Scott received all the Northern votes except the twentynine given for Webster and sixteen given for Fillmore.

The nomination of Scott was a triumph of the Northern 


\section{0

over the Southern Whigs, but the platform was a triumph of the Southern over the Northern Whigs, for in the platform adopted it was resolved that the compromise measures of 1850 , including the Fugitive Slave Law, "are received and acquiesced in by the Whig party of the United States as a settlement in principle and in substance of the dangerous and exciting questions which they embrace." To these resolutions, however, there was strong opposition of a large part of the Northern Whigs.

The Whigs were as unfortunate in their candidate as they were in their platform. They had twice succeeded with a military hero as their candidate, but, though neither Harrison nor Taylor could be called an astute politician, they were far better politicians than Scott. Scott's abilities as a general were universally conceded, but as a politician he was an utter failure. He went on an extensive stumping tour, ostensibly with a view to locate a site for a national asylum for disabled soldiers, and made a lot of commonplace speeches, all filled with fulsome adulation of his audiences, some of them quite ridiculous, as the one in which he told how charming to his ear were the "rich Irish brogue and the sweet German accent." The election following resulted in an overwhelming Democratic victory. Pierce carried all the States but four. Large numbers of the Whigs abandoned their own party and voted for John P. Hale and George W. Julian, the Free-soil candidates for President and Vice-President.

Sometimes Providence, in ordering the affairs of the universe, puts a very small man in a very great place, where he is suddenly confronted with great opportunities, great responsibilities, and great events, events which he has neither the capacity to understand nor the ability to grapple with, and which by their very bigness make his own littleness the more conspicuous. Such a man was Franklin Pierce. ${ }^{2}$ He was accidentally, as it seemed to

${ }^{*}$ A literary friend, after reading the foregoing passage, suggested a more classical illustration, applying to Pierce Alice Meynell's definition 
mankind, placed in the presidential chair. One of his first political acts was to invite into his Cabinct as Secretary of War, Jefferson Davis of Mississippi, who undoubtedly exercised a controlling influence over him during the whole of his administration in shaping his political policy so as to carry out, as far as possible, the plans of the slaveholding interests of the South. When, during the Civil War, the Union soldiers captured the home of Jefferson Davis, they found among the choice treasures there, a letter written on January 6,1860 , by Pierce to Davis, in which the former mentioned "a pleasant interview" that he had just had with a Mr. Shepley, who said that "he would rather fight the battle with you as the standard bearer in I 860 than under the auspices of any other leader," adding that "the feeling and judgment of Mr. S. in this relation is, I am confident, rapidly gaining ground in $\mathrm{New}$ England." In this letter Pierce also assures Davis that he had "never believed that actual disruption of the Union could occur without blood," but that "if, through the madness of Northern Abolitionism, that dire calamity must come, the fighting will not be along Mason and Dixon's line merely. It will be within our own borders, in our own streets. . . Those who defy the law and scout constitutional obligations will, if we ever reach the arbitrament of arms, find occupation enough at home." 1 There is no evidence that Pierce's good opinion of Davis or his friendship for the South ever underwent any change. ${ }^{2}$

of domus angusta: "The narrow house is a small human nature, compelled to a large human destiny, charged with a fate too great, a history too various for its slight capacity."

"McPherson, History of the Rebellion, p. 39r.

- In this letter Pierce spoke for himself, but not for the State of New Hampshire, conspicuous for loyalty to the Union cause. No soldiers in the Civil War made a better record than those of New Hampshire. This is the splendid record of the Fifth New Hampshire Volunteers: "The one regiment in all the Union armies which sustained the greatest loss in battle during the American Civil War was the Fifth New Hampshire Infantry. It lost 295 men, killed or mortally wounded in action 
In his inaugural address, the President assured the country that the public repose on the slavery question "should suffer no shock during his administration." There was now apparently not a cloud in the political skies. Here and there, it is true, there was an occasional outbreak in some parts of the North, showing that there still existed a strong, but apparently latent, anti-slavery sentiment, roused only by some particularly harsh and brutal instance of the enforcement of the Fugitive Slave Law. But both the great political parties had approved the law and the great body of the North had apparently acquiesced in it. The whole country pined for peace, and there was in every section, North and South, a strong love of the Union.

So matters drifted along until the year 1854 when another explosion occurred, as unexpected by the politicians as it was by the people, that threw the whole country into a worse turmoil than ever before. The slaveholders were not content with non-interference with slavery in the States where it then existed. It must expand its territory or die. It would be fatal to it to become hemmed in by free States into which its slaves would be continually escaping, and it must preserve the so-called "equilibrium" of political power by the admission of more slave States to furnish senators and representatives in Congress. Prior to the admission of California in $185^{\circ}$ there were fourteen free and fourteen slave States. The equilibrium was already in danger and it was necessary to restore it.

Whatever may have been in the minds of the politicians and people of the North, it is certain that the political leaders of the South had never lost sight of the doctrines contended for by John C. Calhoun. They had been kept

during its four years of service from 1861 to 1865 ... The losses of the Fifth New Hampshire occurred entirely in aggressive, hard, standup fighting; none of it happened in routs or through blunders." In one battle, that of Fredericksburg, of the total number engaged it lost in killed and wounded over sixty-three per cent.-Fox, Regimental Losses, pp. $2,36$. 
alive by his followers, Jefferson Davis and others, of the school of Calhoun, especially the doctrine of the equilibrium of the States, the equal right of the slave and the free States to the common territory, and the right of the slaveholders while the Territories remained in a territorial condition to take their slaves there the same as the Northern farmer had a right to take his cattle there.

True, out of the great State of Texas, there might have been carved at least six States of the size of Ohio, but the citizens of Texas, proud of their State, which had the area and the resources of an empire, would not hear to its partition into a number of smaller States. There was west of the Mississippi a vast tract called Nebraska, part of the Louisiana Purchase, comprising the territory out of which have since been carved the States of Kansas, Nebraska, the Dakotas, Montana, Wyoming, and parts of Minnesota and Colorado. The northern part of the Nebraska territory was unsuited to slave labor and the slave interests had no expectation or hope of converting it into slave States. Not so with the fertile plains in the portion of the territory adjoining Missouri, afterwards called Kansas, which from its location and climate was especially adapted for making out of it a slave State. Making a slave State out of it would be especially advantageous to Missouri. It would not only be easy of settlement by Missourians, but it would be a protection against the escape of runaway slaves, a danger that would be greatly augmented if it were to be admitted as a free State. Upon the admission of this portion as a slave State the Southern leaders had therefore set their hearts. But the Missouri Compromise stood in the way.

Up to this time the power of Congress to prohibit slavery in the Territories, new as well as old, had been generally conceded in the South as well as in the North, except by Calhoun and the ultra pro-slavery advocates of the South. ${ }^{x}$

'This is clearly shown by Benton, Examination of the Dred Scott Case, pp. 32-75. 


\section{I94 Political History of Secession}

Moreover up to this time nobody in the North, and probably but few in the South, seemed to have thought of an out-and-out repeal of the Missouri Compromise, which, it was supposed, would be certain to arouse intense antagonism in the North, and would probably defeat any territorial bill in which it might be incorporated. Nor does it seem to have occurred to any one prior to the introduction of the Kansas-Nebraska bill that there was any inconsistency between the Missouri Compromise and the compromise measures of 1850 . No such inconsistency is apparent to the ordinary mind. We have Democratic authority, no less than that of James Buchanan, that "it is impossible to conceive how it could be inferred that the compromise of 1850 , on the question of slavery in the Territories, would be inconsistent with the long previous Missouri Compromise of 1820 ; because each applied to distinct and separate portions of our territorial domain. Whilst the Missouri Compromise was confined to the territory acquired from France under the Louisiana Purchase, that of $185^{\circ}$ provided only for the new territory long afterwards acquired from Mexico under the treaty of Guadalupe Hidalgo. The compromise measures of 1850 contain no words to repeal or invalidate the Missouri Compromise. On the contrary, they expressly recognize it, as we have already seen, in the act providing for the cession of a portion of Texas to New Mexico."

In the Senate debates Senator Chase denied that any such supposed inconsistency had ever been hinted at before. But, by assuming to be true that there was such inconsistency, it was hoped to shift responsibility for the repeal of the Missouri Compromise upon the Congress which passed the compromise measures, and thus avoid, or at least diminish, the anticipated indignation in the North. Therefore this assumption of inconsistency was made the cornerstone of the subsequent legislation.

×Buchanan's Administration, p. 27. See also Benton, Examination of the Dred Scott Case, p. 165. 
On January 4, Senator Stephen A. Douglas, then chairman of the Senate Committee on Territories, reported a bill for a territorial government under the name of $\mathrm{Ne}$ braska without any provision prohibiting slavery, the accompanying report stating that it was "a disputed point whether slavery is prohibited in the Nebraska country by valid enactment," and that "in the opinion of those eminent statesmen who hold that Congress is invested with no rightful authority to legislate upon the subject of slavery in the Territories, the eighth section of the act preparatory to the admission of Missouri is null and void," and that "the prevailing sentiment in large portions of the Union sustains the doctrine that the Constitution of the United States secures to every citizen an inalienable right to move into any of the Territories with his property, of whatever kind and description, and to hold and enjoy the same under the sanction of law," and that "the compromise measures of 1850 affirm and rest upon the following propositions." The report then states these propositions, the first of which was that all questions pertaining to slavery in the Territories, and in the new States to be formed therefrom, are to be left to the decision of the people residing therein, by their appropriate representatives to be chosen by them for that purpose." $s$

The cue thus given was at once taken up by the advocates of slavery, and Dixon, a Whig Senator from Kentucky, introduced an amendment to the bill which declared that "the citizens of the several States or Territories shall be at liberty to take and hold their siaves within any of the Territories of the United States or of the States to be formed therefrom," thus virtually repealing the Missouri Compromise. Senator Sumner of Massachusetts at once gave notice of his intention to introduce an amendment providing that nothing in the bill should be considered as abrogating or in any way contravening the Missouri Compromise. After considerable discussion Douglas, on January 23, as

× Senate Reports, 33d Cong., Ist sess., No. 15. 


\section{I96 Political History of Secession}

chairman of the Senate Territorial Committee, reported a new bill, as a substitute for the one reported on January 4, providing for the organization of two Territories, the southern portion to be called Kansas, the northern portion to be called Nebraska. The fourteenth and the thirtysecond sections of the bill, as reported, the one applicable to Nebraska, the other to Kansas, each provided that: "The Constitution and laws of the United States which are not locally inapplicable, shall have the same force and effect within the said Territory as elsewhere in the United States, except the eighth section of the act preparatory to the admission of Missouri into the Union, approved March 6, 1820, which was superseded by the principles of the legislation of I850, commonly called the compromise measures, and is declared inoperative."

By this report the framers of the bill sought to make the country believe that they had not killed the Missouri Compromise, but that they had found it dead and surmised that it had been killed by the compromise measures of I850. As Benton puts it" :And thus, three years after the event, and by a sort of political coroner's inquest, the Missouri Compromise Act was found to be dead, and killed by those who, in much part, composed the jury, and who for a long time had remained ignorant of what they had done." The discovery that the Missouri Compromise was dead, and had been since 1850 without anybody having before suspected its death, was indeed a startling surprise to the country. The pretense that it had been virtually repealed by the compromise measures of $185^{\circ}$ finds little support. Indeed the opinion of at least one political writer of acknowledged authority is that "the Kansas-Nebraska bill was really as much a repeal of the compromise of 1850 , as of the compromise of $1820 . " 2$

The Senate and House committees having the bill in charge made some changes in the phraseology but later

Examination of the Dred Scott Case, p. 165.

2 Johnston, American Political History, Woodburn's ed., vol. ii., p. 125. 


\section{Repeal of the Missouri Compromise 197}

agreed to report it substantially in the shape in which it was finally passed. But how to phrase the clause repealing the Missouri Compromise was still a troublesome question. Just when or by whom the clause above quoted, as it appears in the bill as passed, was invented is not certainly known. It was deemed advisable before reporting the bill to get some assurance from President Pierce that he would approve it. Time was precious; the next day, January 22, was Sunday and it was important that the committee should report the bill on the following Monday. The aid of Jefferson Davis, Secretary of War, was sought because he was supposed to have more influence than any other member of the Cabinet over the President. Thereupon Davis undertook to bring about a meeting between the committee and the President on the following Sunday, although Davis was careful to state that the President had great conscientious scruples against doing any political work on the Sabbath day. What followed is thus told by Davis ${ }^{2}$ :

"On Sunday morning, the $22 \mathrm{~d}$ of January, r854, gentlemen of each committee called at my house, and Mr. Douglas, chairman of the Senate Committee, fully explained the proposed bill, and stated their purpose to be, through my aid, to obtain an interview on that day with the President, to ascertain whether the bill would meet his approbation. The President was known to be rigidly opposed to the reception of visits on Sunday for the discussion of any political subject; but in this case it was urged as necessary, in order to enable the committee to make their report the next day. I went with them to the executive mansion, and leaving them in the reception-room sought the President in his private apartments, and explained to him the occasion of the visit. He thereupon met the gentlemen, patiently listened to the reading of the bill and their explanations of it, decided that it rested upon sound constitutional principles, and recognized in it only a return to that rule which had

Rise and Fall, vol. i., p. 28. 


\section{I98 Political History of Secession}

been infringed by the compromise of 1820 , and the restoration of which had been foreshadowed by the legislation of I850."

There is some conflict of evidence as to who actually wrote the "inconsistent" clause in the twenty-first section of the bill. Some accounts state that Pierce himself wrote it. I Davis, however, expressly states that "this bill was not, therefore, as has been improperly asserted, a measure inspired by Mr. Pierce or any of his Cabinet." 2 However this may be, the clause repealing the Missouri Compromise, as incorporated in the final draft of the bill, was approved by both Pierce and Douglas. On the following day Douglas reported the bill substantially as it was when finally passed. Senators Chase and Sumner and Representative Giddings and others at once issued an address entitled, "The Appeal of the Independent Democrats in Congress to the People of the United States." 3 The address was a strong presentation of the objections to the repeal of the Missouri Compromise and commanded widespread attention. It denounced in clear and vigorous language the proposed repeal of the Missouri Compromise and called the attention of the country to the threatened danger and to the necessity of prompt and vigorous opposition by all who were opposed to the further extension of slavery. The address had not been issued on Sunday, although by some mistake of the writer or printer it bore the date of January 22, which was Sunday. Douglas took occasion at the first opportunity to denounce the address because it purported to have been issued on Sunday. "Thus it appears," he said in a speech for the bill in the Senate, "that on the holy Sabbath, while

${ }^{*}$ Wilson, Rise and Fall, vol. ii., pp. 382, 383; Ray, Repeal of the Missouri Compromise, pp. 214-215.

${ }^{2}$ Davis, Rise and Fall, vol. i., p. 28. See also on this subject, Nicolay and Hay, Lincoln, vol. i., pp. 337-351; Bancroft, Life of Seward, vol. i., chap. xviii., p. 333 .

3 The address was prepared chiefly by Chase and Giddings. See Schucker's Life of Chase, p. I40; Rhodes, History of United States, vol. i., pp. $44^{1-443}$. 


\section{Repeal of the Missouri Compromise}

other Senators were engaged in attending divine worship, these Abolition confederates were assembled in secret conclave, plotting by what means they should deceive the people of the United States . . . in the name of our holy religion." Remembering that the Sunday on which Douglas mistakenly supposed the address to have been issued was the very Sunday on which he and President Pierce, Jefferson Davis, and others were holding their secret caucus over the Kansas-Nebraska bill and concocting the phraseology of the clause for the repeal of the Missouri Compromise, this sudden outburst of professed piety on the part of Douglas, smacks strongly of hypocrisy and demagogyso strongly in fact that the impression created by it forms a very unpleasant contrast to that created by Douglas's many admirable qualities and his subsequent patriotic services to his country.

The debates that followed opened up again the whole subject of slavery and rekindled all the slumbering embers of sectional controversy. On the final passage of the bill every Southern Democratic Senator and every Southern Whig Senator, except Bell of Tennessee and Clayton of Delaware, voted for it. Every Northern Democratic Senator also voted for it, except Allan and James of Rhode Island and Walker of Wisconsin. The only opposition to it came from the Whig Senators of the North, and particularly those whose sympathies were with the Free-soil party. Chase spoke on February 3.

"Who," he asked, "is responsible for this renewal of strife and controversy? Not we, for we have introduced no question of territorial slavery into Congress-not we who are denounced as agitators and factionists. No, sir; the quietists and the finalists have become agitators; they who told us that all agitation was quieted, and that the resolutions of the political conventions put a final period to the discussion of slavery. This will not escape the observation of the country. It is Slavery that renews the strife. It is Slavery that again wants room. It is Slavery, with its 
insatiate demands for more slave territory and more slave States. And what does Slavery ask for now? Why, sir, it demands that a time-honored and sacred compact shall be rescinded-a compact which has endured through a whole generation-a compact which has been universally regarded as inviolable, North and South-a compact the constitutionality of which few have doubted, and by which all have consented to abide."

As to the alleged inconsistency between the Missouri Compromise and the compromise measures of 1850 , Chase maintained that the assumption that there was any such inconsistency "was untrue in fact and without foundation in history," and asserted that "no man North or South during the whole of the discussion of those acts [the compromise acts] here or in that other discussion which followed their enactment throughout the country ever intimated any such opinion," and that no such supposed inconsistency was thought of in the early stages of the Kansas-Nebraska bill. $^{2}$

Forecasting the dire consequences of the passage of the bill, he said:

"I believe that we are upon the verge of another era. That era will be the era of reaction. The introduction of this question here, and its discussion, will greatly hasten its advent. We, who insist upon the denationalization of slavery, and upon the absolute divorce of the general government from all connection with it, will stand with the men who favored the compromise acts, and who yet wish to adhere to them, in their letter and in their spirit, against the repeal of the Missouri prohibition. But you may pass it here. You may send it to the other House. It may become law. But its effect will be to satisfy all thinking men that no compromises with slavery will endure, except so long as they serve the interests of slavery; and that there is no safe and honorable ground for non-slaveholders to stand

× Cong. Globe, $33^{\mathrm{d}}$ Cong., Ist sess., App., p. 134.

IId., p. 134 . 


\section{Repeal of the Missouri Compromise 20I}

upon, except that of restricting slavery within State limits, and excluding it absolutely from the whole sphere of Federal jurisdiction. The old questions between political parties are at rest. No great question so thoroughly possesses the public mind as this of slavery. This discussion will hasten the inevitable reorganization of parties upon the new issues which our circumstances suggest. It will light up a fire in the country which may, perhaps, consume those who kindle it.

"I cannot believe that the people of this country have so far lost sight of the maxims and principles of the Revolution, or are so insensible to the obligations which those maxims and principles impose, as to acquiesce in the violation of this compact. Sir, the Senator from Illinois tells us that he proposes a final settlement of all territorial questions in respect to slavery, by the application of the principle of popular sovereignty. What kind of popular sovereignty is that which allows one portion of the people to enslave another portion? Is that the doctrine of equal rights? Is that exact justice? Is that the teaching of enlightened, liberal, progressive democracy? No, sir; no! There can be no real democracy which does not fully maintain the rights of man, as man. Living, practical, earnest democracy imperatively requires us, while carefully abstaining from unconstitutional interference with the internal regulations of any State upon the subject of slavery, or any other subject, to insist upon the practical application of its great principles in all the legislation of Congress." $x$

Seward spoke on February 17. In the course of his speech, addressing himself to the Senators from the slaveholding States, he said: "I see in the changes of the times only the vibrations of the needle, trembling on its pivotI know that in due time it will settle and when it shall have settled it will point, as it must point forever, to the same constant polar star that sheds down influences propitious to freedom as broadly as it pours forth its mild, but in-

- Cong. Globe, 33d Cong., Ist sess., App., p. 140. 
vigorating light. . . . You, too, suppose that you are securing peace as well as victory in this transaction. I tell you now, as I told you in $185^{\circ}$, that it is an error, an unnecessary error, to suppose, that, because you exclude slavery from these halls to-day, it will not revisit them to-morrow. You buried the Wilmot Proviso here then, and celebrated its obsequies with pomp and revelry; and here it is again today, stalking through these halls, clad in complete steel as before. Even if those whom you denounce as factionists in the North would let it rest, you yourselves must evoke it from its grave. . . . You will not cease to cherish slavery. Do you see any signs that we are becoming indifferent to freedom? On the contrary, that old, traditional, hereditary sentiment of the North is more profound and more universal now than it ever was before. The slavery agitation you deprecate so much is an eternal struggle between conservatism and progress, between truth and error, between right and wrong. You may sooner, by act of Congress, compel the sea to suppress its upheavings, and the round earth to extinguish its internal fires, than oblige the human mind to cease its inquirings, and the human heart to desist from its throbbings. . ..."

Richardson's House bill, which was similar to that of the Senate, had a stormy passage through the House but was finally carried by a vote of I I 3 yeas to Ioo nays. The yeas included forty-four Northern and fifty-seven Southern Democrats and twelve Southern Whigs. The nays included forty-five Whigs, including seven from the South, and forty-two Democrats, including two from the South. The House bill after its passage in the House reached the Senate on May 25, I854, where it was vigorously opposed by the few anti-slavery members of that body. Seward again spoke against it.

Seward's optimism was one of his characteristics. It sometimes led him to make predictions that were not fulfilled; but in his speech in opposition to the Kansas-

× Seward's Works, vol. iv., pp. 46I, 462. 


\section{Repeal of the Missouri Compromise 203}

Nebraska bill he accurately forecast the doom of the Democratic party. "I see," he said, "one more sign of hope; the great support of slavery in the South has been its alliance with the Democratic party of the North. By means of that alliance it obtained paramount influence with this government about the year 1800 , which from that time to this, with but few and slight interruptions, it has maintained. While Democracy in the North has thus been supporting slavery in the South, the people of the North have been learning more profoundly the principles of republicanism and of free government. It is an extraordinary circumstance ... that at this moment when there seems to be a more complete divergence of the Federal government in favor of slavery than ever before, the sentiment of universal liberty is stronger in all the free States than it ever was before. With that principle the present Democratic party must now come into a closer contest. Their prestige of democracy is fast waning by reason of the hard service which their alliance with their slaveholding brethren has imposed upon them. That party perseveres, as indeed it must, by reason of its very constitution, in that service, and thus comes into closer conflict with the clement of true democracy, and for that reason is destined to lose, and is fast losing, the power which it has held so firmly and so long. That power will not be restored until the principle established here now shall be reversed, and a constitution shall be given, not only to Kansas and Nebraska, but to every other national Territory, which will be not a tabula rasa but a constitution, securing equal, universal, and perpetual freedom." ${ }^{\prime}$

The last speech against it in the Senate was made by William Pitt Fessenden of Maine. He had been elected to the House at thirty-four years of age, and had now just entered the Senate at the age of forty-seven, having been elected by a combination of the Whig and anti-slavery Democrats of the Maine Legislature. Blaine pays to him

'Seward's Works, vol. iv., p. 479. 


\section{Political History of Secession}

a high but deserved compliment": "He never enjoyed popularity in the sense in which that word is ordinarily used, but he had the absolute confidence and admiration of his constituents. He possessed that peculiar strength with the people-the most valuable and most enduring that a public man can have-which comes from a sense of pride in the ability and character of the representative. . . As a debater Mr. Fessenden was exceptionally able. He spoke without apparent effort, in a quiet, impressive manner with a complete mastery of pure English. He preserved the lucidus ordo in his argument, was never confused, never hurried, never involved in style. ... In his later years his speeches may be taken as models for clearness of statement, accuracy of reasoning, felicity of expression, moderation of tone. There have been members of the Senate who achieved greater distinction than Mr. Fessenden, but it may well be doubted whether in the qualities named he ever had a superior in that body." Sumner said of him "that his arrival was like a reinforcement on a field of battle. . . . Not a Senator loving freedom who did not feel on that day that a champion had come." 2

Twenty Years, vol. i., p. 316.

3 The crowning glory of Fessenden's political life was his firm and patriotic course in the proceedings for the impeachment of President Andrew Johnson. Johnson had traits of character that were despicable; his conduct in the presidential office was disgraceful; but the nation was better able to endure the disgrace of Johnson than its own had Johnson been convicted. Indeed his conviction would have been taken as a precedent for impeachment of Presidents for political reasons, a precedent that, if followed, would have been certain to lead to the destruction of the Republic.

Fessenden had not only the foresight to foresee this, but he had also t'ine moral courage to oppose it. The moral courage required was of the highest quality. The radical Republican leaders, backed by a large element in the party, were fierce in their demands for conviction. Each of the seven recalcitrant Republican Senators who stood out against the conviction doubtless felt as did Senator Grimes of Iowa, who said that in voting "not guilty" he felt that "he was with his own hands digging his political grave." 


\section{Repeal of the Missouri Compromise 205}

In a colloquy with Senator Butler of South Carolina, who had made a speech threatening dissolution of the Union if the demands of the South were not granted, Fessenden said that "he had heard threats of a dissolution of the Union until he was fatigued with the sound"; and when Butler replied that "if Mr. Fessenden's sentiments were to prevail he wanted a dissolution right away," Fessenden at once replied, "Do not delay on my account." Such outspoken

One of the impeachment managers was Benjamin F. Butler, he who had gained notoriety in the Democratic National Conventions of 1860 , now converted from a rabid Northern pro-slavery Democrat into a radical Republican of the most bloodthirsty type. After the first vote on the impeachment trial Butler circulated stories, probably believed by few then, but now known to have been foul and baseless slanders, intended to create at least a suspicion that four of the seven Republicans, including Fessenden, had been bribed in favor of Johnson. Nevertheless, all stood by their convictions. When the votes were taken the first of the seven whose name was called was Fessenden. When he voted "not guilty" he uttered these impressive words: "In the words of Lord Eldon upon the trial of the Queen, "I take no notice of what is passing out of doors because I am supposed constitutionally not to be acquainted with it.' And again, 'It is the duty of those on whom a judicial task is imposed to meet reproach and not court popularity.' The people have not heard the evidence as we have heard it. The responsibility is not on them but upon us. They have not taken an oath 'to do impartial justice according to the Constitution and the laws.' I have taken that oath. I cannot render judgment upon their convictions nor can they transfer to themselves my punishment if I violate my own. And I should consider myself undeserving the confidence of that just and intelligent people who imposed upon me this great responsibility, and unworthy a place among honorable men, if for any fear of public reprobation and for the sake of securing popular favor, I should disregard the convictions of my judgment and my conscience. The consequences which may follow, either from conviction or acquittal, are not for me, with my convictions, to consider" (Fessenden, Life of Fessenden, vol. ii., p. 272). These were great words uttered on a great occasion and remind us of the memorable works of Lord Mansfield in the Wilkes case. By his vote Fessenden lost for a time his standing in the Republican party, but he gained an exalted place in history, while Butler's chief claim to distinction is that of being one of the worst of the worst class of American politicians. 
words of defiance by men of the North had not often been heard in the Senate of the United States and gave great satisfaction to the opponents of slavery.

Douglas closed the debate on March 3, I854. ${ }^{3}$ He began speaking near midnight and spoke until daybreak. The galleries were crowded; all listened with bated breath. The opposition he had encountered in Congress, the opprobrium heaped on him in the North seemed only to inspire him with fresh courage. He appeared to leap into the debate as a trained gladiator bounds into the arena, conscious of his strength, confident of victory, and eager for the contest. His boldness in attacking his opponents, the skill with which he parried their blows, the plausibility of his argument, his eloquent periods, all combined to extort the admiration of even his political opponents.

No satisfactory abridgment of his speech can be made. Some idea of its character may be obtained in the following extracts, which, so far as they go, give Douglas's exact words. He referred particularly to the speeches of Chase and Sumner in connection with the "Appeal of the Independent Democrats," and to the fact that he had been burned in effigy in Ohio and in Massachusetts. Of Chase's speech he said:

"The Senator says, also, that he never intended to do me injustice and he is sorry that the people of his State have acted in the manner to which I have referred. Sir, did he not say, in the same document to which I have already alluded, that I was engaged, with others, in 'a criminal betrayal of precious rights, ' in an 'atrocious plot'? Did he not say that I and others were guilty of 'meditated bad faith'? Are not these his exact words? Did he not say that 'servile demagogues' might make the people believe certain things, or attempt to do so? Did he not say everything calculated to produce and bring upon my head all the insults to which I have been subjected, publicly and privately-not even excepting the insulting letters which I

'Cong. Globe, 33d Cong., App., p. 325. 


\section{Repeal of the Missouri Compromise}

have received from his constituents, rejoicing at my domestic bereavements, and praying that other and similar calamities may befall me? All these have resulted from that address. I expected such consequences when I first saw it. In it he called upon the preachers of the Gospel to prostitute the sacred desk in stimulating excesses; and then, for fear that the people would not know who it was that was to be insulted and calumniated, he told them in a postscript, that Mr. Douglas was the author of all this iniquity, and that they ought not to allow their rights to be made the hazard of a presidential game! After having used such language, he says he meant no disrespect-he meant nothing unkind! He was amazed that I said in my opening speech that there was anything offensive in this address; and he could not suffer himself to use harsh epithets, or to impugn a gentleman's motives! No, not he! After having deliberately written all these insults, impugning motive and character and calling upon our holy religion to sanctify the calumny, he could not think of losing his dignity by bandying epithets or using harsh and disrespectful terms!"

Referring to Sumner's speech he said: "Sir, even in Boston I have been hung in effigy. I may say that I expected it to occur even there, for the Senator from Massachusetts lives there. He signed his name to that address; and for fear the Boston Abolitionists would not know that it was he, he signed it 'Charles Sumner, Senator from Massachusetts.' The first outrage was in Ohio, where the address was circulated under the signature of 'Salmon P. Chase, Senator from Ohio.' The next came from Bostonthe same Boston, sir, which under the direction of the same leaders, closed Faneuil Hall to the immortal Webster in 1850 , because of his support of the compromise measures of that year, which all now confess have restored peace and harmony to a distracted country. Yes, sir, even Boston, so glorious in her early history,-Boston, around whose name so many historical associations cling, to gratify the heart and exalt the pride of every American,- could be led astray by 


\section{8 Political History of Secession}

Abolition misrepresentations so far as to deny a hearing to her own great man, who had shed so much glory upon Massachusetts and her metropolis! I know that Boston now feels humiliated and degraded by the act. And, sir [addressing himself to Mr. Sumner], you will remember that when you came into the Senate, and sought an opportunity to put forth your Abolition incendiarism, you appealed to our sense of justice by the sentiment, 'Strike, but hear me first.' But when Mr. Webster went back in 1850 to speak to his constituents in his own self-defense, to tell the truth, and to expose his slanderers, you would not hear him, but you struck first!" Then referring to the fact that both Chase and Sumner had been elected by coalition of both Democratic and Whig opponents of slavery he said: "I must be permitted to tell the Senator from Ohio that I did not obtain my seat in this body either by a corrupt bargain or a dishonorable coalition! I must be permitted to remind the Senator from Massachusetts that I did not enter into any combinations or arrangements by which my character, my principles, and my honor were set up at public auction or private sale, in order to procure a seat in the Senate of the United States! I did not come into the Senate by any such means."

This roused both Chase and Sumner, and Chase angrily exclaimed, "Whoever says that I came here by a corrupt bargain states what is false." Afterwards Chase made an unsatisfactory explanation of that part of his address which Douglas construed as charging him with introducing the Kansas-Nebraska bill as a "presidential bid," whereupon Douglas returned to his attack on the authors of the address as follows: "I wish to examine the explanation of the Senator from Ohio, and see whether I ought to accept it as satisfactory. He has quoted the language of the address. It is undeniable that that language clearly imputed to me the design of bringing forward this bill with a view of securing my own election to the presidency. Then, by way of excusing himself for imputing to me such a purpose, the 
Senator says that he does not consider it 'an unworthy ambition'; and hence he says that, in making the charge, he does not impugn my motives. I must remind him that, in addition to that insinuation, he only said in the same address, that my bill was a 'criminal betrayal of precious rights'; he only said it was 'an atrocious plot against freedom and humanity'; he only said that it was 'meditated bad faith'; he only spoke significantly of 'servile demagogues'; he only called upon the preachers of the Gospel and the people at their public meetings to denounce and resist such a monstrous iniquity. In saying all this, and much of the same sort, he now assures me, in the presence of the Senate, that he did not mean the charge to imply an 'unworthy ambition'; that it was not intended as a 'personal imputation' upon my motives or character; and that he meant 'no personal disrespect' to me as the author of the measure. In reply, I will content myself with the remark, that there is a very wide difference of opinion between the Senator from Ohio and myself in respect to the meaning of words, and especially in regard to the line of conduct which, in a public man, does not constitute an unworthy ambition."

$\mathrm{He}$ dealt more mildly with Fessenden. "I wish the Senator from Maine [Mr. Fessenden], who delivered his maiden speech here to-night, and who made a great many sly stabs at me, had informed himself upon the subject before he repeated all these groundless assertions. I can excuse him, for the reason that he has been here but a few days, and, having enlisted under the banner of the Abolition confederates, was unwise and simple enough to believe that what they had published could be relied upon as stubborn facts. He may be an innocent victim. I hope he can have the excuse of not having investigated the subject. I am willing to excuse him on the ground that he did not know what he was talking about, and it is the only excuse which I can make for him."

In vindicating himself against the charge that by introducing the Kansas-Nebraska bill he had reopened the 
slavery agitation he said: "The opponents of the bill tell us that agitation is no part of their policy, that their great desire is peace and harmony; and they complain bitterly that I should have disturbed the repose of the country by the introduction of this measure. Let me ask these professed friends of peace and avowed enemies of agitation how the issue could have been avoided? They tell me that I should have let the question alone - that is, that I should have left Nebraska unorganized, the people unprotected, and the Indian barrier in existence, until the swelling tide of emigration should burst through and accomplish by violence what it is the part of wisdom and statesmanship to direct and regulate by law. How long could you have postponed action with safety? How long could you maintain that Indian barrier and restrain the onward march of civilization, Christianity, and free government by a barbarian wall? Do you suppose that you could keep that vast country a howling wilderness in all time to come, roamed over by hostile savages, cutting off all safe communication between our Atlantic and Pacific possessions? I tell you that the time for action has come, and cannot be postponed. It is a case in which the 'let-alone' policy would precipitate a crisis which must inevitably result in violence, anarchy, and strife. You cannot fix bounds to the onward march of this great and growing country. You cannot fetter the limbs of the young giant. He will burst all your chains. He will expand, and grow, and increase, and extend civilization, Christianity, and liberal principles. Then, sir, if you cannot check the growth of the country in that direction is it not the part of wisdom to look the danger in the face, and provide for an event.which you cannot avoid? I tell you, sir, you must provide for continuous lines of settlement from the Mississippi Valley to the Pacific Ocean. And in making this provision you must decide upon what principles the Territories shall be organized; in other words, whether the people shall be allowed to regulate their domestic institutions in their own way, according to the provisions 


\section{Repeal of the Missouri Compromise 211}

of this bill, or whether the opposite doctrine of congressional interference is to prevail. Postpone it, if you will; but whenever you do act, this question must be met and decided. The Missouri Compromise was interference; the compromise of $185^{\circ}$ was non-interference, leaving the people to exercise their rights under the Constitution. The Committec on Territories were compelled to act on this subject. I, as their chairman, was bound to meet the question. I chose to take the responsibility, regardless of consequences personal to myself."

The main purpose of the bill, he said, was to give to the people of the Territories the right of self-government. "The principle which we propose to carry into effect by the bill is this: that Congress shall neither legislate slavery into any Territory or State, nor out of the same; but the people shall be left free to regulate their domestic concerns in their own way, subject only to the Constitution of the United States. In order to carry this principle into practical operation, it becomes necessary to remove whatever legal obstacles might be found in the way of its free exercise. It is only for the purpose of carrying out this great fundamental principle of self-government that the bill renders the eighth section of the Missouri act inoperative and void. ... The eighth section of the Missouri act standing in the way of this great principle must be rendered inoperative and void, whether expressly repealed or not, in order to give the people the power of regulating their own domestic institutions in their own way, subject only to the Constitution. ... Therefore, the doctrine of the Abolitioniststhe doctrine of the opponents of the Nebraska and Kansas bill, and of the advocates of the Missouri restrictiondemands congressional interference with slavery, not only in the Territories, but in all the new States to be formed therefrom. It is the same doctrine, when applied to the Territories and new States of this Union, which the British Government attempted to enforce by the sword upon the American colonies. It is this fundamental principle of 
self-government which constitutes the distinguishing feature of the Nebraska bill. . . W Withdraw the slavery question from the political arena, and remove it to the States and Territories, each to decide for itself, such a catastrophe can never happen."

In closing he said: "I have nothing to say about Northern rights or Southern rights. I know of no such divisions or distinctions under the Constitution. The bill does equal and exact justice to the whole Union, and every part of it; it violates the rights of no State or Territory, but places each on a perfect equality, and leaves the people thereof to the free enjoyment of all their rights under the Constitution. ... I say, frankly, that, in my opinion, this measure will be as popular at the North as at the South, when its provisions and principles shall have been fully developed and become well understood. The people of the North are attached to the principles of self-government; and you cannot convince them that that is self-government which deprives a people of the right of legislating for themselves, and compels them to receive laws which are forced upon them by a legislature in which they are not represented. We are willing to stand upon this great principle of selfgovernment everywhere; and it is to us a proud reflection that, in this whole discussion, no friend of the bill has urged an argument in its favor which could not be used with the same propriety in a free State as in a slave State, and vice versa. No enemy of the bill has used an argument which would bear repetition one mile across Mason and Dixon's line. Our opponents have dealt entirely in sectional appeals. The friends of the bill have discussed a great principle of universal application, which can be sustained by the same reasons and the same arguments, in every time and in every corner of the Union."

All opposition to the bill was in vain and it passed the Senate by a vote of thirty-five to thirteen, and "amid the firing of cannon and the shouting of its friends it was sent to the President for his signature at three o'clock in the 
morning of May 26, 1854."' The bill was promptly approved by the President. ${ }^{2}$

Recently the claim has been made that the credit or discredit of the passage of the Kansas-Nebraska bill was due not to Douglas but to Senator David Atchison of Missouri. ${ }^{3}$ It is true that the clause repealing the Missouri Compromise was not in the original draft of the KansasNebraska bill, and it is probably true that such repeal had not been thought of by Douglas himself until after the original draft had been reported. It is not probable, however, that the idea of injecting such repeal into the bill was first conccived by either Atchison or Dixon. It is more probable that it was hatched in the brain of Jefferson Davis and others of the Calhoun school. However this may be, the overwhelming weight of contemporary authorities is that after the repealing clause had been incorporated in the bill Douglas became its chief champion, and that it was by his skillful parliamentary tactics, in which he had no superior, and by his untiring and unceasing efforts that the passage of the bill was assured.

The repealing section of the bill as finally passed, after reciting the provision in the act of 1820 restricting slavery, concluded as follows, "which being inconsistent with the principles of non-intervention by Congress with slavery in the States and Territories, as recognized by the legislation of 1850 [commonly called the compromise measures] is hereby declared inoperative and void; it being the truc intent and meaning of this act not to legislate slavery into any Territory or State, nor to exclude it therefrom, but to leave the people thereof perfectly free to form and regulate their domestic constitution in their own way, subject only

Seward's Works, vol. iv., p. 26.

2 Benton gives a concise account of the congressional proceedings resulting in the repeal from the introduction of Douglas's report to the final adoption of the House bill, in his Examination of the Dred Scott Case, pp. $154^{-1} 78$.

3 Ray, The Repeal of the Missouri Compromise. 
to the Constitution of the United States." Benton characterized this part of the bill as "a little stump speech which is stuck into its belly."

The clause, "subject only to the Constitution of the United States," was what in modern political parlancewould be called the "little joker." Most persons probably interpreted it as simply a reaffirmation of similar clauses in former enabling acts to the effect that the laws and regulations adopted by the people of the Territories should conform to the Constitution of the United States, a meaning that the courts would have implied even if it had not been expressed.

As Douglas then interpreted the Kansas-Nebraska act, it established in the Territories what he designated "popular sovereignty," but which was generally known as "squatter sovereignty"; the theory of it being that Congress should have no power either to establish or to prohibit slavery in the Territories, but that the people residing there should have the power to determine for themselves whether slavery should be legalized or not. But when was this power to be exercised? Douglas held out the idea to the people of the North that the voters of the Territory had a right to exercise this power as soon as a territorial government should be formed, "so as to keep slavery out of the Territory. "The Southern slaveholders maintained that neither Congress nor the people could keep slavery out of a Territory so long as it remained a Territory, but could only exercise the power to exclude it when they should come to the adoption of a constitution preparatory to admission as a State.

By this act the barrier was broken down which, since the enactment of the Missouri Compromise, had protected against the encroachment of slavery the vast tract lying north of thirty-six degrees thirty minutes, containing over four hundred thousand square miles-larger than the area of the thirteen original States. To say that the introduction and passage of the Kansas-Nebraska bill was like dropping a lighted match into a powder magazine would feebly 


\section{Repeal of the Missouri Compromise}

describe its effect. The force of the explosion would be better described by comparing it to that of those cataclysms that rend continents. It sent to the four winds the scattered fragments of the old Whig party, split the Democratic party in the North into two hostile and warring factions, and obliterated all political issues except the one of slavery extension or restriction.l

While the bill was being debated in Congress public meetings denouncing it were held all over the North, participated in by men of all parties. Petitions and memorials signed by thousands protesting against its passage poured in from every quarter. At last the churches were aroused, and thousands of clergymen signed remonstrances. One such remonstrance by the clergymen of New England had over three thousand signatures. The North was now united as it never had been before against the further extension of slavery.

Douglas for a time was the most unpopular man in the North. It is said that "he could ride from Boston to Chicago by the light of his blazing effigy in the night and in sight of his hanging effigy by day." When after the adjournment of Congress he returned to Illinois and attempted to speak in Chicago, flags were hung at half-mast, bells were tolled, and at one of his meetings the hooting, jeering crowd refused to hear him and after vainly attempting for several hours to make himself heard, he was com-

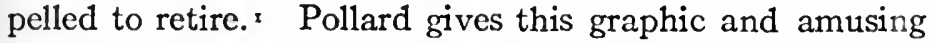
account of the meeting: "It was a remarkable struggle of the persistence of a single, brave, and clear-toned speaker, with the clamor of a hoarse and brutal mob. For four long hours, from eight o' clock in the evening, Mr. Douglas struggled for a hearing, edging in a word wherever he could, expostulating, defying, shaming, entreating, as the moods of the mob appeared to vary. Finally, when the hour of midnight was struck, he took out his watch, looked at it

'Life of Jefferson Davis, p. 38. 
very deliberately, and said: 'It is Sunday morning; I have to go to church and you may go to $\mathrm{h}-1$ !"

Rhodes's statement of the political effect of the passage of the Kansas-Nebraska act is not overdrawn. "It is safe to say that, in the scope and consequences of the KansasNebraska act, it was the most momentous measure that passed Congress from the day that the senators and representatives first met to the outbreak of the Civil War. It sealed the doom of the Whig party; it caused the formation of the Republican party on the principle of no extension of slavery; it roused Lincoln and gave a bent to his great political ambition. It made the Fugitive Slave Law a dead letter at the North; it caused the Germans to become Republicans; it lost the Democrats their hold on New England; it made the Northwest Republican; it led to the downfall of the Democratic party." $x$

× Rhodes, History of the United States, vol. i., p. 490. 


\section{CHAPTER XI}

NULLIFICATION AND HIGHER LAW IN THE NORTH

FROM the beginning of the government there had been continual friction between the North and the South caused by the escape of fugitive slaves from the slave into the free States, aided by the Abolitionists of the North; and by the kidnapping of free negroes in the North and taking them to the South.

The original Federal Fugitive Slave Law was passed in 1793. . It authorized the owner of the fugitive to seize or arrest him and take him "before any judge of the Circuit or District Courts of the United States, residing or being within the State, or before any magistrate of a county, State, or town corporate, wherein such seizure or arrest shall be made," and, upon making the proof required, to get a certificate from such judge or magistrate authorizing the removal of the fugitive to the State from which he fled.

In the case of Prigg v. The Commonwealth of Pennsylvania, ${ }^{2}$ decided in 1842 , the act was held constitutional, but in the opinion of the majority, which was pronounced by Justice Story, occurred this significant sentence: "As to the authority so conferred upon State magistrates, while a difference of opinion has existed, and may still exist, on the point in the different States, whether State magistrates are bound to act under it, none is entertained by this court that State magistrates may, if they choose, exercise the authority unless prohibited by State legislation." Chief Justice Taney

I U. S. Stat., 302; Brightley's Digest of Laws of the U. S., p. 294.

- 16 Peters, 539. 
and Justice Daniel dissented from so much of the opinion as denied the obligation of the State authorities to perform the duties imposed on them by the act. The cue given in the opinion of Justice Story was promptly taken up by Vermont and Massachusetts, which passed statutes, known as personal liberty bills, forbidding the State officers, under severe penalties, to assist in the capture of fugitive slaves, and prohibiting the use of the State jails for their detention. ${ }^{2}$ These acts were followed later by similar acts in Pennsylvania and other Northern States. Story's decision, as he himself predicted, virtually sapped the life out of the Fugitive Slave Law of I793, and in States like Massachusetts, where a strong anti-slavery sentiment prevailed, the law practically became a dead letter. ${ }^{2}$ It was because of continued and vehement complaints by the Southern slaveholding States of the insufficiency of the old Fugitive Slave Law of 1793 that the Fugitive Slave Law of 1850 was passed as one of the compromise measures of that year.

Mention has already been made of the harsh character of its provisions, which rendered it so odious in the North. The most obnoxious features of the law were not fully seen and appreciated in the North until attempts were made to enforce it. Of these the one which aroused the bitterest antagonism was that which imposed upon the people of the community where the fugitive might be found the duty of assisting the slave-catcher to capture him and return him to his master. A few in the North, but very few, voluntarily obeyed this provision. There was almost a universal feeling of sympathy with the fugitive, such as most men instinctively feel even for a panting hare when hotly pursued by the hounds. Opposition to the law was expressed in various ways and degrees of intensity. Some were for openly defying the law and were ready to use force, if necessary, in rescuing the fugitive from his captors, but the

1 Mass. Session Laws, 1843, p. 69; Vermont Session Laws, 1843, p. I1.

'Wilson, Rise and Fall, vol. i., pp. 471-473; Buchanan's Adm., pp. 16-18. 


\section{Higher Law in the North}

great majority were unwilling to go to such an extreme. While they would not forcibly rob the slave-catcher of his prey if he could succeed in capturing the fugitive, they would not voluntarily assist in his capture. If commanded by a United States marshal or his deputies to join a posse they might obey, but reluctantly and only in order to escape the penalties of the law for refusing. Many would not do even this much, preferring to run the risk of such penalties. There were many, generally a majority, in nearly every Northern community who would not deny the fugitive shelter from the storms or a crust to relieve the pangs of hunger, and who rejoiced when he succeeded in making good his escape. Many felt as did Theodore Parker when hé said: "There is a law of God, written on the heart, that cannot be altered or revoked-that we should do unto another as we would that others should do unto us. When the laws of Massachusetts or the laws of the Union conflict with the laws of God, I would keep God's law in preference, though the heavens should fall. We have officers who tell us that they are sworn to keep the laws of the State and of the United States and we are born citizens, born to obey the laws; but every bone of my body and every drop of blood in my system swears to me that I am amenable to, and must obey, the laws of God." Many in the North, although they did not publicly express their belief, believed as Parker believed.

This, it is true, was the "higher law" doctrine, pure and simple, applied to the Fugitive Slave Law. With men who believed as Parker believed all arguments based on abstract theories of government and the necessity of obedience to the Fugitive Slave Law, as well as all other laws, were as so much chaff. Indeed the convictions of conscience are seldom influenced by mere arguments. They are the conclusions drawn from innate conceptions of truths, or supposed truths, which are accepted as axiomatic and therefore incapable of being either proved or disproved by argument. Nor do such convictions yield to threats of penalties 
or punishments for violation of human laws, as is proved by the deaths of countless martyrs whose consciences remained unconquered although their bodies were burned at the stake.

It may be conceded that the "higher law" doctrine, if generally applied, would be incompatible with any practical theory of human government; nevertheless, when the supreme law comes into conflict with the supreme moral element of a community, the question for the individual citizen to decide is as puzzling as the ancient problem which supposes an irresistible force to come into contact with an immovable body. At any rate, recognizing actual conditions and not mere theories, it has been found in the practical operation of government to be a fact-often a very stubborn and troublesome fact-that although a law may have the seal of the lawmakers and may be backed by all the power of government, it never can be successfully enforced in any community where it is condemned as vicious in principle by the united moral sentiment of the people. Men may not rise in open rebellion against it, but, rather than obey it, they will suffer the penalties for disobeying it. As already stated, the moral sentiment in many communities in the North condemned the Fugitive Slave Law as not only unconstitutional but as wicked in principle, and no arguments, not even the arguments of so great a reasoner and expounder of the Constitution as Webster, could convince them that it was their duty to help the slavecatcher catch and manacle the fugitive and drag him back into bondage.

Never did any law enacted by Congress more completely fail of its purpose than did the Fugitive Slave Law of 1850 . Instead of bringing about more amicable relations between the North and the South and smoothing over the longstanding disputes about the return of fugitive slaves, it only furnished another firebrand to inflame still further the people of both sections. The South was disappointed in its results and angered by the increasing opposition of the North to the enforcement of the law. In the North 
every attempt to enforce it scrved to disclose more clearly the repulsive features of slavery and the obnoxious provisions of the law.

For a short time after its passage the pcople of the North seemed, if not to approve the law, at least to acquiesce in it. But when the slave-catcher appeared in a Northern community and the people were commanded to assist him in catching the fugitive and returning him to bondage there was an almost universal expression of disgust and defiance, including all classes and parties. Charles Sumner spoke for multitudes and not for himself alone when, to a question whether he would obey the law, he replied, "Is thy servant a dog that he should do this thing?" Joshua R. Giddings spoke still more strongly, but spoke the sentiments of many others, in a letter to an anti-slavery meeting at Palmyra, Ohio, in $185^{\circ}$, in which he said: "The Fugitive Slave Law commands us to participate in arresting and sending victims to this Southern immolation by torture a thousand times more cruel than ordinary assassination. I would be as willing to handle the scourge, to sink the thong into his quivering flesh, and to tear from him the life which God has given him, as to seize him and hand him over to his tormentors with the full knowledge and conviction that they will do it. . . . From my innermost soul I abhor, detest, and repudiate this law. I despise the human being who would obey it, if such a thing has existence. I should regard such a man as a moral nuisance, contaminating the air of freedom, and would kick him from my door should he attempt to enter my dwelling." Upon another occasion Giddings said: "I never saw a panting fugitive flying from bondage that I did not pray God most earnestly to speed him in his flight and to enable him to make good his escape. The whole sympathy of my nature is at once enlisted in his behalf. I always fecl anxious that he may escape from the crushing power under which he has been

${ }^{1}$ Speech in the House of Representatives, on December 10,1856 . Cong. Globe, $34^{\text {th }}$ Cong., $3^{\text {d sess., p. } 80 .}$ 
borne down. And yet, the President assumes to lecture me because I choose to obey God rather than him. Why, sir, gentlemen may listen while I tell them that I have seen at one time nine fugitives dining in my house-fathers, mothers, husbands, wives, and children, fleeing for their liberty, and in spite of the President's censure I obeyed the Divine command to feed the hungry and clothe the naked. I fed them. I clothed them. I gave them money for their journey and sent them on their way. Was that treason? If so, make the most of it."

Opposition to the law became more and more pronounced with every attempt to enforce it. This opposition at first found expression in forcible rescues or attempted rescues. The Shadrach case in Boston, Massachusetts, in February, 185I, was one of the first and most notable. Shadrach was arrested and held in custody as an alleged fugitive slave. While in custody of the deputy United States marshal, a mob of negroes forced open the doors and carried Shadrach away. Aided doubtless by white sympathizers, Shadrach was at once sent to Canada. The affair raised a great commotion. The President of the United States issued a special proclamation commanding all Federal officers, civil and military, to aid in the arrest of the rescuers; the Secretary of War and the Secretary of the Navy issued orders to like effect; and the matter gave rise to a protracted and angry discussion in the United States Senate. Indictments were found against several prominent citizens of Boston but upon the first trial the jurors refused to convict and so the prosecutions came to naught.

Another notable case, known as the "Jerry Rescue Case," occurred in Syracuse, New York, afterwards characterized by Webster as "that laboratory of abolitionism, libel, and treason," where a negro named Jerry was arrested as a fugitive slave on October I, I85I, and was taken before a United States commissioner. As soon as the arrest became publicly known, an Abolition convention then in session in the city adjourned, the fire bells were rung, and a crowd 
rushed to the commissioner's office and took Jerry from the officers. The officers rallied a posse and recaptured him and confined him in jail, but during the night a mob stormed the jail and spirited Jerry off to Canada. ${ }^{\mathrm{x}}$

Opposition to the enforcement of the Fugitive Slave Law was not confined to any one class or party. Andrew D. White relates that in the Jerry rescue "one of the most determined leaders was a rough, burly butcher of Syracuse who had been all of his life one of the loudest pro-slavery Democrats and who, until he saw Jerry dragged in manacles through the streets, had been most violent in support of the Fugitive Slave Law."2

James Freeman Clarke says ${ }^{3}$ that one Barnes, formerly United States marshal in Boston under a Democratic administration, once told him: "When I was a marshal and they tried to make me find their slaves, I would say, 'I don't know where your niggers are, but I will see if I can find out'; so I always went to Garrison's office [William Lloyd Garrison, publisher of the Liberator] and said, 'I want you to find such and such a negro; tell me where he is.' The next thing I knew the fellow would be in Canada." But it must be admitted that there were few United States marshals like Barnes.

The leading Democratic and Whig politicians exerted themselves to the utmost to suppress further agitation of the slavery question. Wilson states ${ }^{4}$ that before the close of the Thirty-first Congress "a compact was entered into by some of the leading members of both parties declaring their purpose to make the compromise measures a final settlement of the slavery question and pledging themselves not to 'support for President or Vice-President of the United States, for senator or representative for Congress, or for

In interesting account of this rescue is given in Andrew D. White's A utobiography, vol. i., pp. 6I-63.

- Autobiography, vol. i., p. 64.

3 Anti-Slavery Days, p. 87.

4 Rise and Fall, vol. ii., pp. 360, 361 . 
member of a State legislature, any man of whatever party who is not known to be opposed to the disturbance of the settlement aforesaid and to the renewal in any form of agitation upon the subject of slavery,' " and that this compact received thirty-three signatures from the slaveholding and ten from the free States.

In pursuance of the object of suppressing further agitation of the slavery question, so-called Union meetings were held throughout the North, particularly in the large cities and commercial centers, addressed by leading Democratic and Whig speakers. The object of these meetings was to create a sentiment in the North favoring acquiescence in the compromise measures of 1850 , and especially to allay Northern opposition to the Fugitive Slave Law, and to unite men of all parties and classes, manufacturing and commercial interests, churches and colleges-in fact, all the potent and controlling influences of society-against further agitation of the slavery question.

At a great Union-saving meeting in Castle Garden, in New York City, on October 30, I850, presided over by the Mayor and addressed by prominent Democratic and Whig speakers, the compromise measures were approved; a Union-saving Committee of one hundred was appointed and a large amount of money was contributed with which to employ eminent men to aid in the enforcement of the Fugitive Slave Law. × A similar meeting was held in Faneuil Hall, Boston, on November 26, 1850 , which is a fair example of such meetings. " The citizens of Boston and its vicinity," so the call read, "who revere the Constitution of the United States; who wish to discountenance a spirit of disobedience to the laws of the land and refer all questions arising under these laws to the proper tribunal; who would regard with disfavor all further popular agitation of subjects which endanger the peace and harmony of the Union, and who deem the preservation of the Union the paramount duty of every citizen, are requested to meet and express their sentiments

'Wilson, Rise and Fall, vol. ii., p. 316. 


\section{Higher Law in the North}

on the present posture of public affairs in Fancuil Hall, November 26, I850, at four o'clock P.M." The venerable Doctor Warren, a kinsman of General Warren of Bunker Hill fame, presided. Resolutions were adopted strongly favoring acquiescence in the compromise mcasures. Speeches in accordance with the resolutions werc made by Benjamin R. Curtis, B. F. Hallet, Rufus Choate, and others. Choate made an eloquent speech in which he said: "No, fellow citizens, there is something more and other for us to do. And what is that? Among other things, chiefly thisto accept that whole body of measures of compromise, as they are called, by which the Government has sought to compose the country in the spirit of 1787 , and then that henceforward every man, according to his measure, and in his place, in his party, in his social, or his literary, or his religious circle, in whatever may be his sphere of influence, set himself to suppress the further political agitation of this whole subject. . . . Accepting, then, these measures of constitutional compromise, in the spirit of union, let us set ourselves to suppress or mitigate the political agitation of slavery.":

The substance of all the speeches was, like that of Choate, "Hush! don't agitate!"-as if the mighty billows of public opinion after it has been stirred to its very depths could be instantly calmed by the voice of man, saying, "Peace, be still."

At all these meetings it was solemnly resolved that the compromise measures made a finality of the slavery question. Indeed, the resolutions all took on somewhat of the form of a coroner's verdict in finding that slavery agitation was now dead. But notwithstanding the fact that the slavery question had been so often and so solemnly adjudged to be thoroughly dead, and that the epitaph "Finality" had been inscribed on its tombstone, the supposed corpse in some unaccountable manner escaped from the grave to

- See pamphlet report of Proceedings of the Constitutional Meeting at Faneuil Hall, November 26, 1850. 
which it had been consigned, showed signs of marvelous vitality, and persisted in stalking about the earth and vexing the souls of the living. Then renewed efforts were made to stay its progress and speakers were sent over the land to denounce the wicked Abolitionists for the crime of the resurrection. Foremost of these was Daniel Webster. He made a speech in Albany, New York, on May 28, 185I, in which he argued not only that the Fugitive Slave Law was constitutional, but that its passage was a necessary and a just concession to the South, and that it would be neither wise nor prudent to repeal it. He denounced the "higher law" doctrine and stigmatized the resolutions of various anti-slavery conventions in New York, Massachusetts, Ohio, and elsewhere, against the enforcement of the Fugitive Slave Law, as "distinctly treasonable." The rescue of Shadrach, he said, was "clear treason." Only a few months before the Jerry rescue he made a speech in Syracuse, New York, in which he asserted in substance that the Fugitive Slave Law would be and should be enforced. In a speech in June, I85I at Capon Springs, Virginia, he bitterly denounced the Abolitionists and the "higher law," saying: "When nothing else will answer they invoke religion and speak of a 'higher law.' Gentlemen, this North Mountain is high, the Blue Ridge is higher still, the Alleghany higher than either; and yet this higher law ranges farther than an eagle's flight above the highest peaks of the Alleghany. No common vision can discern it, no conscience, not transcendental and ecstatic can feel it; the hearing of common man never listens to its high behests and therefore one should think it is not a safe law to be acted on in matters of the highest practical moment. It is the code, however, of the fanatical and factious Abolitionists of the North."2

But opposition to the law continued and it was intensified by every effort to enforce it. The law soon developed a class of men who made slave-catching a lucrative business-

${ }^{x}$ Webster's Works, vol. ii., p. 577 .

Wilson, Rise and Fall, vol. ii., 36r. 


\section{Higher Law in the North}

the professional slave-catchers, detested in the North and despised by all respectable people in the South. Whenever one of these men appeared in a Northern community he was looked upon as a hostile invader and his appearance was the signal for an angry uprising of the people. He seemed to be the personification of slavery itself and the people fancied that they could see him cracking his lash over them and could hear the clanking of chains. The fancy approached reality when a United States marshal with his posse appeared commanding them to assist in riveting real chains upon the fugitive under threats of prosecution in Federal courts where many of the Federal judges seemed to vie with the marshals in their efforts to compel the people of the North to do the bidding of the slave-catchers.

Far more dreaded than the professional slave-catchers were the kidnappers. From them no negro, slave or free, was safe. He was liable to be dragged from his bed in the dead of night, manacled and hurried off to some Federal commissioner for a hearing that was often little more than a farce, a hearing at which he was not allowed to testify in his own behalf, a hearing not infrequently had on perjured testimony trumped up by his captors. Indeed, most of the United States commissioners' courts were little more than way-stations on the road back from the North to slavery.

But it soon became apparent to the opponents of slavery that it was preferable to keep the fugitive slaves from getting into the clutches of the Federal officers rather than to try to get them out after they were once in, and that more would probably be lost than gained by attempting forcible rescues like those of Shadrach and Jerry. Indeed it became evident early in the administration of President-Pierce that the whole power of the government, legislative, executive, and judicial, backed if necessary by the entire army and navy, would be used to force submission to the Fugitive Slave Law. Many of the United States marshals and commissioners seemed eager to display their zeal in aiding the slave-owners. The alleged fugitive could get no aid from 
the State courts. In some of the Federal courts the fugitive and his friends fared no better than they did before the Federal commissioners. Everywhere, it seemed that the law had closed the door of hope against the black man.

A case involving the rights of a person arrested by a United States marshal under the provisions of the Fugitive Slave Law having come before Judge Grier of the Supreme Court of the United States, then holding court in Pennsylvania, that eminent jurist delivered an opinion in which he used this language: "If habeas corpuses are to be taken out after this manner, I will have an indictment sent to the United States Grand Jury against the person who applies for the writ or assists in getting it, the lawyer who defends it, and the sheriff who serves the writ, to see whether the United States officers are to be arrested and harassed whenever they serve a process of the United States." Commenting on this language, the New York Evening Post said: "Judge Grier bears so strong a likeness to Jeffreys in his behavior on the bench whenever a matter touching the Fugitive Slave Act comes before him that, in reading a report of the proceedings, one might imagine himself reading an account of what happened under the later Stuarts." The conduct of Judge Kane, a Federal Judge in Pennsylvania, in the noted case of Passmore Williamson was even more severely criticized than that of Judge Grier. ${ }^{x}$

Those who attempted to oppose the enforcement of the law were liable to even more serious legal consequences than indictments for its violation and civil suits for damages. They were liable to be indicted for treason. In September, I 85I, a Maryland slave-owner with a Federal deputy marshal and his posse attempted to arrest William Parker on the claim that Parker was his escaped slave. The party went to Parker's house in Lancaster County, Pennsylvania, and attempted his capture. An alarm was given and the neighborhood was aroused. Two Quakers, Castner Hanway and Elijah Lewis, tried to preserve peace and advised the slave-

$\therefore$ Wilson, Rise and Fall, vol. ii., pp. 448-51. 


\section{Higher Law in the North}

owner and his posse to withdraw. Thereupon the deputy marshal ordered them to join his posse. This they refused to do. A mellée followed in which shots were exchanged and in which the slave-owner and his son were killed and the alleged fugitive escaped. Hanway and Lewis had taken no part in the affair except in endeavoring to avoid bloodshed and had done nothing in violation of the law except in refusing to join the marshal's posse and help capture the fugitive; but for this they were indicted in the Federal court for treason. Hanway's trial lasted ten days but the jury acquitted him. ${ }^{3}$

Upon the surface of things it now seemed that the Fugitive Slave Law was to be enforced at all hazards and that the whole country was, as Whittier expressed it, "about to become the hunting ground of the slave-catcher." But every attempt to enforce the Fugitive Slave Law, even though successful, only made the law itself more odious, as is always the case with attempts to enforce an odious law, and left in every community where the attempt was made a deep and lasting feeling of resentment.

Opposition to the enforcement of the Fugitive Slave Law reached its climax in Wisconsin in the celebrated Glover rescue case and the litigation growing out of it. It strikingly illustrates the hostility in many sections of the country to the execution of the Fugitive Slave Law and how deeply it caused the South Carolina doctrine of nullification to take root in the North.

In the spring of 1854 , a negro, Joshua Glover, was living near Racine, Wisconsin. One Garland, a Missouri slaveholder, claiming that Glover was his slave, and was a fugitive, in company with two deputy United States marshals and four assistants surprised Glover at his cabin on the evening of Friday, March 10, I854. After these seven white men had effected an entrance into the cabin, they proceeded at once to fell Glover with a bludgeon and next to manacle him. Glover, bleeding and nearly senseless

'Wilson, Rise and Fall, vol. ii., pp. 328-329. 
from his injuries, and only partially dressed, although the night was very cold, was placed in a wagon and driven twenty-five miles across the country to Milwaukee, where the party arrived on the next morning. Glover was confined in jail for safe keeping until the papers could be made out for his return to Missouri. News of his capture speedily reached Racine, causing intense excitement. A public meeting was called at which inflammatory speeches were made and denunciatory resolutions were adopted. The meeting also appointed a large committee to go to Milwaukee and see that Glover was given a fair trial. Meantime, news of Glover's capture had also reached Milwaukee, creating as much or more excitement there than at Racine, and soon came to the knowledge of Sherman M. Booth. Booth was a graduate of Yale, had taken an active part in the anti-slavery movement in Connecticut, and had afterwards settled in Milwaukee, where at this time he was publishing an Abolition paper-the Free Democrat. Booth at once mounted a horse and rode through the streets, shouting as he went: "Freemen to the rescue; slavecatchers are in our midst; be at the Court House at two o'clock." A great crowd, estimated at five thousand in number, responded to the call and before the close of the meeting they were joined by the delegation from Racine. Meantime, an unsuccessful effort had been made to secure Glover's release on a writ of habeas corpus issued by the county judge, but the United States marshal refused to obey the writ, and it became known that on the following Monday Glover would be carried off to Missouri. Fiery speeches were made and a frenzied crowd rushed to the jail, battered down the doors, and liberated Glover, who was at once taken in charge by an underground-railroad agency and spirited away to Canada. As he went through the streets he aroused the enthusiasm of the crowds to a still higher pitch by holding up his manacled hands and shouting, "Glory, Hallelujah!"

Within a few days afterward Booth was arrested on a 
warrant, issued by a Federal commissioner, charged with having violated the provisions of the Fugitive Slave Law by aiding and abetting the escape of Glover and was recognized to appear before the United States District Court of Wisconsin, then presided over by Judge A. V. Miller. Booth at first gave bond for his appearance but it was determined to apply again for a writ of habeas corpus and so he was surrendered by his bondsmen and confined in jail, and then he at once made application for a writ of habeas corpus to Judge Aaron D. Smith, one of the judges of the Wisconsin Supreme Court. The writ was granted and after a hearing Judge Smith ordered Booth's discharge upon the ground, stated in an elaborate opinion, that the Fugitive Slave Law was unconstitutional for several reasons, the chief of which was that it denied the fugitive the right of trial by jury. Afterwards the case was heard before the full bench of the Wisconsin Supreme Court, which affirmed the ruling of Judge Smith. The majority opinion was delivered by Chief Justice Edward V. Whiton, who closed his opinion with this vigorous language: "But they [the free States] will never consent that the slave-owner, his agent, or an officer of the United States, armed with power to arrest a fugitive from service, is clothed with entire immunity from State authority to commit whatever crime or outrage against the laws of the State; that their own high prerogative writ of habeas corpus shall be annulled, their authority defied, their officers resisted, the process of their courts contemned, their territory invaded by Federal force, the houses of their citizens searched, the sanctuary of their homes invaded, their streets and public places made the scene of tumultuous and armed violence, and State sovereignty succumb, paralyzed and aghast, before the process of an officer unknown to the Constitution, and irresponsible to its sanctions. At least such shall not become the degradation of Wisconsin without meeting as stern remonstrance and resistance as I may be able to interpose, so long as her people impose upon me the duty of guarding their rights 
and liberties, and of maintaining the dignity and sovereignty of their State."

Chief Justice Whiton's opinion was eloquently expressed, but the United States Supreme Court afterwards said that it was not good law.

Not long afterwards Booth was indicted by the Federal Grand Jury, on the same charge for which he had been first arrested, and he was again arrested and a day was set for his trial. His journey to Madison to attend the trial was in the nature of a triumphal march. He was escorted to the railroad station in Milwaukee by a great procession of sympathetic citizens preceded by a band, and heralded by the booming of cannon. His trial lasted three days. An unwilling jury, under the instructions of the presiding judge, finally brought in a verdict against Booth upon which the judge sentenced him to one month's imprisonment and to pay a fine of $\$ 1000.00$ and costs amounting to $\$ 45$ I.0o. Again the Supreme Court of Wisconsin released him on a writ of habeas corpus, basing its second judgment, as it did the first, upon the alleged unconstitutionality of the Fugitive Slave Law. The United States marshal was granted an appeal from the first judgment to the Supreme Court of the United States, but when he attempted to appeal from the second judgment the Wisconsin Supreme Court refused to allow its clerk to certify the record. Jeremiah Black, the United States Attorney-General, afterwards managed to get a certified copy of the record and upon that the Federal Supreme Court took jurisdiction of the appeals of the United States marshal from both the judgments of the Wisconsin Supreme Court, but by reason of various delays no ruling was made on either appeal until the term beginning in December, 1858 .

Meantime Garland began a civil action against Booth for damages for the loss of his slave and his services. The case was tried before the same Federal judge who had tried the indictment and resulted in a judgment against Booth for $\$ 1000.00$ and $\$ 243.00$ costs and Booth's printing 
establishment was levied on and sold to satisfy the judgment. This gave rise to further litigation, not important in this connection, in which Booth sought, but unsuccessfully, to recover his property.

The United States Supreme Court, by a unanimous decision, at its term beginning in December, 1858 , reversed both the judgments of the Wisconsin Supreme Court in the Booth habeas corpus cases, holding the Fugitive Slave Law to be constitutional and that the exclusive power to decide whether a Federal law is constitutional or not is vested in the Federal and not in the State courts. The opinion was pronounced by Chief Justice Taney, but not until after his opinion in the Dred Scott case, which had greatly weakened the respect felt in the North for any opinion given by him involving the interests of slavery.

That part of the opinion of Chief Justice Taney which asserts the jurisdiction of the Supreme Court of the United States to be paramount to that of all State courts in the decision of the question of the constitutionality of Federal statutes has ever since been generally approved as a correct exposition of the powers conferred upon the Federal Supreme Court by the Federal Constitution. To all arguments in support of a contrary view the results, as stated by the Chief Justice, afford a conclusive answer, "for no one will suppose that a government which has now lasted for nearly seventy years, enforcing its laws in its own tribunals and preserving the union of the States, could have lasted a single year or fulfilled the high trusts committed to it if offenses against the laws could not have been punished without the conserit of the State in which the culprit is found." But it does not follow, because the Federal Supreme Court has jurisdiction to decide a given question, that its decision is correct. Jurisdiction is the power to decide a given question, although the conclusion upon which the decision is based may be erroneous, a definition not always clearly understood by those who are not, and by some who are, members of the legal profession. A court may 


\section{Political History of Secession}

have the power to decide a given question, but its decision may be wrong. It may be based upon an erroneous conception of the facts, or upon an erroneous conclusion as to the law applicable to them. If its decision is wrong, it is not necessarily final, for it may be modified or reversed by the same judges or by their successors. But until so modified or reversed, it is essential to the orderly administration of government that the decision shall be regarded as the law of the land. If it is a law that is construed, it must remain the law as the supreme judicial power has construed it until overruled or repealed by the supreme lawmaking power.

These were the views of the conservative people of the country and especially of the members of the legal profession, including many who, notwithstanding the decision of the Supreme Court, still thought the Fugitive Slave Law to be unconstitutional. They regarded the Supreme Court decision in the Booth cases in much the same way as they did the decision in the Dred Scott case, as wrongly decided, but not as a nullity; a decision that, if not approved, should be obeyed until overthrown in the orderly methods provided by the Constitution.

A large number of people in the North did not at that period share in these conservative views. They had no respect for the Fugitive Slave Law, which, as before stated, they believed to be not only unconstitutional but wicked in principle. Nor did they have any great respect for the decisions of Chief Justice Taney, formerly himself a slaveholder, whose decisions involving the interests of slavery had uniformly been in favor of the slaveholder. In the State of Wisconsin the various proceedings in the Booth cases had inflamed the people of that State to a high pitch of excitement. During the early part of these proceedings and before the decision of the Federal Supreme Court, Booth was represented by Byron Paine, then a young and rising lawyer of Milwaukee. Paine made a strong argument in the habeas corpus cases against the constitutionality of 
the Fugitive Slave Law, for which he received the warm praise of Charles Sumner, Wendell Phillips, and other noted Abolitionists. ${ }^{2}$

As Judge Smith's term expired in 1858 , it was necessary at the State election in Wisconsin in that year to elect his successor. Although Smith was a Democrat, the Democratic party of Wisconsin passed him by and nominated in his stead a lawyer of high standing in Wisconsin, William P. Lynde. The Republicans nominated as his opponent Byron Paine and, strangely enough, the election turned on the question of States' Rights. In the campaign that followed one of the most zealous of Paine's supporters was Carl Schurz, who in one of his speeches thus clearly defined the issue: "Our poor State has suffered much; its credit is ruined, its prosperity blighted, its political honor has been forfeited by wholesale corruption and maladministration. There is almost nothing to be proud of but that gallant independence of our Supreme Court and the spirit of liberty which caused the people to sustain them. Will you sacrifice that also? Will you suffer the enemies of your liberty to nestle in your own citadel? Will you see Judge Miller's opinions and pretensions infest the highest Court of this State? [Cries of No! Never!] Will you see the dirty finger marks of Buchanan's administration on the Supreme Bench of Wisconsin? If not, place a man there who dares to be himself. Let the friends of liberty and self-government present an unbroken front. Their banner bears the inscription 'States' Rights and Byron Paine." Of course there was no withstanding such appeals and "States' Rights and Byron Paine" won."

s There were some in the South also who believed the Fugitive Slave Law to be unconstitutional as an infringement upon State sovereignty. This was the view of the Charleston Mercury and of Rhett of South Carolina and of Jefferson Davis.-Victor, History of the Southern Rebellion, vol. i., p. 139; Davis, Rise and Fall, vol. i., p. 81.

-Schurz in his Reminiscences tells us that he had scarcely begun practice when his political services were demanded, naively adding that "he was in great dejection of mind about the loss of a cow case in the 


\section{Political History of Secession}

As already stated, several years elapsed between the time of Booth's first arrest and the decision of the Supreme Court of the United States. The decision was accompanied with an order, usual in such cases, directing the Wisconsin Supreme Court to reverse its decisions in the two habeas corpus cases and to return Booth into Federal custody. But the Wisconsin Supreme Court not only refused to obey the order but refused even to allow it to be entered on its records. Nevertheless, Booth was again arrested on the original judgment of the Federal District Court and imprisoned in the Milwaukee custom-house. He again applied to the Wisconsin Supreme Court for a writ of habeas corpus, but in the meantime Judge Paine had become one of the judges and was disqualified, by reason of having been Booth's counsel, to sit in the hearing of his application for the writ, and the two other judges disagreed, so that Booth could get no relief from the Wisconsin Supreme Court and remained in prison.

The people of Wisconsin were now wrought up to the highest pitch of excitement. Indignation meetings were held in many places in Wisconsin. At one of these it was "Resolved, that we cannot look on the course of Judge Miller with the least degree of allowance, and that we regard him as a disgrace to the name of judge, a tyrant when clothed with a little brief authority, an old granny, and a miserable doughface."

The General Assembly of Wisconsin, by a vote of fortyseven to thirty-seven in the Assembly and thirteen to twelve in the Senate, adopted a set of resolutions, among which were the following:

"Therefore Resolved, the Senate concurring, that we re-

court of a justice of the peace." He also says that he did not include his "States' Rights and Byron Paine" speech in the collection of his speeches afterwards published, because he became convinced that the conclusions expressed in the speech above quoted, "as to the functions and necessary powers of government, were unsound."-Reminiscences, vol. ii., pp. 105, I13. 


\section{Higher Law in the North}

gard the action of the Supreme Court of the United States in assuming jurisdiction in the case before mentioned, as an arbitrary act of power; unauthorized by the Constitution and virtually superseding the benefit of the writ of habeas corpus and prostrating the rights and liberties of the people at the feet of unlimited power.

"Resolved, that this assumption of jurisdiction by the Federal judiciary in the said case and without process is an act of undelegated power and, therefore, without authority, void, and of no force.

"Resolved, that the government formed by the Constitution of the United States was not made the exclusive or final judge of the extent of the powers delegated to itself; but that, as in all other cases of compact among parties having no common judge, each party has an equal right to judge for itself, as well of infractions as of the mode and measure of redress.

"Resolved, that the principle and construction contended for by the party which now rules in the councils of the nation, that the general government is the exclusive judge of the extent of the powers delegated to it, stop nothing short of despotism, since the discretion of those who administer the government, and not the Constitution, would be the measure of their power; that the several States that formed that instrument, being sovereign and independent, have the unquestionable right to judge of its infraction; and that a positive defiance by these sovereignties, of all unauthorized acts done or attempted to be done under color of that instrument, is the rightful remedy."

It will be noted that most of the last resolution is almost a verbatim copy of the Kentucky resolution of 1799, substituting for "nullification" in the Kentucky resolution, the words "a positive defiance"; and that the resolutions fully embodied Calhoun's "compact" theory.

These resolutions were signed by the Governor, thus uniting the judicial, the executive, and the legislative departments of Wisconsin in favor of nullifying the Fugitive 
Slave Law. Here then we have the Legislature, the Governor, the Supreme Court, and the people of Wisconsin committed to nullification as rank as anything of the kind ever advocated by Calhoun or the authorities of South Carolina. All this goes to illustrate the old spelling-book story which teaches the lesson that in the practical application of abstract principles of law, especially in "practical politics," it makes a great difference whose ox is gored. The "ins" are for large national powers; the "outs" are opposed.

But indignation meetings and legislative resolutions could not get Booth out of jail. His only hope now was in executive clemency and he presented a petition for pardon to President Buchanan, who referred the application to the Attorney-General, Jeremiah Black. Black could find no evidence that either Booth or the Wisconsin community had repented. Moreover, Black thought that the enormity of Booth's offense had been aggravated by a "lawless court" and so he advised against granting the pardon. But after Black had been succeeded by Stanton the latter recommended the pardon. Probably both Stanton and the President thought that the rebellion in the South was all that the Administration could manage without encouraging another in Wisconsin. So on the 'ast day of Buchanan's Administration, Booth was pardoned. ${ }^{x}$

x For a statement of the facts in the Booth cases, I have drawn principally from the following authorities: Paper by Vroman Mason on “The Fugitive Slave Law in Wisconsin, with Reference to Nullification Sentiment," found in the Proceedings of the State Historical Society of Wisconsin, at the Forty-third Annual Meeting held December 12, I 895, p. II 7; Paper by Judge John B. Winslow of the Wisconsin Supreme Court, on "The Booth Case; A Chapter from the Judicial History of Wisconsin," found in the Proceedings of the Illinois State Bar Association, at the Twenty-ninth Annual Meeting in May, I905, Part 2, p. 43; Paper by Stephen S. Gregory, President of the American Bar Association, on "A Historic Judicial Controversy and some Reflections Suggested by it," found in the Proceedings of the Indiana State Bar Association, at its Annual Meeting in July, 1912, p. 268; Flower, History of the Republican Party, pp. 120-131. The legal proceedings are officially reported in 
Not long after the Glover rescue case in Wisconsin, the case of Antony Burns in Boston stirred Massachusetts to its very depths. This occurred soon after President Pierce had signed the Kansas-Nebraska bill and furnished another and striking object-lesson of the workings of the Fugitive Slave Law. Burns, an alleged fugitive slave, had been arrested, and after a trial before a Federal commissioner was given over into custody to be taken back to his Southern master. To guard against threatened rescuc, a great military force had been gathered of cavalry, artillery, and infantry, which included several battalions of United States troops besides twenty-two companies of Massachusetts infantry and the United States marshal's civil posse of one hundred and twenty-five men. Surrounded by this formidable military force, and over the indignant but futile protests of the citizens of Boston, the poor fugitive was marched through the streets, along which American flags were hung draped in mourning, to the harbor, where he was transferred to a United States revenue cutter, placed at the disposal of the slave-catchers by order of President Pierce, which conveyed him back to Virginia. Thus the majesty of the Fugitive Slave Law was vindicated, and thus President Pierce, for a time, awed into submission his rebellious subjects in Massachusetts, as King George had done before him. Of course, such a scene, enacted under the very shadow of Bunker Hill monument, aroused the people of Boston to a frenzy, and the protests against it reached far beyond the boundaries of Massachusetts.

From this period there were fewer forcible rescues because there were fewer captures; there were fewer captures because of the increased activities of anti-slavery men in aiding fugitives to elude their pursuers. The old antislavery societies redoubled their efforts; new ones were

the reports of the decisions of the Supreme Court of Wisconsin and of the Supreme Court of the United States in 3 Wis., I-197; II Id., 517558; 2 I How. U. S., 506. 


\section{Political History of Secession}

formed; the operations of the underground railway were largely extended. Of the new anti-slavery societies, one in Boston was formed on an entirely new and novel plan. It was called the "Boston Anti-Man-Hunting League." It is described as "a secret organization, with its grips and passwords, its object being to protect the fugitives, if need be by kidnapping the kidnapper. It consisted of more than one hundred men and was composed of lawyers, physicians, literary men, merchants, men of ability, character, social position, and influence." $\mathrm{I}$

Wilson minutely describes the plan of operations of the members of the League, some of them nearly eighty years old, and their grotesque drill which included the use of billies instead of firearms and drilling in the "practice of seizing, holding, and carrying away any one they wanted to capture and remove." Looking at the matter from one standpoint, we might see in it only the contrast between the lofty purposes of the League, and the comic character of its drills, and accept it as illustrating the truth of the saying that "there is but one step from the sublime to the ridiculous." But looking at the matter from a different standpoint, we see clearly how intense must have been the feeling against slavery - even though it be called fanaticism-that inspired men, venerable with age and of the highest character and social standing, to join in such a movement.

The State authorities of no other State went so far in defying the provisions of the Fugitive Slave Law as did those of Wisconsin. Nevertheless, several Northern States which before had no personal liberty laws now proceeded to enact them. Other States like Vermont and Massachusetts which already had such laws passed others still more stringent. ${ }^{2}$

The object of most of these laws was to prevent kidnapping of free negroes and to provide for a fair trial of the

× Wilson, Rise and Fall, vol. ii., pp. 441-443.

'A synopsis of several of these laws is given in McPherson's History of the Rebellion, pp. 44-47. 
alleged fugitives. Massachusetts, without legislating in open defiance of the Fugitive Slave Law, went as far as it was deemed prudent to go in making slave-catching in that State both difficult and hazardous. ${ }^{x}$ Vermont went further and passed an act approved November 25, 1858 , in which, among other provisions, were the following, which made no exceptions on account of the national Fugitive Slave Law.

"Sec. 6. Every person who may have been held as a slave who shall come, or be brought into this State, with or without the consent of his or her master or mistress, or who shall come, or be brought, or be, involuntarily or in any way, in this State shall be free.

"Sec. 7. Every person who shall hold, or attempt to hold, in this State, in slavery, or as a slave, any person mentioned as a slave in the sixth section of this act, or any free person, in any form, or for any time, however short, under the pretense that such person is or has been a slave, shall, on conviction thereof, be imprisoned in the State prison for a term not less than one year nor more than fifteen years, and be fined not exceeding \$2000."

There were, however, no such provisions as those of the Vermont act in the personal liberty laws of Massachusetts or of any other Northern State.

Such was the opposition of the people of the North to the enforcement of the Fugitive Slave Law, especially after the repeal of the Missouri Compromise, that from that time to the beginning of the Civil War the law became practically a dead letter in many sections of the free States. After the year 1854 , comparatively few fugitive slaves who succeeded in reaching the free States were ever captured, but were effectually concealed or were sent by the underground railroad to Canada. The few captures nearly always angered the local communities and inflamed still more the anti-slavery sentiment of the North.

${ }^{3}$ Mass. Session Laws, 1855, p. 489.

2 Vermont Session Laws of 1858, p. 42. 


\section{Political History of Secession}

It was in attempting to make slave-catchers of the people of the North that the power of slavery received its first serious check. No Congress, no Supreme Court, no President, nor all combined, could suppress in the hearts of the men of the North the instincts of manhood and the natural feelings of humanity. Against these the power of slavery dashed and broke in vain, as vainly as the ocean billows dash and break against the rugged cliffs of a rockbound coast. 


\section{CHAPTER XII}

\section{POPULAR SOVEREIGNTY IN PRACTICE}

\section{PROFESSOR SPRING quotes: Theodore Parker as}

saying in 1856 in reference to the slavery struggle in Kansas: "I know of no transaction in human history which has been covered up with such abundant lying from the death of Ananias and Sapphira down to the first nomination of Governor Gardner." The difficulty of picking out the truth from the conflicting stories will be admitted by all who have made the attempt. It is not within the province of this volume to recount in detail the story of the early troubles in Kansas. It is necessary, however, briefly to refer to it in order to get a clear understanding of subsequent events and especially of the Lecompton Constitution.

Immediately after the passage of the Kansas-Nebraska act, a determined effort was made to make Kansas a slave State, and large numbers from the slave States, but mostly from Missouri, some with their slaves, began moving into the Territory. This effort to convert the Territory into a slave State was met by an equally determined effort in the North to make it a free State. The New England Emigrant Aid Society was chartered by the Legislature of Massachusetts with the avowed object of aiding emigrants who wished to find homes in Kansas. Societies with similar objects were afterwards formed in other parts of the North. Undoubtedly a large majority of those sent out under the auspices of these societies were hostile to slavery, but they went as peaceful citizens and for the bona fide purpose of securing cheap homes.

$\therefore$ In preface to Kansas. 


\section{Political History of Secession}

The first colony of about thirty came in July, I854, and pitched their camp on what is now the site of Lawrence near the Kaw River. They were soon joined by another colony of about seventy. They brought a sawmill and began to make preparations for building houses and establishing a permanent settlement. Other Northern colonists followed and settled in various parts of the Territory.

These movements speedily attracted the attention of those whose hearts were set on making Kansas a slave State and they at once set about organizing "Blue Lodge," "Sons of the South," and other secret oath-bound societies, chiefly in Missouri but also in other places in the South, whose avowed object was to make Kansas a slave State. For the same purpose a persistent effort was made through the newspapers and by public meetings to encourage emigration from the slave States to Kansas and to discourage emigration from the free States. General Stringfellow addressed a public meeting in St. Joseph, Missouri, at which he said: "I tell you to mark every scoundrel among you who is in the least tainted with Abolitionism or Free-soilism and exterminate him. Neither give nor take quarter from the damned rascals." Dr. John H. Stringfellow, a brother of General Stringfellow, made himself specially notorious in the work of making the Territory a slave State. The Atchison Squatter Sovereign said: "We can tell the impertinent scoundrels of the Tribune that they may exhaust an ocean of ink, their Emigrant Aid Societies spend their millions and billions, their representatives in Congress spout their heretical theories till doomsday, and his Excellency Franklin Pierce appoint Abolitionist after Freesoiler as our Governor, yet we will continue to lynch and hang, to tar and feather and drown every white-livered Abolitionist who dares to pollute our soil." I But Northern immigrants continued to pour into the Territory, and it was soon perceived that stronger measures must be adopted to stay the tide of Northern immigration, else the free-

'Quoted in Phillips's Conquest of Kansas, p. 6r. 


\section{Popular Sovereignty in Practice}

State men would soon outnumber the slave-State men and Kansas would be forever lost to slavery. Then began organized raids from Missouri into the Territory, the raiders burning houses, driving off cattle, intimidating, and sometimes murdering, the free-State settlers; after which the "border ruffians," as they were called, would escape over the border into Missouri.

The free-State settlers at Lawrence were still occupying their temporary tents when a gang of border ruffians, numbering over one hundred, armed with bowie-knives, revolvers, and rifles, suddenly made their appearance and went into camp nearby, remaining there two days uttering dire threats of instant extermination should the settlers refuse forthwith to tear down their tents and leave the Territory.: Such outrages upon the free-State settlers naturally excited feelings of indignation and resentment and led some of them to acts as lawless as those of their enemies.

The excitement in Kansas soon spread throughout the nation. Many of the immigrants now coming from the North came armed and rifles were sent from the East to those not already provided with them. These were shipped secretly, of course, sometimes consigned as "dry goods," sometimes as "books," and sometimes, it was charged, as "Bibles," and "Beecher's Bibles" became the "best sellers" in the religious literature of the Territory. At a public meeting at Plymouth Church, Henry Ward Beecher declared that for the pro-slavery men of Kansas a Sharps rifle was a greater moral agency than a hundred Bibles; "you might just as well," he said, "read the Bible to buffaloes as to those fellows who follow Atchison and Stringfellow; but they have a supreme respect for the logic that is embodied in Sharps rifles." Colonel Buford, of Alabama, took to Kansas a battalion of two hundred and eighty men from his own State, Georgia, and South Carolina. Before starting they were duly blessed and provided with

3 Phillips in Conquest of Kansas, p. 27, gives a graphic description of this visitation. 
Bibles by some of the Southern ministers, having been already provided with rifles. Indeed the ministers both in the North and in the South seemed to lay great stress upon the efficacy of rifles as well as Bibles.

The first Governor appointed by President Pierce was Andrew H. Reeder, of Pennsylvania, and the first election held was that for the election of a territorial delegate to Congress. This was held on November 29, 1854, when several hundred armed men from Missouri persisted in voting. The next election was one held on March 30, 1855, for members of the territorial Legislature. At this election several thousand men from Missouri, under the lead of Senator David Atchison and Doctor Stringfellow, took forcible possession of all the polling places, except a few in remote parts of the Territory. Nearly one thousand of these, armed with rifles, pistols, bowie-knives, and two pieces of artillery, went into camp in the vicinity of Lawrence and forcibly took possession of the polls, driving off the legally appointed election officers and putting others of their own choosing in their places, doing all this without any pretense of legal right of any kind, and proceeded to elect, or to declare elected, those chosen by them as members of the Legislature, and declared all of them except two to be so elected. Governor Reeder, recognizing the fraudulent character of the election, issued a proclamation for a second election, when several hundred Missourians again appeared and voted in one of the precincts, the twelfth.

On July 2, 1855, the territorial Legislature first elected met, unseated all the members elected at the second election except those elected in the twelfth precinct, and changed the seat of government from Pawnee to Shawnee Mission, one half mile from the Missouri line. Assembling at Shawnee Mission, they elected Doctor Stringfellow presiding officer, and proceeded to enact a lot of laws. Among them was one declaring that no term of residence in the Territory should be required as a qualification of a voter. Not having the time or inclination to go through the ordinary forms of 


\section{Popular Sovereignty in Practice}

legislation, the Legislature took a short cut by enacting in a body the Missouri laws of a general character, as found in a volume of Missouri statutes. Other laws were passed for the protection of slave property and making it a felony to question in any way the right to hold slaves in the Territory. Many of these laws were passed over the Governor's veto and without the slightest regard to it. This Legislature also provided that a new Legislature should be elected in October, 1857, but should not convene until July, I858. This Legislature also called a Constitutional Convention, which met at Lecompton, in September, 1857 , and adopted what was afterwards known as the Lecompton Constitution and provided for its submission to the people at an election to be held on December 21, 1857. The convention provided for only a limited submission of the constitution to the people by a provision that the ballots should be endorsed "For the constitution with slavery," or "For the constitution without slavery." It was also provided that there should be no amendment of the constitution prior to the year 1864 , and there were other provisions exceedingly obnoxious to the free-State men. ${ }^{x}$

At the election for the submission of the Lecompton Constitution, the free-State men, protesting against the authority of the Legislature which ordered the election, absented themselves from the polls and the pro-slavery voters were in a large majority.

Meantime, the free-State men met at Topeka on September I9, I 855, and adopted a constitution, afterwards known as the "Topeka Constitution," and at later dates provided for elections for territorial delegate, a Governor, various officers, and members of the Legislature. The pro-slavery men, claiming that the elections ordered by the free-State men were illegal, stayed away from them. And so there were dual conventions, dual constitutions, dual governors, dual legislatures, resulting in general confusion.

Such was the critical condition of affairs in the Territory

- See Young, American Statesman, p. 983. 


\section{Political History of Secession}

that Governor Shannon, who had now superseded Governor Reeder, wrote to President Pierce saying: "It is vain to conceal the fact; we are standing on a volcano; the upheavings and agitations beneath we feel and no one can tell the hour when an eruption may take place." $s$ Shannon accordingly asked the President to send United States troops to the Territory and a detachment was promptly sent.

The President's annual message to Congress on December 31,1855 , had in it a little, but only a little, in reference to Kansas affairs. It was followed on January 24, 1856, by a special message in which the President upheld the proceedings of the first territorial Legislature, disapproved the actions of Reeder, the territorial Governor, and denounced as revolutionary the opposition of the free-State men, which if persisted in would, he said, become treasonable. The message mildly disapproved the acts of the Missouri raiders but laid all the blame upon the anti-slavery people of the North, especially the promotors of the Emigrant Aid Societies, who had been "thwarted in the endeavor to impress, through the agency of Congress, their particular views of social organization on the people of future new States," and whose "designs and acts had the necessary consequence to awaken emotions of intense indignation in States near to the Territory of Kansas and especially in the adjoining State of Missouri." The message also recommended the passage by Congress of an enabling act preparatory to the admission of the Territory into the Union as a State. The message was followed by a proclamation issued on February II, I856, "commanding all persons engaged in unlawful combinations against the constituted authorities of the Territory of Kansas or of the United States to disperse and retire peaceably to their respective abodes," and warning such persons that all opposition to the territorial government would be suppressed "not only by the

s Shannon to Pierce, November 28, 1855; Report of Cornmittee on Kansas, p. 98. 


\section{Popular Sovereignty in Practice}

employment of the local militia but also by that of any available forces of the United States." Never in the history of the nation had a President, from either the North or the South, shown such a spirit of truckling servility to the slave power.

Still more rigorous measures were now resorted to in order to prevent free-State men from coming to the Territory and to drive out those already there. S. D. Lecompte, an intense pro-slavery man, had been appointed by President Pierce as Chief Justice of the Territorial Court, and he signalized his arrival by charging the Grand Jury to find indictments for treason, actual or constructive, against all those who, by acts or words, opposed, or even questioned, the validity of the territorial laws or government. Under these instructions the willing Grand Jury ground out indictments for treason by the wholesale against Robinson, Lane, and nearly all the prominent free-State leaders in the Territory and also against the publishers of several of the free-State newspapers, including the two at Lawrence, The Herald of Freedom and The Kansas Free-State. It was desired in some way to compass the destruction of the freeState hotel, a new three-story building erected by the New England Emigrant Aid Society, but as an indictment for treason could not be found against a pile of stone and mortar it was indicted as a nuisance, the charge being that: "The building known as the 'Free State Hotel' in Lawrence has been constructed with the view to military occupation and defense, regularly parapeted and portholed for the use of cannon and small arms, and could only have been designed as a stronghold of resistance to law, thereby endangering the public safety, and encouraging rebellion and sedition in this country"; wherefore the jury "respectfully recommended that steps be taken whereby this nuisance may be removed." s

Ex-Governor Reeder and Lane succeeded in making their escape from the Territory, but Robinson was arrested

× Phillips, Conquest of Kansas, p. 259. 
and imprisoned in jail for four months, charged with treason. In order to find some pretext for "wiping out" Lawrence, J. B. Donaldson, the territorial United States marshal, issued a proclamation stating that there was danger of forcible resistance to the service by him of writs against the citizens of Lawrence, for which reason he summoned to his assistance a large posse of "the law-abiding citizens of the Territory." Pursuant to this proclamation there was a hasty gathering of pro-slavery clans in Kansas and Missouri, but chiefly in Missouri, including the numerous bands from other slave States which were temporarily sojourning there, and on May 21, I856, a force numbering some seven or eight hundred men was concentrated in the vicinity of Lawrence under the lead of one of Donaldson's deputies, accompanied by Samuel J. Jones, a territorial sheriff, who had some writs to serve. The entire force was armed, some with muskets belonging to the United States that had been furnished by the Federal officers having them in charge. Part of the force was mounted. They had five cannons. They formed in military organizations as shown by the names of some of them, such as the Douglas County Militia, the Kickapoo. Rangers, and the Platte County Rifles. Upon their flags were inscribed such mottoes as "South Carolina," "Southern Rights," and other mottoes expressive of the character of the organization. The posse was made up in part from the pro-slavery settlements of the Territory on the eastern border, but largely from Missouri and slave States farther south. This is evident from the names of the many distinguished generals, colonels, majors, and captains who had offered their services for the preservation of "law and order" in Kansas, such as General Atchison, the Missouri Senator, General Stringfellow and Colonel Boone of Missouri, Colonel Zadoc Jackson of Georgia, Colonel Wilkes of South Carolina, and Colonel Titus of Florida.

The deputy marshal and Sheriff Jones having served all their writs without any resistance, there was, of course, nothing more that they and the posse could legally do but to 
leave the town. Instead of leaving they remained and proceeded to carry out the real purpose of their coming and the sack of the town began. The offices of the two freeState newspapers were gutted and their contents were cast into the river or were otherwise destroyed. The artillery was turned on the free-State hotel, but failing to destroy it by bombardment, an unsuccessful attempt was made to blow it up and then it was burned. The house of Robinson, the free-State Governor, was rifled of its contents and burned, and private residences throughout the town were broken open and looted and such of their contents as were not stolen were destroyed.

That these outrages were committed in flagrant defiance of all laws, national, territorial, human, or divine, is patent. It is equally clear that they were not committed in the sudden heat of passion, but that they had been carefully premeditated for the boasted purpose of "wiping out" Lawrence. This triumph of "law and order" caused great rejoicing among the pro-slavery people in Kansas and elsewhere, as expressed in the account given in the Lecompton Union which was published under flaring headlines as a "Glorious Triumph of the Law and Order Party over Fanaticism in Kansas."

The country did not fail to note- the North with indignation, the South with satisfaction-that President Pierce uttered no word of censure for the participants in these lawless acts. Probably none was expected, considering that in his political conduct he was guided chiefly by the counsel of his Secretary of War, Jefferson Davis.

On July 4 following when the newly elected members of the free-Statc Legislature assembled in Topeka they were dispersed, pursuant to a proclamation of President Picrce, by a force of United States troops under the command of Colonel Sumner. ${ }^{\mathrm{x}}$

Matters now went on from bad to worse. Pro-slavery pickets were stationed along the river who stopped and ' Afterwards a distinguished Union general in the Civil War. 
searched boats bringing immigrants to the Territory, and all who sought ingress into the Territory by water or land were rigidly catechized to ascertain their orthodoxy on the slavery question, and if their answers were unsatisfactory they were turned back by threats or violence. But Northern immigrants found new routes through Iowa and $\mathrm{Ne}$ braska and men, money, and arms now flowed into the Territory from New England and other Northern States. Secret, oath-bound free-State societies were organized and also military companies which were fully armed and drilled; a sort of guerrilla warfare was carried on throughout the Territory; business was almost wholly paralyzed; men went armed and in bodies to till the fields; at election times armed bands took possession of the polls; election returns were forged; towns were sacked; homes were burned; citizens were murdered; and the stories told of atrocious butcheries by the border ruffians were offset by stories of equally atrocious butcheries by the free-State men. Doubtless, as is always the case in such turbulent periods, many of these outrages were committed by ruffians who were not impelled by any sense of devotion to either slavery or freedom but who took advantage of the license afforded by the times to commit crimes that would not have been excused or tolerated under different circumstances in any community.

It was in these troublous times that John Brown of Ossawatomie first became conspicuous. He was of old Massachusetts Puritan stock, sixth in line of descent from Peter Brown who came over in the Mayflower. He had gone to Kansas with several of his sons and he took an active part in the political struggles and in the guerrilla warfare there. At a place in Kansas called Black Jack, Brown with a few men had encountered and captured a largely superior force of Missourians under command of Captain Pate. Thenceforth the encounter was dignified with the title of the "Battle of Black Jack," and Brown was exalted as a hero. Once he and his band invaded the border counties of 
Missouri, killing a slave-owner, liberating several slaves, and destroying property. Some of his bloody deeds exceeded in atrocity any of those committed by the border ruffians. One cannot, even at this day, read without a shudder the story of the Pottawatomie massacre in which Brown and his band, consisting of himself, four of his sons, and three others, dragged from their beds five defenseless men, two of them mere boys, and savagely butchered them, for no offense except that they were pro-slavery men and for no purpose except to strike terror to the hearts of the Missouri border ruffians. For this brutal murder no excuse can be found. It cannot be excused as one of the incidents of war, for even in time of war only barbarians or guerrillas butcher defenseless prisoners in cold blood. The only excuse given by Brown himself was that, disguised as a surveyor, he had obtained the views of the murdered men and found that they "had exch committed murder in his heart, and, according to the Scripture, they were guilty of murder, and I felt justified in having them killed," a theory which Brown's latest biographer admits to be a most extraordinary "confusion of ethics and morals." This brutal crime shocked the entire Territory and was promptly and almost universally denounced by the free-State men. Nevertheless some of Brown's deroted admirers even now insist upon crowning him with the title "Liberator of Kansas."

The barbarous acts that characterized the contest in Kansas in some respects exceeded the horrors of the Civil

- A full account of this massacre is given by Mr. Villard who can find nothing either to justify or to mitigate its atrocity. Mr. Villard's conclusion of this matter is: "For John Brown no pleas can be made that would enable him to escape coming before the bar of historical judgment. There his wealth of self-sacrifice and the nobility of his aims do not avail to prevent a complete condemnation of his bloody crime at Pottawatomie, or a just penalty for his taking human life without warrant or authority. If he deserves to live in history, it is not because of his cruel, gruesome, reprehensible acts on the Pottawatomie but despite of them. "-Villard, John Brown, chapter v., pp. 148-1 88. 


\section{Political History of Secession}

War, for that war was fought mainly by brave men on both sides, the flower of the land, who scorned the part of brutal ruffians, prowling guerrillas, and sneaking assassins.

On March 12, Douglas, as chairman of the Senate Territorial Committee, submitted a majority report on so much of the President's message as related to Kansas affairs, the report upholding the President's position. With the report a bill was submitted authorizing the admission of the Territory as a State on certain specified conditions. Senator Collamer of Vermont submitted a dissenting minority report. Douglas threw himself into the forefront of the battle and supported his report and bill in a speech delivered on March 20, I856. ${ }^{\mathrm{x}}$

No unprejudiced person can read the full report of his speech without admitting that it was a powerful argument, strongly supporting the majority report and the bill accompanying it. After quoting the resolutions of various freeState conventions, he said that no man could doubt that it was the fixed purpose of the free-State men "to put a State government in operation in conflict with the existing territorial government and in defiance of the authority of Congress," and that it was "a case of open and undisguised rebellion." Quoting a portion of the minority report which declared it to be clear that the proceedings of the free-State men "should not be met and denounced as revolutionary, rebellious, insurrectionary, or unlawful, nor does it call for or justify the exercise of any force by any department of this government to check or curtail it," Douglas scornfully answered: "A movement should not be called "revolutionary' when its origin, progress, and aim consist in nothing but revolution! It should not be called 'rebellious' when its authors, in an event certain to happen, avowed their 'ultimate determination' to be rebellion! It should not be called 'insurrectionary' when its first act, and each successive act, proclaim violent resistance to the laws of the Territory, even to 'a bloody issue'! It should not be called

¿Cong. Globe, 34th Cong., Ist sess., App., p. 280. 
'unlawful' when its avowed object was to overthrow by force the whole system of laws under which they lived! Neither the government nor any department of it should use any force to 'check or control' this revolutionary movement, even when the supremacy of the laws could be maintained in no other way! Such are the conclusions of the minority report!"

Seward had introduced a bill for the admission of Kansas under the Topeka Constitution, but the convention which adopted that constitution had been held without any semblance of Federal authority and the Constitution had never been legally ratified by the people. Therefore, proving that the proceedings of the pro-slavery territorial Legislature ought to be set aside did not prove that the Territory should be admitted under the Topeka Constitution. To have admitted Kansas under the Topeka Constitution without submitting it to the people of the Territory, and thereby arbitrarily forcing it upon them, would have been an arbitrary and unjust exercise of congressional authority. On this proposition Douglas had the decided advantage. ${ }^{x}$

Moreover, Douglas had looked into the Topeka Constilution and found that it contained a provision prohibiting negroes from entering the State, wherepuon he turned the tables on Seward in this ingenious fashion: "The constitution which your friends have formed at Topeka, under which the State government has recently been organized, and with which the Senator from New York [Mr. Seward] proposes to admit the State into the Union, forbids the negro forever to enter the State. You profess to be the especial friends of the negro; your consciences are greatly disturbed lest he will not be well treated in Kansas, and, at the same time, you are in favor of a proposition which denies to him forever the right to enter, live, or breathe, in the proposed State of Kansas. If the negro be free you will not let him come! If he be a slave, you will not let him

\& See Von Holst, Const. and Pol. Hist., vol. v., p. 28r. 


\section{Political History of Secession}

stay! And yet you are so much aggrieved at his sad condition that you are willing to blot out and destroy the whole system of laws for the protection of white folks on account of the injustice which you fear will be done to the poor negro!"'

Again, commenting on the proceedings of the emigrant aid societies, he said: "From these facts it is apparent that the whole responsibility of all the disturbances in Kansas rests upon the Massachusetts Emigrant Aid Company and its affiliated societies. The remedy for these evils must be found in the removal of the causes and abandonment of the policy which produce them, and in faithfully and rigidly carrying into effect the provision of the Kansas-Nebraska act, which guarantees to the people of that Territory the perfect right 'to form and regulate their domestic institutions in their own way, subject only to the Constitution of the United States."'

The arguments advanced by Douglas were skilfully presented and were supported by a great array of evidence drawn from official reports, resolutions of public meetings, and other documentary evidence. If Douglas had not completely riddled Collamer's minority report he had left it in a badly damaged condition.

Douglas's speech extorted admiration even from his political opponents. They felt that, if unanswered, it would prove to be exceedingly detrimental to the anti-slavery cause in the coming presidential campaign and they anxiousiy looked about for a champion to answer. Hale, Wilson, Fessenden, and others made speeches in answer to it, but Chase was absent, having been elected Governor of Ohio, and the main dependence was now upon Seward, who spoke on April 9, speaking with great force and eloquence. In the course of his speech he said, addressing the free-State Senators: "Senators of the free States, I appeal to you. Believe ye the prophets? I know you do. You know, then, that slavery neither works mines and quarries nor founds

× Cong. Globe, 34th Cong., Ist sess., App., p. 399. 


\section{Popular Sovereignty in Practice}

cities, nor builds ships, nor levies armies, nor mans navies. Why, then, will you insist on closing up this new Territory of Kansas against all enriching streams of immigration, while you pour into it the turbid and poisonous waters of African slavery? Which one of you all, whether of Connecticut, or of Pennsylvania, or of Illinois, or of Michigan, would consent thus to extinguish the chief light of civilization within the State in which your own fortunes are cast, and in which your own posterity are to live? Why will you pursue a policy so unkind, so ungenerous, and so unjust towards the helpless, defenseless, struggling Territory of Kansas, inhabited as it is by your own brethren, depending on you for protection and safety? Will slavery in Kansas add to the wealth or power of your own State, or to the wealth, power, or glory of the Republic? You know that it will diminish all of these. You profess a desire to end this national debate about slavery, which has become for you intolerable. Is it not time to relinquish that hope? You have exhausted the virtue for that purpose that resided in compacts and platforms, in the suppression of the right of petition and in arbitrary parliamentary laws and in abnegation of Federal authority over the subject of slavery within the national Territories. Will you even then end the debate, by binding Kansas with chains, for the safety of slavery in Missouri? Even then you must give over Utah to slavery, to make it secure and permanent in Kansas, and you must give over Oregon and Washington to both polygamy and slavery so as to guarantee equally the one and the other of those peculiar domestic institutions in Utah, and so you must go on, sacrificing on the shrine of peace Territory after Territory, until the prevailing nationality of freedom and of virtue shall be lost, and the vicious anomalies which you have hitherto vainly hoped Almighty wisdom would remove from among you without your own concurrence shall become the controlling elements in the Republic. He who found a river in his path, and sat down to wait for the flood to pass away, was not more unwise than he who 


\section{Political History of Secession}

expects the agitation of slavery to cease, while the love of freedom animates the bosoms of mankind.

"The solemnity of the occasion draws over our heads that cloud of disunion which always arises whenever the subject of slavery is agitated. Still the debate goes on, more ardently, earnestly, and angrily, than ever before. It employs now not merely logic, reproach, menace, retort, and defiance, but sabers, rifles, and cannon. Do you look through this incipient war quite to the end, and see there peace, quiet, and harmony, on the subject of slavery? If so pray enlighten me, and show me how long the way is which leads to that repose. The free States are loyal and they always will remain so. Their foothold on this continent is firm and sure. Their ability to maintain themselves, unaided, under the present Constitution, is established. The slave States, also, have been loyal hitherto, and I hope and trust they ever may remain so. But if disunion could ever come, it would come in the form of a secession of the slaveholding States; and it would come, then, when the slaveholding power, which is already firmly established on the Gulf of Mexico and extends a thousand miles northward along both banks of the Mississippi, should have fastened its grappling irons upon the fountains of the Missouri and the slopes of the Rocky Mountains. Then that power would either be intolerably supreme in this Repubic, or it would strive for independence or exclusive domination. Then the free States and slave States of the Atlantic, divided and warring with each other, would disgust the free States of the Pacific, and they would have abundant cause and justification for withdrawing from a Union productive no longer of peace, safety, and liberty to themselves and no longer holding up the cherished hopes of mankind."

- Seward's speech made a profound impression upon the nation. Its eloquence was of the highest order, surpassing that of Douglas, but it must be admitted that in skilful presentation of facts and statistics, in ingenuity of argu- 


\section{Popular Sovereignty in Practice}

ment, in closeness of reasoning, it does not quite equal the speech of Douglas.

The specch of Charles Sumner is the subject of another chapter.

While the Kansas bill introduced by Douglas on March 17, 1856, was still under discussion, an attempt was made in the Senate to get a more definite construction of the meaning of the term "popular sovereignty" as defined in the Kansas-Nebraska act. That act had now been in force over two years and yet no one could tell whether the "popular sovereignty" with which it clothed the people of the Territory gave them a right, while it remained in a territorial condition, either to establish or to exclude slavery. As Senator Trumbull of Illinois said, the Kansas-Nebraska act "is discussed very differently in different sections of the country. It has a Northern and a Southern look."

For the purpose of getting a construction of it by the Senate, Trumbull offered an amendment, the substance of which was to declare it to be the true intent and meaning of the Kansas-Nebraska act that every slave taken to Kansas by his owner for the purpose of scttlement should be free, unless authorized to be held as a slave "by some valid act of the duly constituted legislative assembly of said Territory." I This amendment was promptly voted down and then Trumbull offered another, declaring it to be the true intent and meaning of the Kansas-Nebraska act "to confer upon or leave to the people of the Territory of Kansas full power at any time, through its territorial Legislature, to exclude slavery from said Territory, or to recognize and regulate it therein." 2 This amendment also was defeated.

The doubts as to the proper construction of the words in the Kansas-Nebraska act supposed to confer "popular sovereignty" upon the people of the Territory arose out of the words "subject only to the Constitution of the United States," as explained by Senator Cass of Michigan. "It

'Cong. Globe, 34th Cong., 1st sess., App., p. 796.

IId., p. 796. 
is said that there is a difference of construction between the North and the South of the Kansas-Nebraska act. Necessarily it must be so; and if the honorable gentleman from Illinois [Mr. Trumbull] could not see that, he was not able to see very far into this millstone. Those who believe that slavery goes to the Territories under the Constitution proprio vigore, of course believe that no power is given to the legislature to prohibit slavery. But those who believe, as I do, that there is no such constitutional provision, believe, of course, that the territorial legislature has the power to legislate on this as on any other subject. The difference does not result from the words of that bill, but from the nature of things. The North and the South construe the Constitution differently. The South consider that the Constitution gives them the right of carrying their slaves anywhere in the Territories. If they are right you can give no power to the territorial legislature to interfere with them. The major part of the North believe that the Constitution secures no such right to the South. They believe, of course, that this power is given to the legislature. I repeat to the honorable Senator from Illinois [Mr. Trumbull] there is nothing equivocal in the act. The different constructions of it result from no equivocation of it, but from the fact that here is an important constitutional question, undetermined by the supreme judicial authority; and in the meantime individuals in different sections of the Union put their own construction on it. We are necessarily brought to that state of things. There is no power which the Senator from Illinois can use-no words which he can put into an act of Congress-that will remove this constitutional doubt until it is finally settled by the proper tribunal." I

If the object of Trumbull was to put the Democratic party or Douglas himself "on record" as giving some definite meaning to "popular sovereignty" the attempt failed. "In vain is the net spread in the sight of any bird." Douglas was too wary to be caught in Trumbull's net. $\mathrm{He}$

× Cong. Globe, 34th Cong., Ist sess., App., pp. 797-8. 
opposed the amendment, ostensibly on the ground that it was "putting on the bill a matter which does not belong to it," but really because, as he said, "he knew very well what the object was," which, as he asserted, was in order that it might "figure on the stump this summer to make the people believe that it is something different from what we know it to be here," and he declined to commit himself further than to say: "I say, then, the act does give this power to the territorial legislature, unless the Constitution of the United States prohibits it. That is the way in which the friends of the Nebraska bill have argued the question, but its opponents wish to know how I think the court will decide the constitutional question. I say I am willing to leave that to the Supreme Court of the United States, because the Constitution has entrusted it there. Now, I am ready to meet my colleague [Trumbull] if he wants to go on the stump on this question. We vote down his proposition because it is improper to attach it to this bill. I intend to hold them to their votes. They have now said by their votes that it was the true intent and meaning of that act to allow the people of a Territory to prohibit slavery through their territorial legislature. I hope my colleagues will never deny that hereafter. Everybody on the other side of the chamber has said by his vote that it was the true intent and meaning of that act to leave the question to the legislature of the Territories. They have so voted because they say it is pertinent to this bill to declare that. Then I hope that when they come to argue the question with us before the people they will not deny that this was the true intent and meaning of the act. They know that we vote against putting it on this bill because it is improper to put it here, although it is just what the act declares. Now we understand each other and I hope, therefore, we shall have no further controversy." $x$

In the encounter between Trumbull and Douglas we see more politics than statesmanship. They were, to use a : Cong. Globe, 34th Cong. Ist sess., App., p. 797 . 
military phrase, "skirmishing for position" in the approaching presidential campaign, getting ready to "go on the stump," and each was trying, using the language of politicians not of the highest class, to put the other "in a hole." It is not as a mere political acrobat that either Douglas or Trumbull shows to the best advantage.

So that after all the discussion of the Kansas-Nebraska bill, in and out of Congress, nobody could say whether it vested in the people of the Territories the right, while they remained in a territorial condition, to establish or to exclude slavery, and the discussion still left in doubt the vital question, one of construction of the Constitution of the United States, to be ultimately decided by the Supreme Court of the United States. It was not then generally known, and no reference was made in the congressional debates to the fact, that at that very time the Dred Scott case was pending in the Supreme Court of the United States, in which the precise question was involved, the decision of which wiped out of existence the whole doctrine of "popular sovereignty" and adopted to its fullest extent the extreme doctrine of Calhoun that the Constitution of the United States went with the slaveholder to the Territories, and prohibited either Congress or the territorial legislatures from interfering with his right of property in his slaves so long as the Territories remained in a territorial condition. But the doctrine of "popular sovereignty" still retained vitality sufficient to tide the Democratic party over another presidential campaign.

For a long period Northern writers in commenting on Douglas's speeches, while conceding his ability, expressed doubts as to his sincerity. They compared his speeches with those of a skillful advocate who can almost convince a jury that black is white and who displays the same zeal in arguing a bad case that he does in arguing a good one. We should, however, do Douglas the justice to suppose it to be not improbable that he may have been entirely sincere in the opinions which he originally entertained of the pro- 


\section{Popular Sovereignty in Practice 263}

slavery men of Kansas and the Northern Abolitionists but that his opinions were changed by subsequent events, as were the opinions of many men in the North whose political views underwent a radical change between 1856 and 1860 . In less than two years after Douglas's speech in 1856 he denounced the lawless proceedings of the pro-slavery men of Kansas with the same vehemence, the same power, the same skill in debate that he employed in defending them in 1856 , and this too when, if tempted by considerations of political advantage to himself, we should have expected him to stick to his party.

Not less curious to the political philosopher than the transformation of Douglas himself is the transformation that has taken place in the public estimation of him. History has dealt kindly by him in his last years. His faults have not been denied; not all of them have been condoned; but his better qualities, his heroic courage, his undoubted patriotism in opposing secession from the start, are now better understood and appreciated. Moreover, the historical student will probably note the change in the relative positions of Douglas and Seward in the public mind. In 1856 Douglas was execrated by large portions of the North; for his advocacy of the Kansas-Nebraska bill he was burned or hanged in effigy in many places. On the other hand Seward was then the idol of the opponents of slavery. He was their chosen champion. If Seward has not lost in popularity with his countrymen, Douglas has surely gained.

We shall soon see Douglas in a new rôle, battling against the attempt of a Democratic Administration to force a proslavery constitution upon the people of Kansas, and, still later, defying, on one side, the whole power of Buchanan's Administration, scheming for his political destruction, and, on the other, the opposition of the Republican party, aggressive, confident of victory, and led by its greatest leader, Abraham Lincoln. 


\section{CHAPTER XIII}

THE CRIME AGAINST KANSAS AND THE CRIME AGAINST SUMNER

CHARLES SUMNER entered the Senate as Webster's $\checkmark$ successor December 1, 1851. He was a graduate from Harvard, as his father had been before him. He was highly educated not only in all branches of college learning, but also in the arts and sciences and in polite literature. He had the classics at his tongue's end. As a young lawyer he won the esteem and patronage of Justice Story. With a highly eulogistic letter of introduction from that eminent jurist, Sumner traveled extensively in England and in other foreign lands and was everywhere welcomed with distinguished honors by great judges, learned men, and men of rank. He enjoyed a wide personal acquaintance with statesmen, jurists, and learned celebrities in this as well as in foreign countries. He had acquired his ideas of men more from books than he had by mingling with mankind in everyday life. His intellect was of fine fiber, but it lacked the rugged strength of that of a self-made man like Douglas. He had not had the political training of which Seward had the benefit, and he lacked Seward's poise. He did not have the keen insight into human nature that Lincoln had acquired, not by the study of books, but by mingling with men and studying them, the impulses that move them and the arguments that appeal to their reason. For these reasons Sumner found it difficult to adapt his theories of political reform to actual existing political conditions. He was pure in thought, conscientious, fear- 


\section{The Crime against Kansas and Sumner 265}

less in his devotion to duty as he saw it, but, like all theoretical reformers, he was better in starting reforms than he was in completing them. Hc, like others of his class, was impatient with Lincoln because he did not with a single stroke of his pen abolish slavery at a time when the country was not ripe for it, and when the attempt to do so would probably have resulted in irretrievable disaster to the Union cause.

Sumner had been spurred by Douglas's denunciations of the Massachusetts Emigrant Aid Society to put all his strength into a reply to Douglas, and this he did in his celebrated speech of May 19 and 20 on the "Crime Against Kansas." I Two days before delivering his speech Sumner had written to Theodore Parker that he "should pronounce the most thorough philippic ever uttered in a legislative body." 2 But the speech does not rank with the great orations recorded in history and, but for circumstances accompanying and especially those following its delivery, it would long since have lost any historical significance.

It had been prepared with great care but the smell of the lamp spoiled its eloquencc. One of its most striking passages was so close an imitation of one of Demosthenes' great orations that Sumner was charged with plagiarism. The speech was crowded with quotations in Latin, French, and Italian; quotations from classic orators, Demosthenes, Cicero, Burke; quotations from poets, ancient and modern, Virgil, Ovid, Milton, Lowell. Precedents were sought in the history of the ancient Egyptians, from the Druids, from northern mythology. Some illustrations were drawn from the battleficlds of Marathon, Crécy, Agincourt, but more from the massacre of St. Bartholomew, the Spanish Inquisition, the cannibals of the Fiji Islands, and the diabolical atrocities of the Thugs and Assassins. Occasionally we catch a glimpse of a hero-of Miltiades, William Tell,

' Cong. Globe, 34th Cong., rst sess., App., 529; Sumner's Works, vol. iv., p. 125.

'Weiss, Life of Parker, vol. ii., p. 179, quoted in Rhodes, vol.ii., p. 132. 


\section{Political History of Secession}

Milton-but the prominent characters that we see stalking across the stage are those of the worst monsters and fiends of history and fable,--Mephistopheles, Catiline, Verres, and Danton, with Satan at the head of the procession.

Nothing said in the speech could be attributed to the heat of debate, for every word in it had been carefully selected, weighed, and measured in Sumner's study, and only those words had been selected that had in them the sharpest sting; the Scriptures had been ransacked for words, not of peace, but of wrath, and then the whole had seemingly been saturated with vitriol. For example he described the proslavery men of Kansas as "murderous robbers from Missouri, hirelings picked from the drunken spew and vomit of an uneasy civilization, having the form of men," and "leashed together by secret signs and lodges" in order to "renew the incredible atrocities of the Assassins and the Thugs-showing the blind submission of the Assassins to the Old Man of the Mountain in robbing Christians on the road to Jerusalem, and the heartlessness of the Thugs, who, avowing that murder is their religion, waylay travelers on the great road from Agra to Delhi-with the more deadly bowie-knife for the dagger of the Assassin, and the more deadly revolver for the noose of the Thug."

Indeed it seemed to be Sumner's aim to concentrate in his denunciation of slavery all the bitterness of the English language; but its extravagance, and the bitterness of its vituperation, offset its reasoning. It confirmed the hostility of the Abolitionists to slavery; it also confirmed the Southern hatred of the Abolitionists; but it convinced nobody. It lacked what Carlyle calls "the virtue to produce belief." It lacked the strength of Chase's speeches; it lacked the dignity of those of Seward; it added nothing to the arguments which they had presented. The marked difference between Sumner's and Lincoln's manner of debating with Douglas is at once apparent by comparing the speech on the crime against Kansas with the speeches of Lincoln in the Lincoln-Douglas debates. 


\section{The Crime against Kansas and Sumner 267}

The most irritating parts of the speech were those in reference to Senator Butler of South Carolina and to Senator Douglas, all the more irritating to Senator Butler and his friends because Butler was not present in the Senate at the time when the speech was delivered. Comparing Butler and Douglas with Don Quixote and Sancho Panza, Sumner said: "The Senator from South Carolina has read many books of chivalry, and believes himself a chivalrous knight, with sentiments of honor and courage. Of course he has chosen a mistress to whom he has made his vows, and who, though ugly to others, is always lovely to him,-though polluted in the sight of the world, is chaste in his sight; I mean the harlot Slavery. For her his tongue is always profuse in words. Let her be impeached in character, or any proposition be made to shut her out from the extension of her wantonness, and no extravagance of manner or hardihood of assertion is then too great for this Senator. The frenzy of Don Quixote in behalf of his wench Dulcinea del Toboso is all surpassed. The asserted rights of Slavery, which shock equality of all kinds, are cloaked by a fantastic claim of equality. If the slave States cannot enjoy what, in mockery of the great fathers of the Republic, he misnames Equality under the Constitution-in other words, the full power in the national Territories to compel fellow-men to unpaid toil, to separate husband and wife, and to sell little children at the auction block-then, sir, the chivalric Senator will conduct the State of South Carolina out of the Union! Heroic Knight! Exalted Senator! A second Moses come for a second exodus!"

Later in his speech he again referred to Senator Butler, saying:

"With regret I come again upon the Senator from South Carolina [Mr. Butler] who, omnipresent in this debate, overflows with rage at the simple suggestion that Kansas has applied for admission as a State, and with incoherent phrase, discharges the loose expectoration of his speech, now upon her representative, and then upon her people. 
There was no extravagance of the ancient parliamentary debate which he did not repeat; nor was there any possible deviation from truth which he did not make- with so much of passion, I gladly add, as to save him from the suspicion of intentional aberration. But the Senator touches nothing which he does not disfigure-with error, sometimes of principle, sometimes of fact. He shows an incapacity of accuracy, whether in stating the Constitution or in stating the law, whether in details of statistics or diversions of scholarship. He cannot ope his mouth, but out there flies a blunder."

The speech delighted the Abolitionists of the North and so entranced one enthusiastic admirer of Sumner with its melody and grandeur that he wrote to the Liberator: "It came over me like the sound of many waters. I laid down the paper and still there seemed to press around me a solemn majestic anthem from a mighty organ." The speech was widely circulated in pamphlet form as a Republican campaign document in 1856 . It angered the proslavery men of the South as much as it pleased the anti-slavery men of the North. Denunciations of slavery had been heard before from Hale, Chase, Seward, and others, but never before had there been heard in the Senate a speech so full of gall and wormwood as that of Sumner.

The delivery of Sumner's speech occupied parts of two days-May 19 and 20, 1856 . In the discussion that followed Douglas and Sumner each lost his temper and so far forgot himself as to resort to offensive personalities, unbecoming in senatorial debate and more befitting a barroom brawl. Douglas charged that Sumner's speech was made up of old pieces like a Yankee bed-quilt and sneered at the classical quotations by saying: "We have had another dish of the classics served up-classic allusions, each one only distinguished for its lasciviousness and obscenity-each one drawn from those portions of the classics which all decent professors in respectable colleges cause to be suppressed, as unfit for decent young men to 


\section{The Crime against Kansas and Sumner 269}

read. Sir, I cannot repeat the words. I should be condemned as unworthy of entering decent society, if I repeated those obscene, vulgar terms which have been used at least a hundred times in that speech. It seems that his studies of the classics have all been in those haunts where ladies cannot go, and where gentlemen never read Latin." Sumner's charges against some of his fellow-members, Douglas said, were not made in the heat of debate. On the contrary Douglas charged: "It happens to be well known, it has been the subject of conversation for weeks, that the Senator from Massachusetts had his speech written, printed, committed to memory, practiced every night before the glass with a negro boy to hold the candle and watch the gestures, and annoying the boarders in the adjoining rooms until they were forced to quit the house! (Laughter). It was rumored that he read part of it to friends, and they repeated in all the saloons and places of amusement in the city what he was going to say. The libels, the gross insults which we have heard to-day have been conned over, written with cool, deliberate malignity, repeated from night to night in order to catch the appropriate grace, and then he came here to spit forth that malignity upon men who differ from him-for that is their offense." But the most offensive part of Douglas's speech was that in which he said: "Is it his [Sumner's] object to provoke some of us to kick him as we would a dog in the street, that he may get sympathy upon the just chastisement?"

To Douglas's personalities Sumner retorted as follows ${ }^{x}$ : "Sir, this is the Senate of the United States, an important body under the Constitution, with great powers. Its members are justly supposed, from age, to be above the intemperance of youth, and from character to be above the gusts of vulgarity. They are supposed to have something of wisdom and something of that candor which is the handmaid of wisdom. Let the Senator bear these things in

Cong. Globe, 34th Cong., ist sess., App., p. 547; Sumner's Works, vol. iv., p. 254. 
mind, and let him remember hereafter that the bowie-knife and bludgeon are not proper emblems of senatorial debate. Let him remember that the swagger of Bob Acres and the ferocity of the Malay cannot add dignity to this body. The Senator has gone on to infuse into his speech the venom sweltering for months,-ay, for years; and he has alleged facts that are entirely without foundation, in order to heap upon me some personal obloquy. I will not go into details which have flowed out so naturally from his tongue. I only brand them to his face as false. I say also to that Senator, and I wish him to bear it in mind, that no person with the upright form of man can be allowed-[Hesitation.]

"Mr. Douglas. Say it.

"Mr. Sumner. I will say it,- - no person with the upright form of man can be allowed, without violation of all decency, to switch out from his tongue the perpetual stench of offensive personality. Sir, that is not a proper weapon of debate, at least on this floor. The noisome, squat, and nameless animal to which I now refer is not a proper model for an American Senator. Will the Senator from Illinois take notice?

"Mr. Douglas. I will-and therefore will not imitate you, sir.

"Mr. Sumner. I did not hear the Senator.

"Mr. Douglas. I said, if that be the case, I would certainly never imitate you in that capacity-recognizing the force of the illustration.

"Mr. Sumner. Mr. President, again the Senator has switched his tongue, and again he fills the Senate with its offensive odor."

It is hardly necessary to add that Sumner's characterization of Douglas was not drawn from the classics, but it was none the less offensive and insulting. Had Douglas been minded to compare Sumner with a "skunk" he would have used the word without any circumlocution. Sumner used other words and more of them but 


\section{The Crime against Kansas and Sumner 271}

they did not change the odor of the animal nor lessen the offensiveness of the insult. This illustrates the difference between the vituperation of Douglas and that of Sumner. The one was blunt, often coarse; the other was finely polished but nevertheless vituperation.

On Tuesday May 22, two days after the delivery of his speech, Sumner, during a temporary recess of the Senate, was sitting alone at his desk in the Senate chamber engaged in writing. His position was such that he could not rise from his chair without pushing it back. While so engaged, according to his statement, he became aware that some one whom he did not know was standing in front of his desk addressing him. The person so addressing him was Preston Brooks, a member of the House from South Carolina and a relative of Senator Butler, who had come to the Senate chamber for the express purpose of chastising Sumner for his speech, attended by Lawrence Keitt, another member of the House from South Carolina, who had accompanied Brooks in order to render him any assistance that might be found to be necessary. According to Sumner's sworn statement ${ }^{x}$ the stranger who addressed him began by saying: "I have read your speech twice over carefully. It is a libel on South Carolina and Mr. Butler, who is a relative of mine"- and then his assailant, without waiting to complete the sentence or to hear any explanation, and before Sumner could extricate himself from his chair, began beating him with a heavy cane on his bare head, which so stunned him that he could not see, and after that he lost consciousness. The story of what followed was continued by James W. Simonton, a reporter for the New York Times, who testified that as soon as he saw the situation of Sumner he hurried to his assistance, when Keitt rushed in saying, "Let them alone; let them alone"; and threatened Simonton and others who attempted to interfere; that Brooks continued beating Sumner, striking him at least a dozen, perhaps twenty blows, until Sumner fell

'Sumner's Works, vol. iv., p. 260. 
unconscious to the floor. His impression was that Keitt's precise words were, "Let them alone, God damn you." William Y. Leader, another eyewitness, who testified on the prosecution of Brooks before a civil magistrate, swore that after Sumner fell to the floor Brooks continued to beat him until his cane broke in pieces and that "no one attempted to interfere though a number of persons gathered around crying, 'Don't interfere! Go it Brooks! Give the damned Abolitionists hell." ",

Shortly afterwards Sumner, still stunned, his head and face covered with blood, was rescued from his assailant and taken from the Senate chamber.

In the course of the proceedings in the Senate, Senator Wilson of Massachusetts asserted that, "Mr. Sumner was stricken down on this floor by a brutal, murderous, and cowardly assault," whereupon Senator Butler of South Carolina responded, "You are a liar," and shortly afterwards Brooks sent Wilson a challenge which was delivered by Senator Joseph Lane of Oregon. Wilson declined the challenge, saying: "I have always regarded dueling as the lingering relic of a barbarous civilization, which the law of the country has branded as a crime," but refusing to qualify the words he had used and adding that he "religiously believed in the right of self-defense in its broadest sense."

Senator Slidell of Louisiana stated that he and others who were in the anteroom of the Senate heard of the beating of Sumner but that "we heard this remark without any particular emotion; for my own part I confess I felt none." Senator Toombs of Georgia stated: "As for rendering Mr. Sumner any assistance, I did not do it. As to what was said, some gentleman present condemned it in Mr. Brooks. I stated to him or to some of my own friends, probably, that I approved it. That is my opinion." 3

The Senate could do nothing but to refer the matter to

× Sumner's Works, vol. iv., pp. 269-270.

2 Cong. Globe, 34th Cong., Ist sess., p. 1304.

${ }^{3}$ Id., p. I305. 


\section{The Crime against Kansas and Sumner 273}

the House, which refused to censure Keitt. A majority, but not the two thirds necessary to expulsion, voted for Brooks's expulsion, whereupon Brooks resigned. Brooks resigned on July 14,1856 , but before doing so he made an elaborate explanation to the House, ${ }^{\mathrm{I}}$ in the course of which he said: "I went to work very deliberately, as I am charged -and this is admitted-and speculated somewhat as to whether I should employ a horsewhip or a cowhide; but knowing that the Senator was my superior in strength, it occurred to me that he might wrest it from my hand, and then-for I never attempt anything I do not performI might have been compelled to do that which I would have regretted the balance of my natural life." Later in his explanation he referred to Comins of Massachusetts who had made a speech denouncing the assault. Brooks said: "In my country the cock that crows and won't fight is despised by the hens and even by the pullets, who know a thing or two instinctively," at which, so the report says, "there was great laughter."

Brooks was at once reëlected by his South Carolina constituents and soon after again took his seat in the House.

In the House the most vigorous speech made in denunciation of the assault was that of Anson W. Burlingame of Massachusetts. His speech and the colloquy between him and Keitt are thus narrated ${ }^{2}$ :

"On the 22d day of May, when the Senate and the House had clothed themselves in mourning for a brother fallen in the battle of life in the distant State of Missouri, the Senator from Massachusetts sat in the silence of the Senate chamber, engaged in the employments appertaining to his office, when a member from this House, who had taken an oath to sustain the Constitution, stole into the Senate, that place which had hitherto been held sacred against violence, and smote him as Cain smote his brother.

- Cong. Globe, 34th Cong., Ist sess., App., pp. 831-833.

'Sumner's Works, vol. iv., pp. 303-4; Cong. Globe, 34th Cong., Ist sess., App., p. 656. 


\section{Political History of Secession}

"Mr. Keitt, (in his seat). That is false.

"Mr. Burlingame. I will not bandy epithets with the gentleman. I am responsible for my own language. Doubtless he is responsible for his.

"Mr. Keitt. I am.

"Mr. Burlingame. I shall stand by mine. One blow was enough; but it did not satiate the wrath of that spirit which had pursued him through two days. Again and again, quicker and faster fell the leaden blows, until he was torn away from his victim, when the Senator from Massachusetts fell in the arms of his friends, and his blood ran down on the Senate floor. Sir, the act was brief, and my comments on it shall be brief also. I denounce it in the name of the Constitution it violated. I denounce it in the name of the sovereignty of Massachusetts, which was stricken down by the blow. I denounce it in the name of humanity. I denounce it in the name of civilization which it outraged. I denounce it in the name of that fair play which bullies and prize-fighters respect. What! strike a man when he is pinioned-when he cannot respond to a blow! Call you that chivalry? In what code of honor did you get your authority for that? I do not believe that member has a friend so dear who must not, in his heart of hearts, condemn the act. Even the member himself, if he has left a spark of that chivalry and gallantry attributed to him, must loathe and scorn the act. God knows I do not wish to speak unkindly, or in a spirit of revenge; but I owe it to my manhood and the noble State I, in part, represent, to express my deep abhorrence of the act."

On account of these words Brooks sent a challenge to Burlingame. Upon several occasions before this challenges had been given by Southerners to Northern members of Congress, which had been declined by the recipients for reasons similar to those expressed by Senator Wilson in his answer to the challenge of Brooks, and thereby the challengers, without incurring any danger, had achieved some notoriety among their constituents. But much to the 


\section{The Crime against Kansas and Sumner 275}

delight of many in the North, and probably much to the surprise of Brooks, Burlingame promptly accepted the challenge, selected Lewis D. Campbell, of Ohio, for his second, and as he had a right under the code governing dueling to name the terms he fixed them as follows: "Weapons, rifles; distance, twenty paces; place, District of Columbia; time of meeting, the next morning." The place of meeting was afterwards changed by. Burlingame's second to Canada, but Brooks's friends declined to accept the terms on the pretense that it would be dangerous for Brooks to travel through the North in order to reach Canada, and so the duel did not come off.

Whatever may be said of Sumner's speech, it did not mitigate, far less justify, the brutality of the assault. But it was not merely the brutality of the assault that incensed the North; it was the justification of it by the Southern leaders and papers, which not only justified it, but gloated over it with intense satisfaction, which they made no attempt to conceal, extolling it as the highest exhibition of Southern chivalry.

From contemporaneous accounts we have it is clear that the South with great unanimity approved Brooks's assault. At many places in the South, especially in South Carolina, meetings were held in which resolutions of approval were passed. Jefferson Davis wrote regretting his inability to be present at a public dinner given to Brooks in his district expressing his "sympathy with the feeling which prompts the sons of Carolina to welcome the return of a brother who has been the subject of vilification, misrepresentation, and persecution, because he resented a libelous assault upon the reputation of their mother." The students of the University of Virginia voted a cane having "a heavy gold head which will be suitably inscribed, and also bear upon it a device of the human head, badly cracked and broken," which the Richmond Enquirer approved, adding that "the chivalry of the South, it seems, has been thoroughly aroused."

Sumner's Works, vol, iv., p. 277. . 


\section{Political History of Secession}

Still more insulting was the comment of the Richmond Enquirer of June 12, in which it said:

"In the main, the press of the South applaud the conduct of Mr. Brooks, without condition or limitation. Our approbation, at least, is entire and unreserved. We consider the act good in conception, better in execution, and best of all in consequence. The vulgar Abolitionists in the Senate are getting above themselves. They have been humored until they forget their position. They have grown saucy, and dare to be impudent to gentlemen! Now, they are a low, mean, scurvy set, with some little book learning, but as utterly devoid of spirit of honor as a pack of curs. Intrenched behind 'privilege,' they fancy they can slander the South and insult its representatives with impunity. The truth is, they have been suffered to run too long without collars. They must be lashed into submission. Sumner, in particular, ought to have nine-and-thirty early every morning. He is a great strapping fellow, and could stand the cowhide beautifully. Brooks frightened him, and at the first blow of the cane he bellowed like a bull-calf. There is the blackguard Wilson, an ignorant Natick cobbler, swaggering in excess of muscle, and absolutely dying for a beating. Will not somebody take him in hand? Hale is another huge, red-faced, sweating scoundrel, whom some gentleman should kick and cuff until he abates something of his impudent talk. These men are perpetually abusing the people and representatives of the South, for tyrants, robbers, ruffians, adulterers, and what not. Shall we stand it? . . .

"Mr. Brooks has initiated this salutary discipline, and he deserves applause for the bold, judicious manner in which he chastised the scamp Sumner. It was a proper act, done at the proper time, and in the proper place."

The assault shocked and angered the entire North. This is indicated by the titles of the editorials in the Northern newspapers, some of which were as follows: "The Attempt

I Sumner's Works, vol. iv., p. 277. 


\section{The Crime against Kansas and Sumner 277}

to Mưrder Mr. Sumner,"-"Ruffianism National,""Blood in the Senate,"-_"Outrageous Assault on Senator Sumner,"-"Brutal and Cowardly Assault upon Charles Sumner,"-"Ruffianism in Washington,"-"A Crisis at Hand,"-"The Outrage on Mr. Sumner,"-"Atrocious Outrage,"-"Disgraceful Assault upon a Senator,""Another Outrage upon Massachusetts,"-"A Border Ruffian in the Senate, "- "The Last Argument of Slavery," - "Barbarism at the Capitol."

Massachusetts was stirred to its very depths. The Massachusetts Legislature adopted a series of resolutions, copies of which were forwarded to Congress, in which the assault was denounced as "an assault which no provocation could justify, brutal and cowardly in itself, a gross breach of parliamentary privilege, a ruthless attack upon the liberty of speech, an outrage of the decencies of civilized life, and an indignity to the Commonwealth of Massachusetts." 2

The shock of the assault was felt even across the Atlantic and moved the London Morning Star to denounce it as "without parallel in the annals of civilized communities."

So much space has been given to Sumner's speech and the assault which followed because they show more clearly than anything else that occurred at that period the intense feeling over the slavery question that then existed in both the North and the South; both were now in fighting mood. They show, even if there were no other evidence, although there is abundance, that the country was then on the brink of civil war and that had Frémont been elected in 1856 , secession would have begun four years earlier than the time when it did begin.

Sumner was for a long time under medical treatment and unable to resume his seat in the Senate. The subject of his first notable speech after his return to the Senate was aptly styled "The Barbarism of Slavery."

Sumner's Works, vol. iv., p. 257.

Id., p. 3 I 5. 


\section{CHAPTER XIV}

BIRTH OF THE REPUBLICAN PARTY AND ITS FIRST BATTLE

SINCE the repeal of the Missouri Compromise, the $S$ slavery propagandists had everywhere grown more and more bold and aggressive. They were now invading New England and were attacking Garrison and his Abolition followers in their stronghold, and proclaiming to the people of Massachusetts the manifold blessings that slavery shed on whites and blacks alike. Of this a significant illustration is seen in the speech of Senator Robert Toombs of Georgia, delivered in Boston, on January 24, I856. He was presented to his audience in a highly complimentary introduction by Caleb Cushing, then Attorney-General in Pierce's Cabinet. Toombs's speech was devoted wholly to a discussion of slavery. His two main propositions were, first, "That Congress has no power to limit, restrain, or in any manner to impair slavery, but on the contrary it is bound to protect and maintain it in the States where it exists and wherever its flag floats and its jurisdiction is paramount"; second, "That so long as the African and Caucasian races coexist in the same society, the subordination of the African is its normal, necessary, and proper condition, and that such subordination is the condition best calculated to promote the highest interest and the greatest happiness of both races and consequently of the whole society." Some of the worst evils of slavery, he contended, had been caused or aggravated by the Abolitionists. His conclusion was that slavery's "political wisdom is vindicated in its effects on society; its morality, by the practices of the patriarchs and the teachings of the apostles." $x$

${ }^{2}$ The speech will be found in Cluskey's Political Textbook, p. 512. 278 


\section{Birth of the Republican Party}

Toombs's speech is all the more significant when considered in connection with the events which preceded and those which followed it. It was delivered shortly after President Pierce had made such an ostentatious display in Boston of all the power of the national government-executive, judicial, military, and naval-in his obsequious zcal to aid the slave-catchers to carry Antony Burns back into bondagc. It was made shortly before an honored Senator of Massachusetts had been struck down on the floor of the Senate by a representative of Southern chivalry.

Toombs's words sounded strangcly in Boston, especially to those who recalled the stirring appeals for liberty that had been made by those whose memories were still cherished in Massachusetts; to those who had been thrilled by the impassioned eloquence of Wendell Phillips. Should Faneuil Hall no longer be called the Cradle of Liberty? Could it be possible that the boast attributed to Toombs might yet come true, "that he expected to live to see the day when he could call the roll of his slaves at the foot of Bunker Hill monument"?:

The times were now ripe for the formation of a new political party. There was no longer any hope of opposing the further extension of slavery through either the Democratic or the Whig party. So far all efforts to convert the Whig party of the North into an anti-slavery party had been of no avail. The shores of the political ocean were strewn with abandoned hulks bearing such names as Conscience Whigs, Anti-Nebraska Democrats, Barnburners, Free-soilers, and the like that had been wrecked in trying to carry anti-slavery crews and cargoes. And so men of all parties in the North now set about to construct a new party that would voice their opposition to the further extension of slavery.

I In justice to Toombs, it should be added that in a letter to B. F. Hallett in 1855 he denied ever having used the words above quoted, saying that they originated in a misrepresentation of Senator Hale of New Hampshirc. See Stovall, Life of Toombs, p. 119. 
The Republican party was not the successor of any other, although it appropriated many of the ideas formerly held by the Whigs and the Federalists. It was, when formed, the political protest of the North against the extension of slavery. In one respect political parties are like poetsthey are born, not made. At least they are not made by politicians. Politicians may shape but they cannot create a political party. On the contrary, the political forces that seethe under the surface usually find vent notwithstanding the efforts of the politicians to repress them.

It may require many years to form an enduring political party and put it on a stable foundation. The people must first of all be convinced of the existence of the wrongs to be redressed and of the feasibility of the proposed plan of political reform. To evolve theories of reform is one thing; to put them into practical operation is quite another thing. Then the practical reformer must be willing to make reasonable concessions and alliances. He must keep up with the people but not get too far ahead of them, and he must plan, like a skillful general, to strike at the right time and at the right point.

The calamity-howler who does nothing more than to cry - out against existing evils, without suggesting any practical method of reform, has done something, but not enough. Moreover, one man will have one remedy and another man a different one. Selfish interests will be found to have so interwoven themselves about the roots of old abuses that it is difficult to cut them loose. Again, such is the strength of old party ties, that men will persist in clinging to their old party long after having been convinced that it is wrong, in the hope that it may eventually right itself.

So that, for all these reasons, the development of enduring political parties in this country has been very slow. Indeed, although there have been many in the United States, most of them, such as the Anti-Mason, the American or KnowNothing, the Granger, the Greenback, and others, have been of an ephemeral character. Only four have endured 


\section{Birth of the Republican Party}

long enough to elect a President-the Federalist, the AntiFederalist, afterward known as the Republican and then as the Democratic, the Whig, and the present Republican party.

Prior to the formation of the Republican party, no great political organization in the nation, unless the Free-soil party be so regarded, had ever declared opposition to the further extension of slavery, and, until the passage of the Kansas-Nebraska act, what opposition there had been in the North secmed to be dwindling away.

The disintegration of old parties in the North began immediately after the passage of the Kansas-Nebraska act, and gained force from day to day. Early in I854, A. E. Bovay, of Ripon, Fond du Lac County, Wisconsin, a Whig; Mr. Bowen, a Democrat, and Mr. Baker, a Whig, called a meeting, which was held in a Congregationalist church of that place, and was largely attended by men of all parties, at which it was resolved to "throw old party organizations to the winds and organize a new party on the sole issue of the non-extension of slavery." This circumstance is referred to not as indicating that the Republican party took its rise at Ripon and spread from there, but as an illustration of a spontaneous movement that was going on all over the North.

It was necessary to find an appropriate party name. A rose may smell as sweet by any other name, but not so with a political party. Of those opposed to the extension of slavery the Democrats would not fight under the old Whig name, nor would the Whigs fight under the Democratic, nor would either Whigs or Democrats fight under the Abolition banner; while the Abolitionists, as already stated, would not coöperate with voters of any other party than their own and many of them would not vote at all. Mr. Bovay, before mentioned, is credited with first suggesting that the new party be christened as the Republican party, which he did in a letter to Horace Greeley on February 26, $1854^{x}$;

'Flower, History of the Republican Party, p. 160. 
but the first State convention to adopt the name was one which met pursuant to a call for a mass meeting of all opposed to the extension of slavery to meet at Jackson, Michigan, July 6, 1854. No hall was large enough to hold the meeting, and so it was held under the friendly canopy of some adjacent oaks, and is now celebrated as "the convention under the oaks." Among the resolutions adopted at this meeting was the following: "Resolved that, in view of the necessity of battling for the first principles of republican government and against the schemes of an aristocracy the most revolting and oppressive with which the earth was ever cursed or man debased, we will coöperate and be known as 'Republicans' until the contest be terminated." $x$

The convention nominated a full State ticket, which was elected by a large majority. Such was the formal birth of the Republican party. But the name was not generally adopted by those opposed to the extension of slavery until a much later date, not indeed until 1856. In New York and Massachusetts the Whigs held out for a year or two longer, refusing to disband. In other States most of the Whigs went into the American or Know-Nothing party. In some, as in Indiana and Pennsylvania, the Whigs, AntiNebraska Democrats, Know-Nothings, and Free-soilers made common cause under the name of the People's party. But under one name or another the political elements opposed to the extension of slavery after the repeal of the Missouri Compromise made rapid progress toward consolidation.

For a time after the passage of the Kansas-Nebraska act other political topics partially obscured the slavery question and distracted public attention from it. Maine had passed a prohibitory liquor law in 1854 , and similar laws were enacted in several other States, and in that and in the following year there was a general, and in many States, as in Indiana, a very heated, discussion of so-called sumptuary laws.

I Flower, History of the Republican Party, p. 175 . 


\section{Birth of the Republican Party}

About the same time a new secret political party, called the American, but more generally known as the KnowNothing party, sprang up. It was based on opposition to foreigners and particularly to the Roman Catholic Church, and was probably an outgrowth of the Native American party which began in 1837 and developed considerable strength in 1844 . It was a secret, oath-bound organization, with lodges, rituals, grips, and passwords, which spread over the country like wildfire. In I 855 it elected governors in nine Northern States and forty-three members of the national House of Representatives.

But the temperance agitation speedily waned and the Know-Nothing party lasted for only a year or two and disappeared almost as suddenly as it had appeared. In the break-up of the old parties it was a sort of gateway through which large numbers of anti-slavery Whigs and Democrats passed after leaving their old parties and before reaching the Republican ranks. The slavery question was now rapidly becoming the one cardinal question upon which men everywhere were dividing. While they still retained their old convictions as to tariff, internal improvements, national banks, and other questions upon which campaigns in the past had been so vigorously fought, slavery was now uppermost in the minds of all. The struggle in Kansas was agitating the entire nation. By this time it was plain to all that slavery and freedom could no more dwell together peaceably in a Territory than they could in a State. It was also plain that the theory of popular sovereignty, especially under an administration like that of Pierce, was a hollow mockery.

Near the close of 1855 a call was issued by the chairmen of the State Republican committees of Maine, Vermont, Massachusetts, New York, Pennsylvania, Ohio, Michigan, Indiana, and Wisconsin (not signed, however, by the Maine, New York, and Indiana chairmen), for an "informal convention," to meet in Pittsburg on February 22, I856, for the purpose of perfecting a national organization and to 


\section{Political History of Secession}

provide for the holding of a Republican national delegate convention to nominate candidates for President and VicePresident for the next presidential election. The convention assembled at I I o'clock A.M., in Lafayette Hall, on the day fixed. The call did not contemplate a nominating convention, nor even a delegate convention, composed of delegates selected as they are ordinarily selected, but invited all "the Republicans of the Union" to meet "in informal convention." Without this explanation it might be a matter of wonder who were the constituents of the delegates from Virginia, South Carolina, and some other Southern States, and what authority the delegates had to represent them.

The accounts we have of this celebrated convention are rather meager. The convention ordered, "That the official proceedings of the convention be published in pamphlet form by the Republican Association of Washington City." I The official report shows that "a committee of three, in conjunction with the temporary officers, were appointed to obtain the names of the delegates to the convention," but if the committee reported a list it is not contained in the printed report. ${ }^{2}$

The following is a list of the names of all the delegates that have been preserved, gathered chiefly from the official report and from Mr. Errett's list. The names included in

× Pursuant to this order a pamphlet report of twenty-four pages was issued, entitled, "Official Proceedings of the Republican Convention, convened in the city of Pittsburg, Pennsylvania, on the 22d of February, 1856," published at Washington, D. C., in 1856.

2 Mr. Russell Errett, a delegate from Pennsylvania, and one of the secretaries of the convention, has given his recollection of the proceedings and also a partial list of the delegates, in a paper on the "Formation of the Republican Party in I856," Magazine of Western History, vol. vii., p. I80. Hon. George W. Julian who was also present as a delegate from Indiana has contributed his recollections of the proceedings in a paper on "The First Republican Convention," American Historical Review, vol. iv., p. 313. In Curtis's Republican Party, vol. i., p. 250, there is also an account of the proceedings of the Pittsburg convention, including a report of the proceedings compiled by Charles W. Johnson. 


\section{Birth of the Republican Party}

parenthesis are taken from Mr. Errett's list, except the name of Mr. Bond, of South Carolina, which is given only in Mr. Johnson's report of the proceedings. There are many discrepancies in the spelling of the names. In such cases the name as given in the official report is first given, next that of Mr. Errett in parenthesis.

New England: Maine - George M. Weston, Horatio G. Russ, Abner R. Hollowell (A. A. Hallowell). New Hampshire-J. C. Beaman (I. C. Beman), Francis (F.) C. Johnson, George C. Fogg, (Horatio G. Russ). VermontLawrence C. Brainerd. Massachusetts-James (J.) W. Stone, Charles G. (C. G.) Davis, George Bliss, E. Rockwood (E. R.) Hoar, Nathaniel P. Banks. Rhode Island-Edward Harris, R. G. Hazzard, William Chase, Jr. (- Chase). Connecticut-Josiah Brewer (Brown), James M. Bunce, Gov. C. F. Cleaveland (George Cleveland), Mark Howard (Howell), John M. Niles.

Middle States: New York-John A. King, Preston King, Simeon Draper, Isaac Dayton, Horace Greeley, E. D. Morgan, Abijah Mann, Jr., William A. Sackett, George M. Grier, A. Oakey Hall, - (Silas M.) Burroughs, C. S. Crosby, P. Dorsheimer, A. M. Clapp, C. Hitchcock. New Jersey-D. Ripley, W. P. Sherman, F. Devereaux, C. M. K. Paulison (E. M. K. Pollison). Pennsylvania-Gen. B. Randall, L. L. Lord, Gen. Joseph Markle, Russell Errett, John Allison, Charles Thumm, Sigismund Low, William R. Thomas, B. B. Chamberlain, Passmore Williamson, David Wilmot, - Gassam, (D. N. White, J. H. Moorhead, W. W. Wise, J. Weyand, E. O. Goodrich, C. P. Markle, R. B. McCabe, C. Randall, O. K. A. Hutchinson, Dr. J. Carothers, George Darsie, George Raymond, William T. Clark).

West and Northwest: Ohio-L. G. Van Slyke (Vandyke), John (J.) A. Foote, Joshua R. Giddings, W. H. Gibson, R. (Rufus) P. Spaulding, D. R. Tilden, Charles Reemelin, A. P. Stone, — (James M.) Ashley, - (F. D.) Kimball, (James) Elliott, - (G. H.) Frey, (Jacob Brinkerhoff, 
H. E. Peck, C. Spink, J. M. Brown, Dr. O. White, William Dennison, Jr., Jacob Heaton, R. Brinkerhoff, E. Pardee, H. Howard, Henry Everts, I. McFarland, O. Harmon, Thomas Bolton, L. H. Hall, R. Steadman, Dudley Baldwin, Seth Day, H. Carter, Frederick Wadsworth, S. E. Edgerton, Dudley Seward, Joseph Medill, D. E. Doon, R. D. Harrison, I. M. Benson, A. J. Page, I. H. Wilkinson, R. Rogers, W. B. Fish, I. L. Wharton). Indiana-William Grose, George W. Julian, Oliver P. Morton. Illinois-Owen Lovejoy, John H. Bryant, Ichabod Codding, John (I.) H. McMillan, John (J.) C. Vaughan, E. S. Leland, - (W. F. M.) Arney, (—-Carlin). Michigan-Gov. K. S. Bingham, F. C. Beman (Beaman), Jacob M. (J. M.) Howard, Zachariah Chandler, Whitney Jones, Charles Dickey, (Rufus Hosmer, - Sinclair). Wisconsin-Charles Durkee, David Jones, Israel S. Love, (I. S. Lovett), Calvin C. Bayley, Wyman Spooner. Iowa-W. P. (Penn) Clarke, Andrew (A.) J. Stevens, C. G. Hawthorne. Minnesota-T. M. Newson.

Southern States: Delaware-O. U. (A.) Johnson, W. H. Dennison. Maryland-Francis P. Blair (Sen.). Virginia - Joseph (James) Farley, Richard Brannin. KentuckyW. (William) S. Bailey, John G. Fee. Tennessee-H. Jarvis. Missouri-James Redpath, F. Kemper (N. Kampa). South Carolina-F. O. Willington, (- Bond).

Pacific States: California-D. H. Spratt.

District of Columbia: Louis Clephane.

Territories: Kansas-S. N. Wood, Nebraska-(S. P. Rankin).

It may be noted that there were many well-known opponents of slavery who were conspicuous by their absence. This fact is commented on by both Mr. Julian and Mr. Errett. The latter says: "The eye of the reader will be struck with the fact that it [the list] is more remarkable for the names not on it than for those that are. But prominent men were more anxious to see what would follow than to take part. The times were perilous and full of uncertainty and danger. The opposition party in Congress were 
trembling lest the convention should go too far and the country contained many fearful souls."

The convention was called to order by the Hon. Lawrence Brainerd, of Vermont. John A. King, of New York, acted as temporary chairman, and the Rev. Owen Lovejoy, of Illinois (brother of Elijah, who had been murdered at Alton), opened the proceedings with a prayer in which he prayed the Lord "to enlighten the mind of the President of the United States [Franklin Pierce] and turn him from his evil ways, and, if this were not possible, to take him away so that an honest and God-fearing man might fill his place." We are told that this happy blend of piety and politics wrought up the assembled delegates to the very highest pitch of enthusiasm.

Francis P. Blair, of Maryland, was elected president of the convention. The president made a short speech but submitted a long paper in behalf of his Southern constituents in which he seemed to regard the readoption of the compromise measures of 1850 as a panacea for all existing political evils. The proposition was heard respectfully but evidently it did not suit the temper of the convention, which heard with enthusiasm the far more radical utterances of speakers like Owen Lovejoy and Joshua R. Giddings.

Horace Greeley, Zachariah Chandler, of Michigan, David Wilmot, of Pennsylvania, and Col. W. H. Gibson, of Ohio, one of the strongest stump speakers of his day, and Charles Reemelin, an influential German and former Democrat of Cincinnati, Ohio, also made speeches, and a vigorous letter by Cassius M. Clay, of Kentucky, was read to the convention.

The committee on address and resolutions, of which Abijah Mann, of New York, was chairman, submitted a long paper, the reading of which consumed over two hours, in the shape of an address to the people of the United States in which the history of the slavery agitation was elaborately reviewed, touching also upon the annexation of Texas, the repeal of the Missouri Compromise, the invasion of Kansas, 
and the general tendency of Federal legislation on the subject of slavery, and declaring the objects for which unity of political action was desired to be as follows:

"I. We demand and shall attempt to secure the repeal of all laws which allow the introduction of slavery into territories once consecrated to freedom, and will resist by every constitutional means the existence of slavery in any of the Territories of the United States.

"2. We will support by every lawful means our brethren in Kansas in their constitutional and manly resistance to the usurped authority of their lawless invaders, and will give the full weight of our political power in favor of the immediate admission of Kansas to the Union as a free, sovereign, and independent State.

"3. Believing that the present national administration has shown itself to be weak and faithless, and that its continuance in power is identified with the progress of the slave power to national supremacy, with the exclusion of freedom from the Territories, and with increasing civil discord, it is a leading purpose of our organization to oppose and overthrow it."

Before adjournment the convention appointed a national executive committee, of which Edwin D. Morgan, of New York, was chairman, and adopted the recommendation of the committee on organization advising the holding of a national Republican convention for the nomination of candidates for President and Vice-President to be held at Philadelphia, on June 17,1856 . The convention, having concluded its labors, adjourned on February 23, I856. The address was printed in pamphlet form and thousands of copies were sent broadcast over the North.

Taking it all in all, this was a most notable polilical convention. Though only the beginning, it was a great beginning of a great political party. Of this convention Mr. Julian says": "This convention represented all of

s Paper on "The First Republican Convention," American Historical Review, vol. iv., p. 321. 


\section{Birth of the Republican Party}

the sixteen Northern and eight of the Southern States. Its members came together in the dead of winter when no candidates were to be nominated and no offices were to be divided. Probably a majority of them had passed the meridian of life, but all seemed equally in earnest and absorbed in their work. A few of them were already known to political fame, such as Joshua R. Giddings, Preston King, and David Wilmot, while others like Zachariah Chandler, Edwin D. Morgan, and Oliver P. Morton were afterward to * become honorably conspicuous. The great body of the members had never devoted themselves to the business of politics, and this was indicated by the composition of the several committees selected by the convention for the execution of its work. It was a season of unparalleled political chaos, in which doubt and apprehension largely ruled the hour. Good men sometimes lost their way or saw but dimly the path of safety. Politic statesmen took counsel of their fears. A number of notable men in the convention took little or no part in its proceedings. Many undoubtedly failed to attend because they thought it wiser to wait upon the teaching of events. It was the element of uncalculating radicalism which baffled the policy of timidity and hesitation and saved the cause."

Pursuant to the direction of the Pittsburg convention, a call was issued on March 29, 1856, for the holding of a National Republican Convention at Philadelphia on June 17. The convention was held on the day fixed-the anniversary of the battle of Bunker Hill. It met in Musical Fund Hall in Fourth Street, south of Market. The hall was not large enough to accommodate more than two thousand persons.

The delegates were not chosen with reference to thcir preferences for presidential candidates, but chiefly as representative men who could be trusted to determine what was best to be done to oppose the further extension of slavery. There were delegates from Delaware and Maryland and a few scattering delegates from Virginia and some other 
Southern States. Many leading men of the old parties in the North seemed to be standing aloof, probably not wishing to commit themselves to the support of a party so new and untried. Nevertheless, there were many wellknown men there. From New York were Thurlow Weed, Simeon Draper, James Watson Webb, John A. King, Preston King, Philip Dorsheimer, and Edwin D. Morgan; from Michigan, Zachariah Chandler and Isaac Christiancy; from Connecticut, Gideon Welles; from Ohio, George Hoadley, Judge Rufus B. Spalding, and Joshua R. Giddings; from Virginia, John C. Underwood; from Pennsylvania, Thaddeus Stevens, Henry C. Carey, David Wilmot, and others; from Indiana, Henry S. Lane and John D. Defrees.

Henry S. Lane of Indiana was elected president of the convention, and David Wilmot of Pennsylvania was made chairman of the committee on resolutions.

An amusing episode in connection with the selection of Lane as permanent chairman is thus told by Mr. Russell Errett, who was present as a delegate from Pennsylvania $^{\mathrm{x}}$ :

"The president of the convention was Henry S. Lane of Indiana a long, lank, raw-boned man, who gave but poor promise in appearance of possessing any talent, but the moment he opened his mouth the people knew him for an orator. He was a man of the Henry Clay stamp, full of natural eloquence, and his short speech on taking the chair so carried away the Eastern men, who were taken completely by surprise, that they burst into a spasm of noisy enthusiasm. He came near, however, putting the fat in the fire when he sat down, for his first act was to lay his heavy cane on the table, tilt back his chair, and elevate his feet so as to confront the audience with them as he asked, 'What is the further pleasure of the convention?' Eastern propriety was at first shocked, and then amused, for the whole Eastern part of the convention broke into a quiet laugh and × "Republican Nominating Conventions of 1856 and I860," Magazine of Western History, vol. x., p. 257. 


\section{Birth of the Republican Party}

settled down to the conviction that it was a mere specimen of the Western spirit of freedom. The Western delegates were too familiar with such things to be astonished. His splendid burst of oratory was a full atonement for any subsequent 'roughness."

The chief plank of the platform was the second, which affirmed: "That the Constitution confers upon Congress sovereign power over the Territories of the United States for their government, and that in the exercise of their power it is both the right and duty of Congress to prohibit in the Territories those twin relics of barbarism-polygamy and slavery."

Looking at the first national platform of the Republican party, we see in it little resemblance to those of later date. In 1856 the general feeling was that it was necessary for the preservation of freedom that all opposed to the further extension of slavery should, for a time, subordinate all other issues in order to stand together on this, and that in order to get recruits it was advisable to abstain from approving the dogmas of any one of the old parties that might repel the adherents of the others. Hence, we do not find in the first national Republican platform a word about the tariff, banks, or currency. The furthest it went in favor of internal improvements was a resolution recommending government aid in favor of building a railroad to the Pacific, and another in favor of reasonable appropriations for necessary river and harbor improvements.

Nearly all the cardinal principles contained in the later platforms of the party have been taken on since its formation. Some of them were absorbed from the old Whig and Federal parties. Most of them have been promulgated to meet new political issues. In later Republican as well as in later Democratic platforms we may trace the development of new and exciting political questions of which the politicians in 1856 had little or no conception, presaging others yet to come upon which political parties will be arrayed and the people will be divided, not upon any 
"geographical lines," so much dreaded by Thomas Jefferson, but upon lines equally dangerous.

Edwin D. Morgan, of New York, and Godlove S. Orth, of Indiana, were appointed tellers. Upon the first ballot for President John C. Frémont received 359 votes to 196 for John McLean, of Ohio; one for Nathaniel P. Banks of Massachusetts; two for Charles Sumner, and two for William H. Seward. But the vote for Frémont was immediately made unanimous. On the next day, William L. Dayton of New Jersey was nominated for Vice-President, receiving 250 votes, while I Io were cast for Abraham Lincoln of Illinois and scattering votes were also cast for David Wilmot, Charles Sumner, and others.

Without an explanation it might be cause for surprise that Seward received only two votes for the presidential nomination, when he was everywhere recognized as the Republican party's greatest leader and logically the one who should be its standard-bearer in the coming election. It was reasonably certain before the convention met that the slavery plank in the platform would be one that Seward could consistently stand upon, and yet no one knew but that it might be too radical or too conservative. No one, however, could predict with any certainty before the adoption of the platform what it would say on the KnowNothing question. It was well understood that there was in the Republican party a large, but unknown and uncertain, Know-Nothing element; to this element Seward had always been opposed, and this element was opposed to him. Seward had long been a pronounced Whig and it was uncertain whether his nomination would be acceptable to the new converts from the Democratic party. The conservatives of the country were still shivering from Seward's higher law pronouncements. For these reasons Seward was not just the kind of a presidential candidate that the Republican political managers were looking for. They were looking for a "vote-getter," one who would not scare away either Democrats, Whigs, or Know-Nothings, but 


\section{Birth of the Republican Party}

who would at the same time inspire enthusiasm. All these reasons were obvious to Seward; there is no doubt that they were obvious to his political manager, Thurlow Weed, who knew that Seward could not be elected if nominated, and who had no faith in the election of any Republican in the ensuing campaign. For these reasons Weed knew that it would be better for Seward himself to bide his time until I 860 when a Republican nomination would be far more profitable than a nomination in 1856 . Weed advised against the nomination of Seward, and Seward himself acquiesced in Weed's advice; at any rate Seward made no effort to secure the presidential nomination.

In looking for a vote-getter the Republican political managers discovered Frémont. He had acquired some experience in military life and as an explorer in the far West. Altogether there was enough in his past life out of which to manufacture a sort of halo that dazzled the eyes of the young voters far more than the profound orations of Seward. In fact Frémont was probably the best vote-getter that the Republicans could have found.

The Democratic National Convention met in Cincinnati on June 2, and nominated James Buchanan for President and John C. Breckinridge of Kentucky for Vice-President. A long platform was adopted but it is sufficient now to call attention to those portions only relating to the question of slavery in the Territories. Talleyrand once said that "the chief use of language was to conceal thoughts," and the language of the Cincinnati platform of 1856 upon the question of slavery in the Territories seems to have been chosen in view of Talleyrand's definition. In one resolution it was resolved "that we recognize the right of the people of the Territories, including Kansas and Nebraska, acting through the legally and fairly expressed will of the majority of the actual residents, and whenever the number of their votes will justify, to form a State constitution, with or without domestic slavery, and be admitted into the Union upon terms of perfect equality with the other States." Here was 
a seeming endorsement of Douglas's "popular sovereignty" doctrine, but when carefully analyzed it is at once apparent that there was in fact no recognition whatever of the doctrine of "popular sovereignty" as defined by Douglas himself. No right was given to the people of a Territory when the number of inhabitants justified the formation of a territorial government to organize such a government prohibiting slavery, but only the right, which had never been denied, to prohibit slavery when the number of inhabitants justified forming a constitution for admission as a State.

In the only other resolution on this subject it was resolved "that the American Democracy recognize and adopt the principles contained in the organic laws establishing the Territories of Nebraska and Kansas, as embodying the only sound and safe solution of the slavery question ... and non-interference of Congress with slavery in the Territories or in the District of Columbia."

But what was the status of slavery in a Territory in case of non-interference by Congress; that is, provided Congress should pass no law either allowing or prohibiting it? Upon this question the platform was silent.

Prior to the Dred Scott decision it had generally been conceded, at least in the North, and by some in the South, that the Federal Constitution, of itself, and without any congressional legislation, did not legalize slavery in the Territories, and that Congress had the power to prohibit slavery while such Territories remained in a territorial condition. This was the view of Benton and of other Southern Democrats and Whigs. Another view was that of those of the South who, while conceding that the Federal government had the power to prohibit slavery in the Territories, contended that it would be unjust to do so for reasons that had been urged by Calhoun and others referred to in a former chapter. Still another view was that of Southern extremists of the Calhoun school who maintained that while a Territory remained in a territorial condition 


\section{Birth of the Republican Party}

neither Congress nor the territorial legislature had any power to prohibit slavery there.

No one was authorized to say what the platform meant on this subject and Buchanan in his letter of acceptance avoided saying what he thought it meant, and so every Democrat, North and South, construed the platform according to his own notions, with the result that in the North it was generally construed as meaning what Douglas said it meant, while in the South it was construed by some according to the ideas of Calhoun and his followers and by others in accordance with the ideas of Benton and those who thought as he did.

Juggling platforms so as to make them convey one meaning in one section of the country and quite a different meaning in another section has since been developed to a high state of perfection, but the Cincinnati platform is a fair specimen of early art.

It is quite probable that if the platform had been construed in the North as Jefferson Davis and those of the Calhoun school construed it, the North would have been as solidly Republican in 1856 as it was in 1860 . It is not quite so clear, however, what the result would have been in the South if the platform had been generally understood there as meaning what Douglas contended that it meant, because Douglas had a far larger following in the South than Jefferson Davis had in the North.

The American party held its convention in Philadelphia, on February 22, but split on the slavery question. Those who remained in the convention nominated Millard Fillmore for President and Andrew J. Donelson for Vice-President, and these nominations were indorsed by the scattered fragments of the Whig party in a convention held in Baltimore on September i 7 .

The Democratic nominee for President had been a lifelong political ally of the slave power. Governor Wise, of Virginia, vouched for him as ever true to the interests of the South, and "as reliable as Mr. Calhoun himself." The 


\section{Political History of Secession}

Richmond Examiner enumerated eleven reasons why he should receive the votes of the South, among them being these :

"In I $836 \mathrm{Mr}$. Buchanan supported a bill to prohibit the circulation of Abolition papers through the mail.

"In $\mathrm{I} 837$ he voted for Mr. Calhoun's famous resolutions, defining the rights of the States and the limits of the Federal authority, and affirming it to be the duty of the government to protect and uphold the institutions of the South.

"In I 838 , I 839 , and I 840 he invariably voted with Southern senators against the consideration of anti-slavery petitions.

"In 1856 he approved the repeal of the Missouri restriction, and supported the principles of the Kansas-Nebraska act.

"He never gave a vote against the interests of slavery, and never uttered a word which could pain the most sensitive Southern heart."

The political campaign of 1856 was a memorable one; exciting events followed so closely upon one another that interest never flagged. Affairs in Kansas steadily grew worse and more warlike. Nearly every day the papers reported some lawless raid by Stringfellow, Pate, and their gangs of Missouri border ruffians or some equally lawless raid by Colonel Lane and John Brown of Ossawatomie and their followers. Scenes almost as shocking and as bloodthirsty were at the same time being enacted in the very halls of Congress. The brutal assault of Brooks upon Senator Sumner of Massachusetts was still fresh in the public mind. All these events served to keep the public in a state of continual ferment and to inflame still more the angry passions, already at fever heat, of those who advocated and of those who opposed the extension of slavery.

New leaders were now coming to the front. John C. Calhoun, the great leader of the South, died in 1850 . Daniel Webster and Henry Clay, the idol of the Whigs, both died in

Q Quoted in Clarke, Anti-Slavery Days, p. II3. 
1852. Jefferson Davis survived and succeeded Calhoun as the leader of the Southern Democrats. Thomas H. Benton had lost caste with the Southern Democrats by his refusal to accede to their demands and this cost him his seat in the Senate which he had held for thirty years. In 1852 , he was elected to the House of Representatives, but was defeated for reëlection on account of his opposition to the KansasNebraska act. He died in 1858 . General Lewis Cass lived long enough to become a member of Buchanan's Cabinet at the age of seventy-five.

Robert Toombs and Alexander H. Stephens of Georgia had now become prominent, the former in the United States Senate, the latter in the House. Howell Cobb of the same State also became prominent as member and Speaker of the House and as Secretary of the Treasury in the Cabinet of President Buchanan. Various other men had also come into prominence in the South, but there was no such an upheaval there, such a tearing down of old leaders and coming to the front of new ones, as there was in the North.

The younger rather than the older members of the Democratic party went over to the Republicans. Most of the older Democratic leaders in the North who still remained with the party retained their influence in it and many who were prominent in 1856 had been prominent before. Douglas was, however, the acknowledged Democratic leader in the North, especially of the younger element of the party.

Most of the Republican leaders came from the old Whig and Democratic parties and some like Seward had already achieved national renown. John P. Hale of New Hampshire entered the House in 1843 and the Senate in 1847 and was reëlected in 1855. Hannibal Hamlin of Maine, after serving as member of the House in the Twenty-eighth and Twenty-ninth Congresses, was elected to the Senate in 1848 to fill a vacancy and was reelected in $185 \mathrm{I}$. William Pitt Fessenden entered the House in $184 \mathrm{I}$ and the Senate in 1854. David Wilmot of Pennsylvania was a member of the 
House from 1845 to $185 \mathrm{I}$ but did not enter the Senate until 186I. Lyman Trumbull of Illinois, after having served in the House in the Thirty-fourth Congress, was elected to the Senate in I855. Charles Sumner of Massachusetts, and Benjamin F. Wade of Ohio entered the Senate in I85I, Sumner as the successor of Webster, and Zachariah Chandler of Michigan, as the successor of General Cass $=$ in 1857 . John Sherman of Ohio served in the House in the Thirtyfourth, Thirty-fifth, Thirty-sixth, and Thirty-seventh Congresses, but did not enter the Senate until I86I. Thaddeus Stevens of Pennsylvania, Joshua R. Giddings of Ohio, Henry S. Lane and George W. Julian of Indiana were also known in national politics. James G. Blaine of Maine had already become prominent in the politics of that State but did not enter Congress until 1862. Abraham Lincoln had been one of the five nominees of the Illinois Whigs for presidential electors in 1840 . He had served one term in the House from 1847 to 1849 , but had not done or said anything worthy of special note as a member of Congress; although he had, as already stated, become well enough known to receive I Io votes in the National Republican Convention of 1856 for nomination for Vice-President. Many others who soon became prominent, like Oliver P. Morton of Indiana, had scarcely acquired a State reputation in 1856 , but everywhere in the North younger men were coming to the front and displacing the old political leaders. Indeed, one of the advantages of the Republican party was that so many of its leaders were, comparatively speaking, young men with all the fire and vigor of youth. Of all the

I It is told of Sumner that on his admission to the Senate Senator Thomas H. Benton of Missouri congratulated him, but added to his congratulations these remarks, which forcibly illustrate the unreliability of political prophecies: "You have come upon the stage too late, sir, not only have our great men passed away, but the great issues have been settled also. The last of these was the national bank and that has been overthrown forever. Nothing is left you, sir, but puny sectional questions and petty strifes about slavery and fugitive slaves, involving no national interest." 


\section{Republican Party's First Battle}

Republican leaders Seward still maintained his supremacy. While there were other strong men it was chiefly to Seward that the Northern opponents of slavery had long looked, and still looked, for guidance. He took an active part in the campaign in New York, making speeches there and elsewhere. He saw clearly that the allegiance of the Democratic party to slavery which made it strong in the South made it vulnerable in the North, and it was against its most vulnerable point that Seward directed all his attacks, always avoiding claptrap but speaking with dignity, and with a force and eloquence that not only charmed the ear but appealed strongly to the judgment and conscience of his hearers.

In some respects the campaign was like that of 1840 . It was characterized by great meetings and great enthusiasm. It was also a singing campaign and the songs were quite as idiotic as were those of 1840 . One of the most popular of the Republican songs was called "The White House Race," and was sung to the tune of "Camptown Races." The words were as follows:

There's an old gray horse whose name is Buck,

Du da, du da,

His name was Folly and his sire Bad Luck,

Du da, du da day.

Chorus:

We're bound to work all night,

We're bound to work all day.

I'll bet my money on the Mustang Colt,

Will anybody bet on the Gray?

The Mustang Colt is strong and young,

Du da, du da,

His wind is sound and his knees not sprung,

Du da, du da day.

The old gray horse is a well-known hack,

Du da, du da,

He's long been fed at the public rack,

Du da, du da day. 
The Mustang is a full-blood colt,

Du da, du da,

He cannot shy and he will not bolt,

$\mathrm{Du}$ da, du da day.

The old gray horse, when he tries to trot,

Du da, du da,

Goes round and round in the same old spot,

Du da, du da day.

The Mustang goes at a killing pace,

Du da, du da,

He's bound to win in the four-mile race,

Du da, du da day.

Then do your best with the old gray hack,

Du da, du da,

The Mustang Colt will clear the track,

Du da, du da day.

Final Chorus:

We're bound to work all night,

We're bound to work all day;

I'll bet my money on the Mustang Colt,

You'd better not bet on the Gray.

The "Tippecanoe and Tyler too" song of 1840 was parodied in 1856 in a song which began as follows:

Have you heard of one Frémont, mont, mont,

So honest and true;

He's just the man that'll do all he can

For liberty here and in Kansas too!

For liberty here and in Kansas too!

And with him we'll beat old Buck, Buck, Buck,

And his slavery crew!

And with him we'll beat old Buck!

Of course Colonel Frémont's wife, "Our noble young Jessie, the flower of the land" was a prominent figure in the songs. ${ }^{x}$ It is almost incredible that sensible people should howl themselves hoarse in singing such miserable doggerel, but it is an indisputable fact that they did. In time of

- The foregoing songs are copied from Songs for Freemen, published in 1856 by $\mathrm{H}$. H. Hawley, Utica, N. Y. 


\section{Republican Party's First Battle}

great political excitement men scem to become boys again in their fondness for noise, and the songs they sing operate as escape pipes through which to blow off the superabundant enthusiasm.

There was, however, this marked difference between the campaign of 1840 and that of 1856 . In both campaigns the people shouted and sang, but in the campaign of $184^{\circ}$ they did nothing else and apparently thought about nothing but making log cabins bedecked with coonskins, and mimic canoes, and getting up monster meetings. In the campaign of 1856 the people, while they shouted and sang, were nevertheless intensely interested in the great principles at stake. In the North, as well as in the South, men were fast getting into warlike mood.

Although there was great enthusiasm for Frémont, interest in the political campaign of 1856 centered far more in the cause than in the candidate of the Republican party. Frémont was a son-in-law of Thomas H. Benton. He was credited with the honor of having been the first to plant the American flag upon certain high Western peaks, one of which was named after him. The most was made that could be made out of Frémont's "Rough Rider" characteristics but these qualifications were not such as to recommend him to the people as fit for the Presidency. Some of his prior financial operations were such as to need a great deal of explanation. Moreover, there was a suspicion, that had great weight with many of those who had belonged or were inclined to the Know-Nothing party, that he leaned toward the Roman Catholic Church.

The Democratic party was strongly intrenched in power. It had the President and a large majority in both houses of Congress. Nearly all the Federal judges, marshals, and other Federal officeholders were Democrats. Many of the old Whigs after the new alignment of voters on the slavery question went to the Democratic party. Others who were opposed to the further extension of slavery still clung to the Whig organization and name and looked askance at the 
new Republican party. The conservative interests of the country were undoubtedly alarmed by the Southern threats of secession in the event of Frémont's election and for this reason many of this class, whose sympathies were with the Republican candidates, were induced to vote for Fillmore and Donelson, the American or KnowNothing candidates. Considering all the circumstances, the vote received by Frémont was surprising and showed the great depths to which the people of the North had been stirred by the slavery question. Buchanan was elected, receiving the electoral votes of all the Southern States except Maryland, which gave its eight votes to Fillmore. Buchanan received also the electoral votes of Pennsylvania, Indiana, Illinois, California, and New Jersey.

There is little doubt that an attempt at secession would have been made if Frémont had been elected. The secession feeling was especially strong in South Carolina, which had felt the galling restraints of the Union ever since Jackson suppressed nullification there in $\mathbf{1 8 3 2}$. Since that time there had always been an element there that would have welcomed a favorable opportunity to secede and that would have gladly seized upon the election of Frémont or any other Republican as a pretext for secession. As evidence of this we need not rely on the ravings of such fire eaters as Brooks and Keitt. The only significance to be attached to their utterances is the enthusiasm with which they were received by the people to whom they were addressed. ${ }^{\mathrm{I}}$ More significance is attached to what Senator Butler of South Carolina said: "When Frémont is elected we must rely upon what we have-a good State government. Every governor of the South should call the legislature of his State together, and have measures of the South decided upon. If they did not and submitted to the degradation, they would deserve the fate of slaves. I should advise my State to go at the tap of the drum." 2

See Greeley and Cleveland, Political Text-Book for I860, p. I70.

Id., p. 170 . 
The secession sentiment was not confined to South Carolina. Senator James M. Mason of Virginia wrote on September 29,1856 , that "should the dominant sectional vote be directed to bring into power those pledged in advance to break down the barriers interposed by the compact of federation for the security of one section against the other, then, in my calmest judgment, but one course remains for the South-immediate, absolute, and eternal separation." $x$ The Richmond (Va.) Enquirer said: "If Fremont is elected the Union will not last an hour after Mr. Pierce's term expires. If Fremont is elected it will be the duty of the South to dissolve the Union and form a Southern Confederacy. Let the South present a compact and undivided front. Let her, if possible, detach Pennsylvania and southern Ohio, southern Indiana, and southern Illinois, from the North and make the highlands between the Ohio and the lakes the dividing line. Let the South treat with California and, if necessary, ally herself with Russia, with Cuba, and Brazil."”

Nor did those favoring secession in the event of Fremont's election confine themselves to mere talk. There is circumstantial evidence of a conclusive character that meetings of Governor Henry A. Wise of Virginia and other Southern governors were held, and that there was an extensive correspondence carried on having for its purpose the perfecting of plans for secession in the event of Frémont's election. ${ }^{3}$

Looking back at the result of the election it does not now seem to have been a calamity of such magnitude as it was then deemed to be by the Republicans. As already stated, South Carolina would undoubtedly have made an attempt to secede had Frémont been elected. How many of the Southern States would have joined in such a movement at

Quoted in Sumner's Works, vol. iv., p. 274.

2 Quoted in Political Text-Book for 1860 , p. 171 .

${ }^{3}$ Wilson, Rise and Fall, vol. ii., pp. 520-22; Political Text-Book for I860, p. I 70 . 
that period, and what the result might have been, is now a matter of conjecture only, but it is certain that in the interval between the election and the inauguration of the newly elected President we should have had Pierce as President instead of Buchanan, and Jefferson Davis as Secretary of War instead of Floyd. Moreover, Frémont, judging him by his career before and after the beginning of the Civil War, would in all probability have been wholly unequal to the responsibilities of the situation. Ill-prepared as was the North to meet secession in I86I, it was probably in a far better condition than it would have been in 1857 , with Fremont at the head of the government. This is the view of writers whose opinions carry great weight.

"In reviewing the past," John Sherman says, ${ }^{\mathrm{x}}$ "it is apparent that the election of Buchanan was necessary to convince the people of the North that no successful opposition to the extension of slavery could be made except by a party distinctly pledged to that policy. Mr. Buchanan encountered difficulties which no human wisdom could overcome. Whatever may have been his desire, he was compelled, by the prevailing sentiment in his party, to adopt measures that made a conflict between the sections unavoidable. The election of Fremont would probably have precipitated this conflict before the North was ripe for it. His conduct during the early period of the war proves that he would have been unequal to such an emergency. His defeat was the postponement of the irrepressible conflict until it became apparent to all that our country must be all free or all slave territory. This was the lesson taught by the Administration of Buchanan, and Lincoln was best fitted to carry it into execution."

Andrew D. White ${ }^{2}$ expresses substantially the same opinion:

"Certainly Providence was kind to the United States in that contest. For Frémont was not elected. Looking back over the history of the United States I see, thus far,

Recollections, p. I Io.

2 Autobiography, vol. i., pp. 75-76. 
no instant when everything we hold dear was so much in peril as on that election day.

"We of the Republican party were fearfully mistaken, and among many evidences in history that there is 'a Power in the universe not ourselves, which makes for righteousness,' I think that the non-election of Fremont is one of the most convincing. His election would have precipitated the contest brought on four years later by the election of Lincoln. But the Northern States had in 1856 no such preponderance as they had four years later. No series of events had then occurred to arouse and consolidate antislavery feeling like those between 1856 and 1860 . Moreover, of all candidates for the Presidency ever formally nominated by either of the great parties up to that time, Fremont was probably the most unfit. He had gained credit for his expedition across the plains to California, and deservedly; his popular name of 'Pathfinder' might have been of some little use in a political campaign, and some romantic interest attached to him on account of his marriage with Jessie Benton, daughter of the burly, doughty, honest-purposed, headstrong Senator from Missouri. But his earlier career, when closely examined, and, even more than that, his later career, during the Civil War, showed doubtful fitness for any duties demanding clear purpose, consecutive thought, adhesion to a broad policy, wisdom in counsel, or steadiness in action. Had he been elected in 1856 one of two things would undoubtedly have followed: either the Union would have been permanently dissolved, or it would have been reēstablished by anchoring slavery forever in the Constitution. Never was there a greater escape."

Pierce's last annual message was transmitted December 2, 1856. ${ }^{\mathrm{x}}$ A considerable portion of it was devoted to a defense of the repeal of the Missouri Compromise act, which the President claimed "was already obsolete and also null for unconstitutionality," all the effect of the repeal being, as he argued, "to relieve the statute book of an

'President's Messages, vol. v., p. 397. 
objectionable enactment, unconstitutional in effect and injurious in terms to a large portion of the States." The deluded people of the North who had opposed the repeal had been "drawn into one evanescent political issue of agitation after another," and "then followed the cry of alarm from the North against imputed Southern encroachments, which cry sprang in reality from the spirit of revolutionary attack on the domestic institutions of the South," all of which in the recent presidential election "had been rebuked by the voice of a patriotic people." He also devoted a considerable part of his message to a defense of his Kansas policy. While not approving the lawless acts of the Missouri border ruffians and their pro-slavery allies in their efforts to force slavery upon Kansas, he was careful to state that they had been provoked into the commission of them by a "long series of acts of aggression" on the part of the North, "the first being a strenuous agitation by citizens of the Northern States in Congress and out of it of the question of negro emancipation in the Southern States." It afforded him "unmingled satisfaction thus to announce the peaceful condition of things in Kansas, especially considering the means to which it was necessary to have recourse for the attainment of the end, namely, the employment of a part of the military force of the United States." He denounced indiscriminately all those-Abolitionists, Republicans, and Democrats alike- who had opposed the repeal of the Missouri Compromise or his own Kansas policy, as enemies of the country, who had "entered into a path which leads nowhere unless it be to civil war and disunion." Without referring to the Republican party by name he denounced it as a "geographical" and "sectional" organization which had had the audacity to attempt "to usurp the control of the government of the United States." Against this party he charged atrocious acts and diabolical designs, the most malignant of such charges not being made openly but by covert insinuation and innuendo. This he did in the following spiteful language: "To accomplish their objects they 
dedicate themselves to the odious task of depreciating the government organization which stands in their way and of calumniating with indiscriminate invective not only the citizens of particular States with whose laws they find fault, but all others of their fellow-citizens throughout the country who do not participate with them in their assaults upon the Constitution, framed and adopted by our fathers, and claiming for the privileges it has secured and the blessings it has conferred the steady support and grateful reverence of their children. They seek an object which they well know will be a revolutionary one. They are perfectly aware that the change in the relative condition of the white and black races in the slaveholding States which they would promote is beyond their lawful authority; that to them it is a foreign object; that it cannot be effected by any peaceful instrumentality of theirs; that for them and the States of which they are citizens the only path to its accomplishment is through burning cities and ravaged fields and slaughtered populations, and all there is most terrible in foreign, complicated with civil and servile war; and that the first step in the attempt is the forcible disruption of a country embracing in its broad bosom a degree of liberty and an amount of individual and public prosperity to which there is no parallel in history, and substituting in its place hostile governments, driven at once and inevitably into mutual devastation and fratricidal carnage, transforming the now peaceful and felicitous brotherhood into a vast permanent camp of armed men like the rival monarchies of Europe and Asia. Well knowing that such, and such only, are the means and the consequences of their plans and purposes, they endeavor to prepare the people of the United States for civil war by doing everything in their power to deprive the Constitution and the laws of moral authority and to undermine the fabric of the Union by appeals to passion and sectional prejudice, by indoctrinating its people with reciprocal hatred, and by educating them to stand face to face as enemies, rather than shoulder to shoulder as friends." 


\section{Political History of Secession}

This portion of the message bore upon its face unmistakable marks indicating that, if not written, it was at least inspired by the two most influential members of his Cabinet, Caleb Cushing, Attorney-General, and Jefferson Davis, Secretary of War. ${ }^{\text {I }}$

The President's message greatly angered the Republicans. Of all the responses to it in Congress that of John Sherman, then a member of the House from Ohio, was the most outspoken and caustic. This was a speech on the President's message delivered in the House on December $8,1856,^{2}$ a speech which added greatly to Sherman's reputation in the North and to his prestige as a leader in the new and growing Republican party. Sherman denounced the message as a perversion by the President of the prerogative before exercised by his predecessors of communicating to Congress in a respectful manner such information and recommendations as the public welfare might require, and said that he had "embodied in his message a stump speech in defense of his policy," filled with "unmannerly imputations" and "misrepresentations of the principles of his political opponents." What made this all the more galling was, as Sherman expressed it, that the Republicans were expected to "listen to the message patiently and not open their mouths in reply; and not only that, but to order thirty thousand or forty thousand extra copies to be distributed among the people." Taking up in detail the charges in the message against the Republican party, Sherman denied them all in severe and sarcastic language. He denied that the Republican party was an Abolition party or that he himself was an Abolitionist, or that either had any intention of interfering with slavery in the States where it already existed. To the charge that the Republican party was responsible for the angry passions that had

- This was directly charged by Benton, Examination of the Dred Scott Case, p. I45, and by Joshua R. Giddings in a speech in the House on December Io, 1856 (Cong. Globe, 34th Cong., 3d sess., p. 79).

2 Cong. Globe, 34 th Cong., 3 d sess., p. 53. 


\section{Republican Party's First Battle}

been raised during Picrce's term, Sherman retorted by comparing the peaceful and prosperous condition of the country at the beginning of his term, as portrayed by him in his first annual message, and its condition at the close of his term, all this being attributable, as Sherman claimed, to the repeal of the Missouri Compromise and to Pierce's own course in letting the pro-slavery men have everything their own way in Kansas. Sherman ridiculed with merciless sarcasm the President's "fancy sketch" about "burning cities and ravaged fields and slaughtered populations and all there is most terrible in foreign, complicated with civil and servile war," saying that he knew of no burning cities, except Lawrence and Ossawatomie, "nor of any 'ravaged fields and slaughtered populations,' except on the plains of Kansas," and that these "had been allowed, yea produced, by the President himself." Not the least bitter part of Sherman's speech was that in which he taunted the President with having been deserted by his own party, by his own State, and even by his own town, adding that the prospect of the President's speedy retirement from office had given Sherman himself and the country at large unbounded satisfaction.

This was practically the last of Pierce. Of William IV. it has been said that "nothing perhaps in his life became him like to the leaving of it," and the same may be said of Pierce's official life. During his administration the slave power rose to the height of its influence and in idolatrous worship of it the Government itself sank to the lowest depths of humiliation. Indeed the history of Pierce's administration presents an unbroken record of abject, servile submission to the slaveholders and leaves but a single consoling thought-that the secession movement was not fully hatched during Pierce's reign when it would have had the fostering care of an administration even more / sympathetic than that of Buchanan; an administration whose controlling spirit was Jefferson Davis, then Secretary of War and in after years the leader of the Southern Con- 
federacy. Indeed it has been said of Pierce's Administration that, in comparison with that of Buchanan, it made the latter respectable.

In the Democratic National Convention at Charleston, South Carolina, in 1860 , on one of the fifty-seven ballots Pierce received one and only one vote for the presidential nomination. Pierce was conspicuous among the Presidents of the United States because, and only because, he was the most subservient of them all to the slaveholding interests of the South. Jefferson Davis dominated his administration and after its close Pierce's sympathies were entirely with the South, as is evidenced by his letter to Davis, mentioned in a former chapter. It is unprofitable to speculate upon impossibilities, but we cannot repress the thought that it would spare the nation a most humiliating chapter, and relieve Pierce's memory of some of the odium that now attaches to it, if the story of his presidential career could be entirely wiped off the pages of American history.

NoTE. - I have a very distinct recollection of the campaign of 1856 . I was then a lad of about sixteen, living in Franklin, the county seat of Johnson County, Indiana. The county had been peopled largely by settlers from Kentucky, Virginia, North Carolina, and Tennessee and was strongly Democratic, but my own predilections were Republican. The public interest was intense and party feeling ran high. The Republicans were never so called but were always referred to as "Black Republicans" by their Democratic opponents. The campaign was characterized by monster meetings and I attended all, Republican and Democratic, far and near, that I could reach, and in this way I heard many of the noted speakers of the day. The meetings were generally entertained by glee clubs, which got all of the music possible out of the doggerel campaign songs. To these meetings long processions would come, often from great distances, usually headed by some neighborhood political chief astride a dashing steed. An invariable feature of these processions was a gayly decorated wagon filled with beautiful young ladies representing the various States of the Union. On the Democratic wagons were usually inscribed on canvas the words, "Give us white husbands or none," "God save us from nigger equality," or some such orthodox Democratic sentiment. The handsomest lady in the Republican wagon usually represented "Bleeding Kansas." At this period the old-fashioned 


\section{Republican Party's First Battle}

Kentucky barbecues were popular. On such occasions long trenches were dug in which beeves and sheep were roasted whole, accompanied in the late summer and fall with roasting ears and potatoes, and the multitudes were fed in both body and mind. At one of the barbecues I first heard Governor Oliver P. Morton, the Republican candidate for governor, then in his prime. In his speech he quoted the dying words of Madame Roland, when, just before her execution, she pointed to the statue of Liberty and said, "Oh, Liberty! what crimes are perpetrated in thy name!" The dignity of gesture and the impressiveness of manner with which he repeated the quotation made an impression upon my youthful mind that has never been effaced.

Perhaps it was because my mind was young and plastic that the speeches I then heard made so great an impression, but I do not, even now, after the lapse of nearly sixty years, recall any subsequent political campaign in Indiana that called forth greater interest or a higher class of political orators. On the Republican side were Henry S. Lane, Oliver P. Morton, Caleb B. Smith, Schuyler Colfax, Daniel Pratt, George W. Julian, Benjamin Harrison, Albert G. Porter, Samuel Parker, William Cumback, John Coburn, Godlove S. Orth, and others afterward noted in the politics of the State. Prominent on the Democratic side were Joseph A. Wright, then Governor; Ashbel P. Willard, candidate for Governor; Jesse D. Bright, then United States Senator; John L. Robinson, United States marshal; Thomas A. Hendricks, then commissioner of the United States land office; Daniel W. Voorhees, David Turpie, Graham N. Fitch, Cyrus L. Dunham, William H. English, Joseph E. McDonald, Oscar B. Hord, and Michael C. Kerr. Richard W. Thompson, a former Whig, and later an American, did not become a Republican until a subsequent date.

All these were men of marked ability. Nearly all were then or afterward members of Congress or filled other high official places in the State or nation. Lane, Morton, Willard, Hendricks, and Porter became governors of Indiana. Fitch, Lane, Morton, Pratt, Hendricks, Voorhees, Turpie, and McDonald became members of the United States Senate. Caleb B. Smith became a member of Lincoln's Cabinet, and Thompson a member of Hayes's Cabinet. Various others afterward held important Federal offices. Colfax and Kerr became Speakers of the House and the former and Hendricks became Vice-Presidents, and Harrison, President of the United States.

Caleb S. Smith, Henry S. Lane, Samuel Parker, Daniel Pratt, Richard W. Thompson, Graham N. Fitch, Joseph C. Wright, and Jesse D. Bright were past forty; nearly all the others were between twenty-five and thirty-five, averaging about thirty. Lane was forty-five, McDonald thirty-seven, Hendricks thirty-seven, Morton thirty-three, Colfax thirty-one, Voorhees twenty-nine, Turpie twenty-seven, and Harrison 
twenty-three. Most of the Republicans had been Whigs. Morton and perhaps a few others had been Democrats.

The leading political speaker on the Republican side was Henry S. Lane, who had formerly been a Whig. He had served with distinction as Lieutenant-Colonel in the Mexican War; he had also served a term in Congress. He was witty and ready, impassioned in his delivery, fluent of speech, and exercised great power over his audience. Next to him was Morton. He had formerly been a Democrat. He had never held a political office, and had had little experience as a political campaigner. He rarely attempted to tell a funny story. He never indulged in anything bordering on the "spread-eagle" style of oratory. But all who heard him felt that a new and great force in politics had come to the front. Before the campaign was over all recognized in him a political orator of matchless strength. Others like Lane or Willard or Voorhees might sway the multitude and for the moment make them captives to their oratory, but Morton battered down all the arguments of his political enemies and left them no alternative but retreat or surrender. On the Democratic side Ashbel P. Willard was easily the great political orator. A clear, bell-like voice, commanding presence, exquisite grace of delivery and diction, impassioned utterance, indeed all the graces of oratory combined, stamped him as probably the most eloquent political stump-speaker that Indiana ever produced. "He was," says Senator Turpie, "a born prince of the hustings," and in the power to entrance political audiences he has never had an equal in Indiana. He died, still a young man, before the expiration of his term of office as Governor. There were other able and influential political speakers on the Democratic side, but Hendricks, Voorhees, and others had not then achieved the renown they afterward acquired.

Many of the men I have named I came to know personally, some of them intimately, in later years. In 1909 , I acted as one of the pallbearers at the funeral of Senator David Turpie. He had outlived all his contemporaries of 1856 who have added luster to the history of Indiana. He had survived by several years President Harrison, who was four years his junior. Of his old-time political friends,

"The names he loved to hear

Had been carved for many a year

On the tomb."

It has been said that, "Old age ne'er cools the Douglas blood"; but not so with Senator Turpie, for the mellowing influences of time had softened the spirit that animated him in his early political contests. As a candidate for Congress he had been personally opposed to Schuyler Colfax; as a candidate for Lieutenant-Governor he had been opposed to Oliver $\mathrm{P}$. Morton. He had been active in great political campaigns 


\section{Republican Party's First Battle}

that engendered bitter passions, often lasting resentments; but all these, if any remained, he seemed to have buried in the graves of the political opponents who had gone before him, and in his later years one saw only the gentleness and nobility of his character. In his Skelches of My Own Times, written a few years before his death, he has told a charming story of early Indiana pioneer life. In this little book, in which not a trace of political rancor can be detected, he has also paid kindly tributes to the political friends and foes alike of his earlier years. 


\section{CHAPTER XV}

\section{THE DRED SCOTT CASE}

W ${ }^{\mathrm{HEN}}$ James Buchanan was inaugurated President $V$ of the United States on March 4, 1857, it looked, upon the surface of things, as though the Democratic party had gained a new lease of life, land that there was nothing to obscure the delightful vision spread out before him of a four years' happy reign, in which no wicked Abolitionist would dare to pester him; for back of him were a solid South and the great Democratic party of the North.

In the North the Abolitionists had dwindled into an insignificant band, and were almost everywhere in disrepute; opposition to the Fugitive Slave Law had apparently nearly run its course; the people of the North seemed to be weary of the story of "Bleeding Kansas," and many of the people in that section wished, as far as they could, to shut their eyes to slavery as an ugly picture to be kept in the background and out of sight. Judging by Buchanan's inaugural address, it seemed to him that his election had settled the political storms bred by the discussions of the slavery question and had ushered in a political millennium. "When the people," he said, "proclaimed their will, the tempest at once subsided and all was calm. The voice of the majority, speaking in the manner provided by the Constitution, was heard and instant submission followed." Referring to the question of slavery in the Territories, he paid a high tribute to the Kansas-Nebraska bill. "What a happy conception," he said, "was it for Congress to apply this simple rule, that the will of the majority shall govern 
the settlement of the question of domestic slavery in the Territories. Congress has neither to legislate slavery into any Territory nor to exclude it therefrom, but to leave the people thereof perfectly free to regulate their domestic institutions in their own way, subject only to the Constitution of the United States." True it was that "a difference of opinion had arisen in regard to the point of time when the people of a Territory shall decide the question for themselves." This very small fly in the ointment was, however, he thought, "happily a matter of but little practical importance. Besides it is a judical question which legitimately belongs to the Supreme Court of the United States, before whom it is now pending, and will, it is understood, be speedily and finally settled." In saying this, he referred to the Dred Scott case, then pending in the Supreme Court. Although professing ignorance of what the decision might be, he gave it as his "individual opinion" that "under the Kansas-Nebraska act, the appropriate period would be when the number of actual residents in the Territory shall justify the formation of a constitution with a view to admission as a State into the Union." To the decision of the Court, whatever it might be, he thought it the duty of all good citizens to "cheerfully submit:" All this having been accomplished, there would be little left for political partics to quarrel over and nothing for the people to do but to cultivate contentment. "The whole territorial question being now settled upon the principle of popular sovereignty in the people, as ancient as free government itself, everything of a political nature has been decided. No other question remains for adjustment. .. . May we not then hope that the long agitation on this subject is approaching its end, and that the geographical parties to which it has given birth, so much dreaded by the Father of his Country, will speedily become extinct."

Never had there been a time in the history of the nation when all outward signs so fully augured acquiescence in the decision about to be made. It was announced on March 


\section{Political History of Secession}

6, I857, only two days after Buchanan's inauguration, and startled the whole country from one end to the other.

Briefly stated the case was this: Dred Scott was a negro slave. His master, one Emerson, an army surgeon, formerly residing in Missouri, had taken him to a United States military post in Illinois, where he lived several years; thence to a United States military post at Fort Snelling, situated in what was then Upper Louisiana Territory. Later Emerson returned to Missouri, taking Scott with him, and afterwards sold Scott to one Sandford, who continued to hold Scott and his family as slaves. Afterwards Scott brought suit against Sandford, which was virtually a suit to recover his freedom, in the United States Circuit Court of Missouri. The defendant filed a plea in abatement to the jurisdiction of the Court, alleging that "the said plaintiff, Dred Scott, is not a citizen of the State of Missouri, as alleged in his declaration, because he is a negro of African descent; his ancestors were of pure African blood and were brought into this country and sold as negro slaves." To this plea Scott filed a demurrer which was sustained, and the defendant then filed an answer the second paragraph of which set up substantially the facts above stated. The case was tried upon an agreed statement of facts which were substantially as above stated and thereupon the Court gave judgment for the defendant, from which Scott appealed to the Supreme Court of the United States. The full report of the case covers two hundred and forty-one pages of the official report. ${ }^{x}$

For seventy years the Supreme Court had possessed the respect and confidence of the people of all sections, and during all this time no suspicion had ever been entertained that any of its decisions had been influenced by any political bias. The Court, as then constituted, consisted of the Chief. Justice, Taney, then eighty years of age, and eight associate justices, Wayne, Daniel, Campbell, Catron, Grier, Nelson, McLean, and Curtis. The Chief Justice and four

s Howard's Reports, vol. xix., pp. 393-633. 
of the associate justices, Wayne, Daniel, Campbell, and Catron, were all from slave States. Four of them were slaveholders and the Chief Justice had been a slaveholder, and all were Democrats except Wayne, who was a Southern Whig; Grier of Pennsylvania and Nelson of New York were Democrats; Curtis of Massachusetts was a conservative Whig whose charge to the grand jury in the cases growing out of the attempt to rescue Antony Burns had been burned, along with the Constitution, by William Lloyd Garrison. McLean of Ohio was the only Republican on the bench. Montgomery Blair and George Ticknor Curtis appeared as attorneys for Scott, and Henry S. Geyer and Reverdy Johnson as attorneys for Sandford, the slave-owner.

Chief Justice Taney, though not measuring up to the judicial stature of his illustrious predecessor, Marshall, the great expounder of the Constitution, had nevertheless achieved high eminence as a lawyer and as a judge; his personal integrity was never questioned, and his conduct on the bench was courteous and dignified; but it is fair to assume that, viewing slavery as it was viewed by a Southern slaveholder, he believed, and honestly believed, that slavery was right, and that the slaveholder had as much right to take his slaves to the new Territories as the owner of cattle had a right to take them there, and that the affirmance of this principle by a decision of the Supreme Court of the United States would forever settle the question and take it out of the domain of politics.

The chief questions ultimately decided by the Supreme Court were these:

First: Whether a negro of slave descent could become a citizen of the United States, so as to entitle him to sue in the United States courts.

Second: Whether the Missouri Compromise Act of 1820 was constitutional.

It was possible, however, to decide the case upon its merits without deciding either of these questions, for the Supreme Court followed the decisions of the Supreme 


\section{Political History of Secession}

Court of Missouri, which held that when a negro slave, although he may have temporarily resided in a free State or Territory, returned to Missouri, the condition of slavery revived, and this was the ground upon which it was at first determined to base the decision of the Court. So late as April 8, 1856, a majority of the judges were of opinion that it was not necessary to decide the question as to the constitutionality of the Missouri Compromise. ${ }^{x}$

The case in the Supreme Court was first argued at the December term, 1855, but the judges were very much divided in opinion. Nelson was appointed to prepare the opinion of the Court, and we know what the opinion of the Court then was from Nelson's opinion published in the official reports, which was substantially the opinion prepared by him as the opinion of the Court after the first argument. In this opinion the decision is based wholly upon the Missouri decisions that when Scott returned to Missouri his condition of slavery revived, and the opinion carefully avoids any discussion of any of the other questions so elaborately argued in the other opinions subsequently filed. Indeed, we are told by Curtis's biographer that the "astuteness with which this opinion avoided a decision of the question arising out of the residence of Scott in a Territory of the United States where slavery was prohibited by an Act of Congress, and the remarkable subtlety of the reasoning that this too was a matter for the State courts to decide, because the law of the Territory could have no extraterritorial force except such as the State of Missouri might extend to it under the comity of nations - show very distinctly that after the first argument of the case in the Supreme Court it was not deemed.by a majority of the bench to be either necessary or prudent to express any opinion upon the constitutional power of Congress to prohibit slavery in the Territories of the United States."2

After the first argument Nelson was in doubt and on his

${ }^{x}$ Letter of Curtis to Ticknor, April 8, 1856, in Life of Curtis, vol. i., p. I80.

Id. p. 203. 
motion the case was set down for a second argument, which was had on December 18, 1856. Curtis's biographer, speaking guardedly and with due deference to the "patriotic motives of Wayne," states that "after this second argument, and at some time during the same term, $\mathrm{Mr}$. Justice Wayne became convinced that it was practicable for the Supreme Court of the United States to quiet all agitation on the question of slavery in the Territories by affirming that Congress had no constitutional power to prohibit its introduction. With the best intentions, with entirely patriotic motives, and believing thoroughly that such was the law on this constitutional question, he regarded it as eminently expedient that it should be so determined by the Court. In the short observations which he read in the Court, referring to the constitutional questions involved, he said that 'the peace and harmony of the country required the settlement of them by judicial decision, and it is well known from his frank avowals in conversation at the time that he regarded it as a matter of great good fortune to his own section of the country that he had succeeded in producing a determination on the part of a sufficient number of his brethren to act upon the constitutional question which had so divided the people of the United States. He persuaded the Chief Justice, Judge Grier, and Judge Catron of the public expediency of this course, and being perfectly convinced, as he somehow had convinced himself, that the appellate court could hold that the circuit court had no jurisdiction of the case, because a free negro could not be a 'citizen,' and yet could go on and decide all questions arising upon the merits, he could conscientiously concur, as he did, in every part of the opinion which the Chicf Justice, after the second argument, felt called upon to write, and which was denominated the opinion of the Court, although no other judge, excepting Mr. Justice Wayne, concurred in all its points, reasonings, and conclusions." $\mathrm{x}$

'Curtis, Life of Curtis, vol. i., pp. 206-207. 
The second argument was had upon the questions discussed upon the first and also upon several additional questions suggested by Chief Justice Taney. Between the first and second arguments, and in the absence of Justice Nelson, but after his opinion had been written, it was set aside, and Chief Justice Taney was selected to write an opinion "as the opinion of the Court" on all the questions that had been argued, each judge "to deal with them as his judgment dictated." ${ }^{\prime}$ Upon the second argument all the judges excepting Curtis and McLean were still of the opinion that the lower Court was right in following the Missouri decisions, but did not concur with Nelson in basing the opinion of the Supreme Court upon that ground alone, as did Nelson, and as the majority, after the first argument, had determined, for the majority were now ready to go a great deal further than Nelson was willing to go. The actual judgment of the Supreme Court was that the Missouri Circuit Court "had no jurisdiction in the case and could give no judgment in it. Its judgment for the defendant must consequently be reversed and a mandate issued directing the suit to be dismissed for want of jurisdiction."

Chief Justice Taney delivered what is called in the official report "the opinion of the Court." Each of the associate judges delivered a separate opinion, but none concurred with the Chief Justice throughout except Wayne, who concurred "entirely in the opinion of the Court as it has been written and read by the Chief Justice-without any qualification of its reasoning or its conclusions."

Chief Justice Taney decided:

First: That Dred Scott was not and could not be, because he was of slave descent, a citizen of the United States and could not sue in the United States courts.

Second: That the Missouri Compromise Act of $\mathbf{I 8 2 0}$

See letter of Judge Campbell, Tyler, Memoir of Taney, p. 384. See also Campbell's address before the Bar Meeting in Memory of Judge Curtis, 20 Wallace Reports, p. xi. 


\section{The Dred Scott Case}

was unconstitutional and void because Congress had no power under the Constitution to prohibit slavery in the United States Territories.

Upon these two propositions all the judges except Nelson, Curtis, and McLean agreed. Catron went cven further than Tancy and held the Missouri Compromise unconstitutional because it violated "the most leading feature of the Constitution-a feature on which the Union depends and which secures to the respective States and their citizens an entire equality of rights, privileges, and immunities." Nelson expressed no opinion on the constitutional question and Curtis and McLean dissented in toto from the opinion of Taney. Taney, Wayne, and Daniel also held that the Ordinance of 1787 expired with the old confederation.

Such was the diversity of opinion that, according to a witty contemporary critic: "Four of the judges are of one opinion; two are of the opposite; two will give no opinion; and one is divided. ... There is no majority in favor of anything but a majority against everything suggested; unless it should be claimed that Judge Grier is in favor of something " and that "the result is that three judges are for reversing the decision of the Court below on the plea of abatement; and six are against a reversaltwo, because it is right, one because the Court has no authority to examine it, and three without giving any reason. There is no majority for anything-to reverse, affirm, or waive."I

The leading opinion of the majority was that of Chief Justice Tancy; the leading opinion in opposition to it was that of Justice Curtis. Both were masterpieces of judicial reasoning. It is not within the scope of this chapter to criticize or even to attempt to analyze the arguments by which they were supported. Nevertheless it may help to a better understanding of the case to refer to some well-settled general legal rules. One is that when an appellate

'Quoted in Wilson's Rise and Fall, vol. ii., p. 525. 
court decides that a lower court had no jurisdiction, there is properly nothing more to decide, for an appellate court has no jurisdiction to decide any question that the lower court had no jurisdiction to determine.

Another well-settled general rule is that when a judge goes "out of the record," as lawyers say, to decide a question not properly before him, his remarks are regarded as obiter dicta, and, whatever weight may be given to his opinion as an individual, it does not have the binding force of a judicial decision.

These propositions were pressed with great vigor in his dissenting opinion by Justice Curtis, who contended that the question of the validity of the Missouri Compromise was not properly before the Supreme Court after its ruling that the lower Court had no jurisdiction. On this point he said that the majority "having first decided that they were bound to consider the sufficiency of the plea to the jurisdiction of the Circuit Court, and having decided that this plea showed that the Circuit Court had not jurisdiction and consequently that this is a case to which the judicial power of the United States does not extend, they have gone on to examine the merits of the case as they appeared on the trial before the Court and jury on the issues joined on the pleas in bar, and so have reached the question of the power of Congress to pass the act of 1820 . On so grave a subject as this I feel obliged to say that, in my opinion, such an exercise of the judicial power transcends the limits of the authority of this Court, as described by its repeated decisions, and as I understand, acknowledged in this opinion of the majority of the Court. . . . I do not consider it to be within the scope of the judicial power of the majority of the Court to pass upon any question respecting the plaintiff's citizenship in Missouri, save that raised by the plea to the jurisdiction, and I do not hold any opinion of this Court or any court binding, when expressed on a question not legitimately before it. The judgment of this Court is that the case is to be dismissed for want 
of jurisdiction because the plaintiff was not a citizen of Missouri, as he alleged in his declaration. Into that judgment, according to the settled course of this Court, nothing appearing after a plea to the merits can enter. A great question of constitutional law, decply affecting the peace and welfare of the country, is not, in my opinion, a fit subject to be thus reached."

In meeting this argument the ingenuity and subtlety of reasoning of the Chicf Justice were chiefly conspicuous. His opinion displayed his profound knowledge of the ancient rules of law relating to pleas in abatement, a species of learning that flourished in England at a time when pleadings were written in law French, a mongrel compound of Latin and Norman-French; when the rules of pleading, and particularly the rules relating to pleas in abatement, were wrapped in a maze of technicalities expressed in legal jargon wholly unintelligible to laymen, requiring for their understanding a clear conception of Coke's distinction between certainty to a common intent, certainty to a certain intent in general, and certainty to a certain intent in every particular, the last kind of certainty being that which was required in a plea in abatement, a distinction which it is doubtful if the lawyers even in Coke's time clearly understood.

There are lawyers at this day who still find diversion in discussing the technical legal puzzles in the Dred Scott case. $^{\mathbf{2}}$ But the people at the time when the decision was announced did not much concern themselves about the ruling on the plea in abatement and it is not that ruling which has given historic interest to the case. The great mass of the people, not being versed in law, knew little and cared less about pleas in abatement or whether any part of the opinions in the Dred Scott case was obiter

"See paper of Edward S. Corwin on the "Dred Scott Decision in the Light of Contemporary Legal Doctrines, " in American Historical Review, vol. xvii., p. 52; paper by Morris M. Cohn on "The Dred Scott Case in the Light of Later Events," in American Law Review, vol. xlvi., p. 548. 
dictum or not. There was a very general opinion in the North, shared by lawyers as well as laymen, that the Supreme Court had not only gone out of the record but that it had trumped up a pretext for doing so in order to give judicial sanction to the political doctrines advocated by the ultra pro-slavery men of the South.

This was Benton's view, expressed in a scathing review of the Dred Scott decision soon after it was published. ${ }^{x}$ Ex-President Martin Van Buren said of it: "For the first time since the formation of the present government the Supreme Bench, considerably changed in the political complexion of its members, and tempted doubtless more or less under the pressure of an all-absorbing popular influence at the South, to borrow a leaf from the book of our political opponents, has undertaken to control, adversely to the views of those opponents, a great political question by an extrajudicial decision of the Court." 2

Most people, whether lawyers or not, understood that part of the opinion of Chief Justice Taney in which he asserted that the portion of the Declaration of Independence which asserts that "all men are created equal" and endowed with "certain inalienable rights," including "life, liberty, and the pursuit of happiness," did not include the "enslaved African race." They were shocked by that portion of the opinion of the Chief Justice in which, speaking of the African race and how those of that race were regarded prior to the adoption of the Declaration of Independence, he said that "they had for more than a century before been regarded as beings of an inferior order and altogether unfit to associate with the white race, either in political or social relations, and so far inferior that they had no legal rights which the white man was bound to respect; and that the negro might justly and lawfully be reduced to slavery for his benefit. He was bought and sold as an ordinary article of merchandise and traffic whenever a profit could be made of it."

Examination of the Dred Scott Case.

? Political Parties, p. 374. 


\section{The Dred Scott Case}

This language of the Chief Justice was construed, and justly construed, as at least strongly indicating that he himself concurred in that opinion. This was shocking to the moral sense of the great majority of people in the North. Lawyers who dissented from the reasoning and conclusions of the majority of the Court, relied chiefly on the able and exhaustive arguments in the dissenting opinions of Justices Curtis and McLean. But people who are not lawyers do not adopt a lawyer's way of determining whether a judicial decision that involves a great moral question is right or wrong. They determine the question, not on technical legal reasoning, but on the strength of arguments based, as they believe, on immutable principles of justice. Nor are they awed into silence by any reverence for the sanctity of courts and the sacredness of judicial decisions. A judge may add luster to his court; he can borrow but little from it. The dignity of his court, however high, cannot be imparted to the judge so as to shield him from criticism for his known bad conduct and decisions. Indeed one of the worst monsters in English history was Jeffreys who wore the ermine of Lord Chief Justice of England while holding the Bloody Assizes and ordering judicial butcheries by the wholesale.

With many in the North, however, it was not necessary in order to destroy respect for the Dred Scott decision to prove that the majority of the judges who made it were guilty of any misconduct or were influenced by any corrupt motive; it was enough to know that five of the judges, constituting the majority, were slaveholders and that Grier, the sixth, was the same judge whose harsh enforcement of the Fugitive Slave Law had rendered his name odious to all the anti-slavery people of the North. Such persons attached no importance whatever to what they regarded as Chief Justice Taney's fine-spun sophistry. Indeed, they believed that, if he had thought it necessary to so decide, he could have found as plausible arguments for deciding the Ten Commandments unconstitutional as 
those which he found for deciding against the constitutionality of the Missouri Compromise.

What most startled the people of the North was the decision of the majority of the judges that the Missouri Compromise was unconstitutional for the reason that the Constitution itself guaranteed the right of a slaveowner to take his slaves into any Territory and protected his right of property in them there so long as the Territory remained in a territorial condition, and that while it so remained, neither ${ }^{\circ}$ Congress nor the people of the Territory could exclude it, and that it could be excluded only by the constitution which the people might adopt preparatory to admission into the Union as a State.

It was at once apparent that this was precisely the political doctrine advocated by John C. Calhoun and those of his school. Taney had used somewhat different language, but he had not improved upon the arguments of Calhoun and the conclusions which he reached were identically the same as those of Calhoun. Calhoun's arguments and conclusions had been opposed and condemned by Webster, Clay, Benton, Dix, and other great Democratic and Whig leaders; they, had been rejected by Congress; they had never been promulgated by any national Democratic or Whig conventions, by any Northern convention of any kind. If Calhoun's doctrine, or anything like it, had ever been advocated in the halls of Congress, it had been so advocated only in the speeches of Calhoun himself and others of the most ultra type of slavery propagandists. But now for the first time in the history of the Supreme Court, that time-honored tribunal sought to impart its sanction to the political doctrine advocated by Calhoun throughout his lifetime, and after his death, persistently but hitherto vainly, contended for by Jefferson Davis and others of the Calhoun school as a doctrine which it was indispensable for the continuance and extension of slavery to have grafted upon the Constitution and adopted as a fundamental principle of governmental 
policy. As most of the people of the North believed, the majority of the judges had not only gone outside the record, but they had distorted the law, spurned all precedents, and trumped up an excuse for making a decision that would satisfy the most exacting demands of the slaveholding interests of the South. It was this conviction that inflamed the North.

The decision also made plain the meaning of the words in the Kansas-Nebraska bill, "subject only to the Constitution of the United States," attached to the clause supposed to give to the people of the Territories the right to determine the question of slavery for themselves. There had been a violent protest in the North against the repeal of the Missouri Compromise, but the opposition had been partially allayed by what seemed to be a guaranty of "popular sovereignty," giving the people of the Territories the right themselves to admit or exclude slavery, and the words "subject only to the Constitution of the United States" had been universally construed in the North as meaning only that the laws and the constitutions which they might make in the regulation of their domestic institutions should conform to the Constitution of the United States, a provision similar, as before stated, to that in many other enabling acts and one that would probably have been implied whether expressed or not. But under the new doctrine of the Dred Scott decision, the supposed right of popular sovereignty, as applied to the people of the Territories, was seen to be a barren right. The Constitution, under this doctrine, itself admitted slavery into the Territories, and the only right the people had to exclude it was a right, which had always been conceded, to exclude it when permission was given them by Congress, through an enabling act, to form a constitution preparatory to admission into the Union as a State.

But Congress was not bound even then to admit them under a constitution prohibiting slavery, and so might keep them out of the Union indefinitely, if they persisted 
in coming in under a free State constitution. That is precisely what was done with Kansas, which was excluded from admission until I86I, when the Republicans, by reason of the resignation of several Senators from the seceding States, had acquired a majority in the Senate.

There was also a sentence in the opinion of Justice Nelson that had a sinister look, all the more ominous because, when the opinion was originally prepared, he had expressed the view of the majority of the judges. "A question," he said, "has been alluded to on the argument, namely: the right of the master with his slaves, of transit into or through a free State on business or commercial pursuits, or in the exercise of a federal right, or the discharge of a federal duty, being a citizen of the United States, which is not before us. This question depends upon different considerations and principles from the one in hand and turns upon the rights and privileges secured to a common citizen of the Republic under the Constitution of the United States. When that question arises, we shall be prepared to decide it." Could it be doubted what would be the decision in such a case if it should come before the same judges that decided the Dred Scott case?

The decision in the Dred Scott case, whether so designed or not, was a fitting sequel to the repeal of the Missouri Compromise. That repeal had broken down the congressional barrier to the admission of slavery into the Territories, and now came a decision of the Supreme Court of the United States protecting it after its admission from all interference either by Congress or by the territorial legislatures. No one could foresee, but all opponents of slavery dreaded, the future consequences. The next step would probably be the passing of a federal slave code for all the remaining Territories, a code patterned after that of South Carolina, or some other slave State-it mattered little which one, for the best of the slave codes were barbarous, codes that virtually suppressed freedom of speech and of the press, codes that inflicted inhuman punishments 
for trivial offenses against slavery. Such codes, supplemented by subservient federal judges, commissioners, and marshals, would bring under the dominion of slavery every foot of the remaining Territories.

Moreover, if the Constitution guaranteed the right of a slaveholder to take his slaves, as well as his cattle, into a Territory because they were alike his property, how long would it be until it would be adjudged that he had a right to take his slaves into a free State? Might not the same Court which decided the Dred Scott case invent some specious reasoning by which a slaveholder would be protected in taking his slaves into a free State as wcll as into a free Territory?

Already, in view of the need of more slaves with which to fill the new Territories, there was a loud demand in various quarters of the South for the reopening of the African slave trade.

And what would be the final outcome? Would slavery ultimately become lawful in all the nation?

The fear in the North that the Dred Scott decision was only the forerunner of others to come that would break down the barriers against slavery even in the free States was aptly expressed by Lincoln in the speech already quoted, in which he said: "It should not be overlooked that by the Nebraska bill the people of the States, as well as the Territories, were to be left 'perfectly free,' 'subject only to the Constitution.' Why mention a State? They were legislating for Territories and not for or about States. Certainly the people of a State are and ought to be subject to the Constitution of the United States; but why is mention of this lugged into this mere territorial law? Why are the people of a Territory and the people of a State therein lumped together and their relation to the Constitution therein treated as being precisely the same? While the opinion of the Court, by Chief Justice Taney, in the Dred Scott case, and the separate opinions of all the concurring judges, expressly declare that the Constitution of the 
United States neither permits Congress nor a territorial legislature to exclude slavery from any United States Territory, they all omit to declare whether or not the same Constitution permits a State, or the people of a State, to exclude it. Possibly this is a mere omission; but who can be quite sure, if McLean or Curtis had sought to get into the opinion a declaration of unlimited power in the people of a State to exclude slavery from their limits, just as Chase and Mace sought to get such declaration, in behalf of the people of a Territory, into the Nebraska bill-I ask, who can be quite sure that it would not have been voted down in the one case as it had been in the other? The nearest approach to the point of declaring the power of a State over slavery, is made by Judge Nelson. He approaches it more than once, using the precise idea and almost the language, too, of the Nebraska act. On one occasion, his exact language is, "except in cases where the power is restrained by the Constitution of the United States, the law of the State is supreme over the subject of slavery within its jurisdiction.' In what cases the power of the States is so restrained by the United States Constitution, is left an open question, precisely as the same question, as to the restraint on the power of the Territories, was left open in the Nebraska act. Put this and that together and we have another nice little niche, which we may, ere long, see filled with another Supreme Court decision, declaring that the Constitution of the United States does not permit a State to exclude slavery from its limits. And this may especially be expected if the doctrine of 'care not whether slavery be voted down or voted up' shall gain upon the public mind sufficiently to give promise that such a decision can be maintained when made.

"Such a decision is all that slavery now lacks of being alike lawful in all the States. Welcome or unwelcome, such decision is probably coming, and will soon be upon us, unless the power of the present political dynasty shall be met and overthrown. We shall lie down pleasantly dream- 


\section{The Dred Scott Case}

ing that the people of Missouri are on the verge of making their State free, and we shall awake to the reality instead that the Supreme Court has made Illinois a slave State."

Coupled with the indignation over the announcement of the Dred Scott decision was a widespread feeling in the North that the seeming recognition of the doctrine of popular sovereignty in the Kansas-Nebraska act was a mere false pretense, and that there was some mysterious connection between it and the Dred Scott decision, indicating that both were parts of some preconceived plot to further the extension of slavery. There was also a general suspicion in the North that Buchanan had something to do with the decision, or that, at least, he knew something about it before its announcement. How the President in his inaugural, without prior information from some source, could have so exactly forecast the decision of the Court, was a question that for a long time afterwards gave rise to great speculation. It was pointed out that the time of announcing the Dred Scott decision was significant. If it had been announced prior to the preceding presidential election, it might have jeopardized the election of Buchanan. It was not made public until after his election had been assured, together with a Democratic majority in both houses of Congress and with another presidential election four years away. These suspicions were no doubt aggravated by the then excited state of public opinion in the North, but they were widely entertained. There was, of course, no direct proof of the plot suspected or of Buchanan's supposed connection with it, but the circumstantial evidence supposed to indicate its existence was summed up by Lincoln, in his Springfield speech, in which he enforced his argument by this homely illustration:

"We cannot absolutely know that all these exact adaptations are the result of preconcert. But when we see a lot of framed timbers, different portions of which we know have been gotten out at different times and places, and by

- Lincoln-Douglas Debates, p. 4. 
different workmen,-Stephen, Franklin, Roger, and James, for instance,- - and when we see these timbers joined together, and see they exactly make the frame of a house or a mill, all the tenons and mortices exactly fitting, and all the lengths and proportions of the different pieces exactly adapted to their respective places, and not a piece too many or too few, - not omitting even scaffolding,-or, if a single piece be lacking, we see the place in the frame exactly fitted and prepared yet to bring such piece in -in such a case, we find it impossible not to believe that Stephen and Franklin and Roger and James all understood one another from the beginning, and all worked upon a common plan or draft drawn up before the first blow was struck." ${ }^{2}$ In the homely illustration used the people readily recognized Stephen A. Douglas, Franklin Pierce, Roger B. Taney, and James Buchanan.

Many, however, who may have been reluctant to believe in the existence of a deliberately premeditated "plot" were quite ready to believe that there was at least a secret communication of some kind between some of the judges of the Supreme Court and Buchanan by which he was given fully to understand what the decision would be before he delivered his inaugural. This, indeed, was expressly charged by Seward in a speech in the Senate on March 3, $1858,{ }^{2}$ in which he said: "Before coming into office he [Buchanan] approached, or was approached by, the Supreme Court of the United States. . . The Court did not hesitate to please the incoming President by seizing this extraneous and idle forensic discussion and converting it into an occasion for pronouncing an opinion that the Missouri prohibition was void, and that by force of the Constitution slavery existed, with all the elements of property in man over man, in all the Territories of the United States, paramount to any popular. sovereignty within the Territories and even to the authority of Congress itself. . . . The day

x Lincoln-Douglas Debates, p. 3.

'Seward's Works, vol. iv., pp. 585-87. 
of inauguration came-the first one among all the celebrations of that great national pageant that was to be desecrated by coalition between the executive and judicial departments, to undermine the national legislature and the liberties of the people. The President, attended by the usual lengthened procession, arrived and took his seat on the portico. The Supreme Court attended him there in robes which yet excited public reverence. The people, unaware of the import of the whisperings carried on between the President and the Chief Justice, and imbued with veneration for both, filled the avenues and gardens as far as the eye could reach. The President addressed them in words as bland as those which the worst of all the Roman Emperors pronounced when he assumed the purple. He announced (vaguely, indeed, but with self-satisfaction) the forthcoming extrajudicial exposition of the Constitution and pledged his submission to it as authoritative and final. The Chief Justice and his associates remained silent. ... The pageant ended. On the 5th of March the judges, without even exchanging their silken robes for courtiers' gowns, paid their salutation to the President in the executive palace. Doubtlessly the President received them as graciously as Charles the First did the judges who had at his instance subverted the statutes of English liberty."

There can be no mistaking the meaning of this speech. Considering that it was made by one who had been Governor of the State of New York, and who was then a United States Senator, and a practitioner in the court which he so vigorously denounced, this was a most extraordinary speech. Whether Seward had any reliable information of the facts upon which his charges were based, or whether he based his conclusions upon circumstances like those upon which Lincoln based his, is not known. For making these charges, Seward was vehemently denounced at the time. Taney, himself, it is said, was so incensed that he avowed his intention to refuse to administer to Seward the oath 


\section{Political History of Secession}

of office in the event, which then seemed not improbable, of Seward's nomination and election to the office of President. " Later historians have apparently scouted the suggestion that the decision was part of a "plot," or that there was any improper correspondence or understanding on the subject between Buchanan and the judges of the Supreme Court. Woodrow Wilson, writing in 1903, expresses such an exalted idea of Buchanan as "a man of unsullied integrity and punctilious in the performance of what he considered to be his duty," as to make "such calumny inexcusable"" ; and Rhodes, so late as I9ro, after offering various speculations as to how information of the nature of the decision, prior to its formal announcement, might have "leaked out," is quite positive that "however Buchanan got his intelligence, his character and that of Taney are proof that the Chief Justice did not communicate the import of the decision to the President-elect. That either would stoop from the etiquette of his high office is an idea that may not be entertained for a moment; and we may be sure that with Taney's lofty notions of what belongs to an independent judiciary he would have no intercourse with the executive that could not brook the light of day." 3 Curtis's biographer also admits that he does "not imagine that Mr. Buchanan was a man who would tamper with the administration of justice, and I am sure that the Chief Justice and Judge Wayne would never have brooked such an attempt." 4 The only explanation given by Buchanan's latest biographer for the remarkable shifting of position in the Dred Scott case between the first and final decisions is that it was owing "to the activity of the minority rather than the majority of the Court." 5

× Tyler, Memoir of Taney, p. 391.

"Contribution on "States' Rights" in The Cambridge Modern History, vol. vii., p. 436 .

${ }^{3}$ History of the United States, vol. ii., p. 269.

4 Life of Curtis, vol. i., p. 236.

5 Moore, Buchanan, vol. x., p. I08 note. 
In a recent number of the American Law Review, the leading law magazine in the country, ${ }^{\mathbf{x}}$ is a paper by George L. Christian on "Roger Brooke Taney," in which Taney is held up as "a great and good man and a great Judge" who was "hounded and denounced by the Abolitionists of that day as few men of this country have ever been at any time in its history," and Seward, for making the charge above quoted, is denounced as the "unscrupulous Senator from the great State of New York" whose whole public career was "strewn with acts of perfidy, duplicity, and falsehood," and the assertion is made that President Lincoln "was either frequently misled by misrepresentations or that he was the pliant tool of his wily and wicked premier." These intemperate assertions were evidently made in entire ignorance of the correspondence on the subject of the intended decision between Buchanan and Judges Catron and Grier. Despite all explanations of the decision there has been something like mystery in connection with the shifting of position of the Supreme Court between the first argument and the final decision of the case, and there has been a suspicion that Buchanan at least knew something about it before he delivered his inaugural.

Recently, and more than fifty years after the decision in the Dred Scott case, there have come to light two letters written by two of the judges of the Supreme Court to Buchanan, while the case was pending. These letters throw a great flood of light upon the history of the case and must necessitate a modification of some conclusions heretofore expressed by eminent historians. They are not sufficient to prove a "plot" but they do nevertheless show, especially in connection with other undisputed evidence, an amazing state of facts wholly inconsistent with the "etiquette of high office" supposed to govern the President of the United States and the judges of the Supreme Court. These letters were both written to Buchanan while the Dred Scott case was under advisement and before Buchanan's inaugural.

: Vol. xlvi., p. I. 


\section{6 \\ Political History of Secession}

One was written by Justice Catron of Tennessee, an old personal friend of Buchanan, the other by Justice Grier of Pennsylvania, also an old personal friend.

These letters cannot, consistently with historic accuracy, be abbreviated and they are here given in full as copied from Moore's Works of James Buchanan. ${ }^{\text {I }}$ It is not known what communications, oral or written, passed between Justice Catron and Buchanan prior to Catron's letter of February 19, 1857, but on that date Catron wrote as follows:

"My DEAR Sir:

"Thursday, Feby. 19th [1857].

"The Dred Scott case has been before the Judges several times since last Saturday, and I think you may safely say in your Inaugural,

"'That the question involving the Constitutionality of the Missouri Compromise line is presented to the appropriate tribunal to decide; to-wit, to the Supreme Court of the United States. It is due to its high and independent character to suppose that it will decide \& settle a controversy which has so long and seriously agitated the country, and which must ultimately be decided by the Supreme Court. And until the case now before it, (on two arguments) presenting the direct question, is disposed of, I would deem it improper to express any opinion on the subject.'

"A majority of my Brethren will be forced up to this point by two dissentients.

"Will you drop Grier a line, saying how necessary it is$\&$ how good the opportunity is, to settle the agitation by an affirmative decision of the Supreme Court, the one way or the other. He ought not to occupy so doubtful a ground as the outside issue-that, admitting the constitutionality of the Mo. Comp. line of 1820 , still, as no domicile was acquired by the negro at Ft. Snelling, \& he returned to

× Vol. x., pp. 106-108. 


\section{The Dred Scott Case}

Missouri, he was not free. He has no doubt about the question on the main contest, but has been persuaded to take the smooth handle for the sake of repose.

"Sincerely yr. frd.

"To Mr. Buchanan."

"J. Catron.

Four days later Judge Grier wrote to Buchanan as follows:

"MY DEAR SIR:

"WASHINGTON, Feby. 23, 1857.

"Your letter came to hand this morning. I have taken the liberty to shew it in confidence to our mutual friends Judge Wayne and the Chief Justice. We fully appreciate and concur in your views as to the desirableness at this time of having an expression of the opinion of the court on this troublesome question. With their concurrence, I will give you in confidence the history of the case before us, with the probable result. Owing to the sickness and absence of a member of the court, the case was not taken up in conference till lately. The first question which presented itself was the right of a negro to sue in the courts of the United States. A majority of the court were of the opinion that the question did not arise on the pleadings and that we were compelled to give an opinion on the merits. After much discussion it was finally agreed that the merits of the case might be satisfactorily decided without giving an opinion on the question of the Missouri Compromise; and the case was committed to Judge Nelson to write the opinion of the court affirming the judgment of the court below, but leaving both those difficult questions untouched. But it appeared that our brothers who dissented from the majority, especially Justice McLean, were determined to come out with a long and labored dissent, including their opinions \& arguments on both the troublesome points, although not necessary to a decision of the case. In our opinion both the points are in the case 
and may be legitimately considered. Those who hold a different opinion from Messrs. McLean \& Curtis on the powers of Congress \& the validity of the compromise act feel compelled to express their opinions on the subject, Nelson \& myself refusing to commit ourselves. A majority including all the judges south of Mason \& Dixon's line agreeing in the result but not in their reasons-as the question will be thus forced upon us, I am anxious that it should not appear that the line of latitude should mark the line of division in the court. I feel also that the opinion of the majority will fail of much of its effect if founded on clashing \& inconsistent arguments. In conversation with the chief justice I have agreed to concur with him. Brother Wayne \& myself will also use our endeavors to get brothers Daniel \& Campbell \& Catron to do the same. So that if the question must be met, there will be an opinion of the court upon it, if possible, without the contradictory views which would weaken its force. But I fear some rather extreme views may be thrown out by some of our southern brethren. There will therefore be six if not seven (perhaps Nelson will remain neutral) who will decide the compromise law of 1820 to be of non-effect. But the opinions will not be delivered before Friday the 6th of March. We will not let any others of our brethren know any thing about the cause of our anxiety to produce this result, and, though contrary to our usual practice, we have thought due to you to state to you in candor $\&$ confidence the real state of the matter.

"Very Truly Yours "D. GRIER.

"Hon. James Buchanan.

"P. S.-It is the weak state of the Chief Justice's health which will postpone the opinion to that time."

The originals of these letters are now on file in the archives of the Pennsylvania Historical Society, but no mention is made of them by Mr. George Ticknor Curtis in his Life of Buchanan, nor were they ever published, so far as I have been able to discover, until published in the Works of James Buchanan edited by Mr. John Bassett Moore. 


\section{The Dred Scott Case}

A concise statement of the facts evidenced by these letters, in connection with other established facts, may aid in arriving at a clearer understanding of them. The important dates should be borne in mind. The first argument in the Dred Scott case was at the December term, 1855; the second argument, on December 18, 1856; Catron's letter to Buchanan was written February 19, 1857; Buchanan's letter to Grier was received February 23, I857; upon the same day Grier wrote to Buchanan; Buchanan delivered his inaugural March 4; the Dred Scott decision was announced March 6.

It is clear that there must have been some communication, written or oral, between Catron and Buchanan, prior to the date of Catron's letter on the subject of the forthcoming decision, because it would be incredible to suppose that Catron, without such communication, would have been so presumptuous as to advise Buchanan as to what "he might safely say" in his inaugural address concerning a case then pending in the Supreme Court of the United States. But Catron not only advised Buchanan as to what he might safely say, but he suggested the precise phraseology in which to say it.

The importance of getting Grier converted to the proper view of the case is evident, when we recall that he concurred with Nelson in the opinion first prepared by him as the opinion of the Court, which left the question of the constitutionality of the Missouri Compromise untouched. In this opinion the majority of the judges concurred, namely, Chief Justice Taney, Justices Wayne, Nelson, Daniel, and Catron. But there were several changes of opinion after the second argument, so that five of the judges finally concluded that the question of the constitutionality of the Missouri Compromise was properly in the case for decision and they were ready to decide the Missouri Compromise unconstitutional. These were Taney, Wayne, Daniel, Catron, and Campbell. These made a majority without Grier. But these were all from the South, and it 


\section{Political History of Secession}

was desired to avoid the danger of having the "line of latitude mark the decision of the court," in which case "the opinion of the majority would fail of much of its effect." There were four Northern men on the bench. It was known that two of these, Curtis and McLean, would dissent and that Nelson was doubtful. It was therefore all the more important to get Grier to join his Southern brethren. But the prospect of settling the slavery question forever by a decision making slavery lawful in all the Territories did not at first seem so alluring to Grier as it did to his Southern brethren. He had first wanted to side with Nelson by deciding the case in such a way as to leave the question of the constitutionality of the Missouri Compromise untouched. Who could have more influence over him than his old personal and political friend Buchanan? And who, other than Catron, another old political and personal friend of Buchanan, could more successfully appeal to Buchanan to help convert Grier? Catron it seems still feared that Grier might seek to avoid responsibility for deciding the Missouri Compromise to be unconstitutional by deciding that "admitting the constitutionality of the Mo. Comp. line of 1820 , still as no domicile was acquired by the negro at Ft. Snelling \& he returned to Missouri, he was not free." Catron assured Buchanan that Grier "has no doubt about the question on the main contest, but has been persuaded to take the smooth handle for the sake of repose," and for this reason Catron urges Buchanan to "drop Grier a line" saying "how necessary it is \& how good the opportunity is to settle the agitation by an affirmative decision of the Supreme Court."

Buchanan lost no time in "dropping Grier a line," for Grier's letter written on February 23 begins with "your letter came to hand this morning."

We do not have Buchanan's letter to Grier and we do not know the precise wording of it, but the substance of it is plainly inferable from Grier's statement that "we," meaning, it is to be presumed from what follows, himself, 
"and our mutual friends" Wayne and Taney, "fully appreciate and concur in your views as to the desirableness of the opinion of the court on this troublesome question."

Grier promptly answered Buchanan's letter, but before answering it he showed it "in confidence to our mutual friends, Judge Wayne and the Chief Justice."

Grier then proceeds to give Buchanan, "in confidence the history of the case with the probable result." From Grier's letter we learn that there were two troublesome questions in the case. One was as to "the right of a negro to sue in the courts of the United States." The other and most important was the one "involving the constitutionality of the Missouri Compromise."

He also tells Buchanan that it was at one time "agreed that the merits of the case might be satisfactorily decided without giving an opinion on the question of the Missouri Compromise," and that the case had been committed to Judge Nelson to write the opinion of the Court affirming the judgment of the Court below, "but leaving both these difficult questions untouched."

It is clear that neither Buchanan nor "our mutual friends" Taney and Wayne, nor Grier, nor Catron, wanted that kind of a decision, but that they wanted a decision like the one which was afterwards rendered, deciding the Missouri Compromise to be unconstitutional for the reason that the Constitution of the United States protected

- Grier did not manifest any compunctions of conscience in telling the President how he and his brethren intended to decide the case. He probably remembered all that Coke had said in his Institutes and in his Commentaries upon Littleton but had forgotten what the great Chief Justice said to King James when he summoned all the twelve judges of England before him to be catechized on what their answer would be to a question put to them concerning the king's prerogative if the question should come before them for decision. Coke's answer ought never to be forgotten so long as any respect is felt for the independence of the judiciary. "When the case happens, I shall do that which shall be fit for a judge to do." Campbell, Lives of the Chief Justices of England, vol. i., p. 286. 


\section{Political History of Secession}

slavery in the Territories, and that while they remained in a territorial condition neither Congress nor the territorial legislatures could prohibit slavery there. But here the "troublesome questions" intruded themselves. Two of the judges, Curtis and McLean, dissented from the views of the majority of their brethren and "were determined to come out with a long and labored dissent, including their opinions and arguments on both the troublesome points," and Judge Nelson's position was doubtful. Moreover, a majority of the judges, "including all the judges south of Mason \& Dixon's line," though agreeing "in the result," did not agree "in their reasons," and there was not only danger of "clashing \& inconsistent arguments," but there was also danger that "the line of latitude might mark the line of decision of the court," in which case, "the opinion of the majority would fail of much of its effect."

In this dilemma Grier says that the advice of Taney was again sought, and so "on conversation with the Chief Justice" it was determined that Taney should write an opinion and that Grier should "concur with him," and that "Brother Wayne and myself will also use our endeavors to get Daniel \& Campbell \& Catron to do the same." It may be noted that Grier in his solicitude to convert his brother Catron was evidently entirely ignorant of Catron's prior efforts to convert Grier himself.

There was also danger that "some rather extreme views might be thrown out by some of our southern brethren," but Grier assures Buchanan that, if worse comes to worst, "there will, therefore, be six out of seven (perhaps Nelson will remain neutral) who will decide the Missouri Compromise of $I 820$ to be of non-effect."

To insure smooth sailing of the plan agreed on between Taney, Grier, and Wayne, Grier says further that "we will not let any others of our brethren know any thing about our anxiety to produce this result."

The secrecy with which Taney, Grier, and Wayne were carrying on their proselyting efforts and keeping to them- 


\section{The Dred Scott Case}

selves the correspondence with Buchanan is also shown by other evidence. Manifestly Grier knew nothing of Catron's letter to Buchanan. If Grier had known what was in it, he might have resented Buchanan's letter to him. Campbell assures us that he had "not the slightest information of any connection between Mr. Buchanan or any other person with the discussions in the court or the conference, or with the preparation of any opinion of either of the judges, save the judges themselves." ${ }^{\mathrm{x}}$ Nelson corroborates Campbell "so far as the facts came within his knowledge." Of course neither Curtis nor McLean could have had even a suspicion of the correspondence between Buchanan and Catron and Grier.

Buchanan in his message on March 4 announced the forthcoming decision in almost the exact phraseology suggested by Catron and the decision came promptly on March 6.

Another unusual, not to say extraordinary, method of procedure characterized the publication of the opinion of Chief Justice Taney. There was a rule of the Supreme Court expressly requiring that "all opinions hereafter delivered by the Court shall immediately on the delivery thereof be in like manner delivered over to the clerk to be recorded." Some time after Taney's opinion had been announced, but before it had been published, Curtis was informed that it had been revised and materially altered. On application to the clerk for a copy, he learned that the Chief Justice had made an order forbidding it to be taken from the files. When he wrote to Taney about it, Taney did not deny the alterations but said, "you will find nothing altered, nothing in addition but proofs to maintain the truth of what was announced and affirmed in the opinion delivered." This of course left Curtis in the dark as to how many pages of "proofs" had been added. But in some memoranda left by Justice Curtis he says that "these

${ }^{2}$ Letter of Campbell in Tyler's Memoir of Taney, p. 384 .

'Id., p. 385. 


\section{Political History of Secession}

additions amount to upwards of eighteen pages. No one can read them without perceiving that they are in reply to my opinion." There was a voluminous and somewhat acrimonious correspondence on the subject between Curtis and Taney and soon after Curtis resigned from the Supreme bench.

The mere statement of the facts above set forth leaves little room for further argument, for the breach of both executive and judicial propriety apparent upon the face of them cannot be made clearer by argument, nor can it by any argument be explained away. They make a chapter without parallel in the history of American jurisprudenceone not at all edifying. They show a disclosure of the secrets of the consultation room far more censurable than the disclosure by a juror of the deliberations of his fellowjurors. They show an effort by the incoming President, at the solicitation of one of the judges of the Supreme Court, to bring to bear the personal influence of the Chief Executive in order to control the opinion of another Judge in a pending case; they show that the Chief Justice himself was not only cognizant of this breach of executive and judicial etiquette, but that it was done with his full knowledge and concurrence; and finally they show something very much like scheming for an excuse to give the sanction of the Supreme Court of the United States to the hitherto rejected doctrine of Calhoun. If all be conceded that is claimed for the patriotic intentions of Buchanan and Taney, it will still be found impossible to reconcile their conduct with any recognized code of legal etiquette or legal ethics.

Much as the people of the North were opposed to the Dred Scott decision, there was nowhere in any respectable quarter any talk of forcibly resisting it. It was hoped to overturn it, but in a legal and orderly manner by subsequent judges, holding the views of the dissenting judges, who would overrule the decision in the same manner that other erroneous decisions have been overruled. This was Lincoln's 
view as expressed in one of his seven joint debates with Douglas, at Quincy, Illinois, on October 13, 1858, in which he said: "We oppose the Dred Scott decision in a certain way.... We do not propose that when Dred Scott has been decided to be a slave by the Court, we, as a mob, will decide him to be free. We do not propose that, when any other one, or one thousand, shall be decided by that Court to be slaves, we will in any violent way disturb the rights of property thus settled, but we nevertheless do oppose that decision as a political rule, which shall be binding on the voter to vote for nobody who thinks it wrong, which shall be binding on the members of Congress or the President to favor no measure that does not actually concur with the principles of that decision. We do not propose to be bound by it as a political rule in that way, because we think it lays the foundation not merely of enlarging and spreading out what we consider an evil but it lays the foundation for spreading that evil into the States themselves. We propose so resisting it as to have it reversed if we can, and a new judicial rule established upon this subject." $\mathrm{I}$

Oliver P. Morton clearly and concisely stated the general opinion of the great body of the North in a speech delivered at Terre Haute on March 10, 1860, in which he said:

"The Dred Scott decision has simply unsettled what had been regarded as settled for more than fifty years. The Missouri Compromise was thought to be settled for more than thirty years, but it was repcaled by the Nebraska bill. It is now idle to talk about the settlement of anything until it shall be done on correct principles. Five slaveholders sitting on the bench of the Supreme Court cannot settle forever vital questions of freedom against eighteen millions of people in the free States. In the course of a few years these judges will have passed away to stand at the bar of another tribunal whose decisions are final, and their places will be filled by new men who will have the same right to

'Lincoln-Douglas Debates, p. 197. 


\section{Political History of Secession}

review their opinions that they had to trample upon the opinions of all who had gone before them." I It is scarcely necessary to add that neither Lincoln nor Morton ever said or hinted at anything that could be construed as giving the least countenance to the newfangled nostrum of recall of judges and judicial decisions.

It is no exaggeration to say that the decision in the Dred Scott case is the most important ever rendered by the Supreme Court. Designed with such infinite care in the hope of giving new life to slavery, it will ever stand in the history of this country as the most imposing of the monuments that mark its death. Upon the decision in the Dartmouth College case there has been built a greater body of law, but it has been for many years developing and it affects chiefly the commercial interests of the country. The development of the Dred Scott decision was soon cut short by the Civil War; but if there had been time to develop it to all its logical consequences, it would have made slavery dominant in this country and would have changed the entire framework of our national government. Shortlived as it was, it is difficult to estimate the enormous consequences of the decision. They were, however, wholly different from those that were anticipated. It had been expected that the decision would operate as oil upon the troubled waters to silence at once and forever all further discussion of the slavery question. On the contrary the decision seemed to open Pandora's box and to let loose all the perplexing questions that had been supposed to be safely shut in. Regarded by a large part of the people of the North as a political decision, it was discredited from the beginning and deprived of all the sanctity that is supposed to hedge about decisions of the great Court that pronounced it.

Looking now over the ruins of slavery, two chief causes for its destruction stand out clearly to view. One of them was the repeal of the Missouri Compromise; the other was

${ }^{3}$ Foulke, Life of Oliver P. Morton, vol. i., p. 7I. 


\section{The Dred Scott Case}

the Dred Scott decision. Together they were more potent than all other political factors combined in rending the Democratic party and in solidifying the anti-slavery sentiment of the North.

The North did not wait to see what might be the fruitage of the Dred Scott decision, but in 1860 presented for the first time a solid front to slavery and demanded a halt. Then came the clash of words and next the clash of arms. 


\section{CHAPTER XVI}

CONTINUATION OF THE IRREPRESSIBLE CONFLICT IN KANSAS AND IN CONGRESS

$A$ FFAIRS in Kansas had steadily gone on from bad to The first two, Andrew J. Reeder of Pennsylvania and William Shannon of Ohio were appointed by President Pierce; three more, John W. Geary of Pennsylvania, Robert J. Walker of Mississippi, and James W. Denver of California were appointed by President Buchanan. All except the last two were removed or forced to resign, and two were compelled to flee the Territory because they would not submit to be tools in carrying out the schemes of the proslavery men to fasten slavery upon Kansas.

Every event of any political significance in Kansas was at once reflected in Congress and in the country at large. On March 19, I856, when the contested election case between John W. Whitfield and Andrew J. Reeder, each claiming a seat in Congress as a territorial delegate from Kansas, was pending in the lower House of Congress, a committee of three, consisting of William A. Howard of Michigan, John Sherman of Ohio, and Mordecai Oliver of Missouri was appointed "to inquire into the troubles" in Kansas generally, and particularly in regard to any fraud or force in reference to the elections." The members of the committee went to Kansas and after spending several weeks in collecting evidence, they made a report on July I, I856. The majority and minority reports, including the testimony taken, fill a volume of 1200 pages. These 


\section{The Conflict in Kansas and Congress}

reports and the volumes that have been written about the troubles in Kansas are now dreary reading, but they establish beyond any doubt that so flagrant a conspiracy to force slavery upon an unwilling people by fraud, intimidation, trickery, and perjury had never before been attempted in the history of the nation and fully sustain the finding of the majority of the committee, "that each election in the Territory, held under the organic or alleged territorial law, has been carried by organized invasion from the State of Missouri, by which the people of the Territory have been prevented from exercising the rights secured to them by the organic law." I

John Calhoun, president of the convention which had framed the Lecompton Constitution, made haste to certify it to President Buchanan, and on February 2 the President transmitted to Congress a special message recommending the admission of Kansas under that constitution.

Pierce, Buchanan, the Supreme Court of the United States, and the border ruffians had done all that it was possible for them to do to make Kansas a slave State. Nothing more remained to be done to make the victory of the slave power complete except the admission of Kansas under the Lecompton Constitution. The hopes of those who wished to see freedom established in the Territory were at the lowest ebb, while their enemies, exulting in the prospect of a speedy victory, were impatiently waiting for the long-expected spectacle, the last scene in the tragic drama, which would exhibit the slave power in triumphal car dragging after it Kansas, a helpless captive in chains.

The scene now shifts to Congress, where, strange as it may seem, the fate of Kansas rested in the hands of one man. Stranger still, that man was Stephen A. Douglas. If to either belongs the title of "Liberator of Kansas," it belongs rather to him than to John Brown. Douglas appeared, not as a champion of freedom, for he said in one of his speeches that "he cared not whether the people

'34th Cong., Ist sess., Report No. 200. 
of Kansas voted slavery down or voted it up." He appeared as the special champion of his cherished doctrine of popular sovereignty. A few days before the convening of Congress he called on the President to remonstrate with him against recommending, as it was then understood to be his purpose, the admission of Kansas under the Lecompton Constitution, and to inform the President that he should oppose it. It has been said that Buchanan endeavored in vain to dissuade Douglas from his announced purpose and finally attempted to intimidate him by threatening him with the removal of his friends who had been appointed to federal offices on his recommendation and the withdrawal of further political patronage, at which Douglas became indignant and retorted with cutting sarcasm by saying, "Mr. President, General Jackson is dead," and, without deigning another word, he strode away.

Douglas's protests were unavailing and following the President's recommendation, bills for the admission of Kansas under the Lecompton Constitution were at once introduced in the Senate and in the House. This was the signal for bitter opposition and violent debate. "Threats of secession again became common. In the House there was great excitement; at one time during an all-night session on the message there was a 'battle-royal'; 'thirty men at least were engaged in the fisticuff.' Keitt of South Carolina attacked Grow of Pennsylvania and was knocked down." I All the Republicans, a portion of the anti-Lecompton Democrats, including Douglas, and a number of the Americans, arrayed themselves in the ranks of opposition to the Administration. It was upon this question that Douglas broke with the President and with the pro-slavery Democrats in the Senate. From this period we see the beginning of the political transformation of Douglas. On March 22, 1858, just before the final vote was to be taken in the Senate on the question of the admission of Kansas under the Lecompton Constitution, Douglas

× Bancroft, Life of Seward, vol. i., p. 445 . 


\section{The Conflict in Kansas and Congress}

rose from a sick-bed and made a great speech, in which he reviewed the entire history of the troubles in the Territory, denounced the attempt to force the admission of the Territory as a State under the Lecompton Constitution as a trick, charging that the so-called constitution had been bolstered up by fraudulent voting, forged returns, and perjury, and vigorously advocated the submission of the constitution to a vote of the people of the Territory.

It was in this speech that Douglas denounced the course of the Buchanan Administration for its efforts to intimidate members of Congress and to compel them to sacrifice their own convictions of duty by yielding to the will of the Executive. No bolder or more vigorous protest against such unwarranted exercise of executive interference has ever been heard in the Senate of the United States.

"Sir," said Douglas, "whenever the time comes that the President of the United States can change the allegiance of the Senators from the States to himself, what becomes of the sovereignty of the States? When the time comes that a Senator is to account to the Executive and not to his State, whom does he represent? If the will of my State is one way and the will of the President is the other, am I to be told that I must obey the Executive and betray my State, or else be branded as a traitor to the party, and hunted down by all the newspapers that share the patronage of the Government? and every man who holds a petty office in any part of my State to have the question put to him, 'Are you Douglas's enemy? If not, your head comes off?' 'Why?' 'Because he is a recreant Senator; because he chooses to follow his judgment and his conscience, and represent his State instead of obeying my executive behest.' I should like to know what is the use of Congresses, what is the use of Senates and Houses of Representatives, when their highest duty is to obey the Executive in disregard of the wishes, rights, and honor of their constituents? What despotism on earth would be equal to this, if you establish the doctrine that the Executive has a right to command the 
votes, the consciences, the judgment of the Senators and of the Representatives, instead of their constituents? . . .

"For my own part, Mr. President, come what may, I intend to vote, speak, and act according to my own sense of duty so long as I hold a seat in this chamber. . . . If, standing firmly by my principles, I shall be driven into private life, it is a fate that has no terrors for me. I prefer private life, preserving my own self-respect and manhood, to abject and servile submission to executive will. If the alternative be private life or servile obedience to executive will, I am prepared to retire. Official position has no charms for me when deprived of that freedom of thought and action which becomes a gentleman and a Senator."

Douglas's courage in thus openly defying the Administration compels our admiration when it is remembered that he was then expecting to be a candidate for reëlection by the Illinois Legislature as Senator from that State, and that he was also a prospective candidate for the presidential nomination by the next Democratic National Convention, to be held in 1860 .

When the bill to admit Kansas under the Lecompton Constitution came to a vote in the Senate, Senator Crittenden of Kentucky moved a substitute providing for the submission of the constitution to the people of the Territory, and in case of its rejection, that they be authorized to choose delegates to frame another constitution, but the substitute was lost by a majority of ten. The bill as reported passed the Senate by a vote of thirty-three to twentyfive, Douglas and two other anti-Lecompton Democrats, and Crittenden, Bell, and Kennedy, Americans, voting with the Republicans against it. When the bill came up in the House Crittenden's substitute was adopted by eight majority. The Senate rejected the substitute, and the result was a conference committee, which reported what is known as the English Bill, a bill that carried both a bribe and a menace to the people of Kansas;- a bribe in the

${ }^{\prime}$ Carr, Life of Douglas, pp. 233-34. 


\section{The Conflict in Kansas and Congress}

shape of a large land grant if they voted to accept the constitution, but a menace that if they rejected it they should not receive the land grant and should be denied admission as a State until the Territory should acquire a population sufficient to entitle it to a Representative in the House. After a long and bitter debate the bill passed the House on April 30, by a vote of 112 to I03, the Republicans and twelve anti-Lecompton Democrats voting against it. On the same day it passed the Senate by a vote of thirty-one to twenty-two, Douglas, Broderick, and Stuart, anti-Lecompton Democrats, and Crittenden, American, voting with the Republicans against it. When the people of Kansas subsequently voted upon the Lecompton Constitution they rejected it by a majority of over 10,000 .

It was to Douglas more than to any other one man that the Lecompton bill owed its final defeat. "Without his aid," it is claimed by Mr. Blaine, "the "crime against Kansas,' so eloquently depicted by Mr. Sumner, would have been complete. With his aid it was prevented." $x$ Douglas's course in opposing the forcing of the admission of Kansas under the Lecompton Constitution gained him increased popularity in the North, but it also brought on his head the maledictions of the slave power and the malignant and unrelenting hostility of the Buchanan Administration.

As might have been expected there was a noticeable abatement of Republican enthusiasm in 1857, partly because of the reaction that always follows a period of intense political excitement, partly because it is truer in politics than in anything else that nothing succeeds like success. The multitudes flock to the successful party in order to share in the distribution of the loaves and fishes. The Democratic party had been victorious; it had control of every branch of the Federal government; it seemed again to be firmly and permanently established in power. All

- Twenty Years in Congress, vol. i., p. I42. 


\section{4 \\ Political History of Secession}

this was as discouraging to the Republicans as it was encouraging to the Democrats. Consequently the State elections of 1857 nearly everywhere showed great Republican losses and corresponding Democratic gains. They also showed that the Democratic party was gaining more than the Republicans from the disintegration of the American party, now going on rapidly.

But the Republicans were not long in recovering from their first defeat and this was greatly hastened by the continued efforts of the Federal Administration to force upon the people of Kansas the Lecompton Constitution and by the aggressive and arrogant tone of some of the extreme advocates of slavery extension.

On March 4, I858, James H. Hammond, Senator and former Governor of South Carolina, delivered a speech in the United States Senate in favor of the admission of Kansas under the Lecompton Constitution. ${ }^{x}$ The speech was not remarkable for the reason that it favored forcing the Lecompton Constitution upon the people of Kansas. Such speeches had ceased to be novel. It was not remarkable as a defense of slavery. History and the Scriptures had been ransacked for arguments to prove that there was no $\sin$ in slavery and with such arguments the people of the North were familiar. Nor was it remarkable for frothy declamation and scurrilous abuse of Northern Abolitionists, in which term were classed all in the North who were opposed to slavery, such as characterized the utterances of many of the Southern orators and newspapers of the lower order of the fire-eating type. Indeed, the speech was quite free from language that exposed it to any such criticism. Nevertheless, it at once attracted great attention, as an exposition, without any attempt at disguise, of the views of the more radical of the Southern leaders. It expressed clearly the consequences of Republican success as viewed in the South, consequences to which it was clear that the South did not intend to submit, preferring a dissolution

× Cong. Globe, 35th Cong., rst sess., pt. I., p. 959. 


\section{The Conflict in Kansas and Congress 355}

of the Union to remaining in it under Republican rule. "What guaranty have we," he said, "when you have this government in your possession, in all its departments, even if we submit quietly to what the Senator exhorts us to submit to-the concentration of slavery in its present territory, and even to the reconstruction of the Supreme Court-that you will not plunder us with tariffs; that you will not bankrupt us with internal improvements and bounties on fish; that you will not restrain us with navigation laws and other laws impeding the facilities of transportation of Southern produce? What guaranty have we that you will not create a new bank, and concentrate all the finances of this country at the North, where already, for the want of direct trade and a proper system of banking in the South, they are ruinously concentrated? Nay, sir, what guaranty have we that you will not emancipate our slaves, or, at least, make the attempt? We cannot rely on your faith when you have the power. "It has been always broken whenever pledged."

A striking feature of the speech was the frankness with which it laid bare the contempt felt by the slaveholders of the South for all the laboring people in the North. The sentiments avowed in the speech were none the less insulting and offensive because they were expressed in polished language.

"In all social systems there must be a class to do the mean duties, to perform the drudgery of life. That is, a class requiring but a low order of intellect and but little skill. Its requisites are vigor, docility, fidelity. Such a class you must have, or you would not have that other class which leads progress, refinement, and civilization. It constitutes the very mudsills of society and of political government; and you might as well attempt to build a house in the air, as to build either the one or the other, except on the mudsills. Fortunately for the South, she found a race adapted to that purpose to her hand. A race inferior to herself, but eminently qualified in temper, 
in vigor, in docility, in capacity to stand the climate, to answer all her purposes. We use them for the purpose, and call them slaves. We are old-fashioned at the South yet; it is a word discarded now by ears polite; but I will not characterize that class at the North with that term; but you have it; it is there; it is everywhere; it is eternal.

"The Senator from New York said yesterday that the whole world had abolished slavery. Ay, the name, but not the thing; and all the powers of the earth cannot abolish it. God only can do it when he repeals the fiat, 'the poor ye always have with you'; for the man who lives by daily labor, and scarcely lives at that, and who has to put out his labor in the market and take the best he can get for it; in short, your whole class of manual laborers and operatives, as you call them, are slaves. The difference between us is, that our slaves are hired for life and well compensated; there is no starvation, no begging, no want of employment among our people, and not too much employment either. Yours are hired by the day, not cared for, and scantily compensated, which may be proved in the most deplorable manner, at any hour, in any street in any of your large towns. Why, sir, you meet more beggars in one day, in any single street of the City of New York, than you would meet in a lifetime in the whole South. Our slaves are black, of another, inferior race. The status in which we have placed them is an elevation. They are elevated from the condition in which God first created them, by being made our slaves. None of that race on the whole face of the globe can be compared with the slaves of the South, and they know it. They are happy, content, unaspiring, and utterly incapable, from intellectual degradation, ever to give us any trouble by their aspirations. Your slaves are white, of your own race; you are brothers of one blood. They are your equals in natural endowment of intellect, and they feel galled by their degradation. Our slaves do not vote. We give them no political power. Yours do vote, and being the majority, they are the depositaries of 


\section{The Conflict in Kansas and Congress}

all your political power. If they knew the tremendous secret that the ballot-box is stronger than an army with bayonets and could combine, where would you be? Your society would be reconstructed, your government reconstructed, your property divided, not as they have mistakenly attempted to initiate such proceedings by meeting in parks with arms in their hands, but by the quiet process of the ballot-box. You have been making war upon us to our very hearthstones. How would you like for us to send lecturers or agitators North to teach these people this, to aid and assist in combining and to lead them?"

The concluding remark above quoted concerning the uses and abuses of the ballot-box probably would have commanded morc serious consideration of the people of the North if they could have foreseen the rise of Dennis Kearney and the sand-lotters of San Francisco, of Herr Most and his followers in New York City, and the ravings of the anarchists and the Haymarket riots in Chicago. But these were not then foreseen and were probably not in the contemplation of even Hammond himself. The portions of the speech referring to the laboring men of the North as mudsills and slaves were those that grated most harshly upon their ears.

More significant than the contemptuous allusions to Northern laboring men were the portions of the speech showing not only that secession had already been contemplated by Southern leaders, but that they had carefully calculated their resources and the probabilities of success. In the course of his speech the South Carolina Senator portrayed the magnificent extent and vast possibilities of the future Eldorado. "I think it not unimportant that I should attempt to bring the North and South face to face, and see what resources each of us might have in the contingency of separate organizations. If we never acquire another foot of territory for the South, look at her. Eight hundred and fifty thousand square miles; as large as Great Britain, France, Austria, Prussia, and Spain. Is 


\section{$35^{8} \quad$ Political History of Secession}

not that territory enough to make an empire that shall rule the world? With the finest soil, the most delightful climate, whose productions none of those great countries can produce, we have three thousand miles of continental shore line, and so indented with bays and crowded with islands, that, when their shore lines are added, we have twelve thousand miles of shore line. Through the heart of our country runs the great Mississippi, the father of waters, into whose bosom are poured thirty-six thousand miles of tributary streams; and beyond we have the desert prairie wastes, to protect us in our rear. Can you hem in such a territory as that? You talk of putting up a wall of fire around eight hundred and fifty thousand square miles so situated! How absurd!

"But, sir, in this territory lies the great valley of the Mississippi, now the real, and soon to be the acknowledged seat of the empire of the world. The sway of that valley will be as great as ever the Nile knew in the earlier ages of mankind. We own the most of that valley. The most valuable part of it belongs to us; and although those who have settled above us are now opposed to us, another generation will tell a different tale. They are ours by all the laws of nature; slave labor will go over every foot of this great valley where it will be found profitable to use it, and those who do not use it are soon to be united with us by such ties as will make us one and inseparable.... On this fine territory we have a population four times as large as that with which these colonies separated from the mother country, and a hundred, I might say a thousand, fold as strong. Our population is now sixty per cent. greater than that of the whole United States when we entered into the second war of independence. It is twice as large as the whole population of the United States was ten years after the conclusion of that war, and our exports are three times as great as those of the whole United States then. Upon our muster-rolls we have a million of men. In a defensive war, upon an emergency, every one of them 
would be available. At any time, the South can raise, equip, and maintain in the field, a larger army than any power of the earth can send against her, and an army of soldiers-men brought up on horseback, with guns in their hands."

Then he compared the wealth-producing resources of the two sections, claiming that former Federal legislation had discriminated in favor of the North and against the South, but that, were the South an independent nation, its resources would largely exceed all its needs, "for the South would never go to war; she would never need an army or a navy, beyond a few garrisons on the fronticr and a few revenue cutters. It is commerce that breeds war. It is manufactures that are required to be hawked about over the world, and give rise to navies and commerce. But we have nothing to do but to take off restriction on foreign merchandise and open our ports and the whole world will come to us to trade. They will be too glad to bring and carry for us, and we never shall dream of a war. Why, sir, the South has never yet had a just cause of war. Every time she has seized her sword it has been on the point of honor, and that point of honor has been mainly loyalty to her sister colonies and sister States, who have ever since plundered and calumniated her."

Not only would the Mississippi Valley, but England, the whole world, would be tributary to the new South, for all would be compelled to pay homage to King Cotton. "If there were no other reason why we should never have a war, would any sane nation make war on cotton? Without firing a gun, without drawing a sword, when they make war on us we can bring the whole world to our feet. The South is perfectly competent to go on, one, two, or three years without planting a seed of cotton. I believe that if she was to plant but half her cotton, it would be an immense advantage to her. I am not so sure but that after three years' cessation she would come out stronger than ever she was before and better prepared to enter 
afresh upon her great career of enterprise. What would happen if no cotton was furnished for three years? I will not stop to depict what every one can imagine, but this is certain: old England would topple headlong and carry the whole civilized world with her. No, sir, you dare not make war on cotton. No power on earth dares make war upon it. Cotton is king."

Hammond's speech, in connection with other evidence, leaves little doubt that, whatever other Southern leaders may have thought, those of South Carolina not only deemed themselves fully prepared for secession, but were ready to accept any plausible pretext for it, and that they would probably have accepted the election of Frémont as an excuse as eagerly as they did the election of Lincoln.

The speech made a greater impression in the North than it did in the South. In the North it was quoted by every Republican speaker and newspaper and was found to be one of the most effective of Republican campaign documents in all subsequent elections.

It was in this year that Seward made his great speech on the Irrepressible Conflict. ${ }^{x}$ It was an arraignment of the Democratic party for its record of subserviency to slavery, such as had never been made before. Rapidly tracing the history of slavery and its effect on society wherever established and the free labor system established in this country by immigrants from Great Britain, Germany, Sweden, and others of German extraction, he went on to show the debasing influence of the slave system on society and the despotic laws required for its maintenance, the radical incompatibility of the system of slave labor with that of free labor, and the certainty that in governments where both existed one must predominate over the other. "These two antagonistic systems," he said, "are continually coming into closer contact and collision results. Shall I tell you what the collision means? They who think that I At Rochester, N. Y., October 25, 1858; Seward's Works, vol. iv., p. 289. 


\section{The Conflict in Kansas and Congress 36r}

it is accidental, unnecessary, the work of interested or fanatical agitators, and therefore ephemeral, mistake the case altogether. It is an irrepressible conflict between opposing and enduring forces and it means that the United States must and will, sooner or later, become cither entirely a slaveholding nation or entircly a free-labor nation."

While he hoped that the land would become one of universal freedom "he did not expect that it would be made so otherwise than through the action of the several States, coöperating with the Federal government and all acting in strict conformity with their respective constitutions." Then he went on to show how the slaveholding interests expected to make the country all a slaveholding nation, the plan of operation being this: "By continued appliances of patronage and threats of disunion they will keep a majority favorable to these designs in the Senate where each State has an equal representation. Through that majority they will defeat, as they best can, the admission of free States and secure the admission of slave States. Under the protection of the judiciary they will, on the principle of the Dred Scott case, carry slavery into all the territory of the United States now existing and hereafter to be organized. By the action of the President and Senate using the treaty-making power, they will annex foreign slaveholding states. In a favorable conjuncture they will induce Congress to repeal the act of 1808 , which prohibits the forcign slave trade, and so they will import from Africa at the cost of only twenty dollars a head, slaves enough to fill up the interior of the continent. Thus, relatively increasing the number of slave States, they will allow no amendment to the Constitution prejudicial to their interests; and so, having permanently established their power, they expect the Federal judiciaries to nullify all State laws which shall interfere with internal or foreign commerce in slaves. When the free States shall be sufficiently demoralized to tolerate these designs they reasonably conclude that slavery will be accepted by those States 
themselves." Continuing he expressed his views in this eloquent passage: "I shall not stop to show how speedy and how complete would be the ruin which the accomplishment of these slaveholding schemes would bring upon the country. For one, I should not remain in the country to test the sad experiment. Having spent my manhood, though not my whole life, in a free State, no aristocracy of any kind, much less an aristocracy of slaveholders, shall ever make the laws of the land in which I shall be content to live. Having seen the society around me universally engaged in agriculture, manufactures, and trade, which were innocent and beneficent, I shall never be a denizen of a State where men and women are reared as cattle and bought and sold as merchandise. When that evil day shall come, and all further effort at resistance shall be impossible, then, if there be no better hope for redemption than I can now foresee, I shall say with Franklin, while looking abroad over the whole earth for a new and more congenial home: "Where liberty dwells, there is my country." Then he showed that the Democratic party was "inextricably committed to the designs of the slaveholders," whatever they might be; that it was "a sectional and local party having practically its seat within the slave States and counting its constituency chiefly and almost exclusively there."

After showing how closely the Democratic party from its organization had allied itself to the slaveholding interests he said: "Such is the Democratic party. It has no policy, State or Federal, for finance, or trade, or manufacture, or commerce, or education, or internal improvements, or for the protection or even the security of civil or religious liberty. It is positive and uncompromising in the interest of slavery-negative, compromising, and vacillating in regard to everything else. It boasts its love of equality, and wastes its strength and even its life in fortifying the only aristocracy known in the land. It professes fraternity, and, so often as slavery requires, allies itself with proscrip- 


\section{The Conflict in Kansas and Congress 363}

tion. It magnifies itself for conquests in foreign lands, but it sends its national eagle forth always with chains and not the olive branch in his fangs."

In Seward's opinion there was only one way in which to defeat the designs of the slaveholders and that was that "the Democratic party must be permanently dislodgcd from the government." As the keynote of all the speeches of Cato was that "Carthage must be destroyed," so the keynote of all Seward's speeches was the destruction of the Democratic party. This specch, free from rant or claptrap, dignified, eloquent, classical in expression, struck at the Democratic party the most powerful blow that it had ever received and marked out the line of Republican attack that was followed by all other Republican leaders until the final triumph of the Republican party in the election of Lincoln.

Extended quotations have been made from the speeches of Hammond and Seward, because, when read together, as they should be to get the full significance of either, they give us a clear insight into the nature of the "Irrepressible Conflict" and how each side viewed the probable consequences of it. Reading these speeches now it is cause for wonder that so few then realized the gravity and the danger of the situation. It is cause for still greater wonder that Seward, who had so accurately diagnosed the disease afflicting the body politic, should himself have been among the last to believe that the crisis was so near at hand.

By the end of the year I858 the Republican party had fully recovered from the depression caused by its defeat in 1856. Everywhere in the North it was well organized, enthusiastic, aggressive, and there was no lack of able and vigorous leaders. 


\section{CHAPTER XVII}

\section{THE LINCOLN-DOUGLAS DEBATES}

THE event which, far more than any other, gave char1 acter to politics at this period was the political duel between Douglas and Lincoln. As the term for which Douglas had been elected United States Senator from Illinois would expire on March 4, I859, it was necessary for the Illinois Legislature to elect his successor. All the House members of this Legislature and part of the members of the Senate were to be elected at the general election in that State in the fall of 1858 . Douglas was a candidate for reellection and had no opposition in his own party except that of the Buchanan Administration, which was not strong enough in Illinois to defeat him. By common consent the Republicans of Illinois turned to Abraham Lincoln as the one man to oppose Douglas. Lincoln was well known in Illinois, not only as a strong lawyer, but also as an effective political speaker. He had often been opposed to Douglas, not only in lawsuits, but also in State politics. He was not wholly unknown outside the State of Illinois. He had appeared as a lawyer in a few cases in the Supreme Court of the United States. He was one of the five Whig nominees for presidential electors in Illinois in 1840 . He had been elected as a Whig member of Congress from Illinois, and had served in the House from 1847 to 1849 . At the Republican National Convention in 1856 , he had received one hundred and ten votes for nomination as VicePresident.

As before mentioned, he had made campaign speeches 
which were favorably received in New England in the political campaign of 1848 . Nevertheless he had left no deep impress, either upon the congressional records or upon the politics of the country outside the State of Illinois. He had visited Thurlow Weed in Albany, N. Y., in 1848, but made so little impression upon that astute politician, who was generally supposed to have an intimate acquaintance, largely personal, with all the prominent politicians of the country, that within a few years Weed forgot that he had ever seen Lincoln.

So it seemed, especially to those outside the State of Illinois, to be a hazardous venture to pit Lincoln against the "Little Giant," who had long before acquired a national reputation. Douglas had had a long experience in Congress in both the House and the Senate. He had served on many important committees. He had the political history of the country at his tongue's end. As a political debater he was recognized as the peer of any of his contemporaries in the Senate. He was the idol of the "Young Democracy" and had acquired the sobriquet of the "Little Giant." At this period, by reason of his bold and vigorous opposition to forcing the Lecompton Constitution upon the people of Kansas, he was regarded by many Republicans in the North, if not as a leader to be followed, at least as a powerful ally whose aid was of the highest value. For this reason, Horace Grecley, whose paper, the New York Tribune, was then by far the most influential paper among Republicans of the North, advised that the Illinois Republicans make no nomination for Senator against Douglas, and many influential Republicans were of the same opinion. But the Republicans of Illinois knew Lincoln better than Greeley knew him and persisted in nominating him.

On the other hand, Douglas, from the start of the campaign, encountered the bitter and persistent opposition of the Democratic national Administration, which sought by the use of all its political patronage, through all the newspapers it controlled, and by all the political methods 
known to politicians, to accomplish the defeat of Douglas. Douglas was also handicapped by his own pet doctrine of popular sovereignty of which he had long been the champion, and he was forced to make the defense of it the leading issue of the campaign, and was thereby compelled to fight on a battle-ground not of his own choosing and in defense of an issue for which he would probably have been glad to substitute another.

Probably there was no man in the country so well qualified as Lincoln to meet Douglas in political debate in Illinois. Lincoln was thoroughly acquainted with both the man and the State. He knew Douglas's political history, his methods of debate, his arts of stump-speaking, all his strong and all his weak points. He knew the people of Illinois, how best to meet Douglas's appeals to them, what appeals to make himself, and how to present them. No other man could have filled Lincoln's place so well as he could fill it himself. He was just the man for the hour and the occasion. A man like either Seward or Sumner in Lincoln's place would have been a misfit. While there were marked differences between Lincoln and Douglas, both were self-made men, with many of the characteristics common to men of that class. For this reason we do not get the striking contrast by comparing them that we see by comparing either with a man like Charles Sumner, who combined all the qualities of a cultured gentleman, $\mathbf{a}$ finished scholar, and a polished orator. Lincoln was born poor, lived poor, and died poor. He never enjoyed the advantages that wealth brings in the way of education, refinement, and social life. Born and reared in the Western backwoods, he had no opportunity of acquiring more than the simplest rudiments of education, or of cultivating the graces of refined society. He knew little of general literature, less of the arts and sciences, and nothing of the Greek and Roman classics. He had but little, if any, personal acquaintance with noted men of learning. He had never traveled in foreign lands nor extensively in his own. Prob- 
ably he never saw a representative of English or European nobility except such as he might have viewed from afar off during his brief sojourn in Washington while there as a member of Congress. Nevertheless, Lincoln had some advantages that Sumner had not, chiefly the independence of character and the development of stout mental and moral fiber that comes to one who starts into the battle of life relying mainly upon himself and goes through it determined, not to succumb to the temptations, the hardships, and the dangers that lie in his path, but to conquer them. Moreover Lincoln had mingled much with men in the daily walks of mankind and he was thoroughly familiar with the affairs of everyday life and with the modes of thought of the great mass of the people and the impulses that move them. He had made a lifelong study of human nature in all its phases. He was naturally gifted with a strong intellect. $\mathrm{He}$ had developed at the bar and in political campaigns conspicuous ability as a strong reasoner and a ready debater. But it was not these qualities that gave him his greatest strength. His guiding principle through life was a strong inherent sense of justice, the belief expressed in his Cooper Institute speech that "right makes might," a belief that pervaded and gave tone to all his political utterances. Moreover his mind was a vast storehouse of information, gained, not from books, but from mingling with men, from which he drew his illustrations, expressed in plain, simple language that all could understand, and that made his speeches far more effective with his audiences than would have been the finest passages of the most polished orations of Sumner. Indeed, in the art of convincing his hearers by apt anecdotes, droll illustrations, and homely phrases Lincoln had no superior.

Long before the beginning of the joint debates, long before the Dred Scott decision, Lincoln, in a speech at Springfield, Illinois, on October 4, I854, had shown that the doctrine of popular sovereignty rightfully interpreted utterly failed to support the application of it which Douglas 
sought to make in defense of the Kansas-Nebraska bill. In this speech Lincoln said: "The doctrine of self-government is right-absolutely and eternally right-but it has no just application as here attempted. . . When the white man governs himself, that is self-government; but when he governs himself and also governs another man, that is more than self-government,- - that is despotism."

Moreover, the Dred Scott decision had sapped out of the doctrine of popular sovereignty all the vitality it ever had. Politicians of less ability or less nerve than Douglas would have shrunk from undertaking to galvanize new life into the corpse of popular sovereignty and attempting to make it do duty in another campaign. But Douglas was not a man to be abashed by the opposition of Presidents or by the decisions of courts. Opposed by the Democratic Administration and by the leaders of the new and vigorous Republican party, Douglas had no alternative but to make the attempt to steer between Scylla and Charybdis on the rickety bark of popular sovereignty, which, as will be hereafter seen, he attempted to patch up with his newly invented theory of "unfriendly legislation."

Douglas's pet doctrine had yet to encounter the inexorable logic, the unsparing criticism of Abraham Lincoln, kind-hearted in everything else, but merciless in his exposure of sophistry of every kind. Douglas was destined to find his peer in debate, not in some cultured college scholar, but in a man self-made like himself; not within the walls of the United States Senate, where crowds had been wont to gather to hear classic orators, but in a country town in a State still regarded in the East as part of the Western backwoods.

Before the beginning of the joint debates, which gave character to the campaign such as no other has ever had before or since, both the candidates had made several speeches at various points in the State. Lincoln's first notable speech was at Springfield on June I7, 1858, accepting his nomination as Senator. In this he sounded the 
keynote, not only of that but of the next presidential campaign. He said: "We are now far into the fifth year since a policy was initiated with the avowed object and confident promise of putting an end to slavery agitation. Under the operation of that policy, that agitation has not only not ceased, but has constantly augmented. In my opinion, it will not cease until a crisis shall have been reached and passed. 'A house divided against itself cannot stand.' I believe this government cannot endure permanently half slave and half free. I do not expect the Union to be dissolved-I do not expect the house to fallbut I do expect it will cease to be divided. It will become all one thing or all the other. Either the opponents of slavery will arrest the further spread of it, and place it where the public mind shall rest in the belief that it is in the course of ultimate extinction; or its advocates will push it forward, till it shall become alike lawful in all the States, old as well as new-North as well as South." I Afterwards Lincoln spoke at Chicago on July ro and at Springfield on the evening of July 17. Douglas spoke at Chicago on July 9, at Bloomington on July 16 , and at Springfield on July $\mathbf{1} 7$.

In his speech at Chicago, on the evening of July 9, 1858 , Douglas said: "I am free to say to you that in my opinion this government of ours is founded on the white basis. It was made by the white man; to be administered by white men in such manner as they should determine."2

On the next evening Lincoln made a speech at Chicago in reply to that of Douglas in which he said: "I protest now and forever against the counterfeit logic which presumes that because I did not want a negro woman for a slave, I do necessarily want her for a wife. My understanding is that I need not have her for either; but, as God made us separate, we can leave one another alone and do one another much good thereby."

On July 24, Lincoln challenged Douglas for a series of

- Lincoln-Douglas Debates, p. 1 .

- Id., p. 11 . 
joint debates. The challenge was accepted and it was arranged for seven joint debates to be held at Ottawa on August 21; at Freeport on August 27; at Jonesboro on September I5; at Charleston on September 18; at Galesburg on October 7; at Quincy on October 13, and at Alton on October $15^{\mathrm{r}}$

At the beginning of the debates neither Lincoln nor Douglas seemed fully to meet expectations. Carl Schurz did not like Lincoln's "jerky" movements and thought that the Little Giant's style "smacked of the barroom." Schurz, however, was a cultivated orator and was more fastidious in his tastes than were most of those who composed the Illinois audiences. Not only were the Illinois audiences eager to hear the debates, but the whole country was equally eager. They were reported in all the leading newspapers and were read and discussed from one end of the country to the other, in the centers of intellectual thought, in every crossroads country store, in every workshop.

These debates have been aptly characterized as "The Battle of the Giants." No debates ever heard in America before or since excited such profound attention or were heard and read with such intense interest. In reading them at this day we miss the high-flown language of the modern spellbinder, the funny jokes of the popular stumpspeaker. Each of the speakers put his whole strength into an effort to convince his hearers and, in order to do this, he used the simplest and plainest words.

If there had been any doubt before, there was none after these debates, of Lincoln's ability to cope with his great adversary. Douglas was master of the art of sophistry, and at times he seemed to stoop to conquer by arts closely bordering on what lawyers call "pettifogging" and

× These debates were published in full by Follett, Foster \& Company, Columbus, Ohio, in 1860 . A tolerably full abridgment of them will be found in an Appendix to John A. Logan's The Great Conspiracy, pp. 675-755. 
politicians call "claptrap." This is always dangerous and generally reacts against the man who resorts to it. It was certain to do so when used against an opponent who was so close a reasoner as Lincoln. Some illustrations of this were seen in the speeches made by Lincoln prior to the beginning of the joint debates. Many other examples may be found in his speeches during the debates.

In the art of convincing his hearers by homely phrases, quaint illustrations, and pertinent anecdotes, Lincoln, as already stated, had no superior. An example of this is seen in the way in which he illustrated his point that the Kansas-Nebraska bill and the Dred Scott decision were parts of a well-understood general plan in which all the leading actors worked harmoniously to a common end, and his characterization of the actors as Stephen, Franklin, Roger, and James, readily understood by the people as designating Stephen A. Douglas, Franklin Pierce, Roger B. Taney, and James Buchanan. Such quaint illustrations were easily understood by his hearers and were very effective. At times, however, Lincoln rose to the highest flights of eloquence.

In his speech at Chicago on July 10, 1858 , Lincoln said, after speaking of the immigrants from other nations who had sought homes in America since the adoption of the Declaration of Independence, the Germans, Irish, French, Scandinavians, and others: "If they look back through this history to trace their connection with those days by blood they find they have none; they cannot carry themselves back into that glorious epoch and make themselves feel that they arc part of us; but when they look through that old Declaration of Independence, they find that those old men say that 'we hold these truths to be self-evident, that all men are created equal,' and then they feel that that moral sentiment taught in that day evidences their relation to those men, that it is the father of all moral principle in them, and that they have a right to claim it as though they were blood of the blood and flesh of the flesh

$$
\text { (1) Supra pp33/.332 }
$$


of the men who wrote that Declaration, and so they are. That is the electric chord in that Declaration that links the hearts of patriotic and liberty-loving men together, that will link those patriotic hearts as long as the love of freedom exists in the minds of men throughout the world."I

To Douglas's assertion that the provisions of the Declaration of Independence were not intended to include negroes as entitled to any inalienable rights, and to his insinuation that the Republicans were in favor of negro equality, an appeal to the prevalent prejudice of the great mass of the white voters of Illinois, Lincoln said in his speech at Ottawa: "Anything that argues me into his idea of perfect social and political equality with the negro is but a specious and fantastic arrangement of words by which a man can prove a horse chestnut to be a chestnut horse. . . . I have no purpose to introduce political and social equality between the white and the black races. There is a physical difference between the two, which in my judgment will probably forever forbid their living together upon the footing of perfect equality, and inasmuch as it becomes a necessity that there must be a difference, I, as well as Judge Douglas, am in favor of the race to which I belong having the superior position. I have never said anything to the contrary, but I hold that, notwithstanding all this, there is no reason in the world why the negro is not entitled to all the natural rights enumerated in the Declaration of Independencethe right to life, liberty, and the pursuit of happiness. I hold that he is as much entitled to these as the white man. I agree, with Judge Douglas, he is not my equal in many respects-certainly not in color, perhaps not in moral or intellectual endowment. But in the right to eat the bread, without the leave of anybody else, which his own hand earns, he is my equal and the equal of Judge Douglas, and the equal of every living man." 2

Douglas often appealed to the prejudice of his hearers

'Lincoln-Douglas Debates, pages 22, 23.

IId., p. 75. 
by insinuating that Lincoln and the Republican party favored negro equality, social as well as political, that they were inclined, as Lincoln put it, "to marry with and hug negroes." Thus, in his specch at Freeport, he told of having seen there a magnificent carriage in which " a beautiful young lady was sitting in the box seat; whilst Fred Douglass and her mother reclined inside, but the owner of the carriage acted as driver"; and continued by saying: "All I have to say of it is this, that if you Black Republicans think the negro ought to be on a social equality with your wives and daughters, and ride in a carriage with your wife, while you drive the team, you have a perfect right to do so." Lincoln's answer to this kind of "counterfeit logic," which assumed that because a white man does not want a negro woman for his slave, he must necessarily want her for his wife, has already been given.

Douglas tried hard to drive Lincoln and the Republican party into a position from which it might be at least inferred that they favored rebellious disobedience of the Dred Scott decision, charging them with intending to array mob-law against it. Lincoln's answer to this was that the Republicans intended to abide by the decision so far as it decided the property right of the owner of Dred Scott, but that they did not intend to adopt it as a rule of political policy; that they believed the decision to be wrong, but would attempt to have it reversed in a legal way, when the judges who decided it should be succeeded by other judges holding different views of the laws, as had often been done before. In his speech at Galesburg Lincoln complained that he could get nothing from Douglas on this subject "except that he swells himself up and says 'all of us who stand by the decision of the Supreme Court are the friends of the Constitution; all you fellows that dare question it in any way are the enemies of the Constitution." " But in his speech at Ottawa, he very ingeniously and effectively turned the tables upon Douglas by referring to the attitude of Douglas himself toward the Illinois Supreme Court. 
"I remind him [Douglas]," said Lincoln, "of another piece of history on the question of respect for judicial decisions, and it is a piece of Illinois history-belonging to a time when the large party to which Judge Douglas belonged were displeased with a decision of the Supreme Court of Illinois, because it had decided that a governor could not remove a secretary of state. You will find the whole story in Ford's History of Illinois, and I know that Judge Douglas will not deny that he was then in favor of overslaughing that decision by the mode of adding five new judges, so as to vote down the four old ones. Not only so, but it ended in the Judge's sitting down on that very bench as one of the five new judges to break down the four old ones. It was in this way precisely that he got his title of Judge. Now when the Judge tells me that men. appointed conditionally to sit as members of a court will have to be catechized beforehand upon some subject, I say: 'You know, Judge; you have tried it.' When he says a court of this kind will lose the confidence of all men, will be prostituted and disgraced by such a proceeding, I say: 'You know best, Judge; you have been through the mill." "r

Lincoln, speaking further on the same subject, in his speech at Quincy, said: "And let me ask you, didn't Judge Douglas find a way to reverse the decision of our Supreme Court, when it decided that Carlin's father-old Governor Carlin-had not the constitutional power to remove a secretary of state? Did he not appeal to the 'mobs' as he calls them? Did he not make speeches in the lobby to show how villainous that decision was, and how it ought to be overthrown? Did he not succeed, too, in getting an act passed by the Legislature to have it overthrown? And didn't he himself sit down on that bench as one of the five added judges, who were to overslaugh the four old ones-getting his name of Judge in that way and no other?" 2

Referring to Douglas's charge of "sectionalism" against

'Lincoln-Douglas Debates, p. 82.

2Id., p. 211. 


\section{The Lincoln-Douglas Debates}

the Republicans, for the reason that a Democrat could make the same kind of speech in the South that he could in the North, while the Republicans dared not do so, Lincoln said in his speech at Galesburg: "I presume that Judge Douglas could not go into Russia and announce the doctrine of our national democracy; he could not denounce the doctrine of kings and emperors and monarchies in Russia; and it may be true in this country, that in some places we may not be able to proclaim a doctrine as clearly true as the truth of democracy, because there is a section so directly opposed to it that they will not tolerate us in doing so. Is it the true test of the soundness of a doctrine, that in some places people won't let you proclaim it? Is that the way to test the truth of any doctrine?" And he continued by predicting, what afterwards proved to be true, that the day was rapidly approaching "when his [Douglas's] pill of sectionalism which he has been thrusting down the throats of Republicans for years past will be crowded down his own throat."

If we study Lincoln's speeches carefully, we shall discover that their main strength was in the wonderful power that enabled him to win the conscience of his hearers; to touch some chord that reached and thrilled their moral natures and roused into fervent enthusiasm some moral sentiment that perhaps had long been dormant.

After all, the strength of oratory is in the force with which it appeals to the best and not to that which is worst in human nature. Even the rabble, though it may applaud the crator who panders to the baser passions, respects the more the orator who appeals to man's nobler impulses. The ordinary politicians take no account of this; the professional politicians do not because they have no conception of a moral sentiment and cannot measure its force as a factor in politics.

In his speech at Ottawa on August 31, 1858, Lincoln said: "Judge Douglas is going back to the era of our Revolution,

' Lincoln-Douglas Debates, pp. 179, 180. 


\section{6 Political History of Secession}

and, to the extent of his ability, muzzling the cannon which thunders its annual joyous return. When he invites any people, willing to have slavery, to establish it, he is blowing out the moral lights around us. When he says he 'cares not whether slavery is voted down or voted up' - that it is a sacred right of self-government-he is in my judgment penetrating the human soul and eradicating the light of reason and the love of liberty in this American people." $\mathrm{x}$

In his speech at Alton in the last of the seven joint debates, speaking of the attitude of the Democratic party toward slavery, he said: "You may turn over everything in the Democratic policy from beginning to end, whether in the shape it takes on the statute book, in the shape it takes in the Dred Scott decision, in the shape it takes in conversation, or the shape it takes in short maxim-like arguments-it everywhere carefully excludes the idea that there is anything wrong in it. That is the real issue. That is the issue that will continue in this country when these poor tongues of Judge Douglas and myself shall be silent. It is the eternal struggle between these two principlesright and wrong-throughout the world. They are the two principles that have stood face to face from the beginning of time; and will ever continue to struggle. The one is the common right of humanity, and the other the divine right of kings. It is the same principle in whatever shape it develops itself. It is the same spirit that says, 'You work, and toil, and earn bread, and I'11 eat it.' No matter in what shape it comes, whether from the mouth of a king who seeks to bestride the people of his own nation and live by the fruit of their labor, or from one race of men as an apology for enslaving another race, it is the same tyrannical principle." 2

The most significant feature of the debates occurred at the second, which was at Freeport on August 27. In his opening speech, Lincoln had propounded to Douglas a ${ }^{x}$ Lincoln-Douglas Debates, p. 83.

${ }^{2} I d .$, p. 234 . 
series of questions, the second of which was: "Can the people of a United States Territory in any lawful way, against the wish of any citizen of the United States, exclude slavery from its limits prior to the formation of a State constitution?" Douglas answered this by saying that in his opinion, "the people of a Territory can, by lawful means, exclude slavery from their limits prior to the formation of a State constitution," and then proceeded to elaborate his theory of "unfriendly legislation" which he had advocated in his speech at Springfield, Illinois, on June 12, 1857. Continuing he said: "It matters not what way the Supreme Court may hereafter decide as to the abstract question whether slavery may or may not go into a Territory under the Constitution; the people have the lawful means to introduce it or exclude it as they please, for the reason that slavery cannot exist a day or an hour anywherc, unless it is supported by local police regulations. Those police regulations can only be established by the local legislature; and if the people are opposed to slavery they will elect representatives to that body who will by unfriendly legislation effectually prevent the introduction of it into their midst. If, on the contrary, they are for it, their legislation will favor its extension. Hence, no matter what the decision of the Supreme Court may be on that abstract question, still the right of the people to make a slave Territory or a free Territory is perfect and complete under the Nebraska bill." I

This was practically proposing territorial nullification of the Constitution of the United States as defined by the Supreme Court, as the only relief of the people against slavery in a Territory while it remained a Territory. Lincoln characterized this as an "outlandish and lawless doctrine." He also exposed the absurdity of it by asking how a thing "may be lawfully driven away from a place where it has a lawful right to go." Douglas himself must have realized the fallacy of this argument, but it was the best he could make and it was necessary for him to make

'Lincoln-Douglas Debates, p. 95. 


\section{Political History of Secession}

it to save the Senatorship. It served its purpose but it lost Douglas forever after the support of the South. Such doctrine in the South was looked upon as no better than out-and-out Abolitionism. Lincoln, with that prophetic political instinct which was one of his chief characteristics, had foreseen this when his Republican friends to whom he had shown the questions to Douglas had tried to dissuade him from asking them lest Douglas might by some plausible answer escape from the dilemma in which he was floundering. But Lincoln persisted, saying that "he was after larger game than the Senatorship, and that Douglas could then never be President and that the battle of 1860 was worth a hundred of this." $x$

Even after the lapse of over half a century, it is possible that there may still exist a difference of opinion as to the relative oratorical merits of Lincoln and Douglas, but all must concede that Douglas was master of the art of political debate. If, in the joint discussion, Lincoln seems to show to better advantage, it must be remembered that Douglas was forced to advocate what seemed then, and still seems, to the great mass of the people of the North to be the worst side of the subject of debate.

The Republicans had a majority of about 4000 on the popular vote of Illinois, but the Democrats, by reason of the Senators who held over from the last preceding election, had a majority of the Legislature and Douglas was reelected. But Lincoln was now known in every corner of the land and was in great demand as a political speaker, not only in Illinois, but in other States as well, and made many speeches afterwards in other States, the most notable of which was one delivered to a great and distinguished audience at Cooper Institute in New York City on February 27, 1860. The debates made Lincoln President. They made Douglas an exile from his party-from so much of it, at least, as dwelt south of Mason and Dixon's line-and resulted in his political destruction.

${ }^{x}$ Reminiscences of Carl Schurz, vol. ii., p. 98.' 


\section{CHAPTER XVIII}

PREPARING FOR THE PRESIDENTIAL CAMPAIGN OF I860; SOURCES OF REPUBLICAN GAINS

THE State elections of 1858 resulted in surprising Republican gains in nearly all the Northern States. The Republicans carried all the States that had voted for Frémont in 1856. Of these New York had gone Democratic in 1857 , and in Ohio and several other States the Republican majorities of 1856 had been prior to 1858 nearly wiped out. The Republicans had lost a Senator in Illinois but had elected their State ticket and four out of the nine Congressmen, the five Democratic Congressmen being all anti-Lecompton or Douglas Democrats. The Republicans also carried New Jersey and, what was more significant than anything else, they triumphed in Pennsylvania for the first time and by a majority of over 26,000. Elsewhere a number of Democratic Congressmen elected were antiadministration Democrats, who subsequently followed the lead of Douglas, so that in the Thirty-sixth Congress, which met on December 5, 1859, there were in the House, out of a total of 237 members, Republicans I I3, administration Democrats 93, anti-Lecompton or anti-administration Democrats 8, Americans 23, no party having a clear majority but the Republicans lacking only 6 of having a majority over all.

Little was done in the political field in the year 1859, except to prepare for the approaching presidential campaign of 1860 . But several things occurred during that year which added fuel to the flames and heated still more 
the political cauldron, already fiercely boiling. One was the bringing into public notice a book published some time before. It was written by Hinton Rowan Helper of North Carolina and was entitled The Impending Crisis. It was not written primarily in behalf of the slaves, but its main object was to show the disastrous effects of slavery upon the whites, and especially upon the poorer class of nonslaveholding whites of the South. It was in fact an attack upon the slaveholding aristocracy of the South and an attempt to show the danger it threatened to the liberty of the poorer classes. The book soon began to attract attention and to excite acrimonious discussions and added intensity to the passions aroused by the discussion of the slavery question in the newspapers and in the congressional debates.

But the event which, far more than Helper's Impending Crisis, stirred the nation to its very depths, was John Brown's invasion of Virginia in the year 1859. After the Pottawatomie massacre it became unsafe for Brown to remain longer in Kansas; so he left and soon after began preparations for carrying out a scheme which he had conceived of making a raid into Virginia, inciting a great insurrection among the slaves, and setting up a free government. In anticipation of this he had called a convention which met at Chatham, Canada, in May I $85^{8}$ and adopted a "provisional constitution and ordinances for the people of the United States," providing for the establishment of courts and congress, president, commander-in-chief, Secretary of war, and other government officials and machinery. The constitution itself was such a crazy patchwork as upon the face of it to create a strong suspicion that its author must have been in a frame of mind closely bordering on lunacy. ${ }^{\mathbf{}}$ After raising in Boston and elsewhere a considerable sum of money and a supply of arms, Brown started on Sunday, October 16, 1859. With a force of seventeen white men

¿Greeley, Am. Conflict, vol. i., p. 287; Villard, John Brown, pp. 33235. 
and five negroes, he succeeded in surprising the sentinels and capturing the United States garrison at Harpers Ferry and holding it until the following Tuesday, when he was himself captured by the combined military forces of the United States and the State of Virginia. He was speedily tried and convicted and on December 2 following he was hanged by the Virginia authorities.

In forming an estimate of Brown's character, opinions vary almost as greatly now as they did fifty years ago. The people of the South then regarded, and still regard, him as a monster. But Emerson, Theodore Parker, and Wendell Phillips eulogized him in extravagant terms. Such are the aberrations of genius that, notwithstanding Brown's lawless and blood-stained record, Emerson was moved to speak of him as "that new saint, than whom none purer or more brave was ever led by love of men into conflict and death-the new saint awaiting his martyrdom, and who, if he shall suffer, will make the gallows glorious like the cross"; and Theodore Parker wrote: "Let the American State hang his body and the American Church damn his soul; still the blessing of such as are ready to perish will fall on him and the universal justice of the infinitely perfect God will make him welcome home. The road to Heaven is as short from the gallows as from the grave."

At John Brown's grave in North Elba Wendell Phillips pronounced an eloquent eulogy. "Marvelous man," he said, "he has abolished slavery in Virginia. You may say this is too much. Our neighbors are the last men we know. The hours that pass us are the ones we appreciate the least. Men walked Boston streets when night fell on Bunker Hill and twitted Warren, saying: 'Foolish man! Throwing away his life. Why didn't he measure his means better?' Now we see him standing colossal on that blood-stained soil and severing the tie which bound Boston to Great Britain. That night George III. ceased to rule in New England. History will date Virginia emancipation 
from Harpers Ferry. True the slave is still there. So when the tempest uproots the pine on your hills it looks green for months-a year or two. Still, it is timber, not a tree. John Brown has loosened the roots of the slave system: it only breathes-it does not live hereafter." Afterwards he said in Boston: "John Brown has gone to God with the shackles of all Virginia's slaves in his right hand."

It would have been impossible for Phillips to speak without speaking eloquently. His judgment was not always equal to his eloquence. To strike the shackles from the slaves in the South required something more than John Brown's raid; something more even than the Emancipation Proclamation; it required great armies of a million men or more, the flower of the youth of the North, with the arguments they carried in their cartridge boxes.

Most of the denunciations heaped on John Brown, as well as the excuses given for him, presuppose that he was sane. If he was sane his crimes were offenses against the moral as well as against human law. It cannot avail him that his ultimate aim was the extermination of slavery. Nothing can be found in moral law justifying the Pottawatomie massacre or his attempt to incite an insurrection in Virginia, which, if successful, would have resulted in wholesale and indiscriminate slaughter of innocent persons - women and children included-in order to redress the wrongs committed by some slaveholders. Their "damnation is just" is the scriptural penalty for doing evil that good may come, although done under pretense that "the truth of God hath much more abounded through my lie unto His glory." Surely there was nothing but evil in the wicked murders which Brown committed and those which he attempted.

Nor will it suffice for his defense to say that he was actuated by a conscientious conviction that in violating the laws of man he was obeying the laws of God. Similar excuses have been made for some of the worst butchers 
in history. It is possible that Booth and Guiteau imagined that they were carrying out God's will. It may be that we cannot accurately determine the moral guilt of such men by any human standards, but these are all we have to go by, and under these if sane men persist in murdering their fellow-beings they cannot escape the penalties of the law by pleading that they were compelled to do so by a sense of duty growing out of a perverted conscience.

If there was any legal or moral defense available to John Brown it was that he was insane, and there are cogent reasons for believing that he was; that he had brooded over the sins of the slaveholders and the wrongs of the slaves until he had become a monomaniac on the subject, possessed with the delusion that he was the chosen instrument of the Lord to smite the slaveholders as David smote the Philistines. But Brown himself would not set up as a defense the claim that he was insane nor permit it to be set up in his behalf. Nor do his admirers, who will have it that he was a martyr, set up any such claim. Indeed the plea that he was insane and the plea that he was a martyr would be wholly repugnant to each other; for if a man has not mind enough to distinguish between right and wrong he deserves neither credit for the one nor censure for the other. If he is sane enough to be a martyr he must be deemed sane enough to be a criminal. We must, therefore, conclude that John Brown was either a criminal or a lunatic; by no process of reason can we make him out a martyr.

Brown's raid opened anew the discussion of the slavery question in the North, vastly enlarged its bounds, and greatly aided in crystallizing the anti-slavery sentiment in the North; for the people there looked beyond the lifeless body of John Brown hanging from the Virginia gallows to the picture of slavery in the background and saw its ugly features more clearly than ever before.

On the other hand, it is certain that Brown's attempt to stir up the slaves of the South to armed revolt was a signal failure. Brown miscalculated the temper of the 


\section{$384 \quad$ Political History of Secession}

slaves themselves. Those in Virginia, at least, had not generally suffered from the barbarities practiced by masters in ancient times, and many of them entertained such feelings of attachment for their masters that they could not be persuaded to rise up and butcher them and their wives and children. This feeling was strikingly shown by the fact that during the Civil War there never was a considerable insurrection of the slaves, though in many sections the blacks largely predominated in numbers, and most of the white men capable of bearing arms were in the Confederate armies and were absent from their homes.

The ridicule heaped on the Southern people because of the panic caused by the insignificant number of invaders was not deserved and only added to their anger. A very small spark may ignite a great powder magazine, and what the people of the South dreaded so much was not the little handful of invaders under John Brown, but the unforeseen consequences of the spread of the fire that they might kindle. Especially was this the feeling of Virginians who had not forgotten the Nat Turner insurrection. Brown's raid also added to the bitterness with which the people of the South regarded the Republicans of the North, whose leaders were believed in the South to have aided and abetted the raid. Henry A. Wise, then Governor of Virginia, asserts that, from the time of Brown's raid, Virginia began to increase her armory and to put the State on a war footing. The recollection of the raid, still fresh in the minds of the Virginians in 1860 and in the early part of $186 \mathrm{I}$, undoubtedly greatly aided those who finally succeeded in inducing the State to secede.

Memorials are still written and monuments are still erected to perpetuate Brown's memory. The heroes we make and worship, like the idols made and worshiped by the heathen, are often made of very common clay. John Brown's soul is still "marching on" in history as well as in song, and it may be that in fifty or one hundred years he will be apotheosized as one of the most illustrious of 


\section{Preparing for Campaign of 1860}

martyrs; but it is yet too soon to class Black Jack with Bunker Hill and to rank John Brown along with General Warren. Nor will history, as Phillips predicted, "date Virginia emancipation from Harpers Ferry." Slavery did not die at Harpers Ferry but at Appomattox, and from one to the other the way was long and bloody. In traveling over it history points out historic figures innumerable. We see that of Lincoln, colossal, towering over all, holding the Emancipation Proclamation and saying that the Declaration of Independence should no longer be called a "glittering generality, a self-evident lie," but that thenceforth it should speak a living, eternal truth. Looking beyond Lincoln we see mighty hosts, powder-begrimed heroes, marching down into the valley of death where the armies of the North contended in mortal combat with the armies of the South, and the flower of the youth of the land were falling like leaves in autumn; it is there, in the smoke of battle, that slavery finally and forever disappeared from our view. ${ }^{x}$

Strenuous and persistent efforts were made by Democratic leaders to implicate some leading Northern Republicans as Brown's confederates, but not a single Republican in the land, of prominence sufficient to be called a Republican leader, was proved to have aided or abetted Brown in any way. Abraham Lincoln said of Brown after his execution: "Old John Brown has been executed for treason against the State. We cannot object, even though he agreed with us

s The latest biography of John Brown is by Oswald Garrison Villard. It is written in classic style and with an evident desire to present a fair and impartial record of Brown's life. In this ponderous volume of seven hundred and thirty-eight pages is a bibliography of twenty-one pages of books, pamphlets, and other literature relating to John Brown. Probably no other American except George Washington and Abraham Lincoln has ever been more written about. The divergency of views as to Brown's character that still prevails is shown by two reviews of Villard's book, one by William D. Howells, entitled, "John Brown after Fifty Years," the other by Henry Watterson, entitled, "An Abortive Hero," in North American Review for January, I9I I, vol. cxciii., pp. 26; 35. 
in thinking slavery wrong. That cannot excuse violence, bloodshed, and treason. It could avail him nothing that he might think himself right." The Republican party, in its national platform of 1860 , denounced his raid in the strongest terms in a resolution which asserted: "We denounce the lawless invasion by armed force of the soil of any State or Territory, no matter under what pretext, as among the greatest of crimes."

The first thing done in the Senate at the opening session of the Thirty-sixth Congress, which met on December 5, 1859, was the appointment of a committee to investigate the John Brown raid. The committee, of which Senator Mason, of Virginia, Jefferson Davis, of Mississippi, and Graham N. Fitch, of Indiana, constituted a majority, began its investigations on December I6, I859, and concluded on June I4, I860, but found nothing implicating any prominent Republican of the North in having incited or approved the raid. The speeches on the subject in the Senate were, as might have been expected, of a highly inflammatory character.

In the House the Republicans nominated John Sherman, of Ohio, for Speaker. He, with other Republicans, had signed some kind of paper which was construed as an endorsement of Helper's Impending Crisis, and this was made the pretext for the introduction of a resolution by one of the Democratic members to the effect that no one who had endorsed Helper's book was fit to be Speaker. A violent debate followed in which threats of disunion by the members of the Southern States were met by sarcastic taunts from Thaddeus Stevens of Pennsylvania and other Northern members, and the excitement at times reached such a pitch that there was great danger of a riot on the floor of the House. The accounts of the disgraceful scenes that took place there would be incredible were they not vouched for by reliable authority. "One day Kellogg and Logan, both of Illinois, had an altercation growing out of a charge made against Senator Douglas; on another, 


\section{Preparing for Campaign of 1860}

a hot personal dispute on the floor of the House between Branch, of North Carolina, and Grow, of Pennsylvania, led to a virtual challenge to a ducl from Branch, which met a dignified refusal from Grow. Both were afterwards arrested and placed under heavy bonds to keep the peace. Another day when Haskin, an anti-Lecompton Democrat from New York, was making exciting and bitter personal remarks about a colleague, a pistol accidentally fell to the floor from the breast-pockct of his coat. Some members, believing that he had drawn the wcapon with the intention of using it, wcre wild with passion. Many Democrats rushed towards the center area near which Haskin stood. The loud cries for order, the nervous demands for the sergeant-at-arms, and the clamor of excitement made a scene of pandemonium. A bloody contest that day was imminent. 'The members on both sides,' wrote Senator Grimes, of Iowa, 'are mostly armed with deadly weapons, and it is said that the friends of each are armed in the galleries.' Senator Hammond told the same story. 'I believe,' he wrote to Lieber, 'every man in both Houses is armed with a revolver-some with two-and a bowie knife." I After forty-three ballots Sherman's name was withdrawn and a compromise was effected, pursuant to which William Pennington, of New Jersey, a Republican, was, on February I, I 860, elected Speaker.

All discerning politicians could now see, none more clearly than the Southern political leaders, that success in the approaching presidential election was of the utmost importance to slavery, and that the election would likely be decisive. They could see that the scepter had departed from the Democratic party, its last and strongest ally in the North, and was about to pass to the Republican party. They reasoned, and it must be admitted that there was much to warrant them in their reasoning, that, inasmuch as revolutions never go backward, in case the Republicans should succeed it would not be long until the Fugitive Slave

' Rhodes, History of the United States, vol. ii., p. 423. 
Law would be repealed; next the abolition of slavery in the District of Columbia, the abolition also of the interstate slave trade, and the final penning up of slavery within the limits of the slave States, where, surrounded by free States, if not sooner put an end to, it would surely die a lingering death. It was worth while, however, to make one more supreme effort to retain control of the Federal government, and, if the effort should fail, to secede from the Union and set up an independent government. This was undoubtedly the reasoning and the policy of the Southern leaders.

The discussions in Congress, outside those pertaining to mere routine business, related chiefly to the acquisition of $\mathrm{Cuba}$, the slave trade, and slavery in general and were marked by extreme party rancor. A significant incident showing the bitterness of feeling between the advocates of slavery and its opponents was a heated controversy between Lovejoy, of Illinois, and Pryor, of Virginia, which came near precipitating a riot on the floor of the House. Lovejoy made a very excited harangue against slavery in which, among other intemperate expressions, he said that "slaveholding was worse than robbery, than piracy, than polygamy"; that it was the "doctrine of Democrats and the doctrine of devils as well," and that there was "no place in the universe outside of the five points of hell and the Democratic party where the practice and prevalence of such doctrines would not be a disgrace." As he uttered these words he advanced toward the Democratic side of the House, shaking his fists. At this point Pryor, of Virginia, objected and insisted that Lovejoy should keep on his own side of the House. Instantly there arose a great uproar, above which could be heard the voice of Lovejoy accusing the Democrats of murdering his brother in Alton, and the voice of Barksdale, of Mississippi, calling Lovejoy a "black-hearted scoundrel and nigger-stealing thief." Potter, the big Republican member from Wisconsin, was conspicuous in the mêlee, shouting and gesticulating like one beside himself and insisting that Lovejoy 


\section{Preparing for Campaign of 1860}

should be heard. Finally order was restorcd but the affair resulted in a challenge being sent by Pryor to Potter. Potter promptly accepted and chose bowie knives for weapons. This choice of weapons was rejected by Pryor's second on the ground that, while it was entirely proper under the code for one gentlcman to murder another in a cold-blooded duel by shooting him with a pistol or running him through with a sword, it was not permissible to chop him in pieces with a bowie knife. As there was no gainsaying this nice point of honor, the proposed duel was indefinitely postponed. For a time, however, the affair made Lovejoy and Potter immensely popular in the North.

Douglas's attitude on the slavery question was now well understood to be hostile to the extreme demands of the ultra pro-slavery leaders of the South. Although a candidate for the Democratic nomination for the Presidency, he had written a letter on June 22, I859, in which he said that "if it shall become the policy of the Democratic party to repudiate their time-honored principles and interpolate such new issues as the revival of the African slave trade or the doctrine that the Constitution carries slavery into the Territories beyond the power of the people to legally control it as other property," he would not "accept a nomination for the Presidency if tendered him."

To the success of the plans of the secession leaders it was necessary to exterminate Douglas, and in the Senate the chief business of Jefferson Davis, and his Democratic followers seemed to be the casting of Douglas out of the Democratic party. As a beginning, Douglas was deposed from his position as chairman of the Senate Committee on Territories, a position which he had held for many years. This was done, as Davis frankly admitted, because the views of Douglas on the question of slavery in the Territories had changed and were no longer regarded as orthodox by his Southern brethren. Morcover, a presidential election was approaching, at which it was well

¿Blaine, Twenty Years, vol. i., p. 151. 
known that Douglas would be a candidate before the Democratic National Convention for the presidential nomination. It was equally well known that, if a candidate, he would receive the enthusiastic support of a great majority of the Democrats in the North. Douglas's late political theories, especially his "unfriendly legislation" theory, were now well known and decidedly unpopular in the South, so that it was deemed necessary by his political enemies to render both him and them more unpopular still by making a platform of principles of such a radical pro-slavery cast that, if Douglas stood upon it, he would be politically ruined in the North, but that, if he refused to stand upon it, he would be ruined politically in the South. For this purpose, on February 2, 1860, Jefferson Davis introduced in the Senate a series of resolutions, six in number. ${ }^{\text {I }}$ For some reason, probably because they were thought to be not quite strong enough for the purpose for which they were offered, Davis withdrew them, and on February 29 he offered as a substitute another set of resolutions, seven in number. ${ }^{2}$ Of these the fourth, fifth, and sixth were as follows:

"4. Resolved, That neither Congress nor a territorial legislature, whether by direct legislation or legislation of an indirect and unfriendly character, possesses power to annul or impair the constitutional right of any citizen of the United States to take his slave property into the common Territories, and there to hold and enjoy the same while the territorial condition remains.

"5. Resolved, That if experience should at any time prove that the judiciary and executive authority do not possess means to insure adequate protection to constitutional rights in a Territory, and if the territorial government shall fail or refuse to provide the necessary remedies for that purpose, it will be the duty of Congress to supply such deficiency.

"6. Resolved, That the inhabitants of a Territory of the

${ }^{2}$ Cong. 'Globe, 36th Cong., Ist sess., pt. i., p. $658 . \quad I d .$, p. 935 . 


\section{Preparing for Campaign of 1860}

United States, when they rightfully form a constitution to be admitted as a State into the Union, may then, for the first time, like the people of a State, when forming a new constitution, decide for themselves whether slavery as a domestic institution shall be maintained or prohibited within their jurisdiction; and they shall be received into the Union with or without slavery, as their constitution may prescribe at the time of their admission."

These resolutions embodied substantially the ultra Southern doctrines on the question of slavery that had been advocated by Calhoun and that had been expressed in the resolutions of the Nashville convention, as well as in the Georgia and Alabama platforms. As explained by Davis, they were intended, not as a basis for any immediate legislation, but as declarations of great fundamental principles on which legislation might thereafter be founded. He might also. have truthfully added that they were great fundamental principles upon which future Democratic platforms, particularly the one for 1860, might be constructed.

Of these resolutions, the fourth dealt a death-blow to Douglas's theory of "popular sovereignty," by reasserting as a political doctrine, what had already been decided in the Dred Scott decision, viz., that neither Congress nor any territorial legislature "had any power to annul or impair the constitutional right of any citizen to take into and hold his slaves in such Territory." The fifth annihilated Douglas's doctrine of "unfriendly legislation," by declaring that if any territorial legislature should fail to provide proper police regulations for the protection of the slave-owners in their property rights, it would then be "the duty of Congress to supply such deficiency." The sixth postponed the exercise of the right of the people of a Territory to have a voice in the admission or exclusion of slavery to the period when they should be permitted to form a constitution preparatory to admission as a State. The seventh was aimed at the personal liberty bills of several of 
the Northern States by declaring that all acts of State legislatures designed to nullify or impair the fugitive-slave laws of the United States and the laws made pursuant thereto were revolutionary and subversive of the Constitution.

It must have been evident to Douglas by this time, if not before, that he had come to the parting of the ways. He must dishonor himself in the North by abandoning his past record; or he must break with the Democrats of the South by refusing longer to travel with them. He did not hesitate, but boldly took up the gauntlet thrown down by Davis and led the opposition to the latter's resolutions. Douglas had now been abandoned by all the Southern Democratic Senators, and of those from the North only George E. Pugh of Ohio remained steadfast. On every side he was beset by his political enemies lying in wait to give him a thrust, so that he may be said to have fought his way, almost single-handed, from the beginning to the end of the session. Part of the time he was in ill health, sometimes confined to his bed, but the attacks of his enemies continued. When able to be on the floor of the Senate he was almost incessantly engaged in combat with his adversaries, fighting with his old-time courage and determination, now parrying a thrust of one of his assailants, now himself giving a keen thrust to another. He yielded nothing; he asked no quarter. The more his doctrine of popular sovereignty was assailed, the more earnestly did he defend it. To the Southern Senators he said: "I am not seeking a nomination. I am willing to take one provided I can assume it on principles that I believe to be sound; but in the event of your making a platform that I could not conscientiously execute in good faith if I were elected, I will not stand upon it and be a candidate. Why? I will never be guilty of the act of being elected on a platform and kicking it over the moment I am elected." Again he said: "I assail nobody. I make no tests on any

'Cong. Globe, 36th Cong., Ist sess., pt. i., p. 424 . 


\section{Preparing for Campaign of 1860}

one, but, at the same time, I am determined never to surrender a conscientious conviction, even to secure the highest place in government. I repeat, if there are no assaults made on me we shall go on in perfect harmony. I have no grievance, but I have no concessions. I have no abandonment of position or principle, no recantation to make to any man or body of men on carth." $x$

In the Senate was another prominent aspirant for the presidential nomination-William H. Seward. On February 29, 1860, he made a speech favoring the admission of Kansas. ${ }^{2}$ His arguments were mainly for the purpose of demonstrating that there was no hostility against the South on the part of the North, or on the part of the Republican party, and that, in the event of the success of that party in the coming campaign, its policy toward the South would be pacific and conciliatory. His speech did not please the extreme anti-slavery men of the North, who saw, or imagined they saw, in it a double purpose on the part of Sewardthat of maintaining his standing in the next national Republican convention, while endeavoring to placate in advance the anticipated hostility of the South to the election of a Republican President, who, it was generally believed, would be none other than William H. Seward. ${ }^{3}$ So far as the speech may have been intended to placate the South it wholly failed of its purpose. The concluding sentences of Seward's speech afford a striking illustration of the overflowing optimism, characteristic of the man, which so often seemed to run away with his judgment. "Mr. President," he said, "we are perpetually forgetting this subtle and complex, yet obvious and natural, mechanism of our Constitution. . . . We are continually looking to see it stop and stand still or fall in pieces. But in truth it will not stop; it was not made to stop, but to keep in

Cong. Globe, 36th Cong., Ist sess., part i., pp. 424, 425 .

Id., p. 910.

${ }^{3}$ See Von Holst's comments on this speech in Const. and Pol. History, vol. vii., p. $15^{8}$. 
motion always and without force. . . . I expect that it will stand and work right on until men shall fear its future no more than we now apprehend that the sun will cease to hold his eternal place in the heavens. . . . The earth seems to be heaving under our feet, and the pillars of our noble fabric that protects us to be trembling before our eyes. But the appointed end of all this agitation comes at last, and always seasonably; the tumults of the people subside; the country becomes calm once more, and then we find that only our senses have been disturbed, and that they have betrayed us. The earth is firm as always before, and the wonderful structure, for whose safety we have feared so anxiously, now more firmly fixed than ever, still stands, unmoved, enduring, and immovable." These were the words of an eloquent orator, but after all they were only glittering generalities; they were not the words of a wise political seer; they did not meet the exigencies of the times.

Another man, outside the senatorial arena, scarcely thought of then as destined to be the central figure of the coming presidential campaign, was also heard. On February $27, \mathrm{I} 860$, two days before Seward's speech in the Senate, a great meeting was held in Cooper Institute to hear Abraham Lincoln. It was a notable gathering, notable not only for its size but for the character of the audience, which comprised many of the intellectual leaders of $\mathrm{New}$ York City. Among them were many who had heard the magical eloquence of the great Webster, the classic orations of Edward Everett, the polished speeches of Seward. Many, doubtless, were drawn by their eagerness to hear a discussion of the momentous questions then agitating the public mind; many others probably came out of curiosity who had heard the stories, even then told, of Lincoln's awkward, ungainly figure, of his quaint style of speech. All were eager to see what kind of man this might be who had so lately "come out of the West," this odd specimen of the genus homo who had shown such courage, such eloquence, such political sagacity, in political contest with the renowned 
"Little Giant." Lincoln made a great speech. If any wondered at his appearance or style of speaking, they wondered but a moment for they sat for two hours listening with rapt attention to the words that fell from Lincoln's lips. While there was in his speech no evasion of the issues of the day, no backdown from his prior political utterances, the general tone of his remarks was moderate and conciliatory toward the South. "Let us have faith," he said in closing, "that right makes might, and in that faith let us, to the end, dare to do our duty as we understand it."

At this meeting Lincoln scored a great success. Before it few, if any, in the East contemplated even the possibility of his being selected as the Republican candidate for the Presidency. He had, it is true, they said, "bushwhacked" with Douglas in the wilds of Illinois, but could he be so presumptuous as to contest for a presidential nomination in a Republican convention with Seward, the great statesman, the polished orator, the idol of the Republican masses? After the Cooper Institute meeting there were many Republicans in the East who, in casting about for a Republican standard-bearer for the coming campaign, looked kindly upon Abraham Lincoln, destined not only to be nominated and elected President, but to "live for the ages."

The gains of the Republican party were all in the North. From its birth to the Civil War no Republican was ever elected a member of Congress from any of the slaveholding States; indeed there were few places in those States where it would have been safe for a man to announce himself as a Rcpublican candidate for any office. It was, therefore, in the Northern States that the Republican party made its gains. Its recruits were chiefly from the old parties. After the repeal of the Missouri Compromise a large number of Democrats left their party altogether and never went back. After the rupture between Buchanan and Douglas those of the Democrats who sided with Buchanan became known as administration Democrats and in the campaign of 1860 as Breckinridge Democrats; those who followed Douglas 
were known generally as Douglas or anti-Lecompton Democrats. But there was a large exodus from the Democratic party in the years 1858,1859 , and 1860 that went directly to the Republican party. After the Whig party went to pieces a few of the Northern Whigs, sometimes called "old line Whigs," went to the Democratic party, but the great mass of Northern Whigs went, some directly, and some by way of the American or Know-nothing party, to the Republican party, into which by I 860 the great mass of Northern Whigs had been absorbed.

There was a very marked change between I850 and I860 in the voice of the clergy, especially in New England, where in I860 denunciations of slavery were thundered from nearly every pulpit. There was a noticeable change also in the colleges of the North, whose influence in 1860 was decidedly in favor of the Republican party. The sympathies of the young voters of the North were also with the new party. Another source of strength from which the Republican party drew more largely in 1860 than ever before was the German vote, particularly in the Western States. The influence of the German vote in this country is fully discussed by Mr. Ernest Bruncken in a pamphlet published in 1904. ${ }^{\mathrm{I}}$ In estimating the number of Germans and their descendants living in the United States this author refers to a table given in Eickoff's Aus der Neuen Heimath, the table having been compiled by Theodore Poesche, for many years statistician in the Treasury Department at Washington, in which it is estimated "that from 1820 to 1860 inclusive, the number of Germans who came to the United States was $1,186,376$. A great tide of immigrants from Germany came between I850 and I860. ${ }^{2}$

The early German immigrants to America were not in

\footnotetext{
- German Political Refugees in the United States during the Period from $1815-1860$.

2 There does not seem to be any accurate information as to the number. In the Preliminary Report of the Eighth Census, page I8, it is computed that the number was 907,780 .
} 


\section{Preparing for Campaign of 1860}

sympathy with either the harsh Puritanical ideas that prevailed in New England nor with those of the slaveholding aristocracy. They shunned equally Massachusetts and South Carolina and settled mostly in Pennsylvania and New York, until after the opening of the Northwest Territory, and then large numbers settled in Ohio, Indiana, Illinois, and Wisconsin, where they have always stood for loyalty to country, for honesty and economy in the administration of public affairs, for sound finances, and for all the essentials of good government.

Of the later German immigrants a considerable number were political refugees, conspicuous among whom were those known as the "Forty-eighters," as those were called who left Germany during or after the year 1848, "the year of revolution." "The political refugees," says Mr. Bruncken, "were mostly men of considerable intelligence and education, of enthusiastic and energetic temperament, and, moreover, men with ideals to which they were ready to devote their activities; as was proven by the fact itself that they had risked their homes, their possessions, and, in many cases, their liberty and lives, in order to change the political condition of their country. Their presence on this side of the Atlantic acted on the inert mass of their countrymen in the United States like a leaven to give a higher and more varied life. This effect was shown first within the body of the German residents themselves. Soon the new vigor began to exercise its influence on the other elements of population, especially in the field of politics. Particularly when the slavery question became a burning issue, the realignment of parties after the rise of Republicanism was determined to a considerable degree by the refugees, who by that time had become the leaders of a great part of the German voters." $x$

As between the old Democratic and Whig parties the great mass of German voters allied themselves with the former. The reasons for this are thus stated by Mr.

Bruncken, p. 1 . 
Bruncken": "To understand why it was that for twenty years and more the great mass of Germans, as of other foreigners, were stout adherents of the Democracy, it is but necessary to consider the principles and tendencies of that party and those of its Whig opposition, and especially to compare the elements of which each was mainly composed. It may be said that one of the foundations on which the Whig organization rested was a strong sense of American nationality. The Whig, whether he reasoned it out or not, was a man who believed that the American people was distinct from all others as an organism with an individuality of its own, and he was proud of the fact. He disliked, instinctively, anything which might tend to efface the self-contained character of this national individuality. Therefore he was apt to look with disfavor on the foreign element, and was inclined to either throw obstacles into the way of its growth or else force it into a more speedy amalgamation with the American'people, provided the foreigners would simply become Americans of the traditional kind, without modifying the popular type by contributing some of their own characteristics. The Nativist movement was nothing but the radical expression of tendencies strongly existing within the Whig party. In the Democracy, on the other hand, the consciousness of national individuality was far less strong, and the force of 'Jeffersonian' ideas about the equality of all men, with their strongly cosmopolitan tinge, much stronger. Where the Whig looked askance at the immigrant, the Democrat welcomed him and facilitated his progress. The Jeffersonian jargon about liberty, equality, and the rights of the people was as apt to flow from the lips of the Whig as from that of the Democrat, but the latter's acts seemed more often in accord with the glittering phrase. Another important characteristic of the Whig party was that its economic principles were, on the whole, those finding special favor among the wealthier classes. The merchant,

- Bruncken, p, 25-26. 


\section{Preparing for Campaign of 1860}

the manufacturer, the banker, the land-speculator was most likely a Whig; the Democrats claimed to favor, and to a great extent really did favor, more particularly the interests of the workingman, the small farmer, and the settler in the West. There was a certain amount of truth at the bottom of the exaggerated charges by the Jacksonians that the Whigs were an aristocratic party, and that the Democrats alone were the party of the pcople and the upholders of true American principles, as laid down in the Declaration of Independence.

"The immigrant was generally poor; he would naturally be drawn toward the party which claimed to be the special champion of the common people against the encroachment of the wealthy. If, in addition, that party took his side when the other party attempted to restrain him in following customs he had learned in his old home, or refused to give him equal political rights with the native citizen, was it not natural that the Democracy was the party for him?

"While such were, undoubtedly, the motives of the masses, the educated German, and particularly the political refugee, had additional reasons for feeling drawn towards Jacksonianism. The doctrines of Thomas Jefferson were on the whole identical with those for which he had fought and suffered in Europe. His highest social and political ideals, like Jefferson's, were 'Liberty and Equality.' He was very apt to identify the Whigs with the aristocracies of European countries; for during many years after his arrival in this country he had the habit of measuring everything with European standards, and he could hardly conceive of political parties except as the respective champions of aristocratic, which he called reactionary, and democratic, which to him were necessarily progressive, principles. Under these circumstances the educated Germans were, like their more ignorant brethren, apt to be Jacksonians, unless like the old settlers of 1835 , they had become well-to-do and Americanized before the German 


\section{0 \\ Political History of Secession}

immigrant had become an appreciable factor in American life."

The radicals among the Germans, almost to a man, were opposed to the repeal of the Missouri Compromise, which sharply presented the conflict between freedom and slavery. Of the eighty-eight German newspapers then published in the United States, eighty were opposed to the repeal, $x$ but after that the prohibition question and the Knownothing question entered into the political field and the Democratic party promptly took the aggressive against both. A few prominent Whigs, conspicuous among whom was William H. Seward, opposed the Know-nothing party, but the Whig party, as a party, did not take a decided stand on either the temperance question or the Know-nothing question, as did the Democratic party, and most of the Germans who were opposed to both prohibition and slavery again sought refuge in the Democratic party.

It was not until after the presidential election of 1856 , when the question of the extension or restriction of slavery became the dominant political question, that the great body of Germans severed their allegiance to the Democratic party. On the question of freedom or slavery the great mass of German voters did not hesitate, especially those of the Western States, and undoubtedly in those States they exercised a large influence. Bruncken and other German writers, indeed, claim that "the success of the Republican party in the Northwest was made possible because the Forty-eighters had succeeded in winning a large proportion of Germans into their ranks. Without this element Lincoln would probably not have been elected."

After the Civil War began great numbers of Germans enlisted in the Union army. Of the 500,000 soldiers of foreign birth who enlisted 175,000 were Germans. Many of the German leaders, like Generals Schurz and Siegel and

× Von Holst, Const. and Pol. History, vol. iv., p. 429. 


\section{Preparing for Campaign of 1860}

Willich, distinguished themselves in the field. It was largely owing to the Germans of Missouri that the State was prevented from seceding. Three fourths of the army of General Lyons, with which heopposed the advance of the Confederate general Price, was composed of Germans, including General Siegcl. ${ }^{x}$

In considering the sources of Republican gains the growth of the West in the twenty years between 1840 and 1860 must not be overlooked. West of the Alleghanies a new political power had appeared. In political conventions and presidential elections before 1840 the political divisions chiefly taken into account were the East and the South, but now the new and growing West was to be reckoned with.

The map in the second volume of McMaster's History of the United States, to which reference was made in a former chapter, ${ }^{2}$ shows at a glance the vast area not included in that of the original thirteen States. All west of the Alleghany Mountains was for a long period vaguely known as "The West" and most of it was terra incognita. In 1840 not a foot of Texas nor of the vast tract ceded by Mexico had been acquired; out of another large tract, the Louisiana Purchase, only three States had been formed: Louisiana in 1812, Missouri in 1821, Arkansas in 1836. From another large tract, not so large as either of those above mentioned, but large enough and with resources sufficient for the making of a magnificent empire - the Northwest Territory lying west of the Alleghany Mountains, east of the Mississippi, and north of the Ohio-four States had been organized: Ohio in 1802 , Indiana in 1816 , Illinois in 1818 , Michigan in 1837 .

The total number of electoral votes to which all the States were entitled in I 840 was 294 , distributed as follows:

'See Bruncken's Pamphlet; Metzner, History of the North American Gymnastic Union, English translation by Theodore Stempfel, of Indianapolis, pp. 36-42; Fox's Regimental Losses, p. 62.

- Chapter VIII., p. 15.3. 


\section{Political History of Secession}

\begin{tabular}{lrlr}
\multicolumn{1}{c}{ Free States } & \multicolumn{2}{c}{ Slave States } \\
Connecticut & 8 & Alabama & T \\
Illinois & 5 & Arkansas & 3 \\
Indiana & 9 & Delaware & 3 \\
Maine & I0 & Georgia & I I \\
Massachusetts & I4 & Kentucky & I5 \\
Michigan & 3 & Louisiana & 5 \\
New Hampshire & 7 & Maryland & I0 \\
New Jersey & 8 & Mississippi & 4 \\
New York & 42 & Missouri & 4 \\
Ohio & 21 & North Carolina & I5 \\
Pennsylvania & 30 & South Carolina & I I \\
Rhode Island & 4 & Tennessee & I5 \\
Vermont & 7 & Virginia & 23 \\
& I68 & & I26
\end{tabular}

The classification further extended is as follows:

$\begin{array}{lll}\text { Free States } & \text { I68 } & \\ \text { Slave States } & \text { I26 } & 294\end{array}$

The States west of the Alleghany Mountains and east of the Mississippi and North of the Ohio, all free States, viz.:

$\begin{array}{lrr}\text { Illinois } & 5 & \\ \text { Indiana } & 9 & \\ \text { Michigan } & 3 & \\ \text { Ohio } & 21 & 38\end{array}$

The States west of the Mississippi River, all slave States, viz.:

$\begin{array}{lll}\text { Arkansas } & 3 \\ \text { Missouri } & 4 & 7\end{array}$

There was still in 1840 an abundance of cheap land in the States carved out of the Northwest Territory. In Indiana, on account of the necessity of first extinguishing the Indian title, the lands in the middle third of the State were not thrown open to settlement until 1821 and the lands in the north third until about $\mathrm{i} 835$.

The vast region beyond the Mississippi was still unsettled; over it buffaloes and antelopes and red men roamed at will. But white men with sharp eyes had spied out the land where now cornfields stretch out miles in extent and wheat- 


\section{Preparing for Campaign of 1860}

fields expand like illimitable oceans, where great cities have sprung up as if by magic, a region rich in all the resources, agricultural, mining, manufacturing, and commercial, that contribute to make rich and populous States. This inviting expanse had been seen by intrepid explorers, traders, hunters, and trappers. The "Forty-niners," the adventurous gold hunters, had seen them on their way to the gold fields of California. To theselands, so full of promise, emigrants from the older States were looking with eager eyes and as fast as the lands were opened for settlement they were filled up and organized, first into Territories and then into States. Between I 840 and 1860 several Western States had been admitted.

\begin{tabular}{lll}
\multicolumn{1}{c}{ Free } & & \multicolumn{1}{c}{ Slave } \\
Iowa & in 1846 & \\
Wisconsin & “ 1847 & Texas in 1845 \\
California & “ 1850 & \\
Minnesota “ & 1858 & \\
Oregon & “ 1859 &
\end{tabular}

In 1860 the total number of electoral votes to which the States were entitled was 303 , distributed as follows:

Free

California

Connecticut

Illinois

Indiana

Iowa

Maine

Massachusetts

Michigan

Minnesota

New Hampshire.

New Jersey

New York

Ohio

Oregon

Pennsylvania

Rhode Island.

Vermont

Wisconsin

Slave

\begin{tabular}{rlr}
4 & Alabama & 9 \\
6 & Arkansas & 4 \\
11 & Delaware & 3 \\
13 & Florida & 3 \\
4 & Georgia & 10 \\
8 & Kentucky & 12 \\
13 & Louisiana & 6 \\
6 & Maryland & 8 \\
4 & Mississippi & 7 \\
5 & Missouri & 9 \\
7 & North Carolina & 10 \\
35 & South Carolina & 8 \\
23 & Tennessee & 12 \\
3 & Texas & 4 \\
27 & Virginia & 15 \\
4 & & \\
5 & & \\
5 & & \\
\hline 183 & & 120
\end{tabular}




\section{Political History of Secession}

The States west of the Alleghany Mountains and east of the Mississippi and north of the Ohio, all free States, viz.:

\begin{tabular}{lr} 
Illinois & II \\
Indiana & 13 \\
Michigan & 6 \\
Ohio & 23 \\
Wisconsin & 5 \\
\hline
\end{tabular}

The States west of the Mississippi:

Free States:

\begin{tabular}{ll} 
California & 4 \\
Iowa & 4 \\
Minnesota & 4 \\
Oregon & 3 \\
\hline
\end{tabular}

15

Slave States:

\begin{tabular}{|c|c|c|}
\hline Arkansas & 4 & \\
\hline Missouri & 9 & \\
\hline Texas & 4 & 17 \\
\hline
\end{tabular}

It was plain long before I860, not only that the free States would increase much more rapidly than the slave States in population and wealth, but also that the overflow from the free States would go into the newly acquired Territories and States. The course of empire was still taking its way westward. But there are some things plainer now, perhaps, than they were then. It is plain now that freedom and slavery could no more have dwelt together in a Territory than they could have so dwelt in a State.

Many of the early immigrants to the southern parts of Ohio, Indiana, and Illinois had come from Virginia, Kentucky, Tennessee, and North Carolina. Cincinnati, by reason of its proximity to Kentucky and by reason of its large commercial dealings with the Southern States, was hostile to the agitation of the slavery question, but northern Ohio, especially the portion known as the Western 


\section{Preparing for Campaign of 1860}

Reserve, had been largely settled by people from the New England States and from an early period opposition to the extension of slavery was as pronounced there as it was in any part of New England. The influence of slavery was felt longer in the southern parts of Indiana and Illinois than in any other free States. Southern Indiana, and particularly southern Illinois, long known as "Egypt," continued for many years to be Democratic strongholds; but the American-born immigrants to the northern portions of both States, especially after I 840 , came largely from the free States. Those from New England and the Quakers from Pennsylvania and North Carolina were almost uniformly hostile to the extension of slavery.

The West had now become recognized as an important political factor, not yet so influential as the East and the South, but necessary to be reckoned with in political conventions and in presidential elections. In the West the Republican party was now exhibiting wonderful growth and strength for a party so new. If it grew like Jonah's gourd, it nevertheless struck its roots deep into the soil.

The new political leaders of the Republican party in the West-men like Salmon P. Chase, of Ohio, "Bluff" Ben Wade of the same State, Zachariah Chandler, of Michigan, Lyman Trumbull, of Illinois, and Oliver P. Morton, of Indiana-were all men of marked ability. All were radicals, known in political vernacular as "fighters," who infused into the new party in the West their own vigor and enthusiasm. All of them quickly attained leading positions in the councils of the party and in the affairs of the nation. 


\section{CHAPTER XIX}

\section{THE POLITICAL CAMPAIGN OF 1860}

$\mathrm{T}$ HERE had never been any political campaign in this country like that of 1860 . In it there was arrayed the solid South against the solid North and upon a single issue - the question of the extension or restriction of slavery. Before that campaign politicians had often succeeded in diverting public attention from the slavery question to other political questions; now there was but one. Before, politicians had often exhibited great agility as political dodgers, and the people had become familiar with those who sought to curry favor with both the North and the South by trying to face both ways; men of the kind described in the old rhyme:

\footnotetext{
He wired in and wired out,

Leaving the people still in doubt,

Whether the snake that made the track

Was going south or coming back.
}

But now every man, at least every candidate, was expected to declare himself on the slavery question in plain, unambiguous language, to face the rugged issue of slavery extension or restriction.

More than in any prior campaign the passions of the people were wrought up to the highest pitch. Those of later generations can have no conception of the intense feeling that characterized politics during this period. From the time of the repeal of the Missouri Compromise there had been scarcely an intermission in the political excitement. 


\section{Political Campaign of 1860}

Politics was everywhere the all-engrossing topic, in the newspapers, in daily conversation, not only during campaigns but between campaigns. The bitterness of feeling exhibited in the debates of Congress and in the newspapers had permeated all classes of people, North and South. In the North opposition to slavery had been intensified by the wide reading of Uncle Tom's Cabin, by the enforcement of the Fugitive Slave Law, by the assault on Senator Sumner and by the universal and openly expressed exultation over it in the South, by the outrages of the Missouri border ruffians, and by the attempt to force upon the people of Kansas the Lecompton Constitution. By the year 1860 the Northern clergymen had found their voices and were now almost a unit in denouncing slavery. Nearly all, especially in New England, had become "political preachers," as they were termed by the Democratic speakers and newspapers.

If Uncle Tom's Cabin created a great sensation in the North, it created a greater sensation in the South, where it was regarded as a malicious libel on Southern society. Helper's Impending Crisis had added fuel to the flames. The operations of the anti-slavery societies of the North, through their secret emissaries in the South and the underground railroad, in aiding the escape of fugitive slaves, the opposition in the North to the efforts of their Southern masters to recapture them, and finally the John Brown raid-all these had combined to throw the whole South into a condition bordering on frenzy.

In the South all Republicans-Black Republicans as they were usually called-were regarded as Abolitionists and all Northern men as Yankees. Mingled with the bitterness felt throughout the South toward the Republicans was a feeling of contempt for what in the South was regarded as the mercenary spirit of the people of the North, and a settled conviction that Northern men who would not fight duels would not fight on the battlefield. The debates in Congress during this period are full of illustrations 
of this spirit on the part of the South. William Howard Russell, the correspondent of the London Times, visited Washington in April, I86I, and met with the South Carolina commissioners and many other leading Southern men, and thus records his impressions of their feeling toward the people of the North, and particularly those of New England: "The tone in which they alluded to the whole of the Northern people indicated the clear conviction that trade, commerce, the pursuit of gain, manufacture, and the base mechanical arts had so degraded the whole race, they would never attempt to strike a blow in fair fight for what they prized so highly in theory and in words. Whether it be in consequence of some secret influence which slavery has upon the minds of men, or that the aggression of the North upon their institutions has been of a nature to excite the deepest animosity and most vindictive hate, certain it is that there is a degree of something like ferocity in the Southern mind towards New England which exceeds belief." I The same spirit is clearly shown in the writings of the Southern historians. Pollard writes": "In the early history of the Northern colonists we find no slight traces of the modern Yankee; although it remained for those subsequent influences which educate nations as well as individuals to complete that character, to add new vices to it, and to give it its full development. But the intolerance of the Puritans, the painful thrift of the Northern colonists, their external forms of piety, their jaundiced legislation, their convenient morals, their lack of the sentimentalism which makes up the half of modern civilization, and their unremitting hunt after selfish aggrandizement, are traits of character which are yet visible in their descendants. On the other hand, the colonists of Virginia and the Carolinas were from the first distinguished for their polite manners, their fine sentiments, their attachment to a sort of feudal life, their landed gentry, their love of field-sports and dangerous adventure, and the prodigal and improvident aristocracy

Diary, p. 63 .

- Lost Cause, p. 49. 


\section{Political Campaign of 1860}

that dispenses its stores in constant rounds of hospitality and gayety.

"Slavery established in the South a peculiar and noble type of civilization. It was not without attendant vices; but the virtues which followed in its train were numerous and peculiar, and asserted the general good effect of the institution on the ideas and manners of the South. If habits of command sometimes degenerated into cruelty and insolence; yet, in the greater number of instances, they inculcated notions of chivalry, polished the manners, and produced many noble and generous virtues. If the relief of a large class of whites from the demands of physical labor gave occasion in some instances for idle and dissolute lives, yet at the same time it afforded opportunity for extraordinary culture, elevated the standards of scholarship in the South, enlarged and emancipated social intercourse, and established schools of individual refinement. The South had an element in its society-a landed gentrywhich the North envied, and for which its substitute was a coarse, ostentatious aristocracy that smelt of the trade, and that, however it cleansed itself and aped the elegance of the South and packed its houses with fine furniture, could never entirely subdue a sneaking sense of its inferiority. There is a singularly bitter hate which is inseparable from a sense of inferiority; and every close observer of Northern society has discovered how there lurked in every form of hostility to the South the conviction that the Northern man, however disguised with ostentation, was coarse and inferior in comparison with the aristocracy and chivalry of the South.

"The civilization of the North was coarse and materialistic. That of the South was scant of show, but highly refined and sentimental. The South was a vast agricultural country; waste lands, forest, and swamps often gave to the eye a dreary picture; there were no thick and intricate nets of internal improvements to astonish and bewilder the traveler, no country picturesque with towns and villages 
to please his vision. Northern men ridiculed this apparent scantiness of the South, and took it as an evidence of inferiority. But this was the coarse judgment of the surface of things. The agricultural pursuits of the South fixed its features; and, however it might decline in the scale of gross prosperity, its people were trained in the highest civilization, were models of manners for the whole country, rivaled the sentimentalism of the oldest countries of Europe, established the only schools of honor in America, and presented a striking contrast in their well-balanced character to the conceit and giddiness of the Northern people."

These are bitter words, tinged perhaps with a feeling of resentment for the defeat of the "Lost Cause." They were written nearly fifty years ago. Probably no Southern historian, not even Pollard were he living, would write them now, for in the years since Pollard wrote them the history of the Civil War has been more fully told. The story of the Bloody Angle and other never-to-be-forgotten fields, where the Stars and Stripes and the Stars and Bars mingled their folds and underneath them men in blue and men in gray fought to the death, has proved beyond question the heroism of the soldiers of the South; it has also proved that the blood of the men who fought at Bunker Hill still coursed through the veins of their descendants. But there is little doubt that before the beginning of the Civil War the feeling towards the people of the North, as expressed by Pollard, was that generally entertained in the South.

At the beginning of the year 1860 all were looking forward to the political conventions that were to frame the platforms and put forward the candidates to be voted upon at the presidential election of that year. The first national political convention held was that of the Democratic party at Charleston, South Carolina. At the time of holding the convention there was probably no place in the United States where Douglas and the doctrine of popular sov- 
ereignty were more detested than they were in Charleston. The convention assembled on April 23, $1860 .{ }^{\text {: }}$

In an introductory note to his report of the proceedings of the Charleston convention Halstead thus aptly states the central questions uppermost in the minds of the delegates: "The Hon. Stephen A. Douglas was the pivot individual of the Charleston convention. Every delegate was for or against him. Every parliamentary war was pro or con Douglas. On the route to Charleston delegates and others who were proceeding to attend the convention talked about Mr. Douglas. The questions on every car and at every way-station were: Would he be? Could he be? Should he be nominated? Could he get the two thirds? Would the South support him if he should be nominated? Would the Administration acquiesce if he were nominated?" In the list of delegates were noted politicians of that day: from New York, Dean Richmond, Isaiah Rynders, August Belmont, Erastus Corning, Sanford E. Church, Peter Cagger; from Massachusetts, Caleb Cushing, Benjamin F. Butler; from Ohio, George W. McCook, George E. Pugh, Washington McLean; from Illinois, W. A. Richardson; from Alabama, W. L. Yancey; from Mississippi, E. Barksdale. Many of the delegates were then, or afterwards became, noted in civil or military life. Other noted men, not named as delegates, were also present. From the North were John A. Logan and John A. McClernand, both

${ }^{2}$ Murat Halstead, then a newspaper reporter, attended all the national political conventions of that year and published a full report of them in pamphlet form entitled A History of the National Political Conventions, \& c., 1860. An official report of the Charleston and Baltimore national Democratic conventions, entitled Proceedings of the Conventions at Charleston and Baltimore, was published under the supervision of the National Democratic Executive Committee in a pamphlet of 255 pages. The recording secretary, John G. Parkhurst, also published a pamphlet of 188 pages entitled Official Proceedings of the Democratic National Convention held in 1860 at Charleston and Baltimore. In this report, at page 27 , is a full list of the delegates, not contained in the report published by the national executive committee. 
of Illinois, who were there in the interest of Douglas. From the South was John Slidell, whose "special mission was to see that Douglas was not nominated"; also Senator Jesse D. Bright of Indiana, who was there for the same purpose. The Mississippians had "the Freeport speech of Douglas with them, intending to bombard Douglas in the convention with ammunition drawn from it." Halstead goes on to say: "The ultra Southern men sneer at the idea of Douglas's nomination and inquire 'Where was he two years ago?' and answer the question themselves'caucusing with Seward-leagued with the Black Republicans against a Democratic Administration.' "

Butler of Massachusetts made himself conspicuous early in the convention. He had a unique political and military career before and after the convention. His political principles were as variegated as the colors of Joseph's coat. He was "everything by turns and nothing long." From the beginning to the end of his life he never was suspected of political sincerity. Halstead says of him: "He is as pro-slavery as possible. ... He admits that he had a Free-soil attack-a sort of political measles-but considers himself all the better for having recovered from it."

Caleb Cushing of Massachusetts, who had been AttorneyGeneral in Pierce's Cabinet, was selected as president of the convention. The committee on platform could not agree and on April 27 submitted two reports, W. W. Avery of North Carolina presenting the majority and George E. Pugh of Ohio the minority report. The resolutions on the subject of slavery recommended by the majority were substantially the same as those introduced by Jefferson Davis in the Senate of the United States. The resolutions on the subject of slavery offered by the minority evaded any direct expression of opinion on the questions involving the right to hold slaves as property in the Territories, but asserted that these were judicial, and pledged the party to abide by the decisions upon them of the Supreme Court of the United States. 


\section{Political Campaign of 1860}

Butler of Massachusetts also presented a minority report, signed by himself alone, proposing the adoption of the Cincinnati platform of 1856 "without addition or alteration." A heated discussion followed. The Southern leaders denounced the minority platform reported by Pugh as shuffling and deceptive, susceptible, like the Cincinnati platform, of one interpretation in the North and of another in the South. Really it meant, so it was argued, that the party must abdicate its function of deciding for itself its political policy, and leave it to the Supreme Court of the United States to define the party's policy on the slavery question. And yet, it was said, no two of the judges of the Supreme Court in the Dred Scott case had agreed throughout, but now it is proposed to bind the party, not only by its past decisions, but also by such as other judges of that Court might make in the future, and substitute their judicial decisions as declarations of the political principles of the Democratic party. Halstead's description of the "smartness" so characteristic of Butler in disposing of the objection to the Cincinnati platform will bear repetition: "General Butler of Massachusetts proceeded to dissect both platforms and did it with an incisive ferocity that was refreshing to behold: 'The Cincinnati platform had had two interpretations placed upon it, eh! So had the Bible and the Constitution of the United States. Gentlemen could not construct a platform that would not have a double interpretation." " Undoubtedly the platform would have better suited Butler if susceptible of forty interpretations instead of only two, for then there would have been a separate interpretation for use in each State and Territory and some to spare. William L. Yancey of Alabama; an eloquent and captivating speaker-the "Prince of the Fire Eaters," as he is designated by Halstead,- - then addressed the convention in a speech of an hour and a half. Yancey was the idol of the Southern delegates. When he began speaking and when he concluded, he was greeted with "tremendous and protracted cheering." According 


\section{I4 Political History of Secession}

to Halstead, "he charged that the defeats of the Democracy in the North were to be traced to the pandering by the party in the free States to anti-slavery sentiments; they had not come up to the high ground that must be taken on the subject in order to defend the South, namely that slavery was right." He denounced Douglas for "refusing to admit Kansas into the Union as a slave State under the Lecompton Constitution." He also spoke of "the deep distrust the South had begun to entertain of the Northern Democracy and urged the fulfilling of the demand of the South that the Democratic party should now take clear and high ground upon a constitutional basis." There were some passages in his speech that were probably gall and wormwood to the Northern delegates. Speaking to them he said: "You are not in the ascendant now because you have tampered with the anti-slavery feeling of that section. ... You advocated that slavery was wrong. ... You gave up the real ground of battle, the key of success, when you acknowledged, what was the foundation of antislavery sentiment, that slavery was wrong. . . . If you had taken the position that has been taken by one gallant son of the North, who proclaimed, under the hisses of thousands, that slavery was right, that anti-slavery demon, if not dead, would long since have been in chains at your feet. But you have gone down under the admission on your part that your opponents placed their feet upon the strong foundation-stone of natural and Divine right; and I tell you, gentlemen, that you will continue to go lower still unless you change front and change tactics." Continuing he said: "Go before your Northern people and appeal to their loyalty to the Union and their loyalty to the Constitution. Make it a question of union or disunion, between you and Sewardism. . . . Take this issue by the horns; throttle anti-slavery in the very heart of its power on the question of the constitutional protection. Let them see that there will be disunion. Do you urge upon them that there will be disunion if we are defeated. . . . 
Go to the wall upon this issue, if events demand it. Accept defeat upon it. Let the threatened thunder roll and the lightning flash through the sky and let the dark cloud be pointed out by you, now resting on the southern horizon. Let them know that our people are in earnest." He closed with an appeal to Northern Democrats, in which he urged that if actuated by "love of God, by love of truth, by love of the great principles of equality," they would let the men of the South "hoe their own row in these Territories," adding: "If you beat us at the end you will be entitled to the palm of victory. If we beat you we will give you good servants for life and enable you to live comfortably, and we will take your poor white man and elevate him from the office of bootblack and from the other menial offices which belong not to the highest order of civilization, will elevate him among the master race and put the negro race to do his dirty work which God designed that they should do."

As soon as Yancey had concluded, George E. Pugh of Ohio took the floor. He was heard with interest, but not with approval, as the spokesman of Stephen A. Douglas. His speech was mainly a defense of the Northern Democracy against the charges of Yancey and other Southern leaders, mingled with supplications for mercy. He told how Northern Democrats had fought against fearful odds, and how so many of its chosen leaders had gone down in battling for the cause of the South. Once only did he betray resentment for the cruel taunts of Yancey. "Now when we come here to debate with you," he said, "you commence by telling us that we are an inferior class of beings; that we shall not assume to have or express any opinions; that we shall not call on you to stand by your plighted faith; that we shall put our hands on our mouths and our mouths in the dust. Gentlemen, you mistake us. We will not do it."

On reassembling on the afternoon of April 28, the sixth day of the convention, the committee on resolutions again 
reported their inability to agree and submitted majority and minority reports. Mr. Avery of North Carolina submitted the report of a majority of the committee. The resolutions relating to slavery were as follows:

"Resolved, That the platform adopted by the Democratic party at Cincinnati be affirmed, with the following explanatory resolutions:

"First, That the government of a Territory organized by an act of Congress is provisional and temporary; and, during its existence, all citizens of the United States have an equal right to settle with their property in the Territory without their rights, either of person or property, being destroyed or impaired by congressional or territorial legislation.

"Second, That it is the duty of the Federal government, in all its departments, to protect, when necessary, the rights of persons and property in the Territories, and wherever else its constitutional authority extends.

"Third, That when the settlers in a Territory, having an adequate population, form a State constitution, the right of sovereignty commences, and, being consummated by admission into the Union, they stand on an equal footing with the people of other States; and the State thus organized ought to be admitted into the Federal Union, whether its constitution prohibits or recognizes the institution of slavery.

"Fifth, That the enactments of State legislatures to defeat the faithful execution of the Fugitive Slave Law are hostile in character, subversive of the Constitution, and revolutionary in their effect."

It will be observed that these resolutions incorporate the substance of those introduced in the Senate by Jefferson Davis for the purpose of exterminating Douglas. Mr. Samuels of Iowa submitted a minority report, the resolutions relating to the slavery question being as follows:

"I. Resolved, That we, the Democracy of the Union, in 


\section{Political Campaign of 1860}

convention assembled, hereby declare our affirmance of the resolutions unanimously adopted and declared as a platform of principles by the Democratic convention at Cincinnati in the year 1856 , believing that Democratic principles are unchangeable in their nature when applied to the same subject-matters; and we recommend, as the only further resolutions, the following:

"2. Inasmuch as differences of opinion exist in the Democratic party as to the nature and extent of the powers of a territorial legislature, and as to the powers and duties of Congress, under the Constitution of the United States, over the institution of slavery within the Territories:

"Resolved, That the Democratic party will abide by the decisions of the Supreme Court of the United States upon these questions of constitutional law.

"3. Resolved, That it is the duty of the United States to afford ample and complete protection to all its citizens, whether at home or abroad, and whether native or foreign born.

"5. Resolved, That the enactments of State legislatures to defeat the faithful execution of the Fugitive Slave Law are hostile in character, subversive of the Constitution, and revolutionary in their effect."

Butler also submitted as his minority report the same one previously offered by him. On Monday, April 30 the seventh day of the convention, the voting on the platform began and the platform reported by the minority was adopted by a vote of 165 to 138 . A division having been ordered, a vote was taken on the resolutions of the minority platform separately, upon which all were adopted except the second. At this point all the delegates from Alabama, Mississippi, Louisiana, South Carolina, and Florida withdrew from the convention. In withdrawing D. C. Glenn of Mississippi said: "At Cincinnati we adopted a platform on which we all agreed. ... What is the construction placed upon that platform in different 


\section{I8 Political History of Secession}

sections of the Union? You at the West said it meant one thing; we at the South said it meant another; either we were right or you were right; we were wrong or you were wrong. We came here to ask you which was right and which was wrong. You have maintained your position. You say that you cannot give us an acknowledgment of that right which, I tell you here now, in coming time will be your only safety in your contests with Black Republicans of Ohio and of the North. ... In such a situation of things in the convention of our great party it is right that we should part. Go your way and we will go ours. The South leaves you-not like Hagar, driven into the wilderness, friendless and alone, but I tell Southern men here, and for them I tell the North, that in less than sixty days you will find a united South, standing side by side with us."

On the 8th day a majority of the delegates from Georgia and also a majority of the delegates from Arkansas withdrew. W. B. Gaulden of Georgia gave his reasons for remaining in the convention, and proceeded to make a speech in which he said that "there was but one remedy at present for the evils the South complained of, and that was to reopen the African slave trade. In this he looked to the Northern Democracy to aid them." The "African slave trade man," he said, "is the Union man-the true Christian man. . . . For the African slave trader goes to a heathen land and brings the savage here and christianizes and moralizes him and sends him down to posterity a happy man." Continuing, he said that "he had himself purchased some slaves in Virginia and had to pay from one thousand to twelve hundred dollars, while he could buy a better negro in Africa for fifty dollars." Gaulden's speech was received with "shouts of laughter and applause, repeated round after round."

Most of the Northern delegates, regarding the slave trade as piracy, as it was declared to be by the laws of nearly all civilized nations, were probably not familiar, before hearing 


\section{Political Campaign of 1860}

Gaulden, with the moral arguments adduced by him in favor of reopening the slave trade as a missionary enterprise, whereby the African barbarians might be rescued from their heathenish surroundings and brought to a land where they could enjoy the blessings of Christian slavery; this too when raw material for Christian converts of the best quality could be got in Africa at $\$ 50$ per head, while an inferior grade in Virginia cost at least \$1200 per head.

The balloting on nominations for President began on the eighth day. Before proceeding to ballot for President a resolution was adopted that no persons should be declared nominated who had not received "two thirds of all the votes the full convention was entitled to cast." On the first ballot Douglas received $1451 / 2$ votes, while the rest were scattered among James Guthrie of Kentucky; Daniel S. Dickinson of New York; Robert M. T. Hunter of Virginia; Andrew Johnson of Tennessee; Joseph Lane of Oregon; Isaac Toucey of Connecticut, and Franklin Pierce of New Hampshire. The balloting continued for three days and 57 ballots were taken. On the last ballot Douglas received $151 \frac{1}{2}$ votes, less than the two thirds required for a nomination. On May 3, the tenth and last day, the convention adjourned to meet at Baltimore, Maryland, on June I8. One of the reasons for adjourning was in order to give the States whose delegates had seceded an opportunity of filling their places with other delegates, and this was provided for in the resolution for adjournment.

The seceding delegates, after withdrawing from the regular convention, met in Charleston on May $I$ and organized under the name of "The Constitutional Democratic Convention," electing James A. Bayard of Delaware president of the convention, styled itself the representative of "The Constitutional Democracy," adopted for a platform one substantially like that which had been reported by the majority of the committee on resolutions at the regular convention, and then adjourned to meet in Richmond, Virginia, on the second Monday in June. 
The Northern delegates probably returned home sadder, possibly madder, if not wiser men. To some, at least, the hard terms of salvation proposed by their Southern allies must have come with something like a shock. Must they go home and preach the new gospel of Democracy according to the apostle Yancey, and exhort their Northern brethren that if they would be saved they must repent and acknowledge the divine right of slavery, else all were doomed to political perdition! Must they tell them to be prepared to accept, at no distant day, as an additional article of faith, the sacred duty of reopening the African slave trade! Must they tell their brethren of the North that they had no further political mission on earth except to be hewers of wood and drawers of water for the slave masters of the South! Was it to such base uses that Northern Democracy had come at last!

In the light of subsequent events we see now that the secession from the Democratic convention of the delegates from the cotton States was a preparatory step to the secession of those States from the Union. This was undoubtedly so intended by Jefferson Davis, Yancey, and other Southern leaders. There is abundant evidence not only that the extreme pro-slavery leaders of the South intended before the assembling of the Democratic National Convention to secede from it if it did not adopt a platform in conformity with their views of slavery, but that they also intended before the Republicans had made any presidential nomination or adopted any national platform, to secede, or at least to make an attempt to secede, from the Union in the event of the election of any Republican to the Presidency. Indeed this was expressly avowed in a letter of C. C. Clay of Alabama, which is published without contradiction and evidently with approval by Jefferson Davis in his history of the Confederacy.: In this letter Clay states that "before the election of Lincoln all the Southern States, excepting one or two, had pledged themselves to

I Rise and Fall, vol. i., p. 307 . 


\section{Political Campaign of 1860}

scparate from the Union upon the triumph of a sectional party in the presidential election.":

The ultimate objects of the seceders from the Charleston convention were not fully understood by the great mass of people in the South and probably few men in the North divined the full meaning of this initiatory step towards secession. At least one Southern statesman, not in sympathy with secession, fully understood the meaning of this preparatory step and forecast the consequences of it. Alexander H. Stephens, of Georgia, in speaking of it said: "Men will be cutting one another's throats in a little while. In less than twelve months we shall be in a war and that the bloodiest in history. Men seem to be utterly blinded to the future. What is to become of us then? God only knows. The Union will certainly be disrupted."

The next national political convention was that representing the remnants of the old Whig and the American or Know-nothing parties, which met at Baltimore on May 9, 1860. From the Northern States there were present delegates from Maine, Vermont, Massachusetts, Connecticut, New York, New Jersey, Pennsylvania, Ohio, Indiana, and Illinois. From the Southern States there were delegates from Delaware, Virginia, North Carolina, Alabama, Mississippi, Georgia, Arkansas, Texas, Tennessee, Kentucky, and Missouri. Among the delegates were Washington Hunt and Erastus Brooks of New York, Richard W. Thompson of Indiana, Governor Allen Trimble and John Scott Harrison of Ohio, George S. Hillard of Massachusetts, W. G. Brownlow and A. J. Donelson of Tennessee, and Leslie Coombs of Kentucky. The convention was called to order by John J. Crittenden of Kentucky, chairman of the executive committee. Washington Hunt, of New York, was made president of the convention. A committee on

\footnotetext{
"See also Phillips, paper on "Georgia and State Rights," in Annual Reports of the American Historical Association, for the year 1901, vol. ii., pp. 164-91; Thomas, paper on "Southern Non-Slaveholders in the Election of 1860," in Political Science Quarterly, vol. xxvi., p. 222.
} 
resolutions was appointed and then the convention adjourned until the next day. On the next day the platform committee reported as the platform of the party a resolution: "That it is both the part of patriotism and of duty to recognize no political principles other than-The Constitution of the Country; the Union of the States; and the Enforcement of the Laws." John Bell, of Tennessee, was nominated for President and Edward Everett of Massachusetts for Vice-President, both "old line" Whigs. Of the platform it was wittily said "that it meant everything in general and nothing in particular." 


\section{CHAPTER XX}

\section{POLITICAL CAMPAIGN OF I 860 (Continued)}

BY this time the Republican party had absorbed nearly $B$ all the Free-soil Democrats and anti-slavery Whigs. A great crowd assembled in Chicago to witness the gathering of the Republican National Convention on May $16,1860$. A temporary building called the Wigwam had been erected for the use of the convention, said to have been large enough to accommodate I0,000 people. The crowd began to gather several days before the meeting of the convention. It is said that over 25,000 from outside the city were in attendance. The hotels were packed, especially the Tremont House where Horace Greeley and Frank P. Blair were stopping. The "boomers" of the various candidates were there, and there was a goodly number of the latter: William H. Seward of New York, Abraham Lincoln of Illinois, Simon Cameron of Pennsylvania, Edward Bates of Missouri, and others. Ohio had a surplus of candidates: Salmon P. Chase, Benjamin Wade, and John R. McLean. Thurlow Weed, a politician noted for his skill in manipulating conventions, was the general manager for Seward, assisted by William M. Evarts and other distinguished New York men, and by Carl Schurz of Wisconsin and otherwellknown Republicans from other States. Lincoln's principal managers were N. B. Judd, David Davis, and O. H. Browning of Illinois. The well-known editor A. K. McClure and others were there to look after the interests of other candidates. There was a bitter contest in the Ohio delegation between the friends of Chase and Wade, which left no 


\section{Political History of Secession}

chance for the nomination of either of them. There was also a considerable undercurrent of opinion favorable to the nomination for President of William Pitt Fessenden of Maine, but this was not encouraged either by him or by his friends. Long before the convention assembled, however, it was well understood that the contest lay between Seward and Lincoln, with the chances seemingly in favor of Seward. The New York delegation made a gorgeous display. The delegates had brought a great crowd with them and marched through the streets 10,000 strong, preceded by a fine band, all shouting for Seward. But this was more than offset by the admirers of Lincoln. In front of the office of the Chicago Press and Tribune were displayed two fence rails, which were vouched for as being part of three thousand cut and split by "Honest Old Abe" in the Sangamon river bottom more than twenty years before. Inside the office were two more, brilliantly lighted. Crowds stood about these sacred relics and gazed on them with mingled awe and admiration and shouted themselves hoarse for the backwoodsman who had fashioned these wonderful specimens of primitive pioneer art. As campaign arguments the rails were quite as effective as the Harrison log cabin of 1840 , with its coonskins and its out-hanging latchstring. Thousands of Illinois Republicans were in attendance, all enthusiastic for Lincoln, who helped to shout for him. The Chicago Republican newspapers were a unit for him. Indeed the local political atmosphere was of a distinct and unmistakable Lincoln hue.

Among other curiosities which served to interest the crowd was a huge bowie knife, seven feet long and weighing over forty pounds, bearing on one side the inscription: "Presented to John F. Potter by the Republicans of Missouri," and on the other: "Will always keep a 'Pryor' engagement."

All the free States were represented by delegates equal in number to the electoral vote to which they were respec- 
tively entitled. There also appeared fifteen delegates from Virginia, twelve from Kentucky, nine from Missouri, six from Texas, six from Delaware, and eight from Maryland. No other slave States were represented.

When the convention assembled on the morning of the 16th, the crowd was such that not more than one fifth could get inside the Wigwam. Among the delegates present were many men alrcady of national renown, and many more who became renowned afterward in civil or military life. From New York were William M. Evarts, the head of the delegation, and Preston King; from Pennsylvania, David Wilmot, author of the celebrated "Wilmot Proviso," Thaddeus Stevens, Andrew H. Reeder, formerly Governor of Kansas, William D. Kelley; from Massachusetts, John A. Andrew, afterwards Governor, George S. Boutwell; from Ohio, D. K. Cartter, Benjamin Eggleston, Fred Hassaurek, Thomas Corwin, Joshua R. Giddings; from Illinois, N. B. Judd, David Davis, O. H. Browning; from Wisconsin, Carl Schurz; from Iowa, John A. Kasson, William B. Allison; from Indiana, Daniel D. Pratt, Caleb B. Smith; from Maryland, Francis P. Blair. Horace Greeley, not having been able to get on the New York delegation, presumably on account of his hostility to Seward, appeared as one of the delegates from Oregon.

When some well-known Republican was recognized on entering the convention, like Horace Greeley, Carl Schurz, or Francis P. Blair, there was great cheering. Horace Greeley "of Oregon" received the greatest ovation thus given. Edwin D. Morgan of New York, chairman of the National Republican Committee, called the convention to order, and nominated David Wilmot of Pennsylvania for temporary president. Committees on permanent organization, on credentials, and on rules were then appointed. The committee on permanent organization reported George Ashmun of Massachusetts for permanent presiding officer, and he was escorted to the platform by Preston King and Carl Schurz. The one was short and fat as a butter-ball 


\section{Political History of Secession}

and the other was tall and slender, and when King attempted to speak to Schurz he was compelled to throw his head back and cock one eye as though gazing at some far-away object high up in the firmament above. All this appealed so strongly to their sense of the ludicrous that the delegates broke out into a general titter. Ashmun proved to be an excellent presiding officer. A committee on resolutions was appointed, including Horace Greeley "of Oregon," and then the convention adjourned until the next day.

At the beginning of the second day's session, Wilmot objected to receiving the delegations of States like Virginia and Texas that had no constituencies, but the committee on credentials reported in favor of admitting the full delegation from Virginia and allowing Texas six.

The report of the minority of the committee on rules was adopted, requiring for a nomination 304 votes, this number being a majority of the whole number of delegates, if all the states were represented in the convention by full delegations.

The next thing was the report of the platform committee. Before a vote was taken upon it, Joshua $\mathrm{R}$. Giddings of Ohio offered an amendment to the first resolution, the object of which was to incorporate in the platform the clause of the Declaration of Independence defining the inalienable rights, but the amendment was voted down. One delegate objected that the amendment was "all gas" and another that "the principles of the Declaration of Independence, though good, would be as much out of place in the platform as would be the Ten Commandments." Probably one of the real reasons for objecting to the amendment was that the delegates were in a hurry to proceed with the balloting, and possibly another reason was the fear that Giddings, a well-known Abolitionist, might, under the guise of an amendment, slip into the platform something that might be construed as pledging the party to Abolitionism. Giddings, deeply grieved, started to leave the convention. On his way out he met George William Curtis. When Curtis 


\section{Political Campaign of 1860 (Continued)}

was informed of the trouble he at once offered substantially the same amendment offered by Giddings, except that it was offered as an amendment to the second resolution. By this neat little parliamentary coup the objection that the amendment was out of order was obviated and Curtis in support of the amendment made a graceful and eloquent speech, in which he said: "I have to ask the convention whether they are prepared to go upon the record and before the country as voting down the words of the Declaration of Independence. I rise simply to ask the gentlemen to think well before, upon the free prairies of the West in the summer of 1860 , they dare to wince and quail before the assertions of the men in Philadelphia in 1776 , before they dare to shrink from repeating the words that these great men enunciated." There was no resisting Curtis's appeal, which took the convention by storm, and the amendment was adopted amid great applause. ${ }^{*}$ The platform contained a plank favoring a protective tariff; another favoring the building of the Pacific railroad; another washing its hands of Know-nothingism; another favoring appropriations for river and harbor improvements of a national character; but the chief interest was in the planks concerning slavery in the Territories. These were the seventh and eighth, which were as follows:

"7. That the new dogma that the Constitution, of its own force, carries slavery into any or all of the Territories of the United States, is a dangerous political heresy, at variance with the explicit provisions of that instrument itself, with contemporaneous exposition, and with legislative and judicial-precedent; is revolutionary in its tendency, and subversive of the peace and harmony of the country.

"8. That the normal condition of all the territory of the United States is that of freedom. That as our republican fathers, when they had abolished slavery in all our national territory, ordained that 'no person should be deprived of life, liberty, or property, without due process

'Julian, Life of Giddings, pp. 372-74. 
of law,' it becomes our duty, by legislation, whenever such legislation is necessary, to maintain this provision of the Constitution, against all attempts to violate it; and we deny the authority of Congress, of a territorial legislature, or of any individuals, to give legal existence to slavery in any Territory of the United States."

As soon as the platform had been adopted the Seward men urged going at once into a ballot for nominations for President, but the clerks had not yet got their tally sheets ready and the convention adjourned until the next day.

At the close of the second day the New York men were in high feather. They deemed the nomination of Seward the next day a certainty. Besides the New York delegates there were many influential New York men present urging Seward's nomination-Thurlow Weed, Moses H. Grinnell, James Watson Webb, and others. Up to this time Seward's candidacy had been managed with consummate skill. His opponents were disheartened. Near midnight Greeley sent a dispatch to the New York Tribune, giving it as his conclusion that Seward would be nominated on the next day. But James G. Blaine, who was present, not as a delegate, but as an interested spectator, although only thirty years of age, knew far more than Greeley and many older men about practical politics. His great political sagacity is manifest from a letter written by him to Fessenden on May 16 the first day of the convention, in which he said ${ }^{x}$ :

"I arrived here Saturday night. . . I I may mention, however, that the Seward force is on the ground and assume an air of dictation which is at once unwarranted and offensive, and which I think will create a reaction before Wednesday. They cannot count up more than a third of the votes from States that can carry the ticket, and how much they intend or expect to make from such delegates as come from slave States has not yet transpired. Should he be nominated by the aid of the delegates that can promise him no support, the Pennsylvanians would consider it a most

' Life and Public Services of William Pitt Fessenden, vol. i., p. 112. 


\section{Political Campaign of 1860 (Continued)}

insulting disregard of their rights and wishes. I do not myself believe that he will be nominated, though a great many here think otherwise. If he is not, I will adhere to the opinion I expressed to you in Portland, that the game lies between Lincoln and yourself-Chase, McLean, Banks, and Bates stand no chance. Cameron is hotly urged by a majority of the Pennsylvanians, but the proposition is scouted on all hands outside of that State. Wade cannot be made a compromise candidate. His speeches in Maine and on the Western Reserve are remembered by ioo large a number."

The ways of political conventions arc past finding out and are even more uncertain than the proverbial uncertain verdicts of juries, as many a politician can testify whose carefully prepared "slate" has been dashed in pieces on the eve of balloting. Strenuous work was done during the night before the balloting to induce the delegates to vote for Lincoln, and possibly arguments were used that had little merit in them. Some, however, were used that had great weight, at least among politicians. It should not be assumed, as has sometimes been hinted, that the Sangamon rails, and the shouting, were the dominating factors in the selection of Lincoln and the defeat of Seward. This would discredit the merits of Lincoln as well as the intelligence of the delegates. Nor did Seward's declaration of the "irrepressible conflict" between frcedom and slavery impair his availability as a presidential candidate. Lincoln had announced the same doctrine in his declaration that "a house divided against itself cannot stand." But Seward's "higher-law" pronouncement was far more radical than anything ever advocated by Lincoln, so extremely radical in fact that it was feared, and justly feared, thai it would weaken Seward's candidacy among the conservative and business voters of the country. Moreover, Seward had taken a strong stand against the Knownothing movement. This rendered him popular with the foreign voters, but it was a question to what extent it 


\section{0 Political History of Secession}

would weaken his candidacy among those who had been formerly workers in, or in sympathy with, the American or Know-nothing party; as before stated that party in $\mathbf{1} 855$ had elected governors in nine Northern States and fortythree members of Congress and its strength in the coming campaign was an unknown and uncertain quantity. Seward had also gained the favor of the Catholics in New York by his siding with them on questions growing out of the distribution of the school funds, but this also, it was feared, might excite the hostility of the members of the old Know-nothing party. Another argument used against Seward was that he could not carry the States of Pennsylvania, Illinois, and Indiana. Andrew G. Curtin, the Republican nominee for governor of Pennsylvania, and Henry S. Lane, the Republican nominee for governor of Indiana, threatened, so it was rumored, that the nomination of Seward meant certain defeat to them, and that if Seward were nominated, both Curtin and Lane would refuse to continue as gubernatorial candidates. This was a most effective argument for at that time both Pennsylvania and Indiana held their State elections on the second Tuesday in October and defeat in October meant certain defeat at the presidential election. That the arguments, whatever they were, were effective, was proved by the balloting on the following day.

The nominations were then made but the greatest applause greeted the nominations of Seward and Lincoln. There was renewed shouting when the nominations of both were seconded. There were many surprises in the first ballot. Upon calling the roll, the New England States divided their votes between Lincoln and Seward. Neither Rhode Island nor Connecticut gave Seward a vote. Virginia, which had been expected to vote for Seward, gave him only eight and gave fourteen for Lincoln. Illinois and Indiana voted solidly for Lincoln, but Michigan, Wisconsin, and Minnesota voted solidly for Seward. The Oregon delegation voted for Bates. On this ballot, Seward received 


\section{Political Campaign of 1860 (Continued)}

173 $1 / 2$ votes and Lincoln 102, the others scattering. On the second ballot the Chase and Fremont votes of New Hampshire all went to Lincoln, and he then got the entire vote of Vermont. The Pennsylvanians gave 48 of their 54 votes to Lincoln. On this ballot Lincoln gained 79 votes, the vote now standing $184 \frac{1}{2}$ for Seward, and Lincoln's $18 \mathrm{I}$, with a few scattering. The number of votes necessary to a choice was 233 , and before the third ballot was concluded Lincoln had received $23 \mathrm{I} 1 / 2$-only lacking $\mathrm{I} 1 / 2$ votes of the number required to nominate him. The excitement was now intense. At this point Cartter of Ohio rose and announced the change of four votes in Ohio from Chase to Lincoln. Mr. Halstead describes the scene that followed": "The deed was done. There was a moment's silence. The nerves of the thousands, which through the hours of suspense had been subjected to terrible tension, relaxed, and as deep breaths of relief were taken there was a noise in the Wigwam like the rush of a great wind in the van of a storm-and in another breath the storm was there. There were thousands cheering with the energy of insanity." "A man who had been on the roof, and was engaged in communicating the results of the ballotings to the mighty mass of outsiders, now demanded by gestures at the skylight over the stage to know what had happened. One of the secretaries, with a tally-sheet in his hands, shouted'Fire the salute! Abe Lincoln is nominated!' As the cheering inside the Wigwam subsided, we could hear that outside, where the news of the nomination had just been announced. And the roar, like the breaking up of the fountains of the great deep, that was heard, gave a new impulse to the enthusiasm inside. Then the thunder of the salute rose above the din, and the shouting was repeated with such tremendous fury that some discharges of the cannon were absolutely not heard by those on the stage. Puffs of smoke, drifting by the open doors, and the smell of gunpowder, told what was going on."

'Halstead, p. 149. 
Then followed speeches from the friends of Sewardthe various delegates who had voted for him-in support of a motion to make the nomination of Lincoln unanimous. Nominations were then made for Vice-President, the principal candidates being Hannibal Hamlin of Maine, and Cassius M. Clay of Kentucky, and on the second ballot Hamlin was nominated, and then the convention adjourned.

As before stated, the conventions of the two rival factions of the Democratic party had adjourned at Charleston, the regular convention to meet at Baltimore on June 18 , the seceders to meet at Richmond, Virginia, on the second Monday in June. The regular convention, the "rump," as Yancey sarcastically styled it, assembled at Baltimore on the appointed day. Trouble began at once in determining the qualifications of those claiming to be entitled to participate in the proceedings of the convention, and this was the first matter to engage the attention of the convention. On the first roll call there were no responses when the States of South Carolina, Georgia, Florida, Alabama, Louisiana, Mississippi, and Texas were called, and but one delegate answered for Arkansas. It appeared, however, that there were a number of persons present claiming seats as delegates from all the States except South Carolina. Some had been appointed originally as delegates to the Charleston convention and some had not; some had been appointed, or claimed to have been appointed, to fill the vacancies made by the Charleston seceding delegates, but there was in nearly all such cases a dispute as to the validity of their appointment. There were also various contests, some between two entire State delegations, each claiming to be entitled to sit as representatives of the same State, and some between individual contestants. The committee on credentials could not agree and on the second day asked further time, and did not make any report until the fourth day, when it submitted a majority and two minority reports. 


\section{Political Campaign of 1860 (Continued)}

The first four days of the convention were almost entirely consumed in wrangles over the claims of those asserting their rights to seats as delegates. During the discussions over these questions considerable feeling was shown, but it was especially marked in the disputes between the Douglas men and the anti-Douglas men in the same delegations. Randall and Montgomery of the Pennsylvania delegation, the one a Douglas, the other an anti-Douglas delegate, got into an altercation that came near to a personal encounter, in which the words "liar," "lying scoundrel," and other abusive epithets were freely bandied. Hunter, an anti-Douglas delegate from Missouri, accused ex-Governor King, a Douglas delegate of the same State, of imitating Benton, who, he said, had tried to destroy the Democratic party of Missouri, as Douglas was trying to ruin the Democratic party in the nation.

The Douglas men vehemently opposed the seating of delegates who had seceded from the Charleston convention or who had announced their intention of seceding from the Baltimore convention if its platform or its nominee for President should not be to their liking. Montgomery of Pennsylvania, speaking on this question, said: "I am opposed to disunion. I am opposed to the advocates of it. I am opposed to secession either from the Union or from a Democratic convention. And when men take the responsibility upon themselves, when they file upon the desk of the secretary of this convention their protest, when they make speeches in my hearing and declare that the principles of the party are not their principles and they will not be bound to vote for its nominee, then I say it is high time, if they ask to come back again, that they shall declare that they have changed their minds."

Ex-Governor King, a Douglas delegate from Missouri, also made a significant speech. He was opposed to seating delegates with "roving commissions." The Richmond seceders' convention had met and adjourned. It had made no nominations, but adjourned from day to day, and the 


\section{Political History of Secession}

delegates to it were in the habit of attending the sessions and mingling with the delegates, of the Baltimore convention, though not taking part in the proceedings. Alluding to them, King said that the Richmond convention "had not adjourned, but simply took a recess; and its members come here as the man went to camp meeting-because he had a right to go. They come here only for mischief, and, if they could not have their own way, intended to go back and nominate some man who had not heels or bottom enough to get the nomination of this convention and run him against the regular nominee of the Democratic party made here. They would never get in here by his vote, so help him God. ... Would not such men have their own way at Richmond? Word was sent from Washington to Richmond by certain parties who had better been minding their own business there, encouraging these seceders to come to Baltimore. 'Come back,' it was said, 'come back and we have good reason to believe your platform will be conceded to you, and, if not, you can go away again.' Then they said Virginia had got to go too, and, of course, Kentucky would follow Virginia. Virginia was almost the only State that the Democrats of this State looked up to. North Carolina they reckoned would go and Tennessee will follow her mammy. . . . Some, he supposed, calculated upon Missouri following suit. And then it had been said that the nomination of Douglas would be denounced as equally sectional with that of Lincoln. If nothing else would do, they would denounce this as a bogus convention. They had the opinion of the highest legal authority, Washington's AttorneyGeneral Black, he supposed, that this convention was functus officio, the moment it adjourned at Charleston, and so these seceders were to go to Richmond and make a nomination, and turn round and call us bogus. He did not believe these men were backed by their constituents, or that they would be able to set the world on fire or dissolve the Union. Let them leave the party if they wished, there were plenty of good men remaining." 


\section{Political Campaign of 1860 (Continued)}

The majority report of the credentials committec recommended the seating of certain delegates named as the duly accredited delegates of the States of Mississippi, Louisiana, Arkansas, Texas, Alabama, and Georgia, and the seating of certain individual delegates whose seats were contested, one in Delaware, one in Missouri, and one in Massachusetts, their recommendations being embodied in a series of nine resolutions accompanying their report. On the fifth day a vote was taken on the main minority report, which was defeated by a vote of 150 to $1001 / 2$. A division having been called for, a vote was taken on each of the resolutions of the majority report separately, which resulted in all of them being adoptcd.

Up to this time the New York delegation had been regarded as a doubtful quantity, but all its thirty-five votes were now cast in favor of the majority report of the credentials committee. The significance of this vote was that it secured for Douglas a majority of the delegates and insured his nomination. At this point the convention began to go to pieces. Russell of Virginia at once announced the withdrawal from the convention of a large majority of the delegation of that State, and this was speedily followed by similar announcements of withdrawals, of a majority, or a considerable part, of the delegations of North Carolina, Tennessee, and Kentucky. On the next day there were more withdrawals and before the balloting began the entire delegations of California and Oregon withdrew, and various others, among them fifteen of the Massachusetts delegation, including Caleb Cushing, the president of the convention, and Benjamin F. Butler. The latter gave as one of his reasons for withdrawing that "he could not sit in a convention where the African slave trade- which is piracy by the laws of my country-is approvingly advocated." This was said in reference to the speech of Gaulden of Georgia advocating the reopening of the African slave trade, a repetition of the same speech which he had made in the Charleston convention. Butler had heard this at Charleston without 
any perceptible shock and remained until the close of the convention, voting on all the fifty-seven ballots. His sudden and unexpected spasm of conscience amused the delegates and was greeted with derisive laughter.

There were few gusts of passion on the part of the seceding delegates. Most of them apparently felt the sobering influence of the responsibility resting upon them, and expressed in their speeches their appreciation of the gravity of the situation and of the weighty consequences likely to follow breaking up the convention and disrupting the old Democratic party under whose flag they had participated in so many hard-fought battles. The most notable exception was the speech of a Northern man, that of Smith of California, who on retiring made a virulent speech insulting to the Douglas men, and so ill-timed and ill-mannered that the president of the convention ruled him out of order. The speeches of the withdrawing delegates, however, while generally courteous in tone, were significant as manifesting a deep-seated determination to yield nothing of the demands of the South.

When Cushing resigned the presidency of the convention he took his seat with the Massachusetts delegation and ex-Governor David Tod of Ohio, one of the vice-presidents, occupied the presiding officer's chair. Then the balloting began on the nominations for President. On the first ballot the whole vote cast was $1901 / 2$ of which Douglas received $173 \frac{1}{2}$, the other votes being scattered. On the second ballot Douglas received $18 \mathrm{I} 1 / 2$ votes and was declared the nominee. Benjamin Fitzpatrick of Alabama was nominated for Vice-President but declined the nomination and Herschel V. Johnson of Georgia was afterwards substituted in his place. At Io P.M. on the sixth day, June 23 , the convention adjourned.

The seceders from the Baltimore convention assembled at the Maryland Institute hall in Baltimore on June 23 and organized by electing Caleb Cushing president of the convention. There were present full delegations from 


\section{Political Campaign of 1860 (Continued)}

Alabama, Mississippi, Louisiana, Texas, Arkansas and partial delegations from Virginia, North Carolina, Tennessee, Kentucky, Missouri, Maryland, and Delaware. There were also present full delegations from California and Oregon, sixteen from Massachusetts, two from New York, and one from Vermont. The convention adopted as its platform the resolutions recommended to the Charleston convention by the majority of the committee on resolutions. John C. Breckinridge of Kentucky and Joseph Lane of Oregon were respectively nominated for President and Vice-President. While the balloting on nominations was in progress, Yancey was loudly called for and made a long speech. The delegates were by this time about worn out; they had been surfeited with speeches; Yancey offered nothing new, and his speech had not the setting, nor the charm that went with it, of his Charleston speech. This was the last of the Baltimore seceders' convention.

It may be noted that South Carolina entircly ignored both the regular and the seceders' conventions at Baltimore. No delegate, accredited or contesting, pro-Douglas or anti-Douglas, responded for the State of South Carolina at either of the Baltimore conventions.

As before stated, the convention composed of the seceders from the Charleston Democratic convention adjourned to meet in Richmond, Virginia, on the second Monday in June. The convention met at the appointed time and place but did nothing except to adjourn from day to day, during the sessions of the regular convention at Baltimore. During this time the members constituted what might be called an "army of observation." On the evening of June 26 , the delegates met and adopted as their platform the declaration of principles that had been recommended at the Charleston convention by the majority of the committee on resolutions. John C. Breckinridge of Kentucky and Joseph Lane of Oregon were respectively nominated as candidates for President and Vice-President, and then the convention adjourned. As there were no 


\section{$43^{8} \quad$ Political History of Secession}

Douglas Democrats present and the anti-Douglas leaders had everything their own way, we may readily accept the account of the Richmond Enquirer which states that the very brief session of the convention was characterized by "great enthusiasm" and that "all the proceedings were conducted with a calmness, dignity, and decorum which we have never seen excelled."

There were the usual formal notifications to the candidates nominated by the various conventions of their respective nominations, of which fact, according to a timehonored political fiction, they were supposed to have been previously wholly ignorant, and then the campaign opened.

The first session of the Thirty-sixth Congress continued until June 25, I860. Davis, after the nomination of Douglas, continued to hang over him like a vampire. Douglas's nomination seemed to have added fresh venom to Davis's hatred of him and the Mississippi Senator availed himself of the first opportunity to make a savage onslaught in the Senate on the doctrine of "squatter sovereignty." In the senatorial debates he so far overstepped the ordinary courtesies of the Senate as to make several personal allusions to Douglas of an offensive character. At one time he said, referring, as every one understood, to Douglas: "I would sooner have an honest man on any kind of a rickety platform you could construct than to have a man I did not trust on the best platform that could be made." I Senator Wigfall of Texas also made a speech in the Senate sneering at Douglas as a man "who had deserted the principles of our party." The Republicans could not help Douglas, because they also were opposed to the doctrine of popular sovereignty, and so remained, for the most part, silent, though far from indifferent, spectators of the battle between the rival Democratic leaders.

Davis continued to press the passage of the resolutions introduced by him in the early part of the session. So

× Cong. Globe, 36th Cong., ist sess., pt. iii., p. 2155 . 


\section{Political Campaign of 1860 (Continued)}

completely did he dominate the Senate that all the resolutions passed by decisive majorities, every Northern Democrat voting for them except Pugh and Douglas, the latter being absent. :

Douglas throughout the session had fought a losing, indeed a hopeless, fight against Davis and his Democratic allies. These were aided by all the power of Buchanan's Administration, which pursued Douglas with a vindictiveness scarcely inferior in its malignant spirit to that of Davis himself. Nevertheless Douglas continued to be, as he had been from the beginning, conspicuous as the hero of the session.

He denounced Yancey and his fellow-bolters from the Charleston convention as disunionists, divining and exposing their plans with marvelous precision. After quoting from the articles of the Southern League and from Yancey's letter to Slaughter he said: "The first article of the Southern League explains Yancey's whole plan-that our motto shall be 'a Southern confederacy.' Mr. Yancey's plan was to remain in the organization of the Democratic party; form the Southern League, bound by secrecy, for a Southern confederacy-involving disunion, of course; wait in the Democratic party until the proper moment came, and then by a sudden movement disrupt the party and plunge the cotton States into revolution. The proof is here clear that disunion was Mr. Yancey's object. A separate Southern confederacy was his whole end. He believed the South could not find safety anywhere else. His plan was to keep in the Democratic party until the proper moment came for revolution, then plunge the cotton States into it, break up the party and with the party the national confederacy. Sir, I cannot doubt but that this was Mr. Yancey's plan. I submit to the Senate and the country whether the 'proper moment' selected by him was not the Charleston convention, and whether the secession of these same States at Charleston was not in obedience to that

r Cong. Globe, 36th Cong., Ist sess., pt. iii., pp. 2321-50. 
plan? I do not mean to say, nor do I believe, that all the men who approved or defended that secession were disunionists, but I $d o$ believe that disunion was the prompting motive that broke up that convention." = $\mathrm{He}$ was unsparing in his denunciation of the Buchanan Administration. "This shows the folly," he said, "of attempting to erect any one man as an idol to be worshipped, whose nod is to be authority to Senators and Representatives. It shows the folly of allowing the President and his Cabinet to tell us what our duty is. I concede to the executive branch of the government freedom of thought and action in the performance of all the functions vested in him by the Constitution; but when it comes to voting on a measure I am as independent of him as he is of me. He has no more right to tell me how I shall vote than I have to tell him what he shall recommend, or whether he shall sign or veto a bill. Sir, whenever I shall recognize the President, be he who he may, of what party he may, as the head of my party to tell me how I shall vote in this chamber, I shall disgrace as well as betray the sovereignty of the State that sent me here. No, sir, republics are a sham unless the representatives of the States are as independent of the executive as he is of them." 2

The Democratic and Republican platforms contained planks on subjects other than slavery, such as the annexation of Cuba, the Pacific railroad, and the tariff, but none of them now interested the people. All interest was focused on the one subject of slavery. The one cardinal question was that of its extension or restriction. It could not be hidden, obscured, or evaded by any sort of phraseology in any platform. It was upon this question that all men talked, wrote, and thought, and probably not a single vote was cast in the ensuing election that was not influenced chiefly by the voter's convictions on this one question.

The American party amounted to but little in the cam-

- Cong. Globe, 36th Cong., ist sess., pt. iii., p. 2154.

$2 I d$., pt. iii., p. 2152. 
paign, except to furnish an excuse for voting for its candidates to those who did not wish to vote for either the Republican or Democratic ticket. Its candidates were respectable. There had been a time when Edward Everett's orations, "classic as marble and as cold," had captivated cultured audiences in both the North and the South, but now the speeches that roused enthusiasm were those like Yancey's of the South and those of a newer generation of orators in the North.

In the enumeration of the political parties in 1860 the Abolitionists should not be overlooked. The Liberty party nominated Gerrit Smith for President and Samuel McFarland for Vice-President, but the Garrisonians continued to abstain from voting, denouncing all political parties alike, including the Republican party, firing fulminations against slavery at long range, but otherwise doing little or nothing to help those who were on the firing line fighting to check its spread. ${ }^{-}$

In the South, especially in the cotton States, the overwhelming tide was for Breckinridge. Jefferson Davis and nearly all the prominent Southern Democratic leaders were for him, and in their speeches openly advocated secession in the event of Lincoln's election.

The Republicans were harmonious and enthusiastic and all over the North they had monster meetings. Prominent among the Republican political organizations were the "Wide Awake" clubs, organizations of a semi-military character, which often marched in uniforms in torchlight processions, numbering on some notable occasions over twenty thousand marchers. There were many speakers who became noted in that or in subsequent campaigns. To enumerate them would fill many pages. Lincoln did not enter upon a speaking campaign and made but few speeches. While the Republican masses shouted for him their trust was more in Seward. The Abolitionists refused to be comforted either by the Republican platform or by the

- Wilson, Rise and Fall, vol. ii., p. 695. 
Republican candidate. "Who is this huckster in politics? Who is this county court advocate?" sneered Wendell Phillips, speaking of Lincoln shortly after his nomination; and Garrison published in the Liberator of June 2, 1860, an article headed, "Abraham Lincoln, the slave-hound of Illinois," beginning with this sentence: "We gibbet a Northern hound to-day, side by side with the infamous Mason of Virginia." $x$

Many of Seward's friends felt that he had been sacrificed in the Chicago convention to expediency, and that Lincoln was wearing the crown that rightfully belonged to Seward. Seward was still facile princeps in the Republican councils and the great body of Republicans in the North still looked to him rather than to Lincoln for counsel and guidance. If Seward himself felt anything like resentment against either Lincoln or the Republican party for his defeat he never showed the least sign of it by word or action. $\mathrm{He}$ did not sulk in his tent but at an early period in the campaign he began an extensive speaking tour in behalf of the Republican ticket that embraced most of the Northern States. His itinerary took him as far west as Kansas and resembled a triumphal tour. Great ovations awaited him at every stopping point, and enormous crowds listened with breathless interest whenever he spoke, and everywhere his words left a deep and lasting impression, especially upon the old Whigs and the Germans. His speech at Detroit to an immense audience on September 4, 1860, was printed in all the principal Republican papers in the North and undoubtedly carried great weight.

In the North one of the most noted of the Republican speakers was Carl Schurz of Wisconsin, a German by birth. He had not only mastered the English language well enough to speak and to write it, but he had become thoroughly familiar with its strength and classic beauty. His speeches were masterpieces of political oratory. They were especially influential with the Germans, many of whom had

I William Lloyd Garrison, by his children, vol. iii., p. 503 . 
allied themselves in 1856 with the Democratic party, some because of its opposition to the Know-nothings, others because of its opposition to the so-called "sumptuary laws." But the Germans were lovers of liberty. They trusted their countryman, Schurz, and in localities where there was a large German vote Schurz's speeches were probably more potent than all others in inducing the voters of that nationality to vote the Republican ticket.

Prominent among the newspapers that espoused the Republican cause was the New York Tribune. Mention has already been made of its influence in the formation of the Republican party. Its editorials in opposition to slavery had left a lasting imprint upon multitudes of Northern voters. It had a great circulation and was a powerful factor in securing the success of the Republican candidates.

Douglas made a bold but hopeless fight. By nature he was of a hopeful disposition. In all his previous political life, in which he had fought many hard-contested political battles, he had been victorious. But, whatever may have been his hope at the beginning of the campaign, he was too discerning a politician not to sec, as the campaign progressed, that all the political signs forecast his defeat. The Republicans of the North were united and enthusiastic. So were the Democrats of the South, but they were enthusiastic for Breckinridge-not for Douglas. In both North and South the Buchanan Administration was fighting Douglas with unrelenting and unceasing vindictiveness. "It is scarcely possible," says one of Douglas's biographers, ${ }^{\text {" }}$ "for the people of this generation to have a proper appreciation of the difficulties under which Senator Douglas labored and the obstacles with which he was confronted during that great campaign. He was a Democrat nominated by a convention which represented a great majority of his party; yet, with all the bitterness and malice of revenge, the President and the whole Administration (a President and Administration to whose success in gaining the election

: Carr, Life of Douglas, p. 100. 


\section{Political History of Secession}

he had contributed more than any other human being) pursued him with malignant hatred from the opening of the campaign to its close. Every possible inducement was still held out to Democrats to turn against Douglas. The best offices within the gift of the President-marshalships, collectorships, postmasterships-were offered to Democrats as a reward for turning against Douglas. Democrats were still given to understand that support of Douglas closed every avenue to position, but that they might be favored if they should make a record of antagonism to Douglas."

One cannot look upon Douglas at this critical period of his life without a feeling of sympathy, not unmingled with admiration. The fates were now against him. Most men in his situation would have been appalled and unnerved; but Douglas, bold and defiant, continued to fight like a lion at bay. He entered upon a speaking campaign, making speeches in many places in the South as well as in the North. To a question put to him at Norfolk, Virginia, whether the Southern States would be "justified in seceding from the Union if Abraham Lincoln was elected President," Douglas, promptly and without any attempt at evasion, replied: "It is the duty of the President and of others in authority under him to enforce the laws of the United States as Congress passes and the courts expound them; and I, as in duty bound by my oath of fidelity to the Constitution, will exert all my power to aid the government of the United States in maintaining the supremacy of the laws against all resistance from any quarter whatever." At Petersburg,Virginia, he said there was "no grievance that can justify disunion." Goaded by the bitter opposition of both the Buchanan Administration and the Southern Democratic leaders, Douglas's courage and patriotism both seemed to rise to the occasion. At Raleigh, North Carolina, he said that "there is one thing remaining to be done, in order to prove us capable of meeting any emergency; and whenever the time comes I trust the Government will show itself strong enough to perform that final deed-hang a 


\section{Political Campaign of I 860 (Continued) 445}

traitor." To Douglas's great credit, it is to be said that throughout the campaign he never abated one iota of his unflinching patriotism in order to court favor in the South. He likewise refused to sanction any coalition with the followers of Breckinridge in any State for the purpose of electing a joint electoral ticket.

At this period the Ohio, Pennsylvania, and Indiana State elections were held in October preceding the presidential election. It was generally conceded that Ohio would go Republican, but both Pennsylvania and Indiana were debatable States and so was Illinois. In the southern parts of Illinois and Indiana, as before stated, there were large numbers who had come, or whose fathers had come, from Kentucky, Virginia, and North Carolina, and these sections were Democratic strongholds in which there wcre many sympathizers with slavery. So that there were many elements of uncertainty in the campaign, but, as it progressed, it was soon seen that Bell and Everett had little strength either in the North or in the South. It was also seen that Douglas had little or no chance of election. $\mathrm{He}$ was, as already stated, bitterly opposed by Jefferson Davis and other Southern leaders in the South and by the Buchanan Administration in the North. By this time his "popular sovereignty" doctrine had been so mutilated that it could no longer serve as a rallying point either in the North or in the South. Indeed, in the South it was now almost as odious as Abolitionism itself. It now became plain that the real contest was between Lincoln and the doctrines for which he stood, and Breckinridge and the doctrines for which he stood.

At the State election in Maine in September, the Republicans carried the State by eighteen thousand majority and "Have you heard from Maine?" became a Republican war cry in other Northern States. In the October elections the Republicans elected their State tickets in Ohio by over twelve thousand majority, in Pennsylvania by over thirtytwo thousand, and in Indiana by over ten thousand. 


\section{Political History of Secession}

It was now plain to Douglas, as to all others, that he could not be elected, but he did not despair. "Mr. Lincoln," he said, "is the next President. We must try to save the Union. I will go South." $\mathrm{He}$ at once canceled all his speaking engagements in the North and made a tour through the South, making an heroic but hopeless effort to stem the rising tide of secession.

In the presidential election in November following, Lincoln received the electoral votes of all the free States except three from New Jersey, 169 in all; Breckinridge the electoral votes of all the Southern States, except those of Virginia, Kentucky, and Tennessee, 72 in all; Bell, the electoral votes of Virginia, Kentucky, and Tennessee, 29 in all; while Douglas received only the electoral votes of Missouri and three from New Jersey, $\mathbf{I} 2$ in all. The popular vote was distributed as follows:

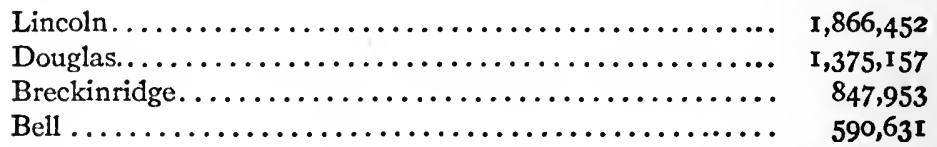

It will be seen from these figures that while Lincoln's majority over Douglas was 491,295, Lincoln lacked nearly one million of a majority of the popular votes. The vote by States showed that Bell and Breckinridge together received more than 400,000 votes in the free States, while Lincoln and Douglas together received less than 200,000 votes in the slave States. Lincoln did not receive a single vote in either North Carolina, South Carolina, Georgia, Tennessee, Louisiana, Mississippi, Alabama, Arkansas, Florida, or Texas. For the first time in the history of the government the question of the extension of slavery had been made a direct and distinct political issue. Practically and for the first time, a solid North was arrayed against a solid South.

The presidential campaign of $\mathbf{I} 860$ will ever be a memorable one, memorable for the importance of the principles 


\section{Political Campaign of 1860 (Continued)}

at stake, for the orators it called forth, for the high pitch of excitement to which the people were wrought up, but more memorable still because in the North the campaign was fought upon a higher moral plane than any other before or since. The voter in order to decide the question at issue did not have to puzzle his brain over it as he would in deciding questions of tariff or finance. It was a plain simple question that went straight to his conscience and demanded a decision by it.

Looking back now over a period of more than fifty years, the picture of Douglas stands out in bold relief. For some years after the passage of the Kansas-Nebraska act, he was looked upon by a large portion of the people of the North with distrust, and by many with aversion. Before the end of the presidential campaign they saw another Richmond in the field. It was indeed the same man who had been so largely instrumental in securing the passage of the Kansas-Nebraska act, but he himself had changed. In all the strange evolutions of American politics, nothing is stranger than the political transformation of Douglas. From a staunch ally of the slaveholding interests of the South, he had become their most courageous and determined antagonist. And when the crisis came with the firing on Fort Sumter, his attitude was that of unswerving and uncompromising loyalty to the Union. He will be remembered in future history, not for his record as a politician, but for his services as a patriot. If he had been loyally supported by the Buchanan Administration, and by the Southern Democratic leaders, he would probably have been elected over Lincoln. Possibly he might have been elected notwithstanding the opposition of the Southern leaders if he had received the support of the Buchanan Administration.

What might have been the result if he had been elected is now only a matter of speculation. It is certain, however, that neither Douglas nor any other man could have reconciled the advocates and the opponents of the extension of slavery. 


\section{Political History of Secession}

Perhaps the election of Douglas might, for a time, have prolonged the Union, but it would also have given slavery a new lease of life, and as long as slavery continued it would have been a disturbing factor in politics and a menace to peace. It was impossible, as Lincoln had said, for the country to endure permanently half free and half slave. It must become all one or all the other. The South would never willingly have consented to its being all free and the North would never have consented to its being all slave. No peacemaker, no Supreme Court decision, no compromise could effect a lasting peace between Freedom and Slavery, and, without the entire reconstruction of the Union itself, there was but one way in which the slavery question could be finally settled and that was by the old method of wager of battle. 


\section{CHAPTER XXI}

\section{SECESSION IN BLOOM}

D

URING the progress of the political campaign of $\mathrm{I} 860$, ominous threats of secession in the event of Lincoln's election were heard coming from the South and predictions that, if elected, he would never be inaugurated. Threats of secession had been heard before, as far back as 1820 , during the discussion of the Missouri Compromise; again, and with greater vehemence, during the discussion of the compromise measures of 1850; and again, in the political campaign of 1856 . These threats became common during the campaign of 1860 . In the North they were regarded as the mere vaporings of Southern fire eaters, and were little heeded, but all were eagerly watching the signs of the coming storm. The storm was not long in coming and between the presidential election and the meeting of Congress in that year startling events followed one another with marvelous rapidity. South Carolina promptly led off in the secession movement. On November 10, 1860, her two Senators resigned their seats in the United States Senate. On December 20 an ordinance of secession was adopted and announced on placards on which was printed in glaring letters, "THE UNION IS DISSOLVED," and on the 2Ist, Robert W. Barnwell, James H. Adams, and James L. Orr were appointed commissioners with directions "forthwith to proceed to Washington, authorized and empowered to treat with the government of the United States for the delivery of the forts, magazines, lighthouses, and other real estate with their appurtenances within the 
limits of South Carolina ... and generally to negotiate as to all other measures and arrangements proper to be made ... and for the continuance of peace and amity between this Commonwealth and the Government of Washington." $\mathrm{x}$

In the light of subsequent developments we can now see more clearly what were the plans, then not generally known, of the leaders of the secession movement. That they contemplated secession in the event of Lincoln's election, there is no doubt. The more radical of them were in favor of secession.long before Lincoln's election and were doubtless glad of the pretext for secession which Lincoln's election furnished. Nor is there any doubt that the leaders of secession contemplated resort to arms, if necessary, to carry out their plans. But it was believed to be possible that the secession movement might be accomplished without resort to arms, or, at least, without resort to arms until the Southern States should be fully prepared for it. In laying their plans, the secession leaders made several miscalculations as will presently more fully appear.

The second session of the Thirty-sixth Congress was convened on December 3, I860. Its proceedings were watched in both North and South with intense interest. Before the assembling of Congress the President had prepared a tentative draft of his annual message and had submitted it to Jefferson Davis, who made some suggestions which the President approved. Davis says that some alterations were subsequently made that he did not approve, but as the principal criticism which he made on the message, as it was delivered, was that it denied the constitutional right of a State to secede, it is fair to infer that the residue of the message met with his full approval."

War Records, vol. i., p. III.

- Davis's account of this matter is given in a manner that leaves no doubt of its accuracy. "While engaged," he says, "in the consultation with the Governor [of Mississippi] just referred to, a telegraphic message was handed to me from two members of Mr. Buchanan's 
The message was devoted almost wholly to a discussion of the distracted condition of the country, for which the blame was laid chiefly on the opponents of the extension of slavery. On the question uppermost in the minds of all men, the threatened secession of the Southern States, the substance of the message was that they had no constitutional right to go out of the Union, but that the Government had no constitutional right to compel them to stay in. $\mathrm{Mr}$. Blaine suggests that there were two Buchanans in the closing months of the administration-one the Buchanan at the meeting of Congress in December, when he was still smarting under the result of the presidential election, the other the Buchanan appalled by the discovery of the fact that secession, so long threatened, was no longer a political bogie, but a frightful reality, and that it was near at hand.

cabinet, urging me to proceed 'immediately' to Washington. This dispatch was laid before the Governor and the members of Congress from the State who were in conference with him, and it was decided that I should comply with the summons. I was afterward informed that my associates considered me 'too slow,' and they were probably correct in the belief that I was behind the general opinion of the people of the State as to the propriety of prompt secession. On arrival at Washington, I found, as had been anticipated, that my presence there was desired on account of the influence which it was supposed I might exercise with the President (Mr. Buchanan) in relation to his forthcoming message to Congress. On paying my respects to the President, he told me that he had finished the rough draft of his message, but that it was still open to revision and amendment, and that he would like to read it to me. He did so, and very kindly accepted all the modifications which I suggested. The message was, however, afterward somewhat changed and, with great deference to the wisdom and statesmanship of its author, I must say that, in my judgment, the last alterations were unfortunate $\rightarrow$ so much so that when it was read in the Senate, I was reluctantly constrained to criticize it. Compared, however, with documents of the same class which have since been addressed to the Congress of the United States, the reader of presidential messages must regret that it was not accepted by Mr. Buchanan's successors as a model, and that his views of the Constitution had not been adopted as a guide in the subsequent action of the Federal government."-Davis, Rise and Fall, vol. i., pp. 58-9. 
But there can be no doubt that the Buchanan who wrote the message was then wholly under the domination of the Southern leaders. Of Buchanan at this period Mr. Blaine says: "Mr. Buchanan had always looked to the statesmen of the South as a superior class; and after a political life wholly spent in close association and constant service with them, it could not be expected that, even in a crisis threatening destruction to the Union, he would break away from them in a day. They had fast hold of him, and against the influence of the better men in his Cabinet they used him for a time to carry out their own ends. Secessionists and Abolitionists Mr. Buchanan no doubt regarded as equally the enemies of the Union. But the Secessionists all came from the party that elected him President, and the Abolitionists had all voted against him. The Abolitionists, in which phrase Mr. Buchanan included all men of antislavery conviction, had no opportunity, even if they had desired, to confer with the President, while the Secessionists, from old and friendly association, were in daily and intimate relations with him. They undoubtedly persuaded the President by the most plausible arguments that they were not in fault; that the whole responsibility lay at the door of Northern anti-slavery men; and that, if these disturbers of the peace could be suppressed, all would be well. It was under these influences, artfully insinuated and persistently plied, that $\mathrm{Mr}$. Buchanan was induced to write his mischievous and deplorable message of the first Monday of December, 1860-a message whose evil effect can never be estimated, and whose evil character can hardly be exaggerated." ${ }^{\prime}$

With his message, the President also submitted an elaborate opinion of Jeremiah Black, the Attorney-General, written on November 20. In this opinion Black argued that "war cannot be declared, nor a system of general hostilities carried on by the central government against a State," and from this he concluded that "an attempt to

"Blaine, Twenty Years, vol. i., pp. 223-24. 
do so would be, ipso facto, an expulsion of the State from the Union" and that "all the States" would then "be absolved from their federal obligations," and concluded by saying that "If this view of the subject be correct, as I think it is, then the Union must utterly perish at the moment when Congress shall arm one part of the people against another for any purpose beyond that of the general government in the exercise of its proper constitutional functions." In another portion of the opinion, however, the AttorneyGeneral had distinctly denied the constitutional right of secession, and also the authority of the President to recognize the independence of a seceding State, and had asserted unequivocally the right of the general government "to preserve itself in its whole constitutional vigor by repelling a direct and positive aggression upon its property, or its affairs."

Black was a man of the highest character, inflexible in his devotion to principle, learned, not only in law, but in many other departments of human knowledge. He had held a high judicial position in the Supreme Court of Pennsylvania, and was the peer of Gibson or of any others of the long line of distinguished jurists who have added luster to jurisprudence there and everywhere. His opinions were conspicuous for great learning, classic expression, and force of argument. Politically he was a strict constructionist. His views on the powers of private corporations as expressed while Chief Justice of the Pennsylvania Supreme Court have often been quoted: "This case requires us to give a construction to the charter of a private corporation. The frequency of such cases excites some surprise, when we reflect that an act of incorporation is and always must be interpreted by a rule so simple, that no man, whether lawyer or layman, can misunderstand or misapply it. That which a company is authorized to do by its act of incorporation, it may do; beyond that all its acts are illegal. And the power must be given in plain words or by necessary implication. All powers not given in this direct 
and unmistakable manner are withheld. It is strange that the attorney-general, or anybody else, should complain against a company that keeps itself within bounds, which are always thus clearly marked, and equally strange that a company which has happened to trangress them should come before us with the faintest hope of being sustained. In such cases ingenuity has nothing to work with, since nothing can be either proved or disproved by logic or inferential reasoning. If you assert that a corporation has certain privileges, show us the words of the legislature conferring them. Failing in this, you must give up your claim, for nothing else can possibly avail you. A doubtful charter does not exist; because whatever is doubtful is decisively certain against the corporation." I He held the same views of the Constitution of the United States.

It would not be profitable here to enter into an elaborate analysis of the opinion. There is room for argument to show that the opinion, taken as a whole, did not justify the construction generally given to it at the time. Black's version of it is clearly and favorably stated in his letters to Senator Henry Wilson. ${ }^{2}$ In view of the subsequent conduct of the Attorney-General, and especially in view of the part taken by him in drafting the answer of the President to the South Carolina Commissioners, it is probable that he did not intend his opinion to bear the construction which was in fact generally given to it at that time and which gave much comfort to the secession leaders and greatly disappointed and discouraged the people of the North.

The secession of South Carolina gave a fresh impetus to the cause of secession throughout the South. To inspire enthusiasm for secession among the people of South Carolina had not been difficult, for in the minds of the people of that State there still rankled the recollection of tine Force bill and of President Jackson's summary suppression of

× Opinion in Commonwealth vs. Erie \& N. E. R. R. Co., 27 Penn. St., $35 \mathrm{I}$.

2 Essays and Speeches of Jeremiah S. Black, pp. 245-92. 
nullification in 1832 . Nor was there much difficulty in gaining converts in the other cotton States-Mississippi, Florida, Alabama, Georgia, Louisiana, and Texas-although in the earlier period of the secession movement there was a considerable anti-secession feeling in Georgia which found expression in a speech of Alexander H. Stephens to the Georgia Legislature on November 14, $1860 .^{1}$

In this speech Stephens declared that the election of Lincoln did not, per se, justify secession and advised waiting until Lincoln should do some "unconstitutional act." The speech was widely heralded in the North as a Union speech and Lincoln wrote to Stephens for a copy of it but got no encouragement from the subsequent correspondence. ${ }^{2}$ When Stephens's speech was carefully examined it was seen that the kind of Union which he had in mind was the same as Calhoun's. He thought that it would be sufficient cause for secession if the Northern States should refuse to repeal their personal liberty bills and redress other grievances enumerated in the Georgia platform. "I stand," he said, "upon the Georgia platform and upon every plank and say that if these aggressions therein provided for take place, I say to you and the people of Georgia, "keep your powder dry and let your assailants have lead if need be." He wanted the question of secession submitted to a convention, and if the convention should determine to go out of the Union he would "bow to the will of the people." But Stephens's protest against secession, mild as it was, availed nothing against the fiery appeals of such men as Howell Cobb and Senators Toombs and Iverson. His loyalty to the Union did not prevent him from accepting the VicePresidency of the Confederacy. A short time after his speech to the Georgia Legislature he made another in Savannah, Georgia, praising the new Confederacy and lauding its constitution, in which he said that "its foundations are laid, its corner-stone rests, upon the great truth

'See McPherson, History of the Rebellion, p. 20.

- See War Between the States, vol. ii., pp. 265-70. 


\section{$45^{6}$ Political History of Secession}

that the negro is not equal to the white man, that slaverysubordination to the superior race-is his natural and normal condition." $x$

But until after the Montgomery congress, which did not convene until February 4, I86I, Virginia, Maryland, North Carolina, Tennessee, Arkansas, Kentucky, and Missouri had refused to join the seceding States. There was a strong Union sentiment in Maryland, Kentucky, and Missouri, in western Virginia, and in eastern Tennessee. The border States hesitated for the further reason that they realized that in the event of civil war these States would be the first to see the invading armies of the North.

There was no cessation, however, in the work of perfecting the plans of the secession leaders for the formation of a Confederate government and putting it upon a war footing. It is amazing to see what was accomplished in the formation of the Confederacy and how it was accomplished. The "protests of conservatives," says Pollard" "were voices against the wind. The Montgomery convention carried everything with swift and irresistible force, and gave neither time for the popular alarm to take effect nor the slightest opportunity for the popular judgment to recover control of its affairs. In truth what the thoughtful historian must most deeply meditate of the causes and origin of the late war is the extent to which the popular element of the South was excluded from its inception. It was in constant subjection from the moment a conspiracy of Southern Senators at Washington held at arm's length the States and dictated their course. Indeed there were cases where it was ignored to the extent of States passing ordinances of secession, even after the legislatures calling the conventions had forbidden the effect of such ordinances until ratified by the vote of the masses. It had no direct representation in the convention at Montgomery. It did not confirm its work. It had nothing to do with the

'Greeley, American Conflict, vol. i., p. 417.

- Life of Davis, p. 94. 
early acts of the war; and briefly the astounding fact appears that the first time the people of the South had direct action on their affairs since the election of Abraham Lincoln was to vote for a President, after Mr. Davis had been 'provisional' chief or practical dictator one whole year, counting from his inauguration at Montgomery. Whether the war was right or wrong is logically not involved in the question whether it was determined by the many or by the few; but certainly history has had few instances of such daring and strident usurpation as that commenced by fourteen men plotting revolution in a committee room at Washington, and consummated by an irresponsible convention proclaiming a war, electing a leader, and organizing a government, without let or hindrance."

Pollard's statement seems, upon the face of it, to be incredible, almost preposterous, and yet it is amply corroborated by other evidence. Mr. Nicolay has given as clear an account as can be given in a short chapter of the manner in which the secession leaders forced the secession of the Southern States. ${ }^{x}$

A Georgia writer has told how Toombs by his "burning words and superb presence" swayed the people of that State; how Yancey "forwarded the 'fiery cross' from the Rio Grande to the northern boundaries of Virginia"; how "the young men clamored to be enrolled in the volunteer soldiery," and how "all classes-the rich and poor, the richer and the poorest-mustered side by side; every man hopeful and confident of the result should the fateful order of 'forward march' be given." 2 Still, when we consider what was accomplished by a few leaders and seek for satisfactory reasons showing how it was accomplished, we find, as has often been found before, that it is easier to understand facts than it is to find reasons for them. Yet the fact that a few leaders exercised such control over the masses of the Southern people is no stranger than the fact

'Outbreak of the Rebellion, chap. i.

-Wylly, The Colony of Georgia, pp. 76-77. 
that in times of profound peace the great mass of intelligent people, like those of New York and Pennsylvania, can be dominated for such long periods by a political machine operated by a few men, ruling conventions, dictating nominations, and controlling elections.

If we wish to understand how easily the mass of the people can be influenced, we have only to recall the memorable campaign of $\mathrm{I} 840$, when the whole country, and particularly the North, sang itself, by the singing of doggerel, into a delirium of excitement, and the election was determined, not by sensible arguments, but by the exhibition of miniature log cabins, coonskins, and hard cider.

It is more difficult to explain how the great mass of nonslaveholding white voters in the South, far outnumbering the slaveholding voters, became equally enthusiastic in the cause of secession, yet this is a well-established fact.

x See the explanation offered by Mr. David Y. Thomas in a paper on "Southern Non-Slaveholders in the Election of $1860, "$ Political Science Quarterly, vol. xxvi., p. 222. 


\title{
CHAPTER XXII
}

\section{PREPARING PEACE PANACEAS}

\begin{abstract}
$\Lambda \mathrm{T}$ the second session of the Thirty-sixth Congress petiA tions and memorials imploring Congress to devise some method by which war could be averted and peace could be secured poured in from every quarter; from legislatures, municipal organizations, commercial bodies, from organizations of all kinds, and from individual citizens. Every man in Congress and out of it seemed to have a peace panacea of some kind.
\end{abstract}

The first matter to engage the attention of Congress was the consideration of the President's annual message, and the discussions turned altogether upon the alarming conditions then confronting the country. On December 4 the House appointed a committee of thirty-three, of which Thomas Corwin of Ohio was chairman, to consider and report upon the condition of the country. Several of the Southern members declined to serve and others failed to attend or take part in the proceedings of the committee.

On December 18 Senator Crittenden of Kentucky introduced a series of compromise resolutions in the Senate. On December 20 the Senate appointed a committee of thirteen members, similar to the House committee of thirty-three, consisting of Senators Powell, Crittenden, Bigler, Hunter, Seward, Toombs, Davis, Rice, Douglas, Collamer, Wade, Doolittle, and Grimes, all strong men representing the various political parties of the country. About the same time some seventy-five of the Senators and Representatives of the fourteen border States held a 
meeting, of which Senator Crittenden was the chairman, and adopted various peace propositions, in the main like those which Senator Crittenden had introduced in the Senate.

On January 8, I86I, the President transmitted to Congress a special message in which he recommended that the members devote themselves exclusively to the consideration of the various peace propositions which had been proposed. "Time," he said, "is a great conservative power. Let us pause at this momentous point and afford the people, both North and South, an opportunity for reflection." Further he said: "A common ground on which conciliation and harmony can be produced is surely not unattainable. The proposition to compromise by letting the North have exclusive control of the territory above a certain line and to give Southern institutions protection below that line ought to receive universal approbation. In itself, indeed, it may not be entirely satisfactory, but when the alternative is between a reasonable concession on both sides and a destruction of the Union it is an imputation upon the patriotism of Congress to assert that its members will hesitate for a moment." $r$

On January I9, I86I, the General Assembly of Virginia adopted a resolution reciting the "unhappy controversy which now divides the States of this confederacy" and that unless satisfactorily adjusted "a permanent dissolution of the Union is inevitable," and resolving: "That on behalf of the commonwealth of Virginia an invitation is hereby extended to all such States, whether slaveholding or nonslaveholding, as are willing to unite with Virginia in an earnest effort to adjust the present unhappy controversies in the spirit in which the Constitution was originally formed and consistently with its principles, so as to afford to the people of the slaveholding States adequate guarantees for the security of their rights, to appoint commissioners to meet on the fourth day of February next in the City of Washing-

× Presidents' Messages and Papers, etc., vol. v., p. 657. 
ton similar commissioners appointed by Virginia, to consider, and if practicable, agree upon some suitable adjustment." Other resolutions were adopted requesting that the commissioners, in case the plan of adjustment that might be agreed upon should require an amendment of the Constitution of the United States, should communicate the same to Congress, but that if they could not agree they should so report to the Virginia General Assembly, the action of the commissioners to be at all times subject to the control of the General Assembly if in session, or, if not, to a State convention. The resolutions also recommended, with some modifications, the general plan of compromise contained in the resolutions presented to the United States Senate by Senator John J. Crittenden of Kentucky. ExPresident Tyler, who was one of the commissioners appointed to represent Virginia in the proposed conference, was also appointed a "commissioner to the President of the United States," and Judge John Robertson was appointed "a commissioner to the State of South Carolina, and the other States that have seceded or shall secede, with instructions respectfully to request the President of the United States and authorities of such States to agree to abstain, pending the proceedings contemplated by the action of this General Assembly, from any and all acts calculated to produce a collision of arms between the States and the Government of the United States."

The Senate Committee of Thirteen considered various peace propositions, some of which were submitted by the members of the committee and others by persons not members. ${ }^{2}$ On December 31 the committee reported its inability to agree.

The House Committee of Thirty-three also considered a great number of propositions. Some of the propositions considered were of a singularly wild and visionary character. None of them now has any historic value beyond showing

- Chittenden, Peace Convention, pp. 9-10.

- See McPherson, History of the Rebellion, p. 70. 
how far sensible men had been swept from their moorings by the flood of secession talk. Of the propositions considered one was submitted by Charles Francis Adams of Massachusetts and was afterwards incorporated in the committee's report. This recommended an amendment of the Constitution providing that "no amendment of the Constitution having for its object any interference within the States with the relations between their citizens and those described in section second of the first article of the Constitution as 'all other persons' shall originate with any State that does not recognize that relation within its own bounds, or shall be valid without the assent of every one of the States composing the Union."

Noel of Missouri proposed that the committee be instructed "to inquire and report as to the expediency of abolishing the office of President of the United States and establishing in lieu thereof an Executive Council of three members to be elected by districts composed of contiguous States as nearly as possible, each member to be armed with a veto power; and also as to whether the equilibrium of free and slave States in the United States Senate cannot be restored and preserved, particularly by a voluntary division of some of the slave States into two or more States."

Anderson of Missouri wanted "to refer the questions at issue between the free and slave States to the Supreme Court of the United States for their opinion, and when obtained, that Congress should pass all necessary laws for giving effect to the opinion of said Court."

Vallandigham of Ohio submitted an elaborate scheme for dividing the States into four sections, Maine, New Hampshire, Vermont, Massachusetts, Rhode Island, Connecticut, New York, New Jersey, and Pennsylvania to constitute one, to be known as the North; Ohio, Indiana, Illinois, Michigan, Wisconsin, Minnesota, Iowa, and Kansas another, to be known as the West; Oregon and California and all new States carved out of the territory west of the Rocky Mountains and the Rio Grande to 
constitute another, to be known as the Pacific; Delaware, Maryland, Virginia, North Carolina, South Carolina, Georgia, Florida, Alabama, Mississippi, Louisiana, Texas, Arkansas, Tennessee, Kentucky, and Missouri to constitute another, to be known as the South; together with a complicated system of checks and balances.

The committee on January I4, I86I, reported a series of propositions, twenty-five in all. Accompanying the report of the majority of the committee were nine minority reports. One of them was by Charles Francis Adams, who, on further reflection, condemned his own proposition, inasmuch as "no form of adjustment will be satisfactory to the recusant States which does not incorporate into the Constitution of the United States a recognition of the obligation to protect and extend slavery." For this reason he was opposed to the further introduction of any measures whatever for the consideration of the House. The absence of so many members of the committee at its meetings and the irreconcilable divergence of views of the remaining number detracted largely from the strength which the report might otherwise have carried. No vote was taken on the propositions of the committee until February 28 and the vote on the last of them was not taken until March I. All were passed but their passage then was too late in the session to secure any good results.

The Crittenden resolutions ${ }^{x}$ proposed six amendments to the Constitution of the United States. Article I provided for the prohibition of slavery north of lattitude $36^{\circ}$ $30^{\prime}$ but that "in all the territory south of said line of latitude slavery of the African race is hereby recognized as existing and shall not be interfered with by Congress, but shall be protected as property by all the departments of the territorial government during its continuance," thus incorporating, not only into the laws, but also into the Constitution of the United States the principle of the Dred Scott decision and providing against the contingency of

' Cong. Globe, 36th Cong., 2d sess., pt. i., p. II4. 
its being overruled by the Court which decided it. Article 2 prohibited Congress from abolishing slavery "in places under its exclusive jurisdiction and situate within the limit of States that permit the holding of slaves." Article 3 prohibited Congress from abolishing slavery in the District of Columbia "so long as it exists in the adjoining States of Virginia and Maryland, or either, nor without the consent of the inhabitants, nor without just compensation first made to such owners of slaves as do not consent to such abolishment." It also prohibited Congress from interfering with the rights of "officers of the Federal government or members of Congress" to "bring and hold their slaves there." Article 4 provided that "Congress shall have no power to prohibit or hinder the transportation of slaves from one State to another, or to a Territory in which slaves are by law permitted to be held, whether that transportation be by land, navigable rivers, or by the sea." Article $\mathbf{5}$ provided: "That in addition to the provisions of the third paragraph of the second section of the fourth article of the Constitution of the United States, Congress shall have power to provide by law, and it shall be its duty so to provide, that the United States shall pay to the owner who shall apply for it, the full value of his fugitive slave in all cases when the marshal or other officer whose duty it was to arrest said fugitive was prevented from so doing by violence or intimidation, or when, after arrest, said fugitive was rescued by force, and the owner thereby prevented and obstructed in the pursuit of his remedy for the recovery of his fugitive slave under the said clause of the Constitution and the laws made in pursuance thereof. And in all such cases when the United States shall pay for such fugitive they shall have the right in their own name to sue the county in which said violence, intimidation, or rescue was committed, and to recover from it, with interest and damages, the amount paid by them for said fugitive slave. And the said county, after it has paid said amount to the United States, may, for its indemnity, sue and recover from the 


\section{Preparing Peace Panaceas}

wrong-doers or rescuers by whom the owner was prevented from the recovery of his fugitive slave, in like manner as the owner himself might have sued and recovered." Article 6 prohibited any further amendment of either of the five preceding articles or of the third paragraph of section two of Article I of the Constitution or of the third paragraph of the second section of Article 4.

The resolutions also contained various recommendations to the effect that "laws ought to be made for the punishment of those who attempt by rescue of the slave, or other illegal means, to hinder or defeat the due execution of said laws [the fugitive slave laws]." $x$ They also recommended the repeal by the States of the so-called "personal liberty" acts calculated to interfere with the Federal fugitive slave laws, and some further amendment of the existing Fugitive Slave Law designed to remove some of its features that were most obnoxious to the North.

The propositions of the meeting of the Senators and Representatives of the border States were not specially considered in Congress, but were doubtless considered along with other propositions considered by the Senate Committee of Thirteen and the House Committee of Thirty-three.

Inasmuch as the invitation of the State of Virginia to the proposed peace convention announced its chief purpose to be "to afford to the people of the slaveholding States adequate guarantees for the security of their rights," the invitation was not received with enthusiasm by the Northern States, in which the recollection of the repeal of the Missouri Compromise, the Fugitive Slave Law, and the Dred Scott decision was still fresh and in which there was a strong feeling that the people of the slaveholding States already had "adequate guarantees for the security of their rights." Moreover it was observed in the North that South Carolina and the other seceding States did not pay

"The words "or other illegal means" were probably intended for the suppression of the Abolition societies of the North. 
the slightest attention to the recommendation of Virginia that while the peace convention was in session the seceding States and the general government should abstain from all acts "calculated to produce a collision of arms," but continued their warlike preparations with unabated vigor. Nevertheless most of the Northern States courteously responded to the invitation and sent commissioners, but with various restrictions on their authority and in several instances expressly declining to commit themselves to an approval of the Virginia plan of adjustment or to admit the necessity of any amendment of any kind to the Constitution of the United States. ${ }^{x}$

The peace conference commissioners met in Washington on February 4, I86I, and proceeded to organize. ${ }^{2}$ ExPresident John Tyler, of Virginia, was selected as permanent president, and he addressed the conference in a speech full of florid rhetoric. Before the close of the convention there were present delegates from Maine and Iowa, which were represented by their respective congressional delegations; delegates from Tennessee, Ohio, Kentucky, Delaware, Illinois, New Jersey, New York, Pennsylvania, Massachusetts, Rhode Island, and Missouri, appointed by their respective legislatures; delegates from New Hampshire, Vermont, Connecticut, Maryland, North Carolina, Indiana, and Kansas, appointed by their respective governors. The following Northern States were not represented: Michigan, Wisconsin, Minnesota, California, and Oregon. The seven States which had already seceded, namely, South Carolina, Florida, Georgia, Alabama, Mississippi, Arkansas, and Texas, were not represented. Louisiana was also unrepresented. One of the rules adopted provided that "all votes shall be taken by States, and each State to give one vote." A committee on resolutions was

× Chittenden, Peace Convention, pp. 454-64.

2 A full report of the proceedings is contained in Chittenden's Peace Convention; see also Appleton's Annual Cyclopedia for 1861 ; McPherson, History of the Rebellion, p. 67. 
appointed consisting of one member from each of the States represented, of which James Guthric of Kentucky was made chairman.

More harmony was shown in the conference than might have been expected and the debates were conducted with decorum. At one time, however, Mr. Stockton, a delegate from New Jersey, whose sympathies were, however, very pronounced in favor of the South, became very much excited over some remark of Lot M. Morrill of Maine, and exclaimed: "If the gentleman from Maine wants to get up a row, we are ready for him. He shall have enough of it right here. I should like to know why he makes such charges against Virginia? They are unfounded; we don't want to hear them."I Stockton, however, was promptly suppressed and afterward the debates went on smoothly.

It is apparent, however, in reading the reports of the proceedings that there was from the beginning an irreconcilable divergence of views and that no substantial results would be gained by the conference. It was clear that the sympathies of the slaveholding States which had not yet seceded were with those which had already done so, and that the former would at once ally themselves with the latter in the event that any attempt at "coercion" should be made by the Federal government. James A. Seddon of Virginia took a very active part in the proceedings, speaking on all the resolutions adopted. In one of his speeches he said: "Why should you undertake to interfere with the policy of a neighboring State concerning a people about which you know nothing? We feel, we know, that we have done that race no wrong. Deep into the Southern heart has this feeling penetrated. For scores of years we have been laboring earnestly in our mission. In all this time we have contributed far more to the greatness of the North than to our own. Yet all this time we have been assailed, attacked, vilified, and defamed by the people of the North, from the cradle to the grave, and you have I Chittenden, Peace Convention, p. 149. 
educated your children to believe us monsters of brutality, lust, and iniquity. . . .

"You say that the whole power of the country, the whole power of the administration, shall be used in future for the final extinction of slavery. This, now, is the ruling idea of your great sectional party. It is simply the rule of one portion of the country over another. There is no difference between attacking slavery in the States and keeping it out of the Territories. It is only drawing a parallel around the citadel at a more remote point. . . . In my deliberate judgment, the Union and the Constitution, as they now stand, are unsafe for the people of the South, unsafe without other guarantees which will give them actual power instead of mere paper rights. Her stake in this controversy is too deep. In my judgment she has asked too little; I think fuller and greater guarantees ought to be required, and that this convention should not stand upon ceremony, but in a free and liberal spirit of concession should yield to us all that we ask." ${ }^{x}$

To this George M. Boutwell of Massachusetts replied:

"I have not been at all clear in my own mind as to when, and to what extent, Massachusetts should raise her voice in this convention. She heard the voice of Virginia, expressed through her resolutions in this crisis of our country's history. Massachusetts hesitated, not because she was unwilling to respond to the call of Virginia, but because she thought her honor touched by the manner of that call and the circumstances attending it. She had taken part in the election of the sixth of November. She knew the result. It accorded well with her wishes. She knew that the government whose political head for the next four years was then chosen, was based upon a Constitution which she supposed still had an existence. She saw that State after State had left that government-seceded is the word used; had gone out from this great confederacy, and were defying the Constitution and the Union.

× Chittenden, Peace Convention, pp. 94, 95. 


\section{Preparing Peace Panaceas}

"Charge after charge has been vaguely made against the North. It is attempted here to put the North on trial. I have listened with grave attention to the gentleman from Virginia to-day, but I have heard no specification of these charges. Massachusetts hesitated I say; she has her own opinions of the government and the Union. . . .

"Massachusetts hesitated, not because her blood was not stirred, but because she insisted that the government and the inauguration should go on, in the same manner they would have done had Mr. Lincoln been defeated. She felt that she was touched in a tender point when invited here under such circumstances. . . .

"I have tried to look upon these propositions of the majority of the committee, as true measures of pacification. I have listened patiently to all that has been said in their favor. But I am still unconvinced, or rather I am convinced that they will do nothing for the Union. They will prove totally inadequate; may, perhaps, be positively mischievous. The North, the free States, will not adopt them-will not consent to these new endorsements of an institution which they do not like, which they believe to be injurious to the best interests of the Republic; and if they did adopt them, as they could only do, by a sacrifice of principles which you should not expect, the South would not be satisfied; she would not fail to find pretexts for a course of action upon which I think she has already determined. I see in these propositions anything but true measures of pacification.

"But the North will never consent to the separation of the States. If the South persists in the course on which she has entered we shall march our armies to the Gulf of Mexico, or you will march yours to the Great Lakes. There can be no peaceful separation. There is one way by which war may be avoided and the Union preserved. It is a plain and a constitutional way. If the slave States will abandon the design which we must infer from the remarks of the gentleman from Virginia they have already formed, 


\section{0

will faithfully abide by their constitutional obligations, and remain in the Union until their rights are in fact invaded, all will be well. But if they take the responsibility of involving the country in a civil war, of breaking up the government which our fathers founded and our people love, but one course remains to those who are true to that government. They must and will defend it at every sacrifice-if necessary, to the sacrifice of their lives."

Salmon P. Chase of Ohio was equally explicit, saying: "I have listened with attention to the appeals made by gentlemen who urge the interests of the South in favor of a settlement of these questions. But you are now prosecuting a plan which will be the subject of debate throughout the country. Adopt your article in either form, and the question, What does status mean? will still remain.

"A majority of the people have adopted the opinion that under the Constitution slavery has not a legal existence in the Territories. The triumph of this opinion is not the result of any sudden impulse. A President has been elected, and a government will soon be organized, whose duty it will be to respect and observe the opinions of the people. You are now seeking, by the adoption of a single section, to change these opinions and this policy. Do not deceive yourselves, gentlemen. You will never accomplish this result so easily. You are presenting such a subject for debate and excitement as the country never had before. It is best we deal frankly." 2

On a later day he said:

"Gentlemen, Mr. Lincoln will be inaugurated on the 4th of March. He will take an oath to protect and defend the Constitution of the United States-of the whole- of all the United States. That oath will bind him to take care that the laws be faithfully executed throughout the United States. Will secession absolve him from that oath? Will it diminish, by one jot or tittle, its awful obligation? Will attempted revolution do more than secession? And if not

${ }^{x}$ Chittenden, Peace Convention, 98-102.

- Id., p. 327 . 
-and the oath and the obligation remain-and the President does his duty and undertakes to enforce the laws, and secession or revolution results, what then? War! Civil war!"'

The final vote on the proposed amendments was taken on February 27, 1861, and they were on the same day transmitted to Congress with the request that that body "submit it to the conventions of the States as Article Thirteen of the Amendments to the Constitution of the United States." The following is a copy of the proposed amendments:

\section{"Article XIII}

"Section I. In all the present territory of the United States north of the parallel of $36^{\circ} 30^{\prime}$ of north latitude, involuntary servitude, except in punishment of crime, is prohibited. In all the present territory south of that line, the status of persons held to involuntary service or labor, as it now exists, shall not be changed; nor shall any law be passed by Congress or the territorial legislature to hinder or prevent the taking of such persons from any of the States of this Union to said territory, nor to impair the rights arising from said relation; but the same shall be subject to judicial cognizance in the Federal courts, according to the course of the common law. When any Territory north or south of said line, within such boundary as Congress may prescribe, shall contain a population equal to that required for a member of Congress, it shall, if its form of government be republican, be admitted into the Union on an equal footing with the original States, with or without involuntary servitude, as the constitution of such State may provide.

"Sec. 2. No territory shall be acquired by the United States, except by discovery and for naval and commercial stations, depots, and transit routes, without the con-

' Chittenden, Peace Convention, p. 433. 


\section{2 \\ Political History of Secession}

currence of a majority of all the Senators from States which allow involuntary servitude, and a majority of all the Senators from States which prohibit that relation; nor shall territory be acquired by treaty, unless the votes of a majority of the Senators from each class of States hereinbefore mentioned be cast as a part of the two-thirds majority necessary to the ratification of such treaty.

"Sec. 3. Neither the Constitution, nor any amendment thereof, shall be construed to give Congress power to regulate, abolish, or control within any State the relation established or recognized by the laws thereof touching persons held to labor or involuntary service therein, nor to interfere with or abolish involuntary service in the District of Columbia without the consent of Maryland and without the consent of the owners, or making the owners who do not consent just compensation; nor the power to interfere with or prohibit Representatives and others from bringing with them to the District of Columbia, retaining, and taking away, persons so held to labor or service; nor the power to interfere with or abolish involuntary service in places under the exclusive jurisdiction of the United States within those States and Territories where the same is established or recognized; nor the power to prohibit the removal or transportation of persons held to labor or involuntary service in any State or Territory of the United States to any other State or Territory thereof where it is established or recognized by law or usage, and the right during transportation by sea or river of touching at ports, shores, and landings, and of landing in case of distress, shall exist; but not the right of transit in or through any State or Territory, or of sale or traffic, against the laws thereof. Nor shall Congress have power to authorize any higher rate of taxation on persons held to labor or service than on land. The bringing into the District of Columbia of persons held to labor or service, for sale, or placing them in depots to be afterwards transferred to other places for sale as merchandise, is prohibited. 


\section{Preparing Peace Panaceas}

"Sec. 4. The third paragraph of the second section of the fourth article of the Constitution shall not be construed to prevent any of the States, by appropriate legislation, and through the action of their judicial and ministerial officers, from enforcing the delivery of fugitives from labor to the person to whom such service or labor is due.

"Sec. 5. The foreign slave trade is hereby forever prohibited; and it shall be the duty of Congress to pass laws to prevent the importation of slaves, coolies, or persons held to service or labor into the United States and the Territories from places beyond the limits thercof.

"Sec. 6. The first, third, and fifth sections, together with this section of these amendments, and the third paragraph of the second section of the first article of the Constitution, and the third paragraph of the second section of the fourth article thereof, shall not be amended or abolished without the consent of all the States.

"Sec. 7. Congress shall provide by law that the United States shall pay to the owner the full value of his fugitive from labor, in all cases where the marshal, or other officer, whose duty it was to arrest such fugitive, was prevented from so doing by violence or intimidation from mobs or riotous assemblages, or when, after arrest, such fugitive was rescued by like violence or intimidation, and the owner thereby deprived of the same; and the acceptance of such payment shall preclude the owner from further claim to such fugitive. Congress shall provide by law for securing to the citizens of each State the privileges and immunities of citizens in the several States." $x$

It will be noted that while the constitutional amendments proposed by the peace convention incorporated the substance of the Crittenden resolutions, they contained various legal terms, such as "status" and "according to the course of the common law," not used in the latter, and having a technical legal meaning, not generally understood and calculated to give rise to endless controversy.

- Chittenden, Peace Convention, pp. 472-73. 
The various sections of the amendments proposed by the convention were voted upon separately. Upon the first section there was the greatest controversy and difference of opinion. The vote upon it was: yeas, Delaware, Illinois, Kentucky, Maryland, New Jersey, Ohio, Pennsylvania, Rhode Island, and Tennessee-9; nays, Connecticut, Iowa, Maine, Massachusetts, North Carolina, New Hampshire, Vermont, and Virginia-8; divided, New York and Kansas; not voting, Indiana.

So that this section was adopted by a vote of only nine States. Moreover, but for the absence of David Dudley Field of New York at the time of voting upon it, the vote of New York would have been against it. ${ }^{I}$ For the reasons already stated the report of the proceedings of the peace convention went to Congress discredited at the time of its presentation. What little respect was paid to it in the Senate was on account of the courtesy felt to be due to the members of the convention. Even this did not prevent some of the Senators from expressing their contempt for the work of the convention. The proposed amendments of the peace convention were more unsatisfactory to the pro-slavery men of the South than they were to the antislavery men of the North. Senator Green of Missouri denounced them as "wishy-washy." Both the Virginia Senators, Hunter and Mason, denounced them as putting the Southern States "in a far worse position than they were occupying under the present Constitution and with the Dred Scott decision." They laid particular stress upon the indefiniteness of the words "status" and "course of the common law" in the first section. Special objection was also made to the concluding clause in Section 7 that "Congress shall provide by law for securing to the citizens of each State the privileges and immunities of citizens in the several States." "Might not this, " it was said, "give Abolition leaders the right to promulgate their doctrines in the slave States?" Various objections were also made to

'Chittenden, Peace Convention, p. 596. 
other sections. They claimed that the Crittenden resolutions were far preferable to those of the peace convention, and also, which was true, as had been argued by Chase in the convention, that the plan recommended by the convention would lead to new controversies far more bitter and more complicated than any that had ever existed before.

Senator Wigfall, of Texas, on March 2, in speaking of the peace convention propositions, ${ }^{x}$ said: "As to the resolutions which the peace congress has offered us, we might as well make a clean breast of it. If those resolutions were adopted, and ratified by three fourths of the States of this Union, and no other cause ever existed, I make the assertion that the seven States now out of the Union would go out upon that. The first proposition is to do what? The Wilmot proviso north of $36^{\circ} 30^{\prime}$ north latitude, and a lawsuit south of it. The next is to give the Federal government the right to declare a free negro a citizen. Those two propositions would be enough of itself to dissolve the Union, if nothing else were offered."

On the final vote in the Senate the peace convention propositions were rejected. Owing to the fact that they were presented to the House only a few days before its adjournment, they could not be taken up without displacing the regular order of business, and this could not be done except by a two-thirds vote, which the propositions failed to receive, and so they failed to get even so much as a hearing in the House.

During the debate in the Senate on the peace convention propositions, Senators Powell of Kentucky charged that "there is and has been a fixed purpose in certain quarters that the peace conference should do nothing," and in support of this charge he read a characteristic letter of Senator Chandler to Governor Austin Blair, of Michigan. ${ }^{2}$

I Cong. Globe, 36th Cong., 2d sess., pt. ii., p. 1373 .

- Chittenden, Peace Convention, pp. 468-69. 


\section{Political History of Secession}

"WAShington, February II, 186 I.

"MY DEAR Governor: Governor Bingham and myself telegraphed you on Saturday, at the request of Massachusetts and New York, to send delegates to the Peace or Compromise Congress. They admit that we were right and that they were wrong; that no Republican State should have sent delegates; but they are here and cannot get away. Ohio, Indiana, and Rhode Island are caving in, and there is danger of Illinois; and now they beg us, for God's sake, to come to their rescue, and save the Republican party from rupture. I hope you will send stiff-backed men, or none. The whole thing was gotten up against my judgment and advice, and will end in thin smoke. Still, I hope as a matter of courtesy to some of our erring brethren, that you will send the delegates.

\section{"Truly your friend, " $Z$. Chandler.}

"His Excellency Austin Blair.

"P. S.-Some of the manufacturing States think that a fight would be awful. Without a little blood-letting this Union will not, in my estimation, be worth a rush."

The letter was not denied by Chandler, but it proves, not that he and others, and there were many of them, who thought as he did were opposed to any compromise, but that they believed it to be hopeless to expect that any compromise that would be acceptable to both the North and the South could be devised by the conference, and that all its proceedings would end, as they did, "in thin smoke."

Crittenden's resolutions had been defeated in the Senate by tacking on an amendment proposed by Senator Clark of New Hampshire on January 16, which took the life out of them; but on March 2, the last day of the session, Crittenden managed to get another vote on them, when they were defeated by a vote of 19 yeas, 20 nays.

The most that was accomplished in Congress in uniting upon any of the peace propositions was the passage by both 


\section{Preparing Peace Panaceas}

Houses of a joint resolution for submitting to the States a constitutional amendment (XIII.) providing that "no amendment shall be made to the Constitution which will authorize or give to Congress the power to abolish or interfere, within any State, with the domestic institutions thereof; including that of persons held to labor or service by the laws of said State." This resolution was passed by the House on February 28, I 86I, by a vote of 133 yeas to 65 nays, ${ }^{x}$ and by the Senate on March 2 by 24 to $12 .^{2}$

At that late date the proposed amendment, even if ratified by all the Northern States, would have been useless in staying secession.

2 Cong. Globe, 36th Cong., 2d sess., pt. ii., p. 1285. "Id., 1403. 


\section{CHAPTER XXIII}

CONGRESSIONAL DEBATES; CLOSE OF THE THIRTY-SIXTH CONGRESS

$\mathrm{T}$ HE whole nation was watching with intense interest the progress of the various peace propositions in Congress and out of it. The views of the people are not always accurately reflected in the utterances of their leaders, but in the debates in Congress we get a clearer idea than we can get from any other source of the feelings of the leaders themselves and of the reasons that controlled their actions.

It would not be profitable to attempt a synopsis of all the speeches in the closing session of the Thirty-sixth Congress upon the condition of the country. Quotations from a few of them will suffice to show their general tenor. ${ }^{x}$

Senator Clingman, of North Carolina, speaking of the President's message, made a courteous and fair presentation of the Southern view. " "As to the general tone of the message," he said, "everybody will say that it is eminently patriotic, and I agree with a great deal that is in it; but I think it falls short of stating the case that is now before the country. It is not, for example, merely that a dangerous man has been elected to the Presidency of the United States. We know that under our complicated system that might very well occur by accident and he be powerless; but I

I deem it preferable to select some of the most striking passages and to give these in the words of the speakers themselves, instead of attempting an abridgment, for in any abridgment we get only the language of the abridger. Fair abridgments will be found in Appleton's Annual Cyclopedia for 1861; Victor's Southern Rebellion, vol, in,

2 Cong. Globe, 36 th Cong., 2 d sess., pt. i., p. 3. 
assert that the President-elect has been elected because he was known to be a dangerous man. He avows the principle that is known as the 'irrepressible conflict.' He declares that it is the purpose of the North to make war upon my section until its social system has been destroyed, and for that he was taken up and elected. That declaration of war is dangerous, because it has been indorsed by a majority of the votes of the free States in the late election. It is this great, remarkable, and dangerous fact that has filled my section with alarm and dread for the future.

"The President says that he may be powerless by reason of the opposition in Congress now; but that is only a temporary relief. Everybody knows that the majority which has borne him into the chair can control all the departments of this government. Why, sir, five or six of our conservative Senators have already to give place to others on the 4th of March; and if the others do not, it is simply because their terms have not expired. Both the Senators from Indiana and the Senator from Illinois [Mr. Douglas], and other gentlemen, would be beaten by that same majority, if it were not that their terms have time to run. They must, however, be cut down at no distant day. Not only that; but if the House of Representatives is divided to some little extent, how long can it be so? We all know that New England has presented an unbroken front for some time past; and does any man doubt that the same organization that elected Abraham Lincoln can make a clear majority of both branches of Congress? The efforts of the Abolitionists will be directed to the few doubtful districts, and they will soon be subjected to their control. So powerful and steady is the current of their progress that it will soon overwhelm the entire North. In this way they must soon control the President, both Houses of Congress, the Supreme Court, and all the officers of the government. The result is that a sectional party will wield-the -entire power over all the departments of the government. ...

"But this is not the worst view of the case. We are not 
only to be governed by a sectional domination which does not respect our rights, but by one, the guiding principle of which is hostility to the Southern States. It is that, Mr. President, that has alarmed the country; and it is idle for gentlemen to talk to us about this being done according to the forms of the Constitution."

Senator Iverson of Georgia said": "You talk about repealing the personal liberty bills as a concession to the South. Repeal them all to-morrow, sir, and it would not stop the progress of this revolution. It is not your personal liberty bills that we dread. Those personal liberty bills are obnoxious to us not on account of their practical operation, not because they prevent us from reclaiming our fugitive slaves, but as an evidence of that deep-seated, widespread hostility to our institutions, which must sooner or later end in this Union in their extinction. That is the reason we object to your personal liberty bills. It is not because that in their practical operation they ever do any harm. But, sir, if all the liberty bills were repealed to-day, the South would no more gain her fugitive slaves than if they were in existence. It is not the personal liberty laws; it is mob laws that we fear. It is the existence and action of the public sentiment of the Northern States that are opposed to this institution of slavery, and are determined to break it down-to use all the power of the Federal government, as well as every other power in their hands, to bring about its ultimate and speedy extinction. ... Disguise the fact as you will there is an enmity between the Northern and Southern people that is deep and enduring, and you never can eradicate it-never! Look at the spectacle exhibited on this floor. How is it? There are the Republican Northern Senators upon that side. Here are the Southern Senators on this side. How much social intercourse is there between us? You sit upon your side, silent and gloomy! We sit upon ours with knit brows and portentous scowls. Yesterday I observed that there was

'Cong. Globe, 36th Cong., 2d sess., pt. i., p. II. 
not a solitary man on that side of the chamber came over here even to extend the civilities and courtesies of life! Nor did any of us go over there. Here are two hostile bodies on this floor; and it is but a type of the feeling that exists between the two sections. We are enemies as much as if we were hostile states. I believe that the Northern people hate the South worse than ever the English people hated France; and I can tell my brethren over there that there is no love lost upon the part of the South."

On another day he said ${ }^{\mathrm{x}}$ : "Let this government pass into the hands of the Republican party, as it is about to do; let them be seated in power, as they are about to be; let them get possession of the two Houses of Congress, as they will get possession of them in less than two years from this time; let them bring all the power and patronage of this government to bear on the border States; let it be understood, as it will be understood, that the government is divorced from slavery, and that it will be left entirely to the people of the States themselves, with no sympathy and aid from the Federal government, to maintain the institution in hours of difficulty and danger; let the post-office and the mails be put into the hands of the Republican party, disseminating their seditious tracts through every hole and corner of the Southern States; let all the power and patronage of the Federal government be brought to bear on the slave States, encouraging incendiarism, John Brown raids, murderings, poisonings, and revolts, and what will be the condition of the border States? Sir, such will be their condition that slavery will become a burden to them instead of a blessing; and to get rid of it, such of their slaves as the underground railroad does not take off to the North and Canada will be sent down to the cotton States to be sold, and Maryland and Virginia and Kentucky and Missouri will, in a few years, add to the power and arrogance of the free States of this confederacy.

"Such, sir, will be the inevitable result, in my opinion, of

'Cong. Globe, 36th Cong., 2d sess., pt. i., p. 49. 
the continuance of this Union; and the slaves thus carried off from the border States and sold to the South will be confined in a few years to some eight or ten of the Atlantic and Gulf States. Well, now, look at the process. We have now in the Southern States four and a half million slaves. They increase, according to the census tables, at the rate of about thirty-two per cent. every ten years. If you precipitate all this slave population into the eight or ten States to which I have referred, in ten years from this time we shall have nearly six million slaves; in twenty years, eight or nine million; in thirty years, twelve or fifteen million. Sir, in less than twenty years from the present time, by this incvitable process, the slave population of the Southern States will be largely predominant over the whites; and then will come universal emancipation by the action of the Federal government, or such scenes of murder between the two races as have never been seen or heard of in the world's history." In the same speech he said: "Sir, what compromise has the North ever observed in good faith that was opposed to their interests or their prejudices? None that the history of the country has ever recorded. I ask, then, how can the South rely upon any guaranties which the North may make to us in the Constitution, especially under the circumstances which now exist, when those guaranties will be wrung from them by duress? For one, I have no confidence whatever in the plighted faith, Punica fides, of our Northern brethren; and I am not willing, for one,-and I believe my constituents are not willing,-to accept any compromise of this question, no matter how plausible it may be upon paper, because we know well that it will be nothing more than a paper guaranty that is not worth the snap of a man's finger. . . . So now you may tinker the Constitution, if you please; you may propose concessions; you may suggest additional legislation; you may present additional constitutional securities; you may attempt by all these ingenious devices to stay the storm which now rages in the Southern States, to prevent that people from marching 
on to the deliverance and liberty upon which they are resolved; but, sir, the words 'too late' that ring here to-day will be reiterated from mountain to valley in all the South, and are now sounding the death knell of the Federal Union."

Senator Mason of Virginia said: "Gentlemen have well said, it is not the failure to execute this Fugitive Slave Law; it is not the passage of these liberty bills, as they are called, in various of the States; it is a social war-so far not a war of arms-a war of sentiment, of opinion; a war by one form of society against another form of society. I possibly may have a misinformed judgment, but I rely upon it until corrected, and my judgment is satisfied that, for some reason, the population in the States having no slaves, feeling their great numerical majority, and having nursed this sentiment, this mere opinion about social forms existing elsewhere, have in some manner unfortunately brought themselves to a determination to extinguish it. I do not mean by any immediate blow-by any present law; but it is their purpose, having obtained possession of the Federal power, to use that power in every form to bring that social condition to a close."

Senator Toombs of Georgia said": "The success of the Abolitionists and their allies, under the name of the Republican party, has produced its logical results already. They have for long years been sowing dragons' teeth, and have finally got a crop of armed men. The Union, sir, is dissolved. That is an accomplished fact in the path of this discussion that men may as well heed. . . A And while this Congress, this Senate and this House of Representatives, are debating the constitutionality and the expediency of seceding from the Union, and while the perfidious authors of this mischief are showering down denunciations upon a large portion of the patriotic men of this country, those brave men are coolly and calmly voting what you call revolution-aye, sir, doing better than that: arming to defend it. They appealed to the Constitution, they appealed to justice, they appealed to fraternity, until the - Cong. Globe, 36th Cong., $2 \mathrm{~d}$ sess., pt. i., p. 35. 2 Id., p. 267. 


\section{Political History of Secession}

Constitution, justice, and fraternity were no longer listened to in the legislative halls of their country, and then, sir, they prepared for the arbitrament of the sword; and now you see the glittering bayonet, and you hear the tramp of armed men from your capital to the Rio Grande. It is a sight that gladdens the eyes and cheers the hearts of the other millions ready to second them."

Senator Wigfall, of Texas, made a bitter speech typical of the views of the most ultra of the Southern members, ${ }^{\mathbf{I}}$ in which he said: "If these States, then, desire to have a new understanding of the bargain, and can agree upon the terms, this Union can be saved; but this Union is not to be saved by flattering, either upon the floor of this Senate or upon the stump. You cannot save this Union by singing hosannas to it. You cannot save this Union by making 4th of July speeches. Whipped syllabub is not the remedy for the patient. You have got to come down to your work, and you have got to do something practical. . . The people of the South-I speak of the people of the different slaveholding States, and especially those upon the Gulf, commonly called the cotton States-are dissatisfied with the present government, as it is about to be administered by the President-elect. There is nothing that can satisfy them except amendments to the Constitution, and those amendments must be made by the Northern States unanimously, or they will not be satisfied, and I say here that they should not be. ... What is the use of our discussing on this side of the chamber what we would be satisfied with, when nothing has been offered us, and when we do not believe that we will be permitted to retain even that which we now have? If the two Senators from New York, the Senator from Ohio [Mr. Wade], the two Senators from Illinois, the Senator from New Hampshire [Mr. Hale], the Senators from Maine, and others, who are regarded as representative men, who have denied that, by the Constitution of the United States, slaves are recognized as property; who have urged

x Cong. Globe, 36th Cong., 2d sess., pt. i., p. 7I. 
and advocated those acts which we regard as aggressive on the part of the people-if they will rise here and say in their places that they desire to propose amendments to the Constitution and beg that we will vote for them; that they will, in good faith, go to their respective constituencies and urge the ratification; that they believe, if these Gulf States will suspend their action, that those amendments will be ratified and carried out in good faith; that they will cease preaching this 'irrepressible conflict' and if, in those amendments, it is declared that slaves are property, that they shall be delivered up upon demand; and if they will assure us that Abolition societies shall be abolished; that Abolition presses shall be suppressed; that Abolition speeches shall no longer be made; that we shall have peace and quiet; that we shall not be called cutthroats and pirates and murderers; that our women shall not be slandered-these things being said in good faith, the Senators begging that we will stay our hand until an honest effort can be made, I believe that there is a prospect of giving them a fair consideration. (Laughter on the Republican side.)

"Senators laugh in my face. I beg that my friend from Kentucky [Mr. Powell], and other Union savers upon this floor, will look and see the derision, the contempt, that is expressed in every Senator's face on the other side when I make these propositions. I trust that they will understand. Fas est $a b$ hoste doceri-learn even from your enemies some wisdom. Waste not your time in idle prattle. Get not into disputes, Senators from the South, with each other as to what you will be satisfied with and what you will take. I tell you, as I have told the people whom I represent, long and long ago, you will not be permitted to keep that which you now have. You are regarded as poltroons; and they talk of force, of coercion, of holding this glorious blood-bought Union, as they regard it, together with hemp. And yet you petition and beg and ask that this 'glorious Union' may be continued, in order that you may be taxed, and that the hard earnings of those 
men whom you represent shall be taken from their pockets in order to build up Northern wealth and property, to clear out their harbors and construct their roads. This is the manner in which you are treated when you talk about compromise. I knew what the result would be. I say to the Senators on the other side that you will have to abolish your Abolition societies if you expect to live long in our company. . . . Thus I say to the different States, as the representative of my State, that within your borders there are presses and there are public speakers, and unless the newspapers have given a false account of the fact, your President-elect a few months, or possibly weeks, before his nomination was a hired Abolition lecturer, delivering at \$IOo a lecture, lectures throughout the country, exciting the people against us. We say to those States that you shall not-that is the word I choose to use, and I reflect the feeling and determination of the people I represent when I use it-you shall not permit men to go there and excite your citizens to make John Brown raids or bring fire and strychnine within the limits of the State to which I owe my allegiance. You shall not publish newspapers and pamphlets to excite our slaves to insurrection. You shall not publish newspapers and pamphlets to excite the non-slaveholders against the slaveholders or the slaveholders against the non-slaveholders. We will have peace; and if you do not offer it to us, we will quietly, and, as we have the right under the constitutional compact to do, withdraw from the Union and establish a government for ourselves; and if you then persist in your aggressions, we will leave it to the ultima ratio regum and the sovereign States will settle that question

Where the battle's wreck lies thickest

And death's brief pang is quickest.

And when you laugh at these impotent threats, as you regard them, I tell you that cotton is king! . . .

"I know that you do not regard us as in earnest. I would save this Union if I could; but it is my deliberate impression 


\section{Congressional Debates}

that it cannot now be done. I have been studying the character of the people that you represent for years past. The family of Dives was the most prolific family that ever breathed or lived upon this earth. Those five brothers would not believe either Moses or the prophets; and if one rose from the dead, we are told that they would not believe him. They were prolific and their descendants have settled in the country in which you live. ... If you suppose that we are to be amused with the claptrap of 4th of July froth and the idea that there is anything of sacredness in a compact between nations, or that nations inherit rights, I simply say that those among whom I live have passed that point. So devoted a friend of the Union am I that when (as I know it must be because I see no disposition to save or to prevent it) the eight cotton States have withdrawn from this Union, as they will in the next two months do, and meet in convention to adopt a federal form of government for themselves, and to establish a foreign department, I for one shall advocate the adoption, without crossing a $t$ or dotting an $i$, of this same old glorious Constitution that was ratified by the old thirteen States; and when Virginia and Tennessee and Maryland and Kentucky and the other border States see what we have done, and know that the States who propose confederation to them will keep their treaty compacts, I have no doubt that one after the other of them will come into our union, and many days or months will not pass before this beautiful fabric will again be the scene of our discussions, in which we will consider not only those matters which appertain to us in our domestic affairs, but our foreign relations with you; and it may be, if war can be avoided, which you desire not to avoid, for you are wiser than that, we may here form a treaty with you.

"You know full well that if this Union is dissolved, and these Southern States go off, and your commerce is cut up, and your merchant princes are bankrupt and go to protest, and your manufactories are stopped, and your operatives are turned out, and your ships, deprived of the navigating 


\section{Political History of Secession}

laws, are laid up to rot, and your sailors turned loose to starve-you know that when these things occur, your heads will not be safe upon your shoulders. But if, in the meantime, you can bring the power of the Federal government to coercion, and before the treasury is drained of its last dollar, you can make soldiers out of your operatives and your sailors, you expect then, amid the heat of the contest, the confusion of ideas, as well as everything else, that you can conceal the facts, and denounce us for the calamities that are on this people; and you expect not to lead but to send them to battle. I understand your game as well as you do. There may, in this general arrangement, be conservative States of the North included. Pennsylvania may see that her iron and coal are about to be dug in the mountains of Tennessee and Virginia and North Carolina; Ohio and Indiana and Illinois may see that the grain, and the meat, and the hemp, and the horses, and the mules which they now furnish to us may be bought in Kentucky and in Missouri and in Tennessee; and they may leave you in the cold and come to us; and when they do, they will understand the blessings of this union from having lived out of it a few months, and they will be prepared to carry out in good faith the compact which they entered into with us. . . . If it were not for the memories of the past and for patriotic sentiment which I have heard from some persons who live in New England, I would regard it as the greatest blessing that had ever befallen the human family, that they could be left to live upon granite and ice. I do not know whether it would have any effect upon them; but it is said that hunger will tame a wolf. I do not know whether it would have any effect on them; but this I do know, that then they would have content themselves with managing their own affairs; and if they permitted their people further to interfere with us the sword would settle the contest, and the next treaty which was signed would be in Faneuil Hall in the town of Boston, and in the State of Massachusetts-there in that place which has been called 
the cradle of liberty, and has proved to be the grave of the Constitution. . . .

"In the State in which I live, and to which I owe my allegiance, and of which I am a citizen, during the last summer there were four towns that I know of, county sites, burned smooth to the ground. There were fourteen other places, as I have seen advertised in the newspapers, and have every reason to believe,-fourteen other settlements or towns, not county sites, - that were burned down. Strychnine was brought and given to our negroes for the purpose of poisoning their masters. An association called the 'Mystic Red' was entered into by members of the Methodist Church North and the John Brown men; and their purpose was to carry out the irrepressible conflict, to burn our towns, burn up the stores of our merchants, burn up the mills, to bring Free-soil Northern capital in, and thus get possession of Texas, and make it a free State, in order, as they said, to belt us round with free States, to starve us out, or cause us, as has been said by one whose language I seldom quote, 'like poisoned rats to die in our hole.' . . . In your schools you teach your children to hate us. In your pulpits you teach it as a religious duty. Upon the hustings you teach it. Your eighteen Northern non-slaveholding States nominate two of the most fanatical of your sect as candidates for President and Vice-President. You elect them; and now you tell us that they shall be inaugurated. . . . So far as this Union is concerned the cold sweat of death is upon it. Your Union is now dead; your government is now dead. It is to-day but lying in state, surrounded, it is true, by pomp and ceremony. They are, Senators, but the mournful ceremonies, pomp, and pageants which are seen around the mighty dead. The spirit has departed, and it has gone back to those who gave it-the sovereign States of this Union."

In another speech in reply to Douglas, which is chiefly significant as showing to how low an estate, in the public opinion of the South, the latter had fallen, Wigfall said: 
"Why, I tell the Senator that that great principle of his [non-intervention] disrupted the Democratic party, and has now disrupted the Union; and but for him and his great principle, this day a Democrat would have been President, and the Union saved. That is the fact about the matter; and when a Senator who has contributed more than any man in the Union, according to his ability, to the destruction of the country, comes here and charges me with complicity in dissolving the Union, and charges in terms that extremes meet, and that I and my friends, and the Freesoilers on the other side, are coopperating for the same purpose; that we are voting together and that we take great comfort in all these exhibitions of the impossibility of saving the Union, I tell him that he is not the man to come here and preach to anybody."

On March 2, only a few days before Lincoln's inauguration " Wigfall made another speech in which he said: "Then, briefly, a party has come into power that represents the antagonism to my own section of the country. It represents two million men who hate us, and who, by their votes for such a man as they have elected, have committed an overt act of hostility. That they have done. You have won the Presidency, and you are now in the situation of the man who had won the elephant at a raffle. You do not know what to do with the beast now that you have it; and one half of you to-day would give your right arms if you had been defeated. But you succeeded, and you have to deal with facts. Our objection to living in this Union, and therefore the difficulty of reconstructing it, is not your personal liberty bills, not the territorial question, but that you utterly and wholly misapprehend the form of government. You deny the sovereignty of the States; you deny the right of self-government in the people; you insist upon negro equality; your people interfere impertinently with our institutions and attempt to subvert them; you publish newspapers; you deliver lectures; you print pamphlets, and

× Cong. Globe, 36 th Cong., $2 \mathrm{~d}$ sess., pt. ii., p. 1400. 


\section{Congressional Debates}

you send them among us, first, to excite our slaves to insurrection against their masters, and next, to array one class of citizens against the other; and I say to you that we cannot live in peace, either in the Union or out of it, until you have abolished your Abolition societies; not, as I have been misquoted, abolish or destroy your schoolhouses; but until you have ceased in your schoolhouses teaching your children to hate us; until you have ceased to convert your pulpits into hustings; until you content yoursclves with preaching Christ, and Him crucified, and not delivering political harangues on the Sabbath; until you have ceased inciting your own citizens to make raids and commit robberies; until you have done these things we cannot live in the same Union with you. Until you do these things, we cannot live out of the Union at peace." In the same speech, only a few hours before Lincoln's inauguration, Wigfall contemptuously referred to him as "an ex-rail splitter, an ex-grocery keeper, an ex-flatboat captain, and an ex-Abolition lecturer."

The kind of constitutional amendment that was desired by Jefferson Davis may be inferred from a resolution introduced by him, which was one of the resolutions considered by the Senate Committee of Thirteen and which was as follows: "Resolved that it shall be declared by amendment of the Constitution, that property in slaves, recognized as such by the local law of any of the States of the Union, shall stand on the same footing in all constitutional and Federal relations as any other species of property so recognized; and, like other property, shall not be subject to be divested or impaired by the local law of any other State, either in escape thereto, or of transit or sojourn of the owner therein; and in no case whatever shall such property be subject to be divested or impaired by any legislative act of the United States, or of any of the Territories thereof."

The Republicans claimed that they had done nothing but to exercise their constitutional right of electing a

× Cong. Globe, 36th Cong., 2d sess., pt. i., p. 190. 
President; that they had not interfered, and did not intend to interfere, with slavery in the States where it existed, and that they would not be driven into recantation of all they had advocated before, and setting aside the verdict of the people in the preceding election, by threats of disunion. Senator Hale, of New Hampshire, very clearly and concisely stated the Republican position $\times$ in a speech on December 5 , I860, in which he said: "I think we might as well look this matter right clearly in the face; and I am not going to be long about doing it. I think that this state of affairs looks to one of two things: it looks to absolute submission, not on the part of our Southern friends and the Southern States, but of the North, to the abandonment of their positionit looks to a surrender of that popular sentiment which has been uttered through the constituted forms of the ballot box, or it looks to open war. We need not shut our eyes to the fact. It means war, and it means nothing else; and the State which has put herself in the attitude of secession so looks upon it. She has asked no counsel, she has considered it as a settled question, and she has armed herself. As I understand the aspect of affairs, it looks to that, and it looks to nothing else except unconditional surrender on the part of the majority. . . . I avow here-I do not know whether or not I shall be sustained by those who usually act with me-if the issue which is presented is that the constitutional will of the public opinion of this country, expressed through the forms of the Constitution, will not be submitted to and war is the alternative, let it come in any form or in any shape. The Union is dissolved and it cannot be held together as a Union, if that is the alternative upon which we go into an election. If it is pre-announced and determined that the voice of the majority, expressed through the regular and constituted forms of the Constitution, will not be submitted to, then, sir, this is not a Union of equals; it is a Union of a dictatorial oligarchy on the one side, and a herd of slaves and cowards on the other. That is it, sir,

r Cong. Globe, 36th Cong., 2d sess., pt. i., p. 9. 


\section{Congressional Debates}

nothing more, nothing less. . . . Let me say further, sir, that if there are gentlemen who look to the settlement of this controversy by further concessions from the North, I think they miscalculate and mistake. I believe the difficulty has been that we have conceded too much; we have compromised too much; and we have got to that position of things that whenever any fault is found, the ever-recurring remedy to the minds of patriots and statesmen is still further concessions from the North. I agree-I have said it here, I have said it to my own people at home, I am willing to repeat it here-I agree that under the Constitution of the United States you are entitled to demand and to have an honest and a fair discharge of that obligation which is imposed on all the States in regard to the rendition of fugitive slaves; and I am willing, perfectly willing, that there shall be an honest, fair, and faithful performance of that pledge."

On a later day he said": "I do not believe, sir, that the remedy is to be sought there. I do not believe that the remedy is to be sought in new constitutional provisions; but in an honest, faithful execution of the things that are already written in the compact and in the bond. I am willing, and I hope the State I represent is willing, to look this matter all over fairly, calmly, and dispassionately, and if there be anything that can be demanded of that State consistent with the dignity that belongs to a free State, and the regard that she owes to the Constitution, I have no doubt that she will render and perform it to the letter and to the spirit. But I say with all deference that I think these new compacts and these amendments are the mere daubing of the wall with untempered mortar."

Again, replying to Senator Clingman, he said": "I want to protest here, for one of the Northern States, against the tone of the Senator's speech, in which, looking to war, he talks to us as if we were the war-making power. Have we seized upon any forts? Have we taken any arsenals and

× Cong. Globe, 36th Cong., 2d sess., pt. i., p. 116.

${ }^{2} I d .$, p. 728. 


\section{4 Political History of Secession}

seized upon any mints? Have we done one single act looking to aggression? Have we fired into any flag, State or national? On the other hand, is not the condition of the Northern States one that subjects them, in the eyes of the world, to the charge of pusillanimity and reproach for wanting manliness in repelling the attacks that have been made upon them? Gentlemen come here and preach peace to us as if we were the aggressive party; as if the responsibilities of war must rest on us. Why, sir, if we have any of the responsibilities of war resting upon $u$, it will be by a course of conduct which subjects us, in the eyes of the world, to the imputation of cowards that lie still and invoke aggression."

Senator Wade, of Ohio, spoke on December I 7." "How is it," he said, "with the leaders of this modern revolution? Are they in a position to complain of the action of this government for years past? Why, sir, they have had more than two thirds of the Senate for many years past, and until very recently, and have almost that now. You-who complain, I ought to say-represent but a little more than one fourth of the free people of these United States, and yet your counsels prevail, and have prevailed all along for at least ten years past. In the Cabinet, in the Senate of the United States, in the Supreme Court, in every department of the government, your officers, or those devoted to you, have been in the majority, and have dictated all the policies of this government. Is it not strange, sir, that they who now occupy these positions should come here and complain that their rights are stricken down by the action of the government? . . . . Why, sir, I can hardly take up a paper-and I rely, too, upon Southern papers-which does not give an account of the cruel treatment of some man who is traveling for pleasure or for business in your quarter; and the lightest thing you do is to visit him with a vigilance committee, and compel him to return: 'We give you so long to make your way out of our coast.' 'What is the accusation?' 'Why, sir, you are from Ohio.' They do not

¿ Cong. Globe, 36th Cong., 2d sess., p. 99. 


\section{Congressional Debates}

even inquire what party he belongs to, or what standard he has followed. I say this is the case, if I may rely on the statements of your own papers; and many of these outrages occur under circumstances of cruelty that would disgrace a savage; and we have no security now in traveling in nearly one half of the Union, and especially the Gulf States of this confederacy. I care not what a man's character may be; he may be perfectly innocent of every charge; he may be a man who never has violated any law under heaven; and yet if he goes down into those States, and it is ascertained that he is from the North, and especially if he differs from them in the exercise of his political rights, if he has voted for Lincoln instead of for somebody else, it is a mortal offense, punishable by indignity, by tar and feathers, by stripes, and even by death; and yet you, whose constituents are guilty of all these things, can stand forth and accuse us of being unfaithful to the Constitution of the United States! Gentlemen had better look at home. ... Then, sir, what is it of which complaint is made? You have had the legislative power of the country and you have had the Executive of the country, as I have said already. You own the Cabinet, you own the Senate, and, I may add, you own the President of the United States as much as you own the servant upon your own plantation. I cannot see, then, very clearly, why it is that Southern men can rise here and complain of the action of this government."

Seward spoke on January $12 .^{x}$ In his speech he made an elaborate argument to prove the advantages of the Union to the whole country; of the calamities that would befall all parts of it if it should be broken into separate, independent, and hostile confederacies. He dwelt also upon the horrors of civil war. He denied that the seceding States had any constitutional or just right to secede, but avoided any expression of opinion as to what the government ought to do or had the power to do if they refused to come back into the Union. He did say, however, that he "did not

r Cong. Globe, 36th Cong., 2d sess., pt. i , p. 34 I. 


\section{Political History of Secession}

know what the Union would be worth if saved by the sword." $\mathrm{He}$ offered various suggestions for bringing about a reconciliation of the seceding States, but the most extraordinary of them was that in which he said: "I should prefer a different course, namely: when the eccentric movements of secession and disunion shall have ended, in whatever form that end may come, and the angry excitements of the hour shall have subsided, and calmness once more shall have resumed its accustomed sway over the public mind, then, and not until then-one, two, or three years hence-I should cheerfully advise a convention of the people, to be assembled in pursuance of the Constitution, to consider and decide whether any and what amendments of the organic national law ought to be made. A Republican now-as I have heretofore been a member of other parties existing in my day-I nevertheless hold and cherish, as I have always done, the principle that this government exists in its present form only by the consent of the governed, and that it is as necessary as it is wise, to resort to the people for revisions of the organic law when the troubles and dangers of the State certainly transcend the powers delegated by it to the public authorities. Nor ought the suggestion to excite surprise. Government in any form is a machine; this is the most complex one that the mind of man has ever invented, or the hand of man has ever framed. Perfect as it is, it ought to be expected that it will, at least as often as once in a century, require some modification to adapt it to the changes of society and alternations of empire."

Of this speech one of Seward's biographers ${ }^{\mathrm{I}}$ says: "Considering the actual conditions and what was most urgent at that time, there is reason to believe that this was as wise, as patriotic, and as important a speech as has ever been delivered within the walls of the Capitol. If Seward had spoken as most of the Republicans had done, or if he had gone no farther than Lincoln had even confidentially expressed a willingness to go, by March 4 there would

× Bancroft, vol. ii., p. 16. 
have been no Union that any one could have summoned sufficient force to save or to reëstablish. To Seward, almost alone, belongs the credit of devising a modus vivendi."

This was not the judgment of Seward's contemporaries; it is not probable that it will be the judgment of posterity. It was able and eloquent but it was as far from meeting the requirements of the hour as would have been one of Demosthenes' orations. It did not stay work upon the plans for the bombardment of Fort Sumter. It did not check the preparations for organizing a Southern confederacy and putting it on a war footing. It was not Seward's speech, but the vigorous measures taken by the loyal members of Buchanan's Cabinet, Black, Stanton, and Holt, with the cooperation of General Scott, that checked the Confederate program for seizing the national capital before the inauguration of Lincoln. Indeed there is no satisfactory evidence that Seward's speech had the slightest weight with the extremists of the South. These now regarded secession as "an accomplished fact." They were already elated by dreams of a mighty confederacy, of which slavery would be the corner-stone, finally absorbing Cuba and Mexico, dominating the whole North American continent, and compelling the world to pay tribute to "King Cotton." It is doubtful if the seceding States would have assented to any union with New England, except on such terms as a conqueror might be expected to dictate to his vanquished foe.

Nor did Seward's speech satisfy the radicals of the North. They thought, as did Patrick Henry in Revolutionary times, that the time had gone by for crying "Peace! Peace!" when there was no peace and nothing remained but to prepare for war. They did not believe in sitting on the banks, to use one of Seward's own metaphors, waiting for the rising flood of secession to run by. They were determined to make no more concessions to slavery such as involved the humiliating recantation of all the doctrines for which they had been contending for years at the moment when they had been 
victorious at the polls. They were unalterably opposed to a dissolution of the Union and believed it to be worth saving, even if it had to be "saved by the sword." They could see nothing but disaster in the proposition to wait "one, two, or three years," until a Southern confederacy should be firmly established, and then endeavoring to patch to it the remaining broken fragments of the old Union. Nor could the radicals be persuaded of the wisdom of the policy that would require them to sit with folded arms until the gathering Confederate armies should take the field and begin their northward march; until, as Wigfall predicted, Confederate Senators and Representatives should fill the halls of the Capitol at Washington; until, in further fulfillment of his threats, some Confederate general should dictate terms of peace to New England in Faneuil Hall.

It is certain that the radical Republicans, instead of looking at Seward's speech as devising a modus vivendi, viewed it as prescribing a fatal opiate which might possibly enable the Union to die peacefully and without a struggle, but with the stigma of cowardice upon its memory, blotting out all that was glorious in its past history.

Seward's speech marks the beginning of his decline as a political leader. He was no longer looked upon as spokesman by his old-time political followers, who were now turning to other leaders, bolder, more outspoken and aggressive.

Douglas spoke on January $3, \mathbf{1} 86 \mathrm{I}^{\mathrm{x}}$ While strongly in favor of the Crittenden resolutions and of exhausting all reasonable efforts at compromise before resort to war he was explicit in his assertion that the secession of South Carolina was "wrong, unlawful, unconstitutional, criminal. ... Unquestionably we have the right to use all the power and force necessary to regain possession of that portion of the United States in order that we may again enforce our Constitution and laws upon the inhabitants."

Upon the general doctrine of the right of secession he said: "I will not argue the question of the right of secession any

${ }^{x}$ Cong. Globe, 36th Cong., $2 \mathrm{~d}$ sess., pt. ii., App., p. 35. 
further than to enter my protest against the whole doctrine. I deny that there is any foundation for it in the Constitution, in the nature of the compact, in the principles of the government, or in justice, or in good faith."

Upon the right and power of the general government to "coerce" the seceding States he was still more explicit. "Nor do I sympathize at all," he said, "in the apprehensions and misgivings I hear expressed about coercion. We are told that inasmuch as our government is founded upon the will of the people, or the consent of the governed, therefore, coercion is incompatible with republicanism. Sir, the word government means coercion. There can be no government without coercion. Coercion is the vital principle upon which all governments rest. Withdraw the right of coercion, and you dissolve your government. If every man would perform his duty and respect the rights of his neighbors voluntarily, there would be no necessity for any government on earth. The necessity of government is found to consist in the fact that some men will not do right unless coerced to do so. The object of all government is to coerce and compel every man to do his duty, who would not otherwise perform it. Hence I do not subscribe at all to this doctrine that coercion is not to be used in a free government. It must be used in all governments, no matter what their form or what their principles." Indeed, upon the vital question then under discussion the bold and outspoken words of Douglas offer a refreshing contrast to the vague and dubious utterances of Seward.

Far more effective and far better suited to the occasion than Seward's speech, perhaps better than any other one speech on the Northern side, was that of Senator Trumbull, of Illinois, on March 2, 1861. ${ }^{x}$

Then, and for months before, the imperative need was for prompt and vigorous action on the part of the Federal government, if the Union were to be saved from destruction.

'Cong. Globe, 36th Cong., 2d sess., pt. ii., p. 1380; White, Life of Trumbull, p. 123 . 
The eloquent eulogies of the Union and of the sacredness of the bonds that for so long had held it together had lost their force with those who were then bent on its destruction. The discourses on the blessings of peace had little weight with the men already preparing for war. All such appeals had failed to save a single fort or arsenal in the seceded territory or to stay preparations for seizing the few that were left. By continuing the debates in Washington, the leaders of secession were not losing but gaining time, time that was precious in enabling them to complete their preparations for organizing and putting the Confederacy upon a war footing. The Federal government needed to be awakened from its lethargy and the people of the North needed to be convinced that, while eloquence might be matched with eloquence and arguments met by arguments, immediate preparations must be made by the government to meet those of the secessionists, to get the sword ready if it should be found necessary to save the Union by the sword, and to prepare to oppose the gathering armies of the South, or else to incur the ignominy of a surrender without a struggle.

Trumbull showed all this in a speech free from rant or vituperation, felicitous in expression, and forceful in argument. He began by acknowledging Crittenden's long public service, his patriotism and devotion to the Union, but claiming that Crittenden was in error in laying all the blame for the distracted condition of the country upon the Republicans of the North and none upon the South. "Does he expect," said Trumbull, "or can he expect, that compromises will be made and concessions yielded when he talks of the great party of this country, constituting a majority of its people, as being wedded to a dogma set up above the Constitution; when he talks of us as usurping all the Territories, as ostracizing all the people of the South, and denying them their rights? Is that the way to obtain compromises? Instead of turning his denunciation upon those who violate the Constitution and trample the flag of 


\section{Congressional Debates}

the country in the dust, he turns to us and talks to us of usurpations; of our dogmas; tells us that for a straw we are willing to dissolve the Union and involve the country in blood. Why are not these appeals made and these rebukes administered to the men who are involving the country in blood? If it is a straw for us to yield, is it anything more than a straw for them to demand? If it is a trifle for us to concede, is it any larger than a trifle which the South demands, and to obtain which it is willing to destroy this Union, which he has so beautifully and so highly eulogized?"

Trumbull then reviewed previous attempts to secede and the continued threats of secession. Of the secession movement in 1860 he said: "In 1860 , by the connivance and the assistance of the government itself, it acquired the strength which it now has. What has been the policy of the expiring Administration? Its Cabinet officers, boasting of their complicity with the men who were plotting the destruction of the government; openly proclaiming in the face of the world that they had used their official power, while members of the Cabinet, and sworn to protect and preserve the government, to furnish the means for its destruction; openly acknowledging before the world that they had used the power which their positions gave them to discredit the government, and also to furnish arms and munitions of war to the men who were conspiring together to assault its fortifications, and seize its property; openly boasting that they had taken care, during their public service, to see that the arms of the Federal government were placed in convenient positions for the use of those who designed to employ them for its destruction. More than this, members, while serving in the other branch of Congress, go to the Executive of the United States, and tell him, 'Sir, we are taking steps in South Carolina to break up this government; you have forts and fortifications there; they are but poorly manned; now if you will leave them in the condition they are until the State of South Carolina gets ready to take possession, we will wait until that time before 
we seize them'; and the Executive of the nation asks that the treasonable proposition be put in writing, and files it away. Why, sir, is there another capital on the face of the globe, to which men could come from State or province, and inform the executive head that they were about to take steps to seize the public property belonging to the government, and warn the Executive to leave it in its insecure and undefended state until they should be prepared to take possession, and they be permitted to depart? Is there another capital on the face of the globe where commissioners coming to the Executive under these circumstances would not have been arrested on the spot for treason? But your government, if it did not directly promise not to arm its forts, certainly took no steps to protect its public property; and this thing went on, until a gallant officer who was in command of less than a hundred men in the harbor of Charleston, acting upon his own responsibility, thought proper to throw his little force into a fort where he could protect himself; and then it was that these insurgents, rebelling against the government, demanded that he should be withdrawn, and the Executive then was forced to take position. Then his Cabinet officers who had been in conspiracy with the plotters of treason, then the Chief Magistrate himself was forced to take position. . . .

"Notwithstanding this, the Executive of the nation, disregarding the advice of the Lieutenant-General who commands the armies of the United States, and who had warned him months before of the movements which were taking place to seize the public property at the South, still leaves the property unprotected; and the insurgents go on in some of the States, before even passing ordinances of secession, and continue to seize the public property; to capture the troops of the United States; to take possession of the forts; to fire into its vessels; to take down its flag; until they have at this time in their possession fortifications which have cost this government more than $\$ 5,000,000$, and which mount more than a thousand guns. All this has been done without any effort 
on the part of the government to protect the public property; and this is the reason that secession has made the head it has. Why, sir, let me ask, is it that the United States to-day has possession of Fort Sumter? Can you tell me why is Fort Sumter in possession of the United States? Because there are a hundred soldiers in it-for no other reason. Why is Fort Moultric in possession of the insurgents? Because there were no men there to protect it; and it is now matter of history that, had the Executive done his duty, and placed a hundred men in Fort Moultrie, a hundred in Castle Pinckney, and a hundred in Fort Sumter, Charleston harbor to-day would have been open, and your revenues would have been collected there, as elsewhere throughout the United States.

"Will it be said that Carolina would have attacked those forts, thus garrisoned? She does not attack a hundred men in Fort Sumter. It is a wonder that she does not. The little, feeble garrison there is well calculated to invite attack; but this thing of secession, under the policy of the Administration, has been made a holiday affair in the South. This great government, one of the most powerful on the face of the globe, is falling to pieces just from its own imbecility. . . . This then, briefly, is the reason that this secession movement has acquired the strength it has. It is because this government has either favored it or refused to do anything to check it. Notwithstanding the mistake of 1854 , the country would have survived it all, had we had a Government to take care of and preserve it."

Coming to the "Crittenden Compromise" he said: "The proposition known as the 'Crittenden Compromise' declares not only that, 'in the territory south of said line of latitude, slavery of the African race is hereby recognized as existing, and shall not be interfered with by Congress'; but it provides further, that, in the territory we shall hereafter acquire south of that line, slavery shall be recognized, and not interfered with by Congress; but 'shall be protected as property by all the departments of territorial government during its 


\section{Political History of Secession}

continuance'; so that, if we make acquisitions on the south of territories now free, and where, by the laws of the land, the footsteps of slavery have never been, the moment we acquire jurisdiction over them, the moment the Stars and Stripes of the Republic float over those free territories, they carry with them African slavery, established beyond the power of Congress, and beyond the power of any territorial legislature, or of the people, to keep it out; and we are told that this is the Missouri Compromise! We are told that slavery now exists in New Mexico; and I was sorry to find even my friend from Oregon [Mr. Baker] ready to vote for this proposition, which establishes slavery. Why, sir, suppose slavery does exist in New Mexico; are you for putting a clause into your Constitution that the people of New Mexico shall not drive it out?

"But, sir, unlike the Senator from Oregon, I will never agree to put into the Constitution of the country a clause establishing or making perpetual slavery anywhere. No, sir, no human being shall ever be made a slave by my vote. No foot of God's soil shall ever be dedicated to African slavery by my act-never, sir. I will not interfere with it where I have no authority by the Constitution to interfere; but I never will consent, the people of my State, the people of the great Northwest, numbering more in white population than all your Southern States together, never will consent by their act to establish African slavery anywhere. ...

"The Senator from Texas [Wigfall] wants to know how we are going to preserve the Union; how we are going to stop the States from seceding? And our Southern friends sometimes ask us to give them something to stand upon in the South. The best political foundation ever laid by mortal man upon which to plant foot is the Constitution. Take the old Constitution as your fathers made it, and go to the people on that; rally them around it, and not suffer 


\section{Congressional Debates}

it to be kicked about, rolled in the dust, spit upon, and their efforts to be wasted in vain efforts to amend it. . . .

"The Southern States have been arming. The Senator from Virginia [Mr. Mason] told us the other day that his State had appropriated $\$ 1,500,000$ to arm its citizens. For what? To arm its citizens to fight against this government; and then tell us that, to a man, they will fight against this government, if it undertakes to enforce its laws, which they call coercion, the coercion of a State! Why, sir, a government that has not the power of coercing obedience to its laws is no government at all. The very idea of a law without a sanction is an absurdity. A government is not worth having that has not power to enforce its laws. If the Senator from Texas wants to know my opinion, I tell him yes, I am for enforcing the laws. Do you mean by that you are going to march an army to coerce a State? No, sir; and I do not mean the people of this country to be misled by this confusion of terms about coercing a State. The Constitution of the United States operates upon individuals; the laws operate upon individuals; and wherever individuals make themselves amenable to the laws, I would punish them according to the laws. We may not always be able to do this. Why, sir, we have a criminal code, and laws punishing larceny and murder and arson and robbery and all these crimes; and yet murder is committed, larcenies and robberies are committed, and the culprits are not always punished and brought to justice. We may not be able, in all instances, to punish those who conspire against the government. So far as it can be done, I am for executing the laws; and I am for coercion. I am for settling in the first place the question whether we have a government before making compromises which leave us as powerless as before.

"Sir, if my friend from Kentucky would employ some of that eloquence of his which he uses in appealing to Republicans-and talking about compromise - in defense of the Constitution as it is, and in favor of maintaining the laws 


\section{Political History of Secession}

and the government, we should see a very different state of things in the country. If, instead of coming forward with compromises, instead of asking guaranties, he had put the fault where it belongs, if he had called upon the government to do its duty; if, instead of blaming the North for not making concessions where there is nothing to concede, and not making compromises where there was nothing to compromise about, he had appealed to the South, which was in rebellion against the government, and painted before them, as only he could do it, the hideousness of the crimes they were committing, and called upon them to return to their allegiance, and upon the government to enforce its authority, we would have a very different state of things in this country to-day from what now exists.

"This, in my judgment, is the way to preserve the Union; and I do not expect civil war to follow from it. You have only to put the government in a position to make itself respected, and it will command respect. As I said before, five hundred troops in Charleston would unquestionably have kept that port open; and if you will arm the government with sufficient authority to maintain its laws and give us an honest Executive, I think you will find the spread of secession soon checked; it will no longer be a holiday affair. But while we submit to the disgrace which is heaped upon us by those seceding States, while the President of the United States says, 'You have no right to secede; but if you want to, you may, we cannot help it,' you may expect secession to spread. . . . Some Senators talk about the Federal government making war. Who proposes it? The Southern people affect to abhor civil war, when they, themselves, have commenced it. Inhabitants of the six seceding States have begun the war. What is war? Is firing into your vessels war? Is investing your forts war? Is seizing your arsenals war? They have done it all, and more; and then have the effrontery to say to the United States, 'Do not defend yourself; do not protect your government; let it fall to pieces; let us do as we please, or else you will have 
war.' The highwayman meets you on the street, demands your purse, and tells you to deliver it up, or you will have a fight. You can always escape a fight by submission. If in the right-and which is far better than to submit to degradation-you can often escape collision by being prepared to meet it. The moment the highwayman discovers your preparation and ability to meet him, he flies away. Let the government be prepared, and we shall have no collision."

In conclusion he said: "I cannot belicve that this mad and insane attempt to break up such a government is to succeed. If my voice could reach them, I would call upon my Southern brethren to pause, to reflect, to consider if this Republican party has yet done them any wrong. What complaints have they to make against us? We have never wielded the power of government-not for a day. Have you of the South suffered any wrong at the hands of the Federal government? If you have you inflicted it yourselves. We have not done it. Is it the apprehension that you are going to suffer wrong at our hands? We tell you that we intend no such thing. Will you, then, break up such a government as this, on the apprehension that we are all hypocrites and deceivers, and do not mean what we say? Wait, I beseech you, until the government is put into operation under this new Administration; wait until you hear the inaugural from the President-elect; and I doubt not it will breathe as well a spirit of conciliation and kindness towards the South as towards the North. While I trust it will disclose a resolute purpose to maintain the government, I doubt not it will also declare, in unequivocal terms, that no encroachments shall be made upon the constitutional rights of any State while he who delivers it remains in power."

The debates in the House were along the same general lines and were of the same general character as those in the Senate. It will suffice here to quote from the speeches of Roger A. Pryor, of Virginia, and Thaddeus Stevens, of 


\section{Political History of Secession}

Pennsylvania. Pryor spoke on January 28, $\mathbf{1 8 6 1 . *}$ "Foremost," he said, "in the catalogue of Southern grievance is the complaint that the fundamental principle of the confederacy, the equality of the States, is subverted by a combination between a majority of States to exclude other States from an equal participation in the common domain, and so to deny them equal advantages of expansion and development under the operation of the Federal government." Another ground of complaint was that the constitutional provision in regard to fugitive slaves had been "shamefully annulled by the Northern States; and by the default millions of Southern property have been confiscated. ... Already," he said, "sovereign States are reduced, in contemplation, to the condition of provincial dependency; and that doom they would speedily realize, but for the indomitable spirit which quails not before all the 'pomp and circumstance' of your martial preparation."

Contrasting the pacific intentions of the South with the warlike designs of the North he said: "Since the fatal 6th of November to the present hour, the representatives of the South have invariably exhibited an accommodating disposition. The first day of our session was signalized by a proposition from a colleague of my own [Mr. Boteler], which contemplated a pacific adjustment of our difficulties. A similar movement, likewise originating with a Southern man, was initiated in the Senate. Meanwhile various schemes of settlement have been submitted in one or the other House of Congress, of which, without much regard to their intrinsic efficacy, we have uniformly avowed our support; while on the other side they have been as uniformly rejected with a contemptuous disdain of compromise. Thus, while the South are willing to remain in the Union with an assurance of their rights, the North declare, by a refusal of all concession, that they will destroy the Union rather than renounce their aggressive designs. In the perverted patriotism of the dominant party, the Constitution

r Cong. Globe, 36th Cong., 2d sess., pt. i., p. 6oI. 
of Washington is substituted by the platform of Lincoln; and rather than be reproached with logical inconsistency, they choose to incur the guilt of civil war. And not in the negative sense of rejected compromise only do this party betray a purpose to push the dispute to the arbitrament of the sword. Instead of a proclamation of conservative policy that should give assurance of peace to a distracted country, their leader announces that his administration is to be directed by the counsels of the champion of the 'irrepressible conflict.' Instead of the sense of justice and patriotic spirit which, we were told, still animate the masses of the Northern people, Northern legislatures vote men and munitions of war to chastise the resistance roused by their own perfidious violations of a constitutional covenant. And here, while with the one hand Republican representatives spurn all overtures of peace, with the other they grasp the sword. No measure of conciliation will they pass; their energies are engrossed in contriving schemes of coercion. Day after day develops the completeness of their system of force. Now it is a bill denying South Carolina the facilities of postal communication; and anon a bill for the compulsory collection of the revenue at Charleston. In the South, frowning fortresses threaten the subjugation of sovereign States; in this District a hireling soldiery are concentrated to impose an obnoxious ruler on an unwilling people. Auspicious inauguration of a Republican President! Happy presage of a liberal administration!"

Spurning with contempt the idea of the "subjugation of the South," he said: "But I dismiss the humiliating thought. No matter what her inferiority of force, you cannot subjugate the South. Smitten she may be, but not subdued; defeated, but never dismayed. Already, by her determined and defiant attitude, she gives you earnest of the spirit that will animate her sons in the hour of trial. From many memorable examples of heroic resistance to wrong, they derive the consolatory assurance that a brave people battling for the right are invincible against any odds. 
Nine million of freemen-and heed not, I admonish you, the treacherous suggestion that the South will not oppose a united front to the foe-nine million of freemen, of a race the most energetic and indomitable recorded in history, glorying in traditions of ancestral prowess, and attached to the cause of liberty with a chivalric devotion-this people, themselves distinguished for valor and the genius of war, contending on their own soil for whatever imparts a felicity to life-this people will laugh to scorn all the imposing array of your military preparation."

Thaddeus Stevens spoke on January 29. In the course of his speech he said: "The secession and rebellion of the South have been inculcated as a doctrine for twenty years past among slaveholding communities. At one time the tariff was deemed a sufficient cause; then the exclusion of slavery from free Territories; then some violations of the Fugitive Slave Law. Now the culminating cause is the election of a President who does not believe in the benefits of slavery, or approve of that great missionary enterprise, the slave trade. The truth is, all these things are mere pretenses. The restless spirits of the South desire to have a slave empire, and they use these things as excuses. Some of them desire a more brilliant and stronger government than a republic. Their domestic institutions, and the social inequality of their free people, naturally prepare them for a monarchy surrounded by a lordly nobility-for a throne founded on the neck of labor."

Continuing he said: "Let no slave State flatter itself that it can dissolve the Union now and then reconstruct it on better terms. The present Constitution was formed in our weakness. Some of its compromises were odious, and have become more so by the unexpected increase of slaves, who were expected soon to run out. But now, in our strength, the conscience of the North would not allow them to enter into such partnership with slaveholding. If this Union should be dissolved, its reconstruction would

'Cong. Globe, 36th Cong., $2 \mathrm{~d}$ sess., pt. i., p. $62 \mathrm{I}$. 
embrace one empire wholly slaveholding, and one republic wholly free. While we will religiously observe the present compact, nor attempt to be absolved from it, yet if it should be torn to pieces by rebels, our next United States will contain no foot of ground on which a slave can tread, no breath of air which a slave can breathe."

Speaking for Pennsylvania he said: "While Pennsylvania would go, as I would, to the verge of the Constitution and of her principles, to maintain peace, I believe it is a libel on the good name of her virtuous people to say that she would sacrifice her principles to obtain the favor of rebels. I believe it to be a libel on her manhood to say that she will purchase peace by unprincipled concessions to insurgents with arms in their hands. If I thought such was her character, I would expatriate myself. I would leave the land where I have spent my life from early manhood to declining age, and would seek some spot untainted by the coward breath of servility and meanness. To her pleasant valleys I would prefer the rugged, bold State of my nativity; nay, any spot in the most barren Arctic regions, amid whose pure icicles dwells manly freedom."

At last above the Babel-like confusion of tongues the voice of Abraham Lincoln was heard." "I will suffer death," he said, "before I will consent or advise my friends to consent to any concession or compromise which looks like buying the privilege of taking possession of the government to which we have a constitutional right; because, whatever I might think of the merit of the various propositions before Congress, I should regard any concession in the face of menace as the destruction of the government itself, and a consent on all hands that our system shall be brought down to a level with the existing disorganized state of affairs in Mexico. But this thing will hereafter be, as it is now, in the hands of the people; and if they desire to call a convention to remove any grievances complained of, or to

s New York Tribune, January 30, 186r; quoted in McPherson, History of the Rebellion, p. 62. 


\section{Political History of Secession}

give new guaranties for the permanence of vested rights, it is not mine to oppose."

Lincoln told Governor Yates, of Illinois, that he would "rather be hanged by the neck till he was dead, on the steps of the Capitol, than buy or beg a peaceful inauguration"; and in a letter to Senator Trumbull written on December Io, I 860, he said: "Let there be no compromise on the question of extending slavery; if there be, all our labor is lost and erelong must be done over again. . . . The tug has to come, and better now than any time hereafter." $x$

Looking back now at the excited condition of the public mind and reading the inflammatory harangues that were made we see clearly how vain and futile were all the peace propositions proposed. The wonder now is how so many sensible men, even statesmen like Seward, closing their eyes and ears to all signs of the approaching storm, should have refused to believe that it was ready to burst forth at any moment, and that they kept on hoping, with Micawberlike serenity, that something would yet "turn up" by which the storm could be averted.

Judge Robertson's mission to the seceded States was as unsuccessful as were the labors of the peace conference. Some of the States contemptuously met the proposition to send commissioners to Washington with a counter-proposition to send commissioners to Montgomery, Alabama. Robertson, instead of converting the seceding States to the preservation of the Union, was himself converted to the cause of secession. ${ }^{2}$

During this session of Congress several other Southern States, following the example of South Carolina, seceded, and as they seceded their representatives in Congress withdrew. Several of the seceding members made speeches, previous to taking final leave. The occasion was impressive and some of the speeches indicated that the speakers were not insensible of the gravity of the situation and of the

${ }^{\prime}$ White, Life of Trumbull, p. II I.

Nicolay and Hay, Lincoln, vol. iii., pp. 228-9. 
weight of responsibility which it imposed upon them, as they were leaving the old Union preparatory to its destruction, and that the passions of the hour had not wholly effaced old memories-memories of old associates, old ties, old friendships - that still clung to the old home. All the speeches were not of this character. One of them was that of Senator C. C. Clay, of Alabama." His speech was wholly destitute of argument, filled with malignant vituperation, and significant only as showing the hatred of the North that animated him and those of the South who thought as he did. In his speech, he charged a long list of crimes to the antislavery spirit which he said dominated the North and had "invaded the borders of Southern States, poisoned their wells, burnt their dwellings, and murdered their people," and had "exerted all the moral and physical agencies that human ingenuity can devise or diabolical malice can employ to heap odium and infamy upon us and make us a byword of hissing and of scorn throughout the civilized world."

Jefferson Davis withdrew on January 21, making an elaborate speech in which he called attention to the distinction between nullification and secession, but justified both.

So all the peace propositions had come to naught. Only those proposed by Senator Crittenden ever had any chance of passage in the House. Even if these had been passed by both the Senate and House, they would never have been ratified in the North. It is certain that they would not have tempted South Carolina back into the Union. It is doubtful if they would have induced any one of the seceding cotton States to return. With them, secession was already, as stated in the debates, "an accomplished fact." It was probably a knowledge of all these facts, clear to some in the beginning, but clearer to all at the close of Congress, which created a general belief that further discussion of the proposed compromises would be fruitless.

The closing session of the Thirty-sixth Congress was as

'Cong. Globe, 36th Cong., 2d sess., pt. i., p. 486. 
memorable for what it did not do as for the little that it accomplished. Notwithstanding the warlike preparations openly going on in the seceded States, no preparation whatever was made by Congress for the national defense, nothing to increase or render more efficient either the army or navy, to recover any national forts or arsenals that had been taken, or to defend those that were left. On the contrary all the bills introduced auchorizing the President to call out the militia, to accept the services of volunteers, and to strengthen the navy were rejected. This is referred to by Buchanan in his defense of his Administration as an excuse for his not doing more than he did to suppress secession in its early stages. $x$ But he had not at any time asked for any such legislation and from the tone of his annual message it is probable that he did not desire any, for it would have been of no use to raise an army and navy in order to "coerce a sovereign State," when according to the message, the President would have no constitutional right to use them for that purpose. Moreover it is clear from the debates on the bills that were introduced that there was not the least possibility of their passage through the Senate while the Senators from the States which were contemplating secession remained members of it. Indeed the national government was in a far more critical condition when Congress adjourned than it was when it began.

'Buchanan's Administration, pp. 160-16I ; Black, Essays and Speeches, pp. 9-24. 


\section{CHAPTER XXIV}

THE CLOSING MONTHS OF BUCHANAN'S ADMINISTRATION

$\mathrm{T}$

HE period intervening between the election of Lincoln and his inauguration was full of important and exciting events. During this period secession made rapid progress. From the evidence we now have it seems that it was originally intended by the secession leaders to defer the formation of a Southern confederacy until everything should be in readiness to confront the incoming Administration, before it could be prepared for it, with a hostile government, organized and fully equipped for war, offensive or defensive. It was taken for granted that the preliminary preparations could be made much more easily and effectually under Buchanan's administration than they could be under that of his successor, but it was not deemed expedient to force matters to such a point during Buchanan's administration as to compel him to assume a hostile attitude, or to embarrass him by throwing upon him any responsibility that, if left to his own choice, he might seek to shift upon the succeeding administration. At any rate, so long as the members of Buchanan's Cabinet retained their places and the Southern members of Congress remained in their seats, much could be done in the way of tying Buchanan's hands, if he should be inclined to favor any measure looking like coercion of the seceding States. For these reasons some of the secession leaders, like Howell Cobb, advised against the formation of a Southern confederacy before the 4th of March. It was hoped, however, to have everything in readiness by that time to launch the new government. 


\section{Political History of Secession}

Every effort was being made, and with confident expectations of success, to induce Virginia and Maryland to secede, and it was hoped that, when this should have been accomplished, the proposed confederacy would take possession of the city of Washington and make it the capital of the new government. ${ }^{\mathrm{x}}$

In making their plans the secession leaders did not expect that Buchanan, upon the formation of the proposed confederacy, would at once abdicate and surrender to it the capital, the army and navy, and all the offices and property of the national government. But they did rely upon Buchanan's supposed sympathy with his lifelong political friends and upon the views expressed by him in his annual message as to the absence of any power in the national government to resort to anything like coercion or the maintenance by arms of its authority in the territory of the seceded States.

More reliance was placed by the secession leaders upon the assumption that they would have the active sympathy and support of a majority of the members of Buchanan's Cabinet. At the time of the election of Lincoln, Buchanan's Cabinet consisted of Lewis Cass, of Michigan, Secretary of State, Howell Cobb, of Georgia, Secretary of the Treasury, John B. Floyd, of Virginia, Secretary of War, Isaac Toucey, of Connecticut, Secretary of the Navy, Jacob Thompson, of Mississippi, Secretary of the Interior, Jeremiah S. Black, of Pennsylvania, Attorney-General, Joseph Holt, of Kentucky, Postmaster-General. Various changes occurred prior to the inauguration of Lincoln. Cobb resigned as Secretary of

× The evidence that this was a part of the general plan of the secession leaders and the efforts to defeat it are fully detailed in a long letter of Holt to Buchanan. While the evidence may not be sufficient to prove any overt act done in the carrying out of such plan, it is amply sufficient to show that it would have been criminal negligence on the part of the national authorities to abstain from taking the defensive preparations that were taken to avert the threatened danger. See report of Holt, dated February 18, I86I; War Rec., vol. i., series 3, pp. 399-40I; McPherson, History of the Rebellion, p. $8 \mathrm{r}$. 
the Treasury on December 10, 1860 , and was succeeded by Philip E. Thomas of Maryland, who resigned on January II, I86I, and was succeeded by John A. Dix of New York. Cass resigned as Secretary of State on December 12, 1860, and was succeeded by Jeremiah S. Black, promoted from Attorney-General, and Black's place as Attorney-General was filled by the appointment of Edwin M. Stanton on December 20, 1860. Floyd resigned on December 29, 1860, and was succeeded by Holt, promoted from PostmasterGeneral, and Holt's place as Postmaster-General was filled by the appointment of Horatio King of New York on February 12, 1861. Jacob Thompson resigned as Secretary of the Interior on January $8,186 \mathrm{I}$, and no successor was appointed. Toucey remained in the Cabinet until the expiration of Buchanan's term.

General Cass, the Secretary of State, was opposed to secession and to the policy of Buchanan in dealing with it and resigned on this account; but, as before stated, he was seventy-five years old and it was believed by the secession leaders that he and Toucey, if inclined to favor coercive measures by the national government, would be overruled by stronger men in the Cabinet, especially by Cobb, Floyd, and Thompson. Moreover the Chief Assistant Secretary of State was William H. Trescott, a native of South Carolina and devotedly attached to the interests of that State. Cobb also was an avowed secessionist and shortly after his resignation he issued a long address advising the secession of Georgia. Afterwards he became President of the Confederate Congress and at a later date a Brigadier-General in the Confederate army. Jacob Thompson was also an open and avowed secessionist and before his resignation he had been appointed by the Mississippi secession convention as a delegate to visit the North Carolina Legislature and endeavor to induce that State to secede, and he had actually gone on that mission while still retaining his place in Buchanan's Cabinet. His conduct so astonished Senator Clingman of North Carolina as to extort from him the exclamation: 


\section{$5 \mathrm{I} 8$ Political History of Secession}

"Was there ever before any potentate who sent out of his own Cabinet members to excite an insurrection against his government?" The man in the Cabinet most dangerous to the Union cause was John B. Floyd. He had been Governor of Virginia, and was the son of John Floyd, a former Governor. For a time he posed as an opponent of secession, and Curtis, Buchanan's biographer, alludes to his "sudden conversion" from an avowed and consistent opponent of secession to "one of its most strenuous supporters," and intimates that it occurred about the time when the President discovered Floyd's complicity in the embezzlement of the Indian bonds, which was about the time of his resignation. It may not be possible to fix the precise instant of his conversion, but there is not the least doubt that it was fully consummated long before his resignation. By his order as Secretary of War a large number of muskets which had been condemned, but which were capable of being remodeled for effective service, had been transferred from Northern to Southern arsenals. Some of the removals had been made nearly a year before Floyd's resignation and these were probably transferred without any criminal intent. But 2500 were sold to the State of Alabama as late as November I4, I860, and 10,000 to G. B. Lamar, a known agent of South Carolina, as late as November 24, 1860. While it could not be proved, the circumstances under which these sales were made were such as to raise at least a strong suspicion that they were made for the purpose of aiding these two States in arming for threatened secession. Although the congressional committee which subsequently investigated the matter did not find evidence sufficient to warrant the finding of any criminal intent in the matter, Floyd, after he had left the Cabinet and had got to Richmond, Virginia, avowed "that he had, while Secretary of War, supplied the South with arms in anticipation of the approaching rebellion."'s But for Floyd's order for the transfer of the heavy ordnance at the arsenal in Pittsburg,

× Crawford, History of Fort Sumter, p. 217. 
Pennsylvania, no historian has ever ventured any cxcuse. On December 20, I860, the day on which South Carolina seceded, Floyd gave a verbal order for the transfer from the Pittsburg arsenal of forty columbiads and four thirty-two pounders to be sent to the fort on Ship Island, near the mouth of the Mississippi, and seventy columbiads and seven thirty-two pounders to the fort at Galveston, Texas. The fort at Ship Island was then unfinished and not ready for armament, and the fort at Galveston had scarcely been commenced and could not be completed within less than five years. This heavy ordnance was not condemned cannon, but cannon of the most improved pattern, and the evident purpose of shipping it South was that it might be seized by the secessionists. ${ }^{2}$ Before the cannon were shipped information of the proposed transfer leaked out and caused such an angry protest of the citizens of Pittsburg that the order of transfer was countermanded, but not until after Floyd had resigned. ${ }^{2}$ Further and convincing proof of Floyd's active efforts in aid of secession will appear in the following pages.

Toucey, the Secretary of the Navy, is wittily described by Justice Curtis as "a person of rather uncommon breadth for a Connecticut man." 3 As already stated, the secession leaders believed that both he and Cass, even if they should be opposed to their plans, would be overruled by Cobb, Floyd, and Thompson. The secession leaders probably counted also upon the passive, if not active support of Black and Holt, but in this, as it turned out, they went wide of the mark.

Before the reorganization of Buchanan's Cabinet the national government was indeed in a pitiable plight, for, besides the avowed secessionists in the Cabinet, Senators from the States which afterwards seceded and which were

${ }^{2}$ See Report of Committee on Military Affairs, February 18, I861; 36th Cong., 2d sess., Rep. No. 85.

2 Crawford, Sumter, p. 216; Curtis, Buchanan, vol. ii., p. 416.

3 Curtis, Life of B. R. Curtis, vol. i., p. 193. 


\section{$5^{20}$ Political History of Secession}

then contemplating secession held the controlling power in the Senate, which enabled them to block all legislation designed to strengthen and protect the government. Astonishing as it may seem, the correspondence brought to light after the close of the Civil War shows that Floyd and Trescott, while yet in the service of the national government, were actively engaged in helping the State of South Carolina to purchase of the United States War Department a lot of guns bought for the avowed purpose of enabling the State to equip an armed force with which to oppose the government in the event of anticipated war between it and South Carolina. The sale was consummated on December 20, I860, the day on which South Carolina seceded. Indeed it seems that for some time after the election of Lincoln Buchanan's Cabinet was a veritable secession hotbed. ${ }^{x}$

For several weeks after Lincoln's election the plans of the secession leaders seemed to be working successfully and with little, if any, opposition on the part of the national government. One of the matters that at an early date impressed itself upon the secession leaders as of prime importance was the getting possession of the national forts in the South, particularly Fort Pickens, commanding the Pensacola navy yard, and those in Charleston harbor. The three forts in Charleston harbor were Fort Sumter, Fort Moultrie, and Castle Pinckney, the first being the most important. They commanded the entrance to the harbor, and to gain possession of them was of the highest importance to the South Carolina authorities; but, until they could complete their preparations for attack, it was essential to prevent their reinforcement. Major Robert Anderson was assigned to the command of the forts on November 15, 1860. He, himself, with a handful of men occupied Fort Moultrie while a small garrison occupied Fort Sumter. Almost as soon as he took possession he began to urge upon the War Department the necessity of reinforcement, but Floyd refused, giving as a reason that "the increase of the force

${ }^{x}$ See Nicolay and Hay, Lincoln, vol. ii., chap. xviii., p. 315. 
under your command, however much to be desired, would, the Secretary thinks, judging from the recent excitement produced on account of an anticipated increase, as mentioned in your letter, but add to that excitement and might lead to serious results." 1 About the same time Major Anderson reported that the South Carolina authorities were demanding the release of some of the workmen employed about the forts in order to enroll them into the military force of the State. Floyd ordered Anderson, if satisfied that the men had been properly enrolled, to "cause them to be delivered up or suffer them to depart." 2 By reason of the action of the wind and waves sand hills had accumulated in the near vicinity of Fort Moultrie of such size as not only to obstruct the fire of the guns of the fort, but also to afford convenient shelter for a party attacking the fort from the land side, the preparations for which were going on every day before the eyes of Major Anderson. He asked permission of the War Department to level these hills, but permission was refused by Floyd, the reason given being that "if deemed essential to the more perfect defense of the work, the leveling of the sand hills which command the fort would not, under ordinary circumstances, be considered as initiating a collision. But the delicate question of its bearing on the popular mind in its present excited state, demands the coolest and wisest judgment. The fact of the sand hills being private property, and, as is understood, having private residences built upon them, decides the question in the negative." 3

On December II, Floyd sent Don Carlos Buell, the Assistant Adjutant-General, to Major Anderson with a lot of verbal instructions. Just what they were we have no means of knowing, except from a memorandum preserved by Buell, which read as follows: "You are aware of the great anxiety of the Secretary of War that a collision of the troops with the people of this State shall be avoided, and

\& War Rec., vol. i., p. 82.

3 Id., p. 92.

3 Id., p. 92. 
of his studied determination to pursue a course with reference to the military force and forts in this harbor which shall guard against such a collision. He has, therefore, carefully abstained from increasing the force at this point, or taking any measures which might add to the present excited state of the public mind, or which would throw any doubt on the confidence he feels that South Carolina will not attempt, by violence, to obtain possession of the public works or interfere with their occupancy. But as the counsel and acts of rash and impulsive persons may possibly disappoint these expectations of the government, he deems it proper that you should be prepared with instructions to meet so unhappy a contingency. He has therefore directed me verbally to give you such instructions. You are carefully to avoid every act which would needlessly tend to provoke aggression; and, for that reason, you are not, without evident and imminent necessity, to take up any position which could be construed into the assumption of a hostile attitude." These extraordinary instructions were communicated without the knowledge of either the President or of General Scott. The clandestine manner in which they were communicated is significant. Still more significant is the fact that they were verbal and not in writing and were not sent through the ordinary channels of official communications. Considering all these circumstances, in connection with Floyd's known sympathy with the secession cause, his prior zeal in prostituting his official position and betraying his trust in order to aid it, the conclusion is almost irresistible that the instructions really given, of which the written memorandum was but an outline, were of so treasonable a character that it was not deemed prudent to write them out in full and to transmit them through the ordinary official channels.

On December I8 Major Anderson again wrote to the War Department that "the sand hills and the houses surrounding the fort will afford safe shelter for sharpshooters,

s War Rec., vol. i., pp. 89-90. 
who may, with ordinary good luck, pick off the major part of my little band, if we stand by our guns, in a few hours"; yet, no reinforcements. About the same time Captain Foster of the Engineers had procured some forty muskets from the United States arsenal at Charleston to supply the men in the forts, but as soon as Floyd heard of it he immediately telegraphed Captain Foster: "I have just received a telegraphic dispatch informing me that you have removed forty muskets from Charleston arsenal to Fort Moultrie. If you have removed any arms, return them instantly. Answer by telegraph." $₹$ Captain Foster correctly interpreted Floyd's dispatch, as appears in one of the former's dispatches: "The order of the Secretary of War of last night I must consider as decisive upon the question of any efforts on my part to defend Fort Sumter and Castle Pinckney. The defense now can only extend to keeping the gates closed and shutters fastened and will cease when these are forced." 2

Major Anderson again appealed for reinforcements, "wishing to God that he had men enough to man fully my guns," but none came. On December 21, Floyd, evidently disappointed over the fact that Major Anderson had not understood his "verbal" instructions as he intended that they should be understood, wrote direct to him this insulting and shameful letter:

"SIR: In the verbal instructions communicated to you by Major Buell, you are directed to hold possession of the forts in the harbor of Charleston, and, if attacked, to defend yourself to the last extremity. Under these instructions, you might infer that you are required to make a vain and useless sacrifice of your own life and the lives of the men under your command upon a mere point of honor. This is far from the President's intentions. You are to exercise a sound military discretion on this subject. It is neither expected nor desired that you should expose your own life or that of your men in a hopeless conflict in defense of these

s War Rec., vol. i., p. 100.

Id., p. 100. 


\section{Political History of Secession}

forts. If they are invested or attacked by a force so superior that resistance would, in your judgment, be a useless waste of life, it will be your duty to yield to necessity, and make the best terms in your power. This will be the conduct of an honorable, brave, and humane officer and you will be fully justified in such action. These orders are strictly confidential, and not to be communicated even to the officers under your command, without close necessity." $x$ This letter is susceptible of only one interpretation. Its sole purpose was to suggest to Major Anderson the manner in which he might betray his trust and yet escape censure as a traitor. Major Anderson was assured that all that was expected of him was to make only a sham defense, and when that was no longer available, to surrender.

On the night of December 26, Major Anderson, finding his position in Fort Moultrie no longer tenable, evacuated it, spiking the guns and transferring his little force to Fort Sumter. The enraged Governor of South Carolina at once demanded that he return to Fort Moultrie, and as soon as the report reached Washington, Floyd telegraphed to Major Anderson stating that "it is not believed because there is no order for any such movement," but demanding that Major Anderson "explain the meaning of this report." Immediately after that the South Carolina military forces took possession of both Fort Moultrie and Castle Pinckney and began to put them in condition for use in the bombardment of Fort Sumter, and at the same time took possession of the United States custom-house and arsenal in the city of Charleston.

In Major Anderson's explanation of December 27 to Floyd he said: "I abandoned Fort Moultrie because I was certain that if attacked my men must have been sacrificed, and the command of the harbor lost. I spiked the guns and destroyed the cartridges to keep the guns from being used against us." 3 But Floyd, still more enraged than were the

I War Rec., vol. i., p. 103.

3Id., p. 3.

${ }^{2} I d$., p. 3. 


\section{Close of Buchanan's Administration 525}

South Carolina authorities, was not satisfied with the explanation and he at once brought all the influence he could bring to bear on the President to order Major Anderson back to Fort Moultric. Buchanan was very much inclined to follow Floyd's advice, for up to this time all his solicitude to avoid any "hostile attitude" that might "produce a collision" seemed to be limited to preparations to defend the forts but not to the open and avowed preparations for attacking them which were being carried on every day.

About this time great frauds were unearthed in the Department of the Interior and it was discovered that a large amount of Indian bonds had been abstracted and that Floyd's acceptances had been substituted in place of them. Buchanan states that as soon as he heard of it, he intimated to Floyd "that he could no longer remain in the Cabinet and that he ought to resign." He adds: "I expected his resignation hourly; but a few days after he came into the Cabinet with a bold front and said he could remain in it no longer unless I would instantly recall Major Anderson and his forces from Fort Sumter." $x$ Floyd had also been indicted by the grand jury of the District of Columbia for alleged complicity in the embezzlement of the Indian bonds and was liable at any moment to be arrested.

The South Carolina Commissioners arrived in Washington on December 26. They came in the character of envoys plenipotentiary, claiming to represent a sovereign and independent State, to negotiate a treaty with the United States government. To receive them as such would be a virtual recognition of the independence of South Carolina. But this would never do. What should be done with them? The President was in a most perplexing and distressing dilemma. Usually he had been able to find some authority or supposed authority in the Constitution but on this question the Constitution was silent. Buchanan could find in the Constitution no authority to decide "what shall be the relations between the Federal government and South

Curtis, Buchanan, vol. ii., p. 408. 


\section{6 Political History of Secession}

Carolina." Nor could any precedent be found in the history of the country. But there were statements in the Commissioners' communication that imperatively required an answer of some kind, particularly the one referring to the "pledges" before made and to his own orders. Finally it was determined to receive the Commissioners, "but only as private gentlemen of the highest character." An informal interview between the commissioners and the President was arranged for I o'clock P.M., on the following day. But on the morning of the 27th the news reached Washington of Major Anderson's removal from Fort Moultrie to Fort Sumter. The discovery of this fact furnished the Commissioners additional and important matter about which to "treat," and added fresh acrimony to the correspondence between them and the President. The news was at once communicated to the President and soon after Jefferson Davis and Senator Hunter of Virginia called upon him. Floyd was sent for and soon after appeared. The President was urged to take immediate action and order Anderson back to Fort Moultrie. "The discussion," according to Trescott, "was long and earnest. At first he [Buchanan] seemed disposed to declare that he would restore the status, then hesitated, said he must call his Cabinet together; he could not condemn Major Anderson unheard." He was also urged to allow a telegram to be sent stating that if Anderson's move had been made without a previous attack he would restore the status, but this he declined to do. The meeting with the Commissioners was adjourned until the next day, when they had their first and only personal interview with the President, who, as Trescott states, "received them courteously and as private gentlemen alone. $\mathrm{He}$ listened to their statement but informed them that it was to Congress that they must look, at the same time expressing his willingness to lay before Congress any proposition they might make to him." At this meeting R. W. Barnwell, chairman of the Commissioners, pressed Buchanan "with ${ }^{2}$ Crawford, Hist. of Fort Sumter, p. 144. 
great zeal and earnestness" to order Major Anderson back to Fort Moultric. "Mr. Buchanan still hesitating, Mr. Barnwell said to him at least three times during the intervicw, 'But, Mr. President, your personal honor is involved in this matter; the faith you pledged has been violated; and your personal honor requires you to issue the order.' Mr. Barnwell pressed him so hard upon this point that the President said: 'You must give me time to consider-this is a grave question.' Mr. Barnwell replied to him for the third time, 'But, Mr. President, your personal honor is involved in this arrangement.' Whereupon Mr. Buchanan, with great carnestness, said: ' Mr. Barnwell, you are pressing me too importunately; you don't give me time to consider; you don't give me time to say my prayers; I always say my prayers when required to act upon any great state affair."'s But the Commissioners failed to persuade the President to order Anderson back to Fort Moultrie, and they prepared a written statement which was formally transmitted to the President on the following day.

By this time the venerable General Scott, who had been confined to his bed by sickness, sent a message to the President, vigorously protesting against the evacuation of Fort Sumter. He also sent a personal message to the President, informing him that up to this date no orders to Anderson or communications to him had been given or received through the army headquarters, but all had been conducted through the office of the Secretary of War. Moreover by this time information of Floyd's secret verbal instructions to Major Anderson had leaked out. It also turned out that some kind of truce had been made between the South Carolina authorities and some authority, presumably acting in behalf of the Administration, that on condition that the South Carolina forces would not fire on Fort Sumter, not only should Fort Sumter not fire on them, but that no attempt should be made to reinforce the fort with men or munitions of war. That some such truce had been made there is no

: Crawford, Hist. of Fort Sumter, pp. 148-9. 
doubt, and there is no doubt that it was made with the knowledge and consent of Floyd, but it is certain that it was not made with the knowledge and consent of General Scott. Buchanan denied that he knew anything about it, but this the South Carolina Commissioners vigorously disputed.

A meeting of the Cabinet was held on the evening of December 27 and from that time until the morning of the 3 Ist the sole topics of discussion in the Cabinet meetings were the questions what should be done with Anderson, and what should be done with the South Carolina Commissioners? In their first written communication to the President on December 28 the Commissioners asserted that the South Carolina authorities "could at any time within the past sixty days have taken possession of the forts in Charleston harbor, but which, upon pledges given in a manner that we cannot doubt, determined to trust to your honor rather than to its own power. Since our arrival, an officer of the United States, acting, as we are assured, not only without, but against your orders, has dismantled one fort and occupied another, thus altering to a most important extent the condition of affairs under which we came." They demanded an explanation of these circumstances, under threat of suspending further negotiations, and closed with this threat: "And in conclusion we would urge upon you the immediate withdrawal of the troops from the harbor of Charleston. Under present circumstances they are a standing menace which renders negotiations impossible, and, as our recent experience shows, threatens speedily to bring to a bloody issue questions which ought to be settled with temperance and judgment." 1 While Buchanan was preparing his answer, the news came to Washington that, without waiting to "treat," Castle Pinckney and Fort Moultrie had been occupied by South Carolina troops, and that they had raised the palmetto flag over the United States custom-house and post-office at Charleston and had

× War Rec., vol. i., p. 109. 


\section{Close of Buchanan's Administration 529}

forcibly taken possession of the United States arsenal there, containing many thousand stand of arms.

From the moment he heard of Major Anderson's removal from Fort Moultrie, Floyd had urged the President to order his return and for a time the President seemed inclined to authorize such an order, but he continued to hesitate, and insisted on submitting the matter to his Cabinet. At the Cabinet meeting held on the evening of December 27, Floyd read to the President in the presence of the whole Cabinet the following extraordinary paper:

"December 27, 1860.

"Sir:

"It is evident now from the action of the commander at Fort Moultric that the solemn pledges of this government have been violated by Major Anderson. In my judgment but one remedy is now left us by which to vindicate our honor and prevent civil war. It is vain now to hope for confidence on the part of the people of South Carolina in any further pledges as to the action of the military. One remedy only is left and that is to withdraw the garrison from the harbor of Charleston altogether. I hope the President will allow me to make that order at once. This order, in my judgment, can alone prevent bloodshed and civil war.

"To the President."

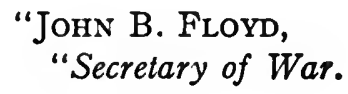

Both Black and Stanton strongly protested against the course recommended by Floyd. Stanton twitted Floyd with complicity in the Indian trust fund embezzlement and bluntly told the President "that no Administration has ever suffered the loss of public confidence and support as this has done. Only the other day it was announced that a million of dollars had been stolen from Mr. Thompson's department. The bonds were found to have been taken from the vault 


\section{Political History of Secession}

where they should have been kept and the notes of $\mathrm{Mr}$. Floyd were substituted for them. Now, it is proposed to give up Sumter. All I have to say is that no Administration, much less this one, can afford to lose a million of money and a fort in the same week." $x$ So heated did the discussion become that at one time there was danger of a personal encounter between Floyd and Stanton. In a day or two afterward Floyd disappeared from Washington, leaving his resignation and giving as a reason for resigning his office: "I can no longer hold it under my conviction of patriotism nor with honor, subjected as I am to the violation of solemn pledges and plighted faith." 2 The resignation was accepted and on December 3I Postmaster-General Joseph Holt was appointed to fill the place left vacant by Floyd. Floyd's departure was probably accelerated by the imminent danger of his arrest on the embezzlement indictment. This was the last of Floyd as Secretary of War. He was next heard of in Virginia, advising the Confederate War Department how best to suppress the "remnant of the Union shriekers" in the southwestern part of Virginia. About the same time, he was given a commission as Brigadier-General in the Confederate army. He belonged to the crop, so plentiful but short-lived in both the North and South, of political generals. He fled from Fort Donelson just before its surrender and never appeared after that in the history of the war. Floyd's services to the Confederacy had been of no value, except those rendered to the enemies of his country at a time when he was acting as its Secretary of War and filling in the Cabinet a trusted position that imposed on him the highest degree of fidelity. The services so rendered were indeed of incalculable value to the Confederacy, but they were of the same kind as those by which Benedict Arnold has secured a place in history. Colley Cibber wrote an Apology for his own life but no man has yet ventured to write an Apology for the life of Floyd.

$\therefore$ Nicolay and Hay, Lincoln, vol. iii., p. 74.

2 Curtis, Buchanan, vol. ii., p. 409. 
The President on Saturday, the 29th, submitted to the Cabinet a draft of an answer to the Commissioners that he had prepared. What followed is told in the biography of Judge Black." "Late in the evening of Saturday, the 29th of December, the President laid before the Cabinet the result of his own reflections in the form of an answer to the South Carolina Commissioners. It was such a paper as none of them expected to see. One member only approved the document and five opposed it, but opposed it for different reasons. Messrs. Black, Holt, and Stanton objected that it conceded too much to the contumacious State; and Messrs. Thomas and Thompson thought its whole tone was so hostile to the claim of South Carolina that it would make the immediate outbreak of civil war inevitable. Mr. Toucey was fully with the President. Not much criticism was bestowed on the document at the time. The members all thought that further discussion would be useless; in their past experience they had seen how inflexible were $\mathrm{Mr}$. Buchanan's resolutions when once formed. Each was left to decide for himself what his duty required him to do. It seemed certain that the Cabinet was about to explode and fly off in opposite directions. On the next morning, Sunday, the 3oth, Mr. Black communicated to Messrs. Stanton, Holt, and Toucey his conviction that the President's mind was fixed beyond all hope of change, and his own determination to resign in consequence. Mr. Toucey told the President, and Mr. Black was sent for. He went reluctantly, dreading the effect upon his own feelings of the appeal which he knew Mr. Buchanan would make to the sacred friendship which had lasted through so many years of prosperity, and which certainly ought not to be broken in that hour of trouble and adversity. What was said between them during that interview need not be told, but it ended in the offer of the President to let Mr. Black take the document in question, strike out what he thought objectionable, and insert what was necessary to make it meet his

r Black's Essays and Speeches, pp. 13-17. 
own views; but this must be done immediately. Mr. Black went to the Attorney-General's office, and there wrote the following paper, which Mr. Stanton copied as rapidly as the sheets were thrown to him. ${ }^{\mathrm{x}}$. . .

× Black here gives a full copy of this important paper as follows:

"Memorandum for the President on the subject of the paper drawn up by him in reply to the Commissioners of South Carolina.

"I. The first and the concluding paragraph both seem to acknowledge the right of South Carolina to be represented near this Government by diplomatic officers. That implies that she is an independent nation, with no other relations to the Government of the Union than any other foreign power. If such be the fact, then she has acquired all the rights, powers, and responsibilities of a separate government by the mere ordinance of secession which passed her convention a few days ago. But the President has always, and particularly in his late message to Congress, denied the right of secession, and asserted that no State could throw off her Federal obligations in that way. Moreover, the President has also very distinctly declared that even if a State could secede and go out of the Union at pleasure, whether by revolution or in the exercise of a constitutional right, he could not recognize her independence without being guilty of usurpation. I think, therefore, that every word and sentence which implies that South Carolina is in an attitude which enables the President to 'treat' or negotiate with her, or to receive her commissioners in the character of diplomatic ministers or agents, ought to be stricken out and an explicit declaration substituted, which would reassert the principles of the message. It is surely not enough that the words of the message be transcribed if the doctrine there announced be practically abandoned by carrying on a negotiation.

"2. I would strike out all expressions of regret that the commissioners are unwilling to proceed with the negotiations, since it is very clear that there can be no negotiation with them, whether they are willing or not.

"3. Above all things, it is objectionable to intimate a willingness to negotiate with the State of South Carolina about the possession of a military post which belongs to the United States, or to propose any adjustment of the subject or any arrangement about it. The forts in Charleston Harbor belong to this government-are its own, and cannot be given up. It is true they might be surrendered to a superior force, whether that force be in the service of a seceding State or a foreign nation. But Fort Sumter is impregnable and cannot be taken if defended as it should be. It is a thing of the last importance that it should be maintained if all the power of this nation can do it; for the command of the harbor and the President's ability to execute the revenue laws may depend on it. 
"The original of this paper went to the President, but Mr. Stanton's copy was retained by him and by him indorsed 'Observations on Correspondence, President S. C. Com., by J. S. B.' Although Judge Black took the entire responsibility of it, indited every word of it himself, and spoke throughout in the first person singular, it undoubtedly

"4. The words "coercing a State by force of arms to remain in the confederacy - a power which I do not believe the Constitution has conferred on Congress,' ought certainly not be retained. They are too vague, and might have the effect (which I am sure the President does not intend) to mislead the commissioners concerning his sentiments. The power to defend the public property - to resist an assailing force which unlawfully attempts to drive out the troops of the United States from one of the fortifications, and to use military and naval forces for the purpose of aiding the proper officers of the United States in the execution of the laws - this, as far as it goes, is coercion, and may very well be called 'coercing a State by force of arms to remain in the Union.' The President has always asserted his right of coercion to that extent. He merely denies the right of Congress to make offensive war upon a State of the Union as such might be made upon a foreign government.

"5. The implied assent of the President to the accusation which the commissioners make of a compact with South Carolina by which he was bound not to take whatever measures he saw fit for the defense of the forts, ought to be stricken out, and a flat denial of any such bargain, pledge, or agreement inserted. The paper signed by the late members of Congress from South Carolina does not bear any such construction, and this, as I understand, is the only transaction between South Carolina and him which bears upon the subject either directly or indirectly. I think it deeply concerns the President's reputation that he should contradict this statement, since if it be undenied it puts him in the attitude of an executive officer who voluntarily disarms himself of the power to perform his duty, and ties up his hands so that he cannot, without breaking his word, 'preserve, protect, and defend the Constitution, and see the laws faithfully executed.' The fact that he pledged himself in any such way cannot be true. The commissioners, no doubt, have been so informed. But there must be some mistake about it. It arose, doubtless, out of the President's anxious and laudable desire to avoid civil war, and his often-expressed determination not even to furnish an excuse for an outbreak at Charleston by reinforcing Major Anderson unless it was absolutely necessary.

"6. The remotest expression of a doubt about Major Anderson's perfect propriety of behavior should be carefully avoided. He is not 
embodies the sentiments of Mr. Stanton also. He commented upon it with strong expressions of delight, and $\mathrm{Mr}$. Holt, who saw it the same day, equally approved it. Mr. Stanton would have resigned with Mr. Black if the views of the latter (which were also his own) had not been adopted; Mr. Holt, perhaps, would have done the same, but he did not say so."

merely a gallant and meritorious officer who is entitled to a fair hearing before he is condemned. He has saved the country, I solemnly believe, when its day was darkest and its perils most extreme. He has done everything that mortal man could do to repair the fatal error which the Administration have committed in not sending down troops enough to hold all the forts. He has kept the strongest one. He still commands the harbor. We may still execute the laws if we try. Besides, there is nothing in the orders which were sent to him by the War Department which is in the slightest degree contravened by his act of throwing his command into Fort Sumter. Even if those orders sent without your knowledge did forbid him to leave a place where his men might have perished, and shelter them under a stronger position, we ought all of us to rejoice that he broke such orders.

"7. The idea that a wrong was committed against South Carolina by moving from Fort Moultrie to Fort Sumter ought to be repelled as firmly as may be consistent with a proper respect for the high character of the gentlemen who compose the South Carolina Commission. It is a strange assumption of right on the part of that State to say that our United States troops must remain in the weakest position they can find in the harbor. It is not a menace of South Carolina or of Charleston, or any menace at all. It is simple self-defense. If South Carolina does not attack Major Anderson, no human being will be injured; for there certainly can be no reason to believe that he will commence hostilities. The apparent objection to his being in Fort Sumter is that he will be less likely to fall an easy prey to his assailants.

"These are the points on which I would advise that the paper be amended. I am aware that they are too radical to permit much hope of their adoption. If they are adopted the whole paper will need to be recast. But there is one thing not to be overlooked in this terrible crisis. I entreat the President to order the Brooklyn and the Macedonian to Charleston without the least delay, and in the meantime send a trusty messenger to Major Anderson to let him know that his government will not desert him. The reinforcement of troops from New York or Old Point Comfort should follow immediately. If this be done at once all may yet be not well, but comparatively safe. If not, I can see nothing before us but disaster and ruin to the country." 


\section{Close of Buchanan's Administration 535}

There are several other versions of this most important Cabinet affair. ${ }^{x}$ In some of these it is stated that the interview between Buchanan and Black was both impressive and affecting and that Buchanan was moved to tears. To lose Black was probably to lose Stanton and Holt also, and to leave Buchanan alone to cope with the plotters of secession on the one hand and an outraged and indignant North on the other. It is plain that by the malign influence of Floyd the President had been tempted to the brink of an abyss, already yawning to engulf in utter ruin Buchanan, his whole Administration, and perhaps the country, and that it was Black that pointed out to him the danger. The memoranfum prepared by Black is, perhaps, the most important of all the State papers of Buchanan's Administration.

Whatever doubts there may have been as to Black's attitude toward secession before, there were none after, the writing of that memorandum. In the preparation of it he had performed, not only for Buchanan, but for the country, a service of inestimable value. It cannot now be determined to a certainty how much of Buchanan's answer to the Commissioners was the President's own conception and how much of it was suggested by Black and Stanton. In reference to the demand of the Commissioners that the Federal troops be removed from Charleston harbor the answer says: "This I cannot do, this I will not do." In this and in similar expressions, so unlike the President's usual mode of stating things, we hear the voice of the President, but we feel the hand of Black.

The President's answer to the Commissioners throws additional light on the alleged "truce" and the "pledges" referred to by the Commissioners in their first communication. As stated by the President, several of the South Carolina representatives had an interview with him on December 8 and they and the President "had an earnest

× McClure, Lincoln and Men of War Times, p. 278; Crawford, History of Fort Sumter, pp. 149-156; Nicolay and Hay, Lincoln, vol. iii., p. 73; Rhodes, History of the United States, vol. iii., pp. 230-3. 
conversation on the subject of these forts and the best means of preventing a collision between the parties, for the purpose of sparing the effusion of blood," and the President suggested that "for prudential reasons" it would be best to put in writing what they said to him verbally. They did so and on December Io they presented a paper to the President as follows:

“WASHington, December 9, 1860.

"His Excellency, James BuchanaN,

"President of the United States:

"In compliance with our statement to you yesterday, we now express to you our strong convictions that neither the constituted authorities, nor any body of the people of the State of South Carolina, will either attack or molest the United States forts in the harbor of Charleston previously to the action of the convention, and we hope and believe not until an offer has been made, through an accredited representative, to negotiate for an amicable arrangement of all matters between the State and Federal government, provided that no reinforcements shall be sent into those forts and their relative military status shall remain as at present." 1

In his answer the President said that at the time the paper was presented to him he objected to the word "provided," inasmuch "as it might be construed into an agreement on his part, which he never would make," and that he "considered it as nothing more in effect than the promise of highly honorable gentlemen to exert their influence for the purpose expressed." In the version afterwards given by some of the South Carolina representatives they confessed their inability to comprehend the President's nice distinction between an "understanding," an "agreement," and a "pledge." "Nor can we understand," they say, "how, 'in a matter of honor among gentlemen,' in which

× War Rec., vol. i., p. 116. 
'no paper or writing is necessary,' the very party who was willing to put it on that high footing can honorably descend to mere verbal criticism to purge himself of what all gentlemen and men of honor must consider a breach of faith." 1

In reference to the verbal instructions given by Floyd to Major Anderson on December I I, the President said that they were never brought to his knowledge until December 21. He failed, however, to state what he did or said after they were brought to his knowledge. Continuing he said: "Under these circumstances it is clear that Major Anderson acted upon his own responsibility, and without authority, unless, indeed, he had 'tangible evidence of a design to proceed to a hostile act' on the part of the authorities of South Carolina, which has not yet been alleged. Still, he is a brave and honorable officer, and justice requires that he should not be condemned without a fair hearing. Be this as it may, when I learned that Major Anderson had left Fort Moultrie and proceeded to Fort Sumter, my first promptings were to command him to return to his former position and there await the contingencies presented in his instructions."

As a further reason for declining to order Major Anderson to return to Fort Moultrie the President referred to the precipitate action of the South Carolina authorities in taking possession of Castle Pinckney and Fort Moultrie, and beginning at once to put them in a condition for service

× War Rec., vol. i., p. 127. In his History of Fort Sumter, p. 25, General Crawford makes this significant statement, which throws further light on the alleged agreement: "On the 22d of March, 1882, I had a long and earnest conversation with Judge Black upon the subject of the interview between the President and the Congressional delegation of South Carolina, as to the understanding or arrangement agreed upon at that interview. The details of this interview with the President, when the Commissioners of South Carolina were in Washington, were stated, when at the end I said: 'Well, then, Judge Black, there appears to be but one inference to be drawn, but one conclusion to be reached; the President did make that agreement.' The Judge rose, and, looking steadily at me for a moment, said, 'Remember, that is your conclusion."

- War Rec., vol. i., pp. I17-118. 


\section{Political History of Secession}

in bombarding Fort Sumter, and also to their taking forcible possession of the United States post-office and customhouse in Charleston without waiting to "treat" further.

On January I, the Commissioners sent to the President a long and bombastic reply, ${ }^{\mathrm{x}}$ still more arrogant and insulting than their original communication. In this they treat the act of Major Anderson in evacuating Fort Moultrie as an act of war. "Scarcely had their commissioners left," they say, "than Major Anderson waged war. No other words will describe his action. It was not a peaceful change from one fort to another; it was a hostile act in the highest senseone only justified in the presence of a superior enemy and in imminent peril. He abandoned his position, spiked his guns, burned his gun carriages, made preparations for the destruction of his post, and withdrew, under cover of the night, to a safer position. This was war." But the most cruel part of the reply was that in which the Commissioners renewed the charges against Buchanan of breach of faith, of the "many and repeated assurances given on your [his] behalf which we [they] cannot believe unauthorized." They wound up their reply with this grandiloquent peroration: "By your course you have probably rendered civil war inevitable. Be it so. If you choose to force this issue upon us, the State of South Carolina will accept it, and relying upon Him who is the God of Justice, as well as the God of Hosts, will endeavor to perform the great duty which lies before her, hopefully, bravely, and thoroughly." What Buchanan thought of this reply may never be known. Possibly his thoughts were something like those expressed in the dying words of Cæsar to his old-time friend Brutus. At any rate, the Commissioners' reply was returned with this short indorsement: "This paper just presented to the President is of such character that he declines to receive it."

This was the first direct setback that the cause of secession had received from the President. The vaulting ambition of the secession leaders had at last overreached

× War Rec., vol. i., p. 120. 


\section{Close of Buchanan's Administration 539}

itself. On January 2, 186I, Senator Wigfall, though still regularly attending the sessions of the Senate as Senator from Texas, telegraphed to M. L. Bonham of Charleston, in command of the South Carolina forces there: "Holt succeeds Floyd. It means war. Cut off supplies from Anderson and take Sumter as soon as possible."

In the reorganization of the Cabinet, Black had now become Secretary of State, Holt Secretary of War, Dix Secretary of the Treasury, and Stanton Attorney-General. Judging from Black's opinion to Buchanan on November 20, 1860, his change of attitude was as disappointing to the secession leaders as it was encouraging to the people of the North. It is possible, as already stated, that this opinion at the time when it was given was not generally interpreted as he himself intended that it should be, and that if he had anticipated the application afterwards sought to be made of it, he would have expressed himself in different language. Whatever change, if any, had taken place in his views of the powers of the general government, and when the change occurred, it is not possible now to determine, but it is certain that he was from the beginning opposed to secession, and that long before the resignation of Floyd he had become one of the staunchest supporters of the Union cause. This was of the highest importance, for, from the time he became a member of Buchanan's Cabinet, he had exercised a great influence over him.

The new Secretary of War was also a disappointment to the secession leaders. Born in Kentucky, but long a resident of Mississippi, and during his prior life intimately associated with the Southern political leaders, he was, nevertheless, from the beginning, outspoken in his opposition to secession and throughout the Civil War was a staunch friend of the Union, and as such he was prominent later during the Administration of Lincoln.

Dix, likewise a lifelong Democrat, and prominent in politics in the State of New York, had been appointed largely on the recommendation of the business men of New York 
City. His celebrated dispatch, sent while the South Carolina Commissioners were still in Washington, to the New Orleans collector,- " If any man attempts to haul down the American flag, shoot him on the spot,"-came to the North like an inspiration, but coming from a member of Buchanan's Cabinet was as unexpected as a voice from the tomb.

History speaks for Stanton, the new Attorney-General. $\mathrm{He}$ had been appointed chiefly upon the recommendation of Black. With all Stanton's faults, for like other great men, he had some great faults, his name is inseparably connected with the history of the Civil War, and with the memory of Lincoln as his great war secretary.

These four men-especially Black and Stanton-now became the controlling factors in the Cabinet. The reorganization of the Cabinet was the turning point in $\mathrm{Bu}-$ chanan's administration; it was also the turning point in the Union cause and preserved the national government until the coming of Buchanan's successor. If his Cabinet had remained the same as it was when Lincoln was elected, there is little doubt that by the time fixed for his inauguration Lincoln would have found Washington in the possession of the Confederates, with Jefferson Davis seated in the White House and an army and navy and all the machinery of the government at his command. But none of the four men named, nor all together, could change the character of Buchanan, nor instill into him their own courage and determination. That was as impossible as changing a leopard's spots.

Another result of the resignation of Floyd was the bringing of General Scott, who had been practically ignored by Floyd, into consultation with the new Secretary of War and the members of the Cabinet, thereby giving them the benefit of his advice and cooperation.

A few days afterward the President was persuaded by the majority of his Cabinet to attempt the reinforcement of Fort Sumter. It was then too late, as both General Scott and Major Anderson advised, for the works erected in the 


\section{Close of Buchanan's Administration 54I}

vicinity of the fort were then so far advanced that no vessel could hope to pass them safely. Still the attempt was made and on January 3 the Star of the West sailed from New York with troops and provisions for Fort Sumter. But there had been a misunderstanding of orders, and when, on January 9, the vessel attempted to reach the fort it was fired on and driven from the harbor by the South Carolina batteries on Morris Island and those of Fort Moultrie, and so the expedition resulted in a dismal failure.

Buchanan also ventured to send a special message to Congress on January $8, \mathrm{I} 86 \mathrm{I}$, in which he asserted that, as the Chief Executive under the Constitution of the United States, it was his duty "to collect the public revenues and to protect public property so far as this might be practicable under existing laws," and that "the right and the duty to use military force defensively against those who resist the Federal officers in the execution of their legal functions and against those who assailed the government are clear and undeniable." This was probably not going as far as his new Cabinet might have wished, but it was a great and encouraging advance from the views pronounced by him in his annual message of December 4. From this time until the close of his Administration the policy of the President, if he had any clearly defined policy of his own, scemed to be to postpone the evil day that all men now saw to be coming until after the inauguration of his successor, and until that time to shift all responsibility, as far as he could, upon Congress. If he had any other policy he made no sign. Notwithstanding the open affront to the national flag by the firing on the Star of the West, characterized by Secretary Black himself in a letter to General Scott as an "intolerable outrage," of itself an overt act of war, notwithstanding that the Union was crumbling to pieces about him, Buchanan still hesitated, apparently appalled and bewildered by the calamities that had overtaken his Administration, and still more by the specter of civil war, now apprcaching with rapid strides, its dread visage growing more and more distinct. 


\section{CHAPTER XXV}

\section{THE CLOSING MONTHS OF BUCHANAN'S ADMINISTRATION}

(Continued.)

QY the efforts of Black, Stanton, and Holt the Adminis$B$ tration began to show signs of returning vitality. Not only were the efforts made, already noted, to relieve Fort Sumter, but preparations were made to defend Fortress Monroe and the arsenal at St. Louis, to concentrate troops at Baltimore and other points, and to protect the city of Washington from capture. Indeed the prospect of the secessionists capturing the capital and bidding Buchanan pack up and be off seems to have convinced the President himself of the necessity of making some preparations to avert so humiliating a catastrophe. But the reorganization of the Cabinet and putting it upon a Union basis, and the preparations, such as they were, to preserve the national government from utter destruction, while greatly encouraging to the North, only added fresh fuel to the secession fires in the South, where all these movements were looked upon as preparations for "coercion."

As before stated, it is now manifest that in laying their plans, the secession leaders erred, or were lacking in foresight, in several important particulars. They had not anticipated such a turn of affairs as would take their fast friends, Cobb, Thompson, and Floyd, out of Buchanan's Cabinet before the expiration of his term. They were surprised and disappointed by the unexpected loyalty of Holt and Black. Holt, as already stated, though coming from a Southern State, was, from the beginning, strongly against secession and in favor of upholding the authority of 
the government in the seceded States, and Black, notwithstanding the opinion he gave to Buchanan, proved to be one of the strongest advocates in the Cabinet for the preservation of the Union. The secessionists had not dreamed of the entrance into Buchanan's Cabinet of two such staunch opponents of secession as Stanton and Dix. They had not anticipated the reorganization of the Cabinet upon a Union basis. They had not believed it possible that Buchanan himself, after solemnly asserting in his annual message that the national government had no constitutional power to coerce a sovereign State, or to use the military power of the government in any way to suppress secession, would take the steps, hesitating as they were, which he did take to vindicate the authority of the national government. They were both disappointed and enraged by the measures, such as they were, to retain the national forts and arsenals and to preserve the government from destruction. They erred in counting upon recognition, and, as a last resort, upon intervention, by foreign powers. They erred in supposing that, in the event of civil war, the seceding States could rely upon the support and sympathy of any considerable part of the North. They erred in assuming that because Northern men would not fight duels they would not fight battles. And lastly they erred in supposing that, after the secession movement had begun, the hot-heads in the South could be controlled so as to travel only so fast and only upon such lines as the leaders had planned. South Carolina could not be restrained from immediate secession. It had been difficult to dissuade the authorities of that State from bombarding Fort Sumter long before the secession leaders were prepared to do so, and thus precipitating civil war before they were ready for it. The example of South Carolina was contagious and, as in all revolutions, the radicals took the lead, as the radicals finally took the lead in the North. Jefferson Davis tells us that even he was deemed "too slow."

The secession leaders had lost the support of Floyd and

'Rise and Fall, vol. i., p. 58. 


\section{Political History of Secession}

Cobb and Thompson as members of Buchanan's Cabinet, but the Southern States, excepting South Carolina, still had their Senators and Representatives in Congress and in all the departments of the national government, and it was assumed by the secession leaders that in carrying out their plans they could still work to far better advantage under Buchanan's Administration than they could under that of his successor. But Buchanan's term was rapidly drawing to a close and in order to complete the organization of the proposed confederacy before the coming in of the new Administration, it was necessary to make material changes in the original plans of the secession leaders on account of the unforeseen circumstances that had occurred since the election of Lincoln, and it was important to act promptly.

At this juncture Pollard states that a self-constituted revolutionary council was formed, characterized by him as "one of the most extraordinary councils in the history of the country." I This revolutionary body, we are told "sat in the shadow of the Capitol at Washington; and in a few weeks this strange authority had sent over the country the order which led to the seizure of all the forts in the South except two. The council summoned on this occasion at once assumed the powers of a revolutionary junta. It was composed of the Senators from seven Southern States: Florida, Georgia, Alabama, Mississippi, Louisiana, Arkansas, and Texas. It met in one of the rooms of the Capitol, on the night of the 5th January, 186I. The representation was full, two Senators from each of the States named being present; but a body of fourteen Southern men, and those, too, properly acting in a very limited representative capacity, was certainly a small and extraordinary one to determine for the country the concern of peace or war, and to assume the destinies of the South. It was decided to 'recommend immediate secession of their respective States, and the holding of a convention at Montgomery, Alabama, on the 15th day of February.'

× Pollard, Life of Jefferson Davis, p. 6r. 
So much of the proceedings of this extraordinary council were published, and were perhaps legitimate. But it was not then published, and it is only fully known at this day, that this council assumed to themselves the political power of the South, and to control all political and military operations. They seized the telegraph, they controlled the press, they possessed themsclves of all the avenues of information to the South, they dictated the plan of seizing the forts, arsenals, and custom-houses, and they did the whole work of revolution at Washington, while public attention was drawn to the mere incidental movements that seconded the designs of these few men and conccaled the true seat of operations. It was even doubted whether such a council had ever been held in Washington, and whether it was not a fiction of the newspapers. But in any case few had the least suspicion of the extent of their operations. It was a strange assumption of authority that, in the midst of the peaccful and ordinary transactions of public life, a body so small and so foreign to the purpose in hand, of a representative character at once so limited and so peculiar, composed of men who were every day in their accustomed seats in the Senate, who were to some extent privy councilors of the Executive and thus acting under obligations of peculiar confidence, should have succeeded in erecting a revolutionary tribunal in a private committee-room, and been able to dictate from there, without detection or interruption, the plan of a great rebellion.

"In the confusion and multitude of scenes which preface wars and other great events in history the mind naturally inquires for some particular body of men, some well-defined scene where the operation commences, and from which may be traced dramatically the succession of events. Such beginnings are often found in narrow circumstances. In the present instance the scenes of a great war properly open in the small room in Washington City, where fourteen men pledged themselves to overthrow the existing government. They assumed the direction of every affair of the 


\section{Political History of Secession}

South, and from the beginning it was evident that the people were to have no calm and deliberate voice in the matter. An executive committee was appointed, 'to carry out the objects of the meeting.' It consisted of three persons, and one of them was Jefferson Davis. That the council was not merely 'advisory,' that it represented the vigor and determination of a revolutionary purpose, is proved from the fact that its program was carried out with an exactness, a minute correspondence to every proposition that could only have proceeded from the force of command. Everything was done that the council ordered. They did control 'all political and military operations'; they did have forts and arsenals seized, as, one by one, the dispatches from Washington indicated them; they did effect a convention at Montgomery arbitrarily appointed; and in no instance did the movements in the South towards secession vary from the program decided at Washington on the $5^{\text {th }}$ of January. Never was a conspiracy more successful in all its designs and in every detail; and never could such a correspondence of events have been produced by mere councilors, so limited in numbers and in representative capacity, unless there had been concealed in the guise of 'recommendations' the bold and imperious fiat of men who had resolved to rule the people rather than to counsel and then obey them.

"The secret senatorial council of the 5 th of January can then only be historically known as a revolutionary body. It really dates the commencement of the war. To be sure, after this, there was a prolonged farce of a debate in Congress, and such affectations as might proceed from the tactics of the parties; but war was practically determined when Anderson raised his flag at Sumter, and turned inland the frown of his guns." $x$

"See also letter of "Eaton," understood to be Lemuel D. Evans, a Representative from Texas, in the National Intelligencer, of January I $\mathrm{r}$, 1861, reprinted in McPherson's History of the Rebellion, p. 391; Appleton's Annual Cyclopedia for 186r, p. 125. 
At this meeting the following resolutions were adopted:

"Resolved, That in our opinion each of the Southern States should, as soon as may be, secede from the Union.

"Resolved, That provision should be made for a convention to organize a confederacy of the seceding States, the convention to meet not later than the $15^{\text {th }}$ of February, at the city of Montgomery, in the State of Alabama.

"Resolved, That in view of the hostile legislation that is threatened against the seceding States, and which may be consummated before the 4 th of March, we ask instructions whether the delegations are to remain in Congress until that date for the purpose of defeating such legislation.

"Resolved, That a committee be and are hereby appointed, consisting of Messrs. Davis, Slidell, and Mallory, to carry out the objects of this meeting."

One of the questions discussed at the meeting was whether Southern members of Congress "should go out at once," or not. It was thought that the States should secede but that their representatives in Congress should remain for the reasons stated in a letter of Senator Yulee of Florida to Joseph Finegan, written January 7, 186I, in which he said: "The idea of the meeting was that the States should go out at once, and provide for the early organization of a confederate government, not later than 15 th February. This time is allowed to enable Louisiana and Texas to participate. It seemed to be the opinion that if we left here, force, loan, and volunteer bills might be passed, which would put $\mathrm{Mr}$. Lincoln in immediate condition for hostilities; whereas, by remaining in our places until the 4th of March, it is thought we can keep the hands of Mr. Buchanan tied, and disable the Republicans from effecting any legislation which will strengthen the hands of the incoming administration." $\mathrm{F}$

Several Southern members of Congress who remained after the secession of their respective States did so for the reasons stated in Yulee's letter, and also, as it was charged at the time, that they might be in a position where they

'McPherson, History. of the Rebellion, p. 392, App. Am. Cyc. for I86r, p. 126. 


\section{Political History of Secession}

could keep advised of the movements of the national government and communicate them to the secession leaders. Among them was Senator Wigfall of Texas.

From this period secession made rapid progress. Ordinances of secession were passed by Mississippi on January 9; by Florida and Alabama on the IIth; by Georgia on the I9th; by Louisiana on the 2oth, and by Texas on February I. The secession of the Southern States was followed by the withdrawal of most of the Senators and Representatives in Congress and by the seizure of most of the United States forts and arsenals within their respective territories. The work of perfecting the organization of the Confederate government and putting it on a war footing was pushed as rapidly as possible. The Confederate Congress met in Montgomery, Alabama, on February 4, I86I, and elected Howell Cobb of Georgia president. From this time until the beginning of the Civil War, there was scarcely a hitch in the Confederate programme and the tide of secession became so strong that it finally swept from their moorings and into the vortex of secession, not only the cotton States, but also Virginia, North Carolina, and Tennessee, and, but for the proximity of the Federal army, would probably have taken Maryland and possibly Kentucky and Missouri. On February 7, the committee appointed for that purpose by the Confederate Congress reported a plan of a provisional government which at a later date was adopted and ratified by the seceding States. The name "Confederate States of America" was adopted. Jefferson Davis was elected President and Alexander $\mathrm{H}$. Stephens of Georgia Vice-President. There was some discussion about the national flag to be adopted, in which $\mathrm{Mr}$. Miles of South Carolina said that "he had regarded from his youth the 'stars and stripes' as the emblem of oppression and tyranny," and so the emblem selected was the "stars and bars." On the I8th the President and Vice-President were inaugurated at Montgomery. The inauguration ceremonies were conducted with imposing pomp. "The 
hill on which the capitol is situated was crowded with the wealth and beauty, the soldiers and citizens, from the different States. In the evening the city was gorgeously illuminated. The President held a levee at Estelle Hall. Bands of music played, fireworks were displayed, and a grand and general demonstration was made." $\mathrm{z}$ Later the members of the President's Cabinet were selected, Senator Robert Toombs, of Georgia, being chosen for Secretary of State. He afterward resigned and was appointed a Brigadier-General in the Confederate army. Provisions were made for raising an army of 100,000 and also for creating a navy. The President was authorized to negotiate a loan of $\$ 15,000,000$. On March II the permanent constitution was adopted which legalized slavery in all the territories. Commissioners, among whom was William L. Yancey, of Alabama, were sent to England, France, Russia, and other foreign nations to secure recognition of the Confederate States and to make treaties. ${ }^{2}$

Soon after the passage of the ordinance of secession the South Carolina authorities made preparations for the bombardment of Fort Sumter and threatened to begin before the $4^{\text {th }}$ of March. Their impetuosity caused the secession leaders in other States great alarm, not because they were not equally eager to begin, but because they wanted a continuance of peace with the Federal government until they could be the better prepared for war. A precipitate bombardment, especially if unsuccessful, might operate as a frost upon the budding Confederacy. The matter also caused President Buchanan great uneasiness lest the threaened civil war might begin before the expiration of his term of office. Great pressure was brought to bear in order to restrain the belligerent leaders in South Carolina. ExPresident Tyler shared the President's distress of mind. On February 7, 1861, he besought Governor Pickens to

'Appleton's Annual Cyclopedia for 1861 , p. 127.

'An abstract of the proceedings of the Confederate Congress will be found in Appleton's Annual Cyclopedia for 1861, p. 154 et seq. 
stay the bombardment. "Can my voice reach you?" he said. "If so do not attack Fort Sumter. You know my sincerity." $r$ Later, on February 18 , he sent a telegraph dispatch to Governor Pickens in which he referred to a prevalent rumor, "that Fort Sumter would be taken on or before $4^{\text {th }}$ of March, 'without reference to what the Montgomery government may advise or order on the subject," " adding, "This startles the President. Will you quiet him by your reply?"' Finally it was determined to postpone the bombardment until a more auspicious time.

So terrifying to the President was anything bearing the semblance of a display of the military strength of the government that on February 22 he hastened to write a letter to ex-President Tyler apologizing for having permitted two or three companies of Federal troops then in Washington to participate in a public parade there on Washington's birthday. ${ }^{3}$

With the close of the Thirty-sixth Congress came also the close of Buchanan's administration. The best part of it, like that of a tedious discourse, was the end of it. Estimates of Buchanan himself varied in his lifetime and will probably continue to vary. The bitterest criticism of him has come from his former political friends in the South to whose cause he had devoted his life. A Confederate historian" thus speaks of him: "The policy of Mr. Buchanan was unfortunately weak and hesitating-an attempt at ambidexterity, in which he equally failed to conciliate the secessionists and pacify their designs, or to make any resolute effort to save the Union. He had, in his message to Congress, denounced secession as revolutionary; and although he was clear in the constitutional proposition that there was no right of 'coercion' on the part of the Federal government, yet he did but little, and that irresolutely, to put that government in a state of defense, in the event of violence on the part of the seceded States. This timid old

I War Rec., vol. i., p. 254.

3 Crawford, Sumter, p. 274.
2 Id., vol. i., p. 257.

- Pollard, Lost Cause, p. 95. 
man-a cautious, secretive politician, who never felt the warmth of an emotion, and had been bred in the harsh school of political selfishness-attempted to stand between two parties; and the result was embarrassment, doubledealing, weak and despicable querulousness, and, finally, the condemnation and contempt of each of the parties between whom he attempted to distribute his favors."

Blaine's estimate of Buchanan, "though not flattering, is far more lenient than that of Pollard: "It was Mr. Buchanan's misfortune to be called to act in an emergency which demanded will, fortitude, and moral courage. In these qualities he was deficient. He did not possess the executive faculty. His life had been principally devoted to the practice of law in the most peaceful of communities, and to service in legislative bodies where he was borne along by the force of association. He had not been trained to prompt decision, had not been accustomed to exercise command. He was cautious and conservative to the point of timidity. ... It was said of Mr. Buchanan that he instinctively dreaded to assume responsibility of any kind. . . . He was not gifted with independence or self-assertion. His bearing towards Southern statesmen was derogatory to him as a man of spirit. His tone towards Administrations of his own party was so deferential as almost to imply a lack of self-respect. He was not a leader among men. He was always led. . . . If Mr. Buchanan had possessed the unconquerable will of Jackson or the stubborn courage of Taylor, he could have changed the history of the revolt against the Union.. A great opportunity came to him but he was not equal to it. Always an admirable adviser where prudence and caution were the virtues required, he was fatally wanting in a situation which demanded prompt action and strong nerve. As Representative in Congress, as Senator, as minister abroad, as Secretary of State, his career was honorable and successful. His life was singularly free from personal fault or shortcoming. He was honest

- Twenty Years, vol. i., pp. 240-41. 


\section{$55^{2}$ Political History of Secession}

and pure-minded. His fame would have been more enviable if he had never been elevated to the Presidency."

The opinion of General Crawford upon Buchanan and the events of the closing months of his Administration is entitled to great weight. Crawford was in Fort Sumter during the siege and was conversant with the operations for its attack and defense. His military experience won for him a high rank in the Civil War. He had an intimate personal acquaintance with Judge Jeremiah S. Black. After the war he had access to many documents and letters of both an official and private nature relating to men and events connected with Fort Sumter. In his history he shows very fully the earnest and persistent efforts of Black, Stanton, and Holt to persuade the President to adopt measures for the protection and preservation of the United States forts and military supplies, in the seceding States, and particularly measures which might, in the beginning, have been adopted without great difficulty to reinforce Fort Sumter, and how all the opportunities for doing so were frittered away by reason of the timidity, hesitation, and vacillation of the President. Crawford's conclusion expresses, as accurately and fairly as can be put in a single sentence, his own opinion and probably that of posterity: "When history shall come to pen the record of the close of his career it will judge him not from what he did, but what, from his great opportunities and grave responsibilities, he utterly failed to do."x

The defense of Buchanan's course during the last four months of his Administration, briefly summed up, is that he, like most people in the North, and many in the South, did not believe that the secessionists would go to the extreme of making war on the Federal government; that he could not, if so inclined, have suppressed secession by force of arms, for the reason that he had no military or naval force adequate for such purposes; that, even if he had had such a force, the use of it, at least until all reasonable efforts for

${ }^{x}$ Crawford, Sumter, p. 287. 
compromise and conciliation had been exhausted, would not have been sustained in the border States and in other portions of the South, and would have excited formidable opposition even in the North. It must, in fairness, be conceded that there is much of truth in this defense and that when the facts upon which it is based are carefully considered they go far toward vindicating Buchanan from the charge of disloyalty often made against him during his life.

But when his defenders go further and attempt to show that Lincoln, during the first month of his Administration, merely followed the policy of Buchanan' and that Buchanan's policy cannot justly be condemned without condemning that of Lincoln also, the defense ignores the important fact that Lincoln was obliged to begin where Buchanan left off and that at the close of Buchanan's Administration secession was already an established fact; that the Southern Confederacy had already been fully organized and placed on a war footing and that Fort Sumter was then at the mercy of its besiegers.

In determining what, degree of blame should be charged to Buchanan for his failure to do more than he did to suppress secession, the important question is not what he did or might have done after secession had got under full headway, but what he might or ought to have done before. Prior to the reorganization of his Cabinet the general tone of his Administration was one calculated, if not intended, to give encouragement to the advocates of secession. His annual message to the Thirty-sixth Congress was generally regarded by the Southern leaders as a pledge that Buchanan would not use the military and naval force at his disposal to suppress secession or to interfere in any way with the carrying out of any of their plans. This and the ill-concealed sympathy of the majority of the leading members of his

I "Little are the objectors aware that the policy of Mr. Lincoln's Administration, until after the attack on Fort Sumter, was identical with that of Mr. Buchanan."-Curtis, Buchanan, vol. ii., p. 35 I. 


\section{Political History of Secession}

Cabinet and the zealous efforts of Floyd, his Secretary of War, in using all the power of his great office to aid the secession cause, all tended still further to encourage the secession leaders and to discourage the friends of the Union and to demoralize the Union sentiment everywhere. It was this general tone that gave a coloring to Buchanan's policy that Lincoln's never had.

Possibly no President, not even Andrew Jackson, could have averted the Civil War, and it may be, and probably is, true that Buchanan has been unduly blamed; nevertheless, the general belief in the North to this day is that, even conceding that Buchanan was actuated by patriotic motives, his patriotism was of a different and easily distinguishable brand from that of Andrew Jackson.

If at the time of Lincoln's election a man like Jackson had been in the presidential chair, a man with Jackson's patriotism, his courage, his determination, his promptness, his vigor of action, he might have done much to quench the fire when it first started in South Carolina; he might have done much to stop its spread, and he might have greatly circumscribed the area of the conflagration and shortened its duration. He could, at least, have done something to encourage and strengthen the Union sentiment in the South, particularly in Virginia, in Tennessee, and even in Georgia; he could have made an effort to save to the United States the forts and arsenals in the seceding States that were surrendered without a struggle; he could have made an effort to save the immense quantity of arms and munitions of war that were surrendered to the Confederates and prevent their being used by them to equip the Confederate armies; and in these ways, if civil war had not been averted, its duration might have been very much shortened. Instead of pursuing such a course, Buchanan's ill-concealed sympathy with the secession leaders in the beginning of the secession movement, his irresolution, his timidity, his vacillation, his constant efforts to shirk all individual responsibility and shift it upon Congress and his successor, added 


\section{Close of Buchanan's Administration 555}

fuel to the flames, and fanned them into a conflagration that during the remainder of his term grew to such vast proportions as to envelop the whole of the South and to threaten the entire nation. ${ }^{x}$

- In Buchanan's Administration he has himself stated his own defense. McClure, in Lincoln and Men of War Times, p. 273, has also made a strong plea defending Buchanan against the charge of disloyalty. See also pamphlet of W. U. Hensel, ex-Attorney-General of Pennsylvania, entitled Buchanan's Administration on the Eve of the Rebellion. The strongest defense of Buchanan's Administration during the closing months of it is that of Jeremiah S. Black in his two letters to Henry Wilson, Black's Essays and Speeches, pp. 245-92. 


\section{CHAPTER XXVI}

\section{DEVELOPMENT OF WAR SPIRIT'IN THE NORTH}

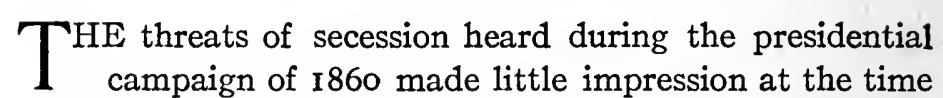
on the people of the North. They had been heard before in I820 during the discussions of the Missouri Compromise; again during the discussions of the compromise measures of $\mathbf{I 8 5 0}$, and again in the presidential campaign of $\mathbf{I} 856$. They were repeated with increased emphasis during the presidential campaign of $\mathbf{1} 860$, but were regarded by most Northern voters as mere cries of "wolf." "Did not we submit to the election of Buchanan," said the Republicans, "and why should not the Democrats submit to the election of Lincoln?" "If a majority shall not be allowed to rule, what is there left of value in a republican form of government?" The events following the election made a profound impression on the Northern States. The first shock to the North came with the news of the secession of South Carolina. It was no longer the mere cry of "wolf." The wolf was at the door. Incredulity now gave way to conviction; conviction to alarm; alarm to panic. The Republicans were indeed for a time in a pitiable plight. They had been amazed by the magnitude of their victory; they were now apparently appalled by its threatened consequences. Their political opponents taunted them" with cries of "We told you so," and charged them with responsibility for the distracted condition of the country, with the prospect of disunion, with the threatened horrors of civil war. For a time there was a feverish anxiety to find some way of 


\section{Development of War Spirit in the North 557}

propitiating the South. Rhode Island made haste to repeal its personal liberty laws, and other States prepared to follow the same course.

In the Ohio and in other State legislatures bills were introduced for the adoption of various of the constitutional amendments recommended by the Senate Committee of Thirteen or by the Peace Convention. Immediately after the firing on the Star of the West the New York Legislature had passed resolutions tendering to the President "whatever aid in men and money may be required to enable him to enforce the laws and uphold the authority of the Federal government." But the hostile reception which these resolutions received in the South excited such a feeling of reaction in the State in favor of measures of conciliation that a great memorial was got up by leading capitalists of New York City and forwarded to Washington favoring further concessions to the South, the reformation of the Fugitive Slave Law and the personal liberty bills, and "some adjustment of the rights of all the States of the Union in the new territory acquired by the blood and treasure of all." About the same time a similar memorial was circulated throughout the State receiving over 40,000 signatures. George William Curtis who had been engaged to deliver a lecture in the Republican city of Philadelphia on December 10, 1860, in opposition to the policy of making further concessions to slavery, was warned by the mayor that the attempt to deliver it would probably precipitate a riot, and the meeting was called off. A few days later at a monster meeting in the same city called by the same mayor, among other resolutions adopted, was one which declared that "all denunciations of slavery as existing in the United States... are inconsistent with the spirit of brotherhood and kindness." The mayor, aldermen, and council of Boston and 22,000 citizens of that State petitioned Congress praying for the adoption of the Crittenden compromise measures. Everybody had a peace panacea of some kind. It is now almost incredible that some of the peace propositions 


\section{$55^{8}$ Political History of Secession}

then discussed should have received serious consideration in any quarter in the North. It seemed that many Republicans were anxious to make to the South any atonement demanded for their sin of having elected a Republican President. Indeed, the shameful spectacle of so many Republicans and Republican newspapers apparently cowering in fear and groveling in the dust to appease the wrath of the slaveholding lords of the South, even now brings a blush to all Northern men who fought, or whose-fathers fought, in the Civil War and proved their bravery on so many battlefields.

Generally speaking the people of the North were ranged in four classes on the question of dealing with secession. The first class included those (mainly Democrats who had voted for Breckinridge in the preceding election) whose sympathies were with the South. The second class included those before known as "Abolitionists," who preferred letting the slaveholding States go out of the Union rather than to stay in with slavery. The third class included those, among whom were large numbers of Republicans, who were strongly attached to the Union and who wanted to preserve it, and who, in order to preserve it, were willing to make still further concessions to the slaveholding States. The fourth, or radical, class included those, among whom was a smaller number of Republicans, who were neither in favor of making any further concessions to the slaveholding States nor in favor of letting them go in peace, but were in favor of suppressing secession and preserving the Union by arms, if necessary, even at the expense of civil war.

Many of the Democratic papers and leaders were violently opposed to preventing the Southern States from going out of the Union or bringing them back by anything like armed coercion. The Albany Argus said that to employ force against the seceding States "would be madness," and that "the first gun fired in the way of forcing a seceding State back to her allegiance to the Union would probably prove the knell of its final dismemberment." Utterances of other 


\section{Development of War Spirit in the North 559}

Democratic papers were even more virulent. The Detroit Free Press said: "If there shall not be a change in the present seeming purpose to yield to no accommodation of the national difficulties, and if troops shall be raised in the North to march against the people of the South, a fire in the rear will be opened upon such troops, which will either stop their march altogether or wonderfully accelerate it"; and the Bangor (Me.) Union said: "The difficulties between the North and the South must be compromised, or the separation of the States shall be peaceable. If the Republican party refuses to go the full length of the Crittenden amendment-which is the very least the South can or ought to take-then here in Maine not a Democrat will be found who will raise an arm against his brethren of the South. From one end of the State to the other let the cry of the Democracy be 'Compromise or Peaceable Separation."' At a Democratic meeting in Albany, N. Y., on January 3I, 186I, ex-Chancellor Reuben H. Walworth asserted that "it would be as brutal in my opinion to send men to butcher our own brothers of the Southern States as it would be to massacre them in the Northern States," and at the same meeting ex-Governor Horatio Seymour said: "The question is simply this: Shall we have compromise after war or compromise without war?" and he denounced "successful coercion by the North" as no less revolutionary than successful revolution by the South.

On January 7, 1861, Fernando Wood, Mayor of New York, in a message to the common council of that city suggested that: "When disunion has become a fixed and certain fact why may not New York disrupt the bands which bind her to the venal and corrupt master, to a people and a party that has ever plundered her revenue, attempted to ruin her commerce, take away the power of self-government, and destroy the confederacy of which she was the proud Empire City."

William Howard Russell, the correspondent of the London Times, attended a dinner in New York, on March 
I9, I86I, at which Horatio Seymour, Samuel J. Tilden, and George Bancroft were guests. "The result left on my mind," he records in his Diary" "by their conversation and arguments was that, according to the Constitution, the Government could not employ force to prevent secession or to compel States which had seceded by the will of the people to acknowledge the Federal power." Russell exactly described the condition of affairs in the following statement: "In fact the Federal government is groping in the dark; and whilst its friends are telling it to advance boldly, there are myriads of voices shrieking out in its ears, 'If you put out a foot you are lost:' . . . The Democrats behold with silent satisfaction the trouble into which the Republican triumph has plunged the country and are not at all disposed to extricate them. The most notable way of impeding their efforts is to knock them down with "the Constitution' every time they rise to the surface and begin to swim out." $r$

There were doubtless many who shared the views of one who told Russell that "the majority of the people of New York, and all the respectable people, were disgusted at the election of such a fellow as Lincoln to be President, and would back the Southern States if it came to the split."

But the utterances of leading Republican papers in the North were still more amazing. Few of them, until long after the warlike preparations of the South had been begun, were animated by anything bearing even the semblance of a war spirit. As before stated, the New York Tribune had a large circulation and wielded a greater influence among the Republicans of the North than any other Northern paper. In an editorial on November 9, I860, this paper said: "We hold with Jefferson Davis to the inalienable right of communities to alter or abolish forms of government that have become oppressive or injurious, and if the cotton States shall decide that they can do better out of the Union than in it, we insist on letting them go in peace. . . . And when-

$$
\text { ×Id., p. } 20 .
$$$$
\text { Id., p. I4. }
$$ 


\section{Development of War Spirit in the North 56r}

ever a considerable section of our Union shall deliberately resolve to go out, we shall resist all coercive measures designed to keep them in. We hope never to live in a republic where one section is pinned to the residue by bayonets."

These views of the Tribune were approved by many other influential Republican papers. Jefferson Davis, quoting this, adds: "Nothing that has ever been said by the author of this work, in the foregoing chapters, on the floor of the Senate, or elsewhere, more distinctly asserted the right of secession." $=$

Substantially the same view as that of the New York Tribune was taken by the Albany (N.Y.) Evening Journal, edited by Thurlow Weed, Seward's nearest friend and political manager. The Indianapolis Journal on November 19, I860, said:

"In the present case it seems clear to us that if the enforcement of the Constitution leads to civil war, we shall be better off to let the Constitution be broken and to save bloodshed. ... We are therefore clearly of the opinion that any attempt to restrain by force the secession of any State or combination of States from the Union would be unwise and calamitous to the last degree." On December 7 , speaking of the probable duration of the war between the North and South, it said: "How long would this war last, think you? Ten years? Yes-fifty-forever-for the enmity begotten of it would never die. The very contact of our people and territories would perpetuate it. . . . Then it could never conquer the ten millions, consequently our government instead of being proved strong would be proved to be nothing but a bloody feebleness, a tyrannical stupidity."

In striking contrast to such utterances as those just quoted were the views of men of the type of Oliver P. Morton, representing the radical wing of the Republican party. Morton had no doubt as to the power and the duty

× Davis, Rise and Fall, vol. i., p. 252. 
of the President to "coerce the sovereign State of South Carolina." Nor was he in the least intimidated by the threats of war. In a speech at Indianapolis on November 22, 1860, he said: "If South Carolina gets out of the Union, I trust it will be at the point of the bayonet after our best efforts have failed to compel her submission to the laws. Better concede her independence to force, to revolution, than to right and principle. . . . I trust that we shall not, by surrendering with indecent haste, publish to the world that the inheritance which our fathers purchased with their blood we have given up to save our own. Seven years is but a day in the life of a nation, and I would rather come out of a struggle at the end of that time defeated in arms and conceding independence to successful revolution than purchase present peace by the concession of a principle that must inevitably explode this nation into small and dishonored fragments."

In the interval between the presidential election and the inauguration of Lincoln, the defiant and aggressive attitude of the secession leaders, the seizure of the Southern forts and arsenals, the firing on the Star of the West, the preparations for the bombardment of Fort Sumter, the abandonment by the Administration of nearly every vestige of national authority in the seceded States, made a profound impression on the Northern States. The radical leaders of the Republican party said: "We have not declared war, nor uttered any threats of war, upon slavery in the States where it now exists; we have exercised only our undoubted political rights in electing by constitutional methods a Republican President; the concessions to slavery that have already been offered go to the verge of honor and duty; these have been spurned with contempt; now we are asked to abase ourselves by making still further concessions, concessions that would be deemed an abandonment of vital principles for which we have contended for years and that we still believe in, concessions that would make us appear to the world as a herd of pusillanimous cowards, and that would 


\section{Development of War Spirit in the North 563}

degrade us and our posterity - all in order to make peace with slavery. If war shall come for this, let it come, but let us stand fast for our principles." Such arguments as these made a profound impression upon the people of the North and by slow degrees they recovered their senses, their self-respect, and their courage.

Still, at least up to the time of Lincoln's inauguration, there was a great diversity of opinion in the North on the question of the resort to arms to suppress the threatened secession of the Southern States. This is clear from the expressions of the newspapers and the reports of public meetings between the presidential election and the inauguration of Lincoln. Many of the Democratic newspapers, especially those that had supported Breckinridge for President, continued their denunciations of the "Black Republicans," as the authors of all the impending perils that now hung over the country, and demanded further concessions to the South. There were also many Republicans who were willing to make further concessions to slavery, not because they favored it, but because they were sincerely devoted to the Union, and so were in favor of making still further concessions. The commercial interests also dreaded the effect of war upon trade, and for this reason favored further concessions.

Probably in no quarter was there a greater feeling of suspense than in the border States. These, particularly Virginia, were deeply interested in the preservation of the Union. They could foresee that in the event of war between the North and the South their territory would be the battle-ground. It was early apparent, however, that in the event of such a war the sympathies of the border slave States would be altogether with the seceding States. There were commercial ties binding the border States to the North, but those which bound them to the States adjacent to the Gulf of Mexico and the Mississippi River were much stronger. The social ties that bound them to the South 


\section{Political History of Secession}

were also much stronger than those which bound them to the North. Above all else was the community of interest in the protection of slavery. Moreover, the belief was general in the border States after the formation of the Southern Confederacy that it would be victorious in the event of war. In such event, it was argued, the border States would be bereft of political power and would be unable to protect themselves against further aggressions by the free States against slavery, and it would be only a question of time, and probably not a very long time, when slavery would be extinguished in the slave States which still adhered to the old Union. These were the arguments that inclined the border States to the cause of the States which had already seceded, and that were chiefly instrumental afterwards in causing Virginia to ally herself with the Southern Confederacy. Still there was, even in Virginia, a strong Union sentiment, sufficiently strong, at any rate, to prompt an effort to patch up some sort of compromise that would avert the horrors of civil war.

Secession was now, as had been stated in the debates in Congress, "an accomplished fact." This much, at least, had been settled. But the graver questions still remained: What would the Northern States do? What would the United States Government do? Would it attempt "coercion"? Would there be peace or war? This, of course, depended largely upon the policy of the incoming Administration. But what would be the policy of Lincoln? The Romans never waited with more eager interest to hear the words of a Delphic oracle than did the people of the United States to hear what Abraham Lincoln might say when called upon, as he would be soon, to define his policy. It is certain that no one realized more clearly than he did the responsibilities that now rested upon him. In all the exultations of his followers, amidst all the huzzas of the multitude, he never lost sight of the fact that it was still to be determined whether he would be President of the whole country or President of only a part of it. 


\section{CHAPTER XXVII}

\section{THE COMING OF LINCOLN}

$\mathrm{T}$ was in this distracted condition of the country, under such a gloomy outlook, that Abraham Lincoln started from his home in Springfield, Illinois, to Washington to be inaugurated. Great crowds gathered along the way to see him, but more especially to catch from his words some inkling of his future policy. So persistent were the rumors that an attempt would be made to assassinate him on his passage through Baltimore, that, by the advice of his friends, he partially disguised himself and so passed through in safety, arriving in Washington on February 23. His inauguration took place on March 4.

The occasion was most impressive. The grave condition of the affairs of the country added to its solemnity. A great throng, estimated at thirty thousand, had assembled to witness the cercmonies. President Buchanan and his Cabinet, the principal officers of the government, the judges of the Supreme Court in their robes of office, the chief officers of the army and navy, the ambassadors and other representatives of foreign nations, notable men from all parts of the country-all waited with breathless interest to hear what words of counsel the new and untried man now at the helm might utter, to see if he could point out any ray of hope in the dark clouds that lowered over the country.

Of course Lincoln was the central figure in all this vast and brilliant assemblage, but not least conspicuous was his great competitor, Stephen A. Douglas, who listened with attentive and respectful interest. The swift mutation of 


\section{Political History of Secession}

events had brought about a rapid shifting of position of many men. None was more marked than that of Douglas. A few months before he had been Lincoln's most formidable rival for the office of President; now he was one of Lincoln's staunchest friends, destined soon to become a tower of strength for the incoming Administration.

The inaugural address was intended to be conciliatory. In it Lincoln expressly disclaimed any "purpose directly or indirectly to interfere with the institution of slavery in the States where it exists." "I believe," he said, "that I have no lawful right to do so and I have no inclination to do so." But he left no one in doubt as to his duty as Chief Executive. "His duty is to administer the present government as it came to his hands, and to transmit it, unimpaired by him, to his successor." "In your hands, my dissatisfied fellow-countrymen, and not in mine, is the momentous issue of civil war. The government will not assail you. You can have no conflict without being yourselves the aggressors. You have no oath registered in Heaven to destroy the government, while I shall have the most solemn one to 'preserve, protect, and defend it." " His inaugural address closed with this eloquent and touching appeal: "I am loath to close. We are not enemies but friends. We must not be enemies. Though passion may have strained, it must not break our bonds of affection. The mystic chords of memory, stretching from every battlefield and patriot grave to every living heart and hearthstone, all over this broad land, will yet swell the chorus of the Union, when again touched, as surely they will be, by the better angels of our nature."

The man who spoke these impressive and touching words was by nature one of the kindest and gentlest of men, but his appeal to his "dissatisfied countrymen" fell on hearts closed to any appeal that he might make, and awakened no responsive echo. To the great mass of the people of the South, he had been portrayed as an uncouth monster and a tyrant. His inaugural was tortured into a menace and his 


\section{The Coming of Lincoln}

kindly words to those now maddened with the frenzy of secession were spurned with contempt and derision.

How Lincoln was then regarded in the South is thus told by a Southern historian." "Abraham Lincoln was neither kind nor cruel, in the proper sense of these words, simply because he was destitute of the higher order of sensibilities. His appearance corresponded to his rough life and uncultivated mind. His figure was tall and gaunt-iooking; his shoulders were inclined forward; his arms of unusual length; and his gait a stride, rapid and shuffling. The savage wits in the Southern newspapers had no other name for him than 'the Illinois Ape.' The new President of the United States was the product of that partisanship which often discovers its most 'available' candidates among obscure men, with slight political records, and of that infamous demagogism in America that is pleased with the low and vulgar antecedents of its public men, and enjoys the imagination of similar elevation for each one of its own class in society. Mr. Lincoln had formerly served, without distinction, in Congress. But among his titles to American popularity were the circumstances that in earlier life he had rowed a flatboat down the Mississippi; afterwards been a miller; and at another period had earned his living by splitting rails in a county of Illinois."

It is pleasant to turn from Pollard to later Southern writers; to read from the pages of a prominent Southern man-himself a gallant soldier in the Confederate army and afterwards a member of President Cleveland's Cabinet -a graceful and tender tribute to the memory of Abraham Lincoln, who was, he assures us, "totally misunderstood" by the people of the South prior to his assassination. ${ }^{2}$

The new President's first important official duty was the selection of his Cabinet and in this he was forced to yield somewhat of his own judgment of men to political considerations. By common consent, Seward, his great competitor

\& Pollard, Lost Cause, p. ror.

- Herbert, The Abolition Crusade, pp. 191-2. 
at the Chicago convention, was selected as Secretary of State. In this way the claims of Seward's friends, and of the great State of New York were acknowledged. The selection of other members of the Cabinet was far more difficult and was controlled by other and more complicated considerations. It was desirable to avoid as far as possible giving the Cabinet a sectional cast, but no really representative Southern man would accept a Cabinet position, and so Edward Bates of Missouri was selected for AttorneyGeneral, and Montgomery Blair of Maryland was selected for Postmaster-General. Then it was necessary to avoid taking all the members of the Cabinet from the East or all from the West; to avoid taking all from those who had formerly been Democrats, or all from those who had formerly been Whigs. It was also necessary to recognize the claims of the President's own State of Illinois, as well as the claims of the great Republican States of Pennsylvania and Ohio, which had turned the scale at the presidential election by decisive Republican majorities. So made up, the Cabinet was weakest in places where it should have been strongest, particularly so in Simon Cameron of Pennsylvania, who was selected for Secretary of War, a noted Pennsylvania politician of a type that has not added luster to the State, wholly unfitted for the great responsibilities that now rested upon the incumbent of the important office to which he was appointed.

Notwithstanding the fact that the logic of politics seemed to point irresistibly to the selection of Seward for Secretary of State there was some opposition to his appointment, and the strongest opposition came from leading Republicans in the State of New York, based largely upon the supposed sinister influence over Seward of Thurlow Weed.

We now know more fully, what was surmised at the time, that Lincoln did not favor the selection of Cameron, but that he yielded to it only to avoid what he feared might be greater evils if Cameron should be left out of the Cabinet. One of Lincoln's chief managers at the Chicago convention 
in I 860 was David Davis, ${ }^{2}$ who, contrary to Lincoln's instructions, forbidding any pledges that might bind Lincoln himself, had made some kind of bargain with, or promise to, the Pennsylvania delegation that in the event of Lincoln's nomination and election he would reward Pennsylvania by giving Cameron a Cabinet position. As soon as it was known that Lincoln was elected Cameron's friends began to press his claims. Prominent among his backers was David Davis, who, to quote from Horace White, "clung to Lincoln like a burr." Cameron had the powerful support of Seward and Weed, and by arts known to politicians he succeeded in working up an apparent sentiment in Pennsylvania that made it look on the surface as though Pennsylvania was "solid" for Cameron and would refuse to be comforted if he were not appointed. Nevertheless Cameron's appointment was vigorously opposed by many leading Republicans who protested against it on the ground that he was a tricky and unscrupulous politician and that his appointment would be certain to prove disastrous to the new Administration. ${ }^{2}$

x Afterwards appointed by Lincoln one of the judges of the Supreme Court.

2 This prediction was verified in less than nine months after Cameron's appointment, when outrageous frauds were unearthed in the War Department of so scandalous a character that they were impairing the credit of the government and threatening its destruction. The most mortifying part of the subsequent disclosures was the fact that some of the most flagrant of these frauds had been committed or connived at by those who had been rewarded with appointment in payment for political services in behalf of Cameron. These disclosures finally led to Cameron's virtual expulsion from the Cabinet, although the expulsion was thinly disguised under the form of the appointment of Cameron to be Minister to Russia. Horace White, who, from long experience as a journalist and extensive personal acquaintance of men and affairs in Trumbull's time, probably knew more about them than Trumbull did himself, has told the story of how Cameron got into the Cabinet and how he got out of it (Life of Trumbull, pp. 142, 178). The story does not impair our confidence in Lincoln's honesty of purpose but it shows that Lincoln made a great mistake in yielding his own better judgment to the 


\section{Political History of Secession}

As finally constituted, Lincoln's Cabinet consisted of William H. Seward of New York, Secretary of State; Salmon P. Chase of Ohio, Secretary of the Treasury; Simon Cameron of Pennsylvania, Secretary of War; Gideon Welles of Connecticut, Secretary of the Navy; Caleb B. Smith of Indiana, Secretary of the Interior; Edward Bates of Missouri, Attorney-General; Montgomery Blair of Maryland, Postmaster-General. The strongest men in the Cabinet were Seward and Chase, the one representing the conservative, the other the radical wing of the Republican party. The Cabinet was not harmonious. Apparently the members distrusted the President and distrusted one another. The stories told of their bickerings are not pleasant reading. ${ }^{x}$ It was impossible that a Cabinet so constructed could give the President the united and loyal support to which he was entitled at the time when he most needed it.

Some of the difficulties which confronted Lincoln at the very beginning of his administration are thus clearly and tersely stated in his message of July 4, I86I, to the special session of Congress: "At the beginning of the present presidential term, four months ago, the functions of the Federal government were found to be generally suspended within the several States of South Carolina, Georgia, Alabama, Mississippi, Louisiana, and Florida, excepting only those of the Post-Office Department.

"Within these States all the forts, arsenals, dockyards, custom-houses, and the like, including the movable and stationary property in and about them, had been seized, and were held in open hostility to this government, excepting only Forts Pickens, Taylor, and Jefferson, on and near

persuasions of others whose motives, whatever they were, were not based on patriotic feeling or upon any conviction that Cameron was the best man obtainable for the high office to which he was appointed. Certainly the story adds no luster to the reputation of any, not even of Lincoln himself, concerned in Cameron's appointment.

I The latest contribution on this subject is the Diary of Gideon Welles, Lincoln's Secretary of the Navy. 


\section{The Coming of Lincoln}

the Florida coast, and Fort Sumter, in Charleston Harbor, South Carolina. The forts thus seized had been put in improved condition, new ones had been built, and armed forces had been organized and were organizing, all avowedly with the same hostile purpose.

"The forts remaining in the possession of the Federal government in and near these States were either besieged or menaced by warlike preparations, and especially Fort Sumter was nearly surrounded by well-protected hostile batteries, with guns equal in quality to the best of its own and outnumbering the latter as perhaps ten to one. A disproportionate share of the Federal muskets and rifles had somehow found their way into these States, and had been seized to be used against the government. Accumulations of the public revenue lying within them had been seized for the same object. The navy was scattered in distant seas, leaving but a very small part of it within the immediate reach of the government. Officers of the Federal army and navy had resigned in great numbers, and of those resigning a large proportion had taken up arms against the government. Simultaneously, and in connection with all this, the purpose to sever the Federal union was openly avowed. In accordance with this purpose, an ordinance had been adopted in each of these States declaring the States respectively to be separated from the national union. A formula for instituting a combined government of these States had been promulgated, and this illegal organization, in the character of Confederate States, was already invoking recognition, aid, and intervention from foreign powers."

But all of the difficulties that confronted the new Administration were not so fully known then as they are now. In every department of the government, including even the Supreme Court of the United States, there were men whose ill-concealed sympathies were with the South, and who availed themselves of the opportunities which their positions afforded them of aiding the Confederacy and 


\section{Political History of Secession}

embarrassing the national government, especially by imparting intelligence of every action of the new Administration, which should have been kept secret.

Moreover, the President was besieged day and night by hungry hordes of office-seekers intent only on spoils and eager for the distribution of them to begin. The scramble for office began at Springfield, Lincoln's home, as soon as it was known that he was elected. "They came," so Horace White tells us, ${ }^{x}$ " in swarms from all points of the compass and in the greatest numbers from Illinois. Judging from the Trumbull papers alone it is safe to say that Illinois could have filled every office in the national Blue Book without satisfying half the demands." Russell thus records in his Diary ${ }^{2}$ his disgust with the office-seekers: "In the hotel the roar of office-seekers is unabated. Train after train adds to their numbers. They cumber the passages. The hall is crowded to such a degree that suffocation might describe the degree to which the pressure reaches, were it not that tobacco smoke invigorates and sustains the constitution. As to the condition of the floor, it is beyond description."

George W. Julian, then a Republican Representative from Indiana, gives this graphic description of the rush for office: "Mr. Lincoln, in spite of the troubled state of the country, was obliged to encounter an army of place seekers at the very beginning of his Administration. I think there has been nothing like it in the history of the government. A Republican member of Congress could form some idea of the President's troubles from his own experience. I fled from my home in the latter part of February, in the hope of finding some relief from these importunities; but on reaching Washington I found the business greatly aggravated. The pressure was so great and constant that I could scarcely find time for my meals, or to cross the street, and I was obliged to give my days and nights wholly to the business, hoping in this way I should be able in a little while to finish it; but it constantly increased. I met at every

× Life of Trumbull, p. 139.

? P. 67. 


\section{The Coming of Lincoln}

turn a swarm of miscellancous people, looking as hungry and fierce as wolves, and ready to pounce upon members as they passed, begging for personal intercession, letters of recommendation, etc. During my stay in Washington through the months of March and April there was no pause in this business. After Fort Sumter had been taken and the armory at Harper's Ferry had been burned; after a Massachusetts regiment had been fired on in passing through Baltimore, and thirty thousand men were in Washington for defensive purposes; after the President had called for seventy-five thousand volunteers and the whole land was in a blaze of excitement, the scuffle for place was unabated and the pressure upon the strength and patience of the President unrelieved. This was not very remarkable, considering the long-continued monopoly of the offices by the Democrats; but it jarred upon the sentiment of patriotism in such a crisis, and to those who were constantly brought face to face with it, it sometimes appeared as if the love of office alone constituted the animating principle of the party." $\mathrm{r}$

Nor was Lincoln yet fully trusted by the people of the North. No one doubted his patriotism. He was known to be a skillful lawyer, a great political debater, but with little experience as a statesman, and the question that perplexed even the Republicans was whether he was strong enough to cope with the demands of the hour. Many of the older political leaders of the Republican party, especially the radicals, were distrustful of both Lincoln and of his Cabinet and made no effort to conceal their distrust. So shrewd and competent an observer as Mr. Blaine says": "The extreme men in the Republican party, of the type of Benjamin F. Wade and Owen Lovejoy, believed the Cabinet was so constituted as to insure what they termed 'a disgraceful surrender to the South.' It was a common saying

S Political Recollections, pp. 193-94.

2 Twenty Years, vol. i., pp. 285-86; see also McClure, Lincoln and Men of War Times, p. 157 . 


\section{Political History of Secession}

at the time in Washington among the radical Republicans that Mr. Lincoln's Cabinet did not contain three as absolute and strong defenders of the Union as Dix, Holt, and Stanton, who had just retired with Mr. Buchanan. Thaddeus Stevens, with his accustomed sharpness of speech, said the Cabinet was composed of an assortment of rivals whom the President had appointed from courtesy, one stump speaker from Indiana, and two representatives of the Blair family." It was not until the war had been in progress for more than two years that Lincoln gained the confidence of the radicals in the Republican party. Fessenden wrote on January 14, I862: "We are in a world of trouble here. Everybody is grumbling because nothing is done, and there are no symptoms that anything will be done. The truth is that no man can be found who is equal to this crisis in any branch of the government. If the President had his wife's will and would use it rightly our affairs would look much better." The staunchest friends of the Union among the loyal Democrats were equally distrustful of Lincoln and his Cabinet. Stanton denounced what he termed the "imbecility" of the new Administration, and in a letter to Buchanan, written shortly after the Bull Run disaster, ${ }^{\text {. }}$ he prophesied that "irretrievable misfortune and national disgrace, never to be forgotten, are to be added to the ruin of all peaceful pursuits and national bankruptcy, as the result of Lincoln running the machine," and that Jeff Davis would speedily "turn out the whole concern." Singularly enough, according to McClure, ${ }^{2}$ "The one man who rendered him [Lincoln] the greatest service of all at the beginning of the war was Stephen A. Douglas, his old competitor of Illinois. When the Republican leaders were hesitating and criticizing their President, Douglas came to the front with all his characteristic courage and sagacity and was probably the most trusted of all the Senators at the White House."

× Moore, Works of James Buchanan, vol. xi., p. 2 I3.

- Lincoln and Men of War Times, p. 54. 
Indeed Lincoln was not yet fully known and trusted even by the members of his own Cabinet, as is evidenced by the amazing letter of Seward of April I, more fully noted in subsequent pages.

Until the completion of the organization of the Southern Confederacy the works for the bombardment of Fort Sumter had been in charge of the military forces of the State of South Carolina, but on March I, General Beauregard, by order of the Confederate War Department, was directed to examine and report the condition of affairs at Charleston, care having been taken, however, by the President of the Confederacy, to assure the Governor of South Carolina that "in controlling the military operations in the harbor of Charleston" everything should be done "that may be due to the honor and rights of South Carolina." In Beauregard's report on March 6, after giving a detailed account of the condition of the fort and the Confederate works, he said: "I am of the opinion that, if Sumter was properly garrisoned and armed, it would be a perfect Gibraltar to anything but constant shelling, night and day, from the four points of the compass. As it is, the weakness of the garrison constitutes our greatest advantage, and we must, for the present, turn our attention to preventing it from being reinforced."

Continued efforts were necessary to restrain the impetuous Governor of South Carolina from proceeding to bombard Fort Sumter before the inauguration of Lincoln, but cooler counsels prevailed and he was advised by the President of the Confederacy that "thorough preparation must be made before an attack is attempted, for the first blow must be successful, both for its moral and physical consequences, or otherwise the result might be disastrous to your State in the loss of many of those whom we can least afford to spare. A failure would demoralize our people and injuriously affect us in the opinion of the world as reckless and precipitate." $x$ The South Carolina Governor was also

× War Rec., vol. i., p. 259. 
advised by Wigfall that it was "all important" not to "permit any attack on Fort Sumter without authority of the government of the Confederated States." 1 Every effort was now bent toward completing the Confederate works. Batteries were placed in position at Fort Moultrie, Castle Pinckney, Morris Island, and at all other available points, and cannon of the most improved pattern were imported from England. At the same time it was sought by protracted negotiations and by every other means to prevent the reinforcement of the fort until the completion of the Confederate works.

The Confederate States followed the example of South Carolina in sending to Washington commissioners as the duly accredited representatives of "an independent nation de facto and de jure," possessing a "government perfect in all its parts and fully endowed with all the means of selfsupport," with authority to make overtures for the opening of negotiations, "with a view to a speedy adjustment of all questions which might give rise to controversy, upon such terms of amity and good will as the respective interests, geographical contiguity, and the future welfare of the two nations might render necessary."

It was now clear that the Federal authority could not be maintained in the seceded States, certainly not in South Carolina, without resort to arms. But the regular army was not sufficient to guard the frontiers and the few forts and arsenals that were left in the seceded territory. Moreover, it was known that there was a considerable Union sentiment in west Virginia, in east Tennessee, and in parts of Kentucky, and it was feared that this sentiment might be alienated if war should be begun by the Federal government. Again, there was still a strong sentiment in the North against resort by the Federal government to arms, so long as there were any hopes of compromise, and it was feared that this sentiment might be offended by anything that might be regarded as precipitate action by the national government.

I War Rec., vol. i., p. 26r. 


\section{The Coming of Lincoln}

No preparations for war had been made by the Federal government during the Administration of Buchanan, nor, with one or two exceptions, had any been made by any Northern State. Indeed, the military spirit, which in many portions of the South had been kept alive since the days of the Revolution, seemed to have died out in the North, and there even the "corn-stalk" musters had become memories only of the past. The regular army at that time numbered about 16,000 , but these, as already stated, were not sufficient to guard the Indian frontier and to hold the few forts left in the South. Most of the vessels of the navy were in distant foreign waters. There were only twelve vessels of the home squadron in serviceable condition, and only four of these, carrying twenty-five guns and less than three hundred men, were in Northern ports. Prior to January 24, 186I, fifty-six officers of the navy, including eleven from the Naval Academy, had resigned, nearly all for the purpose of entering the service of the Southern Confederacy.

The State of New York had about 8000 old muskets, and a job lot of about 150 smooth-bore cannon of all sizes, but this was a far better showing than could be made by most of the Northern States. Massachusetts was an exception. Governor Andrew was one of the few governors in the North who had had the foresight to make some preparations for war and when it began the State had 3000 Springfield rifles and clothing and other equipment for 2000 troops. Governor Morton, of Indiana, with equal foresight, had in the month of March gone to Washington and had secured an order for 5000 muskets, but the war began before they could be forwarded. 


\section{CHAPTER XXVIII}

\section{ADMINISTRATION POLICIES}

THE President now had a Cabinet but no well-defined 1 policies. It was far more difficult to formulate a policy than it was to form a Cabinet. From the beginning the ruling idea of Lincoln was to save the Union; to save it by peaceful means, if possible; by war if not possible to save it in any other way, but by war only as a last resort.

In the beginning of his administration the great mass of people in the North believed, even after seven States had seceded and had set up a government of their own, that some compromise might be devised by which the seceded States could be induced voluntarily to return to the Union. Seward believed this and, so believing, aimed to shape the policy of the Administration to accomplish this result. When it became evident, as it did to some sooner than it did to others, that there was no hope of preserving the Union by pursuing any policy based on the expectation that the seceded States would voluntarily return, new questions arose: Should the seceded States and others that might, and probably would, follow their example be permitted to go in peace, or should they be brought back by arms? And these questions involved a multitude of complex problems.

If the right of secession should be recognized by allowing the seceded States to go in peace, where would secession stop? How many more slave States would join them? What assurance was there that the people of southern Ohio, Indiana, and Illinois, where there was a large element favorable to slavery, would not follow, or at least make the attempt? 
What assurance was there that the Pacific States would not form a Pacific confederacy; or that some of the Western States would not form a Northwestern confederacy? That the fear of a Northwestern confederacy was not an idle one is proved by the fact that before the Civil War had been in progress a year strenuous and persistent efforts, that gave the people of the North great concern, were made to establish such a confederacy, with a view of cutting loose from New England and making an alliance with the Confederate government. This, as stated in a letter of Governor Oliver P. Morton to Lincoln on October $27,1862,{ }^{x}$ " is the program and has been for the last twelve months. During the recent campaign it was the staple of every Democratic speech-that we had no interests or sympathies in common with the people of the Northern and Eastern States; that New England is fattening at our expense; that the people of New England are cold, selfish, money-making, and through the medium of tariffs and railroads are pressing us to the dust; that geographically these States are a part of the Mississippi Valley, and, in their political associations and destiny cannot be separated from the other States of that valley; that socially and commercially their sympathies and interests are with the people of the Southern States rather than with the people of the North and East; that the Mississippi River is the great artery and outlet of all Western commerce; that the people of the Northwest can never consent to be separated politically from the people who control the mouth of that river; that this war has been forced upon the South for the purpose of abolishing slavery, and that the South has offered reasonable and proper compromises which, if they had been accepted, would have avoided the war." In the Democratic State Convention in Indiana on January 8, I862, Thomas A. Hendricks, who presided, said: "We are now being so crushed that if we and our children are not to become the hewers of wood and drawers of water for the capitalists of New England and

× Quoted in Foulke's Life of Morton, vol. i., p. 208. 
Pennsylvania, we must look to the interests of our section, and for the first time in my life, I intend to speak as a sectional man.... To encourage and stimulate the people of the South in the production of their peculiar commodities, that they may be large buyers from us, has been, and so long as 'grass grows and water runs' will be, the true interest of the Northwest; and the political party that would destroy that market is our greatest foe. . . . If the failure and folly and wickedness of the party in power render a Union impossible, then the mighty Northwest must take care of herself and her own interests. She must not allow the arts and finesse of New England to despoil her of her richest commerce and trade by a sectional and selfish policy-Eastern lust of power, commerce, and gain." $x$

Again in the event of the establishment of a permanent foreign and hostile government that would hold control of the mouth of the Mississippi, what would be the effect on the commerce of the nation and especially the territory bordering on that river and its tributaries? What, for example, would become of Ohio, Illinois, and Indiana? Morton answered this question in one of his speeches: "We should be shut up in the interior of a continent, surrounded by independent, hostile nations, through whose territories we could obtain egress to the seaboard only upon such terms as might be agreed to by treaty. Immigrants from foreign lands could only come to us by permission of our neighbors and we could not reach any Atlantic port except by passports duly viséd."2

Moreover what assurance could be given that peaceful secession would be followed by a lasting peace between the old and the new government? So long as slavery continued to exist in the South there would be the same disputes between the nations over fugitive slaves and every other question connected with slavery that now existed between the free and the slave States. These disputes would continue to engender the same bitterness of feeling and the

× Quoted in Foulke's Life of Morton, vol. i., p. 175-76.

IId., vol. i., p. 90. 
same angry disputes that existed before. There would also be disputes as to boundaries, as to the rights of navigation, disputes innumerable, certain ultimately to lead to war between nations already inflamed by the recollections of past grievances, real or fancied, and which would be naturally antagonistic so long as slavery existed in one of them.

Again, if it should be determined that civil war was inevitable, it still remained an important question whether the general government should take the initiative, or whether it should let the Confederate government begin it, and thus conclusively demonstrate to the world that it was the aggressor, and that the national government was fighting in defense of the Union and not waging war of its own volition against the South and its institutions.

To frame a policy or policies taking into consideration all these problems was not the work of a day. Such policies must be adapted to rapidly shifting conditions and they were to be dictated by the inexorable logic of events rather than by any one man or set of men.

In the perilous situation in which he was placed a great responsibility was thrown upon Lincoln in the choice of policies. There is no doubt that he fully realized the extent of that responsibility. Neither he nor any living man could then foresee the consequences of a mistake. Virginia, North Carolina, Tennessee, and other slave States were still in the Union and there was in these States, and even in portions of the seceded States, a strong Union sentiment. It was doubtful whether these States would not ally themselves with the seceded States in case of civil war, no matter how initiated. It was certain, however, that they would instantly do so if the general government should institute any movement that could, by any possibility, be construed as an unwarranted armed invasion of the South.

Important as was the consideration of public sentiment in the slave States which had not already seceded, the consideration of the public sentiment in the North was far more important. Lincoln had not received a majority, 
but only a plurality, of the votes cast at the presidential election. Had the Democrats who voted for Breckinridge and Douglas been united on either, Lincoln would not have carried all the Northern States. In the North alone over a million votes had been cast for Douglas. It would have been hopeless to expect that the Republican party of the North alone could wage successful war with the South. It would, therefore, have been suicidal to adopt any war policy that would alienate from the support of the Union the followers of Douglas. Moreover the Republicans were still divided. As already shown, many still preferred letting the seceded States go in peace to coercing them back into the Union at the expense of civil war.

Lincoln saw all these difficulties more clearly than most of his critics. He was not, as some of them charged, irresolute or vacillating or cowardly, but he thought and moved carefully, and sometimes, it was thought, too slowly.

Who can now say that any other man in his situation, with his knowledge and opportunities, would have done better? Would Seward have done better? Would any other Republican have done better? A man like Andrew Jackson, in the situation and with the opportunities of James Buchanan, would undoubtedly have done better than Buchanan did; but wotild even a man like Andrew Jackson, in Lincoln's situation and with his opportunities, have done better than Lincoln?

The war policy that Lincoln ultimately adopted was not of his own voluntary choosing. The first gun fired upon Fort Sumter was notice to the North from the Confederate government of its ultimatum. There was now no choice of policies except to meet war with war, or to surrender upon such terms as the enemies of the old Union might dictate. Lincoln's call to arms was his first announcement of a war policy. It was then clear to all, or all unless it were Seward and the few who still pinned their faith to his dreams of compromise, that the Union, if saved at all, must be "saved by the sword." 
Mention has been made of the composition of the new Cabinet. During the first few weeks Lincoln appeared to be intently studying the men as well as the events about him. He never attempted to compel any of the members of his Cabinet to acquiesce in his views. At a later period he said in a jocose way that "he did not have much influence with this Administration." While deferring respectfully, however, to the opinions of his advisers, he was doing a good deal of independent thinking for himself.

Next to Lincoln the chief figure in the Cabinet meetings was William H. Seward, the Secretary of State. He had been a Whig and was now regarded as a conservative. During the first month it is clear that he exercised a great influence over Lincoln. Seward not only felt but magnified the importance of his office. Welles charges that he was continually interfering with other departments and meddling in affairs that belonged to them. This was offensive to the other members of the Cabinet and excited the ire of Welles in particular, whose hostility to Seward is manifest throughout the former's Diary.

For a time there were no regular Cabinet meetings and during this time the President consulted chiefly with Seward. The other members protested and after that there were regular Cabinet meetings on Tuesdays and Fridays of each week. The climax of Seward's assumption of authority was reached when on April I he submitted to Lincoln the extraordinary "suggestions" mentioned in the following pages.

Seward's peace views were well known. He had been in frequent confidential consultations with leading Southern members of Congress during the closing months of Buchanan's Administration, endeavoring to devise some compromise that would avert civil war, or at least postpone hostilities until after Lincoln's inauguration, when he expected, so it was said, to be chief adviser in the new Cabinet, and be enabled thereby to exercise a controlling influence in the incoming Administration that would enable him to carry 


\section{Political History of Secession}

out his peace schemes, whatever they were. Now that he had succeeded in reaching the place which he had only anticipated when he made his I2th of January speech, it is interesting to note the further developments of the policy so vaguely outlined before.

In the Cabinet meetings Seward from the beginning was strenuously opposed to the reinforcement of Fort Sumter, but was in favor of abandoning it, and also Fort Pickens, if by so doing civil war could be avoided or postponed. To this policy Chase, the Secretary of the Treasury, a former Democrat, now classed as a radical, was opposed. So was Montgomery Blair, the Postmaster-General. The other members sided in opinion with Seward and for a time Lincoln seemed to acquiesce in the opinion of the majority.

The part played by the Confederate Commissioners sent to Washington by the Confederate government was a very important feature in the history of the first month of the new Administration. The Commissioners were Martin J. Crawford, John Forsyth, and A. B. Roman. Although officially unknown in Washington they were extremely active. They worked largely through others, and chiefly by playing upon the hopes and fears of Seward, and perhaps upon his ambition and vanity, for he had no small share of both. From the beginning the Commissioners were guided by the counsels of Jefferson Davis himself, certainly the peer of Seward in all matters of diplomacy and politics.

The Commissioners did not come to treat on terms and conditions preliminary to a return to the Union of the seceded States. There was then no thought in the seceded States of their returning to the Union upon any terms. What they expected was to get all the concessions possible to be gained for the Southern Confederacy. In view of the utterances of some of the leading Republican papers in the North there was some hope that the North might be willing to let the seceded States go in peace, thus avoiding civil war. There was also hope, not entirely groundless, since it came near being realized, that the Federal government 
might be induced to surrender or abandon Fort Sumter and Fort Pickens, at least the former.

Two things were of the highest importance to the Confederate government to be accomplished by sending the Commissioners to Washington. 'One was to stay hostile interference by the gencral government until the Southern Confederacy could be placed on a war footing and be prepared either to defend itself or to initiate aggressive movements against the Federal government. Another object was, in case the Federal authorities should refuse to surrender Fort Sumter and Fort Pickens, at least to prevent the reinforcement of them until the Confederates should be ready to bombard them.

The Commissioners arrived in Washington shortly before Lincoln's inauguration and as soon as practicable they endeavored to get into official communication with the new Administration. They were doubtless apprised before they came of Seward's peace proclivities. It was also surmised by them that Seward would exercise a controlling influence over the President.

Seward, however, was too wary to consent to have any official interview or communication with the Commissioners themselves, as that might be construed into a recognition of the Confederate government; but this obstacle to negotiations was speedily obviated by the intercession of a gobetween, Judge Campbell, of Alabama, who had long been and was still, one of the judges of the Supreme Court of the United States. Seward had often argued cases before that high tribunal while Campbell was on the bench and it was natural to conclude that this fact would give great weight to any suggestions that he might make to Seward. Campbell represented himself as a peacemaker, desirous only of avoiding bloodshed. In fact, he was also at this time acting as an emissary of the Confederate government. He had before told Jefferson Davis that he would remain in Washington "some ten or fifteen days," assuring him that "at present I have access to the Administration that I could not have 
except under my present relations to the government, and I do not know who could have the same freedom"; for all of which Davis assured him that "in any event I will gratefully remember your zealous services in a sacred cause, and hope your fellow-citizens may sometime give you acceptable recognition of your services and appreciate the heroism with which you have encountered a hazard from which most men would have shrunk."

Campbell had several interviews with Seward, the substance of which he promptly reported to the Confederate Commissioners. He as promptly reported to Seward the views of the Commissioners. Campbell soon discovered the pacific views of Seward and was informed, or at least inferred, that he was in favor of the evacuation of Fort Sumter, and probably of Fort Pickens also, as a means of averting civil war. Campbell also got the impression that the majority of the Cabinet agreed with Seward upon this policy. So confident was Campbell that in his report to the Commissioners he expressed "perfect confidence" that Fort Sumter would be evacuated "in the next five days," and for a time the Commissioners were in high feather.

That Campbell and the Commissioners were deceiving Seward, or at least encouraging Seward to deceive himself, by humoring his peace projects, is established by ample documentary evidence. Campbell wrote to Toombs, the Confederate Secretary of State, on March 6: "I have felt it my duty under instructions from your department, as well as from my best judgment, to adopt and support Mr. Seward's policy, upon condition, however, that the present status is to be rigidly maintained. His reasons and my own, it is proper to say, are as wide apart as the poles; he is fully persuaded that peace will bring about a reconstruction of the Union, whilst I feel confident that it will build up and cement our confederacy and put us beyond the reach either of his arms or of his diplomacy."

On March 14, Forsyth wrote to Walker, the Confederate Secretary of War, that "we are feeling our way here 
cautiously. We are playing a game in which time is our best advocate, and if our government could afford the time, I feel confident of winning. There is a terrific fight on in the Cabinet. Our policy is to encourage the peace element in the fight or at least blow up the Cabinet on the question."

Toombs, speaking for Jefferson Davis, wrote to the Commissioners that so long as the United States did not declare war it enabled the Confederate States "to make all necessary arrangements for a public defense and the solidifying of their government more cheaply and expeditiously than they could with the attitude of the United States more definite and decided."

General Crawford," states that he had a conversation after the close of the war with Colonel John Forsyth, one of the Commissioners, in which he told Crawford that "the secret instructions from Montgomery were to 'play with Seward; to delay and gain time until the South was ready." " Other correspondence indicates clearly that, whatever Seward thought of the Commissioners, the Commissioners themselves, under instructions from the Confederate government, were using Seward merely as a cat's-paw.

Meantime, there was a growing feeling in the North that some more energetic policy should be adopted by the new Administration than that which had been shown by the Administration of Buchanan, and especially that something should be done for the relief of Major Anderson; and this was one of the first things to engage the earnest attention of the President and his Cabinet. Military men argued the hopelessness at that late day of endeavoring to reinforce Fort Sumter with either men or munitions of war. It was true that when General Beauregard was first sent to Charleston he had pronounced the fort a Gibraltar. It was also true that Gencral Scott had said that it might easily have been reinforced if the attempt had been made earlier, but in the last months of Buchanan's Administration the entrance to the harbor had been obstructed and batteries

s Hist. of Fort Sumter, p. 333, note. 
commanding the fort had been planted on every foot of ground available for that purpose. Floating batteries had been constructed. By reason of the location of the Confederate batteries, a large number of the guns of the fort were rendered useless. The garrison had been reduced to a mere handful. Small as it was, there were not provisions enough to have lasted a week after its final surrender. On the second day of the bombardment the garrison had nothing to eat but a little pork. Had the bombardment been delayed a week longer the garrison would have been compelled, without firing a gun, either to surrender or to starve. On March I5, I86I, the President addressed a communication to the Secretary of War, asking if it would be wise to attempt to provision Fort Sumter. In his answer, the Secretary quoted the opinions of various army officers. Major Anderson and other officers of the fort were of the opinion that before the fort could be relieved the garrison "would be starved out." 1 In his opinion (March 12) General Scott said: "As a practical military question the time for succoring Fort Sumter with any means at hand had passed away nearly a month ago. Since then a surrender under assault or from starvation has been merely a question of time." 2 Cameron, Secretary of War, said that it might have been done a month before but that "a different state of things now, however, exists. Fort Moultrie is now re-armed and strengthened in every way; many new land batteries have been constructed; the principal channel has been obstructed; in short, the difficulty of reinforcing the fort has been increased ten, if not twenty, fold." 3 The Cabinet was divided in opinion upon the question of ordering Anderson to evacuate the fort. When the question was submitted by the President on March 15, five of the members, Seward, Cameron, Welles, Smith, and Bates, advised against making an attempt to provision the fort, believing that such an attempt could not be successfully made. Chase and Blair

× War Rec., vol. i., p. 197 .
s Id., p. r 98.

'Id., p. I97. 


\section{Administration Policies}

were for making the attempt. Still Lincoln hesitated to sanction the surrender of the fort without making an effort to relieve either it or Fort Pickens. To have done so would have discouraged the loyal people of the North as much as it would have encouraged the secessionists of the South. He was, so Welles tells us," "much distressed with the conclusions of the military officers and the decisive concurrence of the Secretary of State in their conclusions." A few days after this Cabinet meeting Lincoln prevailed upon two of his personal friends, Stephen A. Hurlbut and Ward H. Lamon, to go to Charleston and endeavor to ascertain the situation there. Hurlbut went ostensibly to visit a sister living there, but more especially to get an interview with Judge James L. Petigru, a leading lawyer in Charleston, who had been Hurlbut's legal preceptor, and to ascertain from him whether there was, as Seward insisted there was, a considerable Union sentiment in Charleston. Lamon, formerly Lincoln's law partner, went as a direct representative of the President to see what, if anything, could be done to avert civil war and also to confer with Major Anderson.

Hurlbut reported to the President that he found "no attachment to the Union" and "positively nothing to appeal to" and that "the sentiment of national patriotism, always feeble in Carolina, had been extinguished."

Lamon had a personal interview with Governor Pickens, who received him with characteristic Southern courtesy. Lamon relates: "After saying to him what President Lincoln had directed me to say, a general discussion took place touching the critical state of public affairs. With a most engaging courtesy, and an open frankness for which that brave man was justly celebrated, he told me plainly that he was compelled to be both radical and violent; that he regretted the necessity of violent measures, but that he could see no way out of existing difficulties but to fight out.

Diary, vol. i., p. 9.

2 Nicolay and Hay, Lincoln, vol. iii., p. 91. 
'Nothing,' said he, 'can prevent war except the acquiescence of the President of the United States in secession, and his unalterable resolve not to attempt any reinforcement of the Southern forts. To think of longer remaining in the Union is simply preposterous. We have five thousand well-armed soldiers around this city; all the States are arming with great rapidity; and this means war with all its consequences. Let your President attempt to reinforce Sumter and the tocsin of war will be sounded from every hilltop and valley in the South."'1 The Governor, however, gave Lamon written authority to visit Major Anderson, sending an aide along, "to see that every propriety is observed toward $\mathrm{Mr}$. Lamon." Lamon "found Anderson in a quandary and deeply despondent." Nothing encouraging could be gained from Major Anderson or the men with him and Lamon adds that "war seemed as inevitable to them as to Governor Pickens." When Lamon reported the result of his mission the President "listened with profound and saddened attention to his account of the condition of things in the fort on the one hand and in the State and city on the other." 2

But Lincoln continued his search for further information and succeeded in getting some that he thought justified making an attempt to relieve both Fort Sumter and Fort Pickens, and on March 29 he again submitted the question to the members of his Cabinet. Seward was still of the opinion that Major Anderson should be instructed "to retire from Sumter forthwith," but the majority of the Cabinet, reversing their former decision, agreed with Lincoln that an attempt should be made to relieve both Fort Sumter and Fort Pickens.

On the same day Lincoln addressed a communication to the Secretary of War, stating that he desired "that an expedition, to move by sea, be got ready to sail as early as the 6th of April next, the whole according to memorandum attached, and that you coöperate with the Secretary of the

× Lamon, Recollections of Abraham Lincoln, $2 \mathrm{~d}$ ed., p. 74.

$2 I d$., p. 79. 
Navy for that object." $₹$ Preparations were at once begun for sending two expeditions, one for the relief of Fort Sumter, the other for the relief of Fort Pickens. Two days later (April I) Seward sent to Lincoln a communication which has been characterized" as "unlike anything to be found in the political history of the United States." It was entitled "Some thoughts for the President's consideration." In the first sentence Seward reminded Lincoln that "we are at the 'end of a month's administration and yet without a policy, either domestic or foreign." Seward then outlined a domestic policy for the Administration, his "ruling idea," as he expressed it, being that "we must change the question before the public from one upon slavery, or about slavery, for a question upon union or disunion.

"In other words, from what would be regarded as a party question, to one of Patriotism or Union."

Then followed these extraordinary "suggestions":

"I would demand explanations from Spain and France categorically, at once.

"I would seek explanations from Great Britain and Russia, and send agents into Canada, Mexico, and Central America, to rouse a vigorous continental spirit of independence on this continent against European intervention.

"And, if satisfactory explanations are not received from Spain and France-

"Would convene Congress and declare war against them.

"But whatever policy we adopt, there must be an energetic prosecution of it.

"For this purpose it must be somebody's business to pursue and direct it incessantly.

"Either the President must do it himself, and be all the while active in it, or

"Devolve it on some member of his Cabinet. Once adopted, debates on it must end, and all agree and abide.

"It is not in my special province.

- War Rec., vol. i., p. 226.

- Nicolay and Hay, Lincoln, vol. iii., p. 445. 
"But I neither seek to evade nor assume responsibility." It will be noted that this letter was not written until after it had become apparent to Seward that his advice that Fort Sumter be evacuated would not be followed and that his influence over the President was on the wane.

We may be able to surmise the reasons upon which Seward based some of his suggestions. In his scheme for a domestic and foreign policy he was probably still infatuated by the optimism which made him insensible to the plans, evident to nearly all others, of the secession leaders. There was need of a change of policy but not such a change as Seward suggested. The change from the slavery to the secession question had already come and the change had been brought about, not by the Administration, but by the secession leaders themselves. Appeals to their patriotism and love of the Union had already been made and it was now evident to nearly all but Seward that future appeals of the same kind would probably be as futile as those of the past.

Seward's proposed foreign policy was even more visionary and dangerous than his domestic policy. Evidently he thought that if war could be stirred up with some foreign nation, the secessionists would at once abandon their project of secession and unite with the North in defending the country against a common enemy. In this he entirely misjudged the warlike determination of the secession leaders. Indeed, even after the Civil War had begun, Seward's continued incredulity of the warlike preparations of the South, together with his optimistic temperament, made him believe that the war "would blow over in sixty days." Had Seward's foreign policy been adopted, it would at once have precipitated this country into war with powerful foreign nations, making them formidable enemies of the North and as formidable allies of the South.

But we are left entirely to conjecture when we try to discover what Seward's motives were in writing that part of his communication which virtually advised Lincoln to abdicate, coupled with the maidenlike coyness in suggesting 


\section{Administration Policies}

that, in the event that the duties of the presidential office should devolve upon a regent, Seward, while not seeking to assume, would not decline, the responsibilities of the regency.

Lincoln was master of the art of reading human nature. He understood Seward far better than Seward understood him. Lincoln did not abdicate; he did not adopt the foreign policy recommended by Seward, nor did he dismiss Seward from the Cabinet. Instead he wrote him a letter kind in its tone but of such a character as to leave no doubt that Lincoln intended to remain President himself. "I remark," said Lincoln in his reply to Seward's suggestion about devolving upon some member of the Cabinet a more energetic policy, "that if this must be done, I must do it myself."

Seward now found himself in a very embarrassing position. His policy of abandoning Fort Sumter had been rejected by the President and his Cabinet, and it was now plain that the assurance he had given Campbell that Fort Sumter would be surrendered within five days could not be fulfilled. The five days passed and still there had been no sign of such surrender. The Commissioners had become suspicious of Seward and it is probable that they had got an inkling of some kind indicating that, if the Administration had ever favored Seward's policy, that policy had now been abandoned. Nevertheless Campbell succeeded in getting from Seward, after the latter had consulted the President, authority to write to the Commissioners saying: "I am satisfied the government will not undertake to supply Fort Sumter without giving notice to Governor Pickens." What arguments Campbell used with Seward, and what arguments Seward presented to the President by which authority was obtained for such an answer we do not know. Campbell also inferred that the evacuation of Fort Sumter had been merely delayed and would shortly be ordered.

Crawford also advised Beauregard that he was "authorized to say that this government will not undertake to 


\section{Political History of Secession}

supply Fort Sumter without notice to you," adding: "My opinion is that the President has not the courage to execute the order agreed upon in the Cabinet for the evacuation of the fort, but that he intends to shift the responsibility upon Major Anderson, by suffering him to be starved out," and suggesting that it might be well "to aid in this by cutting off all supplies." I On April 8, Crawford again wrote to Beauregard saying: "We were reassured yesterday that the status of Sumter would not be changed without previous notice to Governor Pickens, but we have no faith in them. The war policy prevails in the Cabinet at this hour." The Commissioners, having gained all the time possible by negotiation, in fact all the time needed to complete the preparations for bombarding Fort Sumter, left Washington on April II, two days before the bombardment began.

Afterwards the Confederates claimed that Seward had deceived the Commissioners and they denounced him and the Administration for duplicity. Judge Campkell said that the Commissioners had been "overreached." Jefferson Davis claimed that "the crooked path of diplomacy can scarcely furnish an example so wanting in courtesy, in candor, and directness, as was the course of the United States Government toward our Commissioners in Washington"; and Alexander H. Stephens asserted that the Commissioners "were met with an equivocation, a duplicity, a craft and deceit, which, taken altogether, is without a parallel in modern times." 2 The fact seems to be that in the game which was being played between Seward and the Commissioners, Seward overestimated his own skill and underestimated that of his opponents. Moreover they had the advantage of knowing his cards, while he was ignorant of theirs. In such a game the boundary line between diplomacy and deception is shadowy, and the question as to which of the players outwitted the other is not one that

× War Rec., vol. i., p. 283.

2 Bancroft, Seward, vol. ii., p. 147 , note. 


\section{Administration Policies}

appeals strongly either to our sense of justice or to our sympathy. Bancroft offers this explanation: "Each side endeavored to overreach and outwit the other. From the previous midwinter until the second week in April, Seward was determined to prevent the outbreak of the Civil War. So, in secret intervicws, anonymous notes, and indirect intercourse, he gave assurances that could surely be fulfilled only in case he, instead of Lincoln, should control affairs. This, he was confident, would be the case. He probably thought, too, that there was no need of great scrupulousness in dealing with those who were trying to destroy the Union." If Seward's rule in diplomacy was that indicated by Bancroft, it was not the rule of Lincoln's Administration; certainly it was not the rule by which Lincoln himself was guided.

Again we see Senator Douglas. Two days before the bombardment of Fort Sumter he sought an interview with Secretary Welles and informed him that he had received information from reliable sources that the Confederates were about to begin their attack, and that immediate and decisive measures should be taken by the government. At Welles's suggestion they called on Seward to whom' Douglas repeated the information he had given to Welles. Seward received him cordially, "took a pinch of snuff; said he would see the President on the subject. He knew there were w ld and reckless men at Charleston, and we should have difficulty with them, but he knew of no way to prevent an assault if they were resolved to make one." $x$ Afterwards Douglas told Welles that he was not disappointed at the interview, giving as a reason that "Seward was not earnest, had no heart in this matter, could not believe the storm was beyond his ability and power to control, but he would soon enough learn that no mere party management or cunning would answer in such an emergency as this. Alluding to his hesitancy in going to Seward, he said he knew it was useless to make any appeal to him. Seward had no idea of

× Bancroft, Seward, vol, ii., p. 148.

- Diary, vol. i., pp. 32-35. 


\section{Political History of Secession}

the necessities of the case and was at that moment, as he, Douglas, knew, carrying on an intrigue with the Rebel leaders, who were deceiving him, whilst he flattered himself that he was using and could control them." Douglas also said that the great point with Buchanan and his Cabinet had been to drift over the fourth of March, and that "Seward had thought that he could then take the reins and manage things as he pleased; had all along treated this mighty gathering tempest as a mere party contest which he and Thurlow Weed could dispose of as easily as some of their political strife in New York." 


\section{CHAPTER XXIX}

\section{THE EFFORTS TO SUCCOR MAJOR ANDERSON}

MAJOR ANDERSON'S position was daily growing I more critical. On April 5 he addressed to the Adjutant-General of the United States Army a letter, almost pathetic in its tone, in which he said: "I am sure that I shall not be left without instructions, even though they may be confidential. After thirty-odd years of service I do not wish it to be said that I have treasonably abandoned a post and turned over to unauthorized persons public property intrusted to my charge. I am entitled to this act of justice at the hands of my government, and I feel confident that I shall not be disappointed. What to do with the public property and where to take my command are questions to which answers will, I hope, be at once returned. Unless we receive supplies, I shall be compelled to stay here without food or to abandon this post very early next week." $\mathrm{r}$ The little garrison had before been getting small daily supplies of provisions from the Charleston markets, but this was stopped on April 7 by orders of General Beauregard, and on April 8 he forbade any mails to or from the fort.

Some of the Civil War historians have done scant justice to Major Anderson. ${ }^{2}$ Born and reared in the South, he had taken his wife from Georgia and he was bound to the

War Rec., vol. i., p. 24 I.

2 A fair statement of his position at Fort Sumter is given in a paper by General George H. Gordon on "Major Anderson at Fort Sumter" in Papers of the Massachusetts Military Historical Society, vol. ix., p. I. 
Southern people by the strongest ties of blood and friendship. Upon the questions growing out of slavery, his sympathies, like those of many other army officers who remained true to the Union cause, were with the Southern people, but not with the cause of secession. He had been a classmate and a lifelong and intimate friend of Jefferson Davis. ${ }^{x}$ For some weeks after he took command of the forts in Charleston harbor he and his brother officers and their families were fêted and toasted in Charleston social circles. It was doubtless hoped, if not expected, by the secession leaders that he would follow the example of General Twiggs and of almost all the officers who had surrendered Southern forts and arsenals in the seceding territory. Floyd had all but commanded him to surrender and had pointed out the way in which he could do so and still make a showing of loyalty to his government. General Beauregard's early correspondence with him usually began with "My dear Major" and was couched in the most chivalrous language. On March 26 General Beauregard assured him that if he would evacuate Fort Sumter no "formal surrender or capitulation" would be demanded, but that Governor Pickens and Beauregard "would be happy to see that he was provided with proper means of transportation" and that all that would be required of him would be his "word of honor as an officer and a gentleman that the fort, all public property therein, its armament, etc., shall. remain in their present condition without any arrangements or preparation for their destruction or injury after you shall have left the fort."

To this Anderson replied on March 26: "I feel deeply hurt at the intimation in your letter about the conditions which will be exacted of me and I must state most distinctly that if I can only be permitted to leave on the pledge you mention I shall never, so help me God, leave this fort alive."3 $\mathrm{He}$ wrote again on the next day regretting that Beauregard

× Davis, Rise and Fall, vol. i., p. 216.

'War Rec., vol. i., p. 223. ${ }^{3} I d .$, p. 222. 
could "for one moment" have the slightest doubt as to the "straight path of honor and duty in which I must, by the mercy of God, ever be found." " In Major Anderson's last letter of April 8 to the War Department he said: "It is, of course, now too late for me to give any advice in reference to the proposed scheme of Captain Fox. I fear that its result cannot fail to be disastrous to all concerned. Even with his boat at our walls the loss of life (as I think I mentioned to Mr. Fox) in unloading her will more than pay for the good to be accomplished by the expedition, which keeps us, if I can maintain possession of this fort, out of position, surrounded by strong works, which must be carried to make this fort of the least value to the United States Government. We have not oil enough to keep a light in the lantern for one night. The boats will have, therefore, to rely at night entirely upon other marks. I ought to have been informed that this expedition was to come. Colonel Lamon's remark convinced me that the idea, merely hinted at to me by Captain Fox, would not be carried out. We shall strive to do our duty though I frankly say that my heart is not in the war which I see is to be thus commenced. That God will still avert it, and cause us to resort to pacific measures to maintain our rights is my ardent prayer." 1

In this letter we catch a glimpse of the inner struggle going on in the mind of Major Anderson. He knew the impossibility of reinforcing or provisioning the fort; he knew from the preparations being made, for they were in full view, that the threatened bombardment was liable to begin at any moment, and he knew, as well as Beauregard, the impossibility of making a successful defense. Under Buchanan's Administration he had been not only neglected, but indignity after indignity had been heaped on him by Floyd. He had a right to expect more favorable consideration from the new Administration and he could not understand why, if it did not succor him in his distress, it should

I War Rec., vol. i., p. 223.

Id., p. 294 
not at least relieve him from the necessity of choosing between the stigma of dishonorable surrender or starvation. He did not know the efforts that Lincoln had been making in his behalf. He did not know, what was the fact, that Lincoln supposed that he had provisions sufficient to last the garrison until a further supply could reach it. Notwithstanding all this, casting behind him all his former friendships and sympathies, the blandishments of Beauregard, the shameful treatment of Floyd, the seeming neglect of the new Administration, he does not for one moment falter in his allegiance to his country. His letter is the despairing cry of a hero determined still to stand by his government even unto death, although it had, as he then saw it, abandoned him to his fate, leaving him no choice except that between destruction and dishonor.

The expedition for the relief of Fort Pickens sailed from New York on April 6 and that for the relief of Fort Sumter on April 9. Here again Seward appears upon the scene under circumstances calculated sorely to try the patience of his friends, of even so patient and steadfast a friend as Lincoln, and again we are called upon, in balancing Seward's account with the nation, to make large allowances for his virtues and liberal deductions from his faults. By his bungling of orders the Powhatan, originally intended to go as the flagship with the expedition for the relief of Fort Sumter, was switched off to the expedition for the relief of Fort Pickens. No great harm resulted from this, however, because Fort Pickens was saved, while Fort Sumter would probably have been lost even if the Powhatan had arrived before the bombardment began. But it turned out that the orders given by Seward were concerning matters not properly belonging to his department, but to the Departments of War and of the Navy, and that they had been given without consultation with either the Secretary of War or the Secretary of the Navy, and without any notice to either of them, or to the President. Moreover, it came 


\section{Efforts to Succor Major Anderson 6or}

out that on April 6 the following dispatch had been sent to Charleston: "Positively determined not to withdraw Anderson. Supplies go immediately supported by a naval escort under Stringham if their landing be resisted.-A Friend." It turned out that the "Friend" was James E. Harvey, a newspaper correspondent, born in South Carolina, and that Seward not only gave him the information but knew of his sending the dispatch. Not only that, but Harvey shortly afterwards was appointed United States Minister to Portugal and when an attempt was made to have him removed because of his dispatch, which it was claimed bordered closely upon treason, Seward objected and allowed him to retain his position.

It is impossible for the most ardent admirer of Seward to read the story of his conduct as Secretary of State up to the firing on Fort Sumter without painful misgivings. The chapter in which Nicolay and Hay describe Seward's course during this period is entitled "Premier or President"; the chapter in Bancroft, covering the same period, is entitled "Seward's Struggle for Supremacy." If the pith of these chapters is fairly expressed in the titles, the titles themselves are significant as indicating what the authors understood to be the leading characteristics of Seward's motives and policies. Bancroft's explanation of Seward's course-it can scarcely be called an apology-is: "The numerous complications in which he so strangely involved himself were the outgrowth of two supreme illusions. The first was that the Southerners had stronger ties to the Federal government than to slavery, and that, if given time to reflect, they would not go to war in the interest of that institution. The second was that he alone could furnish and direct the policy-whether of peace, procrastination and compromise, or of war, civil or inter-continental, or both-by which the country was to be saved. His ambition was for the Union vastly more than for himself. $\mathrm{He}$ sought power and mastery of the Administration and of all difficulties, not because he wanted the glory of a semi- 
dictatorship, but because he honestly believed that that was the way for him to serve and to save the Nation."x

Horace White's conclusion is that "Seward's aims were patriotic but futile. He wished to save the Union without bloodshed but the steps which he took were almost suicidal. What the country then needed was a jettison of compromises and a resolution of doubts." 2

Welles is far less lenient than the writers above quoted. He says" : There is no doubt that Mr. Seward was in communication with the Rebel leaders, or some of them; not that he was implicated in, or a party to, their rebellious schemes, but he tampered with them, felt confident, as Douglas stated, that when he obtained power he could shape events and control them. He overrated his own powers always, and underestimated others. When he was sworn into the office of Secretary he expected and intended to occupy the place of premier, and undoubtedly supposed he could direct the Administration in every department. Mr. Lincoln had, he knew, little administrative experience. Mr. Seward, therefore, kindly and as a matter of course, assumed that he was to be the master-mind of the government. But whilst he always had the regard and friendly wishes of Mr. Lincoln, to whom he made himself useful, and who was impressed with the belief that his Secretary of State had shrewdness, knowledge, political experience, and capability far greater than he actually possessed, the President in a gentle manner gradually let it be understood that Abraham Lincoln was chief. . . . There is no doubt that the President was induced to take whatever steps he did, knowingly, in the matters referred to, through the instrumentality and by the advice of Mr. Seward; but he was not knowing to some of the important matters herein stated, and as soon as he was made acquainted with them he at once disavowed and annulled them. It was a misfortune of Mr. Seward, and one of his characteristics, that he de-

Life of Seward, vol. ii., p. 149.

3 Diary, vol. i., pp. 37-39.

Life of Trumbull, p. 164. 


\section{Efforts to Succor Major Anderson 603}

lighted in oblique and indirect movements; he also prided himself in his skill and management, had a craving desire that the world should consider him the great and controlling mind of his party, of the Administration, and of the country."

Where all is conjecture almost any supposition is within the range of speculation, but it is scarcely credible, as hinted by Welles, that there were then floating through Seward's brain visions conjured by his excessive optimism, mingled with more or less ambition and vanity, visions of a recon-

- Considerable allowance must be made, however, for Welles's strong dislikes. He is sparing in his praises. He disliked Chase; he disliked Seward more; Stanton comes in for unstinted censure; Cameron "is not great but adroit" (Id., vol. iii., p. 16). He had a better opinion of Montgomery Blair than he had of any of the other Cabinet members, notwithstanding Blair's "egotism" (Id., vol. i., p. 205). Indeed, if his associates in the Cabinet had known that Welles would live to write his Diary they would probably have felt as did Lord Brougham when he said that contemplation of the possibility that Lord Campbell might live to write his biography "added a pang to the thought of death." Few of the public men with whom Welles came in contact have received his unstinted praise, but many his censure. Welles detested Senator Hale, Chairman of the Senate Committee on Naval Affairs. Senator Harris of New York was "sly and maneuvering " (Id., vol. iii., p. 16). Senator Chandler's "instincts were low and debasing" (Id., p. 53). Sumner was "domineering, arrogant, insolent, and presuming" (Id., p. 53). Thaddeus Stevens was a "vicious old man" and almost everything he did was "dramatic and for effect" (Id., p. 130). Oliver P. Morton was "a hypocrite," whose "moral stamina was gone" (Id., pp. 345, 350). Senator Wade was "diseased with the Presidential fever" and had apparently "broken his knee joints or backbone" (Id., p. 135). He distrusted Grant. "I am," he says, "becoming impressed with the idea that Grant may prove a dangerous man. $\mathrm{He}$ is devoid of patriotism, is ignorant, but cunning, yet greedy for office and power" (Id., p. 245). To the foregoing might be added many other extracts in which Welles either condemns or damns with faint praise public men with whom he came in contact during his official life. After having completed his Diary it is possible that Welles felt something of the satisfaction of Byron, when, after having vented his gall on everybody and everything he could think of, he wound up by saying, "So now all things are damned, one feels at ease." 
structed Union, in which Lincoln was lost sight of, and Washington was in the background, but showing the figure of Seward standing colossal-sage, patriot, savior of his country!

It is difficult, if not impossible, even at this day, with all the additional light we have now, to fathom Seward's policy. He had said in his speech in the Senate on January I2, I86I, that "he did not see what the Union would be worth if saved by the sword." On March 24 the Russian minister reported to Roman, one of the Confederate Commissioners, that in a conversation he had had with Seward the day before Seward had said that no coercion or blockade would be attempted; that he hoped the seceding States would return to the Union, but if they did not they should be permitted to depart in peace. ${ }^{x}$

There is no doubt that Seward was in favor of surrendering Fort Sumter. He was at first probably in favor of surrendering Fort Pickens also, if such surrender would avert civil war. But it must have been evident to Seward before the end of March that no concessions which the North might be willing to make would stop the Confederates from completing the organization of the Southern Confederacy and putting it on a war footing; that they could not be induced to come back voluntarily by compromise or diplomacy of any kind; that they could be brought back only by arms and at the end of a civil war. Seward, however, had based all his calculations on the success of his peace policy and had no policy adapted to the contingency of war. He is not to be blamed merely because of the failure of his peace policy, for it was not in the wit of any man to have devised a policy that would have kept the seceding States from seceding or would have brought them back without war. If he is to be blamed it is for the stubborn pertinacity with which he continued to cling to the shattered fragments of his peace policy after its utter failure had been so plainly demonstrated that he ought to have realized it himself. Suspicious

× Bancroft, Life of Seward, vol. ii., p. 117 . 


\section{Efforts to Succor Major Anderson 605}

of Seward's sincerity, or doubts as to his suitability for the place of Secretary of State, or both, mingled doubtless with jealousies, for patriotism had not extinguished jealousy either in the Cabinet or out of it, found vent at a later period in a determined effort on the part of the Republican Senators for his removal, ${ }^{x}$ the chief cause of complaint

- A memorandum of the proceedings for Seward's removal was kept by William Pitt Fessenden, then Senator from Maine (Life and Public Services of William Pitt Fessenden, by his son Francis Fessenden, vol. i., pp. 229-53). The movement was started in December, 1862 . This was the darkest period of the Union cause during the Civil War. Disasters had everywhere befallen the Union armies; the removal of Fremont had offended many; there were reports of wasteful contracts in the War Department; the fall elections had gone against the Administration by large majorities. "There was," so Senator Fessenden asserts, "a feeling in the North that the Administration was not vigorous in maintaining and prosecuting the war. There was a desire for the removal of Mr. Seward and the substitution of a man who would be more vigorous than he in pushing the war." The demand for the removal of Seward grew out of a feeling that the President had ignored the other members of his Cabinet and relied too much on the advice of Seward and "that Seward influenced the President in favor of a compromise policy towards the Confederacy." The feeling grew so strong that on December 16, 1862, a secret caucus of the Republican Senators was held at which there was a very pronounced sentiment expressed that Seward should be removed. Senator Morton S. Wilkinson, of Minnesota, said "that in his opinion the country was ruined, and the cause was lost; that the Senate might save it but would not for the reason that Republican Senators would not adopt any united and vigorous course. ... In his judgment the source of all our difficulties and disasters was apparent. The Secretary of State, Mr. Seward, exercised a controlling influence upon the mind of the President. He, Mr. Seward, had never believed in the war-had been averse to it from the beginning-and so long as he remained in the Cabinet nothing but defeat and disasters could be expected." Senator Wade and others followed in the same strain. A second caucus was held on the next evening at which all the Republican Senators except two were present, including Chandler, Collamer, Fessenden, Hale, Lane of Indiana, Morrill, Sherman, Sumner, Trumbull, Wilmot, Wade, Wilkinson, and Wilson of Massachusetts. A set of resolutions was unanimously adopted expressing the sentiments of the caucus and a committee was appointed to present them to the President, the committee consisting of Senators Collamer, Wade, Grimes, 
being that it had seemed to be impossible to convince Seward that civil war, a war of great magnitude, was impending, even after it had begun; that he could not be brought to realize that the day of compromise had passed and that the North must now either fight or surrender; that

Fessenden, Trumbull, Sumner, Harris, Pomeroy, and Howard. A meeting with the President was had on the evening of December 18 at which there was a pretty full discussion of the situation. At the meeting Sumner addressed the President and commented freely upon Seward's official correspondence, averring "that he had subjected himself to ridicule in diplomatic circles at home and abroad; that he had uttered statements offensive to Congress and spoken of it repeatedly with disrespect in the presence of foreign ministers; that he had written offensive dispatches which the President could not have seen or assented to."

The conference with the President lasted several hours but no definite action was taken. Subsequently on December I9 another conference was had between the President and the committee at which all the members of the Cabinet were present except Seward and all the members of the committee except Wade, who was then absent from Washington, and a further discussion was had. At this interview Fessenden told the President that "Seward had lost his confidence before he became Secretary of State and that if he [Fessenden] had been consulted he would not have advised his appointment."

Seward heard of the movement and sent his resignation to the President. Chase also sent in his resignation. The reasons Chase gave to Fessenden were "that Seward and he came into the Cabinet as representing two wings of the Republican party, and if he remained he might be accused of maneuvering to get Mr. Seward out; and he thought he ought to relieve the President of any embarrassment if he desired to reconstruct his Cabinet. Mr. Chase further said that Seward's withdrawal would embarrass him so much that he could not get along with the treasury. He found that very difficult as it was, and if he had to contend with the disaffection of Seward's friends, the load would be more than he could carry." The President himself said that "he had reason to fear 'a general smash up' if Seward was removed and he did not see how he could get along without an entire change in his Cabinet." The upshot of the whole matter was that the President declined to accept the resignation of either Seward or Chase, and Fessenden on December 24 records, "The Cabinet is all back again."

Welles's account of the matter, so far as it goes, is in substantial accord with that of Fessenden.-Diary, vel. i., pp. I94-205. See also 


\section{Efforts to Succor Major Anderson 607}

it was no longer a question of letting the seceding States go in peace, but a question of preparing to repel the Confederate hosts that were threatening the capital of the nation and the invasion of the North; that Seward in hunting for olive branches was wasting precious time that should be employed in putting armies in the field and finding generals fit to command them.

Rhodes, History of United States, vol. iv., pp. 204-206; Nicolay and Hay, Lincoln, vol. vi., chap. xii.; Seward's Works, vol. iv., pp. 14, 15; Schuckers, Life of Chase, 473 et seg. 


\section{CHAPTER XXX}

\section{WAITING FOR THE SOUND OF THE CANNON}

TO the last moment, Lincoln seemed to hope that some1 where out of the gathering clouds of war the dove of peace might emerge; but in the nation at large there was now little thought of peace. If the war spirit had been slower to kindle in the North than in the South, there was now no doubt that it was at white heat in both sections, ready at any moment to burst forth in all-enveloping, all-devouring flames. All signs now pointed to war, though no one in the North or in the South then anticipated its extent, its desolation, its bloody character. All knew that it would begin with the bombardment of Fort Sumter and that the bombardment could not be much longer postponed.

In the South the tension had been so long near the breaking point that there was danger of reaction. Until a few days before the bombardment began the garrison at Fort Sumter had been allowed to get small daily supplies of provisions in the Charleston market, but this was forbidden on April 7 by order of General Beauregard, who had now ceased to address Major Anderson as "My dear Major." On the 8 th, as before stated, the mails were also cut off. But Major Anderson still persisted in his provoking loyalty and in his exasperating refusal to surrender. As the Mobile Mercury expressed it, "The country is sinking into a fatal apathy and the spirit and even the patriotism of the people is oozing out under this do-nothing policy." It was therefore necessary that something decisive should be done pretty soon "either evacuation or expulsion." There must be 


\section{Waiting for the Sound of the Cannon 609}

fresh fuel to keep the fires of secession burning even in the cotton States. There was danger also that the border States might become lukewarm. Moreover, North Carolina and Tennessee were still standing aloof. A prominent citizen of Alabama said that "unless you sprinkle blood in the faces of the people of Alabama they will be back in the old Union in less than ten days." "

Roger A. Pryor of Virginia, whose last speech in Congress has already been quoted, addressed a meeting in Charleston, South Carolina, on April Io, 186I, in which he said: "I thank you especially that you have at last annihilated this accursed Union, reeking with corruption and insolent with excess of tyranny. Not only is it gone, but gone forever. As sure as to-morrow's sun will rise upon us, just so sure will old Virginia be a member of the Southern Confederacy; and I will tell your Governor what will put her in the Southern Confederacy in less than an hour by a Shrewsbury clock. Strike a blow! [Tremendous applause.] The very moment that blood is shed, old Virginia will make common cause with her sisters of the South." 2

The whole country was now waiting for the sound of the cannon. As already stated the expedition for the relief of Fort Sumter started from New York on April 9. It carried no arms or munitions of war-only provisions for the starving garrison of Fort Sumter. The faith of the Administration had been pledged that not even this much should be done or attempted without notice to the Confederate authorities, and notice was given accordingly. If permission to do this much should be refused, if upon so slight a provocation war should be begun by the Confederates, it would at least demonstrate to the North, so

- McPherson, History of the Rebellion, p. I13.

- Crawford, History of Fort Sumter, p. 305. Some Northern historians, in denouncing the sanguinary utterances above quoted, omit to mention the letter of Senator Chandler, quoted in a previous chapter, in which he also recommended that it was necessary to have some "blood letting" in order to rouse the Northern heart up to the fighting point. 


\section{Political History of Secession}

Lincoln reasoned, that war could no longer be avoided by compromise, by anything, in fact, short of surrender to secession. On the other hand, the Confederates reasoned that if by any chance Fort Sumter could hold out until reinforced the effect would be most disastrous, not only to the cause of secession in the border States, but in the cotton States themselves. The preparations for bombarding Fort Sumter were so nearly completed that on April I General Beauregard had telegraphed to the Confederate authorities that he would be ready to open fire on the following Wednesday or Thursday. As soon as the Confederate authorities were apprised of the sailing of the expedition for the relief of Fort Sumter, General Beauregard was ordered to begin the bombardment without further delay.

On Friday, April 12, one more demand for surrender was made of Major Anderson, accompanied with notice that if he refused the bombardment would begin within one hour. Major Anderson refused to surrender and the bombardment began at 4.30 o'clock A.M.

It was a gala day for the people of Charleston. In expectation of the promised spectacle, great crowds had gathered along the shores of the harbor. Others of the South were there that they might be in at the death of the Union. Among them was Wigfall, eager to display not only his zeal but himself ${ }^{x}$ From the mast over Fort Sumter still floated the flag of the Union, the Union that Sumter and Marion and other patriots of the Revolution had so bravely fought to establish, but which their descendants were now bent on destroying. Under that flag South Carolina had marched to glorious victories in the War of 1812 and in the Mexican War. All these memories seemed to have been forgotten and the old flag was now looked upon as a hated emblem, and the expectant crowds were impatiently waiting to see it shot down and trailed in the dust. From every

I The bellicose Senator from Texas had now been transformed into "Colonel Wigfall, aide to General Beauregard." 


\section{Waiting for the Sound of the Cannon 6II}

Confederate battery commanding Fort Sumter, from Fort Moultrie and Castle Pinckney, from Morris Island, from the floating batteries, there now burst forth sheets of flame that illumined the gray morning mists, and shot and shell fell thick and fast upon the fort and its doomed garrison. The dark clouds that hung over Charleston harbor were not imaginary; they were real, intensely real. All peace propositions, all proposed compromises, all truces, all plans for patching up the broken Union had now vanished. THE Civil War had Begun.

If the bombardment of Fort Sumter fired the Southern heart, it fired the Northern heart as well. The echo of the guns reached every Northern home. As if by magic, the war spirit blazed forth with such fervent heat as, at least for a time, to melt all political differences and weld all political parties in the North into one, whose only aim was the preservation of the Union at whatever cost of treasure or men.

On the day of the bombardment of Fort Sumter, Stephen A. Douglas called at the White House and assured the President of his unqualified support. The morning after he said to his old friend, John W. Forney: "We must fight for our country and forget all differences. There can be but two parties-the party of patriots and the party of traitors." We see Douglas for the last time in his last public speech at Chicago, May I, I86I, in which he said: "But this is no time for a detail of causes. The conspiracy is now known; armies have been raised, war is levied to accomplish it. There are only two sides to the question. Every man must be for the United States or against it. There can be no neutrals in this war; only patriots or traitors." In all the North there was probably no other political leader, except Lincoln himself, who brought so

When Douglas made this speech he was suffering from an incurable malady from which he died on June 3,1861 , at the early age of fortyeight. 


\section{Political History of Secession}

great a number of his followers to the support of the Union cause. "He was," says Horace White, " the only man who could have saved southern Illinois from the danger of an internecine war. The southern counties followed him now as faithfully and as unanimously as they had followed him in previous years and sent their sons into the field to fight for the Union as numerously and bravely as those of any other section of the State or of the country."

President Lincoln issued his call to arms Monday, April 15. On the next day the descendants of the men who fought at Lexington and Concord and Bunker Hill were mustering on Boston Common, and within three days after that the Massachusetts Sixth, the first regiment from the North, was marching through the streets of Baltimore. Indeed every nook and corner of the North quivered under the tread of companies and regiments marching to their places of rendezvous. The long pent-up war spirit was now fiercely burning in the North as well as in the South, and the men of both sections seemed to leap, as from leashes that bound them, to bloody battlefields. All had yet to learn the truth of General Sherman's saying, that "War is Hell."

Who would then have thought-strange paradox-that the combatants who for four years had fought one another in deadly conflict, the very men who stood on the firing line, should be the first to be reconciled? Webster hoped that he might never live to see the sun in heaven shining "on the broken and dishonored fragments of a once glorious Union, on States dissevered, discordant, and belligerent; on a land rent with civil feuds, drenched, it may be, in fraternal blood." But there are men still living who have seen what Webster dreaded to see. They have also seen what Webster did not live to see, the old Union, the Union of our fathers, now knit together by ties stronger than any that have ever bound it since the days of the Revolution.

$\therefore$ Life of Trumbull, p. 153. 


\section{TABLE OF CITATIONS}

Adams: New England Federalism, 18.

Adams (JoHn Quincy): Memoirs, 86.

Alba Ny (N. Y.) Argus, $55^{8}$.

ALBANY (N. Y.) Evening Journal, 56I.

American Historical Association Reports, $42 \mathrm{r}$.

American Historical Review, 284, 288, 323.

American Law Review, 323, 335 .

APPLEToN's Annual Cyclopedia for $1861,466,478,546,547,549$.

ATCHISON: Squatter Sovereign, 244.

BANCROFT: Life of William $H$. Seward, ro8, I76, 198, 350, 496, 594, $595,602,604$.

Bangor Union, 559.

Benton: Examination of the Dred Scott Case, 155, 193, 194, 196, 213, 308, 324.

Benton: Thirty Years in U.S. Senate, 16, 27, 36, 60, 67, 72, 101, 105, $110,138,140,145,147,150,181$.

Black: Essays and Speeches, I09, 454, 5I4, 53 I, 532, 55.5.

BlaINe: Twenty Years in Congress, 204, 353, 389, 452, $551,573$.

BRUNCKen: German Political Refugees in the United States, etc., 396, $397,398,401$.

Buchanan's Administration, 194, 2 18, 514, 555.

Calmoun: Discourse on the Constitution, etc., 34.

": Works, 29, 30, 34, 43, 44, 48, 53, 75, 169, 170.

Cambridge Modern History, 334 .

CAMPBELL: Lives of the Chief Justices of England, 341.

CARR: Life of Stephen A. Douglas, 352, 443.

Charleston (S. C.) Courier, $9 \mathrm{I}$.

Charleston (S. C.) Mercury, 235.

Chittenden: Peace Convention of $1861,46 \mathrm{I}, 465,467,468,470,47 \mathrm{I}$, $473,475$.

Christian: Paper on Roger B. Taney, 335.

Clarke: Anti-Slavery Days, I88, 223, 296.

Clusky: Political Text Book, I80, I81, 182, 278.

CoCKRUM: Pioneer History of Indiana, 184.

CoffIN: Reminiscences, 77, 184 .

CoHn: The Dred Scott Case, 323.

Colton: Last Years of Henry Clay, 52.

" : Life of Henry Clay, 58.

1 : Private Correspondence of Henry Clay, 159.

Congressional Debates

20 Cong., II7

Congressional Globe

27 Cong., r3o. 
Congressional Globe (Continued)

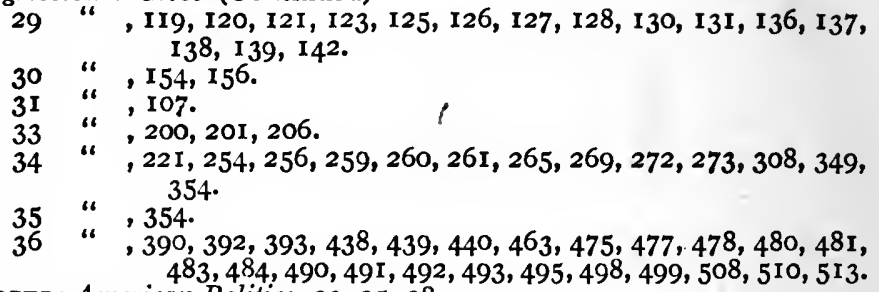

COOPER: A merican Politics, 23, 25, 28

Corwin: The Dred Scott Decision, etc., 323.

CRAwFord: History of Fort Sumter, 519, 526, 527, 535, 537, 550, 552, 587,609 .

Curtis (Benj. R.), Life of Benjamin R. Curtis, 318, 319, 334, 519.

Curtis (Francis): The Republican Party, 284.

CuRTIS (GEoRGE T.): Life of James Buchanan, 68, 75, 338, 519, 525, 530,553 .

Davis: Rise and Fall of Southern Confederacy, 17, 198, 235, 420, 451, $54 \mathrm{I}, 56 \mathrm{I}, 598$.

DE Bow: Industrial Resources, etc., II.

Detroit Free Press, 559.

Dix: Speeches, 50, 59 .

DOyLE: The English Colonies in America, Virginia, etc., 2, 7.

DRAPER: History of the American Civil War, I.

DUNN: History of Indiana, 90.

“: Paper on Slavery Petitions, 90.

ERRETT: The Formation of the Republican Parly in 1856, 284.

": Republican Nominating Conventions, 290.

FESSENDEN: Life, etc., of William Pitt Fessenden, 205, 428, 605.

First Century of the Republic, 7 .

FISKE: Essays, 88.

FLOWER: History of the Republican Party, 238, 281, 282.

FOOTE: War of the Rebellion, 46.

FOULKE: Life of Oliver P. Morton, 346, 579, 580.

Fox: Regimental Losses, 192, 40r.

GARRISON: Life (By his children), 65, 77, 442.

GoRDON: Major Anderson at Fort Sumter, 597.

GREELEY: The Great American Conflict, I71, 380, 456.

GREeley and Clevela ND: Political Text Book for 1860, 302, 303.

GREGORY: Paper on A Historic Judicial Controversy, 238.

HALSTEAD: History of the National Political Conventions of $2860,4 \mathrm{II}$, 4I2, 4I3, 4I 4, 43I.

HENSEL: Buchanan's Administration on the Eve of the Rebellion, 555.

HerberT: The Abolition Crusade, 12, 83, 567.

HILDRETH: History of the United States, 6, 7, 18, 25.

Howe: The Puritan Republic, $2,5$.

HowELLS: John Brown After Fifty Years, 385.

HuTCHINSON: History of Massachusetts, 68.

Illinois State Bar Association Proceedings, 238.

Indiana Historical Society Publications, 77, 90.

Indiana State Bar Association Proceedings, 238.

Indianapolis Journal, 561. 


\section{Table of Citations}

JEFrERSON: Works, 9, 15, 22, 23, 57, 59.

Jounson: Garrison and II Tis Times, 63, 64, 66, 67, 78, 81 .

Johnston: Political History (WoODBURN's ed.): 27, 28, I96.

JuLIAN: Life of Joshua R. Giddings, 427.

" : Political Recollections, I02, 574.

"1 : Rank of Charles Osborn as a Reformer, 77.

“ : Paper on the First Republican Convention, 284, 288.

LAMON: Recollections of Abraham Lincoln, 590.

Lawrence: Paper on Colonial Progress, 7.

Lecompton Union, $35 \mathrm{I}$.

Liberator, The, 64, 442 .

Lincoln-Douglas Debates, 331, 332, 345, 369, 370, 372, 374, 375, 376, 377.

LODGE: Life and Letters of George Cabot, 17, 18.

LoGAN: The Great Conspiracy, 369.

London Morning Star, 277.

Madison: Writings, I6.

Magasine of Western History, 284, 290.

MALLORY: Life and Speeches of Henry Clay, 96

MANSFIEld: Personal Memoirs, io2.

MAsoN: Paper on the Fugitive Slave Law in Wisconsin, 238.

Massachusetts Military Historical Society Papers, 597.

$$
\text { "Session Laws, 218, 24I. }
$$

MetzNer: (StempfeL's translation) History of the North American Gymnastic Union, 401 .

Mobile Mercury, 608.

MOORE: Works of James Buchanan, 334, 336, 338, 574.

MCCLURE: Lincoln and Men of War Times, 535, 555, 573, 574.

MCMASTER: History of the United States, 25, 108, II5, 40I.

McPherson: History of the Rebellion, 19I, 240, 455, 46I, 466, 5I I, 516, $546,547,609$.

National Era, 187.

New Orleans Bee, 92.

New York Evening Post, 228.

New York Tribune, 511, 560.

Nicolay: Outbreak of Rebellion, 457.

NicolAy and HAY: Lincoln, 198, 512, 520, 530, 535, 59I, 607.

NiLES: Register, 115.

": Tippecanoe Text Book, 90, 91, 92.

North American Review, 385.

Norton: Tippecanoe Campaign, 90, 96, 98.

Official Proceedings of the Republican Convention Convened in the City of Pittsburg, Pennsylvania, on the 22nd of February, 1856, 284.

Otmsted: A Journey in the Sea-Board Slave States, $6,7,8$, I 1 .

PARkHURst: Official Report of National Democratic Conventions of 1860 , $4 I I$.

Parton: Life of Horace Greeley, I52, I58.

Pennsylvania Reports, (Sup. Ct.), 454.

Phillips: Conquest of Kansas, 244, 245, 249.

": Paper on Georgia and States Rights, $42 \mathrm{I}$.

PrLlsBury: The Church as It Is, etc., 77.

Political Science Quarterly, 42 I, 458.

POLLARD: Life of Jefferson Davis, 2I 5, 456, 543. ": The Lost Cause, 15, 17, 408, 550, 567.

President's Messages, etc., 67, 305, 460. 
Proceedings of the Constitutional Meeting at Faneuil Hall, November 26, $1850,225$.

Proceedings of the Conventions at Charleston and Baltimore, 4II.

QuiNCy: Life of John Quincy Adams, 71, 73.

RAY: Repeal of the Missouri Compromise, 198, 213.

Report of Committee on Military Affairs, 519.

RHODES: History of the United States, 198, 216, 265, 334, 387, 535, 607.

Richmond Enquirer, 276, 303.

Richmond Examiner, 296.

Russell: My Diary, North and South, 408, 560, 572.

SCHUCKER: Life of Salmon P. Chase, 198, 607.

SCHURZ, CARL: Reminiscences, 235, 236, 377.

SEWARD: Works, 73, IIO, I 74, 202, 203, 213, 332, 360, 607.

Sherman (JoHN): Recollections, 304.

SPRING: Kansas, 243.

STEPHENS: War Between the States, 455.

STOVALL: Life of Senator Toombs, 279.

SUMNER: Works, 265, 269, 271, 272, 273, 275, 276, 277, 303.

ThомAs: Paper on Southern Non-Slaveholders in the Election of 1860 , $421,458$.

TUCKER: History of the United States, 5, 85, 116.

TURPIE: Sketches of My Own Times, 313.

TYLER: Memoir of Roger B. Taney, 320, 334, 343.

United States Census Reports, 396.

" "Constitution, I85.

“ " House Reports, 248.

“ "Senate Reports, 195.

“ "Statutes, 177, 179, 217

“ “Supreme Court Reports, 217, 239, 316, 320.

VAN Buren: Political Parties, 324.

Vermont Session Laws, $218,24 \mathrm{I}$.

VICTOR: Southern Rebellion, 235, 478.

VILLARD: John Brown, 253, 385.

VoN Holst: Constitutional and Political History of the United States, 15, I 8, 25, 86, I44, I 56, I 8I, 255, 393, 400 .

War Records: $450,516,521,522,523,524,528,536,537,538,550,575$, $576,588,591,594,597,598,599$.

Watterson: $A n$ Abortive Hero, 385.

WEBSTER (DANIEL) Works: 31, 32, 33, 39, 51, 97, I 70, I 7 1, 172, 226.

WEBSTER (HOMER): William Henry Harrison's Administration of Indiana Territory, 90.

WEISE: Life of Theodore Parker, 265.

WeLles: Diary, 570, 589, 595, 602, 603, 606.

WHITE (ANDREW): A utobiography, 79, IOI, 186, 223, 304.

White (HoRACE): Life of Trumbull, 499, 512, 569, 572, 602, 603, 612.

WILson, (HENRy): Rise and Fall of the Slave Power, 72, 73, 171,184, 197, I98, 218, 223, 224, 226, 228, 229, 240, 303, 32I, 44I.

WILsoN (WoODRow): Contribution on States Rights, 334 .

Winslow: Paper on the Booth Case, 238.

Wisconsin State Historical Society Proceedings, 238.

Wisconsin Supreme Court Reports, 239.

WoOLlen: Biographical Sketches of Early Indiana, 120

WyLly: The Colony of Georgia, 6, 9, 457.

Young: American Statesmen, 105, 106, 247. 


\section{GENERAL INDEX.}

Note.-In the following index the titles of the chapters are printed in small caps. An analytical index to the contents of the various chapters will be found in the table of contents.

Abolition and Abolitionists: Establishment of Abolition newspapers, 64; rewards offered in South for leading Abolitionists, 66; slaveholders' appeal to Northern legislatures to suppress Abolition societies, 67; attempts to suppress circulation of Abolition newspapers, etc., through the mails, 67 ; President Jackson's message on the subject, 67 ; John C. Calhoun's bill, 67; Northern senators voting for it, 68; Abolition petitions and memorials to Congress, 69 ; Abolition petition presented by James Buchanan, and Calhoun's speech upon it, 75; commercial interest opposed to, 76; attitude of Northern churches and clergymen towards, 76; excuses usually given by clergy, 78; causes of unpopularity of Abolitionists in the North, 79; Abolitionists not responsible for American Civil War, 83; nominate James $G$. Birncy for President and Francis LeMoyne for Vice-President in 1840,89 ; Abolitionists in presidential campaign of 1860,441 ; see AntiSlavery societies; Garrison, Slavery.

See also: FROM I 820 TO 1840 ; GROWTH OF ANTI-SLAVERY SENTIMENT IN THE NORTH, Chap. V., p. 62; NULlIFICATION AND HIGHER LAW IN THE NORTH, Chapter XI., p. 217.
Adams, Charles Francis: nominated by Free Soil party in 1848 for Vice-President, 150; his peace proposition submitted to House Committee of Thirtythree in 36 th Congress, 462 ; he afterwards opposes its adoption, 463; mentioned, 109

Adams, James H.: One of South Carolina Commissioners, 449

Adams, John Quincy: Advocates right of petition, 69; resolution for constitutional amendment prohibiting slavery, 69; presents petition for dissolution of the Union, 72 ; unites in an address opposing annexation of Texas, 105; influence of, in formation of political character of William H. Seward, 108; speech in House on Oregon boundary question, I3I ; his position on question, I3I; mentioned, 62

Administration policies, Chap. XXVII., p. 578

Alabama: passes secession ordinance, 548

Alabama platform: $\mathbf{1 8 2}$

Albany (N. Y.) Argus: opposes coercing the seceding states, $55^{8}$

Albany (N.Y.) Evening Journal: favors letting, seceding states "go in peace," 56I

Alien and Sedition Laws: origin of, and opposition to, 20

Allen, Charles: protests against Whig party skulking on the slavery question, 149

Allen, Philip: 199 
Allen, William: strenuous advocate of policy of Fifty-four Forties, 120; speech in Senate on Oregon boundary question, I2I; his subsequent career, 142

Allison, John: 285

Allison, William B.: 425

Alton (Ills.): murder of Elijah Lovejoy there, 80

Alton Observer: Abolition newspaper, 64

American Anti-Slavery Society: organization, 63; dissolution, 81

American or Know-Nothing Party: its sudden rise, 282; for a time diverts attention from slavery question, 283; splits in 1856 on slavery question, but nominates Millard Fillmore for President and A. J. Donelson for VicePresident, 295; in 1860 adopts meaningless platform, 422; nominates John Bell for President and Edward Everett for Vice-President, 422; arouses no enthusiasm, 44I

Anderson, Thomas L.: his peace proposition, 462

Anderson, Major Robert: assigned to command of United States forts in Charleston (S. C.) harbor, 520; his appeals for reinforcements, 520; orders and correspondence between him and Floyd, Secretary of War, 520; growing feeling in North that something should be done for his relief, 587 ; military authorities advise against attempt, 587; Lincoln submits question to his Cabinet, but majority vote against making attempt, 588; he sends Lamon and Hurlbut to Charleston to confer with Governor Pickens and Major Anderson, 589; their reports to Lincoln, 589; Lincoln again submits question of aiding Major Anderson to Cabinet, which reverses its former ruling, 590; expeditions for relief ordered, 590; Anderson's letters to U. S. AdjutantGeneral, 597; scant justice of
Civil War historians to Major Anderson, 597; his correspondence with General Beauregard, 598; his last letter to U. S. War Department, 599; his unswerving loyalty to his Government, 599; mentioned, 537, 538, 540, 585,608

See EFForTs TO SUCCOR Major Anderson, Chapter XXIX, p. 597.

Andrew, John $A_{\text {.: }}$ his efforts to put Massachusetts on a war footing prior to outbreak of Civil War, 577; mentioned, 425

Anti-Lecompton Democrats: nearly all followed Douglas in 1860, 395

Anti-Slavery Parties in North: great variety of names, 279

Anti-Slavery Societies: organization of, 63; one of causes of irritation of South, 10, 407

Appeal of the Independent Democrats, 198

Archer, William: 140

Arkansas: Petition of people of territory for admission as a state, 55; state admitted, 59; refuses for a time to secede, 456

Arnay, W. F. M.: 286

A shley, James $M$ :: 285

Ashmun, George: selected as permanent chairman of Republican National Convention in 1860 , 425; mentioned, 165

Atchison, David: one of leaders of Missourians in invasion of Kansas, 246; mentioned, 120, 246, 250

Atherton gag: adoption of, in Congress to head off Abolition petitions, 72; opposition to, of Northern Democrats, 73; how anti-slavery petitions disposed of after its abolition, 73

Austin, James T.: his speech at Lovejoy meeting in Boston, 80 Avery, $W$. W.: submits majority report of resolutions committee at Charleston Democratic Convention in 1860,412 ; submits second majority report, 4I6 


\section{Index}

Bailey, William S.: 286

Baker, $\longrightarrow$ : 28I

Baldwin, Dudley: 286

Bancroft, George: on coercing the seceding states, 560

Bangor Union: opposes coercion, 559

Banks, Nathaniel P.: 285, 292

Barksdale, E.: 411

Barksdale, William: 388

Barn-burner Democrats: origin of term, 15I

Barnwell, Robert: one of South Carolina Commissioners, 449; mentioned, 526, 527

Bales, Edward: candidate for presidential nomination in Republican National Convention in 1860, 423; Attorney-General in Lincoln's Cabinet, 570

Bayard, James: clected chairman of Democratic seceders convention at Charleston in 1860 , 419

Bayley, Calvin C.: 286

Beaman, F. C.: 285, 286

Beaman, J. C.: 285

Beauregard, General Peter: reports condition of Ft. Sumter, 575; correspondence with Major Anderson, 598; mentioned, 587, 594,608

Beecher, Henry Ward: steadfast opponent of slavery, 79; on logic of Sharp's rifles, 245

Beginnings of Secession: Chapter II., p. 15

Bell, John: voted against KansasNebraska bill, 199; votes against bill to admit Kansas under Lecompton constitution, 352; nominated for President by American party in 1860, 422; defeated, 446

Belmont, A ugust: $4 \mathrm{II}$

Benson, I. M.: 286

Benton, Thomas $H$.: votes aganist bill to prohibit circulation of Abolition newspapers, etc., through the mails, 67; speech in Senate on Oregon boundary question, 125; aids President Polk in his back-down on Oregon policy, 140; presents petition of people of New Mexico,
154; his quarrel with Senator Foote, 161 ; loses caste in Democratic party by his opposition to demands of slavery, 297; his advice to Senator Sumner on latter's entrance into Senate, 298; review of Dred Scott case, 324; mentioned, 301, 326

Berrien, John M.: speech in Senate on Oregon boundary question, 127; mentioned, 140

Bigler, William : 459

Bingham, K. S.: 286

Birney, James G.: nominated for president by Abolitionists in 1840, 89; nominated for president by Liberty party in 1844 , I07

Birth of the Republican Party AND its First Battle, Chap. XIV., p. 278

Black, Jeremiah $S .:$ his opinion of William H. Seward, 109; as Buchanan's Attorney-General advises against pardon of Sherman M. Booth, 238; his opinion given to President Buchanan on right to coerce seceding states, 452; his character and political vicws, 453 ; points in his opinion, 454; succeeds Cass as Secretary of State, 517; objects to Buchanan issuing order for withdrawal of garrison from Charleston Harbor, 529; suggests amendments to Buchanan's answer to South Carolina commissioners, 531; his efforts in this matter of great value to Union cause, 535; effect of his change of attitude, 539; mentioned, 519,542

Black Jack: battle of, 252

Blaine, James G.: prominent in Maine politics in 1856,298 ; predicts defeat of Seward for presidential nomination in Republican convention of 1860 , 428; his estimate of Buchanan, $451,55^{1}$

Blair, A ustin: 476

Blair, Francis $P$.: president of Pittsburg Republican convention, 287; mentioned, 286, 423, 425 
Blair, Montgomery: one of attorneys in Dred Scott case, 5I7; Postmaster-General in Lincoln's cabinet, 570; opposed to Seward's peace policy, 584; mentioned, 603

Bliss, George, 285

Bolton, Thomas, 286

Bond, - 286

Bonham, M.L., 539

Boone, Colonel, 250

Booth, Sherman M.: his participation in rescue of Joshua Glover, 231; prosecutions and suits against him, in the Federal courts, 23I; released from imprisonment on writ of habeas corpus by Supreme Court of Wisconsin, 23I ; again indicted and imprisoned and again released by Wisconsin Supreme Court, 232; civil action against him by Garland, owner of Glover, 232; U. S. Supreme Court reverses judgments of Wisconsin Supreme Court, 233; points in U. S. Supreme Court decision, 233; Wisconsin Supreme Court refuses to obey mandate of U.S. Supreme Court, 236; Booth again arrested and imprisoned, 236; nullification resolutions of Wisconsin legislature, 236; Booth finally pardoned by President Buchanan, 238

Booth, Wilkes: 383

Border States: meeting of members of Congress to consider peace propositions, 459; sympathies of slave border states with the seceding states, 563

Boston Anti-Man-Hunting League: 240

Boutwell, Geo. M.: speech of, in Peace Convention of 1861,468 ; mentioned, 425

Bovay, A. E.: he and two others call anti-slavery meeting at Ripon, Wis., $28 \mathrm{r}$; credited with originating name of Republican party, 28I

Bowen, $: 281$

Brainerd, Lawrence C.: calls Pittsburg Republican Convention to order, 287 ; mentioned, 285
Branch, Lawrence 0.: 387

Brannin, Richard: 286

Breckinridge, John C.: nominated for Vice-President by Democratic National Convention in r856, 293; nominated for President by Democratic seceders' convention at Baltimore in 1860,437 ; overwhelming sentiment of South in his favor in presidential campaign of 1860 , 441; defeated 446

Brewer, Josiah: 285

Bright, Jesse D.: 31 I, 412

Brinkerhoff, Jacob: 285

Brinkerhoff, $R$.: 286

Broderick, David C.: 353

Brooks, Erastus: $42 \mathrm{I}$

Brooks, Preston: his assault on Senator Sumner, 27 r; after censure by House resigns and is reëlected, 273; mentioned 296

Brown,- 285

Brown, A. B.: 106

Brown, J. M.: 286

Brown, John: conspicuous in Kansas troubles, 252; his Kansas record, 252; his raid on Harper's Ferry, 380; the excuses given for him, 382 ; effect of his raid on the North, 383; effect on the South, 384; his rank in history, 384 ; unsuccessful efforts of Democratic leaders to implicate prominent Republicans in Brown's raid, 385; Lincoln's opinion of raid, 385 ; mentioned, 296

Brown, Peter: 252

Browning, Orville $H$.: one of Lincoln's managers at Republican National Convention in I860, 423; mentioned 425

Brownlow, W. G.: 42 I

Bryant, John H.: 286

Buchanan, James: votes for Calhoun's bill prohibiting circulation of Abolition newspapers, etc., through the mails, 68; presents petition of Pennsylvania Quakers to Congress for abolition of slavery, 75; gratified that resolution for annexation of Texas reesstablished the 
Buchanan, James-Continued Missouri Compromise, IIo; as President Polk's Secretary of State conducts negotiations with Great Britain for settlement of Oregon dispute, 137; pardons Sherman M. Booth, 238; nominated by Democrats for President in 1856, 293; in his letter of acceptance avoids expression of opinion as to meaning of slavery plank in platform, 295: his orthodoxy on slavery question, 295; his election, 302; encouraging Democratic outlook, at time of his inauguration, 314; his inaugural address, $314 ;$ his opinion of the meaning of the Kansas-Nebraska Act, 31 5; his reference to the pending Dred Scott case, 315; supposed understanding between him and some of Supreme Court judges as to scope of its decision, 33I; his correspondence with Justices Catron and Grier, 336; recommends admission of Kansas under Lecompton constitution, 350; threatens Douglas for opposing, 350; submits draft of his annual message to Jefferson Davis, $45^{\circ}$; his message to second session of 36 th Congress, 450; Blaine's description of Buchanan at this period, 451; with his message he submits opinion of Black, AttorneyGeneral, 452; sends special message to Congress recommending consideration of peace propositions, 460 ; members of his cabinet at time of clection of Lincoln, 5I6; disintegration of his cabinet begins, 516; his interviews with Jefferson Davis, Senator Hunter, and Floyd as to ordering Major Anderson to abandon Fort Sumter and return to Fort Moultrie, 526; submits to his cabinet draft of his answer to South Carolina commissioners, 531: Black, Stanton, and Holt object to it, 53I; Black's amendments, 532; Buchanan's version of the alleged "truce," 535; different version given by South Carolina representatives, 536; Buchanan's version of Floyd's verbal instructions to Major Anderson, 537 ; Buchanan declines to order Major Anderson to return to Fort Moultric, 537; final communication of South Carolina commissioners to Buchanan, 538; reorganization of his cabinet the turning point in his administration and in Union cause, 540; he sends special message to Congress, January 8, 1861, 54I: his subsequent policy, 54 I: defensive measures adopted after reorganization of cabinet, 54I; distress over threatened bombardment of Fort Sumter, 550; various estimates of Buchanan, 550; defenses urged in Buchanan's behalf, 552; comparison of last of Buchanan's and beginning of Lincoln's administra. tions, 553; summary of closing months of Buchanan's administration, 554; mentioned, 332, $344,516,582$

Buell, Don Carlos: sent by Floyd, Secretary of War, with verbal instructions to Major Anderson, 521

Buford, Colonel: takes battalion from South to Kansas during troubles there, 245

Bunce, James M.: 285

Burke, Edmund: on necessity of agitation against abuses, 65

Burlingame, Anson: speech on Brooks's assault on Sumner, 273: accepts Brooks's challenge for duel, 274

Burns, Antony: his arrest under fugitive slave law, 239

Burroughs, Silas M.: 285

Butler, Andrew P.: colloquy between him and Fessenden, 205; criticized by Sumner, 267

Butler, Benjamin F.: countenances slanders on Fessenden in proceedings for impeachment of Andrew Johnson, 205; dele- 
Butler, Benjamin F.-Continued gate to Charleston Democratic Convention in 1860, 412; his variegated political principles, 412; his dissenting minority report and speech, 413; secedes from second Democratic Convention at Baltimore, 435; mentioned, 4II

\section{Cagger, Peter: 4I I}

Calhoun, John: sends certified copy of Lecompton constitution to President Buchanan, 349

Calhoun, John C.: resolutions and speech on the Force bill, 29; advocates right of secession, 29; doctrine afterward applied to protect and extend slavery, 36 ; on "equality of rights," 40 ; on "non-interference," 45; his theory of needed amendments to the constitution, 52 ; estimate of, 53 ; his vote on the Missouri questions submitted by President Monroe to his cabinet, 59; reports bill to prohibit circulation of Abolition newspapers, etc., through the mails, 67; speech on Abolition petition presented by James Buchanan, 75; succeeds Upshur as Secretary of State in Tyler's cabinet, I04; his great influence over Tyler, IO4; refuses to allow his name to go before Democratic National Convention in 1844 for presidential nomination, 107; his position on Oregon boundary question, 130; his resolutions declaring slavery in the territories to be protected by U. S. constitution, I45; his letter on "forcing the issues," I45; advises retaliatory legislation by southern states against the North, 146; opposes petition of New Mexico for territorial government, 154; speech on Compromise Measures, I69; his death, 296; mentioned, 326, 344

California: efforts to provide ter- ritorial organization for, 155 , 167; inhabitants vote for free state constitution, I60; President Taylor favors admission under, I60; disappointment of South, I60; passage of bill for admission, 176; see Compromise Measures.

Cameron, Simon: candidate for presidential nomination in Republican National Convention in 1860,423 ; opposition to his appointment as Secretary of War in Lincoln's cabinet, 568; his removal, 569 ; opinion as to attempting relief of Major Anderson, 588; mentioned, 603 Campbell, John A.: one of judges in Dred Scott case, 317; acts as go-between for Seward and Confederate commissioners, 586; his correspondence with Jefferson Davis and Toombs, 586 ; charges that Seward overreached the Confederate commissioners, 594; mentioned, 316 , $339,342,343$

Campbell, Lewis D.: 275

Carey, Henry C.: 290

Carlin,,$: 286$

Carter, H.: 286

Cartter, David K.: 425, 43I

Caruthers, - 285

Cass, Lewis: supports policy of Fifty-four Forties in Oregon controversy, 120, 123; Democratic nominee for President in 1848 , 147 ; speech on meaning of Kansas-Nebraska Act, 259; Secretary of State in Buchanan's cabinet, 516; resigns office of Secretary of State, 516; mentioned, 297, 298, 5 I 7

Castle Garden: meeting to indorse Compromise Measures of $185^{\circ}$, 224

Castle Pinckney: occupied by South Carolina military forces, 524

Catron, John: his opinion in Dred Scott case, $32 \mathrm{I}$; his correspondence with President Buchanan during pendency of case, 336; mentioned, 316, 319, 339, 340, $341,342,343$. 
Caucus system: abandoned in presidential nominations, 86

Cavalier element: in South Carolina, 2

Chamberlain, B. B.: 285

Chandler, Zachariah: enters U. S. Senate, 298; his letter to Governor Blair on the necessity of a little "blood-letting," 475; mentioned, 286, 287, 290, 405, $603,606,609$

Channing, William Ellery: 79

Charleston ( $S$. C.): see Democratic National conventions; Fort Sumter.

Charleston (S. C.) Courier: indorses William Henry Harrison for President in 1840,91

Charleston harbor: Major Anderson assigned to command of forts in, 520

Chase, Salmon P.: his political and civil career prior to 3Ist Congress, 166; speech in 3 Ist Congress on the Compromise Measures of 1850,175 ; assists in preparation of Address to the Independent Democrats, 198; speeches on the Kansas-Nebraska bill, I99; controversy with Douglas, 208 ; candidate for presidential nomination at $\mathrm{Re}$ publican National Convention in 1860, 423; speech in Peace Convention of I86I, 470; Secretary of Treasury in Lincoln's cabinet. 570; represents radical element 570; mentioned, 165, 256, 405, $584,603.606$

Chase, William, Jr.: 285

Choate, Rufus: his prediction as to political effect of Uncle Tom's Cabin, 187; speech against slavery agitation in 1850,225

Christiancy, Isaac: 290

Church, Sanford E.: 4II

Churches and clergy of the North: early attitude against slavery agitation, 76; effect on, of commercial interests, I87; change after 1850,396 ; in 1860 , 407

Cincinnati, Ohio: proceedings of convention there of those favoring occupation of Oregon, I 14
Clapp, A, M.: 285

Clark, William T.: 285

Clarke, W. P.: 286

Clay, $C$. C.: speech on withdrawing from U.S. Senate in 1861,513 ; mentioned, 420

Clay, Cassius M.: letter to Pittsburg Republican Convention in 1856,287 ; defeated for vice-presidential nomination at Republican National Convention in $1860,43 \mathrm{I}$

Clay, Henry: his compromise tariff bill of 1833,36 ; opposed to Tallmadge's amendment to Missouri bill, 56; quarrel with John Randolph, 60; votes against bill to prohibit circulation of Abolition papers, etc., 67; speeches in presidential campaign of 1840 , 96; sacrificed in Whig convention in 1839 , 86; Whig nomince for President in 1844, 107; defeated for presidential nomination in Whig National Convention in, 1848 , 149; Greeley's lament for, 152; his relations to President Taylor, 159; in 3 Ist Congress, 164; compromise measures prepared by, in 3 Ist Congress, I67; his speech on the Compromise Measures of I850, 168; his death, 296; mentioned, 326

Clayton, John M.: proposes to leave question of slavery in the territories to the courts, 154; votes against Kansas-Nebraska bill, I99; mentioned, I40

Cleaveland, C. F.: 285

Cleaveland, George: 285

Clephane, Louis: 286

Clergy in New England: see Churches and elergy

Clingman, Thomas C.: speech on secession in 36th Congress, 478 ; mentioned, 165, 517

CLOSING MONTHS OF BUCHANAN'S ADMINISTRATION: Chap. XXIV., p. 515

CLOSING MONTHS OF BUCHANAN'S ADMINISTRATION: (Continued): Chap. XXV., p. $54^{2}$

Cobb, Howell: Secretary of Treassury in Buchanan's Cabinet, 
$\mathrm{Cobb}$, Howell-Continued 516; advises against forming confederacy until after March 4, I86I, 515; resignation of office of Secretary of Treasury, 516; elected President of Montgomery Confederate Congress, 548; mentioned, 165, 297, 455, 517,519

Coburn, John: 3 II

Codding, Ichabod: 286

Coke, Lord: on the independence of the judiciary, 34I

Colfax, Schuyler: 3 II, 312

Collamer, Jacob: submits minority report on bill for admission of Kansas, 254; member of Senate Committee of Thirteen, in 36 th Congress, 459; mentioned, 605

Colleges in North: change of attitude toward slavery after I850, 396

Colonization: societies for, in the South; purpose of, ro

Comins, Linus B.: 273

Compromise Measures of 1850 : debates and proceedings in 3 Ist Congress, I08; what South gained by, I79; political effect in Mississippi, I8I ; little accomplished by, I 83 ;

See FORCING THE IsSUEs, etc., Chapter IX., p. 159

Confederate commissioners: sent by confederate government to Washington to negotiate treaty with United States, 576; important part played by, 584; attempt of, to open official communication with federal government, 585 ; Justice Campbell of U. S. Supreme Court acts as go-between for them and Seward, 586; Toombs's letter to, 587 ; their negotiations with Seward, 594; whether they overreached Seward or he over-reached them? 594

Confederate Congress: meets at Montgomery, Ala.; its proceedings, 656

Confederate States of America: preliminary work, 456; organization of Confederacy under name of, 548; Jefferson Davis elected President and Alexander $H$. Stephens, Vice-President, 548; measures taken to put, in operation and to place on a war footing, 548 ; send commissioners to Washington, 576

Congress (of the $U$. S.):

3oth Congress: proceedings and debates, I55; secret meetings of southern members, I56; the address issued by them, 156 3 Ist Congress: first session: political complexion of, $16 \mathbf{1}$; political leaders in Senate and House, r64; political resolutions and debates, 167; passage of compromise bills, 176

36th Congress: first session: how members divided politically, 379; efforts to implicate Republicans in John Brown's raid, 386 ; disgraceful scenes in House, 386 36 th Congress: second session: peace propositions considered, 462; joint resolutions, 477; memorable for what it failed to do, 514. See congressional DEBATES, etc., Chap. XXIII., p. 478

CONGRESSIONAL DEBATES; CLOSE OF THIRTY-SIXTH CONGRESS: Chap. XXIII., p. 478

Connecticut: response to Virginia and Kentucky resolutions of I 798, 24

Constitution of United States: concessions in, to slavery, .9; views of John C. Calhoun on question whether it protected slavery in the territories, 48; views of John A. Dix, 50; of Daniel Webster, 5I ; of Thomas H. Benton, $5 \mathrm{I}$; of Henry Clay, $5 \mathrm{I}$

CONTINUATION OF IRREPRESSIBLE CONFLICT IN KANSAS AND IN CoNGRESS: Chap. XVI., p. 348

Coombs, Leslie: $42 \mathrm{I}$

Corning, Erastus: 4I I

Corwin, Thomas: chairman of House Committee of Thirtythree in 36 th Congress, 459; mentioned, I57, 425

Cotton-gin: effect of, on cotton industry and slavery, I I 
Cotton manufactories in New England: effect on discouraging agitation of slavery question, 186

Crawford, General Samuel W.: his opinion of Buchanan, 552

Crawford, Martin J.: one of Confederate commissioners, 584; his advice to General Beauregard, 593

Crawford, William H.: 59

CRIME AGAINST KANSAS AND THE CRIME against sumner: Chap. XIII., p. 264

Critlenden, John J.: votes against bill to prohibit circulation of Abolition newspapers, etc., 67; speech on Oregon boundary, 126; votes against bill to admit Kansas under the Lecompton Constitution, $35^{2}$; his substitute for the bill carried in House but defeated in Senate, 352; votes against English bill, 353; offers series of compromise resolutions in 36th Congress, 459; member of Senate Committee of Thirteen in 36th Congress, 459; chairman of meeting of members of Congress from the border states during $36 \mathrm{th}$ Congress, 460 ; synopsis of his compromise resolutions, 463 ; $h$ is resolutions defeated in Senate by one vote, 476 ; mentioned, 140, 459, 46I, 513, 516

Crosby, L. S.: 285

Cuba: debates on, in 36 th Con. gress, 388

Cumback, William: 3 I I

Curtin, Andrew G.: 430

Curtis, Benjamin R.: Garrison burns his charges to federal grand jury, 77; his dissenting opinion in Dred Scott case, 322; correspondence with $\mathrm{Ch}$. J. Taney, 343; mentioned, 316, $320,327,340,342$

Curtis, George Ticknor: one of attorneys in Dred Scott case, 317

Curtis, George William: speech in Republican National Convention of 1860 in support of Gid- dings's motion to amend platform, 426; warned not to speak in Philadelphia, 557

Cushing, Caleb: elected president of Charleston Democratic Convention, 412; secedes from Baltimore Democratic Convention in 1860,435 ; elected president of Democratic seceders' convention at Baltimore, 436; mentioned, 308, 4II

Dallas, George $M$.: nominated by Democrats in 1844 for VicePresident, 106; mentioned, 120

Daniel, Peter V.: his opinion in the Prigg case, 2I 8; his opinion in the Dred Scott case, 321; mentioned, 316, 321, 339, 340, 342

Darsie, George: 285

Davis, Charles G.: 285

Davis, David: one of Lincoln's managers in Republican $\mathrm{Na}$ tional Convention in 1860,423 ; mentioned, 425

Davis, Jefferson: political and military career prior to beginning of 3Ist Congress, 165; speech on compromise measures of 1850,$176 ;$ his aid sought in passage of Kansas Nebraska bill, 197; succeeds Calhoun as Southern political leader, 297; one of Senate Committee of Thirteen in 36 th Congress, 459: his opposition to Stephen A. Douglas, 389; his resolutions in $3^{6 \text { th }}$ Congress 390,438 ; continued opposition to Douglas, 438 ; consulted by President Buchanan in regard to his annual message to Congress, 450; kind of constitutional amendment desired by Davis, 491; withdraws from Senate, 513; elected president of Confederate government, 548; his supervision of Confederate commissioners, 584; charges Seward with deceiving them, 594; mentioned $165,235,310,326,386,420$, 441, 526, 561, 575, 594

Davis, John: 140

Day, Seth: 286 
Dayton, Isaac: $\mathbf{2 8 5}$

Dayton, William L.: nominated by Republicans for Vice-President in 1856,292 ; mentioned, 140

Defrees, John D.: 290

Delaware: response to Virginia and Kentucky resolutions of I 798, 24

Democratic National Conventions: I840: nominates Martin Van Buren for President, 89; its platform on slavery, 89

1844: platform favors annexation of Texas and occupation of Oregon, 106; nominates James K. Polk for President, I06; reasons for linking together the annexation of Texas and occupation of Oregon, II 7

1848: effort to incorporate in platform the doctrine of "noninterference" with slavery in the Territories, 46; nominates Lewis Cass for President and William O. Butler for VicePresident, I48

1852: the platform, I 89; nominates Franklin Pierce for President, 189

1856: nominates James Buchanan for President and John C. Breckinridge for Vice-President, its platform, 293; conflicting views of platform in North and South, 293

1860: meets at Charleston, S. C., 410; majority and minority reports of resolutions committee, 4I2 ; minority platform adopted whereupon various Southern delegates withdraw, 4I7; failing to make any nominations, convention adjourns to meet in Baltimore in following June, 419; the seceding members hold another convention in Charleston under name of "Constitutional Democracy" and adjourn to meet in Richmond, Va., 419; regular convention meets at Baltimore, 432; secession of the President and other members of the convention, 435; regular convention then nominates Stephen A. Douglas for President and Benjamin Fitzgerald of Alabama for Vice-President, 436; Fitzgerald declines nomination and Herschel V. Johnson, of Georgia, is substituted in his stead, 436; the Baltimore seceders meet there, 436; nominate John C. Breckinridge of Kentucky for President and Joseph Lane, of Oregon, for Vice-President, 436; Charleston seceders meet in Richmond, Va., and nominate Breckinridge and Lane, 437

Democratic Newspapers: oppose President Polk's back-d ow n from Oregon policy, I39, I4I ; on coercion of seceding states, $55^{8}$

Democratic Party: adopts principles of Virginia and Kentucky resolutions of 1798,27 ; reaches zenith of power in 1852, I89; prospects at inauguration of James Buchanan, 314; see Democratic newspapers, Democratic National conventions, Political campaigns.

Democratic-Republican Party: 86

Dennison, William H.: 286

Dennison, Wm. Jr.: 286

Denver, James $W .:$ one of governors of Kansas, $34^{8}$

Detroit. Free Press: denounces coercion of seceding states, 557

Devereaux, F.: 285

DEVELOPMENT OF WAR SPIRIT IN THE NORTH: Chapter XXVI., p. 556; people of North at first incredulous of Southern threats of secession, 556; anxiety to propitiate the South, 556; people of North classified as to policy to be preserved toward seceding states, 558; arguments of radical Republicans, 562; great diversity of opinion in the North up to time of Lincoln's inauguration, 563; war spirit fully aroused by firing on Fort Sumter, 6II

Dickey, Charles: 286

Dickinson, Daniel K.: 419 
District of Columbia: petitions to Congress for abolition of slavery in 69, 159; Gott's resolution for, 155; act abolishing slave trade in, 177

Dix, John A.: views on question of constitution protecting slavery in Territories, 50; Secretary of Treasury in Buchanan's Cabinet, 517 ; his celebrated dispatch inspires North, 540; mentioned, $326,544,574$

Dixon Archibald: his proposed amendment to Kansas-Nebraska bill, 195

Donaldson, J. B.: 250

Donelson, Andrew, J.: nominated by Americans for Vice-President in 1856, 295; mentioned, $42 \mathrm{I}$

Doolittle, James R.: 459

Doon, D. E.: 286

Dorsheimer, Philip: 285, 290

Douglas Stephen A.: resolutions offered by, in House on the Oregon boundary question, 119; supports policy of the Fiftyfour Forties, 120; reports various bills for territorial organization of Oregon, 147; career prior to beginning of 3Ist Congress, 165; his position on the Compromise Measures of 1850, 176; reports territorial bill for Nebraska Territory, 195; speech on bill in Senate, 206; passage of bill due chiefly to efforts of Douglas, 213; his temporary loss of popularity in the North, 215; reports bill for admission of Kansas as a State, 254; his speech in support of bill, 254; attempt of Senator Trumbull to commit Douglas on meaning of the Kansas-Nebraska A c t, 260 ; comments of Northern writers on his speech, 262; change in popular estimate of Douglas, 263; changes in relative standing of Douglas and Seward in public esteem, 263; Douglas's speech in answer to that of Sumner on "The Crime against Kansas," 268; acknowledged leader of Northern Democrats in 1856,297 ; opposes admission of Kansas under Lecompton constitution, 350; his speech, 351 ; idol of the "Young Democracy," 365; many Republicans favor his reêlection to Senate, 365; opposition of Buchanan Administration, 365; handicapped by his "popular sovereignty" doctrine, 366; efforts of Jefferson Davis for Douglas's political extermination, 389; Douglas refuses to yield to proslavery leaders, 392; he is the pivot of Charleston Democratic Convention in $1860,4 \mathrm{II}$; nominated for President by regular Democratic Convention at Baltimore in 1860, 436; his defiant attitude in Senate, 439; opposition to him of Buchanan Administration and of Southern political leaders, 439, 44I; his Southern speaking tour, 444; his bold stand for the Union, 444; his speech in Senate as member of Senate Committee of Thirteen in 36th Congress, 459; other speeches in 36 th Congress, 498; prominent figure at inauguration of Lincoln, 565; trusted adviser of Lincoln, 574; advises Welles and Seward of his apprehensions of Confederate attack on Fort Sumter, 505: on day of bombardment he proffers his aid to Lincoln, 611 ; his last public speech, 6II; mentioned, I65, 167, 446, 459

See: THE LINCOLN-DOUGLAS DeBates, Chap. XVII., p. 364

Draper, Simeon: 285,290

DRED SCOTT CASE: Chap. XV., p. 314: nature of case, 316; the judges of the Supreme Court, 320 ; the legal questions involved, 320 ; diversity of opinions of judges, 321 ; popular opposition in North to the decision, 325; establishes Calhoun's doctrine of constitutional protection of slavery in the Territories, 326; apprehension in North of ultimate results of 
DRED SCOTT CASE,-Continued decision, 329; popular belief in North that decision was part of a plot and that Buchanan was concerned in it, $33 \mathrm{I}$; views of historians, 334; correspondence between Buchanan and Justices Catron and Grier, 335; alteration of Taney's opinion before publication, 343; facts show gross breach of executive and judicial propriety, 339; Northern views as to how decision should be regarded, 344 ; importance of decision, 346; its political consequences, 346

Dunham, Cyrus, L.: 3 II

Durkee, Charles: 286

\section{Edgerton, S. E.: 286}

EFFORTS TO SUCCOR MAJOR ANDERson: Chapter XXIX., p. 597

Eggleston, Benjamin: 425

Eldon, Lord: 205

ELECTION OF PIERCE; REPEAL OF THE MISSOURI COMPROMISE: Chap. X., p. 184

Elliott, James: 285

Emancipation: progress of, in Southern States, Io

Emerson, Ralph Waldo: eulogy on John Brown, 381

English William, H.: his bill for settlement of Kansas troubles, 353; mentioned, 3 II

ENTRANCE OF SLAVERY INTO AMERICAN POLITICS: Chapter I., p. I

Equality of Rights: in Territories; Southern doctrine of, 40

Equilibrium of States: Southern doctrine of, as to slavery, 38 ; so managed for a long period as to keep free and slave States equal in number, 38

Era of good feeling: under President Monroe, 6I

Errett, Russell: $\mathbf{2 8 5}$

Evarts, William M.: at Republican National Convention in 1860 in interest of William $H$. Seward, 423; heads New York delegation, 425

Everett, Edward: as Governor of Massachusetts recommends legislation for suppression of
Abolition societies, 67; nominated for Vice-President by American party in 1860,422 ; arouses no enthusiasm, $44 \mathrm{I}$ Everts, Henry: 286

Faneuil Hall meeting: in Boston to indorse Compromise Measures of 1850,224

Farley, Joseph: 286

Federal courts: supremacy over State courts in deciding on federal statutes, 233

Federal party: opposition of New England Federalists to purchase of Louisiana, I7; some, on this account, favor dissolution of Union, 17; opposition of, to War of 1812, 18; one of chief causes of party's downfall, 19; many Federalists opposed to Alien and Sedition Acts, 21 ; party goes to pieces, 85; see Hartford Convention Fee, John G.: 286

Fessenden, William Pitt: speech in Senate on Kansas-Nebraska bill, 203; estimate of 203; crowning glory of his life his stand in opposition to impeachment of President Andrew Johnson, 204; his reply to Senator Butler, 204; undercurrent favorable to his nomination for President at Republican National Convention in 1860, 424; his opinion of Seward, 606; mentioned, 297

Field, David Dudley: in peace convention of $186 \mathrm{r}, 474$

Fifty-four Forties: character of their appeals, 120; opposition of Southern members of Congress, 120; their complete defeat, 142

See: THE OREGON BOUNDARY QUEsTION, etc., Chap. VII., p. III

Fillmore, Millard: nominated by Whigs for Vice-President in 1848, 149; nominated by Americans for President in 1856, 295

Financial panic of 1837: creates wide-spread distress, 85 
Finegan, Joseph: 547

Fish, W. B.: 286

Filch, Graham H.: one of Senate Committee to investigate John Brown raid, 386; mentioned, 3 II

Fitzpatrick, Benjamin: nominated for Vice-President by regular Democratic Convention at $\mathrm{Bal}$ timore in 1860 , but declines, 436

Florida: passes secession ordinance, $54^{8}$

Floyd, John: introduces resolution in House favoring measures for occupation and governmental control of Oregon country, I16; mentioned, 518

Floyd, John B.: Secretary of War in Buchanan's Cabinet, 516; assumed by secessionists to be friendly to secession, 516; transfer of arms to Southern States, 5I8; his conduct in relation to defense of Southern forts, 523; tries to induce President Buchanan to order Major Anderson's return to Fort Moultrie, 525; indicted for complicity in frauds in Department of the Interior, 525; in Cabinet meeting Floyd peremptorily demands that $\mathrm{Bu}$ chanan issue an order to Major Anderson to withdraw Garrison from Charleston harbor, 529; Floyd resigns and leaves Washington, 530; his subsequent career, 530; mentioned $517,526,537,543$

Fogg, George: 285

Foote, Henry S.: his book on War of the Rebellion, 46; his quarrel with Benton, I6I; resolutions of, in 3Ist Congress for territorial governments for California, Deseret, and New Mexico I67; resolutions submitted to Senate Committee of Thirteen in 36th Congress, 168; censured by Mississippi Legislature for voting for Compromise Measures of 1850 , but sustained by popular vote, $18 \mathrm{I}$

Foote, John A.: 285
Force bill: passage of, 29; Senator Calhoun's speech on, 29; Webster's reply, 30

FORCING THE ISSUES; THE COMPROMISE MEASURES OF 1850: Chap. IX., p. I 59

Forsyth, John: one of Confederate commissioners, $5^{85}$; his letter to Walker, Confederate Secretary of War, 586; his statement as to secret instructions of Confederate government, $5^{87}$

Fort Moultrie: abandoned by Major Anderson and at once occupied by South Carolina's military forces, 524

Fort Pickens: expedition for relief of, 591

Fort Sumter: most important fort in Charleston harbor, 520; Major Anderson assigned to command of, 520; Star of West sent to reẻnforce, 54I; until organization of Confederate government, works for bombardment in charge of South Carolina authorities, 575; preparations for bombardment vigorously pushed, 576; Lincoln orders expedition for relief of, 591; Seward's bungling interference, 600; supplies of provisions and mail cut off by Beauregard, 605; President Lincoln notifies Governor Pickens of intended supply of provisions, 609; Confederate authorities order bombardment without further delay, 6ro; the bombardment begins, 6ro; cffect on the North, 6II; see: Anderson.

Foster, Captain, John G.: ordered by Floyd to return muskets drawn from Charleston arsenal, 523

France: claims of, and treatise with, concerning Oregon country, 112

Free Democrat: anti-slavery paper established by Sherman M. Booth, 230

Free-soil party: in 1848 nominates Martin Van Buren for President and Charles Francis 
Free-soil party-Continued

Adams for Vice-President, I 50, nominates John $T$. Hale for President and George $W$. Julian for Vice-President in I 852,190

Fremont, John C.: nominated for President by Philadelphia Republican Convention in 1856 , 292 ; his qualifications as a votegetter, 293; his qualifications for President, 301

Frey, G. H.: 285

FROM I 820 TO I840: RISE OF ANTISLAVERY SENTIMEN" IN THE NORTH: Chap, V., p. 62

Fugitive Slave Law of 1793: its provisions, 217; effect of decision of Supreme Court of United States in case of Prigg vs. Pennsylvania, 218; passage by Northern States of personal liberty bills, 2r8; see: Prigg case.

Fugitive Slave Law of 1850: bills for, in 3 Ist Congress, 167 ; provisions of, 179; Northern opposition to, 184; failure of, to meet expectations of South 220; continued Northern opposition to, 221 ; efforts of politicians to suppress opposition to, 223; the slave catchers and kidnappers, 227; efforts of Pierce's Administration and federal officers to enforce law, 227; the Glover rescue cases and prosecution of Sherman L. Booth, 229; the Antony Burns case in Boston, 239; law practically a dead letter in North after 1854, 24I

See: NULlification AND HIGHER LAW, Chap. XI., 2 I 7

\section{Garland,_- 229}

Garrison, William Lloyd: establishes The Liberator, an anti-slavery paper, 64; he and his friends burn the United States Constitution, 77; they refuse to vote, 78 ; he is mobbed in Boston, 80; last issue of The Liberator, 82; estimate of his character and work, 82; he denounces Lincoln, after his nomination, 442

Garrison Abolitionists: refuse to vote in presidential election of 1860 and denounce all other parties, 441

Gassam, $\frac{1}{2}: 28$

Gaulden, W. B.: speech in Charleston Democratic Convention in 1860 favoring opening of African slave trade, 418

Geary, John W.: one of governors of Kansas, 348

Genius of Universal Emancipation: an Abolition newspaper established by Benjamin Lundy, 64

Georgia: early opposition to slavery, 6; later effects of slavery in, 7 ; never desired extinction of slavery, 9 ; legislature offers reward for arrest of William Lloyd Garrison, 67; Georgia convention votes to abide by Compromise Measures of 1850, I80; Georgia convention and platform, I8I; early Union sentiment in, 455; passes secession ordinance, 548

Georgia platform: 181

Germans in United States: German immigration to United States between 1820 and 1860,396 ; their political sympathies, 397; radicals among Germans opposed to repeal of Missouri Compromise, 400; sumptuary laws and Know-nothing party confirm allegiance of Germans to Democratic party, 400; on question of freedom or slavery great majority of Germans favored freedom, 400; loyalty to Union in American Civil War, 400; in campaign of 1860 , 443

Geyer Henry S.: one of attorneys in Dred Scott case, 317

Gibson, William H.: 285, 287

Giddings, Joshua R.: unites in address opposing the annexation of Texas, 105; speech in House on the Oregon question, I 3 ; verification of his prediction of President Polk's back- 
Giddings, Joshua R.-Continued down from his Oregon policy, 142; assists in preparation of an address to the Independent Democrats, 198; his opinion of the Fugitive Slave laws, 221; effort in Chicago Republican Convention to incorporate clause of Declaration of Independence in platform, 426; mentioned, $165,285,289,290$, 425

Glenn, D. C.: speech on withdrawing from the Charleston Democratic Convention in 1860 , 417

Glover, Joshua: his arrest as a fugitive slave and his rescue, 229

Goodrich, E. O.: 285

Golt, Daniel: resolution in the House for abolition of slavery in District of Columbia, 155

Grant, Ulysses: 66, 603

Great Britain: controversy with United States over Oregon question, 112; danger of war between, on Oregon controversy, 124

Greeley, Horace: his lament for defeat of Henry Clay for presidential nomination in 1848,152 ; his brief congressional career, 157; his early carcer, I88; founds New York Tribune, 188; member of committee on resolutions at Republican National Convention in 1860,426 ; mentioned, 281, 285, 287, 365, 423, 425

Green, James S.: denounces peace convention resolutions, 474

Greene, Albert, C.: I40

Grier, David: as federal judge, harshly enforces Fugitive Slave Law, 228; opinion in Dred Scott case, $32 \mathrm{I}$; correspondence with President Buchanan during pendency of case, 337; mentioned, 316, 32 I, 324, 339, 340, $341,342,343$

Grier, George M.: 285

Grimes, James W.: 204, 459

Grinnell, Moses H.: 428

Grose, William: 286
Grow, Galusha A.: 350,387

Guileau, Charles G.: 383

Guthrie, James: 419

Hale, John P.: political career prior to entrance into Congress, 164; nominated for President in 1852 by Free-soil party 190; speech in 36th Congress, 492 ; mentioned, 256, $276,297,603,605$

Hall, A. Oakey: 285

Hall, L. H.: 286

Hallett, B. F.: 225, 279

Hamilion, Alexander: opposed to dissolution of Union on account of purchase of Louisiana, 17

Hamlin, Hannibal: nominated for Vice-President by Republican National Convention in 1860 , 432; mentioned, 297

Hammond, James: speech in U. S. Senate in 1858,354

Hannegan, Edward $A .:$ resolutions offered by, in Senate on the Oregon question, 119, 134, 138; his message to Philadelphia Democratic meeting, 120; speech in Senate on the Oregon question, 123; accuses Southern Democrats of bad faith in Oregon matter, 134: his speech in reply to Senator Haywood, 138; his subsequent career, 142

Hanway, Castner: prosecution of, for treason, 228

Harmon, $0 .: 286$

Harper's Ferry: John Brown raid on, 381

Harris, Edward: 285

Harris, Ira: 606

Harrison, Benjamin: signer of Declaration of Independence, 88

Harrison, Benjamin, ex-President: 3 II

Harrison, John Scoll: 421

Harrison, R. D.: 286

Harrison, William Henry: nominated for President by Whigs in r840, 86; his political and civil record, 87; his record on slavery question, 89; his campaign speeches, 97; his inaugural address, 103; his death, 103 
See: THE POLITICAL CAMPAIGN OF 1840, Chap. VI., 85 .

Hartford Convention: its proceedings and objects, 18

Harvey, James $E_{0}:$ his dispatches to Confederate authorities, 60I

Haskin, John B.: 387

Hassaurek, Fred: 425

Hawthorne, C. G.: 286

Hayne, Robert $Y$.: debate between him and Daniel Webster on nullification, 28

Haywood, William H.: speech in U. S. Senate defending President Polk's Oregon policy, 138

Hazzard, R. G.: 285

Heaton, Jacob: 285

Helper's "Impending Crisis": its political effect, 380,407

Hendricks, Thomas A.: favors establishment of a Northwestern Confederacy, 579; mentioned, 3 I I

Herald of Freedom: indicted; office destroyed, 249

Higher law doctrine: William $\mathrm{H}$. Seward's announcement of, 174 ; Joshua R. Giddings on, I74; Lord Brougham on, 175; grounds of, 219; Theodore Parker on, 219; as applied to Fugitive Slave Law, 219; Webster on, 226; Seward's advocacy of, one of causes of his defeat in 1860,429

See: NULLIFICATION IN THE NoRTH, Chap. XI., p. 217.

Hillard, George S.: 42I

Hitchcock, C.: 285

Hoadley, George: 290

Hoar, E. Rockwood: 245

Hollowell, Abner R.: 285

Holt, Joseph: with aid of General Scott prevents capture of Washington by Confederates prior to inauguration of Lincoln, 516; Postmaster-General and afterwards Secretary of War in Buchanan's Cabinet, 517; his loyalty disappoints Confederates, 539; mentioned, 519, 530, 542, 574

Hord, Oscar, B.: $3 \mathbf{I I}$

Hosmer, Rufus: 286

House Committee of Thirty-three: in 36th Congress, 459; considers numerous peace propositions, 46r; reports seven resolutions, together with nine minority reports, 463 ; resolutions passed near close of session, 463

Howard, H.: 286

Howard, Jacob M.: 286, 606

Howard, Mark: 285

Howard, William A.: one of House Kansas investigating committee, 348

Howell, Mark: 285

Hunkers: origin of term, $15 \mathrm{I}$

Hunt, Washington: President of the American National Convention at Baltimore in 1860 , $42 \mathrm{I}$

Hunter, -433

Hunter, Robert M. T.: member of Senate Committee of Thirteen in 36th Congress, 459; denounces peace convention propositions, 474; mentioned, 419, 526

Huntington, Jabez: 140

Hurlbut Stephen A.: sent by Lincoln to Charleston S. C., 589

Hutchinson, O. A. K.: 285

Illinois: Acquiescence of people of, in Compromise Measures of 1850, I86; strong pro-slavery sentiment in Southern part, 405; in presidential campaign of 1860,445

Indiana: acquiescence of people in Compromise Measures of r850, I 86; strong pro-slavery sentiment in Southern part, 405; in presidential campaign of 1856,445

Indianapolis Journal: at first favored letting seceding States "go in peace," $56 \mathrm{r}$

Ingersoll, Charles J.: resolutions introduced by, in House, on the Oregon question, I 19

Irrepressible conflict: See Seward. Iverson, Alfred: speech in 36th Congress, 480 ; mentioned, 455

Jackson (Mich.): first Republican Convention there, 282 
Jackson, Andrew: his election and administration, 62; mentioned, $551,5^{82}$

Jackson, Colonel Zadoc: 250

James Charles T.: 199

Jarvis, H.: 286

Jefferson, Thomas: prepares draft, of Kentucky resolutions of $\mathbf{1 7 9 8}$, 21; his construction of, 27; opposed to prohibiting slavery in Missouri, 57; foreboding on account of members of Congress dividing on geographical lines, 58

Jeffreys, Lord: 325

Jerry Rescue Case: 222

Johnson, Andrew: 166, 204, 419

Johnson, Francis C.: 285

Johnson, Henry: 140

Johnson, Herschel V.: nominated for Vice-President in 1860 , 436

Johnson, O. U.: 286

Johnson, Reverdy: speech on the Oregon question, 125; one of attorneys in Dred Scott case, 317; mentioned, 140

Johnson, Richard $M$.: sung out of campaign of 1840,100 ; presides at Oregon convention at Cincinnati in 1843,114

Jones, David: 286

Jones, Samuel J.: 250

Jones, Whitney: 286

Judd, Norman B.: one of Lincoln's managers in Republican National Convention in 1860, 423; mentioned, 425

Judicial decisions: popular view of, 325

Julian, George $W .:$ nominated for Vice-President in 1852 by Freesoil party, 190; mentioned, 165 , 286, 298, 3I I

Kane, John $K$.: ruling in Passmore Williamson case, 228

Kansas: efforts to make Kansas a slave State, 243; territorial legislature and laws, 246; adoption of Lecompton Constitution, 247; the Topeka Constitution, 247; lawless condition of Territory, 247, 251; President Pierce's message and proclama- tion, 248; Douglas bill for admission of Kansas, 254; debates upon it, 254; affars in Kansas grow worse, 348; Congressional Committee's report, 348; President Buchanan's message recommending admission under Lecompton Constitution, 350; debates upon it, 350; bill defeated in House, 352 ; English bill passed, $35^{2}$

See: POPULAR SOVEREIGNTY IN PRACTICE, Chap. XII., p. 243; CONTINUATION OF THE IRREPRESSIBLE CONFLICT, etc., Chap. XVI., p. 348

Kansas Free State: indicted, 249; office destroyed, 251

Kansas-Nebraska Act: Douglas's bill, 195; new bill reported, 196; origin of clause repealing the Missouri Compromise, I97; debates on bill, 199; final vote on, 212; consequences of the repeal, 214, 216; meaning of repealing clause, 214

See: ELECTION OF PIERCE AND REPEAL OF THE MISSOURI COMPROMISE, Chap. X., p. 184 . KANSAS TROUBLES: see Chap. XII., p. 243

Kasson, John A.: 425

Keitt, Lawrence: mentioned, 271, 273

Kelley, William B.: 425

Kellogg, William: 386

Kemper, F.: 286

Kennedy, Anthony: votes against bill to admit Kansas under the Lecompton Constitution, $35^{2}$

Keniucky: Union sentiment in castern part, 456

Kentucky Resolutions of I790: origin and nature of, 22, 24

Kerr, Michael C.: $31 \mathrm{I}$

Kidnappers, the: $\mathbf{2 2 7}$

Kimball, F. D.: 285

King, A ustin A.: 433

King, Horatio: succeeds Holt as Postmaster-General, 517

King, John A.: 285, 290

King, Preston: $165,285,290,425$

King, Rufus: speech in support of Tallmadge's amendment to the Missouri bill, $5^{6}$ 
Know-nothing party: see American party

Lamar, G. B.: agent of South Carolina in purchase of arms from Floyd, Secretary of War, 5 I 8

Lamon, Ward $H$.: sent by Lincoln to Charleston, 589

Lane, Henry S.: president of Philadelphia Republican Convention in 1860 , his appearance and speech, 290; mentioned, 298, 3 I I , 3 I 2, 430, 605

Lane, James: 296

Lane, Joseph: nominated for VicePresident in 1860,437

Lawrence (Kansas): first settlers, 245 ; sack of, $25^{\circ}$

Leader, William Y.: 272

Lecompte, Judge S. D.: his charge to Kansas grand jury, 249

Lecompton Constitution: 247

Lecompton Constitutional Convention, 247

Legare, Hugh B.: succeeds Daniel Webster as Secretary of State in President Tyler's Cabinet, I04

Leland, E. S.: 286]

Le Moyne, Francis: nominated for Vice-President by Abolitionists in 1840,89

Lewis, Elijah: prosecution of, for treason, 228

Liberator, The: Abolition newspaper established by William Lloyd Garrison, 65

Liberty party: nominates James G. Birney for President in 1844 , 107; nominates Gerrit Smith for President and Samuel McFarland for Vice-President in $1860,44 \mathrm{I}$

Lieber, Francis: 387

Lincoln, Abraham: takes active part in presidential campaign of 1848,151 ; his congressional record I56; receives I Io votes for Vice-Presidential nomination in Philadelphia Republican Convention in 1856,292 ; on the Dred Scott decision, 33I, 345; chosen by Illinois Republicans to oppose Douglas for U. S.
Senate in 1858,364 ; LincolnDouglas debates, 364 ; his visit to Thurlow Weed, 365; Lincoln on John Brown, 385 ; his Cooper Institute speech, 394; candidate for presidential nomination in Republican National Convention of 1860,423 ; his nomination $43 \mathrm{I}$; refrains from entering upon a speaking campaign, 44r; receives plurality but not a majority of the popular vote, 446; his opinion on compromise propositions, 5II; starts from Springfield, Illinois, to Washington to be inaugurated, 565 ; the inauguration, 565; conciliatory tone of inaugural address, 566; how he was then regarded in the South, 567; selection of his Cabinet, 567; difficulties confronting him, 570; the officeseekers, 572; not yet fully trusted in the North, 573; Douglas one of his trusted advisers, 574; selecting a policy, 576 ; who could have done better in his situation? 582 ; his war policy forced upon him, 582; his Cabinet, 583; Seward's "suggestions," 59I; Lincoln's answer, 593; to the last Lincoln hoped for peace, 608; issues call to arms on April 15, 186I, 612 ; mentioned, 298, 564

See: LINCOLN-DOUGLAS DEBATES, Chap. XVII., p. 364; THE COMING OF LINCOLN, Chap. XXVII., p. 565; ADMINISTRATION POLICIES, Chap. XXVIII., p. 578

LINCOLN-DOUGLAS DEBATES: Chap. XVII., 364; doubts as to Lincoln's ability to cope with Douglas, 365; how Douglas was handicapped, 365 ; seven joint debates arranged for, 370; general character of the speeches and characteristics of $t h e$ speakers, 370; Lincoln's answers to Douglas's arguments, 37 I ; secret strength of Lincoln's speeches, 375; examples of his oratory, 375; Lincoln forces Douglas to advocate $h$ is 
INCOLN-DOUGLAS DEBATES-Con. doctrine of "unfriendly legislation," 376; respective abilities of Lincoln and Douglas as political debaters, 378; results of the debates, 378

Linn, Lewis $F .:$ resolutions of, in Senate on the Oregon question, 117

Local self-government: in New England, I

Locke, John: his social contract theory, 20

Logan, John A.: 386, 4 I I

London (Eng.): Oregon treaty concluded there, I 12

Lord, L. L.: 285

Loring, Edward G.: 77

Louisiana: opposition of $\mathrm{New}$ England Federalists to acquisition, 17; division of Territory, 55; State passes ordinance of secession, 548

Love, Israel S.: 286

Lovejoy, Elijah: murdered by antiAbolitionists at Alton, Illinois, 80; meeting to denounce murderers at "Faneuil Hall, in Boston, Mass., 80

Lovejoy, Owen: his prayer in opening Pittsburg Republican Convention, 287; speech in 36th Congress, 388 ; mentioned 286 , 573

Lovelt, I. S.: 286

Low, Sigismund: 285

Lundy, Benjamin: associated with William Lloyd Garrison in publishing the Genius of Universal Emancipation, an Abolition newspaper, 64

Lynde, William P.: 235

Madison, James: his prediction of Southern secession, 16; prepares draft of Virginia resolutions of 1798,23 ; his report, 25; his construction of Virginia and Kentucky resolutions of 1798,27

Maine: admission of State, 59; State election in 1860 encourages Republicans, 445

Maine liquor law: for a time diverts attention from slavery, 282
Mann, Abijah: chairman of resolutions committee in Pittsburg Republican Convention, 287; mentioned, 285

Mann, Horace: 165

Mansfield, Lord: 205

Markle, C. P.: 285

Markle, Joseph: 285

Marshall, Humplirey: 165

Maryland: refuses to secede, 456

Mason, James $M_{\text {.: }}$ letter of, advising secession in event of election of Fremont, 363 ; one of Senate Committee to investigate John Brown raid, 386; denounces propositions of Peace Convention of 1861,473 ; speech in 36th Congress, 483

Massachusells: Presidents from, prior to 1829,62 ; legislative resolutions against annexation of Texas, threatening dissolution of Union, 106; cotton manufactories in, in 1850,186 ; personal liberty laws, 218,241 ; military preparations in anticipation of Civil War, 577; prompt response of, to Lincoln's call for troops, 612

Maverick, Samuel: punished for presenting petition for redress of grievances to Massachusetts General Court, 68

Medill, Joseph: 286

Methodists: general conference in 1836 censures preachers for addressing Abolition meetings, 77

Mexico: war with, 143; by terms of treaty large tract of Territory ceded to United States, 143; Mexico unsuccessfully attempts to get provision in treaty prohibiting slavery in the ceded Territory, 144

See: WAR WITH MEXICo, etc., Chap. VIII., p. 143

Miller, A. V.: 231, 236

Miller, Jacob W.: I40

Milwaukee, Wis.: excitement there over rescue of Joshua Glover, 230

Mississippi: votes against secession in $1850,18 r$; Senator Foote, censured for voting for com- 
Mississippi-Continued promise measure of 1850 but sustained at next election, $18 \mathrm{r}$; State passes ordinance of secession, 548

Missouri: organization of Territory, 55; admission of State, 59; refuses to secede, 456

MISSOURI COMPROMISE; BEGINNING A NEW POLITICAL ERA: Chap. IV., p. 55; petition of inhabitants of Missouri for admission, 55; Tallmadge's amendment prohibiting slavery, 55; arguments for and, against it, 56; Southern threats of secession in connection with it, 57; members of Congress divide on geographical lines, 58; Jefferson's forebodings on this account, 58 ; questions in relation to, submitted by President Monroe to his Cabinet, 59; Clay's efforts for admission of State under slave constitution, 60; compromise favored by Southern leaders, 60; eulogy of compromise by Stephen A. Douglas, 6r; James Buchanan's approval of it, xIo; subsequent efforts to extend Missouri Compromise line to Pacific Ocean, 148; repeal of, 213

See: The Election of Pierce; Repeal of the Missouri Compromise, Chapter X., p. I84

Mob Year (1835): 79

Mobile Mercury: advises attack on Fort Sumter, 608

Monroe, James: elected President, 13; submits questions relating to Missouri Compromise to his Cabinet, 59; his reēlection and the "Era of good feeling," 62

Monroe Doctrine: had no influence in settling Oregon controversy, 112

Montgomery, Ala.: meeting of Confederate Congress there, 656

Moorhead, J. H.: 285

Morgan, Edward W.: appointed chairman of Republican National Committee in 1856,288 ; one of tellers in Philadelphia Republican Convention in 1856 ,
292; calls Republican National Convention in 1860 to order, 425: mentioned, 285, 289, 290

Morrill, Lot M.: in Peace Convention of 1861,467 ; mentioned, 605

Morton, Oliver P.: Republican candidate for Governor of Indiana in 1856,311 ; his speech on the Dred Scott decision, 345; vigorously opposes policy of letting the seceding States "go in peace," 562; his efforts to place Indiana on a war footing, 577; speech on danger of a Southern confederacy to interior Western States, 580; mentioned, 286, 289, 298, 3II, 3I2, 603

McCabe, R. B.: 285

McClernand, John A.: 165, 41I

McClure, A. K.: 423

McCook, George: $4 \mathrm{II}$

McDonald, Joseph E.: mentioned, I65,31I

McFarland, I.: 286

McFarland, Samuel: nominated for Vice-President by Liberty party in $1860,44 \mathrm{I}$

McLean, John R.: candidate for presidential nomination in Philadelphia Republican Convention in 1856, 292; his opinion in the Dred Scott case 320; candidate for presidential nomination in Republican National Convention in 1860 , 523; mentioned, 316, 320, 32I, 340,342

McLean, Washington: $4 \mathrm{II}$

McMillen, John H.: 286

Nashville, Tenn: convention meets pursuant to address of Southern members of Congress in 1850; its proceedings, 180

National Era: publishes Uncle Tom's Cabin, 187

Native A merican Party: rise of, 107 Nebraska: bill for territorial government; Dixon's amendment, 195; see: Kansas-Nebraska bill Nelson, Samuel: opinion of, in Dred Scott case, 318; mentioned, 316, 320, 321, 328, 339, 342,343 
New England: people of English Puritan stock, 1; local selfgovernment in, I; natural antagonism between New England and slave States, II; reason of New England for opposition to slavery agitation after Compromise Measures of 1850, 186; cotton manufactories in New England, 186

New England Emigrant Aid Sociely: organization, 243 ; sends armed emigrants to Kansas, 245

New England Federalists: opposition of, to acquisition of Louisiana, 17; opposition to War of 1812,18

New Hampshire: loyalty in the Civil War, I9I

New Mexico: inhabitants petition for territorial government without slavery, I54

New Orleans Bee: indorses Harrison for President, 92

New York: response of, to Virginia and Kentucky resolutions of 1798, 24; Democratic party in, splits on slavery question in 1848, 150; condition of politics there in 1848, I50; New York delegation in Republican $\mathrm{Na}$ tional Convention in 1860,424 ; strong feeling in, favorable to conciliating the South, 557; military strength at beginning of Lincoln's Administration, 577

New York Evening Post: comments on Justice Grier's conduct in case under Fugitive Slave Law of 1793,228

New York Tribune: its great influence in developing anti-slavery sentiment in the North, 188; influence in presidential campaign of 1860, 443; at first favored letting the seceding States "go in peace," 560; its editorials quoted by Jefferson Davis in support of right of secession, 561

Newsom, T. M.: 286

Niles, John M.: 285

Noell, John W.: his peace proposition, 462
Nom-inlerference with slavery in Territories: Southern doctrine of, 45

Nom-slaveholding white voters in South: how induced to favor secession, $45^{8}$

North, the: difference between Northern and Southern colonies, I; gain of North over South in commercial prosperity, I5; solid North against solid South in 1860, 406; division of sentiment in North as to course to be pursued toward seceding States, 558; shameful concessions to seceding States proposed in North prior to Lincoln's inauguration, 558; North wholly unprepared for war, 577; effect on North of the firing on Fort Sumter, 61 I

See: FROM 1820 TO 1840 ; GROWTH OF ANTI-SLAVERY SENTIMENT IN THE NORTH, Chap. V., p. 62; NULLIFICATION IN THE NORTH, Chap. XI., p. 217 ; DEVELOPMENT OF WAR SPIRIT IN THE NORTH, Chap. XXVI., p. 556.

North Carolina: concessions to slavery in cessions of North Carolina to United States, Io; for a time refuses to secede, 456

Northern churches and clergy: early hostility to slavery agitation, 76,187

Northern colleges: early hostility to slavery agitation, 186

Northwest Territory: failure of slavery to get a foothold in, I3

Northwestern Confederacy: efforts to establish, 579

Nullification: the Kentucky and Virginia resolutions of 1798-9, 25: great debate on, between Daniel Webster and Colonel Robert Hayne, 28; nullification in South Carolina in $\mathbf{1 8 3 2}$, 28

NULLIFICATION AND BIGHERLAW IN THE NORTH: Chap. XI., p. 217 ; opposition in North to execution of Fugitive Slave Law of 1850, 218; Shadrach rescue 
NULlifiCATION, ETC.-Continued case, 222 ; the Jerry rescue case, 222; the Glover rescue case, 229; Wisconsin election turns on question of States'-rights, 235; Wisconsin Supreme Court refuses to obey mandate of Supreme Court of United States, 236; public meetings held in Wisconsin denouncing the federal judges, 236; State legislature passes resolutions affirming nullification doctrine of Virginia and Kentucky resolutions of 1798, 236; Antony Burns case, 239; additional personal liberty laws passed in several Northern States, 240; after I 854 Fugitive Slave Law practically a dead letter in many sections of the North, 24I

See: NULLIFICATION IN THE NORTH, Chap. XI., p. 2 I 7

Ogle, Charles: campaign speech in the U. S. House of Representatives in 1840 against Martin Van Buren, 96

Oglethorpe, Governor: 6

Ohio: acquiescence in Compromise Measures of $185^{\circ}$, I86; opposition to slavery in Northern Ohio, 404; in presidential election of I860, 404, 445; bills favoring adoption of constitutional amendments proposed by peace convention, 557

Oliver, Mordecai: one of House Committee to investigate Kansas affairs, 348

OREGON BOUNDARY QUESTION; POLK'S BACK-DOWN : Chap. VII., p. II I; what included in Oregon country, III; long pending controversy over between Great Britain and United States, III; convention at Cincinnati in 1843 favoring governmental action, II4; resolutions and bills in Congress on subject prior to I844, I I5; President Tyler's message in relation to, II7; Democratic National platform in 1844,117 ; Polk's inaugural address and message, II7; new bills and resolutions in Congress, 119 ; notable speeches, I2I; shifting of party lines in Congress, 130 ; Polk's change of policy, 138; final compromise, 139; complete defeat of the Fifty-four Forties, 142; what the South gained, 142

Orr, James C.: one of the three South Carolina commissioners to treat with the United States, 449; mentioned, I64

Orth, Godlove S.: one of tellers in Philadelphia Republican Convention in 1856,292 ; mentioned, 3I I

Page, A. J.: 286

Paine, Byron: 234, 235

Pakenham, Lord: 139

Pardee, E.: 286

Parker, Samuel: 3 II

Parker, Theodore: steadfast opponent of slavery, 79; on "higher law," 219 ; letter of Sumner to, 265; eulogizes John Brown, 38I

Pate, Captain: defeated by John Brown in battle of Black Jack, 252; mentioned, 296

Paulison, C. M. K.: 285

Peace Convention of 1861 : invita. tion to attend given by State of Virginia, 460; invitation not enthusiastically received in the North, 465; convention meets in Washington and organizes, 466; great divergence of views, 467 ; various constitutional amendments proposed, 471 ; the proposed amendments $\mathrm{de}$ nounced in Senate, 474 ; action of Senate and House, 476

Peace panaceas: various peace propositions considered in 36 th Congress, 461; congressional debates on, 478; attitude of Republicans on, 491; Lincoln's opinion of, $5 \mathrm{II}$; shameful concessions proposed in the North, 557

See: PREPARING PEACE PANACEAs, Chap. XXII., p. 459

Peck, H. E.: 286

Pennington William: elected Speaker, H. R., 387 
Pennsyluania: Republican majority in State election in 1860 , 445

Peoples' party: temporary organization under name of, $\mathbf{2 8 2}$

Personal liberty bills: of Northern States, 218,240

Petilion, right of: attempt in Congress to suppress, 68

Phelps, Samuel S.: 140

Philadelphia (Pa.): strong feeling there in favor of conciliating the South, 557

Philanthropist, the: Abolition newspaper, 64

Phillips, Wendell: his speech at Lovejoy meeting in Faneuil Hall, Boston, 80; praises Byron Payne for argument in the Booth case, 235; eulogizes John Brown, 381; denounces Lincoln, in presidential campaign of I 860, 442

Pickens, Francis W.: Governor of South Carolina; restrained from premature bombardment of Fort Sumter, 549, 575; courteously receives Ward $\mathrm{H}$. Lamon, sent by Lincoln, 589; mentioned, 524

Pickens, Fort: expedition for relief of, 590, 600

Pierce, Franklin: nominated and elected by Democrats for President in 1852, 189, 190; estimate of, I 90; appoints Jefferson Davis Secretary of War, 19I; his prediction of result in event of civil war, 191; his inaugural address, 192; aids in repeal of Missouri Compromise, 197; efforts to enforce Fugitive Slave Law of $1850,227,239$; his efforts to force slavery upon Kansas, 283; his last annual message, 305; his subsequent career, 309

See: THE ELECTION OF PIERCE, etc., Chap. X., p. 184

Pinckney, William: opposes Tallmadge's amendment to Missouri bill, 56

POLITICAL CAMPAIGN OF I 840; TIPPECANOE AND TYLER TOO: Chap. VI., p. 85
POLITICAL CAMPAIGN OF I 860 : Chap. XIX., p. 406

POLITICAL CAMPAIGN OF 1860 (continued): Chap. XX., p. 423

Political Campaigns:

1840: characteristics of, 93 ; the campaign speeches, 96; preeminently a singing campaign, 98; campaign a carnival of hilarity, 100; efforts of politicians during campaign to smother agitation of slavery question, I02; Harrison elected, IO3; see: THE POLITICAL CAMPAIGN of 1840, etc., Chap. VI., p. 85

1844: generally, 107

I848: generally, 148

1852: generally, I89; Democratic party at zenith of its power, 189; marks downfall of Whig party, 189; Compromise Measures of $185^{\circ}$ endorsed by both Democrats and Whigs, I89; overwhelming Democratic victory, 190

1856: generally, 296; new political leaders, 297; campaign characteristics, 299; marked difference between campaign of 1856 and that of 1840,301 ; elements of Democratic strength, 301; Buchanan elected, 302; Southern threats of secession during the campaign, 302; Fremont's defeat not a national calamity, 303; views of John Sherman and Andrew D. White, 304; author's personal recollections of the campaign, 310 , note

See: BIRTH OF THE REPUBLICAN PARTY, etc., Chap. XIV., p. 278.

1860: preparing for the campaign, 379; sources of Republican gains, 395; the German vote, 396; Western vote, 401 ; period of intense political excitement, 406; Southern contempt for people of North, 407; Democratic National Convention at Charleston, S. C., 410; American National Convention, 421 ; Republican National Convention in Chicago, 423; Demo- 
Political Campaigns-Continued cratic National Convention at Baltimore, 432; the Baltimore Seceders' Convention, 436; the Richmond Seceders' Convention, 437; all political interest centers on slavery question, 440 ; American party and its candidates, 44I; the Garrisonian Abolitionists, 44I; progress of the campaign, 44I; Seward's speaking tour, 442; Carl Schurz, 442 ; great influence of New York Tribune, 443; opposition of Buchanan's Administration and Southern pro-slavery leaders to Douglas's Southern speaking tour, 444; the October election favorable to Republicans, 445 ; Douglas cancels Northern speaking engagements and goes South to try to stem secession tide, 446; Lincoln elected by a plurality but not a majority of popular votes, 446; an evermemorable campaign, 446

See: PREPARING FOR PRESIDENTIAL CAMPAIGN OF I860, Chap. XVIII., p. 379; THE POLITICAL CAMPAIGN OF I860, Chap. XIX., p. 406; THE POLITICAL CAMPAIGN OF I860, (continued), Chap. XX., p. 423 .

Political conventions: see special titles

Political machines: power of, $45^{8}$

Political parties: disintegration of old parties prior to $. \mathbf{1 8 2 9}, 86$; after repeal of Missouri Compromise, 280; slow growth of political parties, 280

Polk, James $K$.: nominated and elected President in 1844,107 ; speech in Congress in 1828 , against organizing territorial government for Oregon, I I6; his Oregon policy, I I7; how change of policy was carried through Congress, 138

See: THE OREGON BOUNDARY QUESTION, Chap. VII., p. I I I

Pomeroy, Samuel C.: 606

Popular sovereignty: a makeshift policy, 44; Senator Calhoun opposed to, 44 ; efforts of Trumbull and others to get Douglas to define, 259; seeming endorsement of, in Democratic platform of 1856,293 ; effect on, of Dred Scott decision, 327; Lincoln on, 367 ; doctrine repudiated in South in 1860,445

See: POPULAR SOVEREIGNTY IN PRACTICE, Chap. XII., p. 243.

POPULAR SOVEREIGNITY IN PRACTICE, Chap. XII., p. 243

Porter, Albert G.: 3 I I

Pottawatomie massacre: 253

Potter, John W.: his quarrel with Pryor, 388; mentioned, 423

Powell, Lazarus W.: 459, 475

Pratt, Daniel: 3 I I, 425

PREPARING FOR THE POLITICAL CAMPAIGN OF I860; SOURCES OF REPUBLICAN GaINS: Chap. XVIII., p. 379

PREPARING PEACE PANACEAS: Chap. XXII., p. 459

Prigg case: decision of U. S. Supreme Court in, 217

Pryor, Roger A.: his quarrel with Potter, 388; speech in 36th Congress, 507; speech at Charleston, S. C., 609; mentioned, 423

Pugh, George E.: at Charleston Democratic Convention in 1860 , submits report of minority committee on resolutions, 412; his speech in the convention, 4I5; mentioned, 392, 4II

Puritans: in New England, I; few in Southern colonies, 2; characteristics of New England Puritans, 5

Quakers: of Indiana; silence two preachers in 1842 for opening their meeting houses to Abolition speakers, 77

Quincy, Josiah: his speech against acquisition of Louisiana, I3

Racine, Wis: excitement there over capture of Joshua Glover, 230

Randall, B.: 285

Randall, C.: 285 


\section{Index}

Rondalph, John: during discustion of Missouri bill proposes that Southern members withdraw from Congress, 58; his quarrel with Henry Clay, 60; invents term "Dough-face," 60

Rankin, S. P.: 286

Raymond, George: 285

Redpath, James: 286

Reeder, Andrew J.: one of Governors of Kansas, 306; issues proclamation for new election in Kansas, 306; contested election case between him and John W. Whitfield, 348; mentioned, 348,425

Reemelin, Charles: 285

Republican National Conventions: 1856: The Pittsburg Convention: call for meeting, 283 ; names and character of delegates, 284; Owen Lovejoy's prayer, 287; speeches of Horace Greeley and others, 287 ; resolutions adopted, 288; comments on character of convention and platform, 288

1856: The Philadelphia Convention: call issued for, 289; Henry S. Lane chosen president; his appearance and speech, 290: the platform, 291: John C. Fremont nominated for President and William L. Dayton for Vice-President, 292; Abraham Lincoln received I ro votes for Vice-President, 292; why William $H$. Seward was not nominated for President, 292; Fremont's qualifications as a votegetter, 293

1860: convention assembles in Chicago, 423; the presidential candidates and their "boomers" and managers, 423; campaign curiosities exhibited, 423; prominent delegates present, 425; organization of convention, 425 ; George William Curtis aids Joshua R. Giddings to incorporate in platform part of the Declaration of Independence, 426; the platform, 427; early indications point to nomination of Seward for President, 428; prediction of James G. Blaine,
428; objections urged against the nomination of Seward, 429: the balloting, 432; Abraham Lincoln nominated for President and Hannibal Hamlin for VicePresident, 43I

Republican party: not the successor of any other, 280; meeting of opponents of slavery at Ripon, Wis., 28I ; finding a party name, 281; abatement of enthusiasm of Republicans in 1857,353 : recovery by end of year 1858 , 363; sources of gains, 395 ; change in attitude of Northern churches and colleges, 395; Republican gains from the Germans, 396; gains in the West and Northwest, 40r; new Republican leaders in the West, 405

See: BIRTH OF REPUBLICAN PARTY, etc., Chap. XIV., p. 278

See also: political CAMPAIGNS; POLITICAL CONVENTIONS Rhett, Robert B.: 235

Rice, Henry: 459

Richardson, William A.: his Kansas-Nebraska bill, 202; mentioned, 165, 411

Richmond, Dean: 411

Richmond Enquirer: approves Brooks's assault on Sumner, 276: also advises chastisement of Senators Wilson and Hale, 276; advocates secession in event of election of Fremont, 303

Richmond Examiner: vouches for Buchanan's orthodoxy on the slavery question in 1856,296

Ripley, D.: $\mathbf{2 8 5}$

Ripon, Wis.: meeting there in 1854 of opponents of slavery, 281

Robertson, John: Senator from Illinois, votes in favor of Calhoun's bill to prohibit circulation of Abolition newspapers, etc., 68

Robertson, Judge John: sent by Virginia on peace mission to other Southern States in 1861 , $46 \mathrm{I}$; failure of mission, 512

Robinson, Charles: Free-state Governor of Kansas; arrested and imprisoned by pro-slavery men on charge of treason, 249 
Robinson, John L.: 3I I

Rogers, R.: 286

Roman, Andre B.: one of Confederate commissioners to treat with the United States, 584

Rousseau Jean Jacques: social compact theory, 20

Russ, Horatio G.: 285

Russell, William Howard: his impressions of Southern feeling in $\mathrm{I} 86 \mathrm{I}, 408$

Russia: boundary line between Russia and Great Britain in North America, I I I

Rynders, Isaiah: 4II

Sackett, William A.: $\mathbf{2 8 5}$

Samuels, B.M.: submits report of minority of resolutions committee in Charleston Democratic Convention in 1860,416

Sandford, John F. A.: 316

Schurs, Carl: supports Seward for presidential nomination in $\mathrm{Re}$ publican National Convention in 1860, 423; speeches have great weight with German voters, 442 ; mentioned, 370,425

Scolt, Winfield: nominated by Whigs for President in 1852, 189; his stumping tour, 190; cooperates with Holt, Secretary of War, to prevent capture of Washington by Confederates, 516; incensed at being ignored by Floyd, Secretary of War, 527; Scott's subsequent advice and coopperation, 540; his opinion of feasibility of attempting to aid Major Anderson, 588; mentioned, 587

SECESSION, BEGINNINGS OF: Chap. II., p. I5

SECESSION IN BLOOM: Chap. XXI., p. 449

Secession and Secessionists: beginnings of secession, I6; how doctrine was understood in South, I9; right of secession advocated by John C. Calhoun, 29; Daniel Webster's answer to 30 ; right of, generally believed in South, 36; threats of, during discussions of the Missouri bill, 57 ; threats of, in campaign of
I 856, 302; contemplated before Lincoln's election, 450; Union sentiment in the South, 455; how secession feeling promoted, 457 ; speeches of secession members of Congress on withdrawing, 512; original plans, 515; errors in original plans, 542; change of plans after reorganization of Buchanan's Cabinet, 544; revolutionary council organized at Washington, 544; why secession members of Congress did not all go out at once, 547; ordinances of secession passed by seceding States, 548 ; seizure of U.S. forts and arsenais in the South, 548; organize Confederate government, 548; defiant attitude of secessionists between election and inauguration of Lincoln makes profound impression on the North, 562; feeling in border slave States, 563

See: THE BEGINNINGS OF SECESSION, Chap. II., p. I 5 ; SECESSION IN BLOOM, Chap. XV., 449 Seddon, James A.: speech of, in Peace Convention of 1861,467 Senate Commitlee of Thirteen: in 36th Congress; appointment, results of its deliberations, 459

Seward, Dudley: 286

Seward, William $H$.: early political career, I08; estimate of, 108; his speeches in campaign of 1844 , 109; takes active part in presidential campaign of I 848, I5I ; his higher-law speech in 3 Ist Congress on the Compromise Measures of 1850,174 ; speech on Kansas-Nebraska bill, 20I; second speech on the bill, 202; introduces bill for admission of Kansas under Topeka Constitution, 255; his speech in reply to Douglas on bill for admission of Kansas, 256; change in public estimation of him and Douglas, 263: why he was not nominated in Philadelphia Republican Convention, 292; a prominent Republican leader in campaign 
Seward, William $H$.-Continued of 1856, 299: his charges in relation to the Dred Scott case, 332; his irrepressible conflict speech, 360 ; his speech in 36 th Congress, 393; candidate for presidential nomination at Republican National Convention in 1860,423 ; objections urged against him, 429; his triumphal speaking tour, 44I; Republican masses shout for Lincoln but trust to Seward, 442; member of Senate Committee of Thirteen in 36th Congress, 459; his speech on condition of the country, 495; conflict of opinion as to effects of his speech, 496; Secretary of State in Lincoln's Cabinet, 570; his assumption of authority, 583 ; his peace views, 583 ; deceived by Justice Campbell and the Confederate commissioners, 586; his extraordinary "suggestions" to President Lincoln, 591; Lincoln's answer, 593; Seward's embarrassing attitude toward Confederate commissioners, 593; further negotiations between Seward and the commissioners, 593; explanation of Seward's course in dealing with the Confederate commissioners, 595, 601; Seward's bungling interference with expeditions for relief of Fort Sumter and Fort Pickens, 600; his action in relation to James $\mathrm{E}$. Harvey, 601 ; subsequent efforts of Republican senators to have Lincoln remove Seward from his Cabinet, 605; mentioned, $166,292,335,366,582,590,595$, 603

Seymour, Horatio: on coercion of seceding States, $\mathbf{5 6 0}$

Shadrach rescue case: 222

Shannon, Governor William: succeeds Reeder as Governor of Kansas, 248; mentioned, $34^{8}$

Shawnee Mission (Kansas): territorial legislature meets there, 246

Sherman, John: his services in
House of Representatives, 298; his entrance into Senate, 298: his speech on Pierce's last annual message, 308; appointed in 1856 one of House Committee to in. vestigate Kansas troubles, 348 ; Republican candidate for speaker of the House in 1859, 386; withdraws from contest, 387; mentioned, 605

Sherman, W. P.: 285

Simmons, James F.: 140

Simonton, John W.: 271

Sinclair, - $: 286$

Slade, William: resolutions in 1838 for abolition of slavery in District of Columbia, 71

Slaughter, James L.: 183

Slave-catchers: 227

Slavery: entrance of, into American politics, I; early introduction into Southern colonies, 2; effects on social life and character of slave-holding communities, 3; concessions to slavery in United States Constitution, and in cessions of Virginia and North Carolina, 9i. effect on slavery of introduction of cotton gin, II; events prior to President Monroe's Administration diverting attention from slavery, 12; question whether it would have died out in South if left alone by Abolitionists, 12; failure of slavery to obtain foothold in Northwest Territory, I3; as a factor in the annexation of Texas, I05; also in the Oregon boundary question, 111 ; importance of settling slavery question in new Territories, 167 ; debates on slavery question in 3 oth Congress, 168

See:ENTRANCE OF SLAVERY INTO AMERICAN POLITICs, Chap. I., p. I.

SLAVERY IN THE TERRITORIES, Chap. III., p. 37.

FROM I820 to I840, GRONTH OF ANTI-SLAVERY SENTIMENT IN THE NORTh, Chap. V., p. 62.

Slavery in the Territories: Chap. III., p. 37; question early 
Slavery in the Territories-Cont'd. becomes prominent, 37; denands of South for preservation of the "equilibrium," p. 38; of "equality of rights," 40 ; makeshift policies, "popular sovereignty," 44; " non-interference," 45; doctrine of constitutional protection, 48

Slaves: in the South refuse to aid John Brown, 384; their attachment to masters and their families during the Civil War, 384

Slidell, John: 412

Smith, Aaron D.: 231

Smith, Całeb B.: Secretary of the Interior in Lincoln's Cabinet, 570; mentioned, 31 I, 425

Smith, Gerritt: nominated for President in 1860 by the Liberty party, 44I

South, the: difference between Southern and Northern colonies, I; effect on, of Northern anti-slavery societies, 10; gain of North over, in commercial prosperity, 15; political doctrines peculiar to South, I9; stringent slave laws in South, 66; disappointment over proposition to admit California as a free State, I60; a solid South, against a solid North in 1860 , 406; special causes of Southern irritation in 1860,407 ; in South all Northerners classed as "Yankees" and Republicans as "Abolitionists," 407; contempt in South for laboring men of North, 408; Southern opinion of Northern people in general, 408; war spirit in South fully aroused before firing on Fort Sumter, 6I I

South Carolina: in colonial times, 4; first slave code of, 5 ; never desired extinction of slavery, 9; principles of Virginia and Kentucky resolutions of 1798 adopted by South Carolina political leaders, 27; nullification there in 1832,28 ; legislature of, passes resolutions asking Northern governors to suppress
Abolition societies, 67; convention in 1850 votes against secession, 181 ; leads off in secession in 1860,449 ; secession sentiment strong in, since 1832 , 454; South Carolina military forces occupy Fort Moultrie and Castle Pinckney and U. S. custom-house and arsenal at Charleston, 524; difficult to restrain from precipitate bombardment of Fort Sumter, $\mathbf{5 7 5}$

South Carolina commissioners: appointed by State after secession to treat with United States, 449; their arrival in Washington, 525; interviews and correspondence between them and President Buchanan, 526, 538

Southern Colonies: see South

Southern League: organization in I 858, 182

Spalding, Rufus P.: 285, 290

Spain: claims and treaties with, concerning Oregon country, 112

Spink, C.: 286

Spooner, Wyman, 286

Spratt, D. H.: 286

Squalter Sovereignty: see Popular sovereignty.

Stanton, Edwin $M_{\text {.: }}$ recommends pardon of Sherman M. Booth, 238; appointed by President Buchanan Attorney-General to succeed Jeremiah S. Black, 5I 7; objects to withdrawing garrison from Charleston harbor, 529; aids Black in preparing amendments to Buchanan's answer to South Carolina commissioners, 532; name inseparably connected with history of the Civil War, 540; his opinion of Lincoln at beginning of his administration, 574; mentioned, 533, 542, 574,603

Star of the West: sent to the relief of Fort Sumter, 54I; fired on by Confederates, 54I

Steadman, R.: 286

Stephens, Alexander $H$.: prominent Democratic leader in 1856,297 ; his prediction of result of secession of Southern delegates from Charleston Democratic Conven- 
Slephens, Alexander H.-Cont'd. tion in 1860, 421; his antisecession speech, 455 ; speech in Savannah, Ga., 455; elected Vice-President of Confederate States, 548; charges Seward with deceiving Confederate commissioners, 594

Slevens, Andrew J.: 286

Slevens, Thaddeus: speech in 36th Congress on condition of the country, 510; mentioned, 165 , 290, 298, 425, 603

Slockton, Roberl F.: 467

Stone, A. P.: 285

Stone, J. P.: 285

Stone, James W.: 285

Story, Joseph: his opinion in the Prigg case, 217

Stringfellow, Doctor J. H.: one of leaders of Missourians in invasion of Kansas, 244, 296

String fellow, General: 244, 250, 296

Stuart, Charles E.: 353

Sumner, Charles: assists in preparation of the Address of the Independent Democrats, 198; his controversy with Stephen A. Douglas in debate over Kansas-Nebraska bill, 207: his opinion of the Fugitive Slave Law, 22 I ; enters U. S. Senate as the successor of Daniel Webster, 264; estimate of, 264; his speech on "The Crime against Kansas," 265; reference in speech to Senator Butler of South Carolina, 267; speech delights Northern Abolitionists but angers pro-slavery men of South, 268; controversy between Sumner and Douglas, 268; assault on Sumner by Preston Brooks, of South Carolina, assisted by Lawrence Keitt of same State, 27I; Senate's action on the assault, 272; Brooks's statement in the House, 273; assault generally approved in South, 275; approved by Jefferson Davis, 275; comments of Southern papers, 275; assault excites great indignation in the North, 276; Sumner's return to the Senate,
277; Sumner's opinion of Seward, 606: mentioned, 235. $292,296,298,366,603$

See: THE CRIME AGAINST KANSAS AND THE CHIME AGAINST SUMNER, Chap. XII., p. 264

Sumner, Colonel Edwin V.: $25 \mathrm{I}$

Sumter, Fort: attempt to reinforce during closing months of President Buchanan's Administration, 540; firing on the Star of the West, 541; works for bombardment at first in charge of South Carolina authorities, 575; General Beauregard sent by Confederate government to examine; his report, 575; placing of batteries and other preparations for bombardment, 576 ; effort of President Lincoln to relieve, 588; bombardment begins, 610

Sce: ADMINISTRATION POLICIES, Chap. XXVIII., p. 578; THE EFFORTS TO SUCCOR MAJOR Anderson, Chap. XXIX., p. 597; WAITING FOR THE SOUND OF THE Cannon, Chap. XXX., p. 608.

Talleyrand: on the use of language, 293

Tallmadge, James: proposesamendment to the Missouri bill prohibiting slavery, 55

Taney, Roger B.: his opinion in the Prigg case, 217; his opinion in the Booth case, 233; his character, 317; his opinion in the Dred Scott case, 320, 323, 324; his indignation against Seward, 333; his correspondence with Justice Curtis, 343; mentioned, $316,320,324,335,339,341,342$ SCe: THE DRED SCOTT CASE, Chap. XV., p. 314.

Tappan, Arthur: president of American Anti-slavery Society: reward offered for, by Louisiana Vigilance Committee, 66

Taylor, General Zachary: achieves renown in Mexican War, 144; elected President, 151; a political enigma, 159; he favors admission of California under 
Taylor, General Zachary-Cont'd. a free-state constitution, 160 ; his death, 176

Tennessee: Union sentiment in Eastern part, 456; for a time refuses to secede, 456

Texas: efforts of President Tyler for annexation, 104; arguments in favor of, ro5; passage of joint resolution for annexation, I 1o; controversy between Texas and New Mexico, I47; people of, opposed to cutting up State into smaller ones, 193; passes ordinance of secession, 548

Thomas, Philip, E.: appointed by Presidemt Buchanan Secretary of Treasury to succeed Howell Cobb, 517

Thomas, William R.: 285

Thompson, Jacob: appointed by President Buchanan, Secretary of the Interior, 516; resigns, 517; mentioned, $165,517,519$

Thompson, Richard W.: 31 I, 421

Thumm, Charles: 285

Tilden, D. R.: 285

Tilden, Samuel J.: on coercing the seceding States, 560

Titus, Colonel H. T.: 250

Toombs, Robert: his speech in Boston in 1856,278 ; prominent Democratic leader in 1856,297 ; member of Senate Committec of Thirteen in 36th Congress, 459; his speech on condition of country, 483; Secretary of State in Cabinet of Jefferson Davis, 549; his letter to Confederate commissioners, 587 ; mentioned, 455,457

Topeka (Kansas): constitution adopted there, 247

Toucey, Isaac: appointed by President Buchanan, Secretary of the Navy, 516; mentioned, 4I9, 517,519

Trescott, William H.: Assistant Secretary of State during Buchanan's Administration, 517; efforts to aid South Carolina in purchase of arms from United States War Department, 520

Trimble, Allen: 421

Trist, Nicholas: sent to Mexico to receive peace propositions, I44; his answer to request of Mexico for provision in treaty prohibiting slavery in ceded Territory, 144

Trumbull, Lyman: his attempt to commit Douglas on interpretation of Kansas-Nebraska Act, 259; his entrance into Congress, 298; speech on compromise propositions in 36 th Congress, 499; mentioned, 297, 512, 605, 606

Turner, Nat: starts slave insurrection in Virginia, 66

Turpie, David: tribute to, 312; mentioned, 3 I I

Twiggs, General: 598

Tyler, John: nominated by Whigs for Vice-President, 87; his political antecedents, 87 ; his course after death of President Harrison, 104; his efforts for annexation of Texas, 104; his message on the Oregon question, II7; presides over Peace Convention of I86I, 466; letters to Governor Pickens, 549; mentioned, $46 \mathrm{I}$

Uncle Tom's Cabin: influence in the North, 187; angers the South, 407

Underground railroad: methods of operation, 184 ; increases irritation of South, 184; increased activity after 1854,239

Underwood, John C.: 290

Union-saving meetings in 1850 : 224

University of Virginia: students vote cane to Preston Brooks, 275

Upham, William: 140

Upshur, Abel P.: succeeds Legare as Secretary of State in President Tyler's Cabinet, I04

Utah: efforts to provide territorial government for, 148,167

Vallandigham, Clement L.: his peace propositions, 462

Van Buren, John: nicknamed "Prince John" by the- Whigs in 1840,93 
Van Buren, Martin: elected President, 63: estimate of, 85; changes in political parties prior to end of his term, 85; Democratic nominee for President in 1840,86 ; his record on the slavery question, 89 ; campaign charges against him, 9I ; nominated by Free-soil party for President in 1848, 150; receives enough votes in New York to defeat General Cass and elect General Taylor, 151

Vandyke,_-: 285

Van Slyke, L. G.: 285

Vaughan, John C.: 286

Vermont: response to Virginia and Kentucky resolutions of 1798 , 24 ; personal liberty laws of, 2 I 8 , $24 I$

Virginia: in colonial times, 2 ; concessions to slavery in cessions by, to United States, ro; Presidents from, prior to 1820,62 ; effect upon, of John Brown's raid, 384; Union sentiment in Western part of State, 456; for a time refuses to secede, 456 ; General Assembly passes resolutions inviting other States to attend a Peace Conference in I 861,460 ; recommends convention to adopt peace resolutions of Senator Crittenden offered in 36th Congress, 46r; also appoints Judge John Robertson a peace commissioner, 461 ; why the invitation was not more favorably considered in the North, 465

Virginia Resolutions of 1798 : passage of, 23

Voorhies, Daniel W.: 3I I, 3 I2

Wade, Benjamin: entrance into U. S. Senate, 298; candidate for presidential nomination in Republican National Conven. tion in 1860,423 ; member of Senate Committee of Thirteen in 36 th Congress, 459 ; speech on condition of country in 36 th Congress, 494; mentioned, 405 $573,605,606$

Wadsworth, Frederick: 286
WAITING FOR THE SOUND OF THR CANNon; Chap. XXX., p. 608

Walker, Isaac P.: 155, 199

Walker, Robert J.: one of governors of Kansas, $34^{8}$

Walworth, Reuben: on coercing the seceding States, 559

WAR WITH MEXICO; DIVIDING TIIF. SPOILS OF VICTORY: Chap. VIII., p. 143

Warren, Doclor: 225

Washington City: plans of secessionists to capture, 516

Wayne, James $M_{\text {.: }}$ his activitics in the Dred Scott case, 319: his opinion, 320; mentioned, 316, $320,339,341,342$

Webb, James Watson: 290, 428

Webster, Daniel: great debate between him and Colonel Robert Hayne, of South Carolina, on nullification, 28 ; reply to Senator Calhoun's speech on the Force bill, 30; resents charge of being an "aristocrat" in campaign of 1840, 94; his speeches in that campaign, 96; resigns from Tyler's Cabinet as Secretary of State, I04; his specch on the Compromise Measures of 1850 , 170; speeches in support of Fugitive Slave Law of 1850, 226; his death, 296; mentioned, I40, 155, 326

Weed, Thurlow: influence on formation of political character of William H. Seward, 108; Lincoln's visit to, 365; Seward's manager at Republican $\mathrm{Na}$ tional Convention in 1860,423 ; mentioned, 290, 393, 522, 596

Welles, Gideon: Secretary of Navy in Lincoln's Cabinet, 570; his hostility to Seward, Stanton, and others of his contemporaries, 603; comments on his Diary, 603; mentioned, 290 Wentworth, John: 165

West, the: Webstcr's prediction, as to, 39: growth of, in political power, 401; the new States formed out of Territory acquired by Louisiana Purchase and from War with Mexico, 401 ; electoral votes in 1860,403 
Weston, George W.: $\mathbf{2 8 5}$

Weyand, J.: 285

Wharton, I. L.: 286

Whig National Conventions:

1839: ruled by a few men, 86; fails to adopt any platform of principles, 87: nominates General William Henry Harrison for President and John Tyler for Vice-President, 87

1844: nominates Henry Clay for President, I07

I848: nominates General Zachary Taylor for President and Millard Fillmore for VicePresident, I49; convention skulks on slavery question, 149 1852: rominates General Winfield Scott for President, I89; its platform, 189; strong opposition to, on part of Northern Whigs, 190

IVhig party: rise of, 86; skulks on slavery question in 1848 , I 49 ; its downfall in $185^{2}, 189$; Whigs of New York and Massachusetts cling to party name, 282; ultimately most of Whigs went to the Democratic party in the South and to the Republican party in the North, 396

White, D. HI.: 285

White, O.: 285

Whitefield, George: favors slavery in Georgia, 6

Whitfield, John W.: contested election for territorial delegate between him and Andrew J. Reeder, 348

Whiton, Edward V.: chief justice of Wisconsin Supreme Court; his opinion in the Booth case, 231

Whittier, John G.: lament for Webster, 173

Wide-Awake Clubs: in presidential campaign of $1860,44 \mathrm{r}$

Wigfall, Louis: denounces Stephen A. Douglas in Senate, 438; his speech in 36th Congress on peace propositions, 475; speeches on condition of country, 484, 489, 490; remains in Senate after secession movement has begun, 548 ; his dis- patch to Bonham, commander of South Carolina military forces at Charleston, 539; turns up at bombardment of Fort Sumter as "Colonel Wigfall, aide to General Beauregard," 6ro; mentioned, 576

Wilkinson, I.: 286

Wilkinson, Martin S.: 605

Wilkes, Colonel: 250

Willard, Ashbel P.: 31 1, 312

Williamson, Passmore: prosecution of, before Judge Kane, 228; mentioned, 285

Willington, $F$. O.: 286

Wilmot, David: offers proviso in 3 Ist Congress prohibiting slavery in the Territories, 144 : entrance into Congress, 297; elected temporary chairman of Republican National Convention in 1860,425 ; mentioned, $165,285,287,290,297,423$, 426,605

Wilmot Proviso: see Wilmot

Wilson, Henry: protest in Whig National Convention of 1848 against skulking on the slavery question, 150; speech in Senate denouncing Brooks's assault on Sumner, 272; challenged by Brooks, 272; mentioned, 256, 454,605

Winthrop, Robert C.: 165

Wirt, William: 59

Wisconsin: indignation of people over Booth cases, 234; State election in $185^{8}$ turns on question of "States' Rights," 235; nullification resolutions adopted by General Assembly and approved by Governor 236

Wise, Henry A.: favors secession in event of Fremont's election, 303 ; his opinion as to effect of John Brown raid in Virginia, 384 ; mentioned, 295

Wise, W. W.: 285

Wood, Fernando: suggests secession of New York City, 559

Wood, S. N.: 286

Woodbridge, William: 140

IVright, Joseph A.: 3 I I 


\section{Index}

Wright, Silas: votes in favor of Calhoun's bill to prohibit circulation through the mails of Abolition papers, etc., 68

Yancey, William L.: effort of, to incorporate "non-interference" doctrine in National Democratic platform of 1848,46 ; his speech in House on the Oregon question, 128; drafts Alabama platform, 182; active in formation of Southern League, 182; early advocate of secession, 182; his letter to Slaughter, 183 ; speech on righteousness of slavery in Charleston Democratic Convention in 1860, 413 i intends secession from convention as preliminary step to secession from the Union, 420; one of Confederate commissioners to foreign nations, 549; mentioned, 4 I I, 420, 457

Yales, Richard: 512

Yulee, David L.: advised Southern members of Congress to remain in Congress as long as they could aid secession cause, 547 


MAY 241988

\section{PLEASE dO NOT REMOVE}

\section{CARDS OR SLIPS FROM THIS POCKET}

\section{UNIVERSITY OF TORONTO LIBRARY}




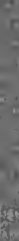

Qt) 4 is

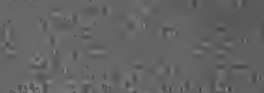

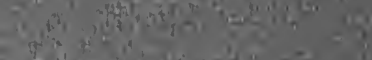

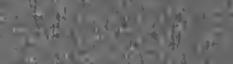

4.

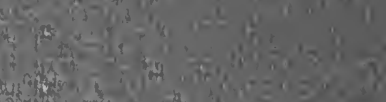
$-6,0,1,7$

3.

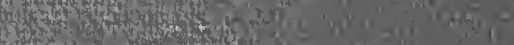

\section{0}

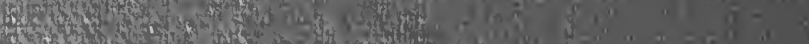

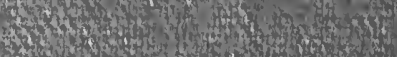
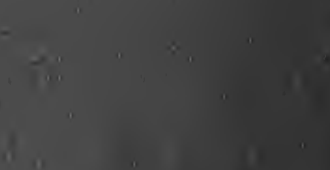